sin

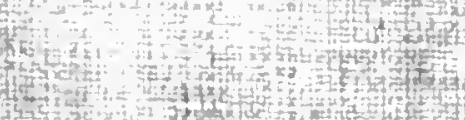

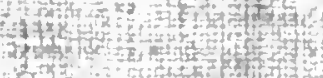

int

H.

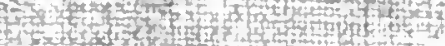

1.t.

(n)

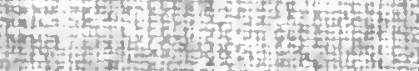

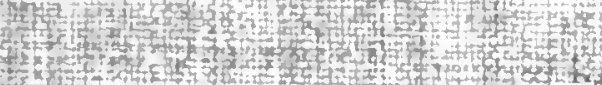

4.

(1)

19.

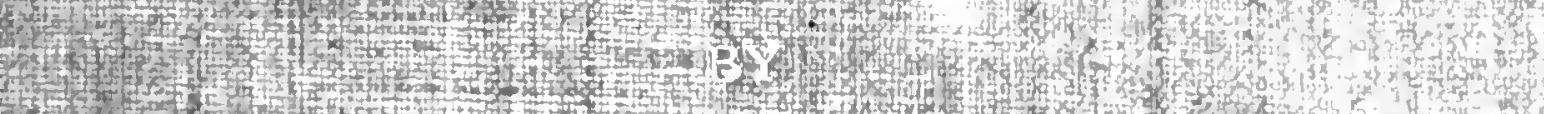

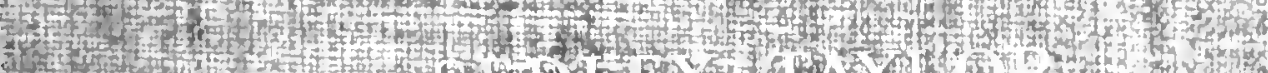

Th

Thy

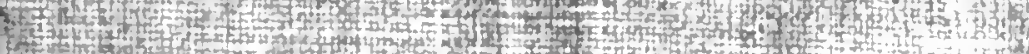

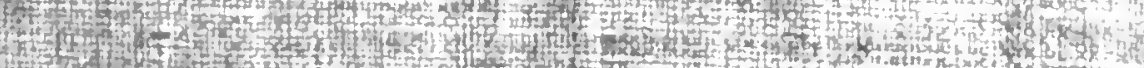

Thy

Frof

In

to

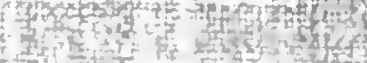

1)

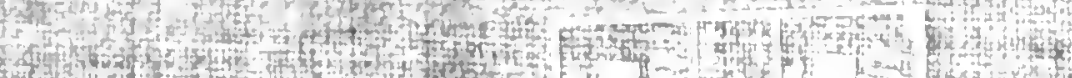

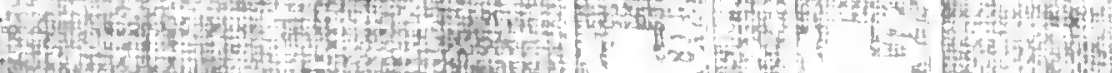

W.

t.

4 (1)

Afr If

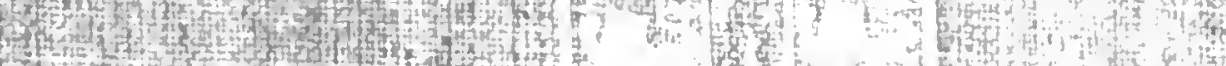

Non

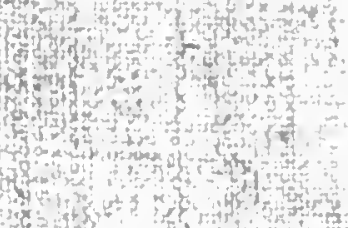

The

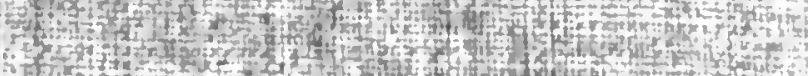

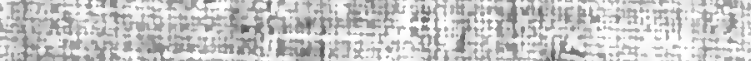






THE INDEBTEDNESS

OF HANDEL

TO

OTHER COMPOSERS 
CAMHRDGE GNAERSTT PRESS WAREHOUSE, C. F. Clay, Maxager.

ZLonoon: FETTKR LANE, E.C.

Blasgow: F', WELLINGTON STREET.

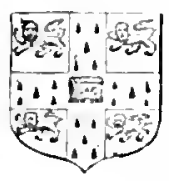

A I.SO

Wonoon: ACGESER ANW CO.

Ilpyig: F. A. BR()CKHAL.

fow bork: G. P. IITTYII's sOSs.

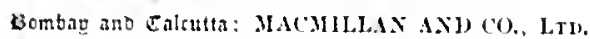




\title{
THE INDEBTEDNESS
}

\author{
OF \\ H A N DEL
}

TO WORKS BY OTHER COMPOSERS

\section{A PRESENTATION OF EVIDENCE}

SEDLEY TAYLOR M.A.

FORMERLY FELLOW OF TRIXITY COLLEGE, CAMRRIMGE

Cambridge

at the University Press

1906 
Pages $\mathrm{i}-\mathrm{xiii}$ and $189-196$ have been printed by IOIS ("LAY, M.A., AT THE INIVERSITY PRESS, CAMBIIUGE, and pages $1-188 \mathrm{ly}$ AlRJ ANI) cOGIILL, I,TH, GLASGOW. 


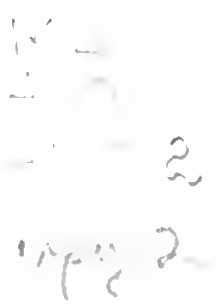

\section{PREFACE.}

TN the following pages I attempt to place betore my readers sufficient materials for forming an independent julgment on Inandels indebterlness to the works of a number of composers who were his predecessons or contemporaries.

The task of singling ont the compositions on which he appeass to have drawn most langely, and the labom of publishing them, have been already performed, pineipally by the late $\mathrm{DH}_{\mathrm{H}}$ Friedrieh Cluysamder, ably followed by Dr Max Seiflert. lint something, I thought, still remained to be done in the presentation of this pioneer-work. before its results could beeome effectively acessilsle to musicians in general.

The published editions of "Mandel-somees" were, indeed, prefired by fiull references to the places in his works where he had nsed specified passages from them, but the proeess of eomparison still neeessitated the acquisition of halt-a-dozen smel rolumes and of a dozen works ly Handel, followed by the hunting-np am confinting of the comesponding passages, not unfiequently eomplicated ly the need of transposition.

Convinced that nothing wonld persuade the British musieal public to take all this tomble, I letermined to present in a singlo volume a study of the whole sulpjeet, based on a selection firm the alworementioned materials, doing ny hest ly suitable collocition of musical

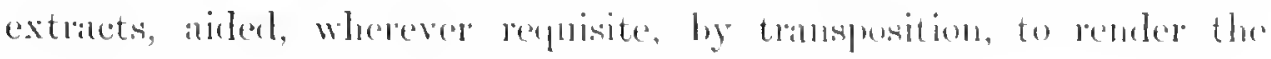
proeess of complatison ats easy as possible. 
After inn Intretuction which slictehes the history of opinion as to Handel's mignality, live ehapters are occupied in proving that he Inrmwent as freely from the comprositions of other masters as he worked up inte new shatpes earlier productions of his own.

In dhapters vi and vil a full presentation is made of the processes by which oller materials were transformed-asometimes really trans-

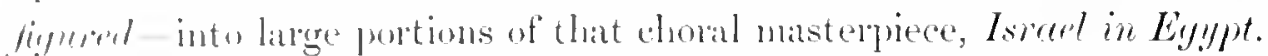
The contents of these chapter's will, I renture to hope, prove of permanent value to students of compusition, as they afford a close view of Itanket obtaining sone of his mightiest effects by methods of the most mexpected and wonderfinl chanater.

'The concluding ehapter contains a discnssion of the question whether Ilandel was morally justified in dealing as he did with workis by other composers.

My varions personal obligitions are ankmowlerlged in the sequel at the points where they are severally incurred, but I wish here to thank the Syndies of the Fitzwillian Musemm in this University, by whose kindness I an enabled to publish extracts from the Handel antongrallis preserved in their custody, which have a decisive bearing on the subject treated in this volume.

My eordial thanks are due to my friend Dr. Charles Wood, who rewd the work in mannscript and afforded me valuable assistance during its passage through the press.

\section{SEDLEY 'TAYLOR.}

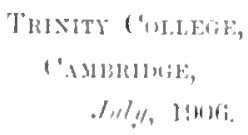




\title{
'TABLE OF ('ONTEN'L'.
}

\author{
PREFACE (Pages $r$, vi).
}

\section{INTROJUCTION.}

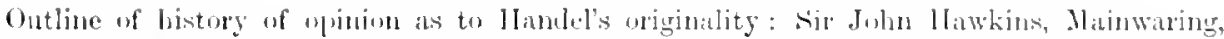

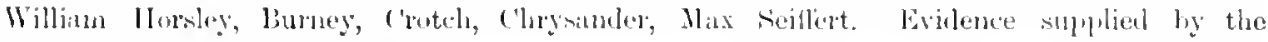
Fitzwillian IIanlel atutegratuls.

Pages ix-xiii

\section{CHAPTER I.}

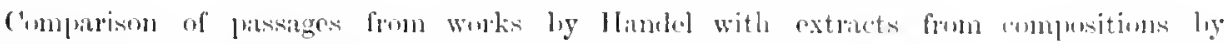

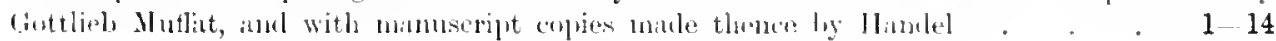

\section{CIIAP'TER II.}

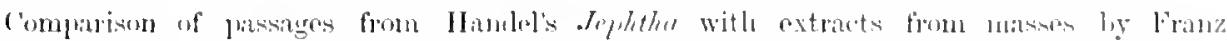

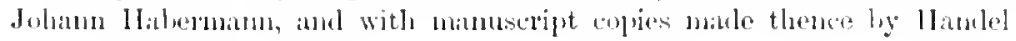

\section{CHAP'TER III.}

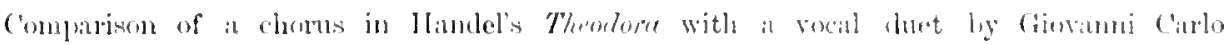
Mariis ('lini

\section{CIAATER IV.}

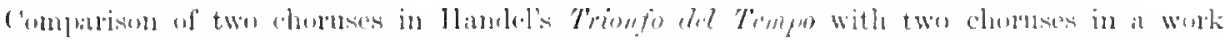

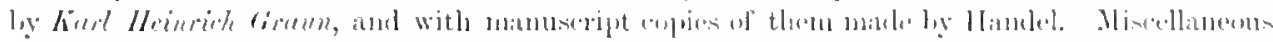
eximples of Ilimulel's llise of this wirk . . . . . . . . . . . . $31-35$

\section{CIAPTER V.}

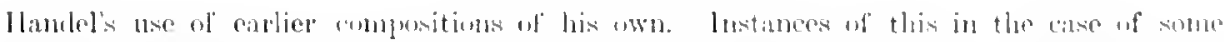

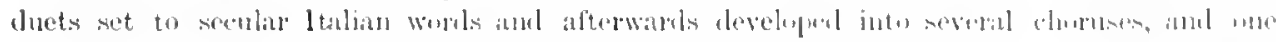
duet, in the Jessuk . . . . . . . . . . . . . . . . . 3646

\section{CHAPTER VI.}

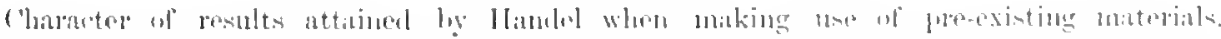

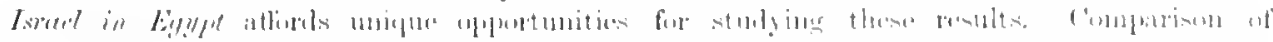

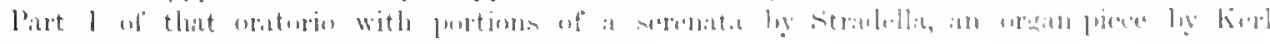

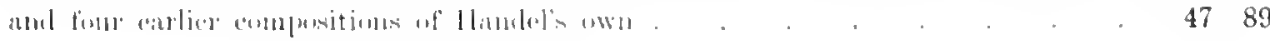




\section{CHAPTER VII.}

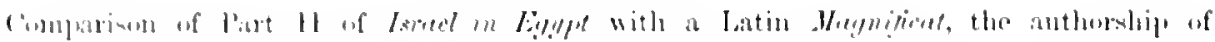

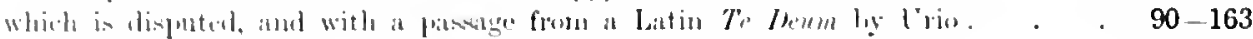

\section{('IAPTTER VIII.}

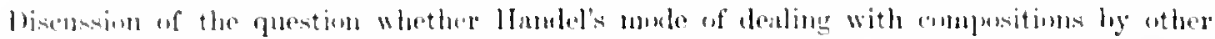
Manter was montly juntilinlle . . . . . . . . . . . . . 164188 Allowile:

lint uf works ly llandel purted from in this volume . . . . . . 191

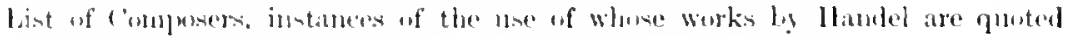
in thin volume. . . . . . . . . . . . . . . . . . . 192

lint if Examples . . . . . . . . . . . . . . . . . . . . $193-194$ IITKX . . . . . . . . . . . . . . . . 195 


\section{INTRODUCTION.}

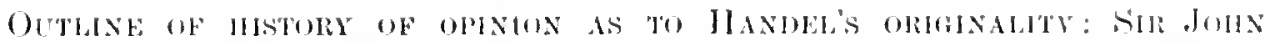

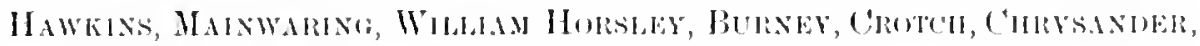

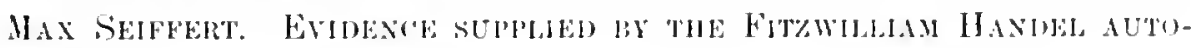
GRAPIS.

II

ANDELS' mote of turning (1) account the works of other compusers is characterised by a writer in the Eneyclopedia Britennica in the bollowing uncompromising terms:

"The system of wholesale plagiarism arried on by him is prophas nuprecelented in the history of musie. Ile pilfered not only single mededies but frequently entire movements from the works of other masters, with fow or 110 alteratious and without a word of acknowledgment."

With this it is instructive to complare an epually swepping, lut diametrically

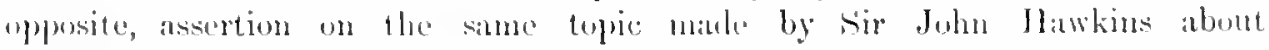
seventeen years after Hambel's death:

"And here it maty not be impertinent to observe, what every person conrorsint with his works will br inclined to belinge, vize that his style was

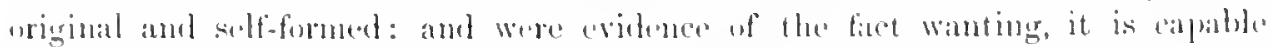
of prow by his own testimony, for in a comversation with a very intolligent

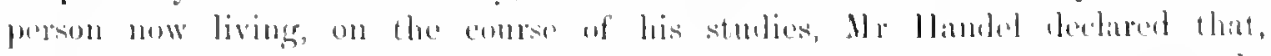

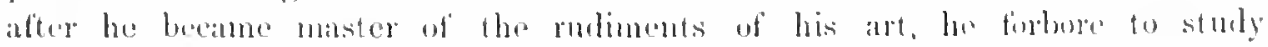
the works of others, atud ever mate it a rule to follow the sugenentions of his "wn filley:".

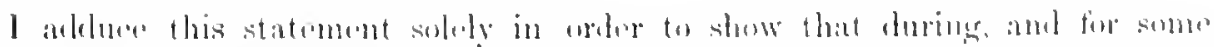

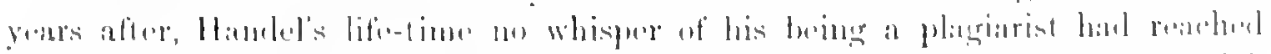

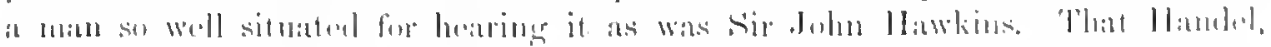

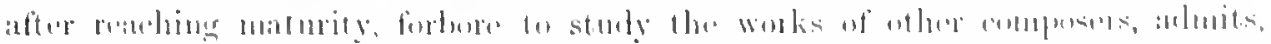

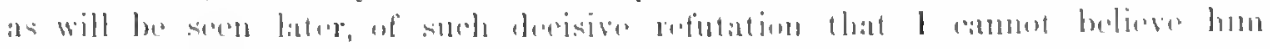

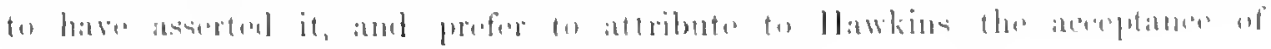

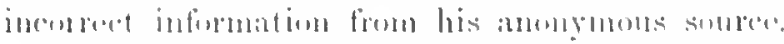

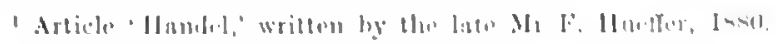

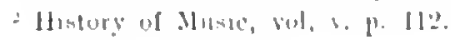




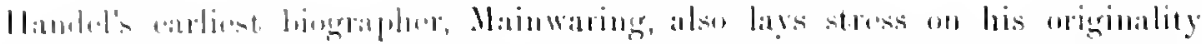

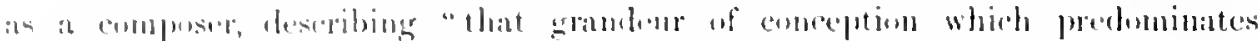
in his elontuses" as "coming purely from Nature" and silying that "in his fingures and owestures he is quitu original" and that "the style of them is peculier to himself and wo waty like that of any Master before him."

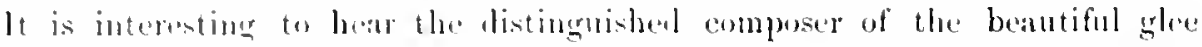

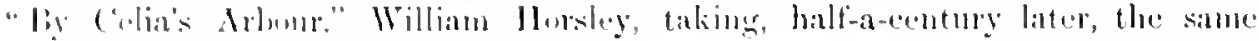

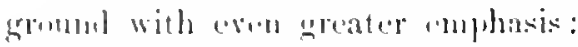

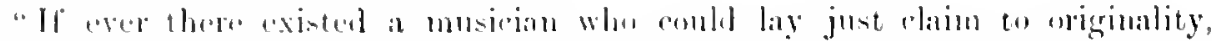
that man was llandel. He drew all bis stome from Nature and fiom the foree of his uwn grenius and was indeloed to no one either for his style or his thrughts. He andel not lend his talents to think after anyberly else; consegons of the strength of his own purers, he distained initation, and tristed confitently to them alone. Itis muse therefore is, properly speaking, his own...."."

This juelgment fairly represents, I think, the practically axiomatic betief in Hamlel's originality entertimed by the bulk of English musicians until quite recent times.

A very different opinon hat meantime been gratually forming itself, the froweress of which shalt noxt he tracel.

Burney, in the pleface to his "Accomnt of the Musical Performanees in Wontminster Abbey and thr Pantheon in commenoration of IJandet," ${ }^{3}$ which tom place in list, says something which may imply that, a quarter of a contury aftor Ifandel's wath, a tendency to question his absolute originality had begun to make itsolf head. Writing in the following year (1785), Bumey romarks:

"I know it has boen said that Handel was not the original and immediate inventor of sobral species of Wusie for which his name has been celebrated, but with respeet to miginality it is a term to which proper limits should be sot before it is applied to the productions of any artist." He goes on to explain that "The scate, harmon! and cadence of Husic being settled, it is impussible for any comproser to invent a genus of comprosition that is mholly and rigorously new, any mure than for a joet to form a langunge, idliom and phrasendury for himsete." Whether the objections which Burney had in view here wre of such a kind as contl be fairly met by these somewhat platitulinums consideratims we are left minformed. Some twenty years later,

" "Memoirs," Inndon, 1760, lp. 192 and 202.

"This passage is taken from an article in the quarterly Musinal heren for 1818, p. 282. The article is unituned, but in my copy of the volune containing it, which belonged to my grandfather, lichard Mackenzie liacon, who was then Editor of that periodical, it is headed in manuscript "W. IIorsley, Esq."

3 London, 175.5.

+ Preface, p. 39. 
loweser, the charge of plagiarisus was formulated against Ilandel with the ntmost directness by mo less at person than Simmel Wesley, ane of the best orgin-players of his time, anthor of that mhimble s-part motet, "In exitu

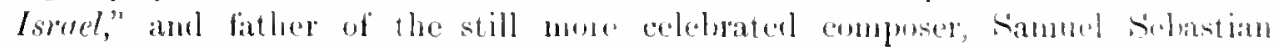
Wesley. In a letter to his friend Jacob, dited Oct. 19, 1s0s, he wrote ats follows:

"Salomon hats said truly and shrewelly enough, that the knglish kmow very little of the IVorks of the German Masters, Handel execptod, why as he observes) came wer hither when there was a great dearth of gound Mluniek, and here he remained (thes are his words) establishing a Riputation wholly constituted upon the spoils of the Continent. This would nette the Himblelians desperately, howerer it is the striet truth, for we all knew low be las pilfered from all mammer of Anthom whonce he combl tileh anything like a thonght worth emborying."

There eam be no dombt that, if llamdel hat commited such depordations on

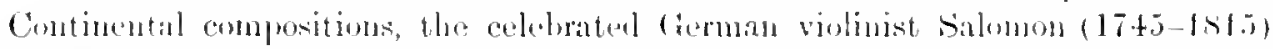
was execptionally gualified, by varied experience on the Continent and long residenee in lingland, to deteet and expose them. But, whatever was the sonder whence Wesley derived his information, he evidently dains for himsolf, his correspondent and their associates, a direet knowledge of the "pilferings" and "filchings" here attributerl to Handel.

In $18: 31$ the nimes of twenty-nine eompusers, whose works lie assented to have been litid nules contribution hy Handel, were published by 1)r Willian Croted, then Professon of IInsic in the University of Oxforl:

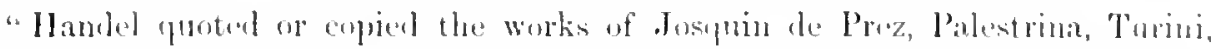

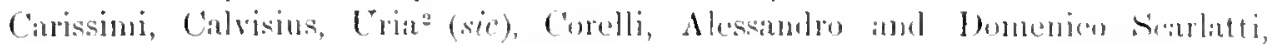

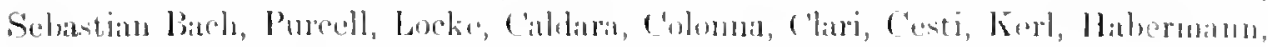

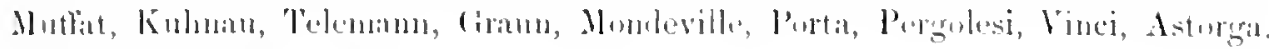
Bonmeini, IItske, "te."

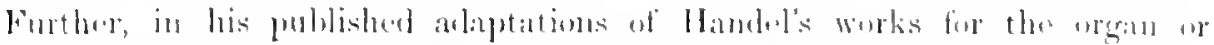

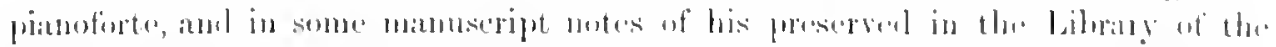

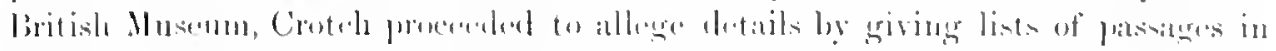

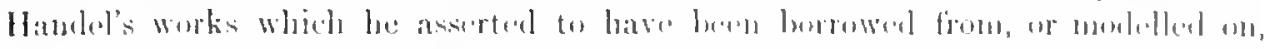

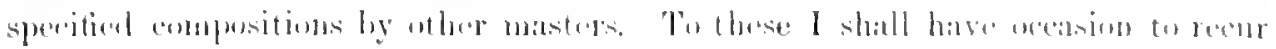

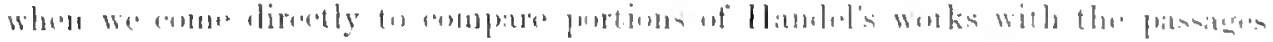

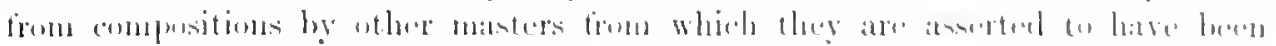

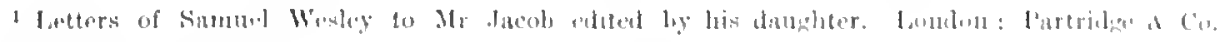
1575. P. 3.

a Shoutal be line

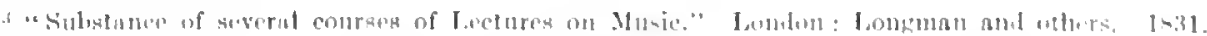
Note on 1) 1:22. 


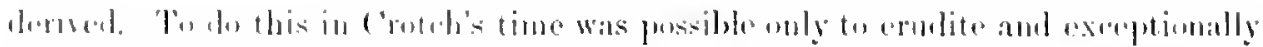
well silnatud musicians like himsolf, the works from which Hambel was allegerl to hatre turrowed being then for the mest part unpublished and practically inaccessible.

This state of things lasted for moro than another half-century until l)r Friedrieh ('brysuder, well knuwh as the learned bingrapher of Handel and as the Eelitor of th" great cermath edition of his works, brought out, ats "Supplements" to

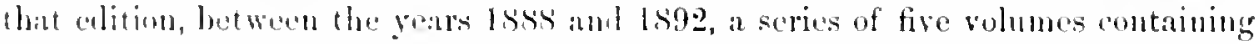
compustions to which, in his opinion, Hamblel was principally indebted.

These compositions, armanged in the order of their publication, are: I. Erba's

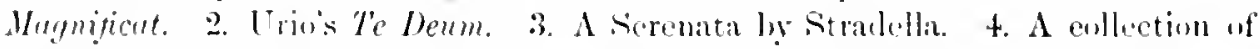

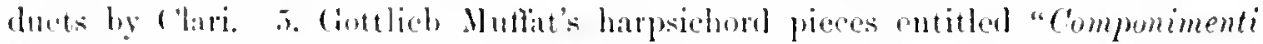
Musiculi." 'Tur these must now be adked an edition of Keiser's opera "Oetavia' which was left in it eomplete state by 1). Chrysander at his death, in 1901, and has sine been published umder the care of his literary executor, Jy llax Sieffert, as No. 6 of the llandel "Supplements." Eich of these volumes, with the reeption of No. 2 , entains a preface emmorating the passages in Handel's works where the eompusition in land has been drawn upon. An edition of four oratorios by Carissimi, from whom Hindel aloo burowed, had been mblished by Chrysander at an carlier date, independently of the landel soriety and without any reference to the use which llaudel had made of them.

In 1903 1)r Seiffert effected an important advance in an articled on Franz Joham IJaberman containing large extracts from masses by that composer, tugether with precise indientions of the places where, am the extent to which, Hambel had userl them. Pr Seiffert is careful to explain that it was Chrysander's intention, if his life were prolonged, to prepare an edition of Habermamn's masses to form the next number in his series of Haulel "Supplements." Lastly, in 1905,

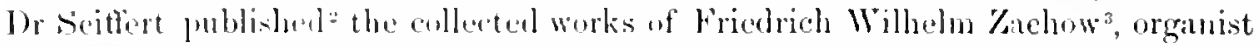
at Halle, and the unly teacher in executive music and composition that Handel erer hikd.

These works show sery fow traces of creative power, which perhaps explains why Handel securs to have borrowel next to mothing from them. But they constitute evilence that Kachow hald an easy control over the forms of composition with which a choimaster in an inpontant North German chmeh at the end of the seventecnth century hat to deal, and that he was acemdingly well fitted to lity a durable foumlation for his great pupil's future superstructure.

In empuiring what is actually poved by the valuable pmblished matter currorily deseribed above, we shall be materially assinted by avilence contained in the collection of IIandel autograph manuseripts preserved in the Fitzwilliam Ilusenun of the University of Cambrilge.

\footnotetext{
"Published in the Kirilenmusiknlisches Jahrluch, Regensburg: Pustel, 1903, pp. 81-94.

"In the Dinkmiller lintscher Tonkunst.

${ }^{3}$ Or, as his name has hitherto been spelt, Zachau.
} 
A number of its pages contain movements-some complete, some incomplete, some eomsisting of more fragnentary scraps a few hats long-which used to be regarded als compositions, or sketelyes for compositions, of llandel's own, but have now been in numerons cases identified as extracts made by him from works by other composers, not a few of which have analugues in his publinherl writings. Where, in such instances, a question of pronity arises, evilence that one of the parties knew, and copinel from, the work of the other is obvismly of great weight. We shall in the sequel conc across several instances in which decisive eviduce of this kind is supplied by the Fitzwilliam autographs.

We will now proceed to a detailed comparison between portions of Itamled's works, and passages in those of other composers from which they are asserted to have been-with greatly varying dengees of alteration, curtathent and aldition-directly taken. The number and extent of the instances where this is alleged are so very consideralile, that to apply such a comparison to anything like all of them would cutail a jrocess of luge length and purtentons wearioneness. Selected cases are, therefore, all that can be dealt with here, and these will be gromped under the names of the several composer's frum whose works the appropriations are allegen to have been minde.

When the printing of this volume was alyeady in its final stage, an accilcut recalled my attention to certain aroments published, in a letter to the Husicul Times', ly Ifr P. Robinson, of Hanchester, supporting the view that Handel may have composed not only the Margnificut attriluted by ('hrywater to Erba, but also the Te Deum and the serenute ascribed by lim to Urio aud Stradellat respectively. I read that letter at the time of its appeamance, but afterwards, to my regret, allowed its contents, whels unght to have been noticed in the septed, to eseape my memory while I was engaged on the present work. All, therefore, that I can now Wh is to refer my readers to Mr Robinson's letter, leaving to further research the task of investigating the issues which he has raised in it.

1 December, 195:. 



\title{
CHAPTER I.
}

\author{
COMPARISON OF PASSAGES FROM WORKS BY HANDEL WITH EXTracts fRuM \\ compositions by Gotrlieb MUfFat, and with manuscript copies made \\ TBENOE BY HANDEL.
}

OTTLIEB MUFFAT (1690-1770), of Vienna, was one of the best composers $\checkmark$ of his time for the harpsichord. His chief work, entitled "Componimenti Musiculi per il Cembulo," is a collection of overtures, fugues, fantasias ete., and of movements in dance-forms, minuets, rigaudons, sarabandes, gigues and the like. The resemblances between eighteen of these and passagres in Handel's works which have been specified by Chrysander are of such a kind as to make it manifest either that Handel copied from Muffat or Muffat from Handel. We have, therefore, to decide between these alternatives. Unfortunately the date at which Muffat's 'Componimenti' were published is so uncertain that it cannot be relied on an an element of comparison. The late Herr C. F. Pohl, in an article on Muftat in Grove's Dictionary of Music,? stated that the work in question was published at Vienna in 1727, and he made a memorandum to that effect in a copy of the 'Cornponimenti' in the Library of the Geselleshaft der Musilifreunde at Vienua, of which he was then Librarian." On the other hand Chrysander in his edition of the 'Componimenti' reproduces the original title-page which states that the work was printed at Angsburg, but bears no date. In the German ${ }^{3}$ preface Mlullit describes his good fortune in having met with his famous "engraver and publisher" ("Kupferstecher und Verleger") who had produced ("verfortiget") the work to his entire satisfaction. According to this evidence, therefore, the "Componimenti" were printed and published at Augsburg, not at Vienna as stated by lohl. The fact that the date is wanting on the original title-page affords, of course, no proof that Pohl did not possess some independent evidence capable of estrblishing it. For us, however, the date which he assigns, 1727, rests on his assertion only. Chrysander, on conjectural grounds, considered the work to have been published "about the year 1795," but, as this view depends on the assumption that "Hande? had the 'Componimenti' in his hand in 1739 or perhaps a year earlier," no weight can, withont circular reasoning, be assigned to it at the present shige of our encluiry.

1 Hiral edition.

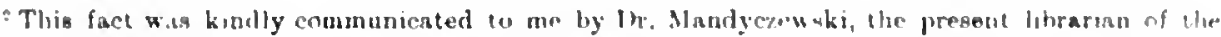

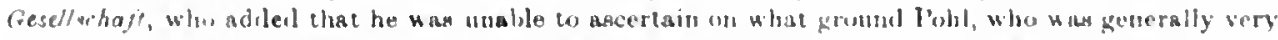

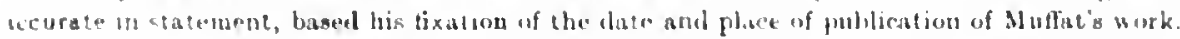

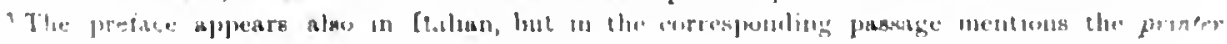
("Iniperesore") only.

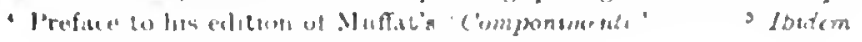


So far, then, the exturnal evidence is inconclusive, but an appeal to that supplied by the Fitzwillian Handel autographs will prove much more fruitful. These contain certain disjointed musical scrajs, of from 3 to 5 bars each, which so experienced a Handelian seholar as Dr. A. H. Mann has not been able to recognize as appearing anywhere in Ilandel's published works, but which he and I between us have identified as agreeing in minute detail with passages in Mufrat's 'Componimenti.' This renders it very insprobable that Mnffiat took these passages from any Handelian source, as he certainly had no access to Handel's private note-books; and therefore estahlishes a strong probability that IIandel copied them from Muffat's publisbed volume. A detailed comparison between the forms in which these passages are presented in the note-books and in the 'Componimenti' will, I think, make it clear that Handel was here the copyist. To this comparison we now proceed.
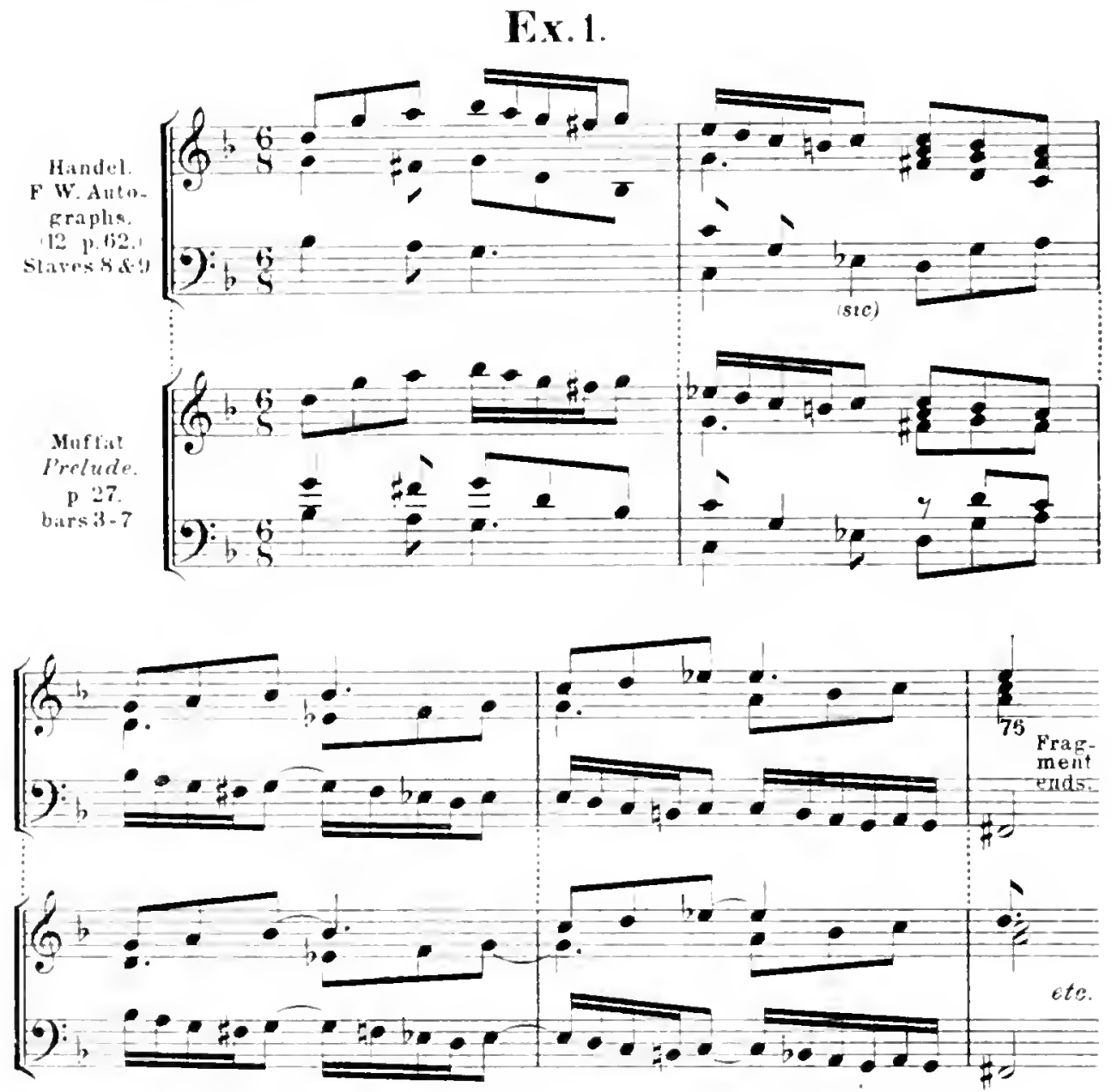
'The occurrence in Handel's version of only one tie (bar 3) as against six in Mulfat (bars 3 and $t$ ) is an indication that Handel is here copying, not composing. The absence of a flat before $\mathrm{E}$ (H. bar 4, Bass, first note) shows that a tic should have been inserted as in Muffat. In the same bar the second $B$ onght to have a flat before it as in Muffat. The absence of a flat before $\mathbf{E}$ (H. bar 2, Treble) and of a 'natural' before the second $\mathrm{F}$ (H. bar 3, Bass) tells the same tale.

\section{Ex. 2.}
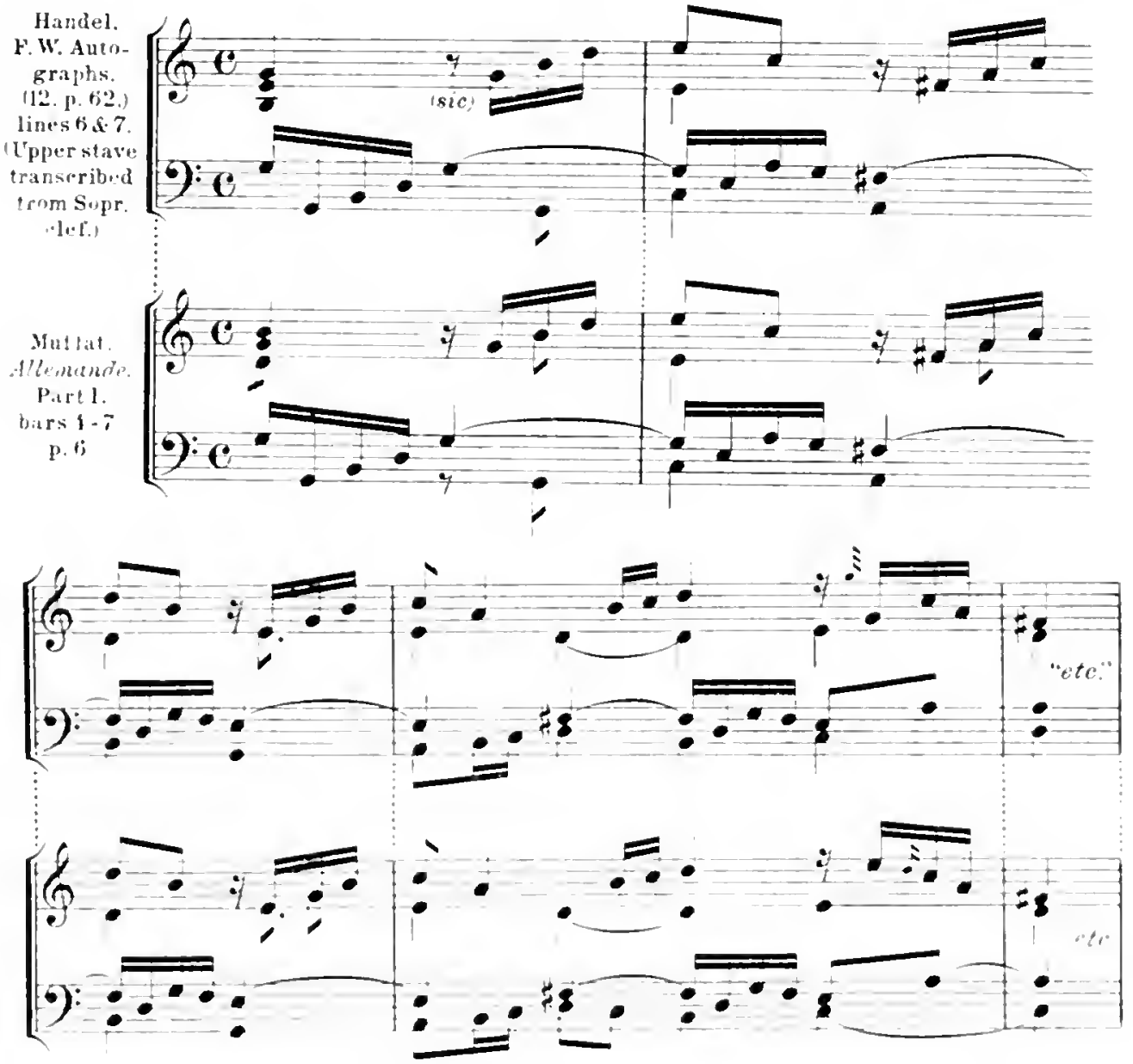

At the beginning of Handel's autograph here lo has first written in the Treble clef and then crossed it out aud replaced it by the soprano clef, which was doubtless that used in Mutfat's original edition. The upper stave in the antograph opens this

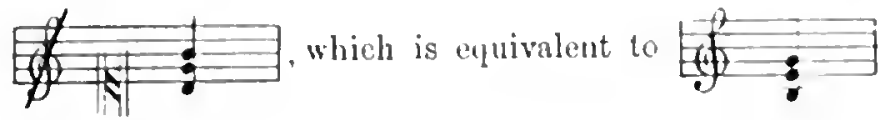


and not consistent with the Bass. I conjecture that Handel made the change of clef after he had written in the opening chom, and forgot to alter it correspondingly when he repheed the Treble by the soprano elef in which therefore it reals as the chord of $E$ minor instead of as that of $G$ major.

Immediately after Handel's "etc." comes a further fragment corresponding to a passage in Part II. of the same Allemande by Muffat, the Treble clef being this time used by Handel.
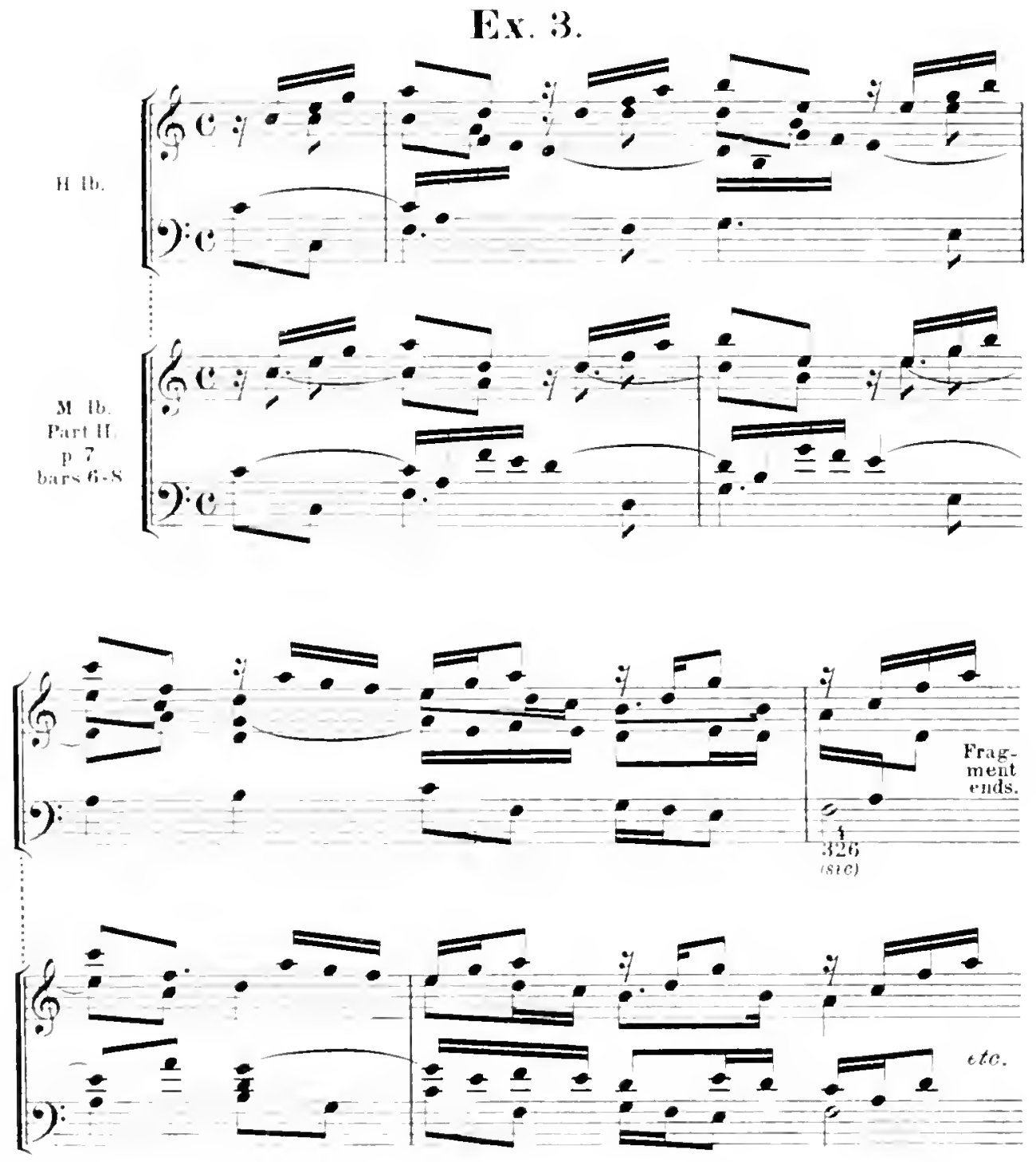
Here the difference of barring makes Handel's version much the better of the two. We camnot suppose that Muffat hal it before him and deliberately worsened its vigorous accentuation, and therefore must here see llandel copying from Muffat and improving on him while doing so.

Ex. 4 .

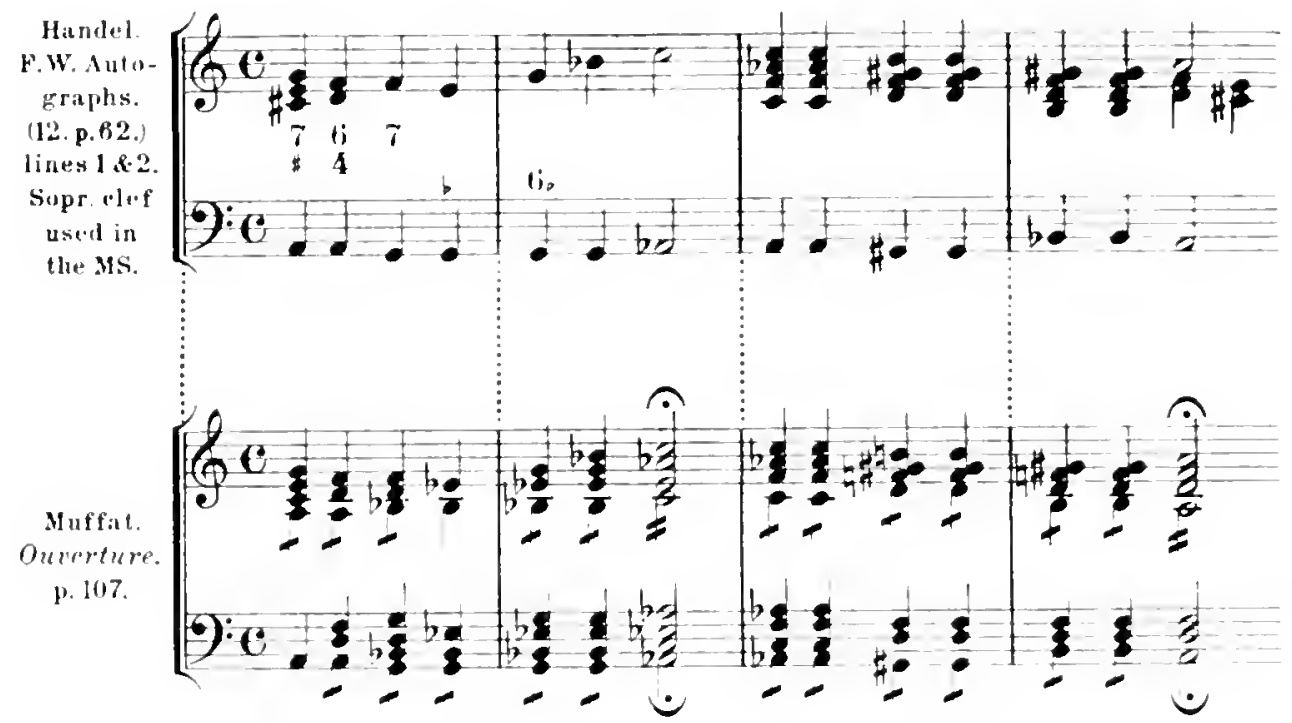

Handel's version here looks on the face of it anything but like a hit of original composition. It begins with a chord in lour parts followed by another in three, both providel with Thorongh-liass figuring from which we learn nothing but what the chords themselves tell us. Next come five notes of 'lreble and Bass only, with incomplete figuring, then six unfigured elords in five parts and one in four. Bars 8 and 4 show wrong notes, $A$ and $A p$ appearing $m$ one ame the same chord in Bar 3 , and $B$ and $B, b$ in bar 4.

It is hardly possible to inagrine Handel gutting his own ideas on paper in this fashion, but quite asy to suppose him jotring lown these notes and scinty figures if his object was to produce, not a copy of what Muffat lad written, but a rough memorandum sulticient to recover its salient fentures if late should subsequently have occasion to malie use of them. So far it las, I think, been established that Handel copied ont, or male memoranda of, pascians tron Mfulfat's 'Compromimente.'

I place next an pample showing Handel at work chaboting a fine accompanied recitative out of apparently unprouising materials laken from the sume quitry. 


\section{Ex. 5.}

Arcompanied Recitative from tho Ode for ste Cecitives Doy.

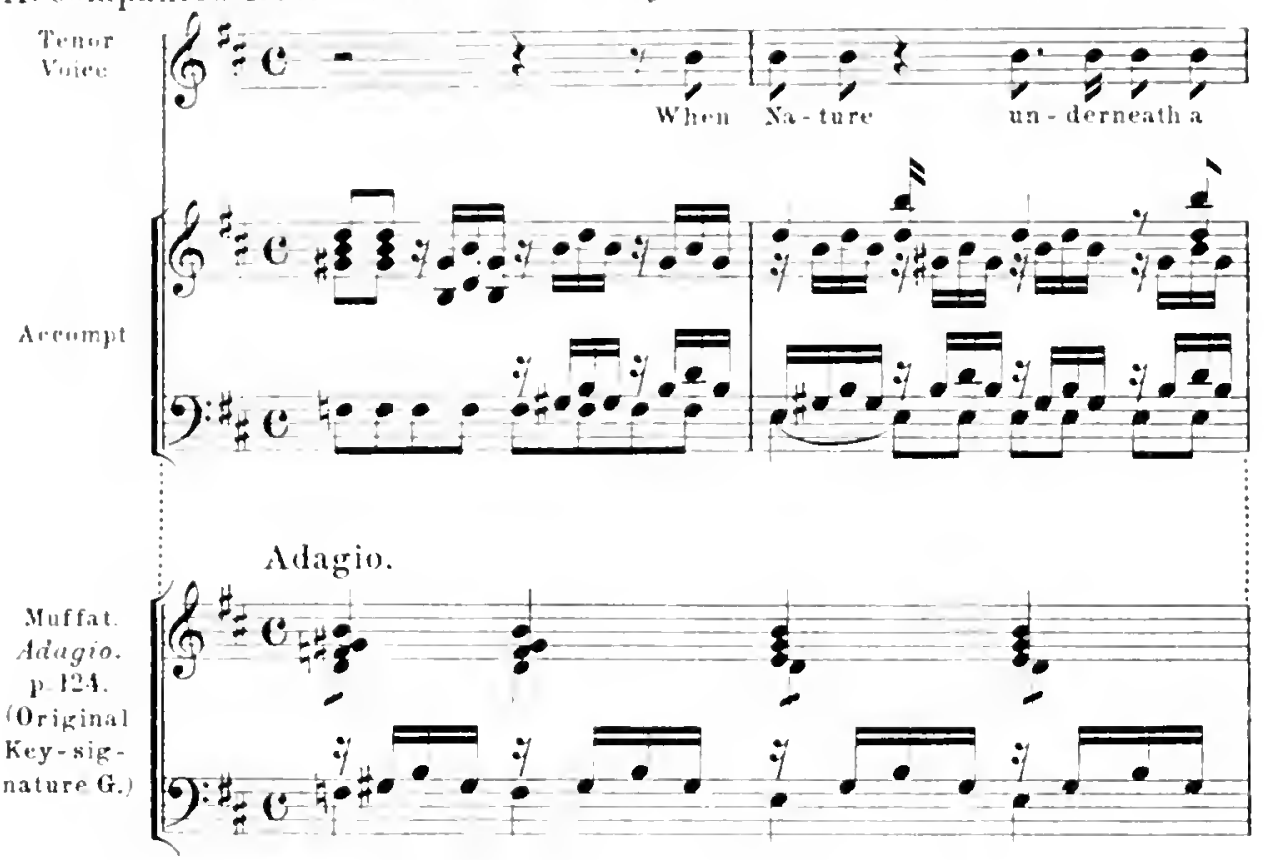

$\oint_{\text {hos }}$

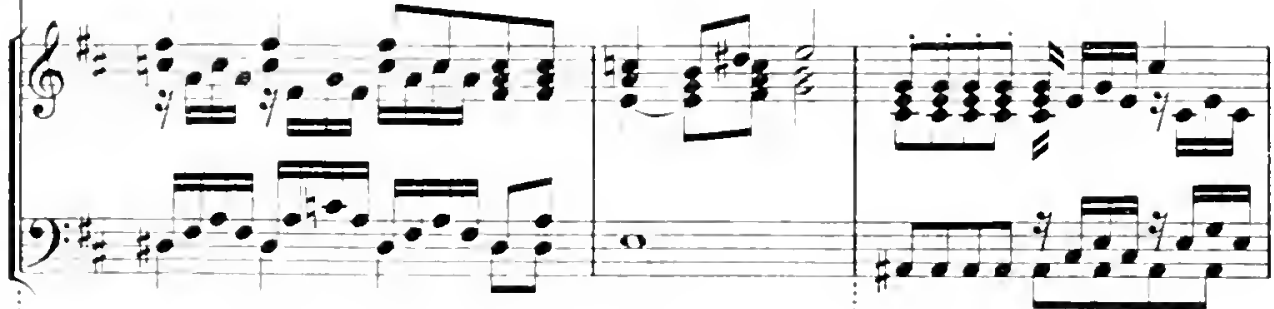

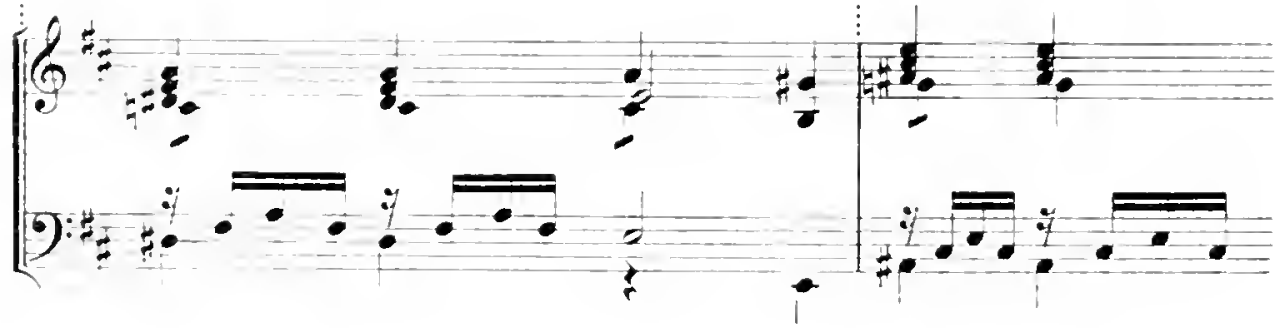


DEVELOPMENT FROM MUFFAT

7
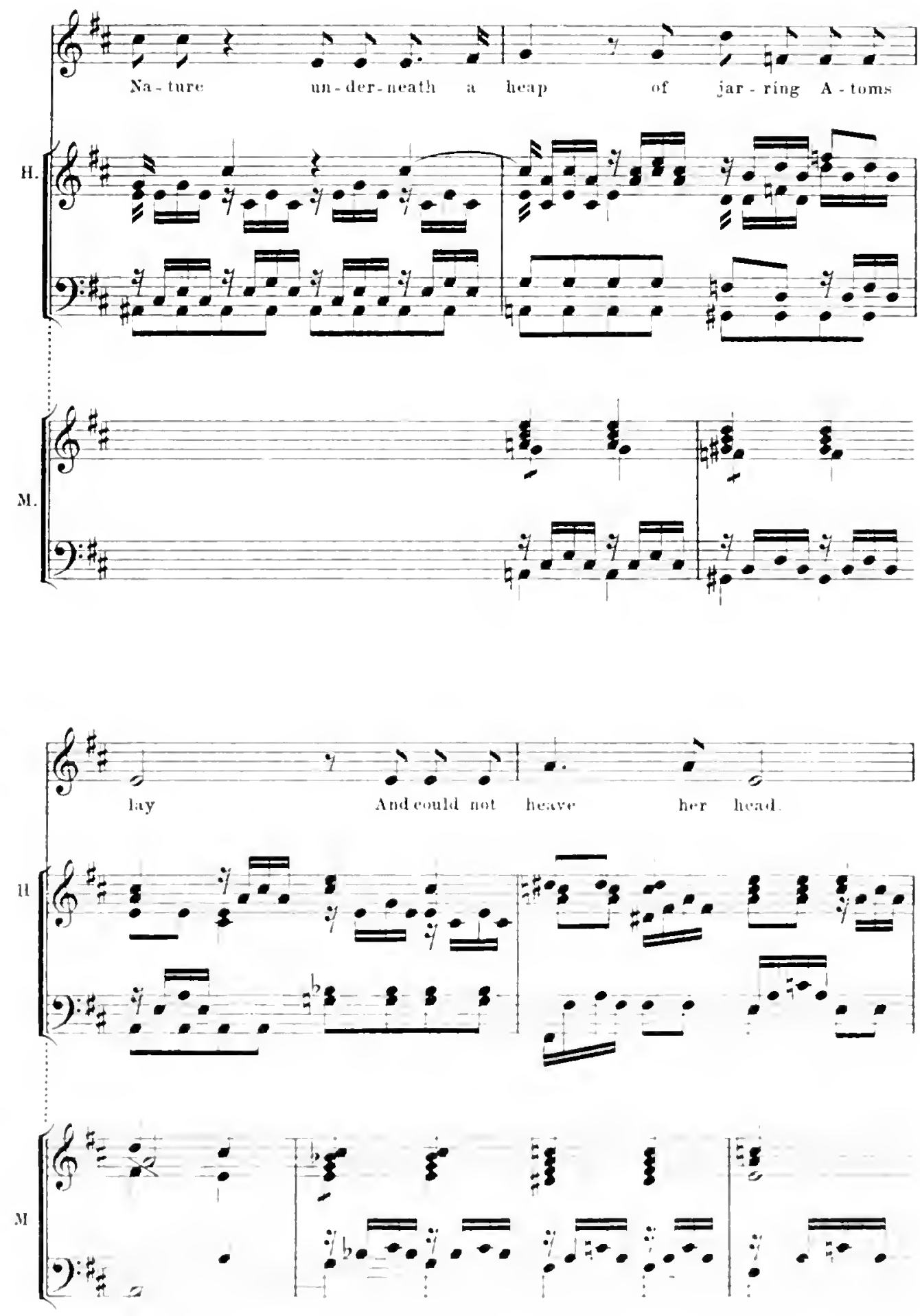


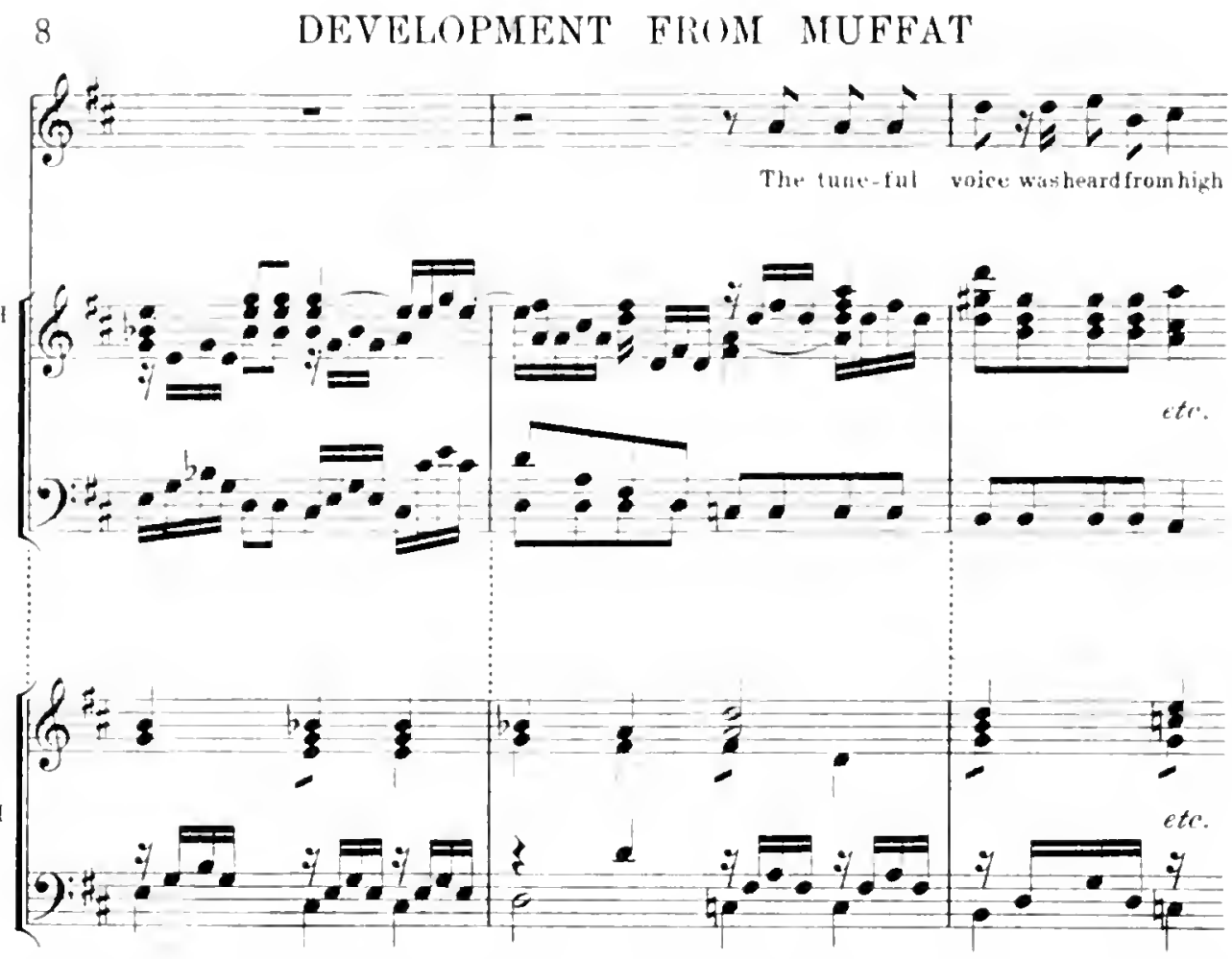

An argument already used above, is equally applicable to this case. Had Muffat seen Handel's mnacompanied recitative he could not by any possibility' have reduced it to the lead level of his Adarjio. Therefore it must have been developed by Handel on the skeleton supplied by Muftat. It is immediately followed in the Ode for St. Cecilia's Day by short unaccompanied recitatives, alternating with two instrumental interlutes identical, save for slight alterations, with passages from a 'Fantaisie' by Muffat, as is shown in the next exauple:

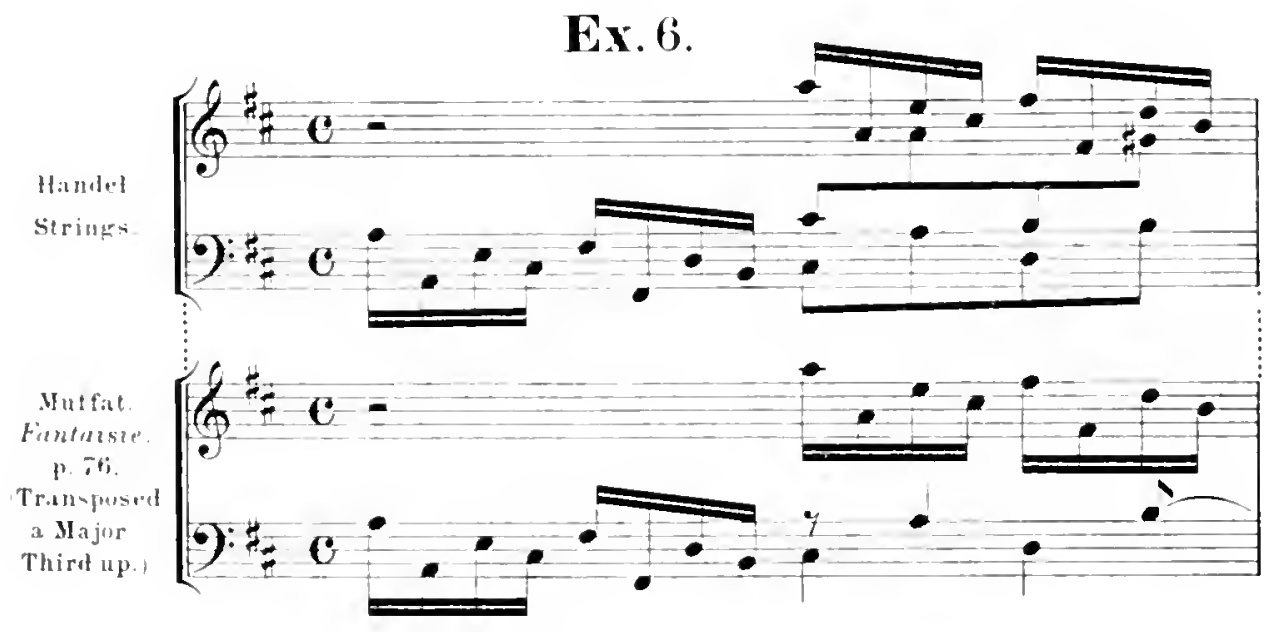




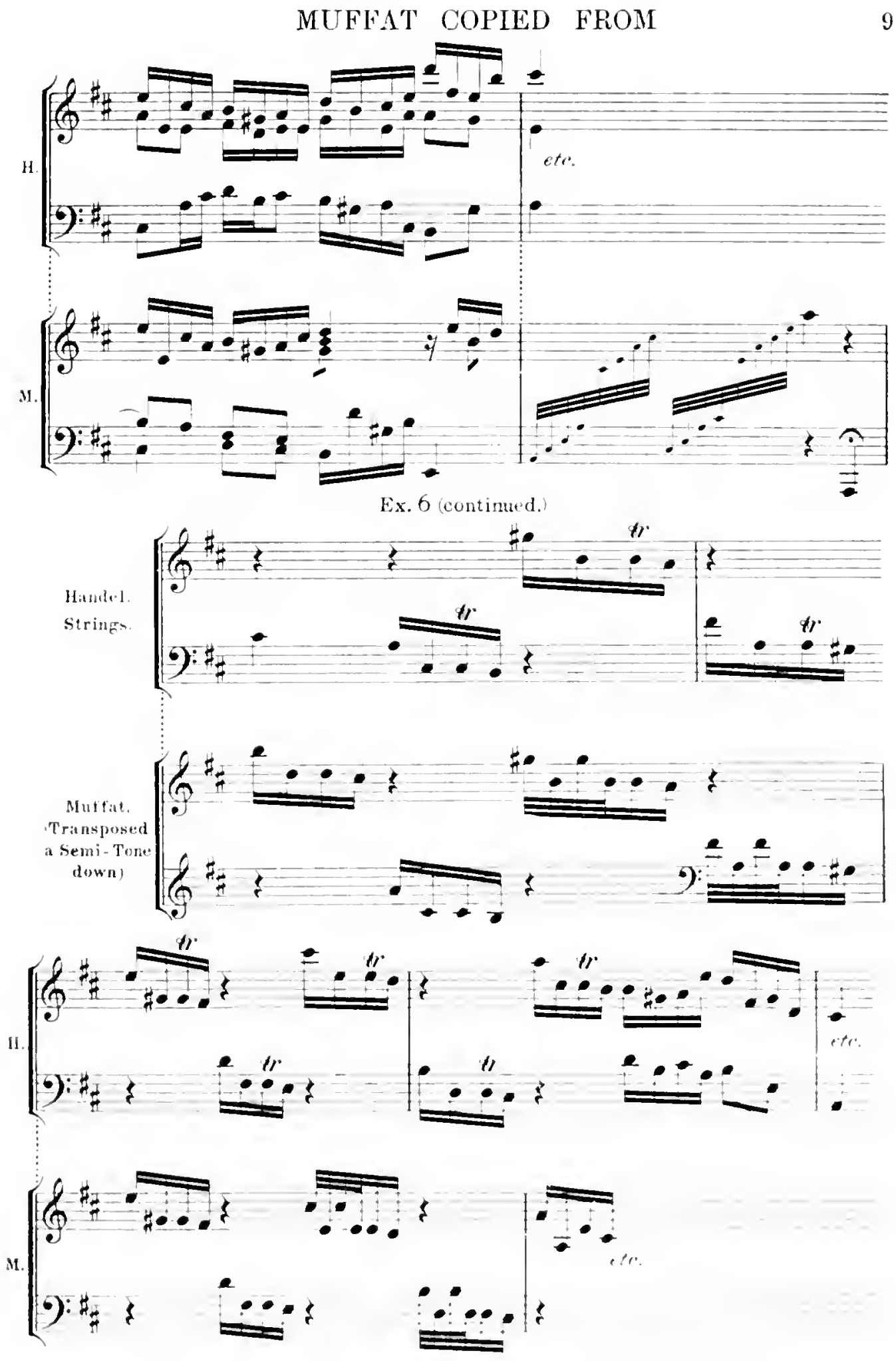


'The superiority of IIandel's part-writing in Ex. 6, bar 2, and of his distribution of parts in the second part of that exauple suffice, as in previous iustances, to show that he inust here, too, be regarrled as copying from, and improving on, Muffat.

The comparisons made above suffice, I think, to establish the fact that Handel borrowed frou Muffat. I add three more, however, before passing away from this composer, on account of their possessing special points of interest; the first and second as being, whth the exception of judicious excisions, slight modifications of key and filling in of harmonies, entire movements simply 'lifted off 'Muffat; the thirit as showing where Handel got the stirring subject of the allegro in his wellknown overture to Sirmsin
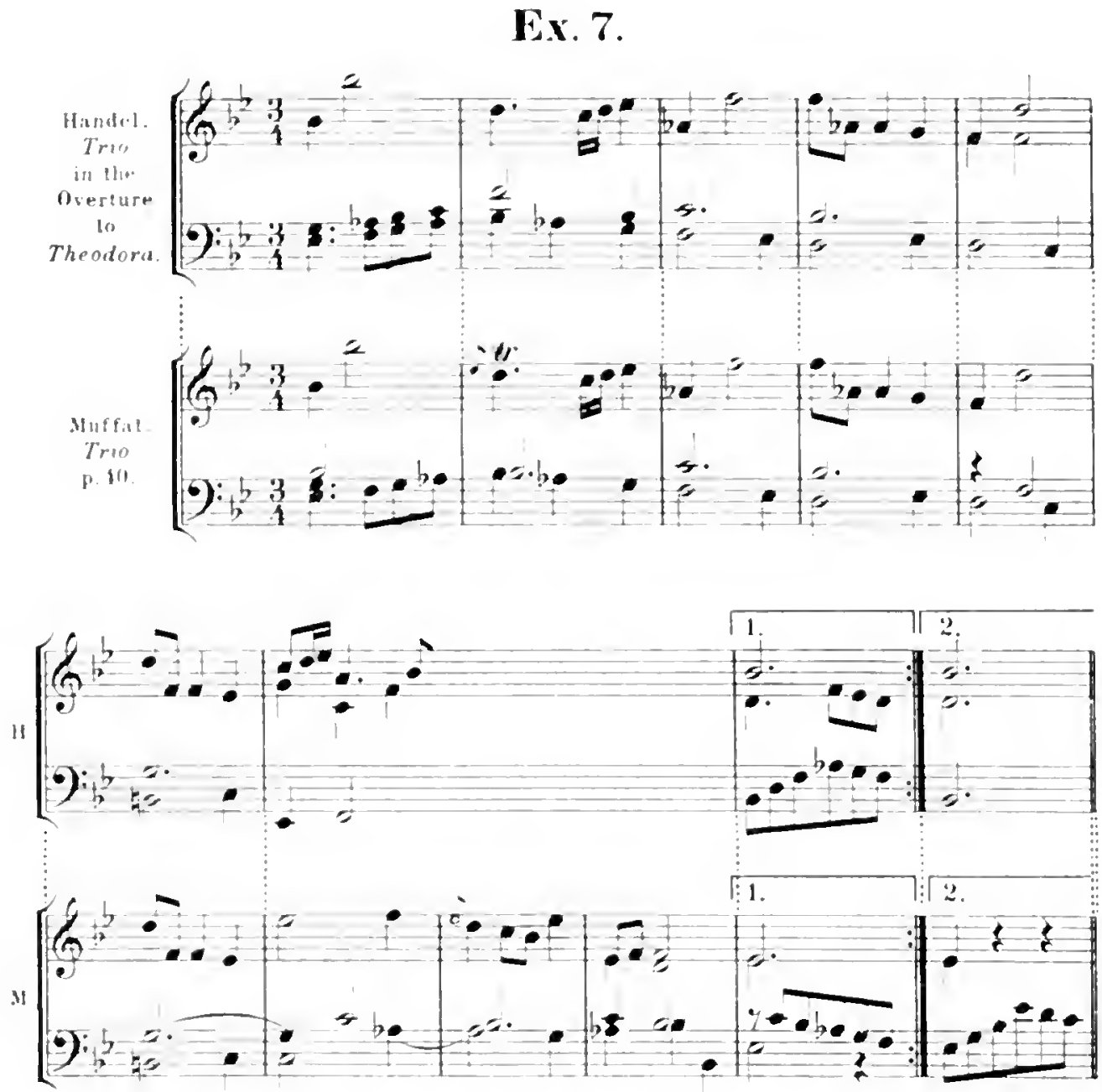

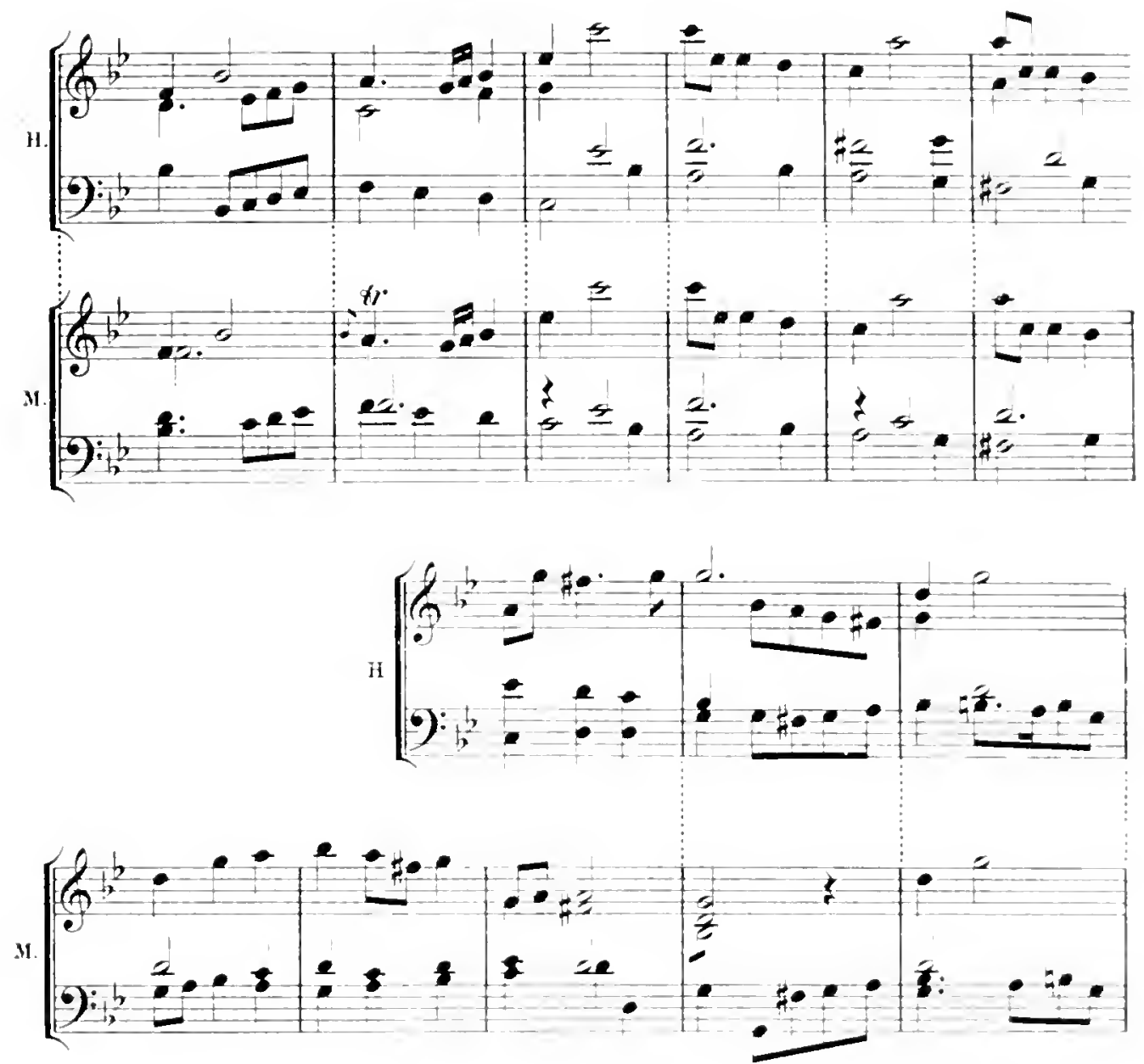

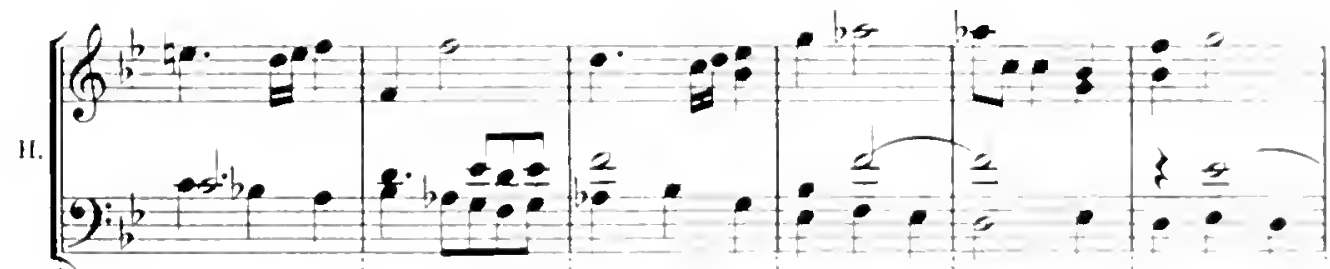

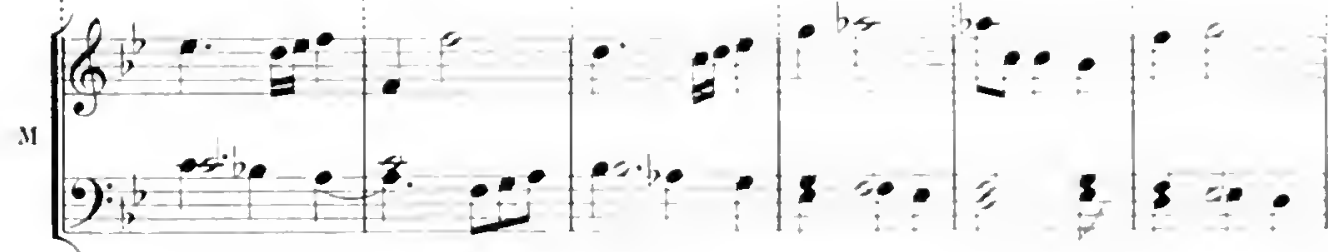


12

MUFFAT COPIED FROM
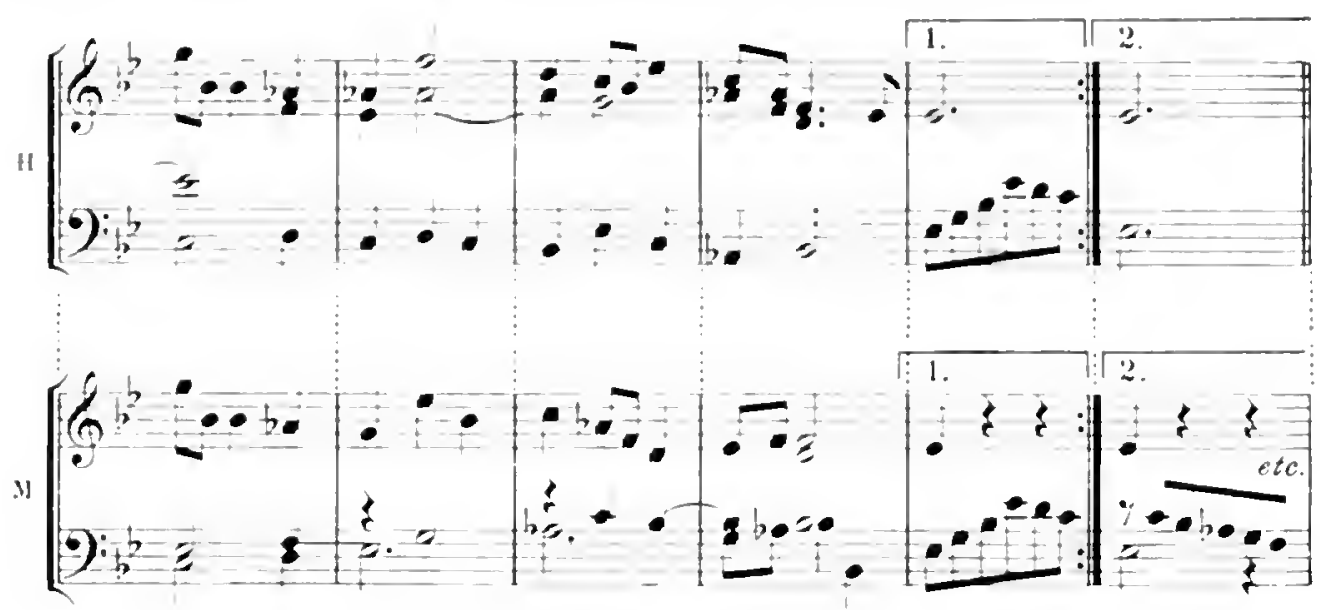

In Muffat's original the key-signature is three flats. I have omitted his very numerous 'graces' here and in the next example.

Ex. 8 .

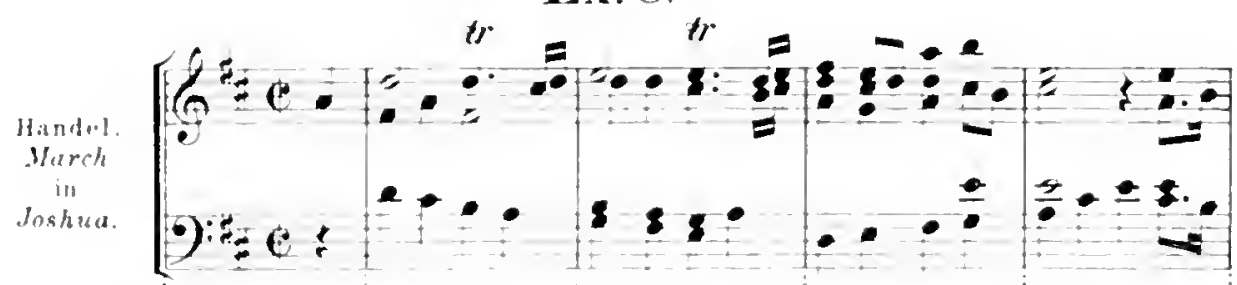

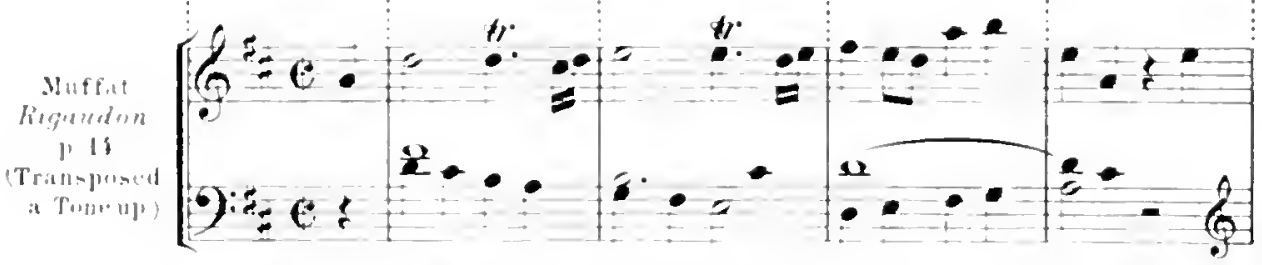
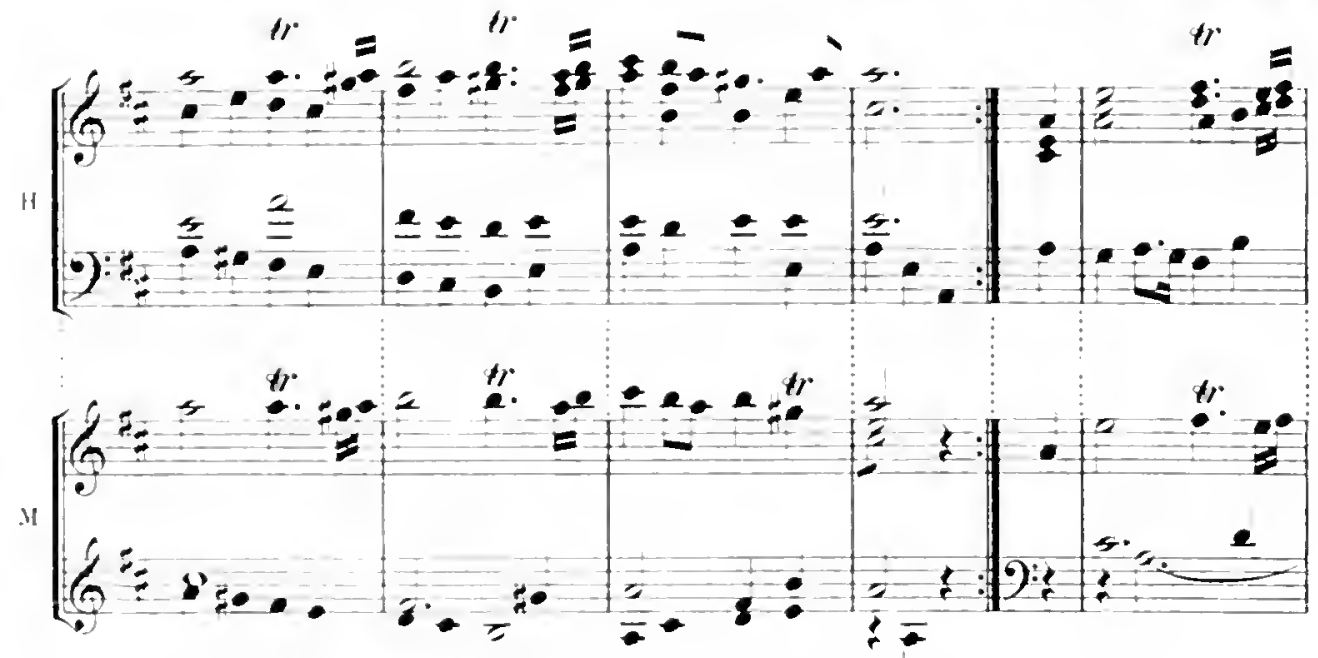
MUFFAT COPIED FROM

13

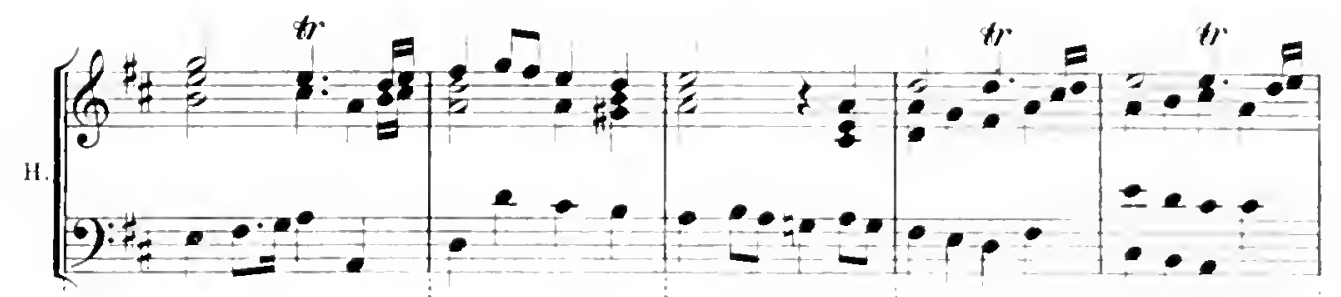

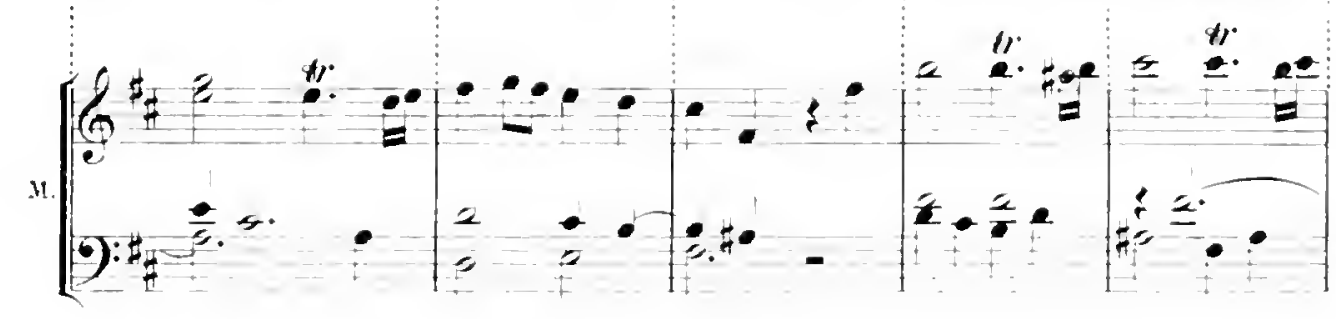
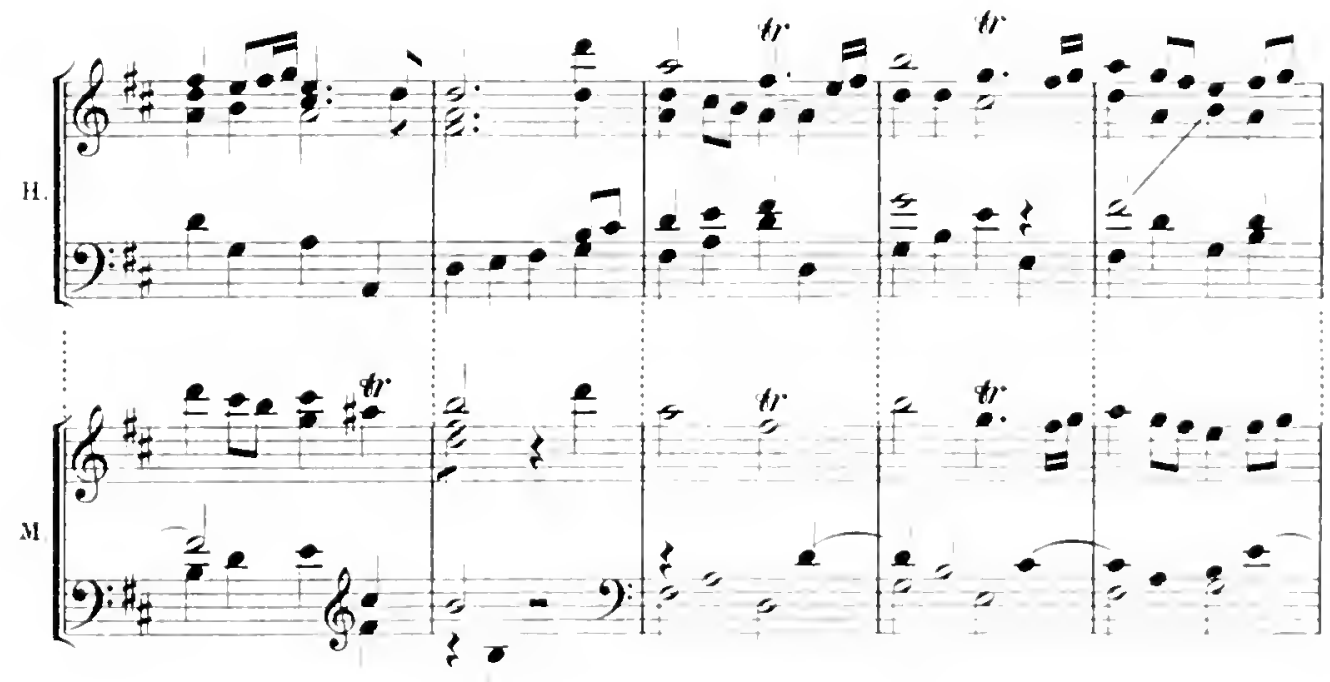

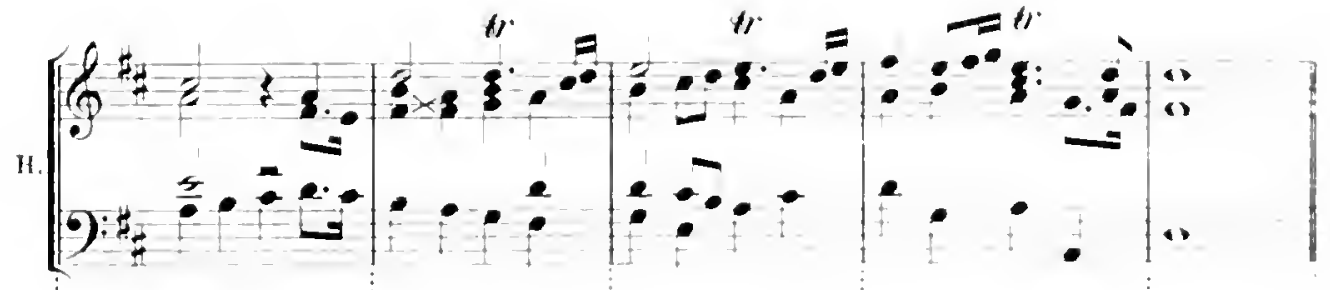

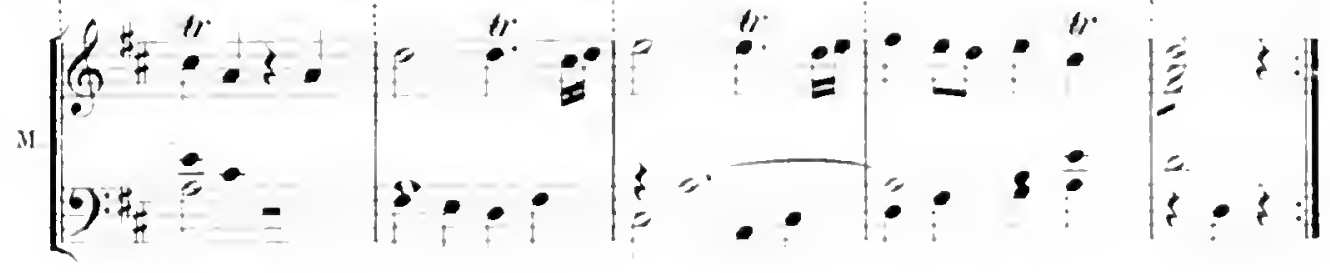


Ex. 9.
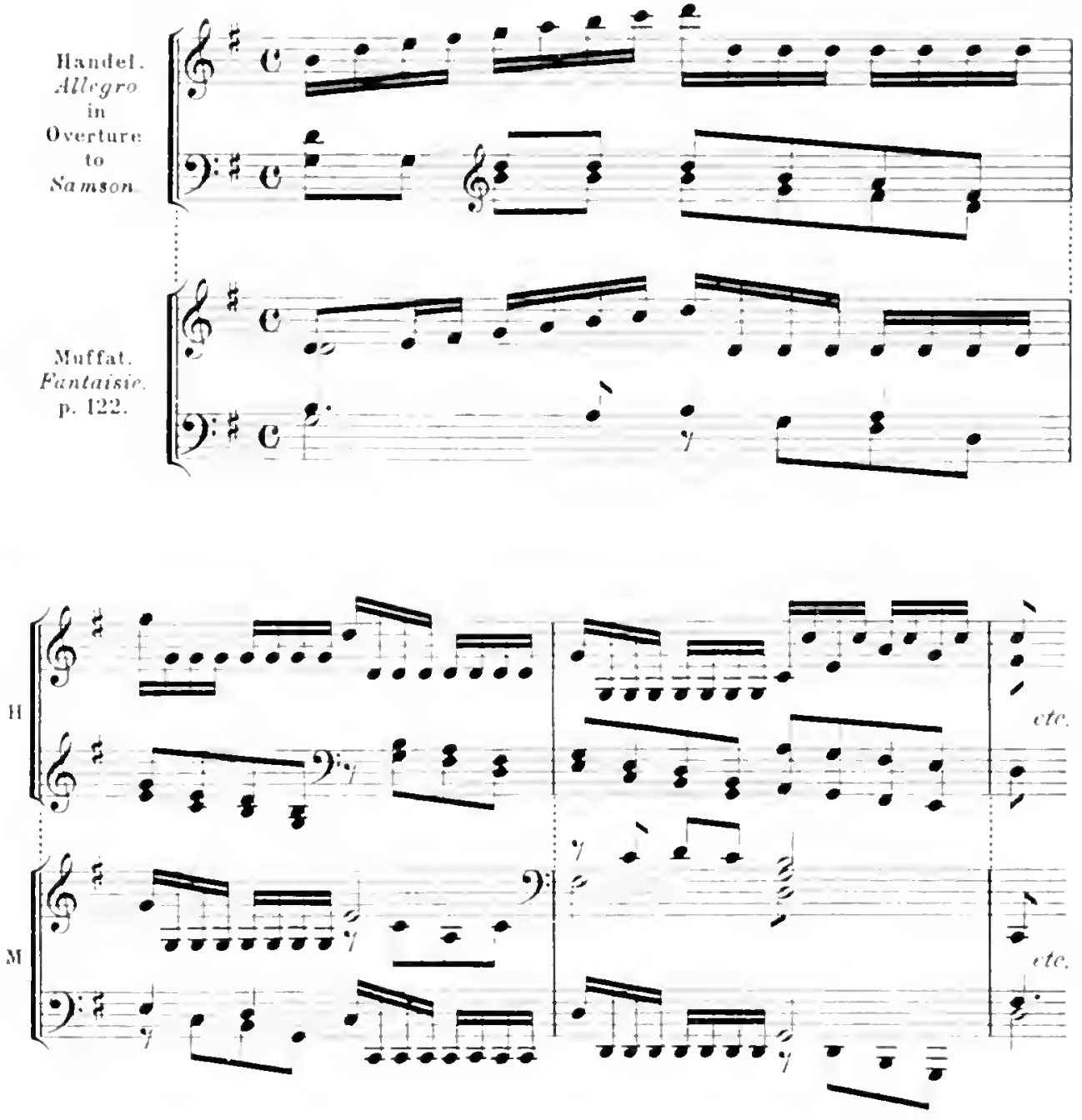


\section{CHAPTER II.}

Comparison of lassages frum Handel's JephrHa with extracts from Masses hy Franz Joliana Habermane, ane with hantscript coples made thesce by HANDEL.

ERANZ JOHANN IIABERMANN (1706-1793) was a composer of Bohemian birth to whom, as Dr. Max Seiffert has shown in a most interesting article," Handel is under consulerable obligations for material taken from five ${ }^{2}$ masses published by him in 1747 and incorporated by IIandel in lis Jephthe which was composed in 1751 . The question of priority is thus lecisively settled by exterual evidence, confirmed, as will immediately be seen, by the Fitzwillian autographs.

The extracts from Habernann's. Masses, which will now be cumpared with the corresponding passages in Handel's works, are all taken from Dr. Seiflert's article.

Ex. 10.

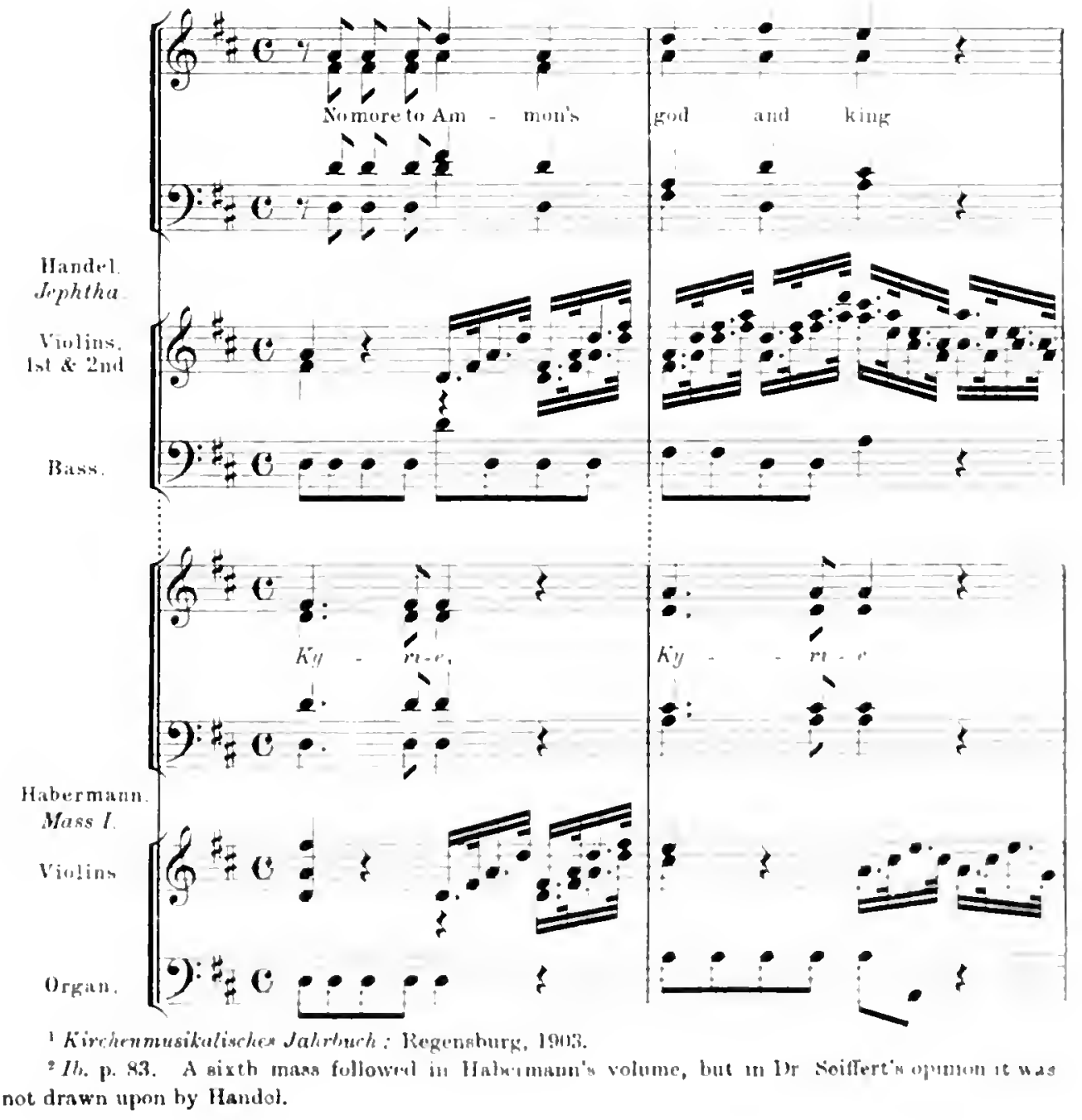




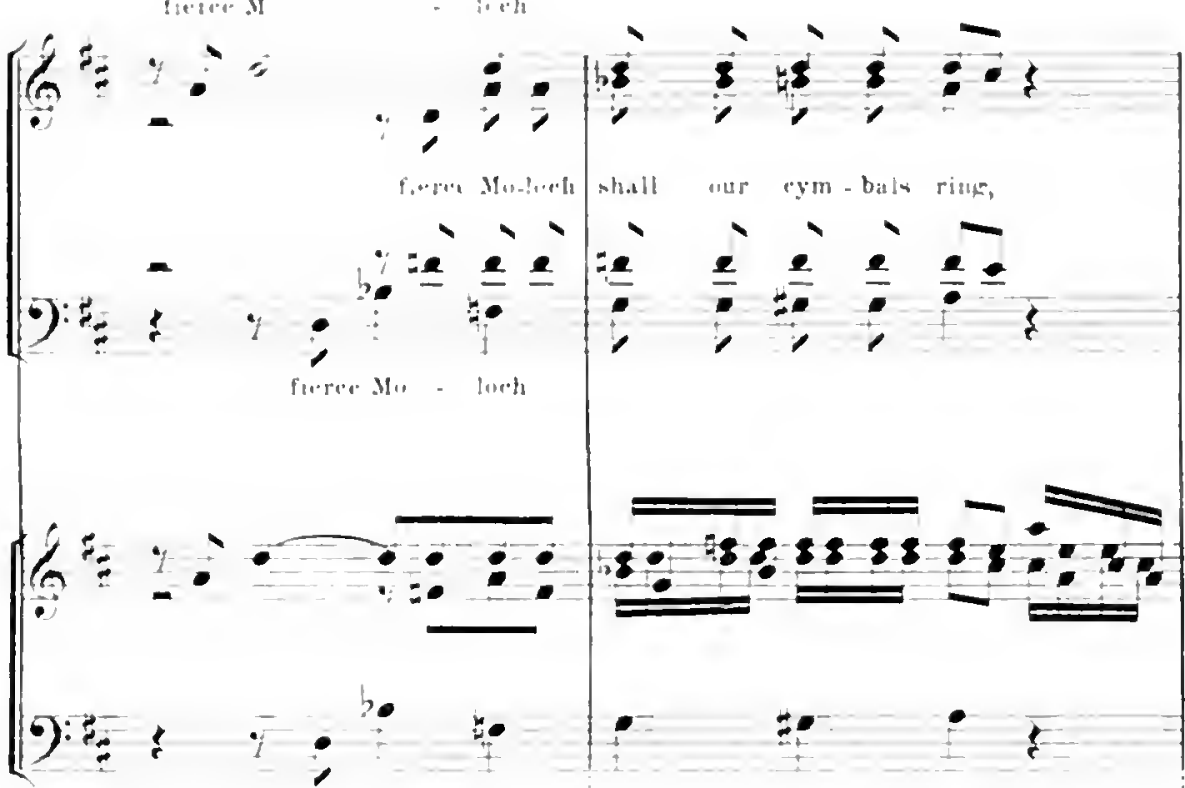

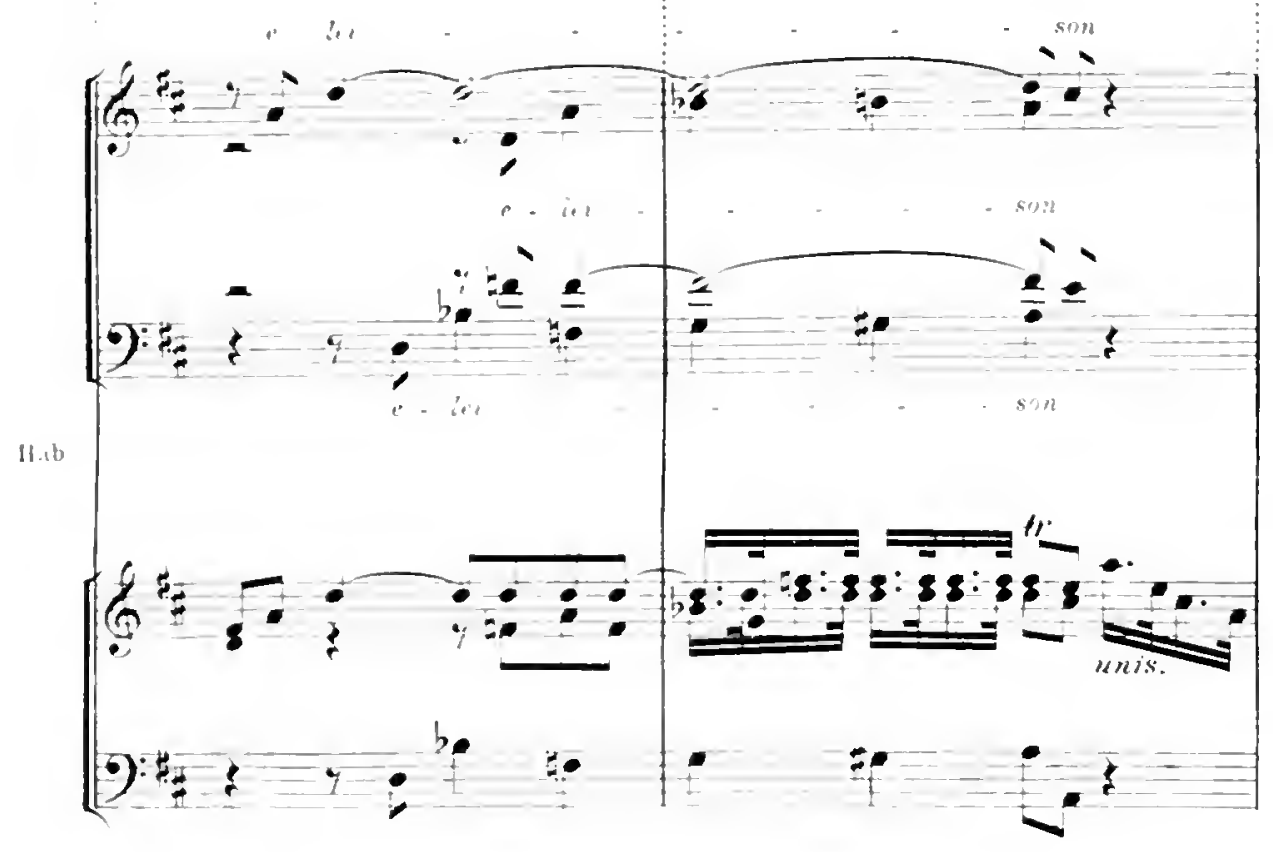




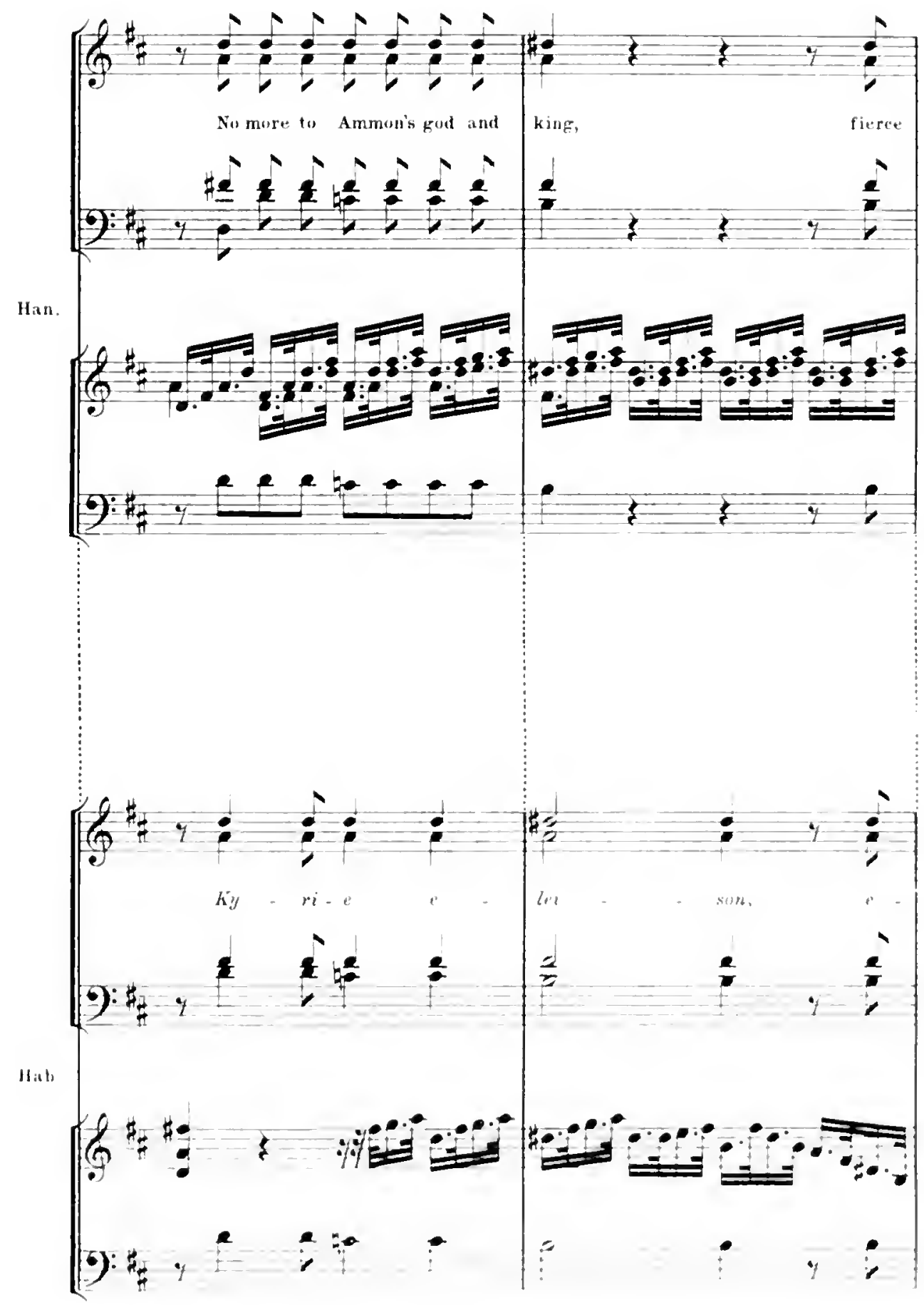




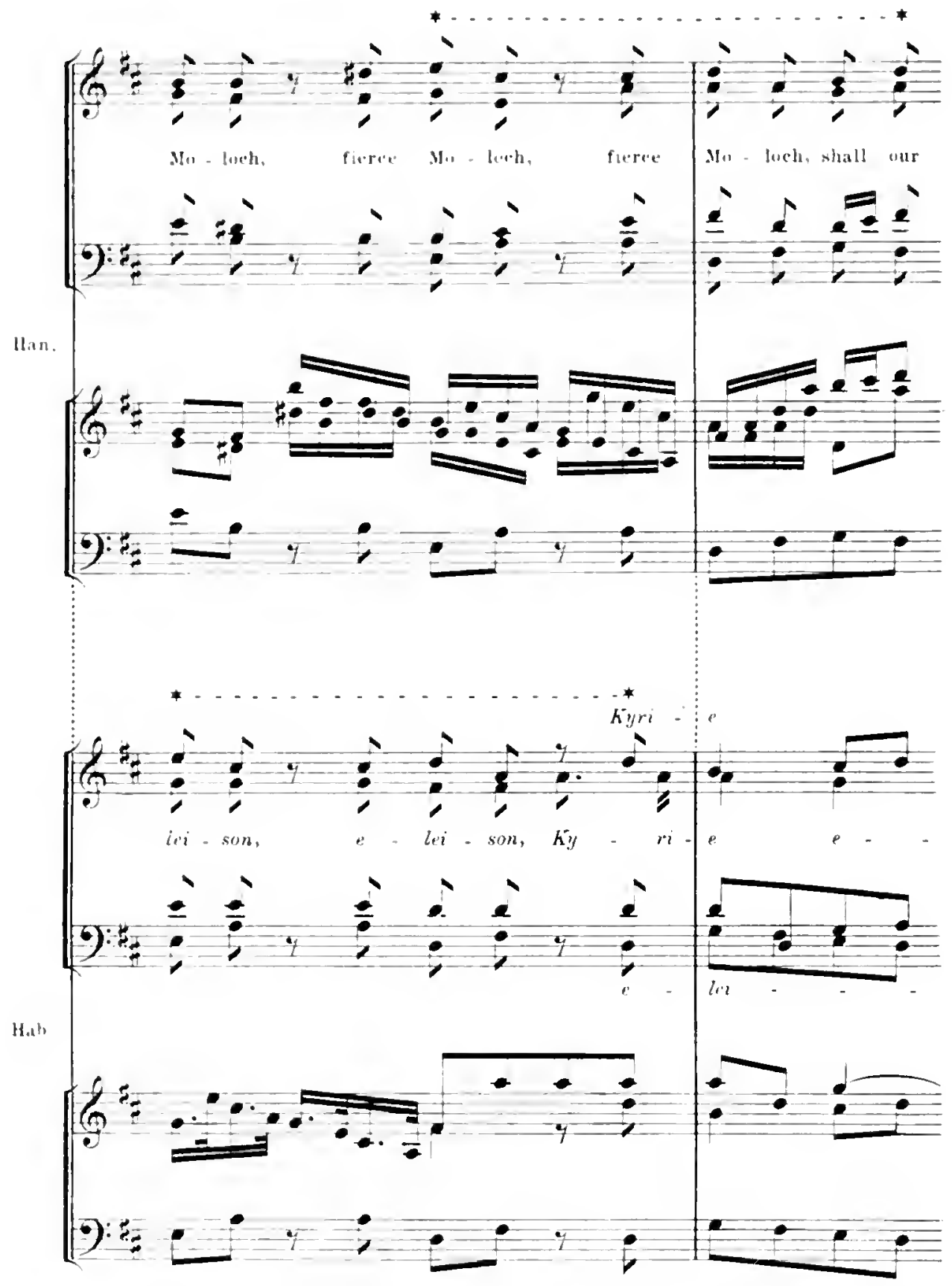

* Compare the pasages thus marked. 

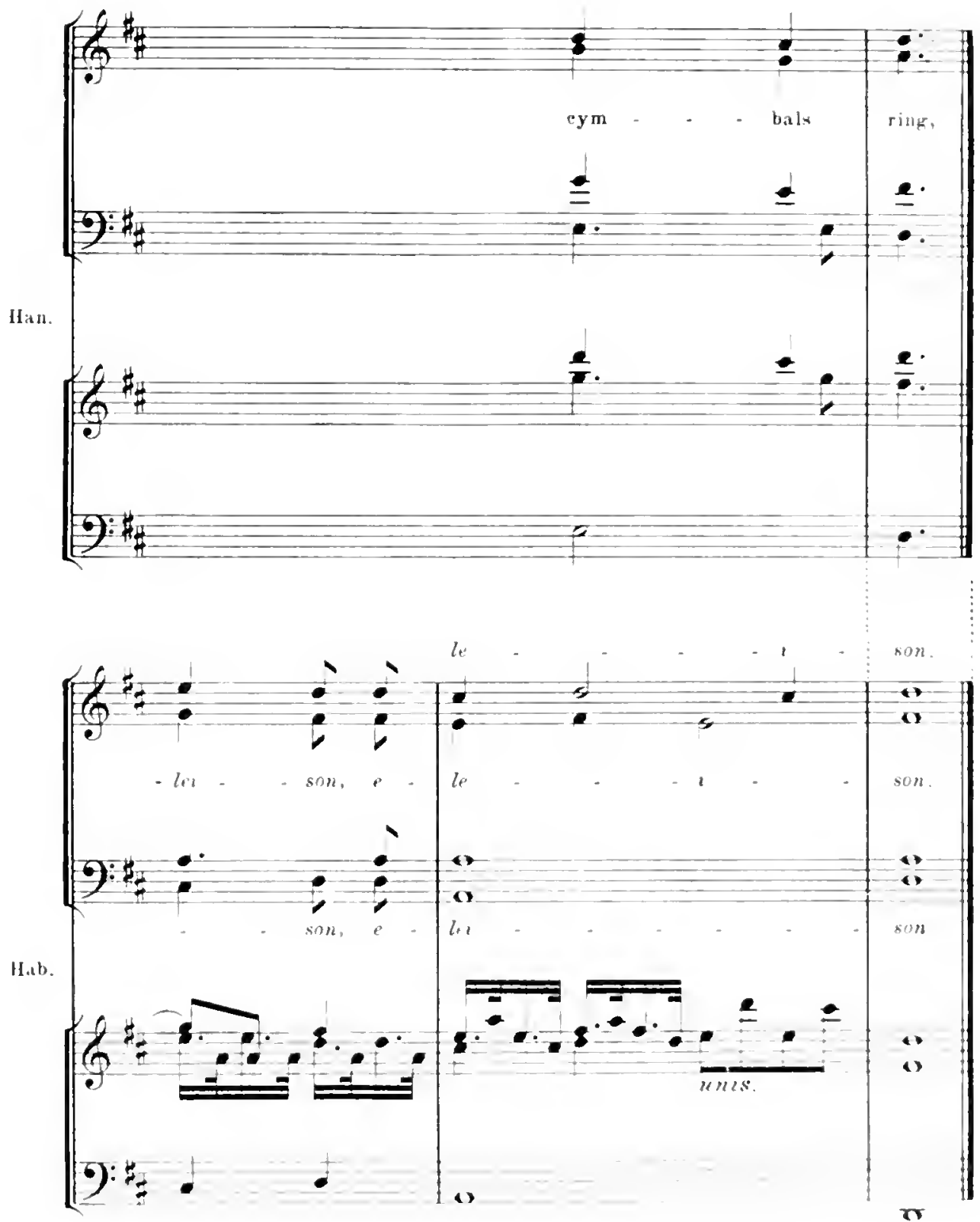

The whole of the extract from Habermann given in Ex. 10 appenrs, copied out in full in Handel's handwriting, but without words or composer's 1sane, in the Fitzwilliam autographs. ${ }^{2}$ This fact supplies, of course, independent evidence, were such waxted, of Handel's indebtedness to Habermann.

The comparisons made in the next six Examples will speak for themselves. 
Ex. 11 .

UANDE.L Symphony to the song "His mighty arm with sudden blow." Sephtha."

sirings
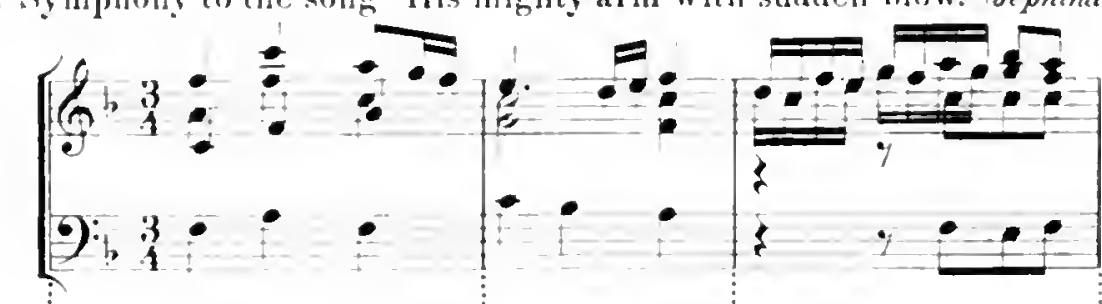

Halitimasis Mass / Introdurtion to "Rex ccelestis"

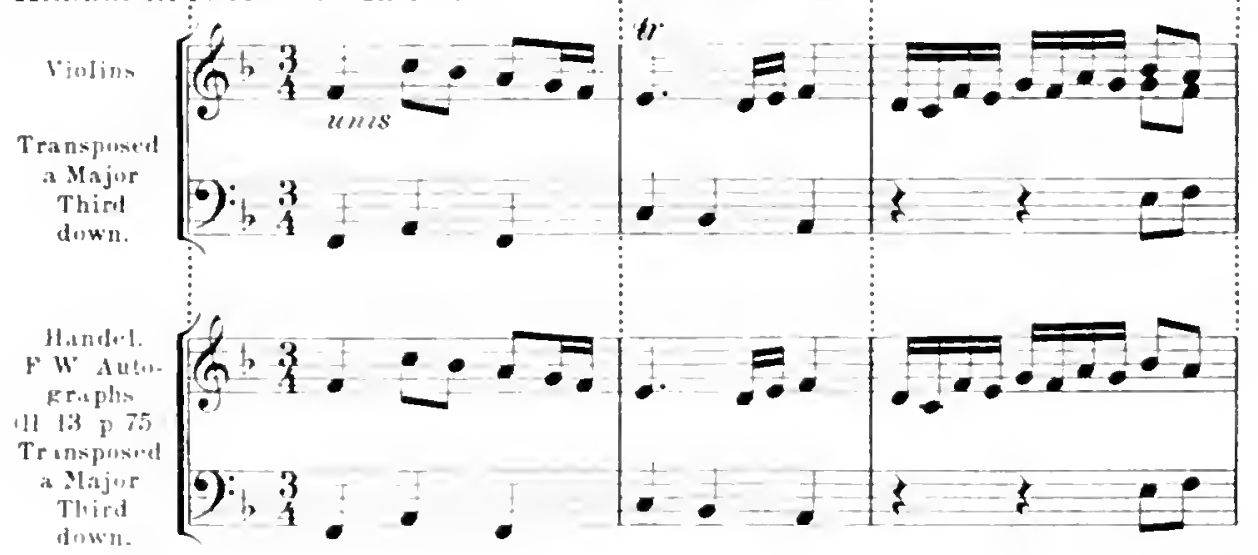

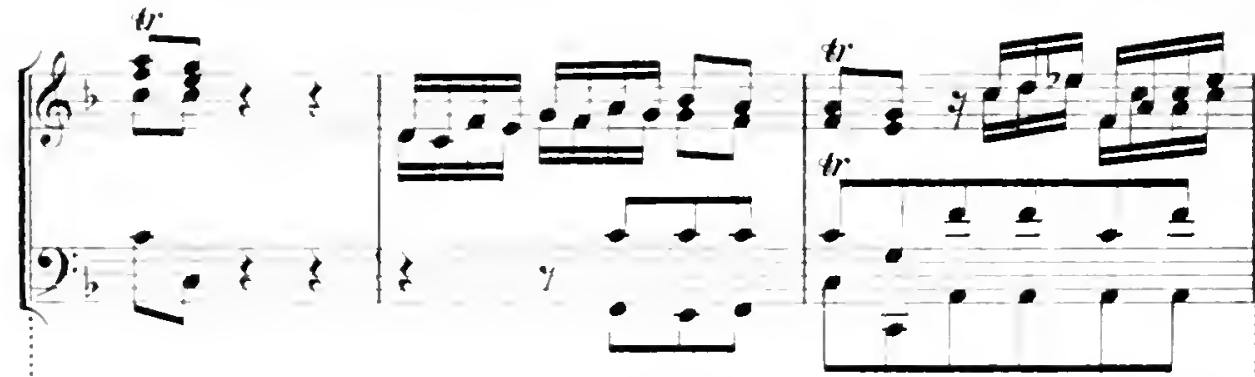

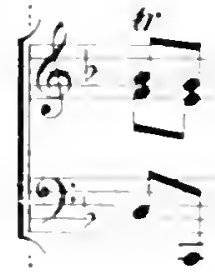

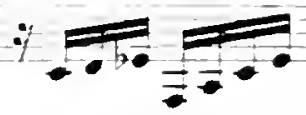

$\left[\begin{array}{l}6^{2}= \\ 6) \div\end{array}\right.$

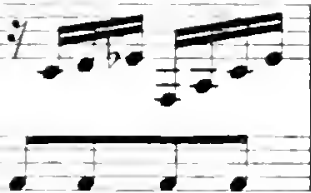




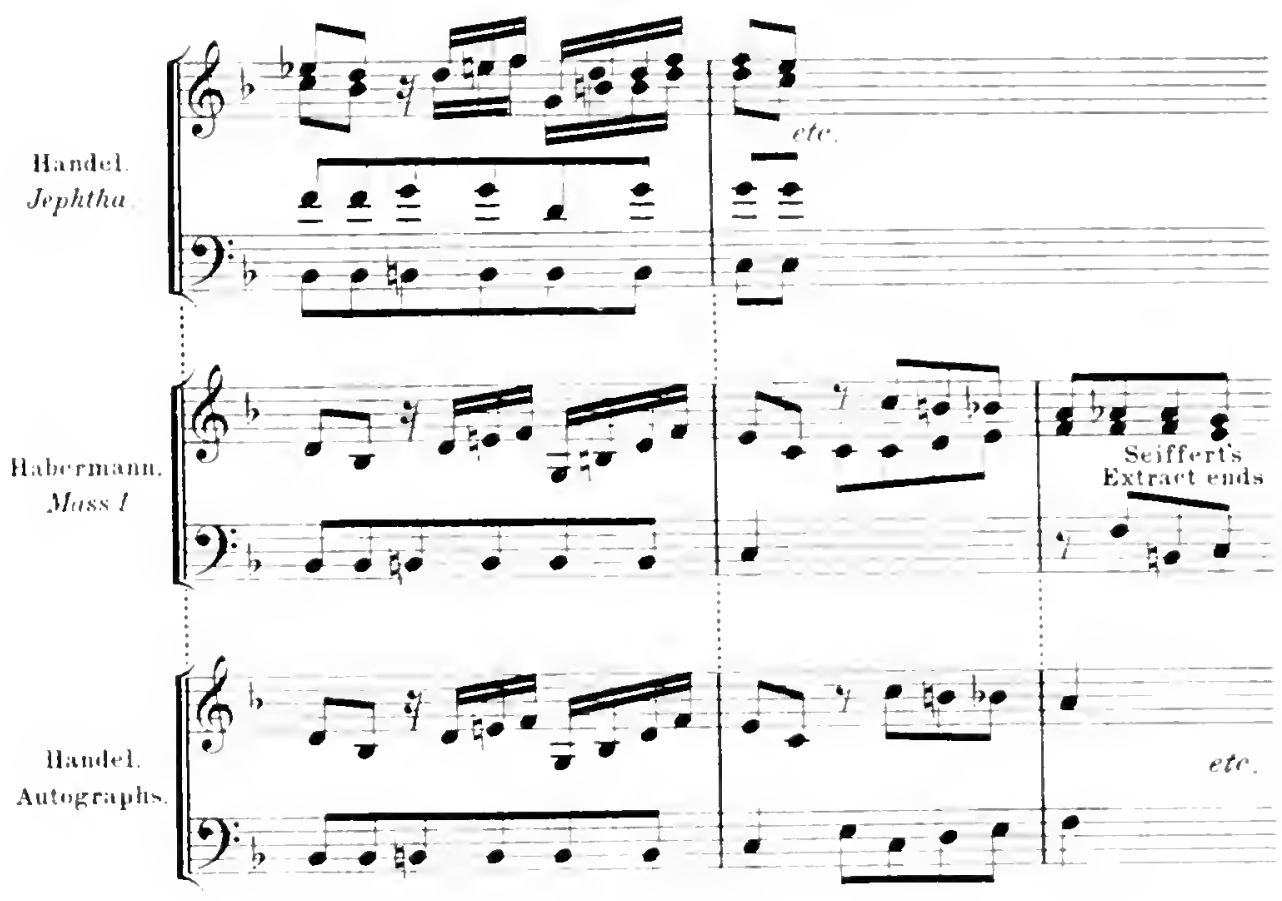

Ex. 12.

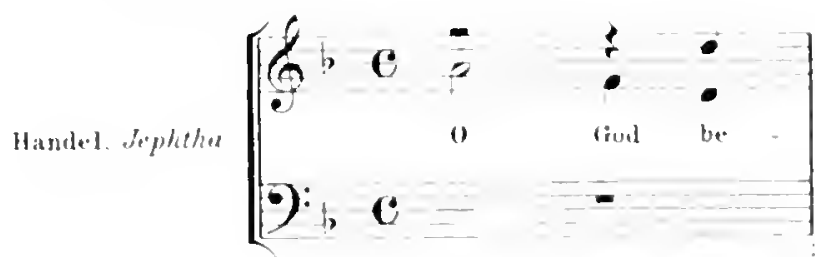

Haburmang Mosel
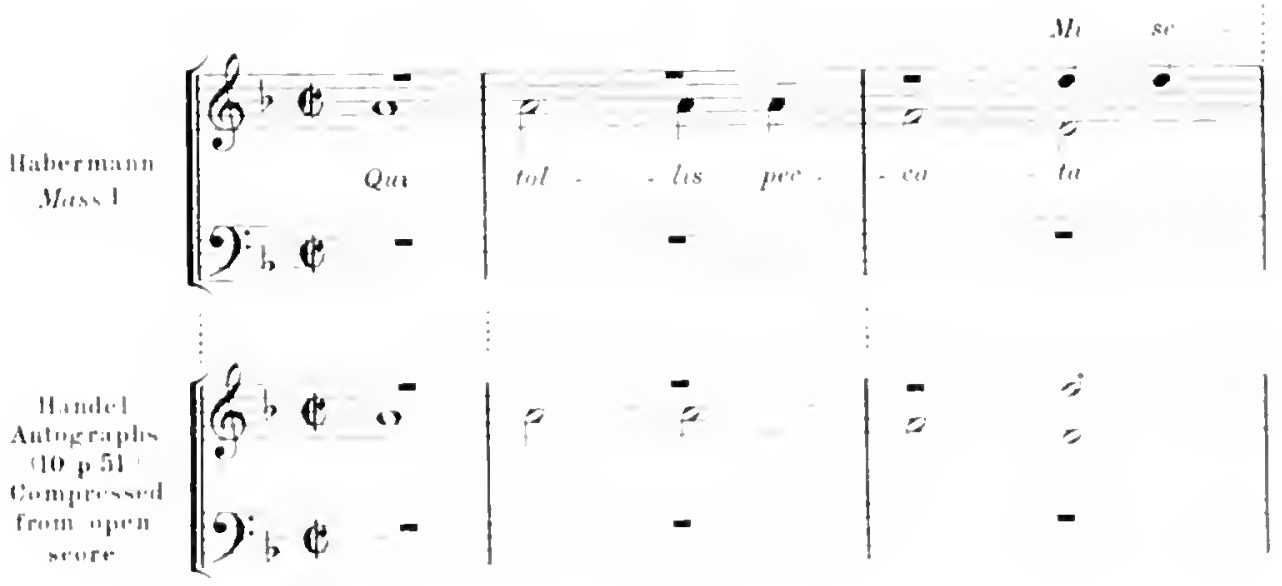
HANDEL AND HABERMANN

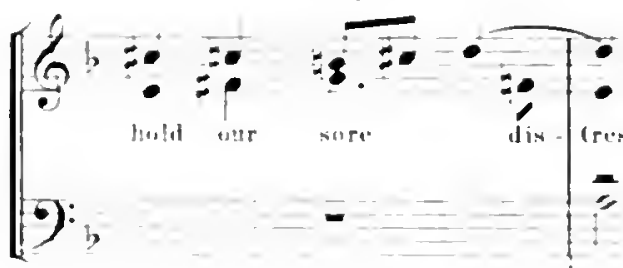

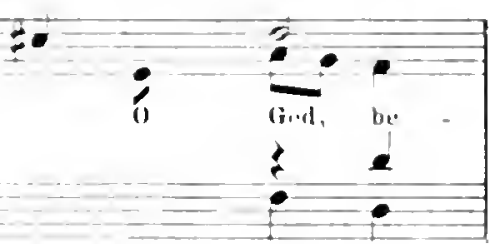

()

Gied

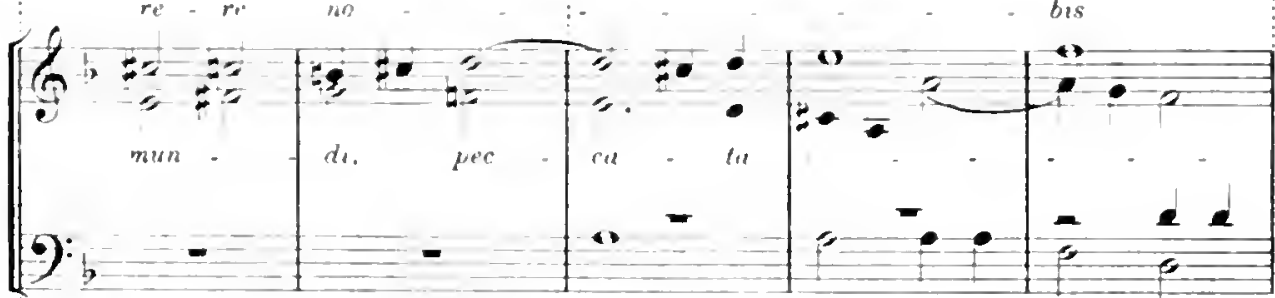

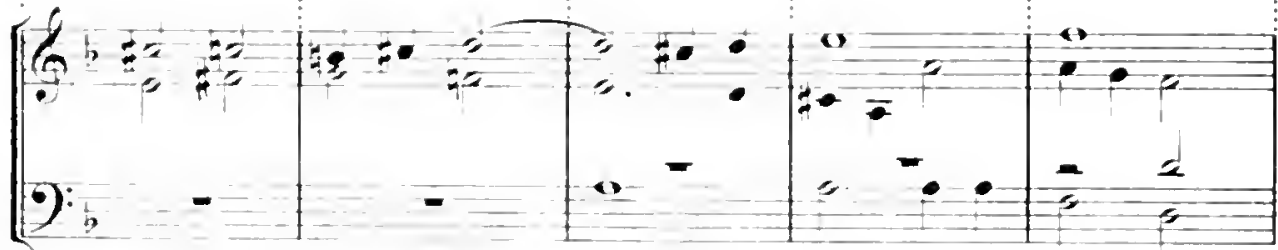

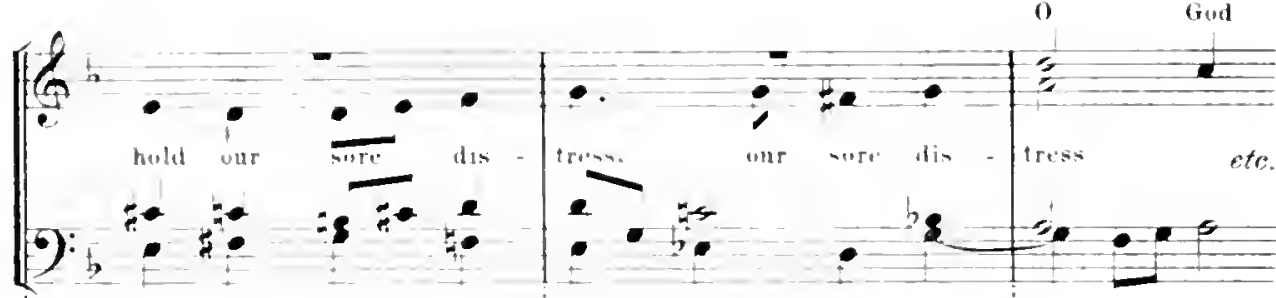

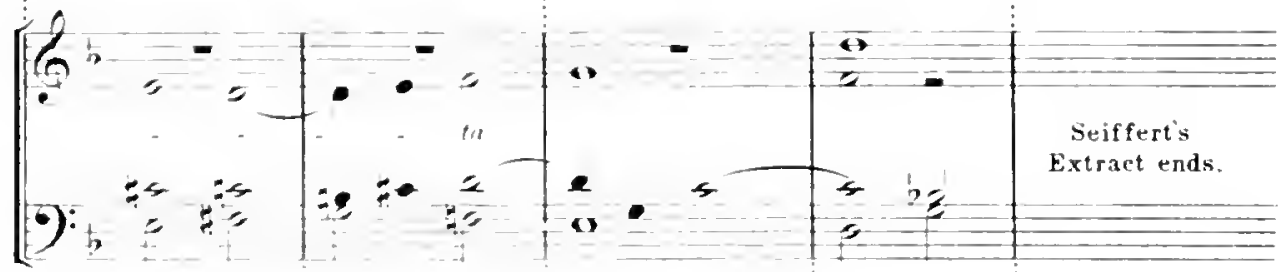

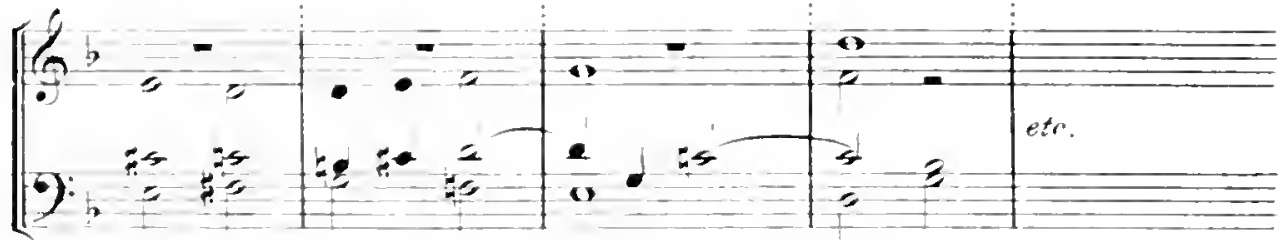


Ex. 1:3.

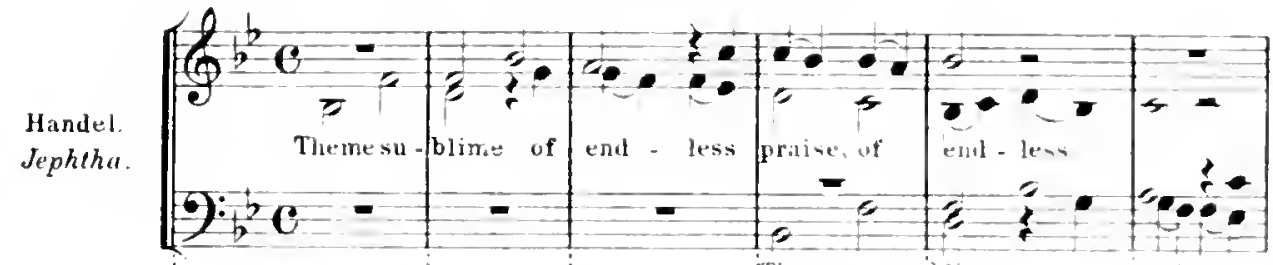

Alla breve.

Theme su - bline

of end-lens

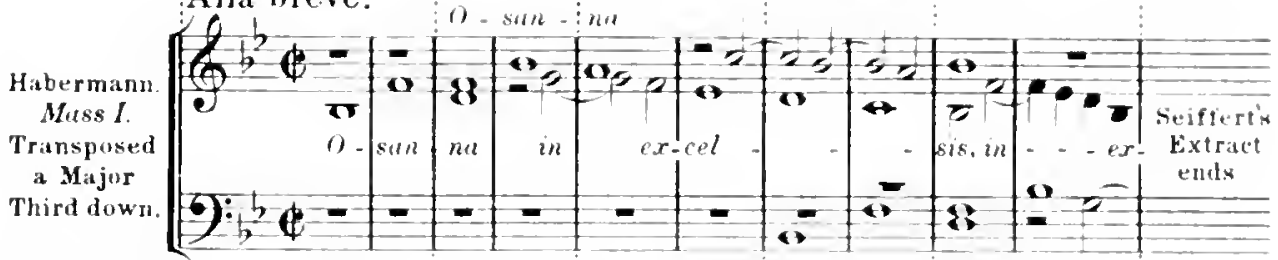

Handel.rw Alla breve. "Theme sublime of endless Praise." MS

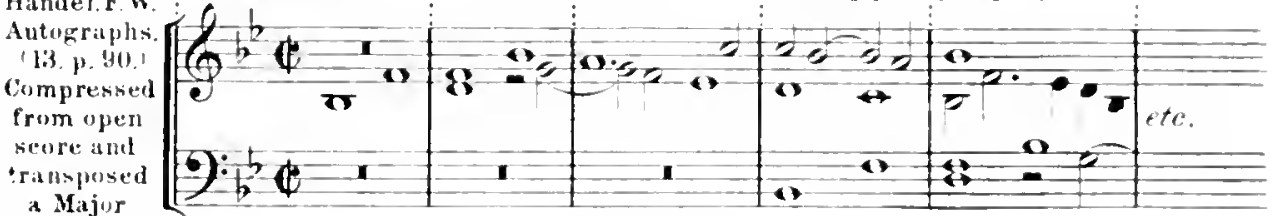

Third duwn.

Ex. 14 .
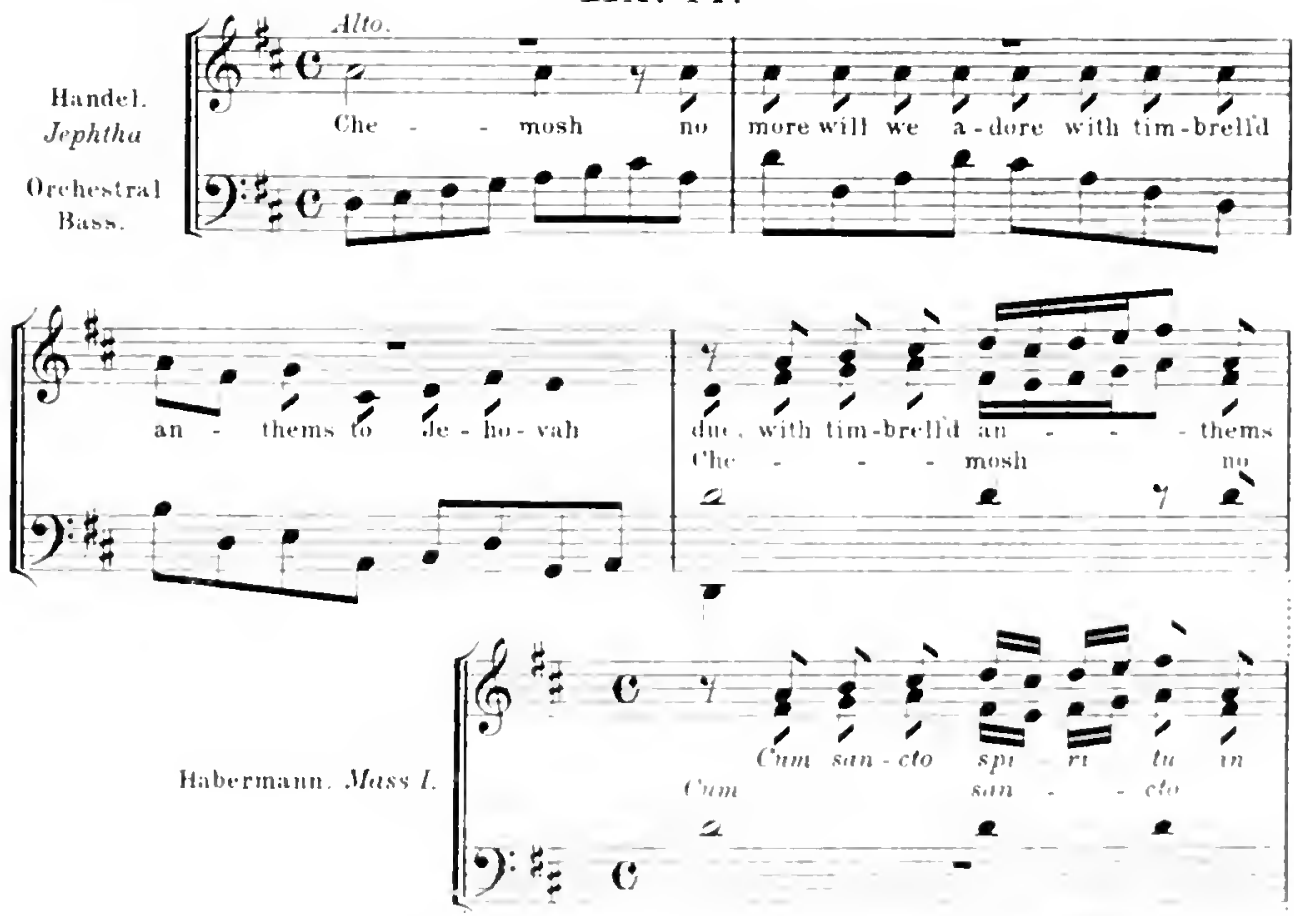

llamlel. F W Antugraples lis $p$ b

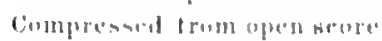

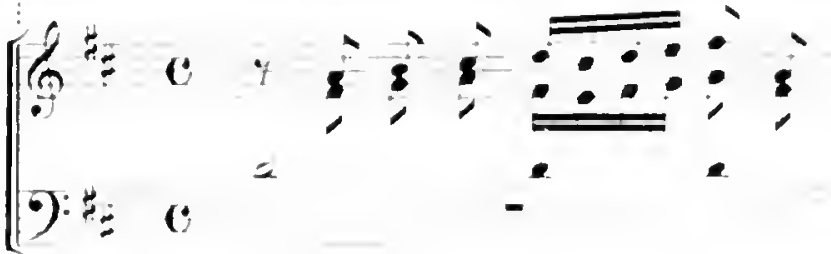




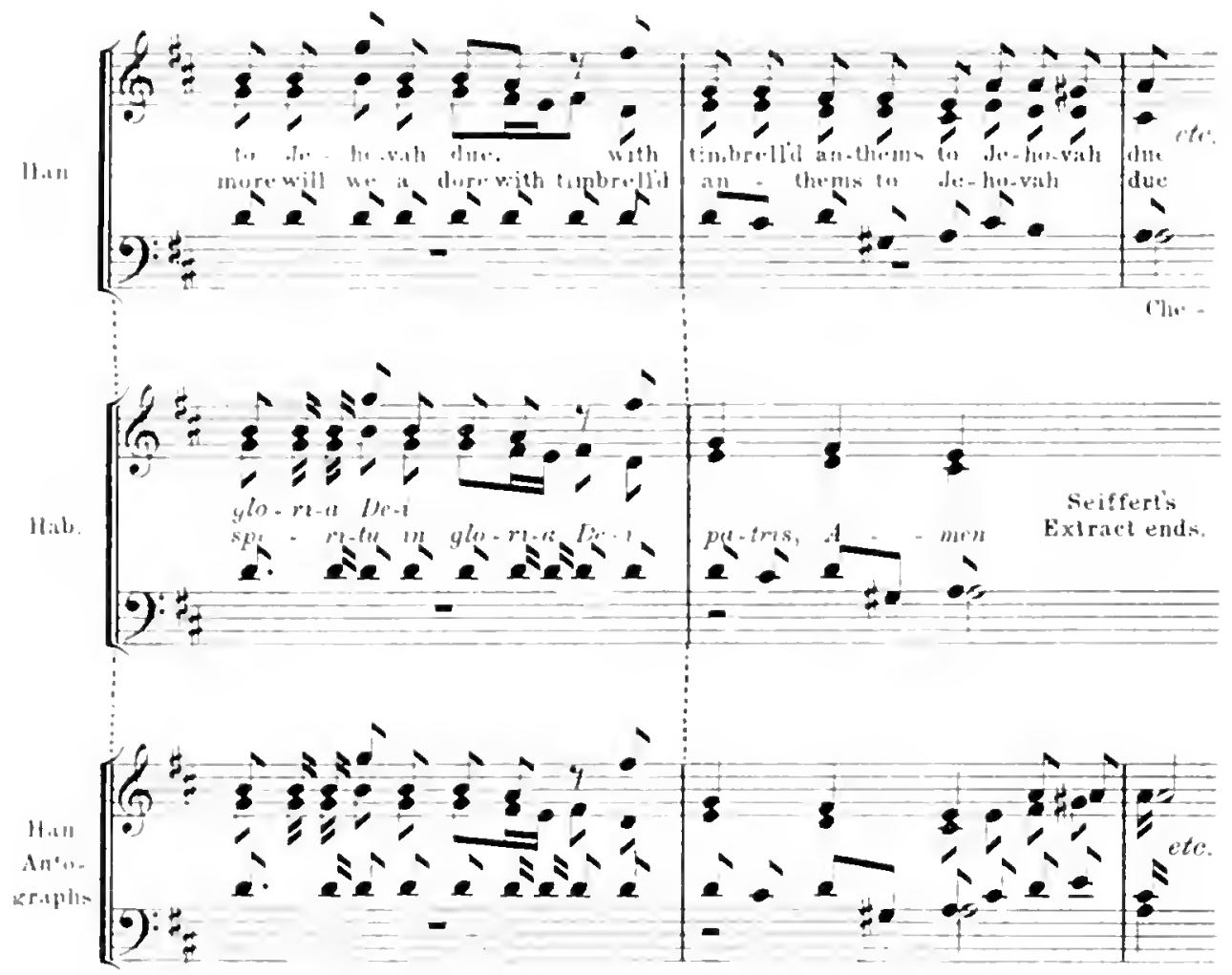

\section{Ex. 15.}

Instrumental Introduction to the Songr "Hide thou thy hated heams." Jephtha."

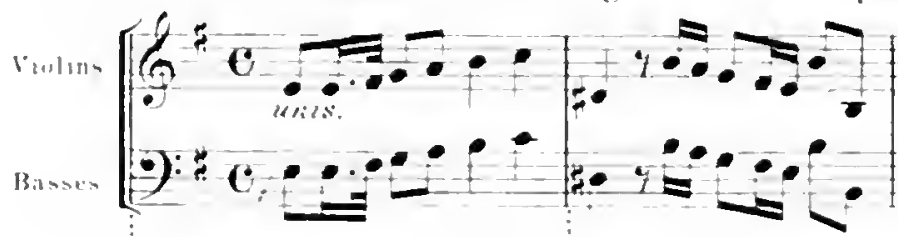

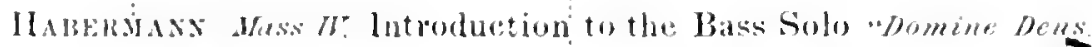

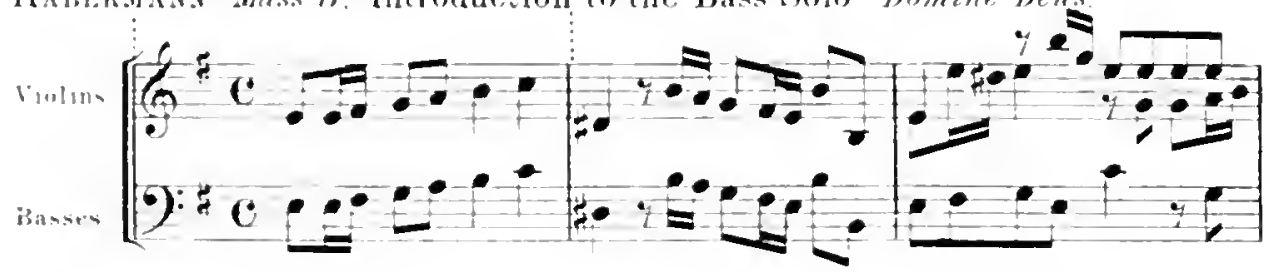




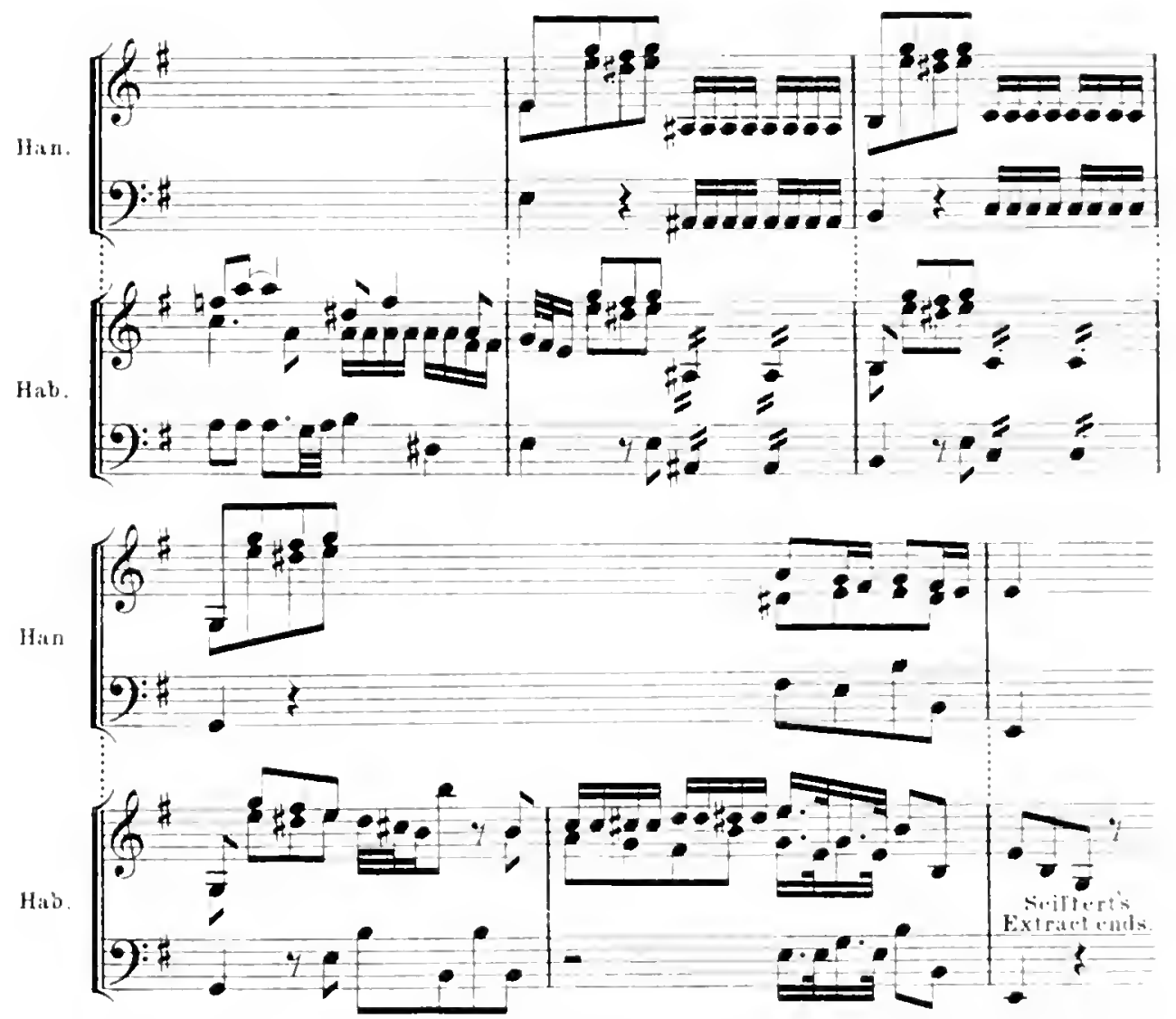

By striking ont Habermann's feeble and ineonsequent third and fouth bars, and similar matter in bis seventh and eighth bars, Handel has greatly improved this little prelude.

Ex. 16.

Symphony to the Song "Pour forth no more unheeded prayers." defhtha

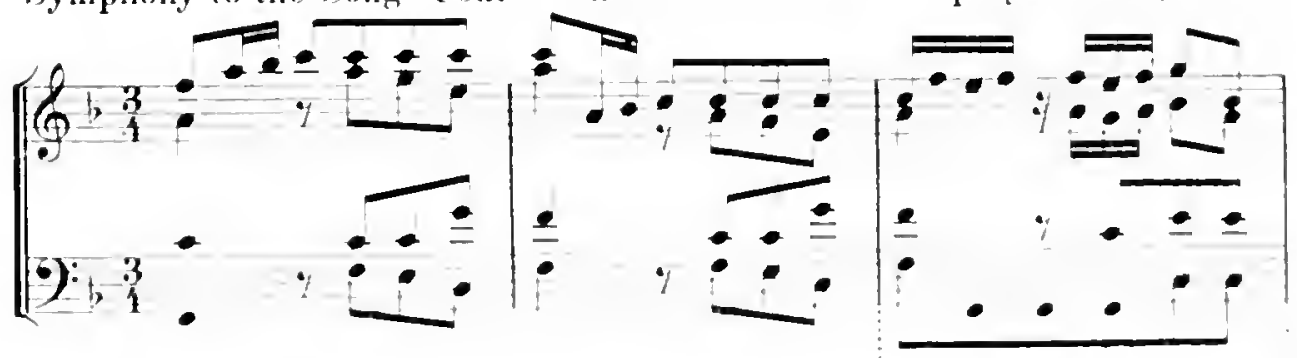

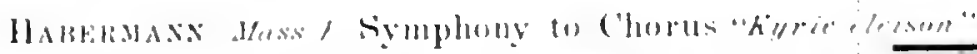

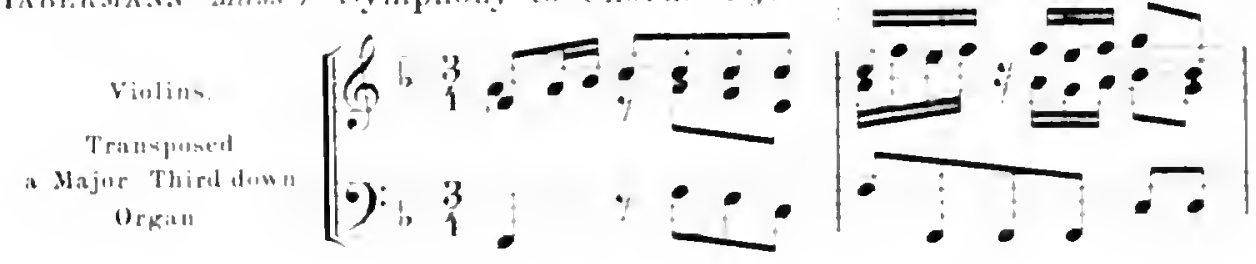



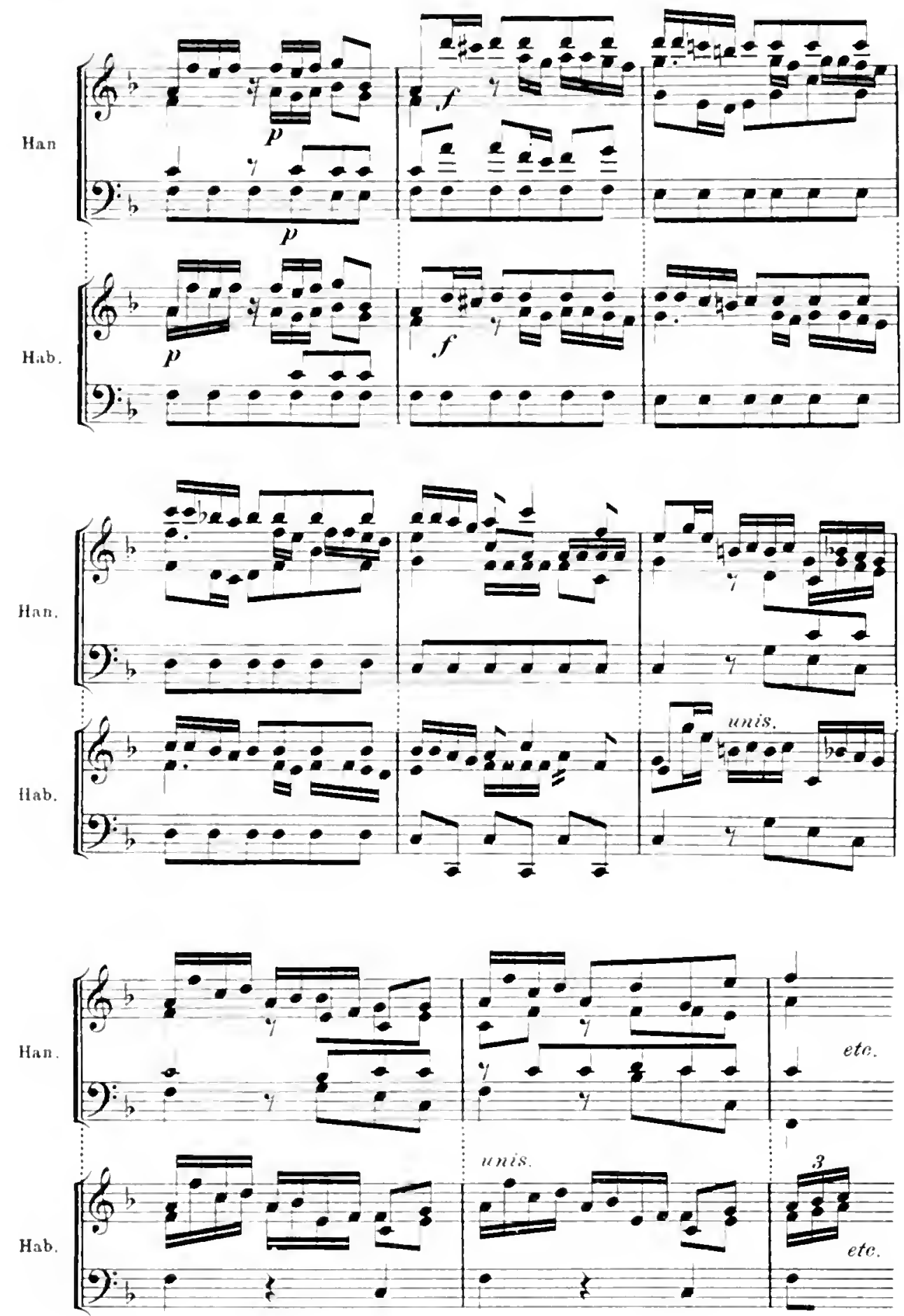

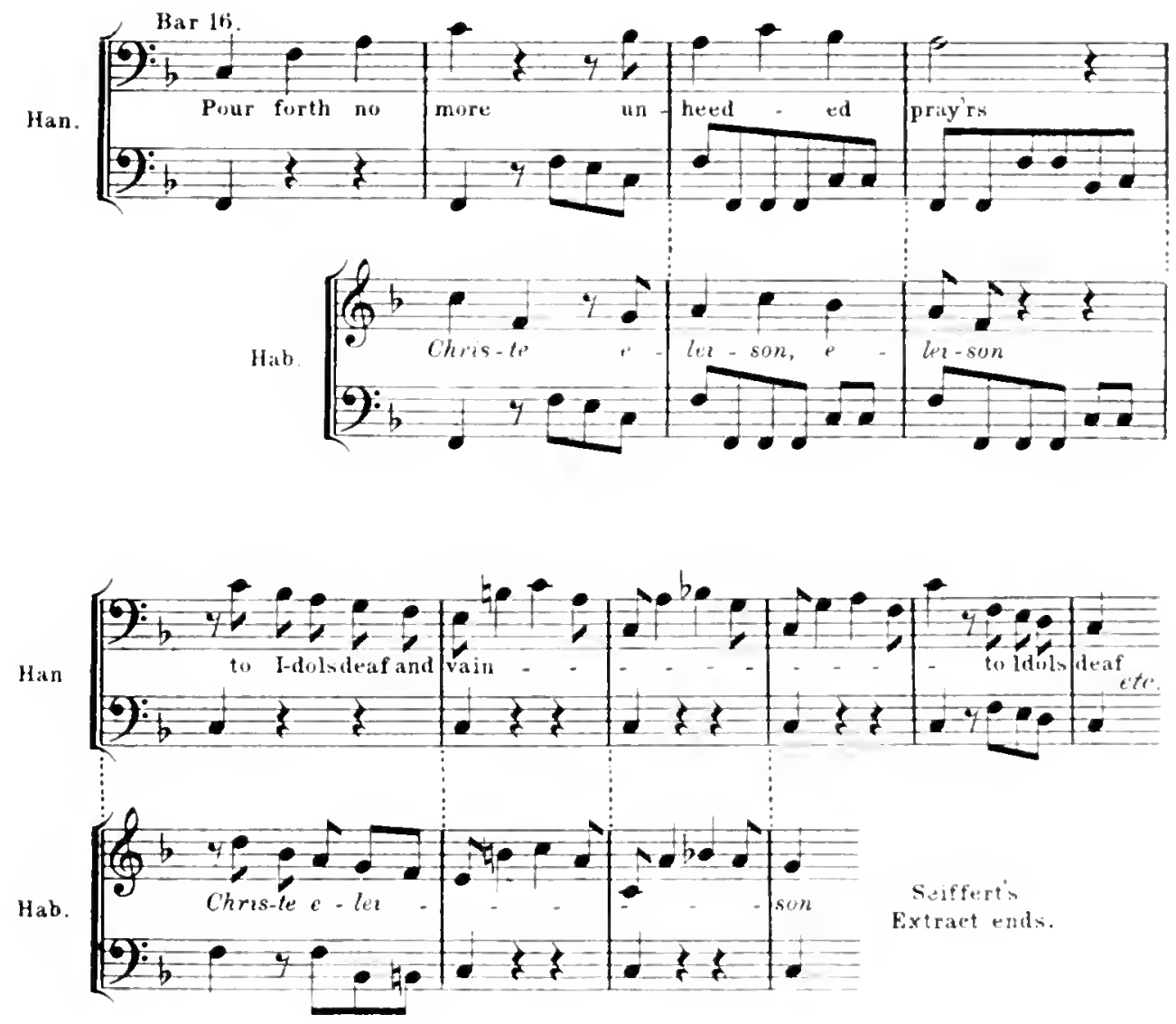

This song, which in Jephtha ocenpies 115 bars, is mainly built on these materials, and the accompaniment is throughout made from Habermann's. 


\section{CHAPTER III.}

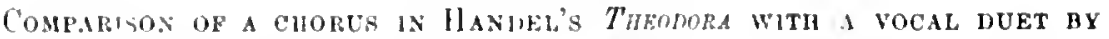 Glovani Carlo Maria Clarb.}

IOVANNI CARLO MAliA CLARI (1669-about 1740) was a dis-
tinguished maestro di capella who wrote a laros amount of sacred and secular music. Amoug the latter were a number of vocal duets, passages in which find more or less close homologies in Handel's Theodora. These passages are contained in six of the duets produced, according to Chrysander, "about 1720 " and published by him, with the exception of one duet, from a "contemporary copy" in his own possession. The excepted duet he inserted from a Paris elition published a century Iater, in 1823. The Fitzwilliam Museum possesses manuscript copies of thirty-seven trios and duets by Clari, including the six which concern us here: each of these is marked either ' 1740 ' or ' 1741 '-dates which Mr. Fuller-Matland thinks probably refer to the first edition of the duets." This would give a date some twenty years later than that assigned by Chrysander, assuming - which I do not feel sure of - that by 'produced' he meaut 'published,' and not inerely' 'composed.' In auy case it may be safely inferred from the dates aftixed to the Fitzwilliam copies that these six luets were in existence by the year 1741. This elears the question of priority, as Handel's Theodora was not performed until $17+9$.

The method employed by IIandel in dealing with the materials supplied by Clari was quite uniform. It consisted in taking theuce short theures fit, or capable by slight alterations of being rendered fit, for contrapuntal treatment, and then working them up by all sorts of fugal, canonic and imitative devices applied with astonishing force and freedom, into elaborate polyphonic movements of the well-known "IIandelian" type. In this manner several entire choruses and a long orchestral movement are, with more or less infusion of other matter, developect out of passages of two or three bars each taken from Clari's unpretentious but charming little compositions. As, later in the present work, we shall see the sarve method applied with supreme skill and stupendous results in one of the grandest of all Iandel's oratorios, I shall content myself with but a single illustration of its employment on Clari's duets, viz. the construction of the chorus "While Grace and Truth" in Themlora.

1 'Catalogue of the .lusic in the Fitzwilliam Museum.' p. 152. 'The Fitzwilliam copies are prorifled with figured hasses, which doea not appear to have been the case with those edited by itirgander. 
Ex. 17 .

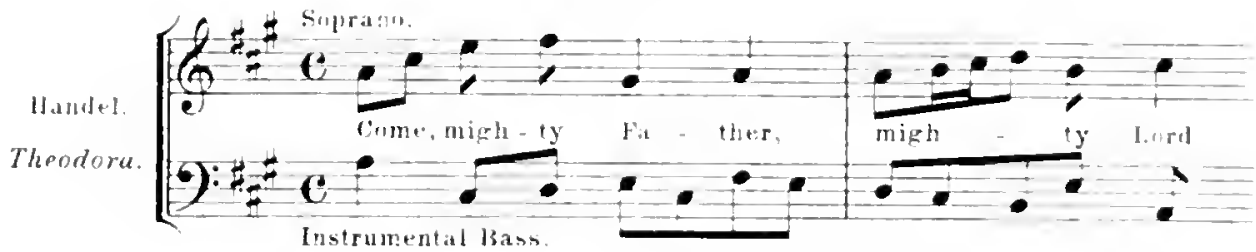

This phrase is constructed by assigning to one voice what Clari divides between two voices.

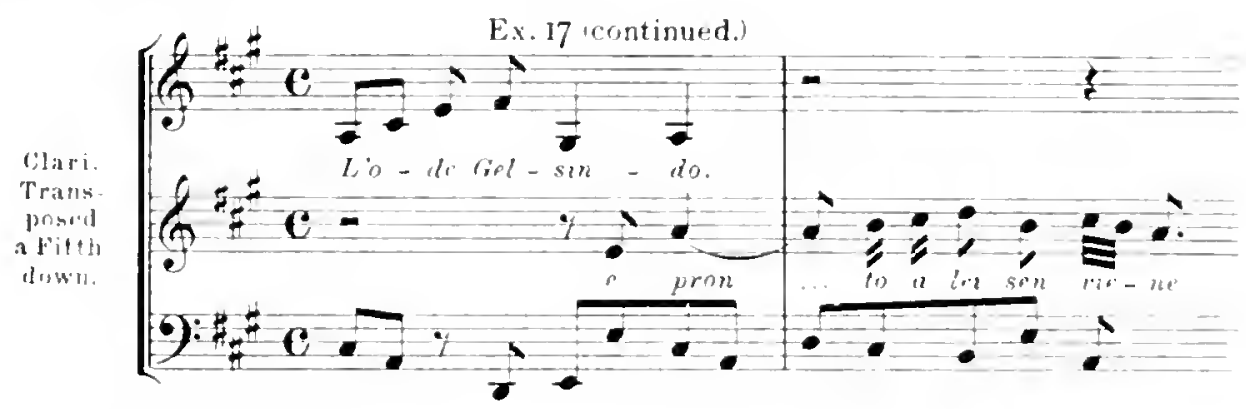

This is followed by
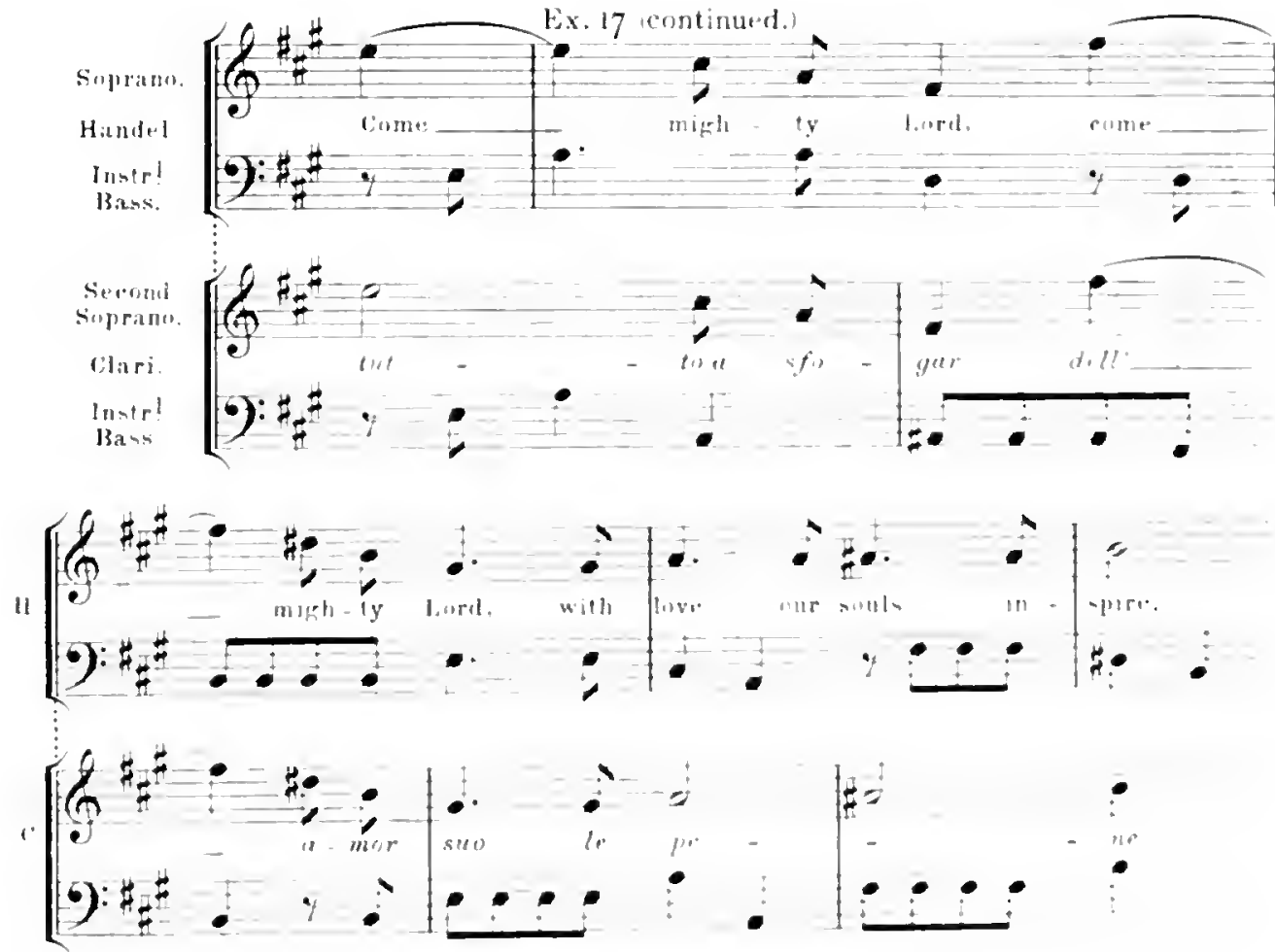
We next come on this theme in Canou:

Hand.I.

reodore
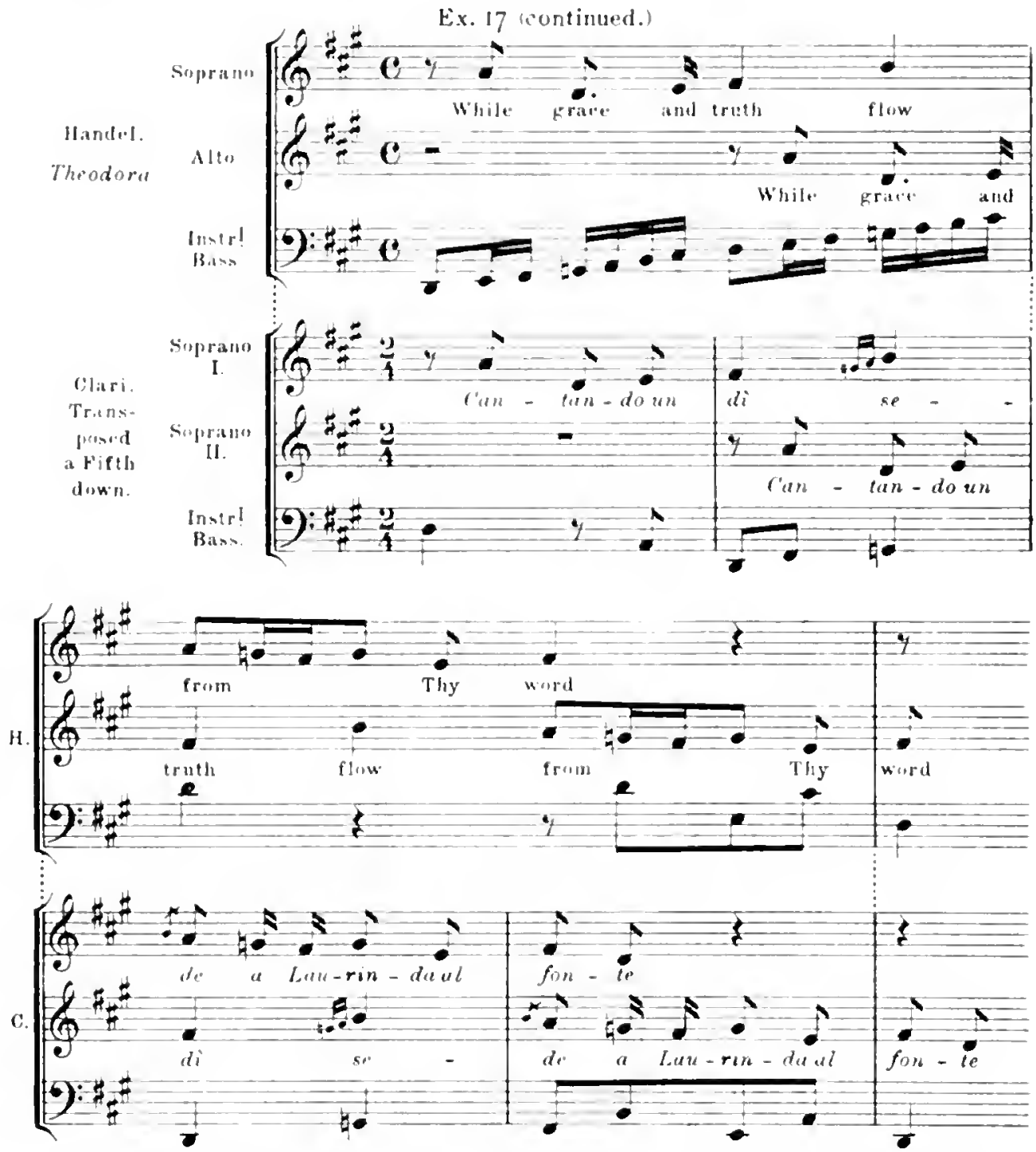

The use of the scale-passage in Handel's Bass here appears to have been suggested by the following bars of Clari:

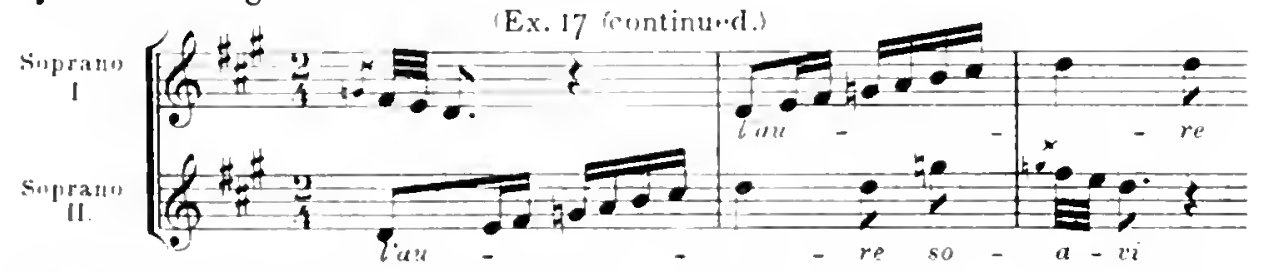

This chorus of Handel, consisting of 60 bars, is cntirely worked up out of the above materials from Clari's duet. 


\section{CHAPTER IV.}

Comparison of two cholises in Handel's 'Thunfo del Tempo witid tho choruses in a work by Kari. Heinrich Graun, and with manuscript copies made of them by Handel. Miscellajeods examples of Handel's use of THIS WORK.

K ARL HEINRICH GRAUN (1701-1759), a six years younger contemporary 1 of Handel, was a German composer of the greatest distinction and public repute, who held posts of Capellmeister at the Courts of Prunswick and Perlin, and whose masterpiece, the oratorio Der Tol Jesu, occupies in Gernany "in some measure the position which is held by the Messiah in England." " That Handel should have transferred almost note for note to his own scores the bulk of two choruses of considerable length taken from a work by one of his most eminent contemporaries seems antecedently incredible. That he did this in the case of a work of Graun's las nevertheless been incontrovertibly proved by Professor Prout ${ }^{2}$ who was enabled to discover the fact by a concatenation of coincidences so extraordinary that my readers will, I feel sure, wish to be made acquainted with it. I proceed therefore to give an abridged account of his article, sometimes using his own words.

The late Rev. J. R Lunn, a Yorkshire clergyman and exceltent uusiciau, formerly Fellow of St. John's Collegt, Cambridge, was asked by a neighbouring Musical Society to recommend them a Handet chorus for performance. He chose the chorus "Ere to dust is changed that beauly" from The Triumph of Iim and Truth (1757), but, while he was examining it, the idea struck him that it resembled a movement which he remembered having copied at Cambridge from Latrobe's Collection of Saered Music. ${ }^{3}$ Mr. Lunn hunted up his old manuscript which contained (1) the chorus "Ere to dust" substantially complete but with different words, (2) three bars of adagio, (3) another chorus (in $F$ minor) also with English words, which, shortened by nine bars, he found, set to Italian words, in Handel's Il Trimfo del Tempe, an earlier version of the same work, lirought out in 1737, which likewise contained the chorus "Lre to dust" set to Italinn words. Both these choruses and the connecting Adayiu were described by

1 Grovo's Dictionary of Music, Iat erlition.

In an articlo publighed in the Montily Musiesl Recomi for May and June, 1894.

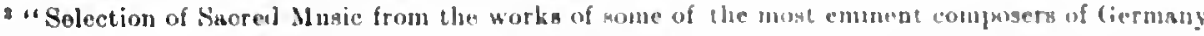

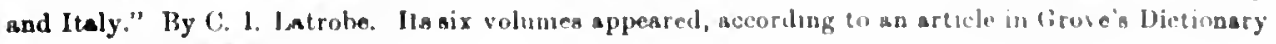
(lat odition), betweou 1806 and 1825 . 
Latrobe as taken from an "Oratorio Passionalc" composed by Graun. Mr. Lunn, puzzled by this ascription to another of what he had always regarded as the property of Handel, communicated with l'rofessor l'ront, who at once took the vicw that, considering IIandel's known habits in such matters, the music was more likely to be Graun's than his, and so Latrobe probably in the right.

Soon after this correspondence with Mr. Lunn, Professor Prout spent a few days at Caubridge with Dr. A. H, Mann, who pronptly conducted him to the Library of the Fitzwilliam Musenm, to examine the Handel antographs. Mr. Mann took down at random the first volume of the collection, the pages of which Professor Prout began turning over. On pp. 21 and 22 he cane upon two scores which had till then been regarded as original drafts for the two ehoruses mentioned above as baving both appeared in the Trionio del Tempo, while but one of them was included in the long subsequent English version of that work. Prout, with the facts to which Mr. Lunn had directed his attention fortunately still fresh in his mind, at once perceived that these scores were not in the form which the Handel choruses in question bear in his published works, but in that of the two movements and intervening short adagio printed as Graun's in Latrobe's collection. This fact, together with a remarkable absence of corrcetions in these autographs as compared with other original scores of IIandel, and with a further piece of evidence to be described in the next paragraph, led Prout to the conclusion that these two clioruses were no compositions of Handel, but copies made by him from some, probably unpublished, work by Graun.

The next three pages of the Fitzwilliam autographs contain ten detached movements, or parts of movements, lescribed in the printed catalogue as "at present unidentified." Below, or in the margin of, several of these Handel has written disjointed German words or pairs of worls, and this is also the case in the short adagio already mentioned. No one had yet discovered the significance of this curious proceeding, but Professor Pront at once hit on the conjecture that these movements, equally with the two choruses which preccded them in the autographs, were extracts made by Handel from Graun, and that the German words were taken from the text to which Graun's music was set, and jotted down by Handel as clues to enable him to recorer with ease the passages in Graun's work from which he had been copying.

Prout soon found himself able to produce decisive confirmation of his theory. He took with him from the Fitzwilliam II useum a German second-hand musicseller's catalogue, as he had noticed a score of Cherubini's in it which he wished to order, and the librarian had hauded over the catalogue to him as of no further use to the Musenm. On looking through this eatalogue he found that it announcerl for sale an old ma!nuscript score of a 'Passion' ly Gram.

Prout, after making some enquiries which convinced him that this would prove to be the unpublished work from which Handel had borrowed, wrote for and 
obtained it. On turning over its first page, which was occupied by a choral, he came at once on the two choruses, and the intervening adagio, exactly as they stand in Latrobe. This left but a single link wanting to complete the proof that Graun was their author, viz. evidence of the priority of his 'Passion' to Handel's Trionfo. Such evidence was to hand on Prout's manuseript score which deseribed the work as the 'Brunswick Passion,' from the name of the place where it was produced. Graun is known to have settled in Brunswick in 1725 and to have quitted it in 1735. The latter is, therefore, the latest limit of time for the produetion of his 'Passion,' whereas Handel's Trionfo was not performed till 1737. This accordingly settles the question of priority and with it that of the authorship of the two choruses.

On examining the rest of Graun's score Prout found in it, with one insignificant exception, all the fragmentary movements which follow the two choruses in the Fitzwlliam autographs. Moreover, in every case where Handel had appended German words, as described above, he "found the same words at the same place in Graun's score."

Finally Prout identified about half of these fragments as having been inade use of by Handel in Alexander's Feast, the Wedding Anthem ${ }^{1}$ and the operas Atalanta and Giustino. These works having all been brought out in 1736, ${ }^{2}$ Graun remains in a clear priority.

Professor Prout sums up as follows the truly "extraordinary" chaiu of circumstanees" which led him to this discovery:

"Harl Mr. Lunu selected any other chorus than "Ere to dust," and had he not also, thirty or forty years before, copied the same chorus from Latrobe, he would not have written to me on the subject. Had Dr. Mann happened to take down from the shelves at the Fitzwilliam Library any other one of the fourteen ${ }^{2}$ volumes of Handel's unanusoripts than the one he took, I should never have seen the extracts from Graun in Handel's writing-and that too at a time when the matter was fresh in my memory, owing to Mr. Lunn's letter, and my having looked at Iatrobe only a few days before. Still more remarkable, if possible, was the incident of the catalogne. Had not my eye been eaught by the score of Cherubini's, I should not have asked to copy it, and thus receivel the catalogue. But the most eurious thing of all is that this eatalogne, which by the merest chance was lying on the table, instead of having been thrown into the waste-paper basket, where I should uever have seen it, should contain the very work needed to reveal the truth-a manuscript score, which probably loes not come into the unatet once in ewenty yoars."

Exanples 18, 19 and 20 enborly three of I'rout's tive identifications mentionod above.

\footnotetext{
In the case of the Widding Anthem It Mum hat alruady rocogumed the connexion with one of the IInidel fragments.

Cirove"s Irictionary.

Their sumber in jilleen.
} 
Ex. 15 .

Instrumental Intrudurtion to the song "obeque al bosen" in Giustimn

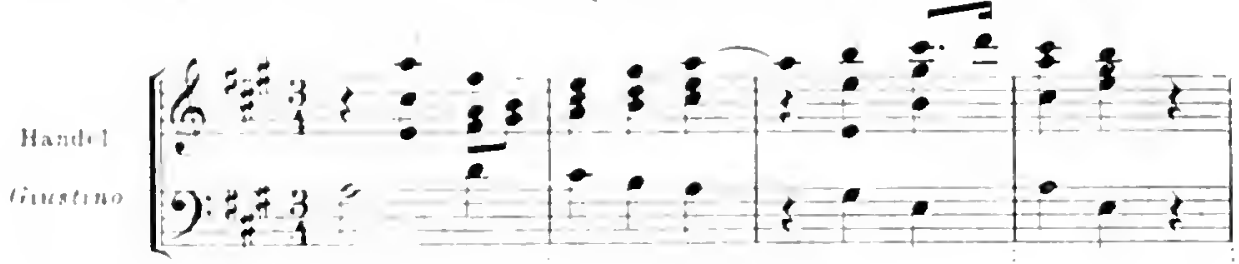

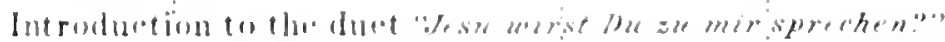

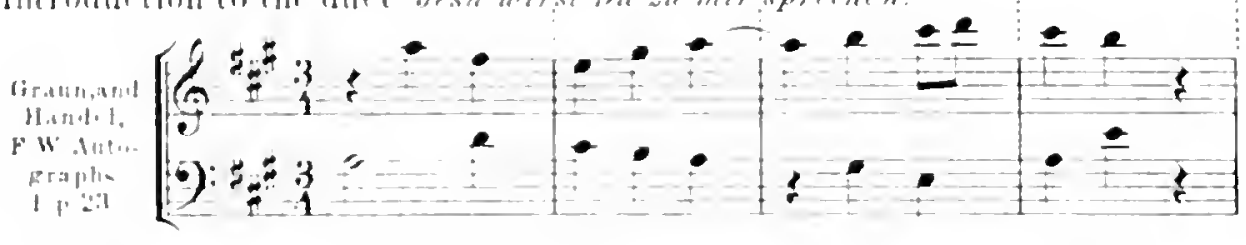

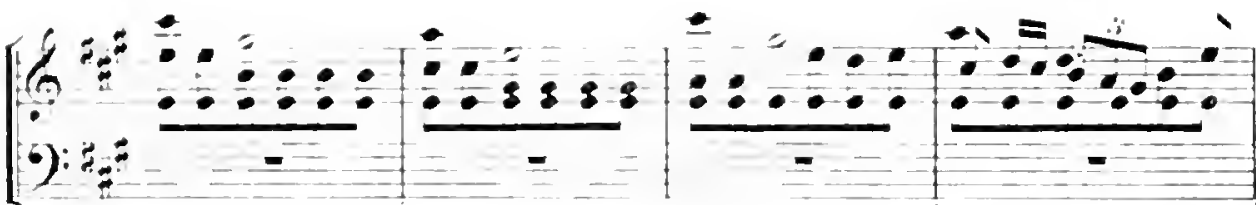
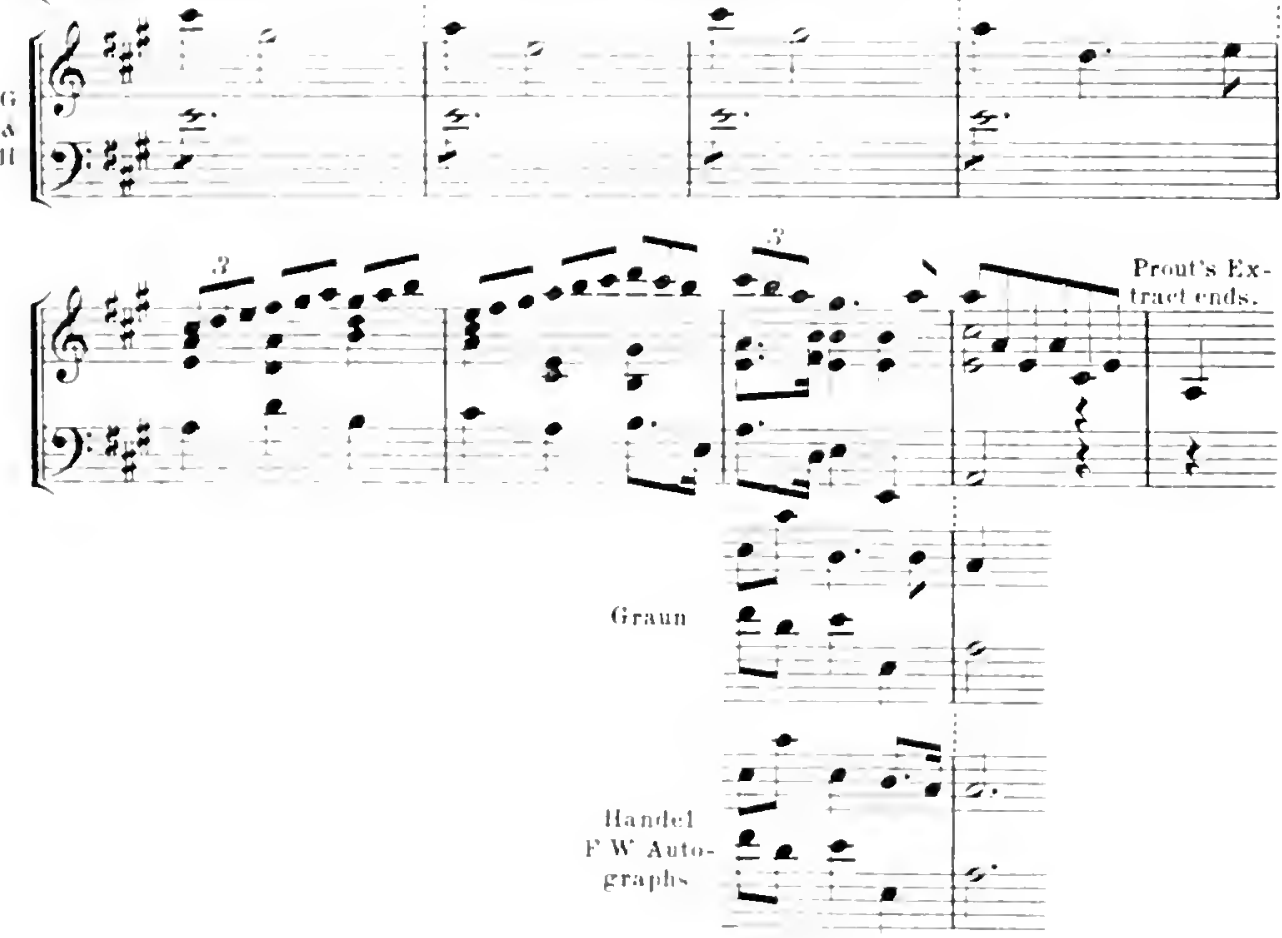
Ex. 19.

Part of the Int rodurtion to the song "Dall"ocrasn in oriente" in Giustimo.

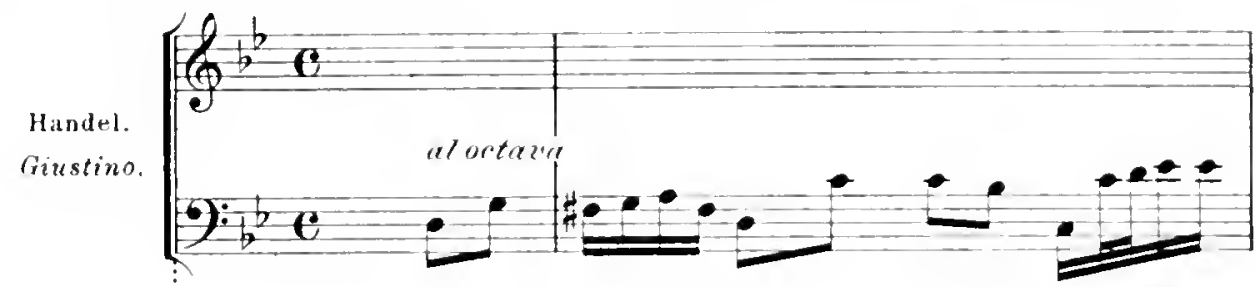

Beginning: of the Introduction to the Bass song "Wein Knerht der Gererhte."
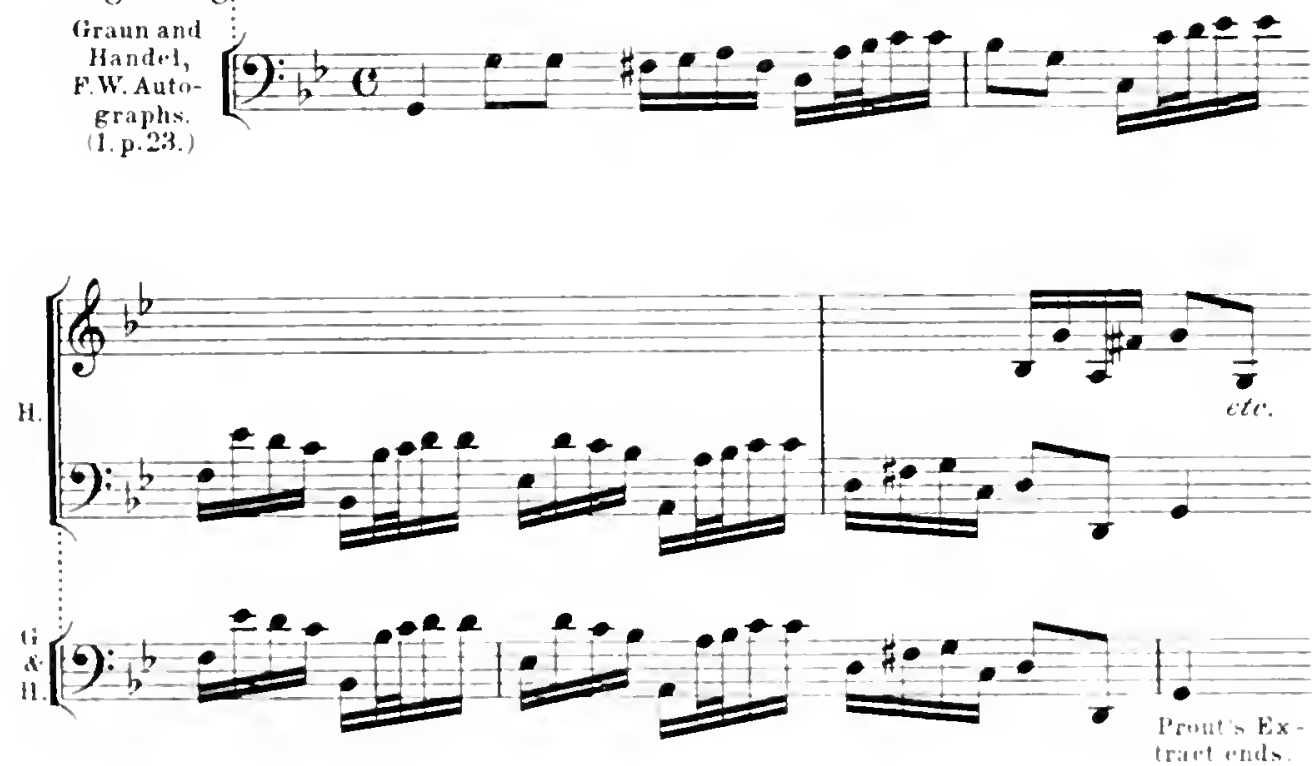

Ex. 20.

Fugue-subject in the chorus "At last divine Cerita came" in Alfander's Frast.

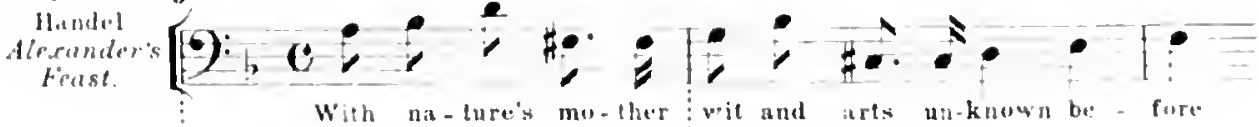
Fugue-suljuet in a chorus from Grams ' Passion.

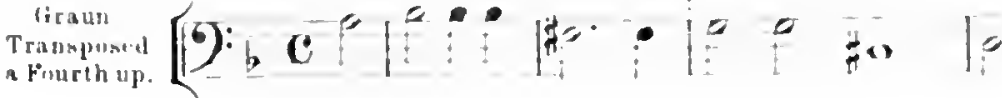




\section{CHAPTER V.}

HANIILL'B UBE OF RARLIER COMPOBITIONS OF HIS OWN. INSTANCES OF THIS IN THE CABE OF BOME DUETA BET TO BECULAR ITALIAN WORDS AND AFTERWARDB deVeloped into geveral ohorubes and a duet in the Mrssiar.

I has, I think, been adequately shown in the preceding chapters that Handel made free and extensive use of compositions by other masters. But he also treated in precisely the same inanner older work of his own, sometimes merely re-setting it, with insignificant modifications, to fresh words, sometimes excising, amplifying or altering it with absolute freedom. We shall subsequently examine instances in Israel in Egypt where he did this with magnificent results: here I shall set out a very striking series of transferences and contrapuntal developments to be seen in his working up of some vocal duets, which he had already composed to secular Italian words, into great choruses and a duet in the Messiah. All but one of these Italian duets were written only a few months before the composition of that oratorio. ${ }^{1}$

In the following comparisons I shall quote leading subjects from movements in the Messiah together with their all but identical originals in the Italian duets. The order followed will be that of the movements in the oratorio: the Italian duets will be quoted from the German Handel Society's edition.

Ex. 21.
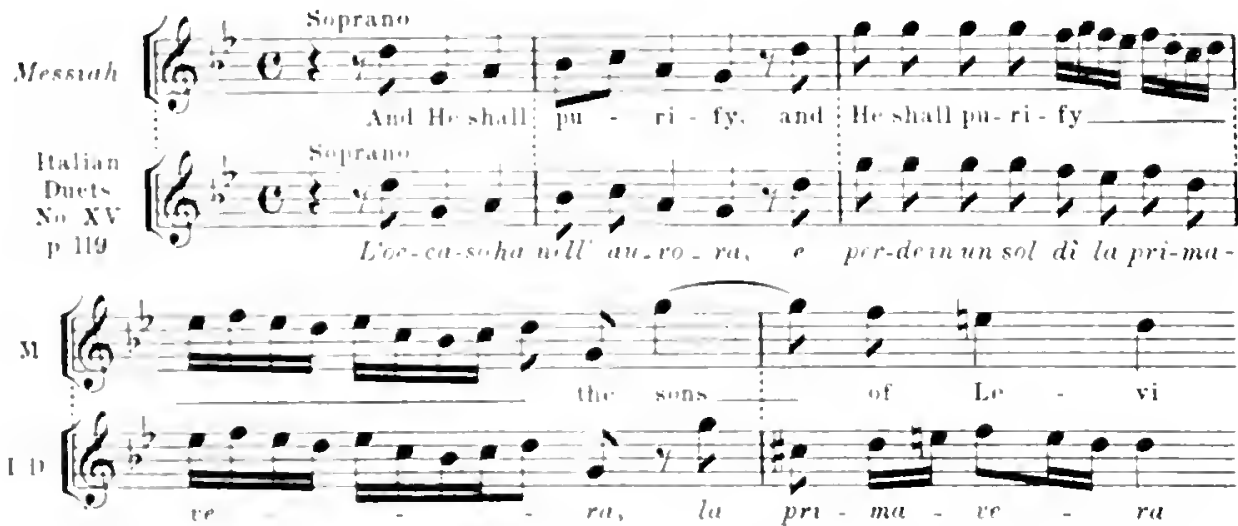

'Chryander, Lifo of Hawdiel, vol. I., p. 371. 
The running passage in bar 4 of the duet scems suggested by the word 'primuvera' (spring), but is hardly appropriate to the word 'purify' to which it is set in an extended form in the chorus. Handel appears to lave felt that something more was wanted than an assemblage of rather mechanical passages and been promptly moved to that stroke of genius the mighty episode:
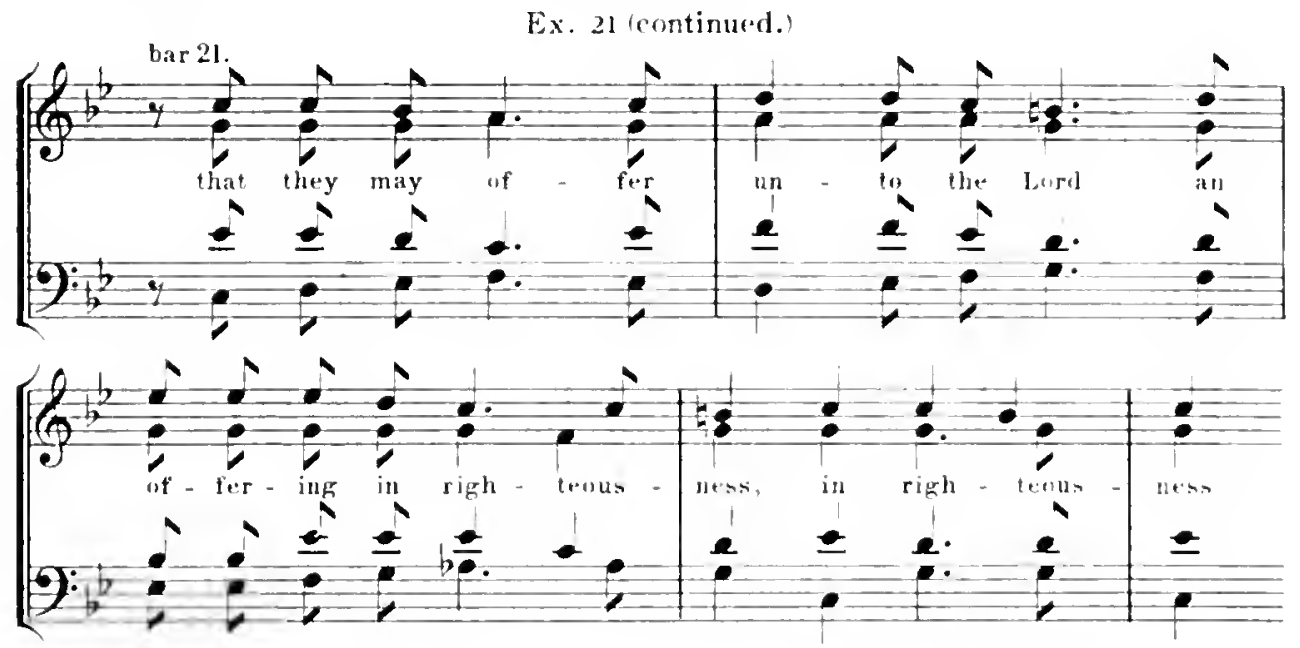

which, repeated in a ligher part of the scale and with somewhat modified harmonic treatment, closes this chorus with such impressive grandeur.
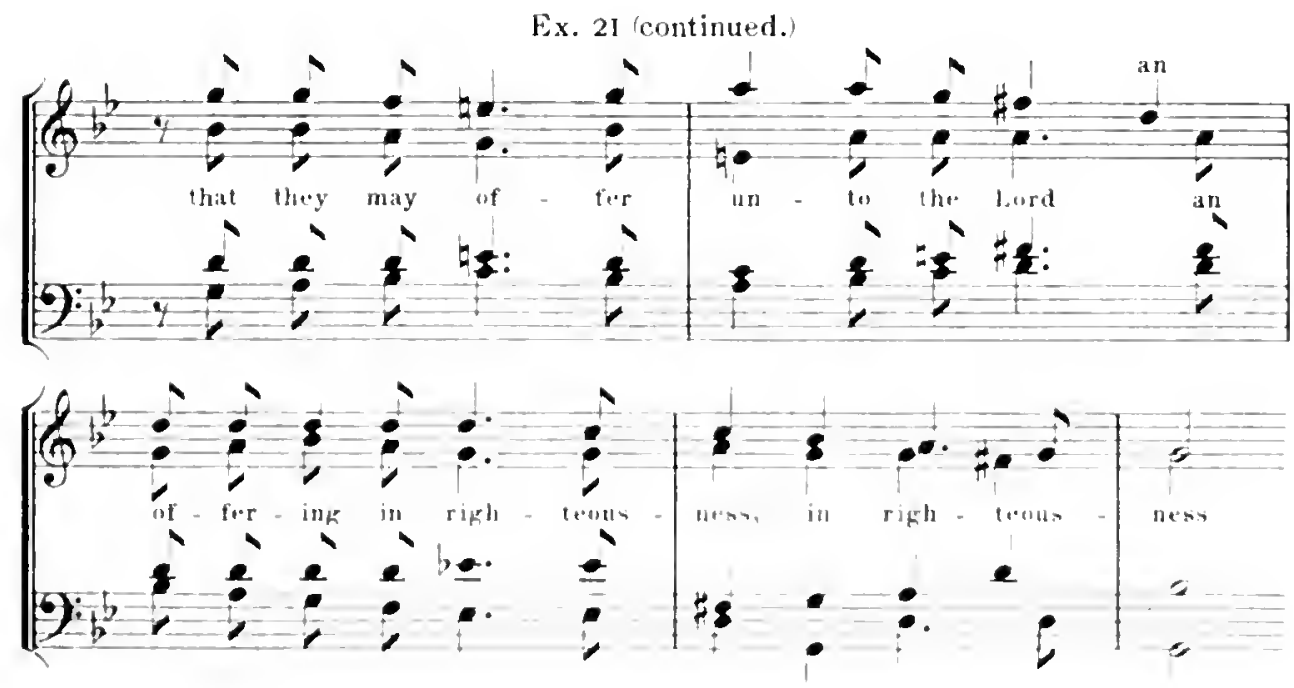

The next two examples show the original destination of subjects which, 
contrapuntally treated, make up the lukk of the famous chorus "For unto us a child is born."

Ex. 22.

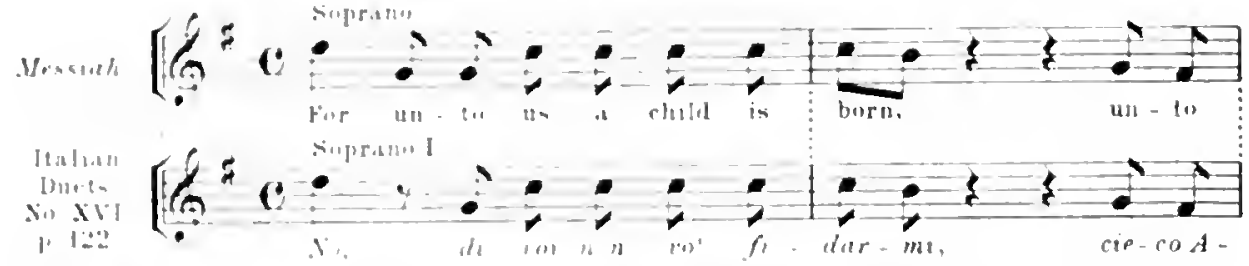

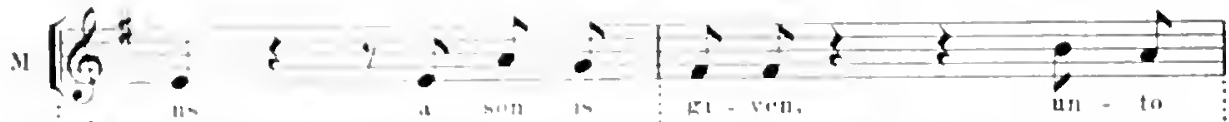

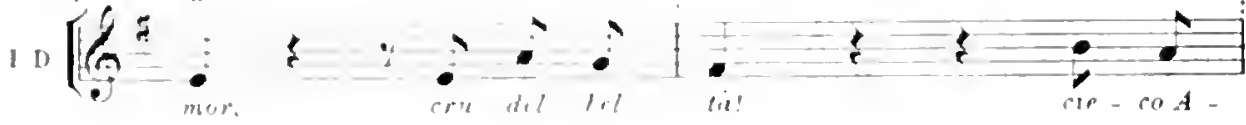

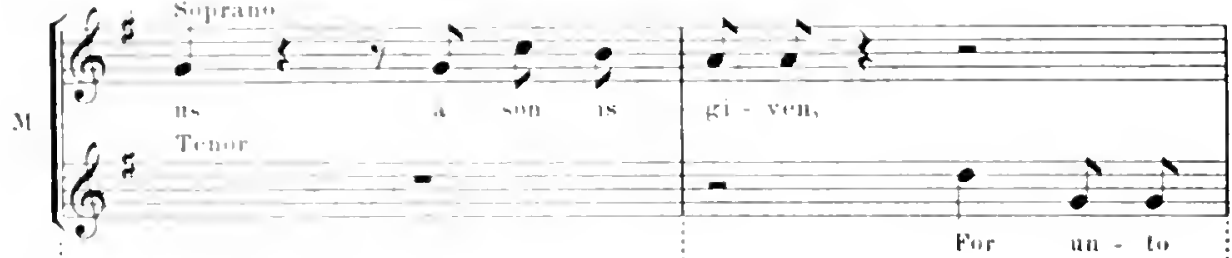

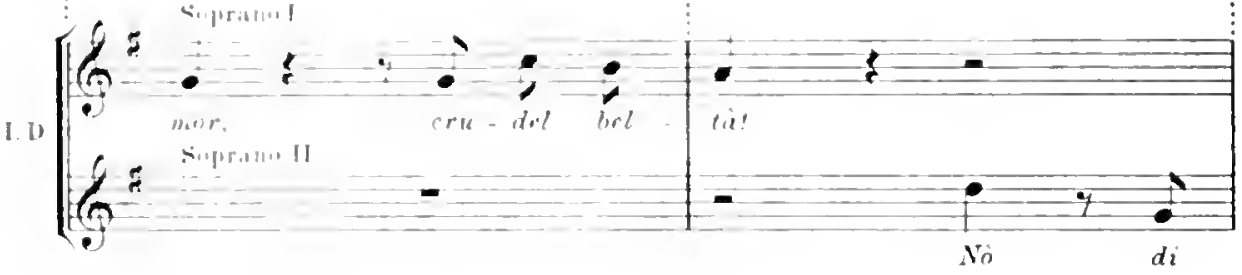

"(

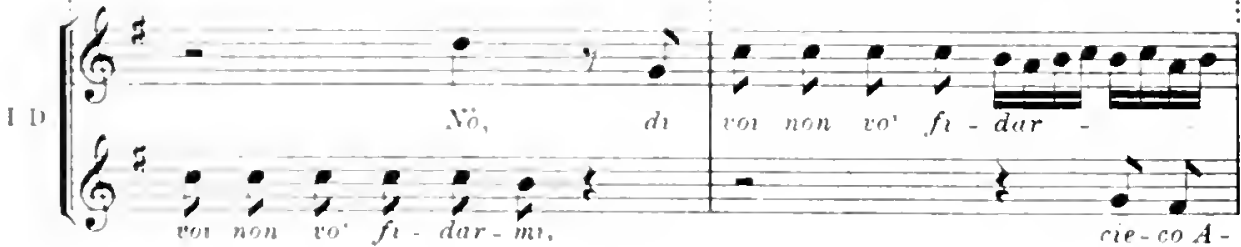




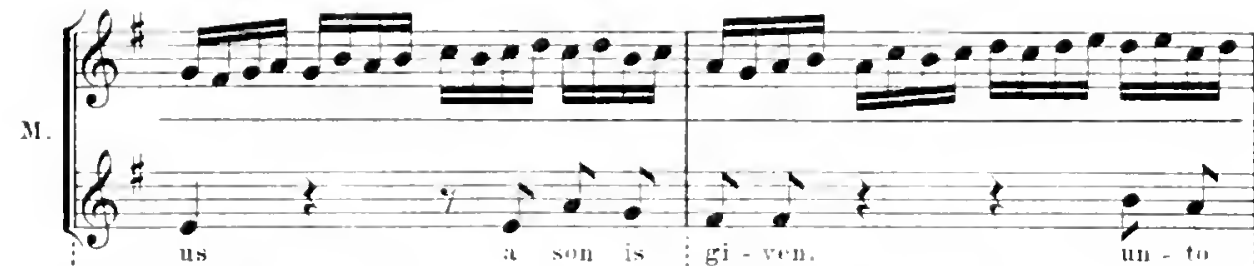

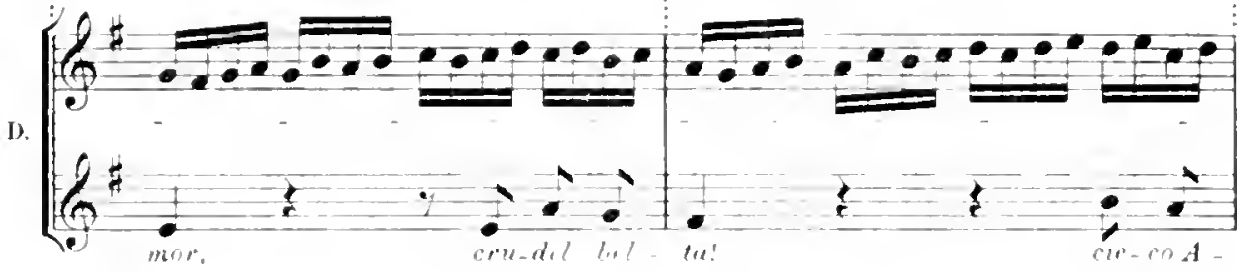

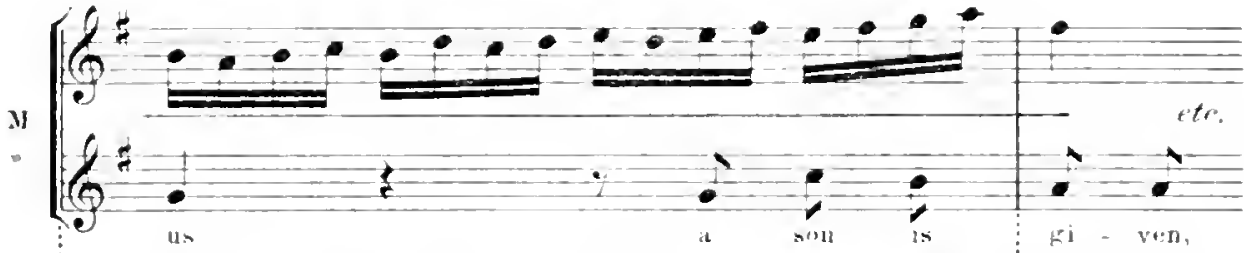

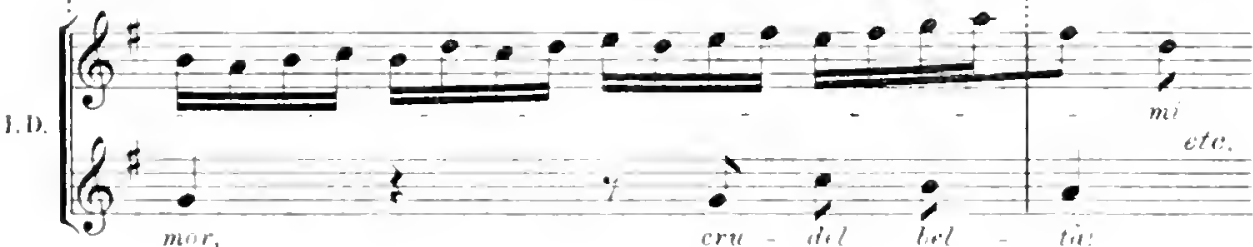

Ex. 22 rontinued.

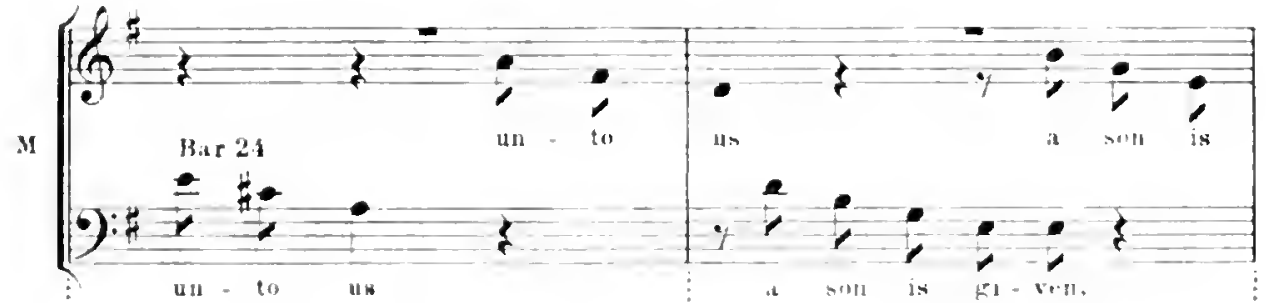

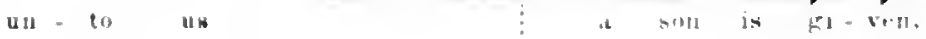

(I)

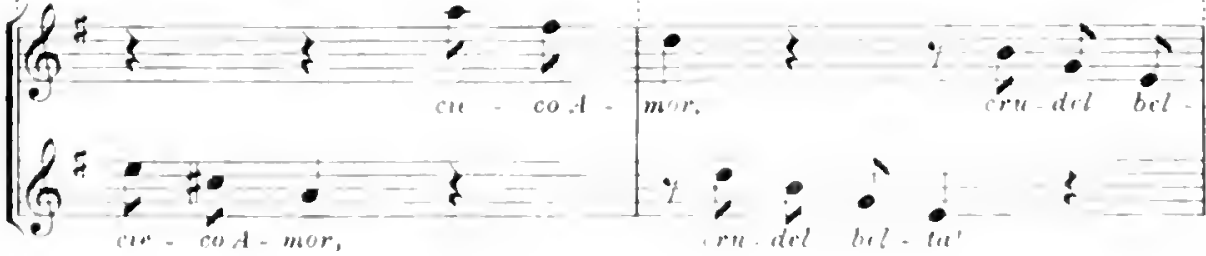


40 ITALIAN DUETS

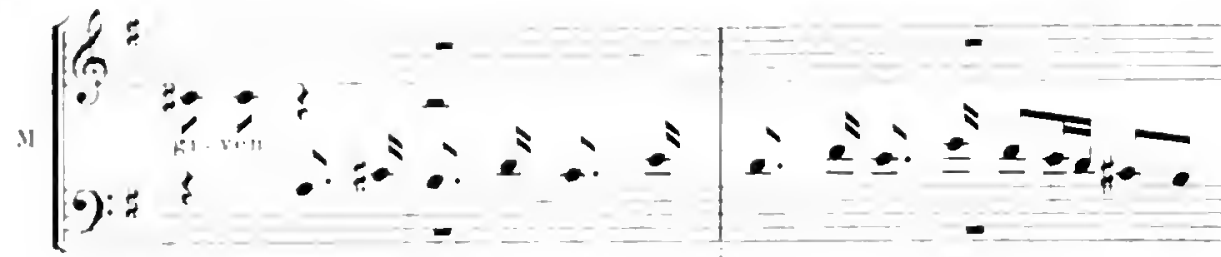

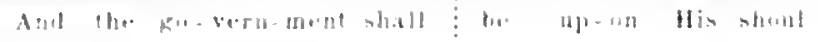

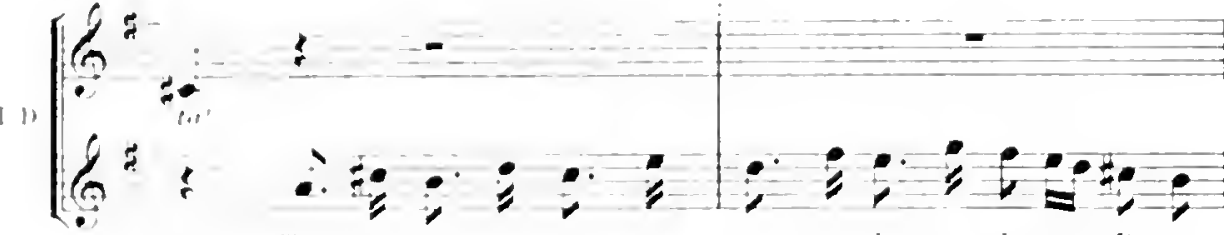

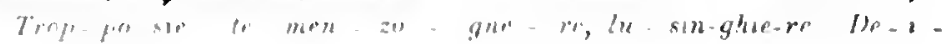

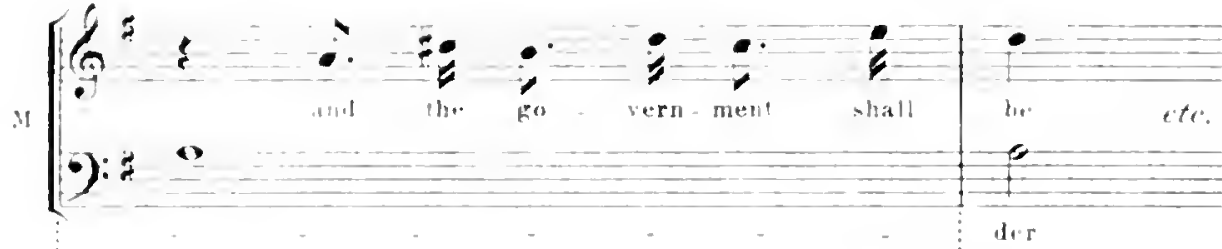

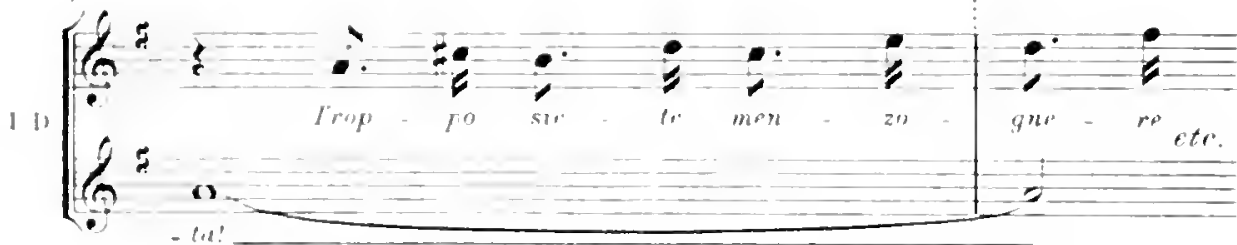

Into this chorus, also, Handel introduced a stroke of genius additional to the unaterial derived from his duet, the great choral shouts:

F.x. 22 continued.

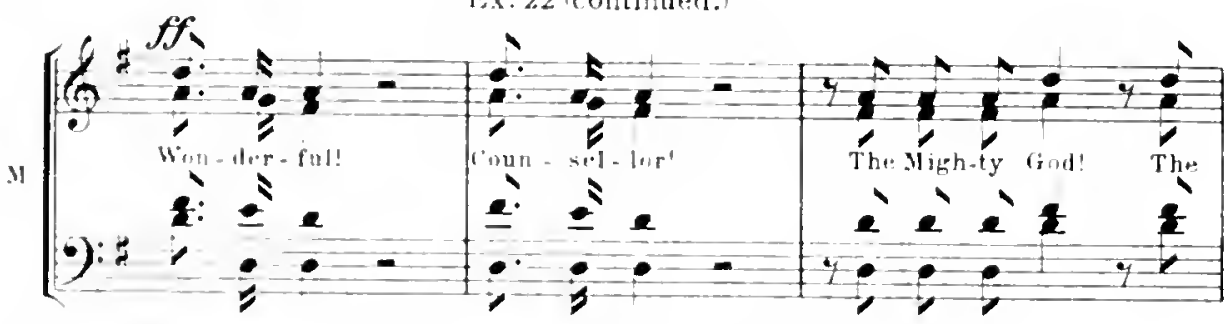

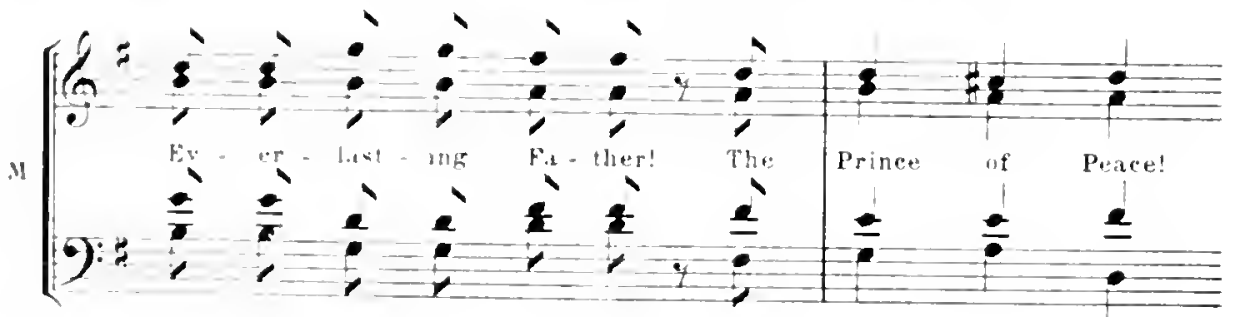


The next example has a special interest as elearing up a difficulty which has doubtless puzzled many admirers of Handel as it used to puzzle me. It occurs in the leading subject of the chorus "His yoke is easy and His burthen is light," where the first syllable of the word 'easy' is set to the following almost grotesquely inappropriate passage:

Ex. 2:3.
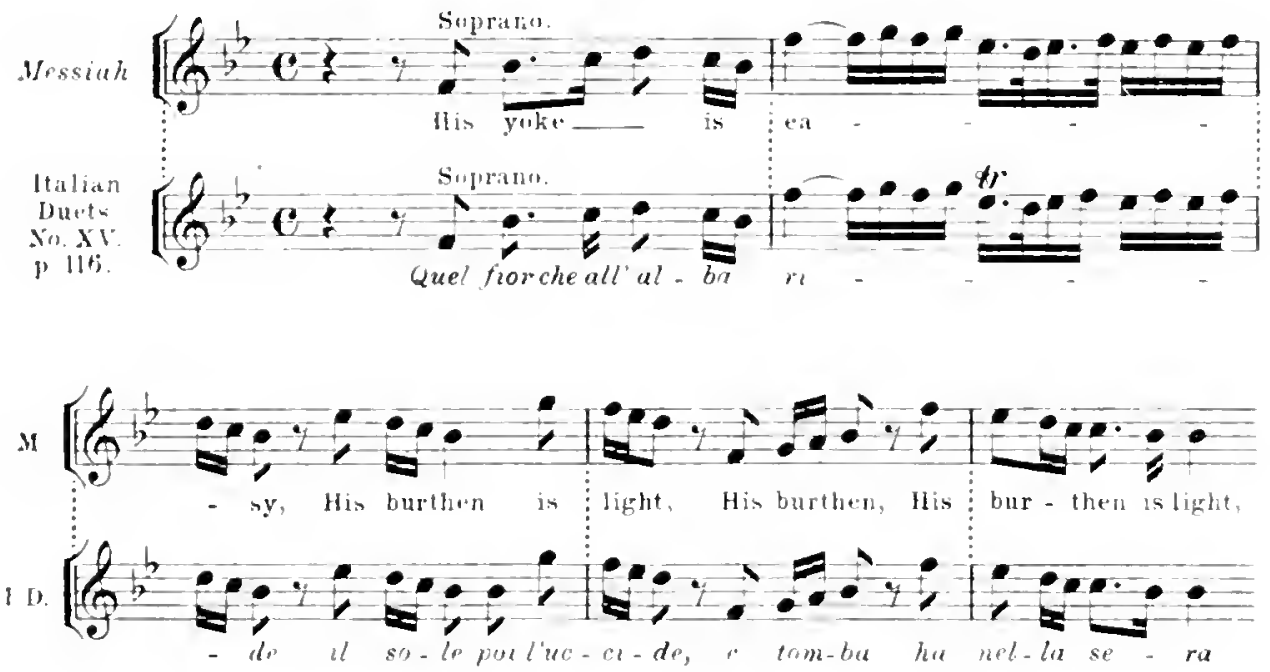

Why Handel should have perpetrated such a monstrosity was to me an iusoluble crux. A glance, however, at the text to which the passage was originally composed suffices to explain the difficulty: "The flower which laughs at dawn is killed by the sun and finds a grave in the evening." The passage with which we are concerned is set to the word 'ride' (laughs) and is therefore evidently a piece of word-painting, quite appropriate in its original position, but grievonsly out of place where it now stands.

The added stroke of genius, for which here too we do not look in vain, ends the chorus with a passage in which beauty and dignity are woudrously mingled.

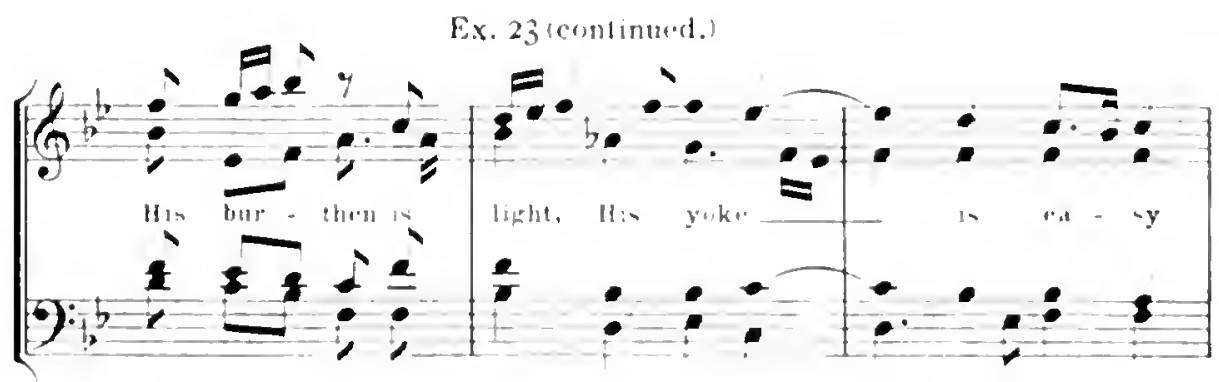




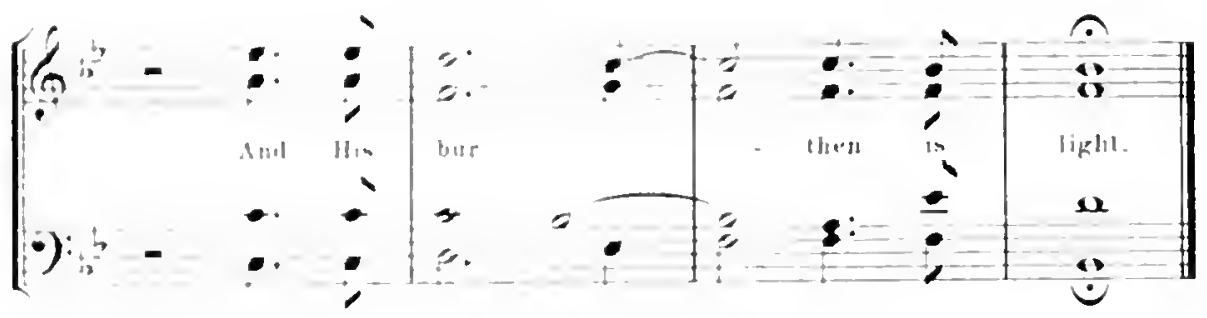

Thro allegro of the choru. "All we like slucel have gone istray" is wholly" buili on subjects from it luet the enslier part of which had already heen drawn upon for the clorus "For unw us a child is knru." Tley are set out in Ex. 24 .

Ex. 24.

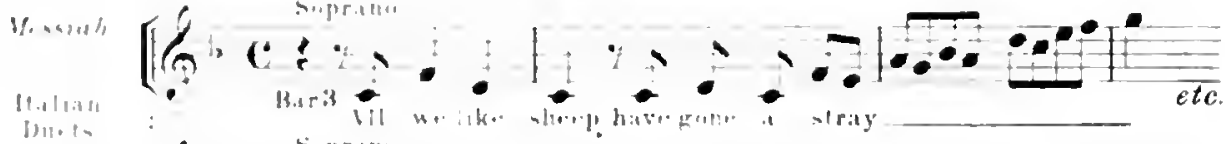

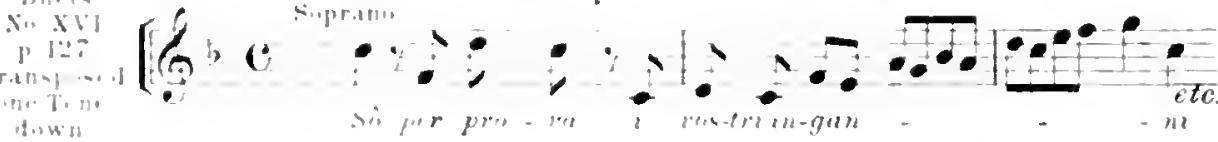

Fix. 21. 1ontinuted

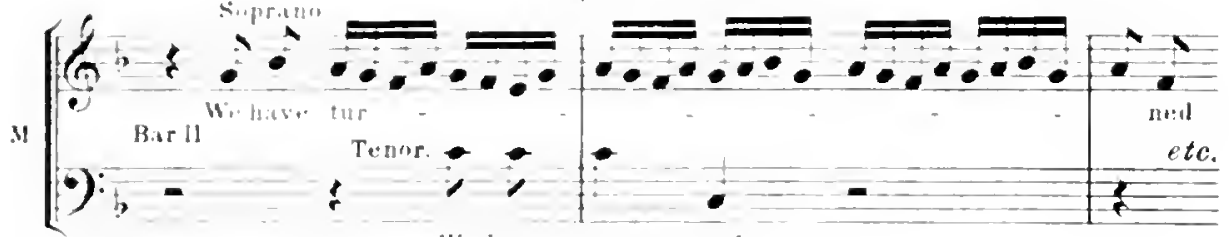

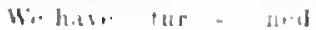

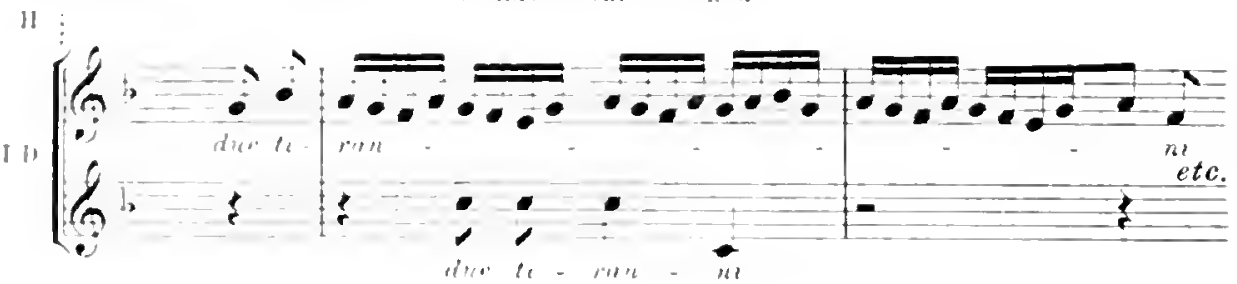

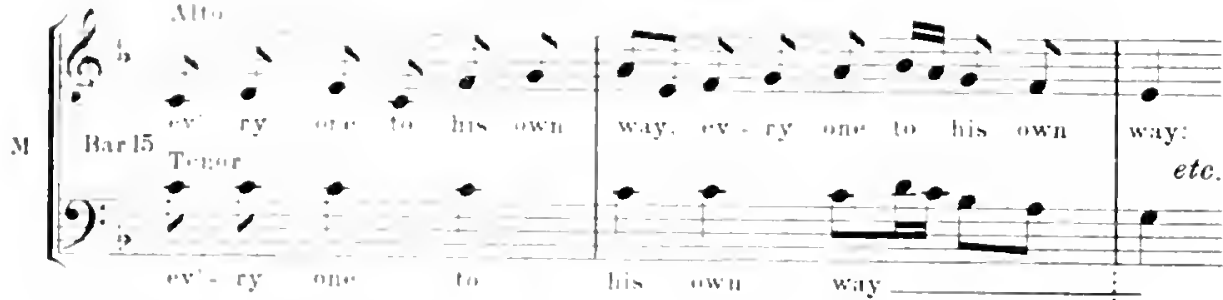

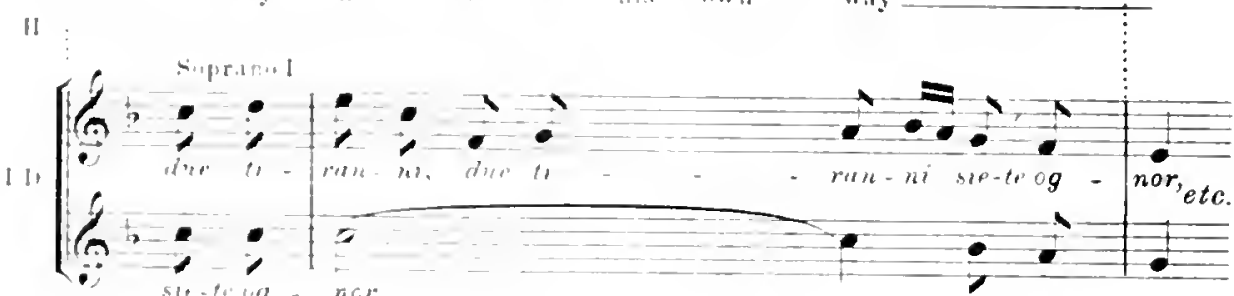




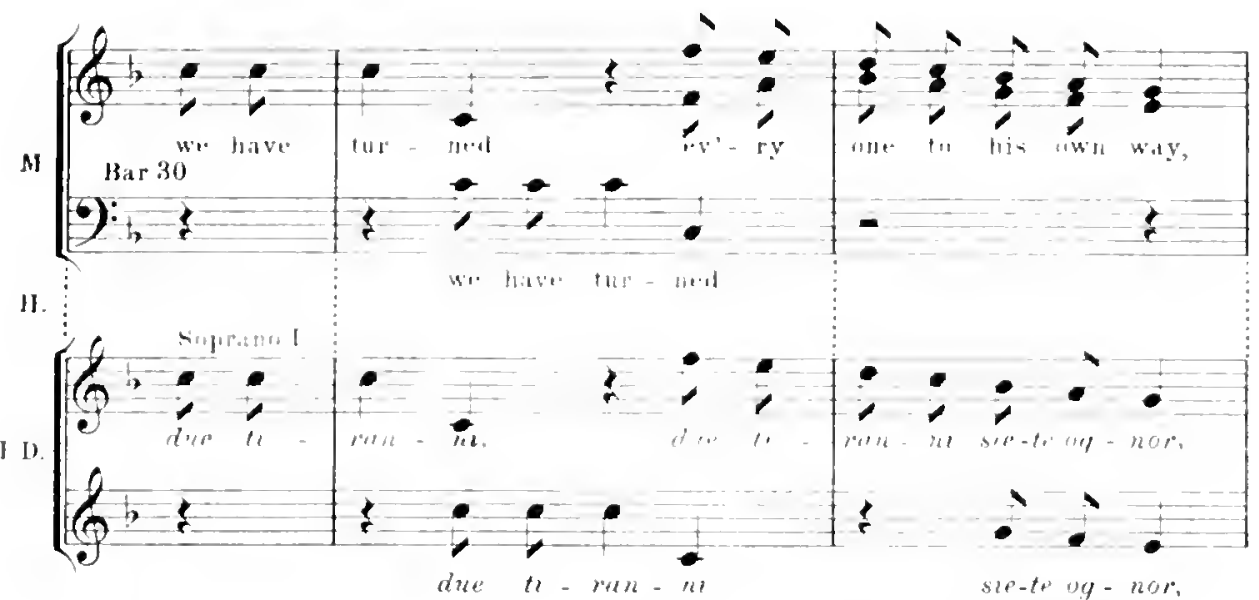

The Italian text is a defiance of "blind love and crnel beauty" whose tyramy and deceits are rounlly denounced from personal experience. The music set to this breathes, when transferred to the chorus, a certain heaven-defying recklessness which a less dramatically-minded composer than Handel would hardly have read into the English words. Arrived, however, at the point where be had thoroughly worked out the material before him, we see this wonderful man girding himself for a final stroke and making the very audacity with which he had treated his text supply him with the means of producing a magnificent effect of contrast. Abruptly changing the time to adagio and passing into minor harmony, he bids the voices enter in solemn canonic sequence, and his chorus ends with a combination of grandeur and depth of feeling such as is at the command of consummate genius only.

\section{Ex. $2.4(0)$ (n)tunted}

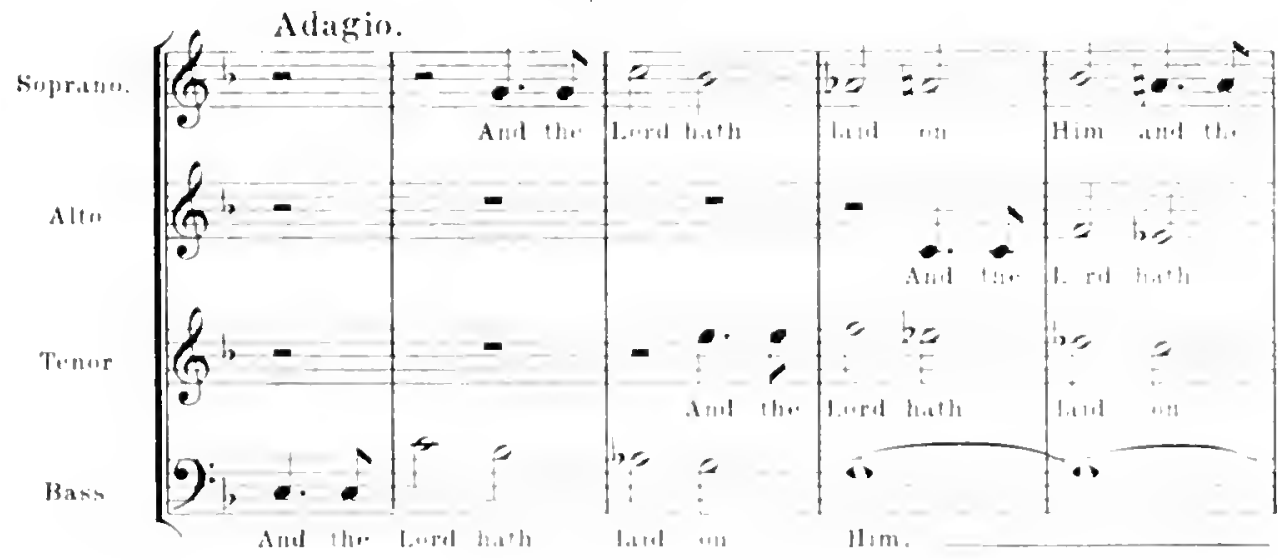



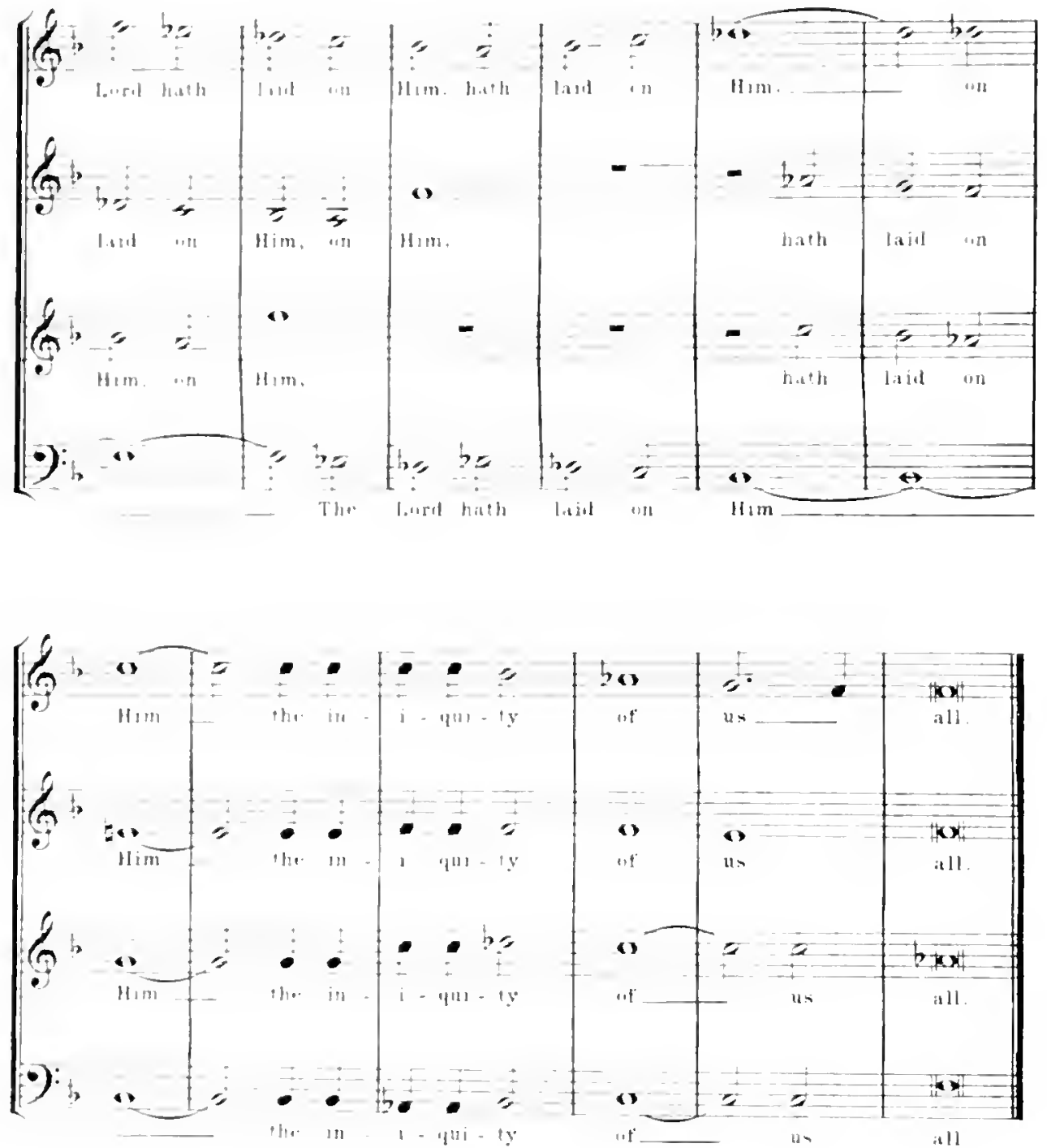

Beside the Italian duets quoted from above there are others written by Handel much earlier, according to Dr. Chrysander as far back as 1712-1720.1 The music of one of these, set to an exhortation to abandon love, is used in the Messiah in the duet " $O$ death where is thy sting?" and also occurs as a subject in the succeeding chorus "But thanks be to God:"

1 Lifo of Handel, vol. L., p. 367. 
Ex. 2อ̄.
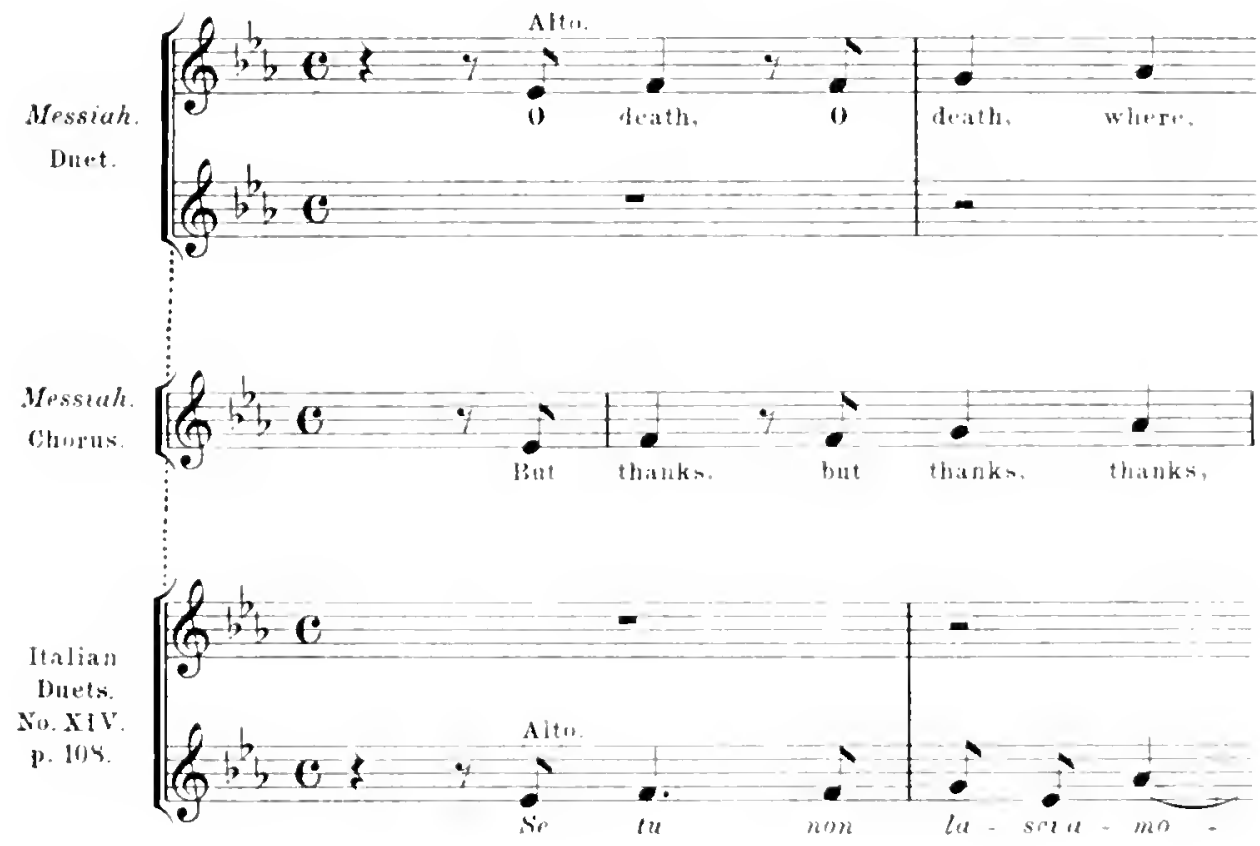

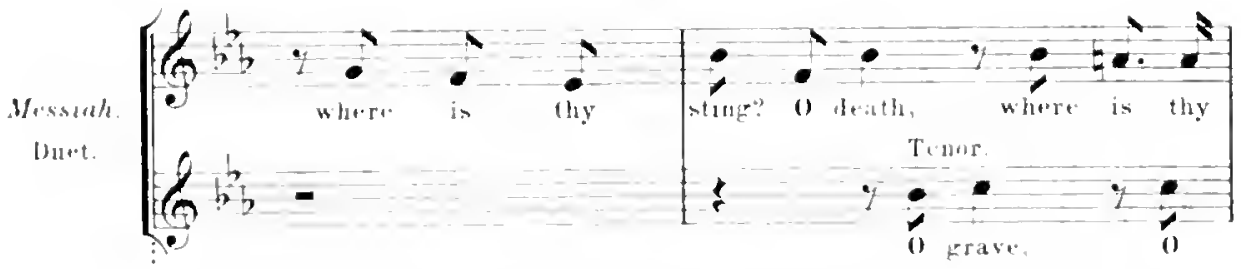

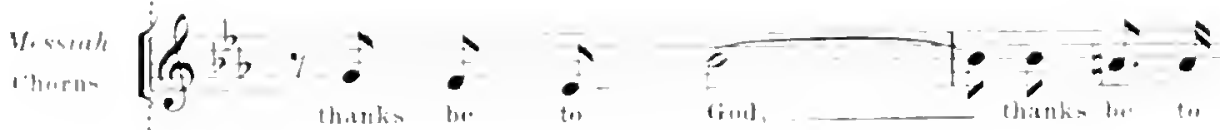

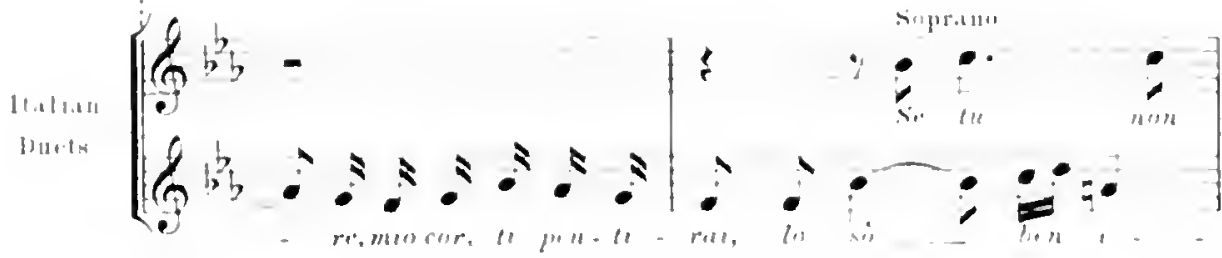




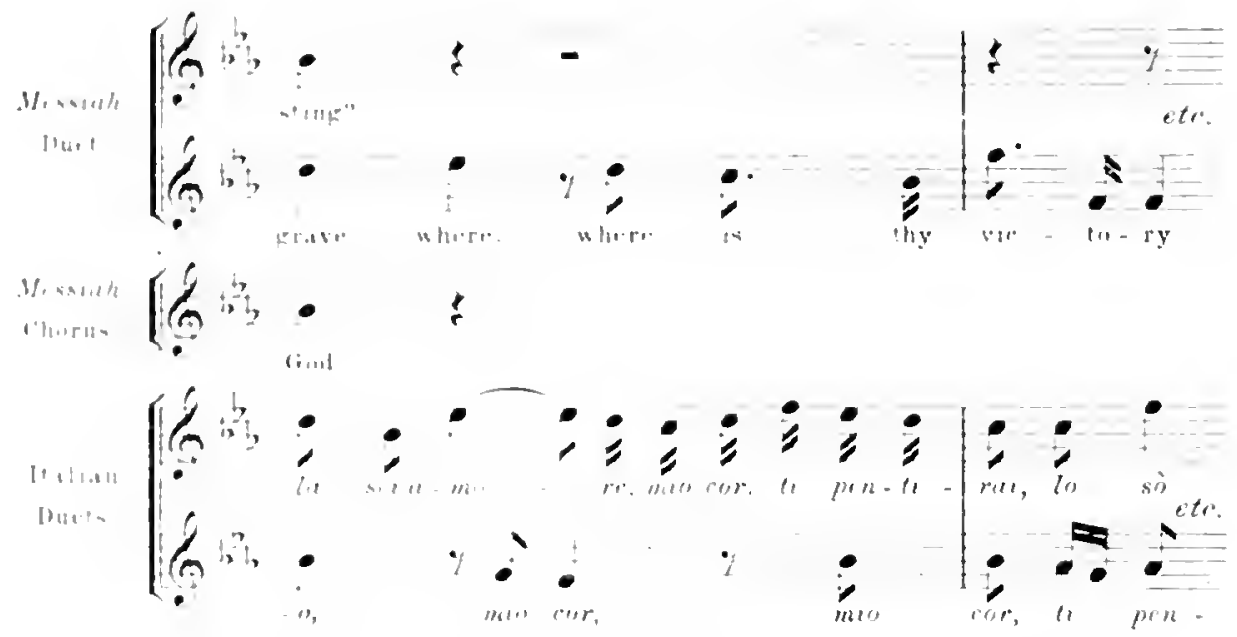

Sonte instances, rendered especially interesting by their occurrence in the Hessiuh, hase ur, been liroduced of the freedom with which Handel utilized compositions of his own which had already done duty in a different sphere. ${ }^{1}$ They are the only ones which have been detected in that masterpiece, where, so far as research has at present gone, not a single instance has been found of the introduction of uusic not composed by Handel himself. One would fain hope that this inmunity is inherent in that sublime work by the deliberate will of the compriser, whose religious emotions are known, from his own statement, to have been deeply stirred while he was engaged on it.

A few genersal renarks on suct transferences will be found on pp. 164, 165. 


\section{CHAPTER Y.}

Character of results attained by Handel when making vge of pre-existing

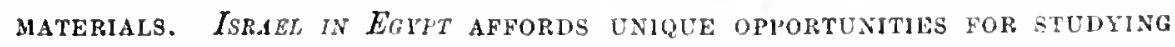
these results. Detalled comparison of Part I. of that oratorlo with portions of a Serenata by Stradella, an organ-piece by Kerl aNd FOUR EARLIER COMPOSITIONS OF HANDEL'S OWN.

$\mathrm{T}^{\mathrm{H}}$

HE fact of Handel's borrowings from other composers' works, and rearrangements of his own, may now, I think, be regarced as established, and we have to consider what is a still more interestiug and instruetive subject, viz. how he dealt with his sources, what kinds of effect he sueceeded in working them up into, and what is the result of comparisons instituted between the merits of his completed work and those of the compositions utilized in their coustruction.

It happens that Handel's choral masterpieee Isicel in Egypt affords an unique opportunity of seeing his node of procedure carried out on ar great seale, and witl results of stupendous grandeur which dwarl into insignificance the, often very meritorious, eompositions used in producing then. I propose, therefore, in order to bring all this out, to make a full examination of that truly astonishing work in reference to the various sources which are now known to have been drawn upon during its construction.

No anteedent sources are known to exist for the first three numbers, viz. the recitative "Now there arose," the double ehorus "And the ehildren of Israel sighed" and the recitative "Then sent lle Moses." No. 4, the chorus "They loathed to drink of the river, lle turned their waters into blood" is formed out of au organ-fugue, No. 5 of a set of six which Ilandel wrote in $1720,{ }^{1}$ but dint not publish until 1735, three years before he eomposed Israel in Fyypt. The fugue, whieh stands in the key of $A$ minor, consists of 74 bars. Handel cut ont 32 of these and tramsposed the rest, extensively remolelled, into the key of $G$ minor. In the following Example I guve th" antise chorus together with all the corresponding matter of thro organ-fugue which, for convenitnce of conparison, I have transposed into the key of the ehorus.

' Chryandor: Lifo of Ilandel, wol. HI. p. :01. 


$$
\text { Ex. } 20 \text {; }
$$

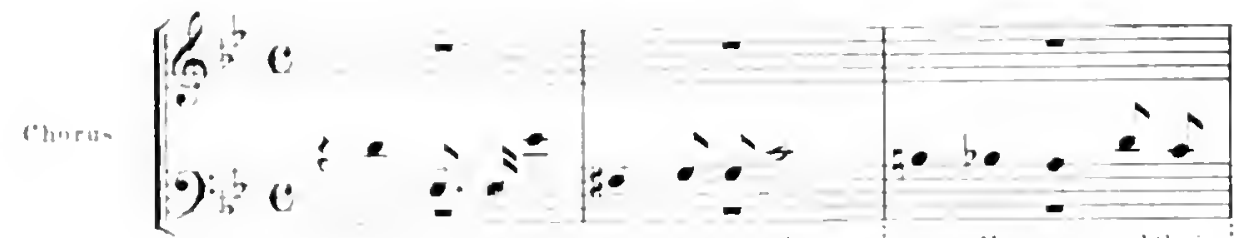

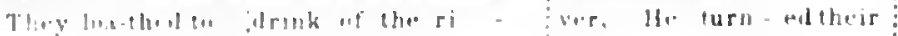

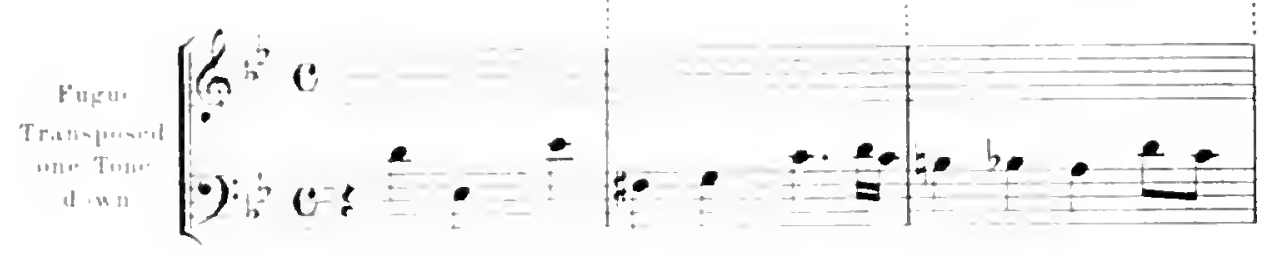

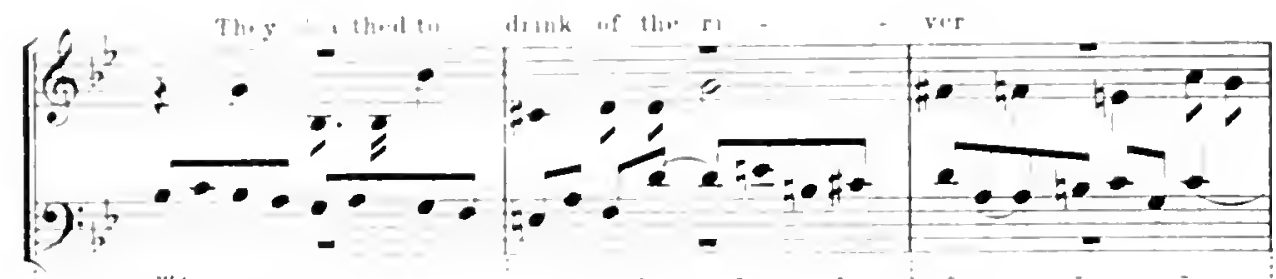

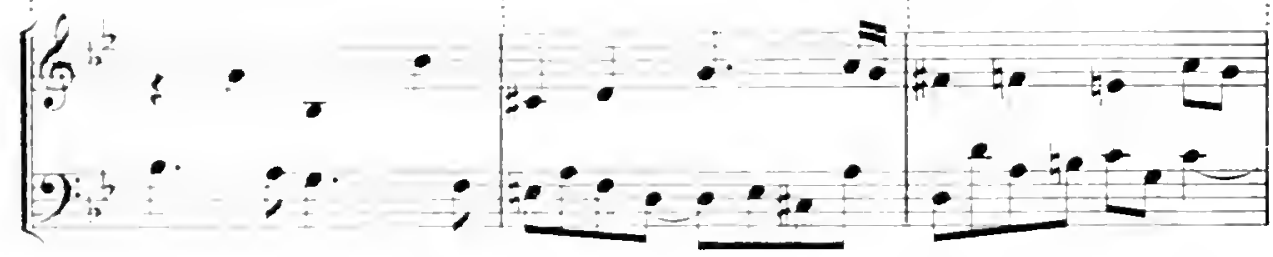

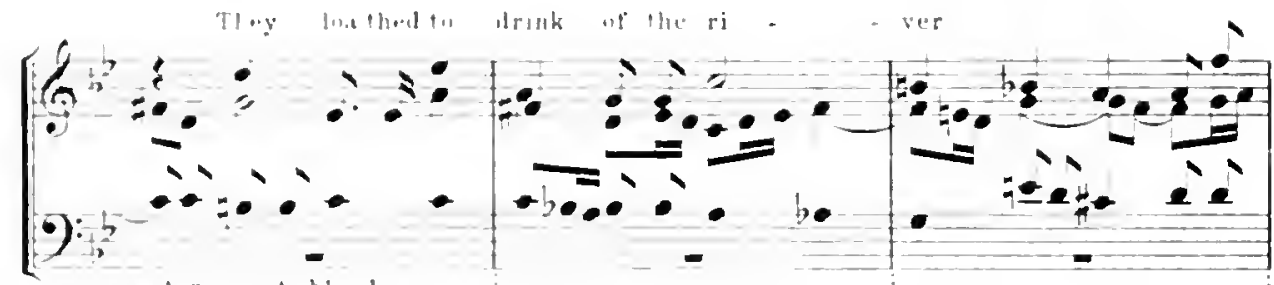

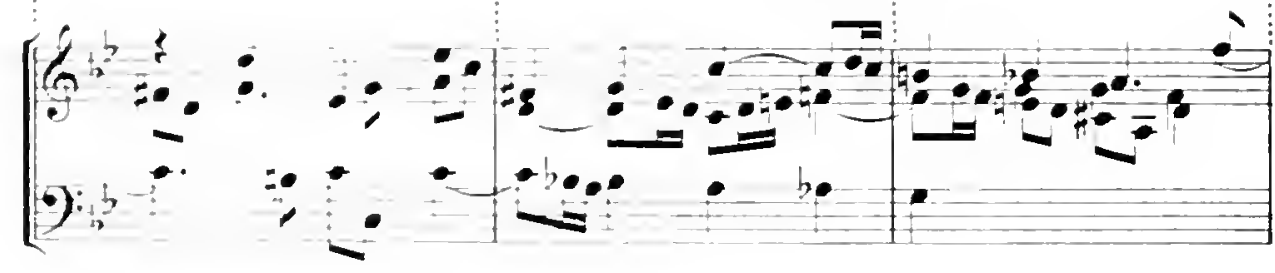


Ex. 26 (continued.)
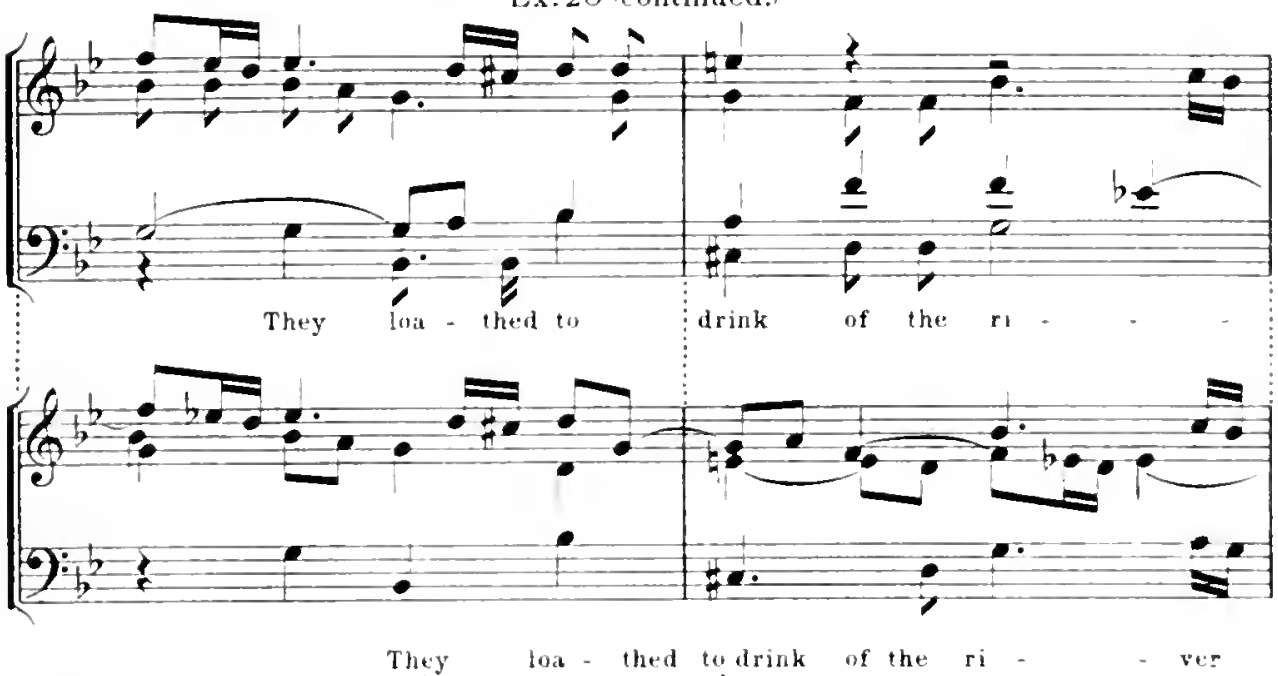

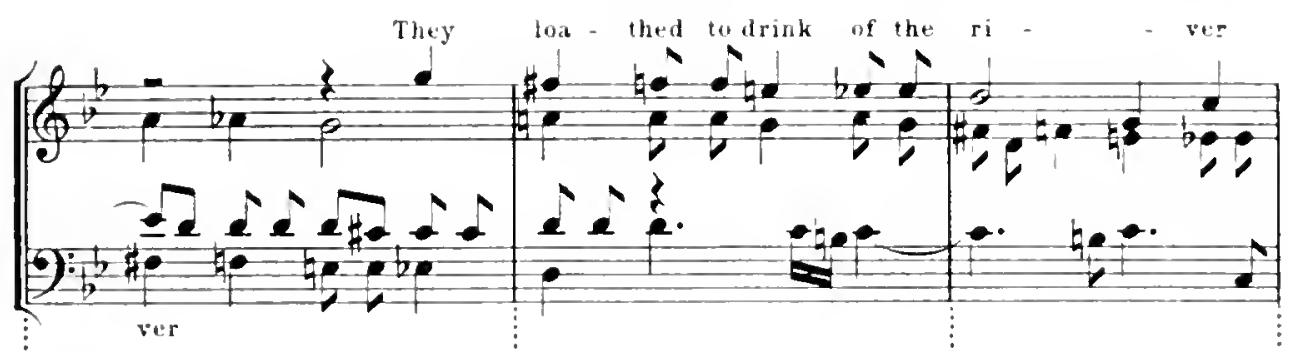

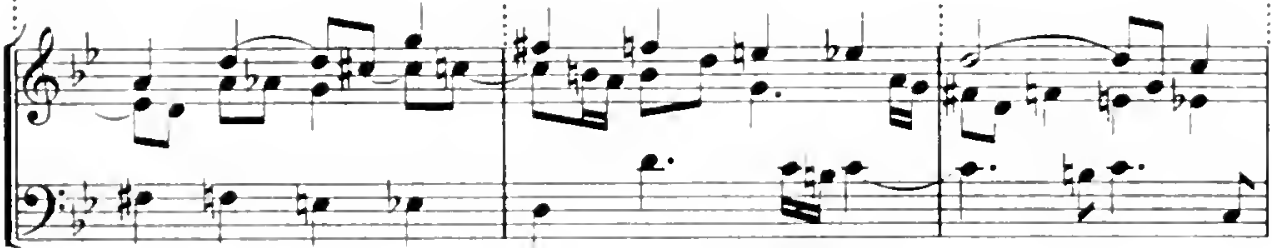

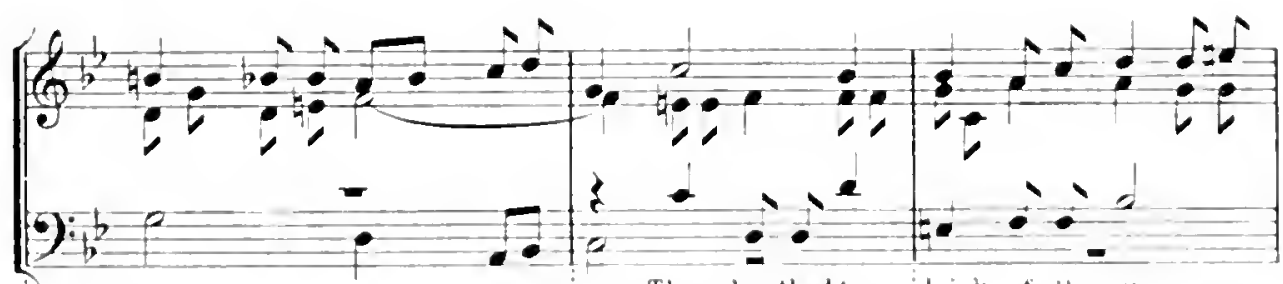
They loz-thedto Strink ut lla :1

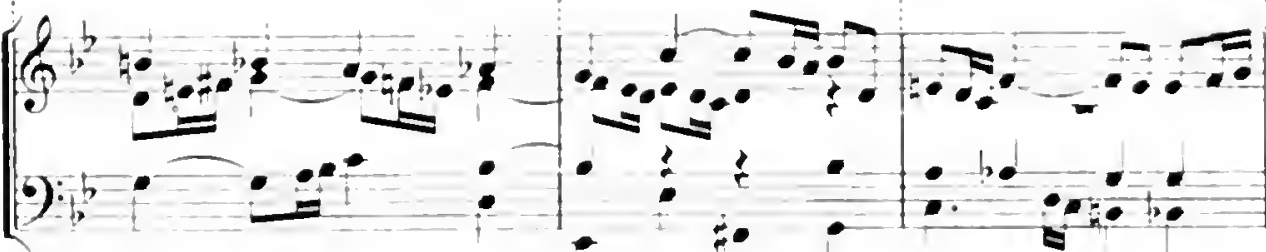




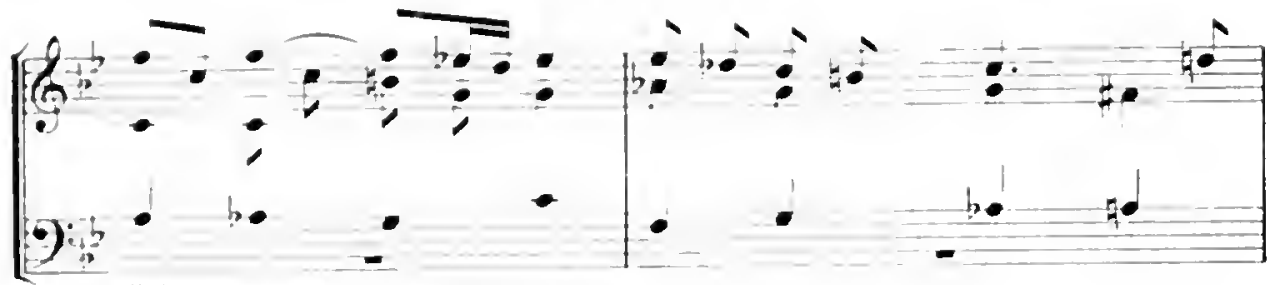

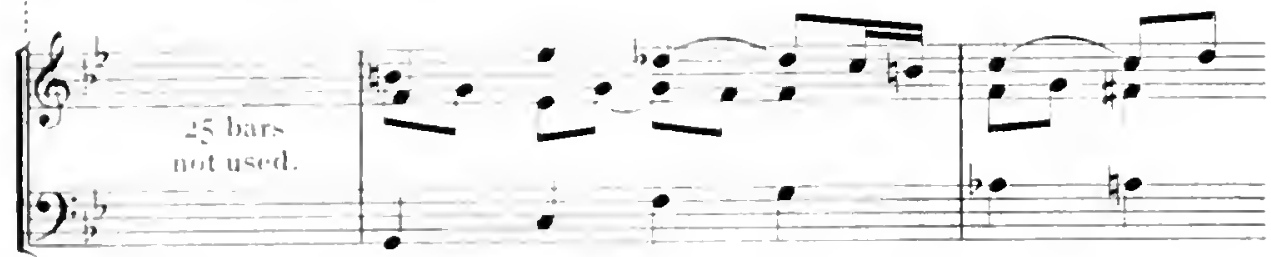

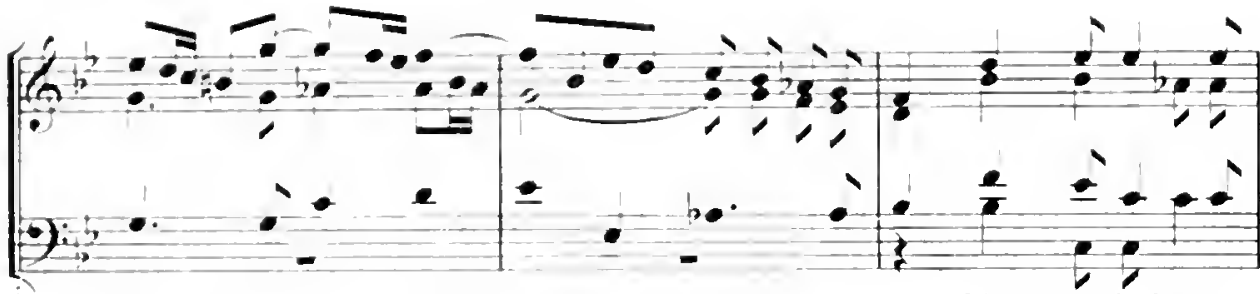

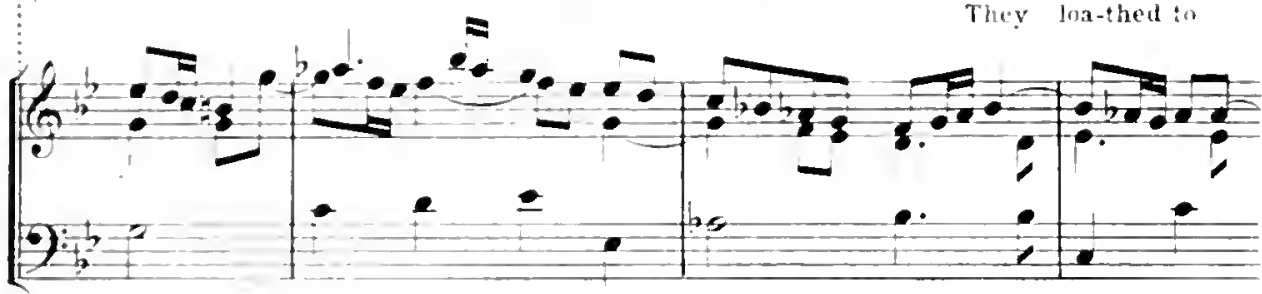

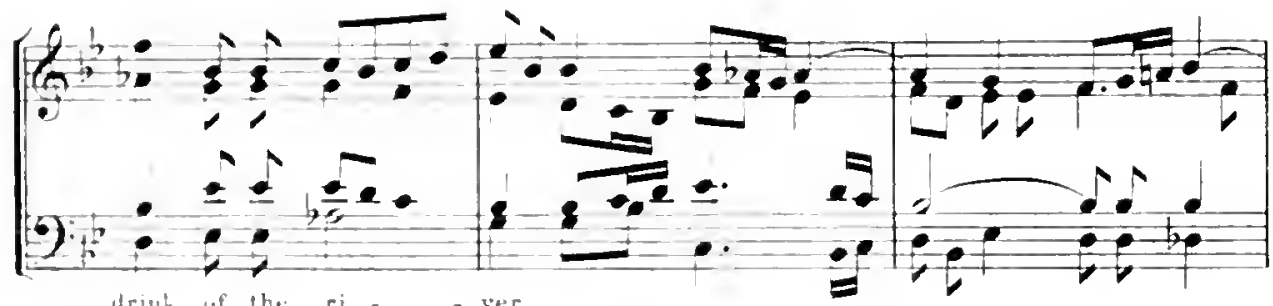

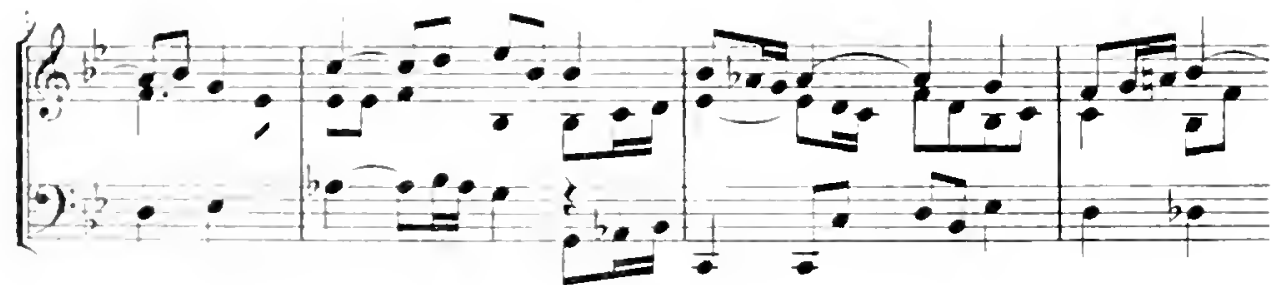


Ex. 26 icontinued.)
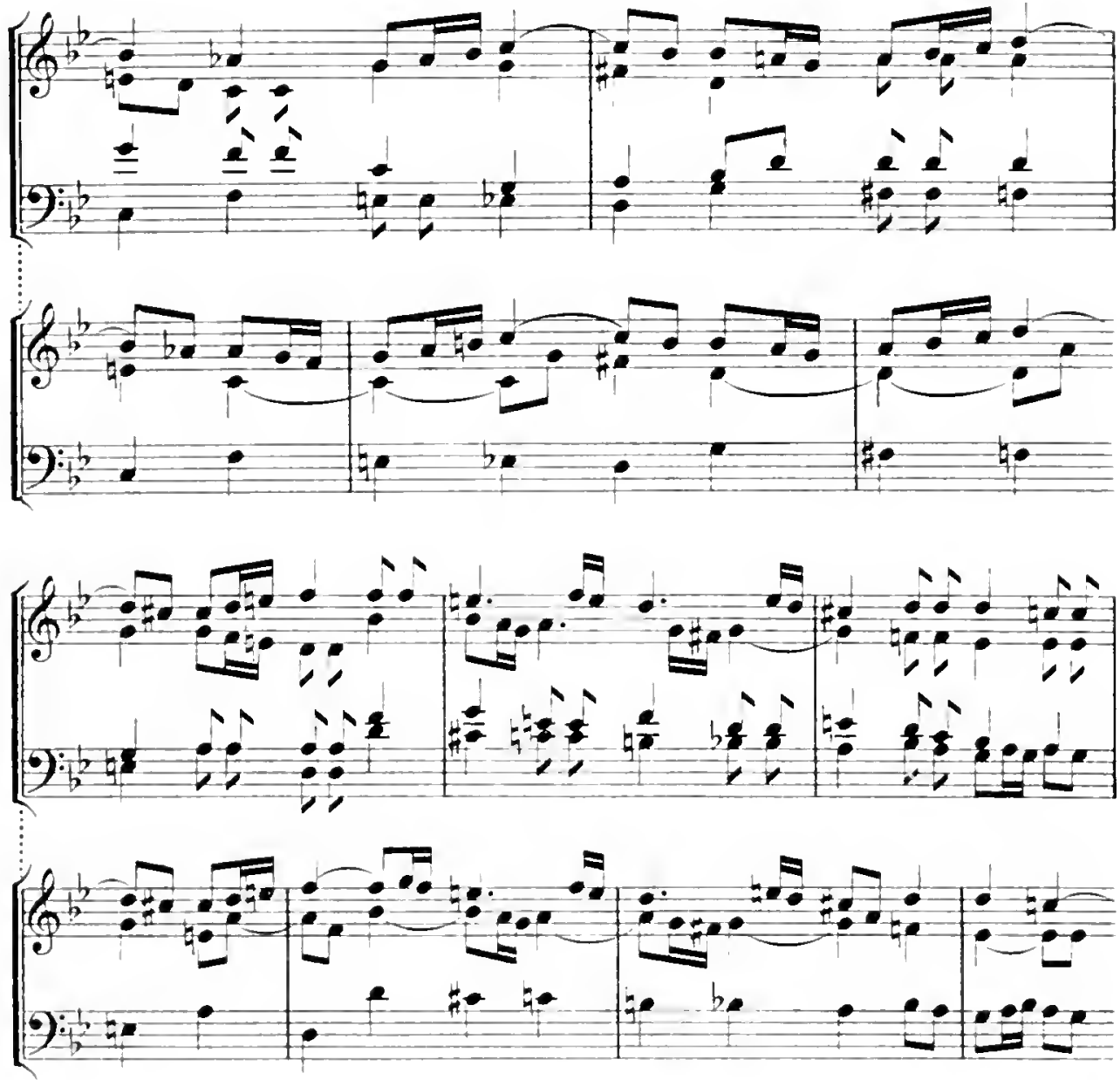

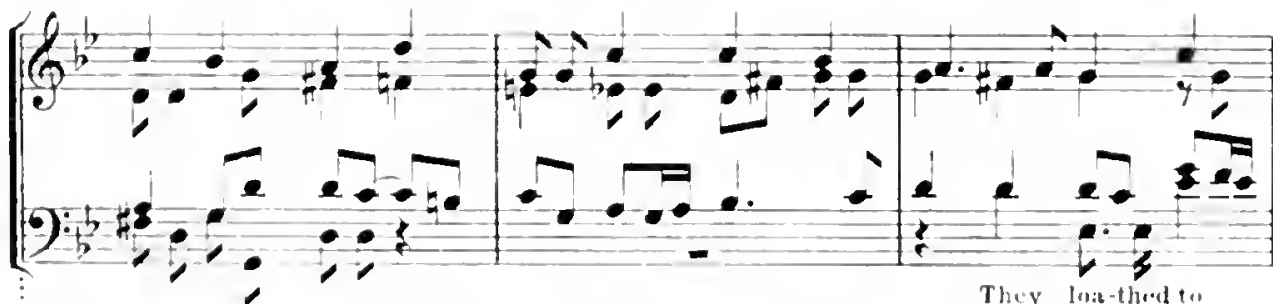

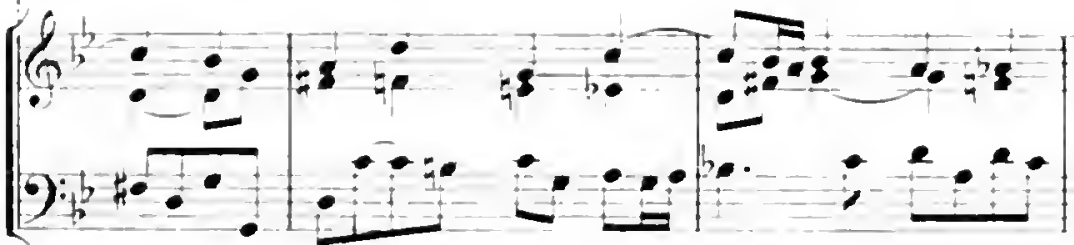


ISRALL IN EGITPT

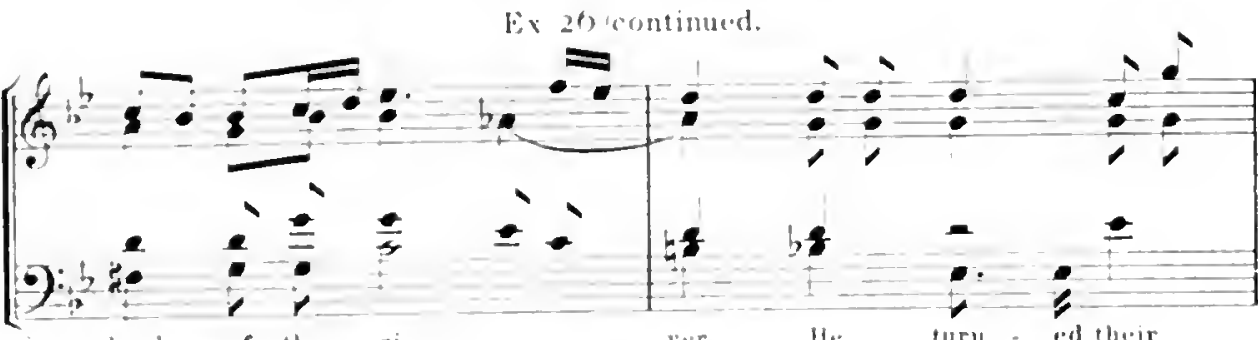

$$
\text { Irink of the ri - ver. Ho turn - ed their }
$$

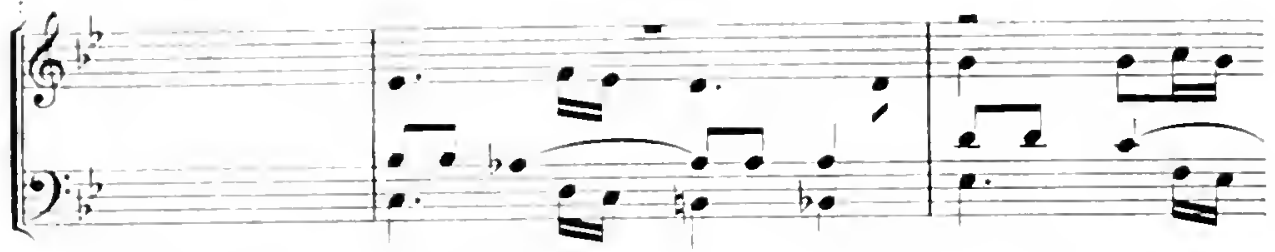

$\mid$

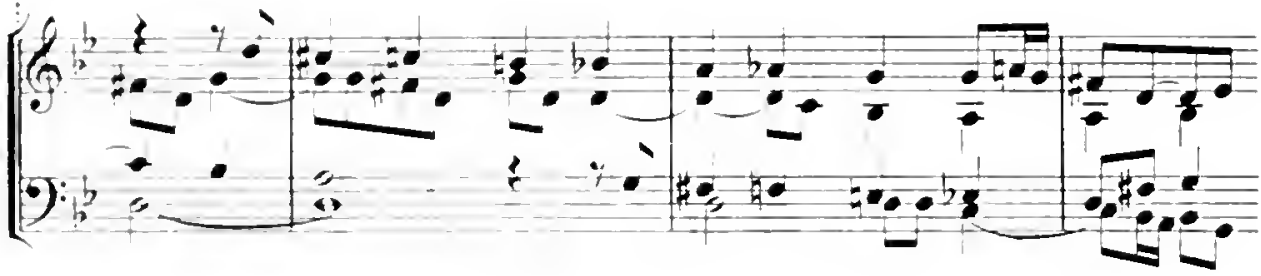

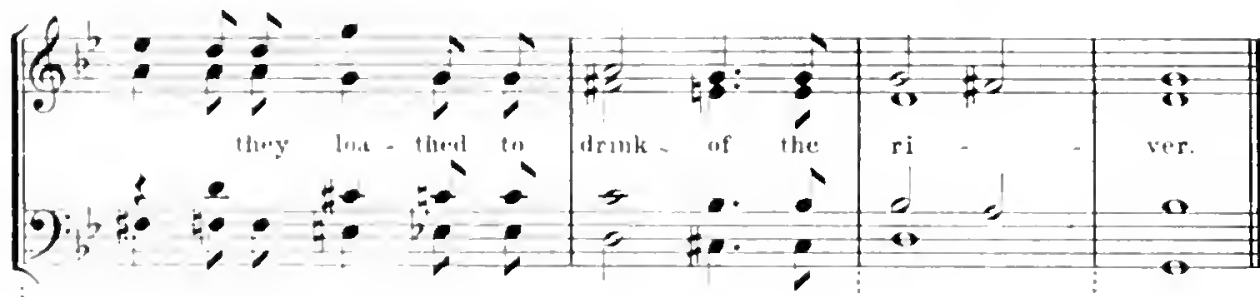

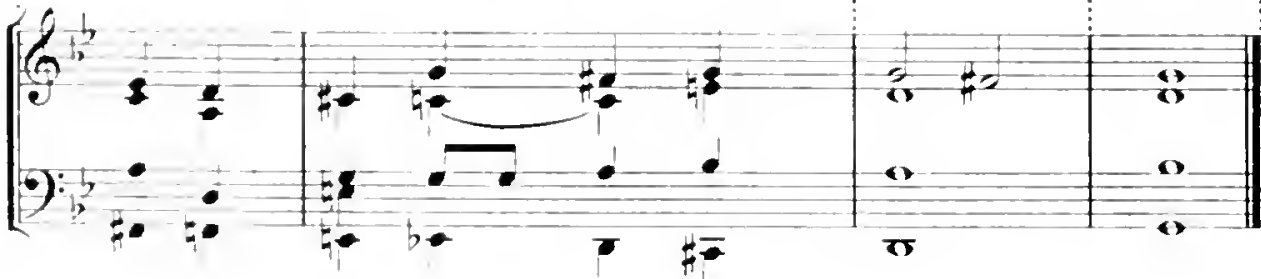


In turning this old organ-fugue into a chorus Handel has evidently effected great improvements in the disposition of his parts, especially in bars 22, 23, 33-36, 38-40. But a power of a much higher order is recognizable in the imagination which could discern in a not exactly inspiring organ-piece the makings of a choral picture so gruesomely descriptive as that which Handel has succeeded in producing. It suffices to play over on the pianoforte first the passages quoted from the organ-fugue and then the chorus, giving effect in the latter to the entries of the subject on "They loathed" and the descending chromatic scale-notes, in order to realize how astonishing this power is.

The Air "Their land brought forth frogs" has not been shown to be derived from any antecedent source.

The ensuing double chorus, (No. 6), "He spake the word," is taken, as far as the choral parts are concerned, with few, but very effective, inprovements, from a secular serenata composed by Alessandro Stradella. This will, therefore, be the proper place to tell the little that is known about that compuser, from whom, as will presently be seen, Handel took a good deal of material.

Alfssandro Stradella was a celebrated Italian composer in the seventeenth century and became the central figure of a romantic story which was afterwards put upon the stage as an opera. ${ }^{1}$ Subsequent researches having reduced the historical value of this story to zero, we learn from Herr Eitner ${ }^{2}$ that the course of Stradella's life is "wrapped in complete darkness." The dates of his birth and death are unknown and nothing of him but a large number of compositions appears to remain.

A score of one of these, entitled "Il Barcheggio," bears evidence that it was composed for a wedding-festivity which took place in 1681 . This date is written on two pages of the score, as is also a statement that $I$ Barcheggio was Stradella's last "sinfoniu" or "composizione." 3 No question of priority, therefore, can arise between a work by Handel aud one by Stradella, whose last composition is thus fixed at a date four years earlier than Handel's birth.

Dr. Chrysander published, in 1888, as No. 3 of his "Supplements," an edition of the serenata by Stradella which concerns us here, together with indications of where Handel had used it. The movement on which the chorus "He spake the word " is built up is an orchestral interlude for two separate groups of instruments, one scored for two violins and a bass, the other for a quartet of strings with doubled parts. These two groups alternate with each other throughont the movement in phrases varying from half-a-bar to two bars in length. This arrangement may well have suggested to Handel the idea of turning the movement into a double

\footnotetext{
1 Set to musie both by Flotow and by Niedermeyer in the fame year, 1837, (Art. in Frove' Dictionary.) 'M usiknlisches Quellen-Lexicon, article 'Stradella.'

Grove's Dictionary. lat ed. vol. 111. p. 723 uote 1.

Seo anto p. xi.
} 
chorus, which is what he din by adling a fourth part to Stralella's sualler groul, revising his cumberpoint with occasional masterly touches and composing deseriftive passages of orchestral acconpanment. Handel's chorus and the movement from struldela's serenata-the latter taken from Dr. Chrysancler's edition-are given in full in the following example:
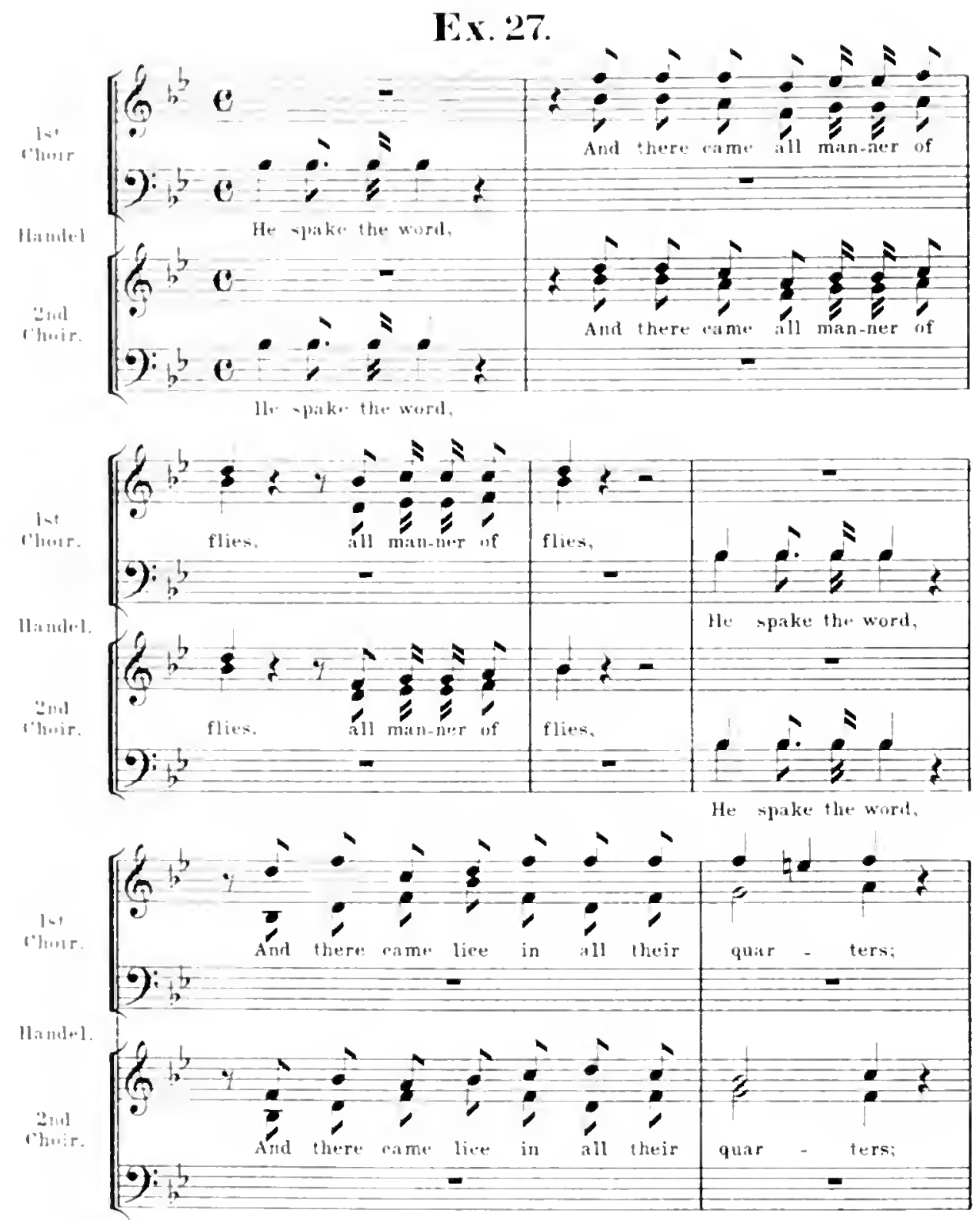


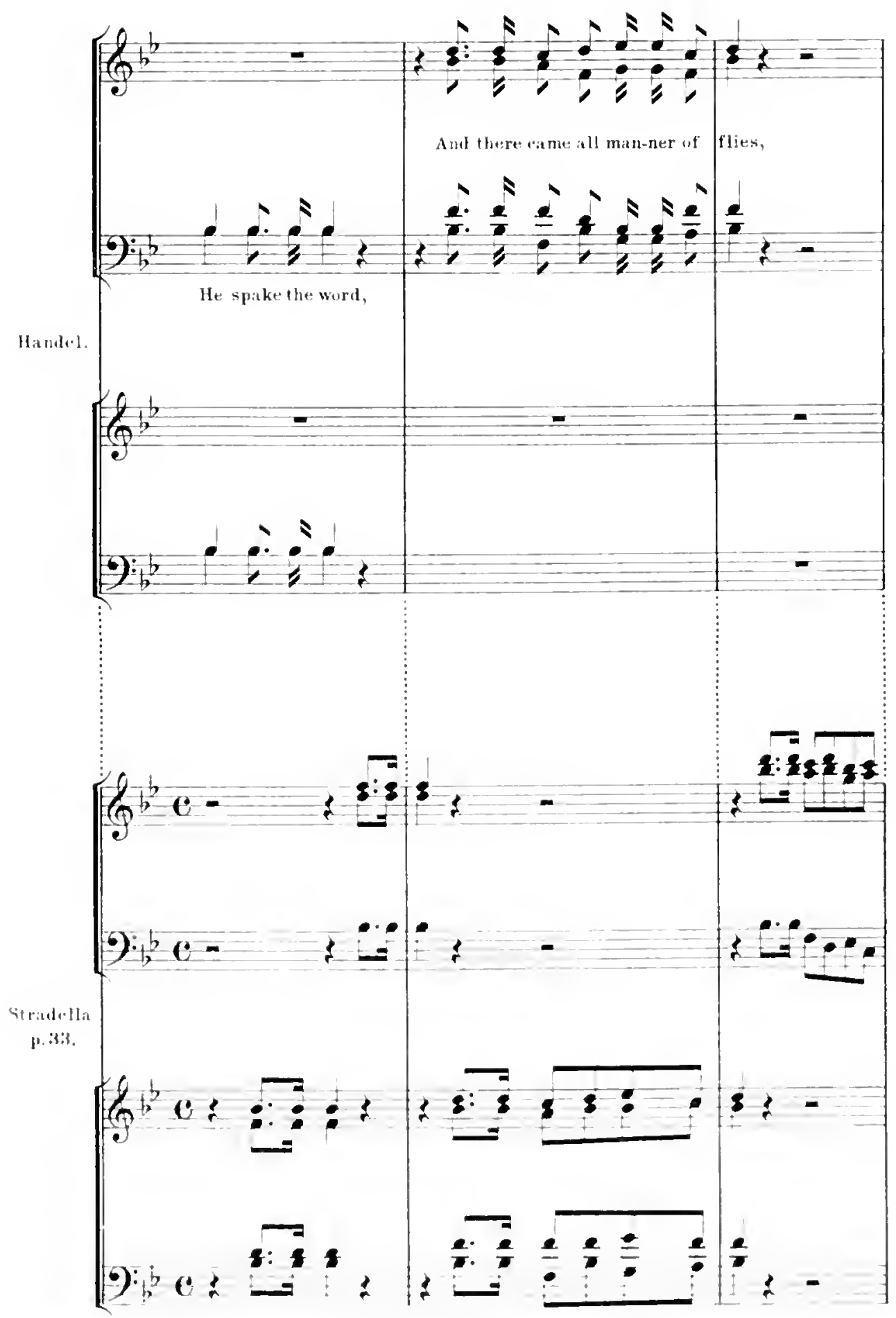




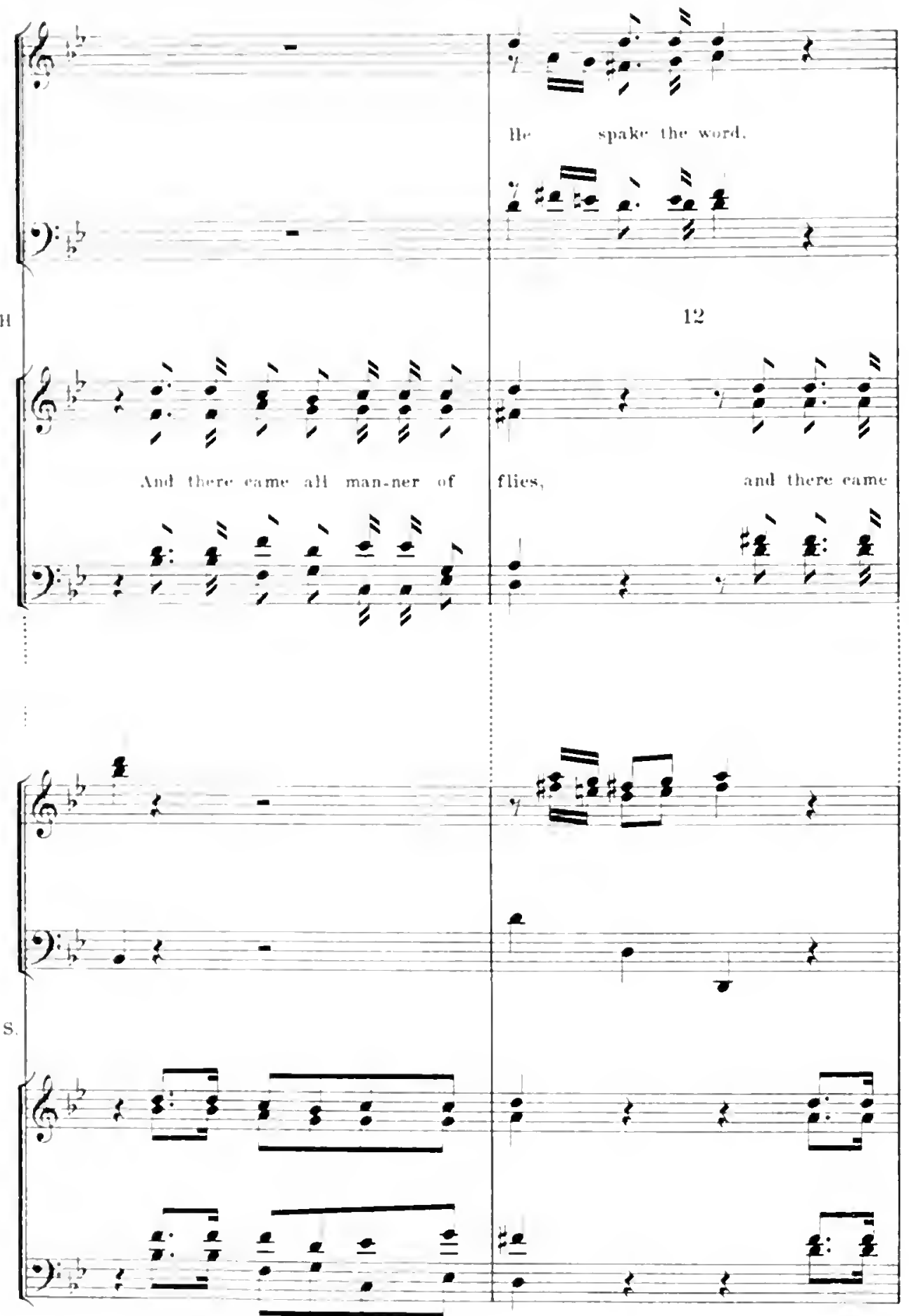




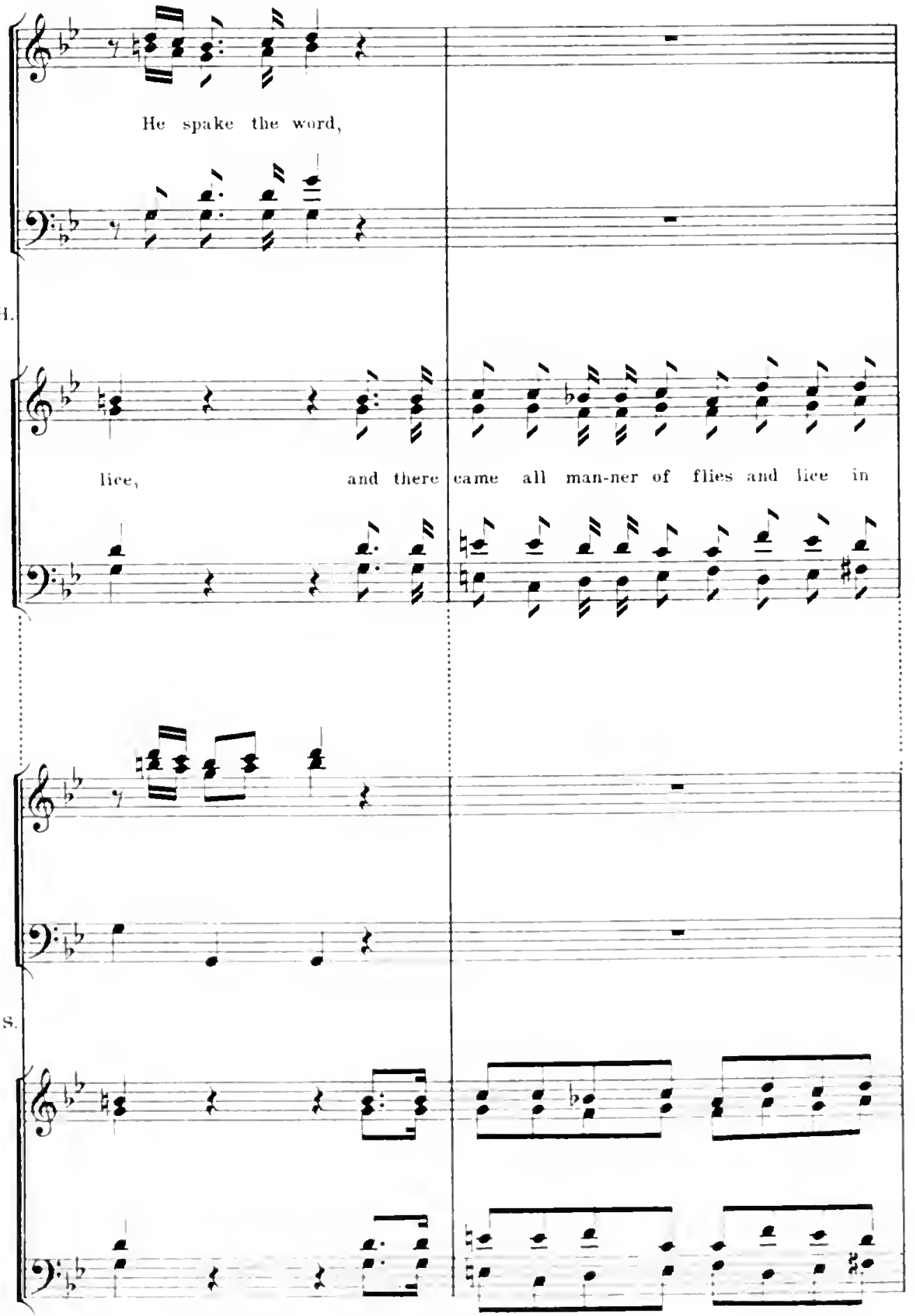




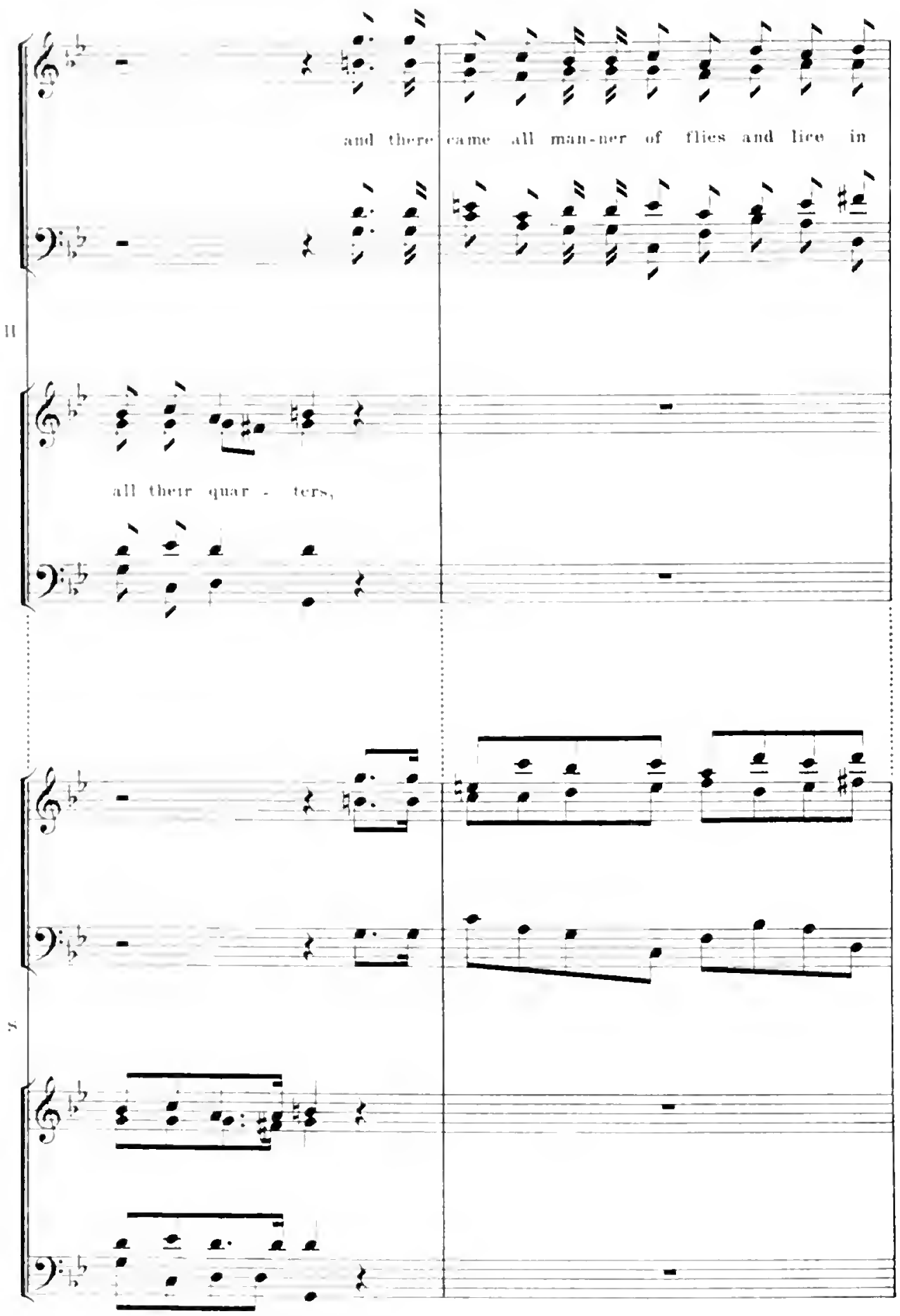



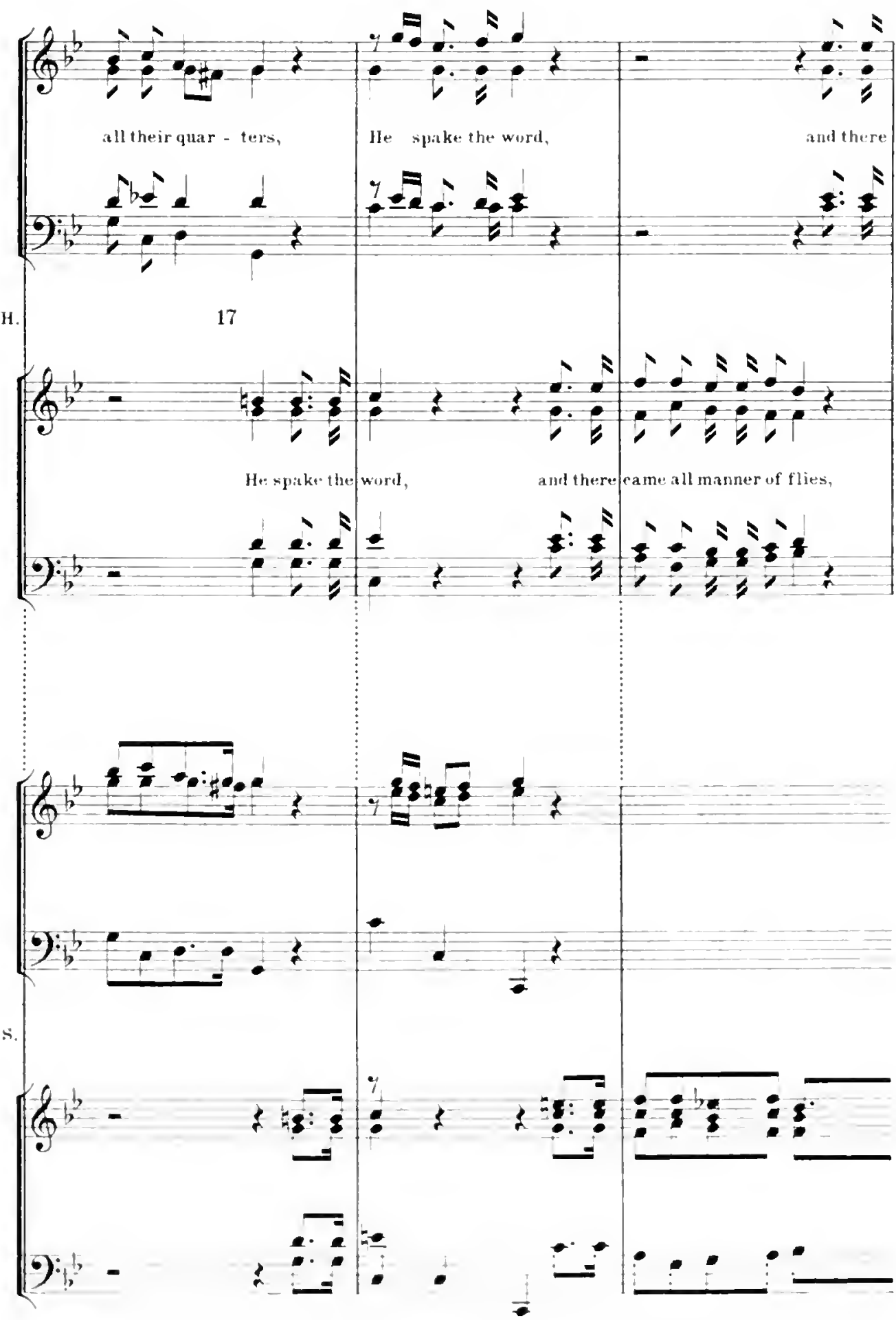


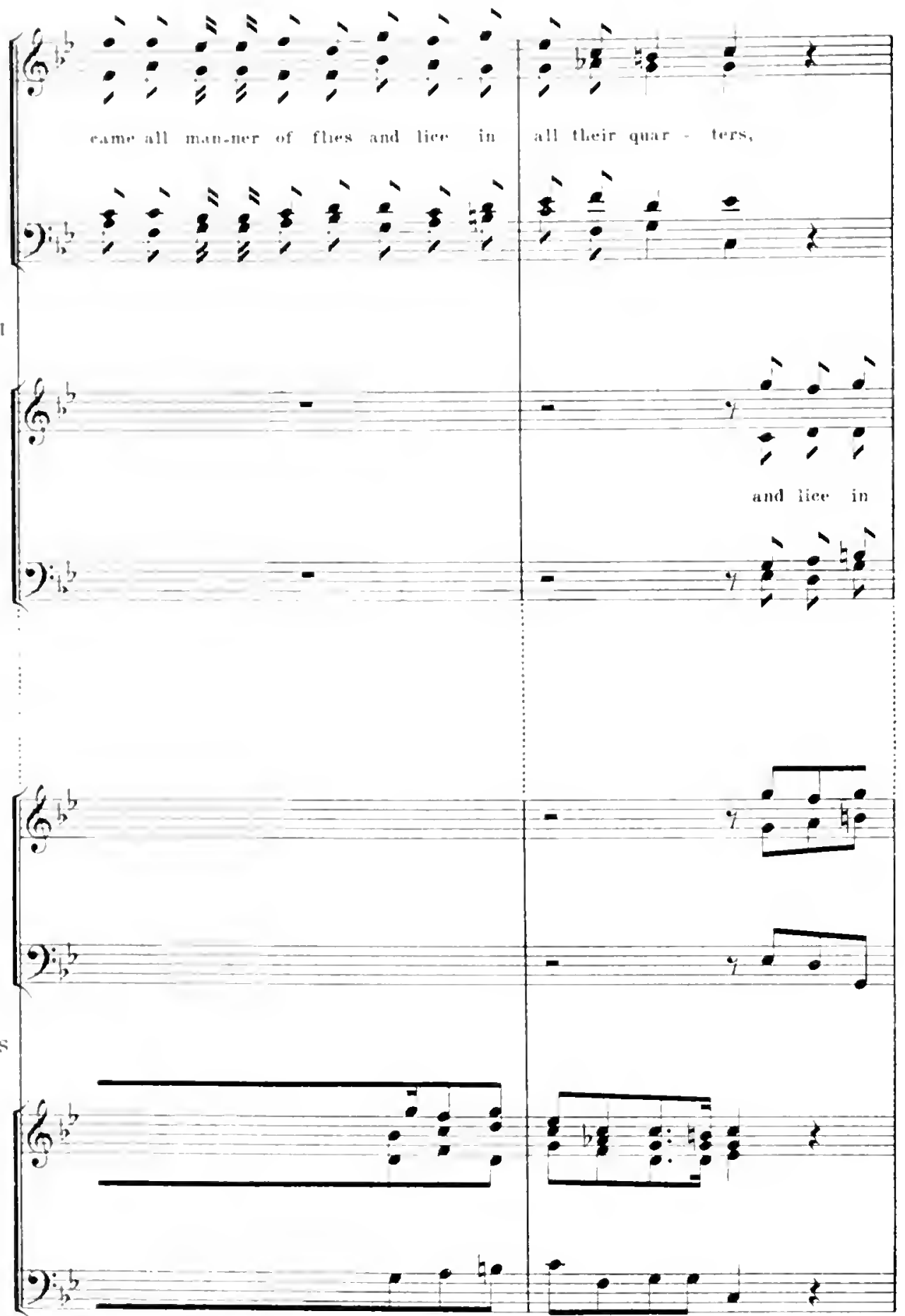


ISRAEL IN EGYPT

61

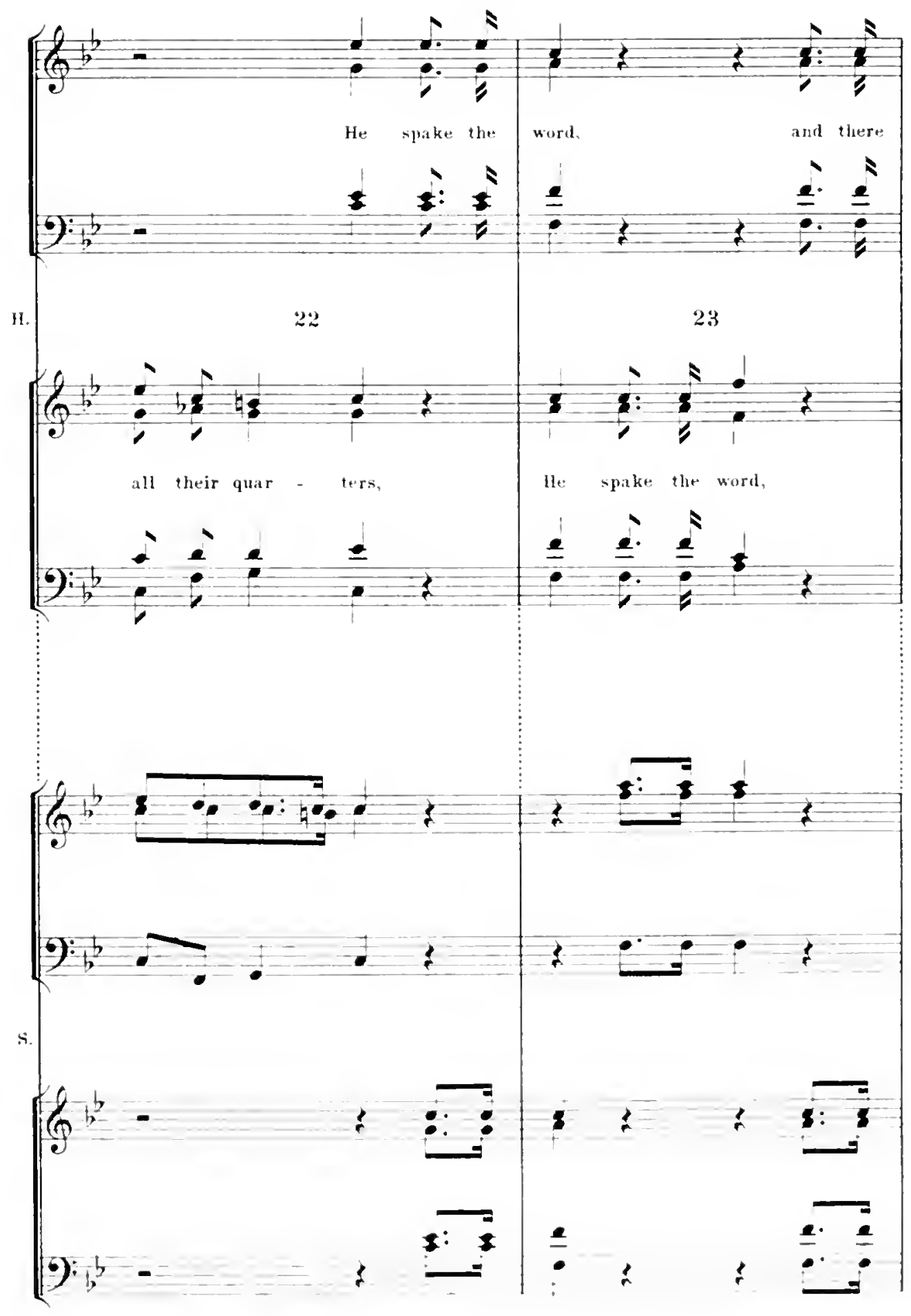




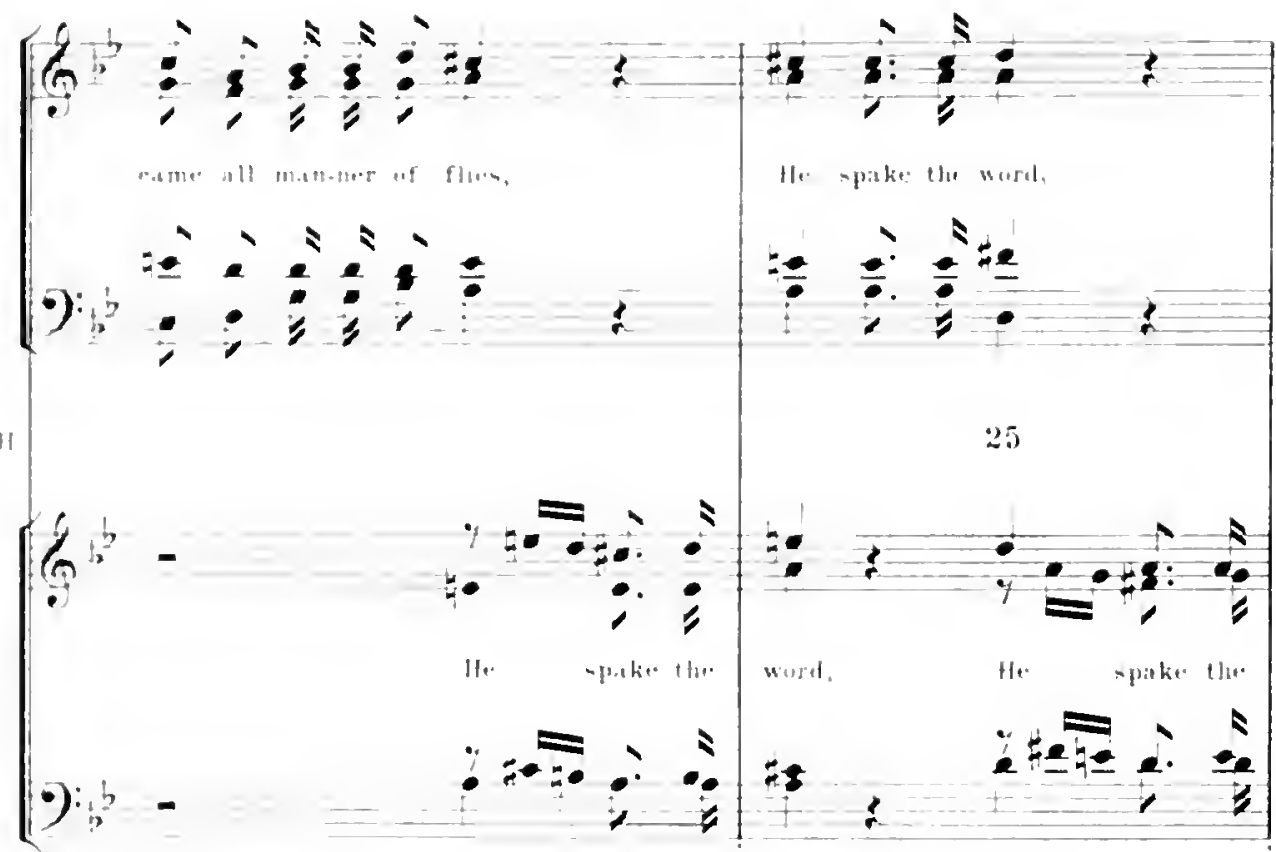

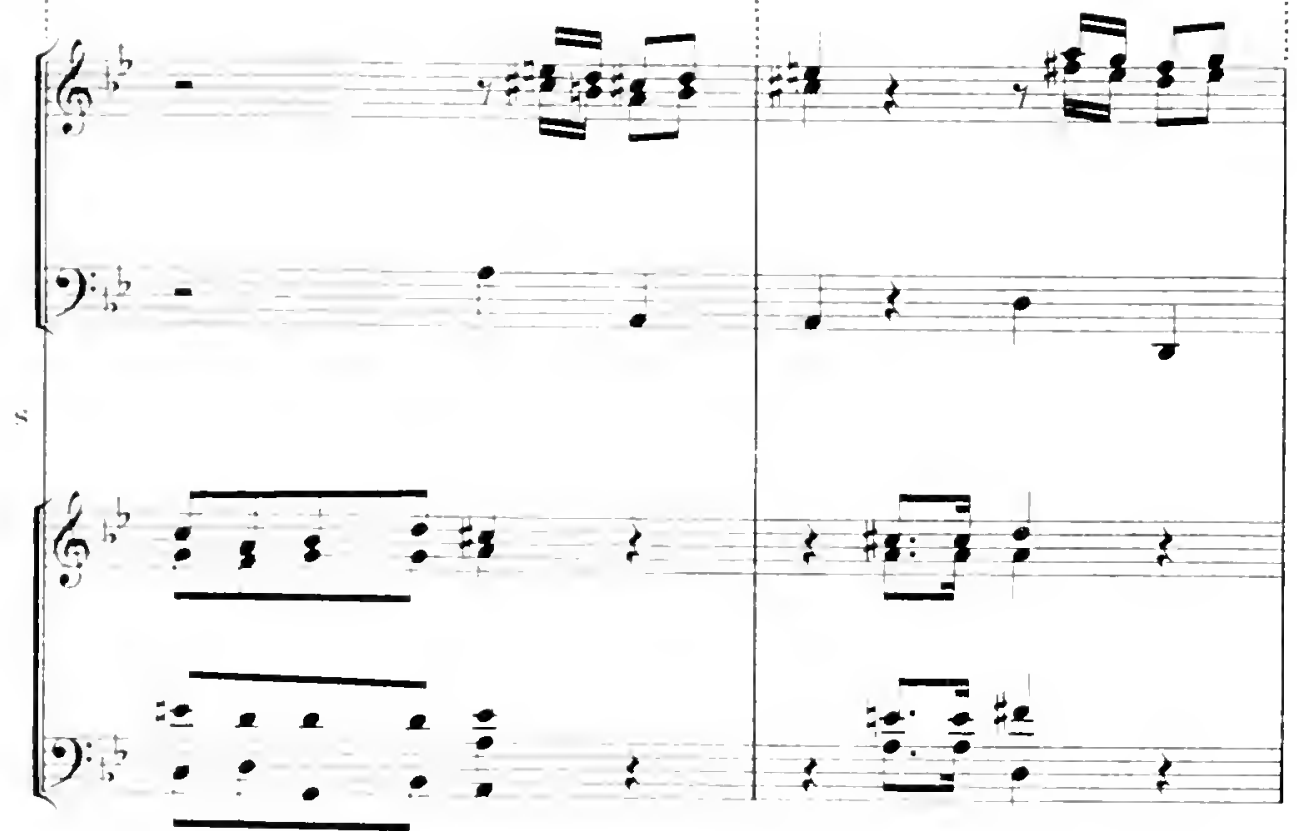



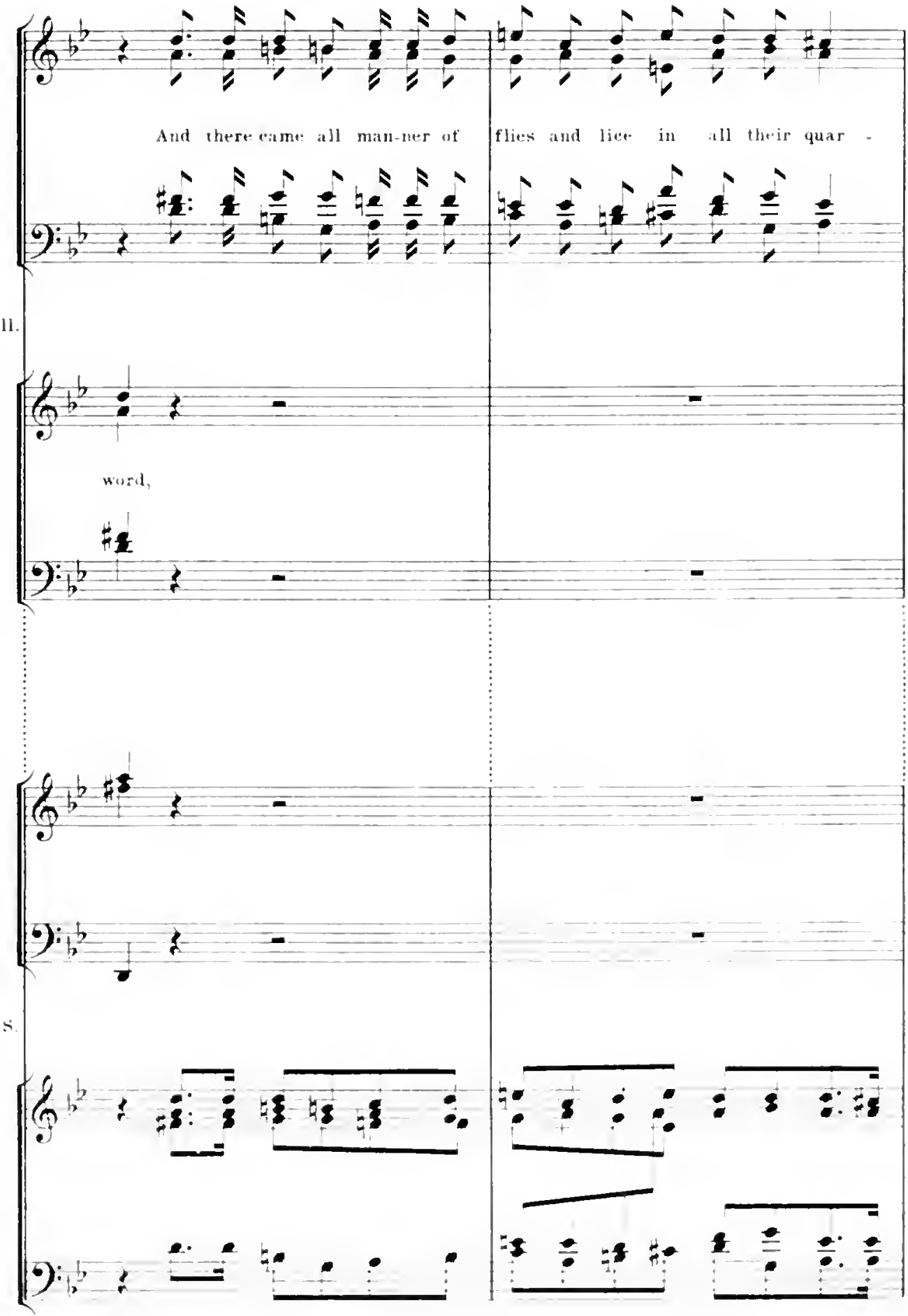


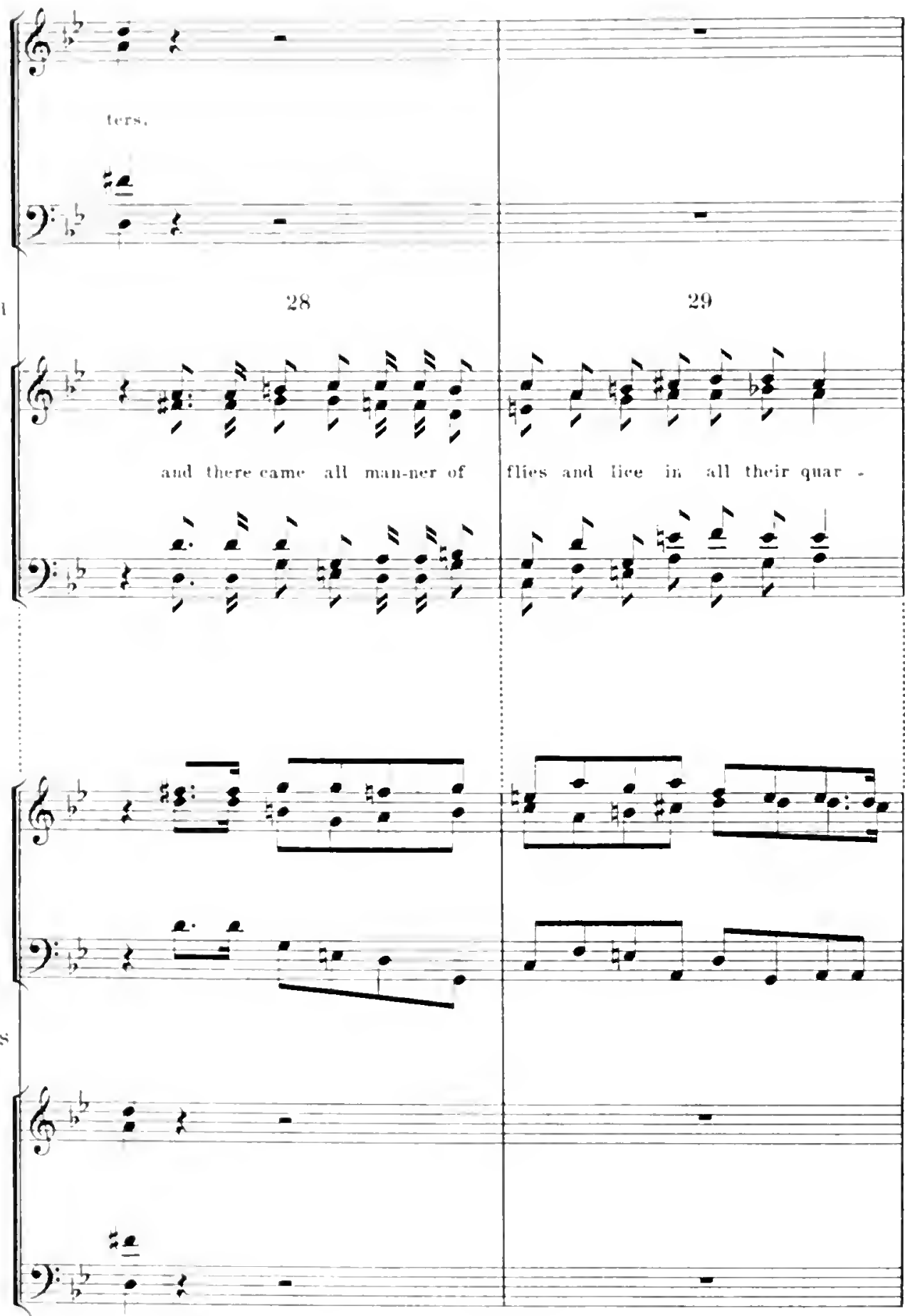




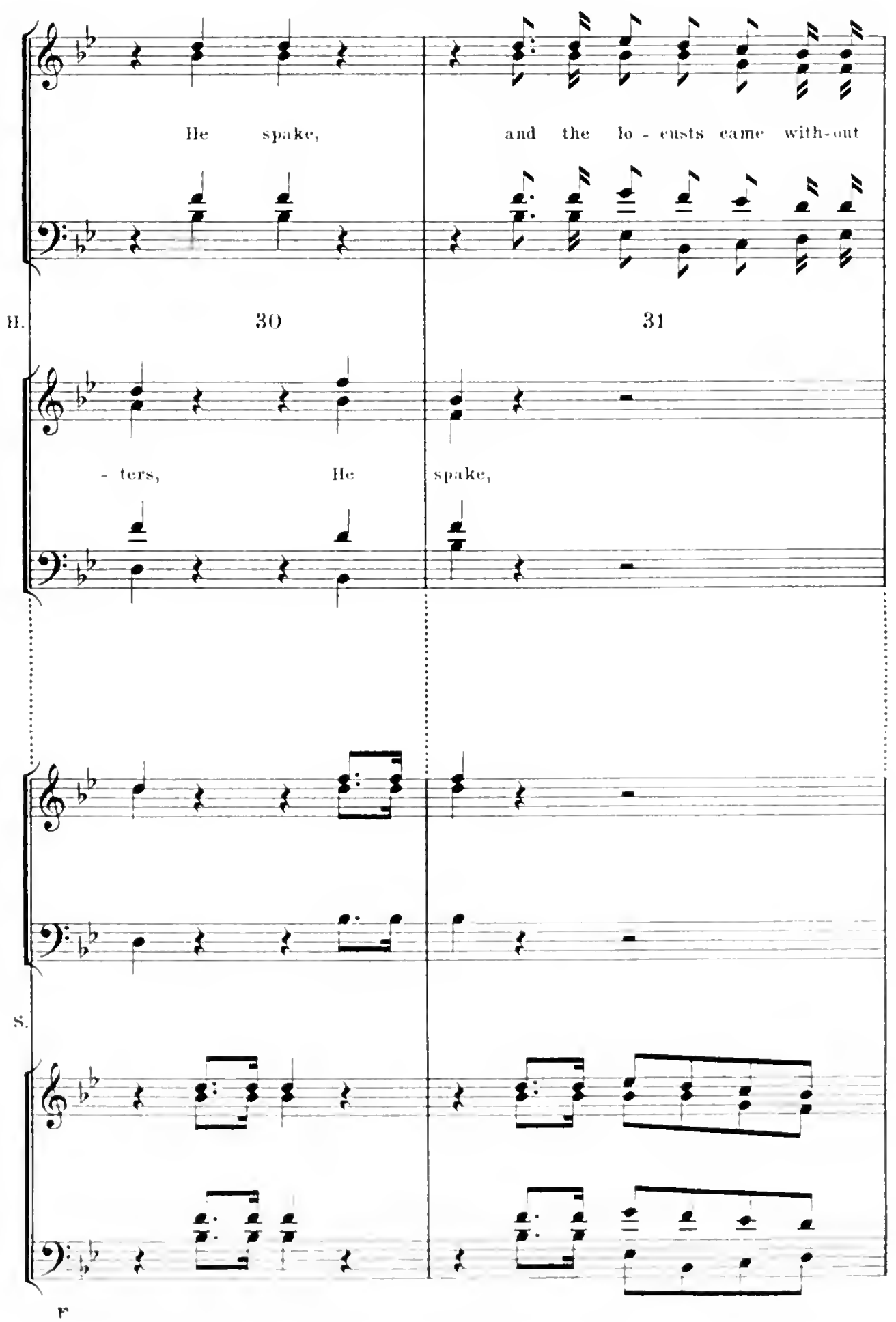




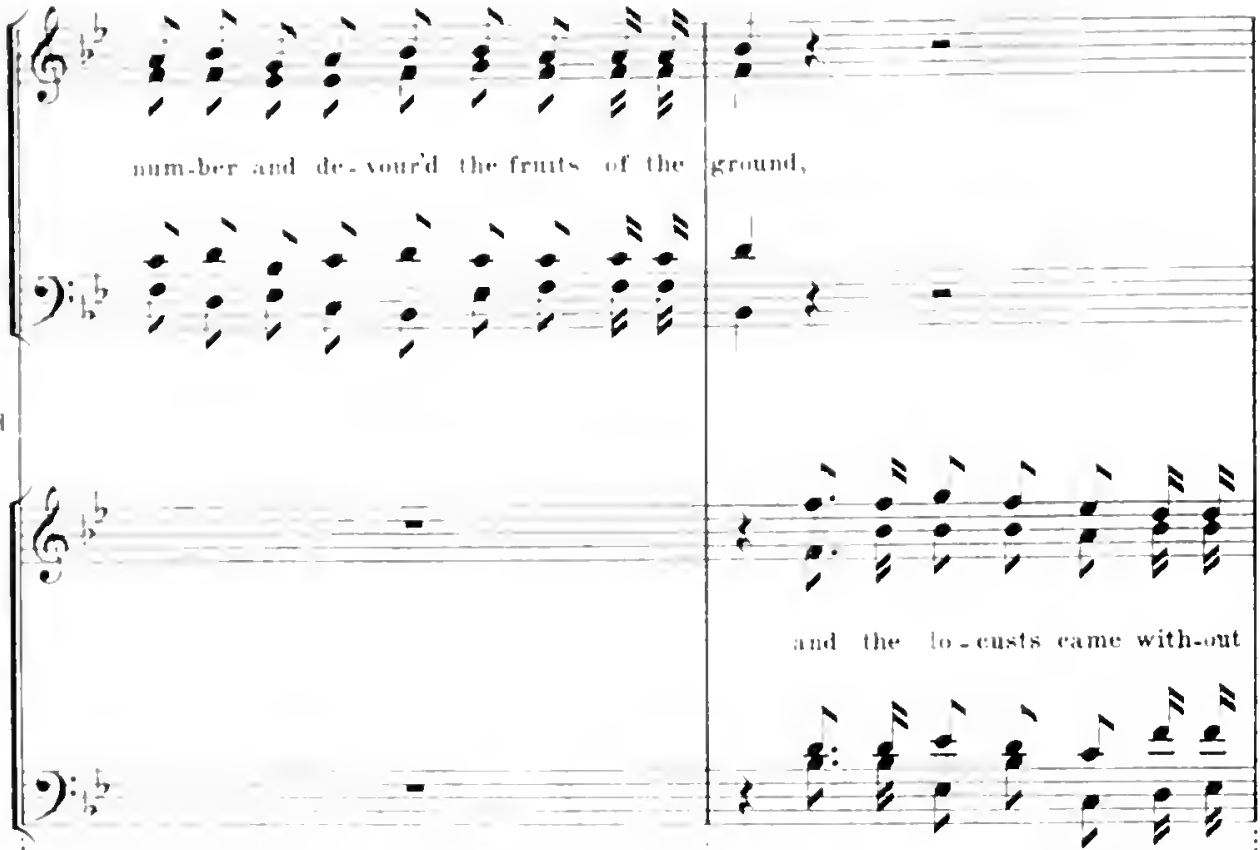

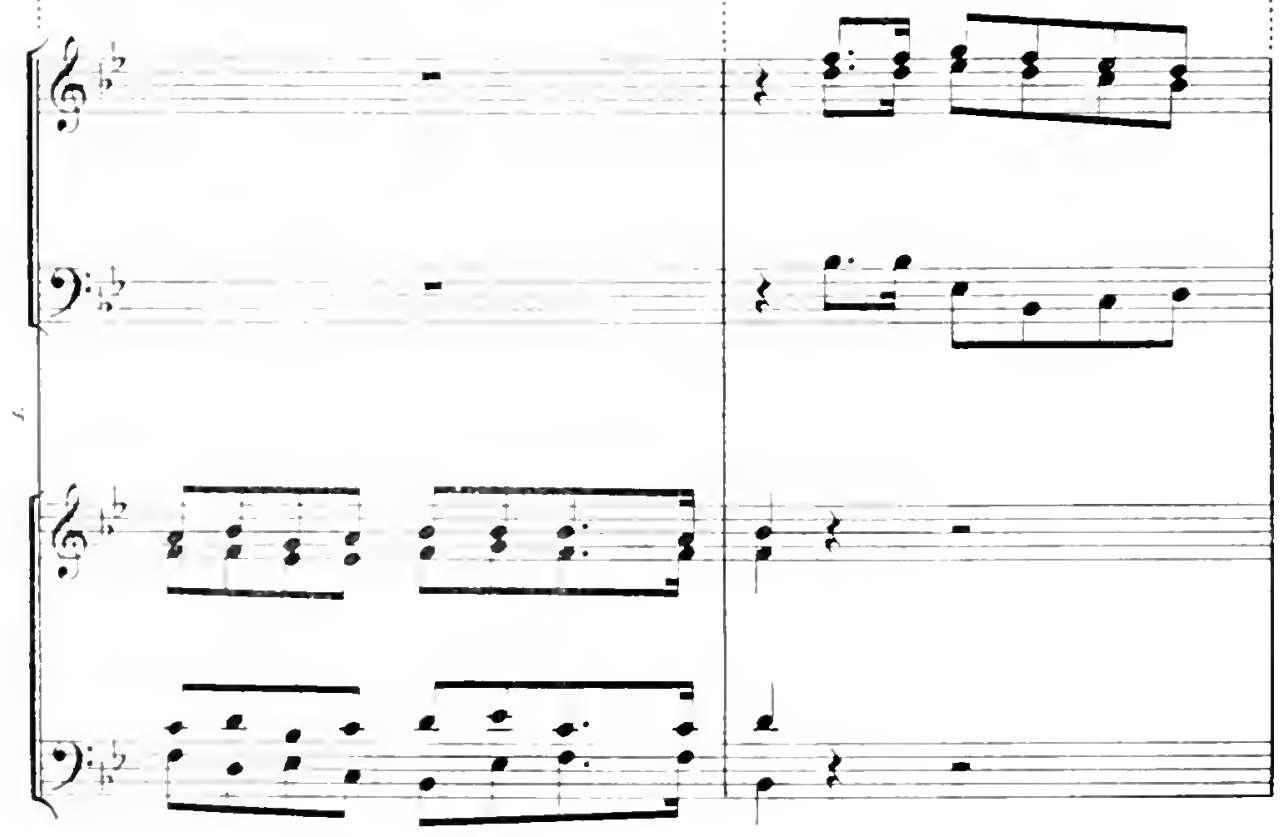




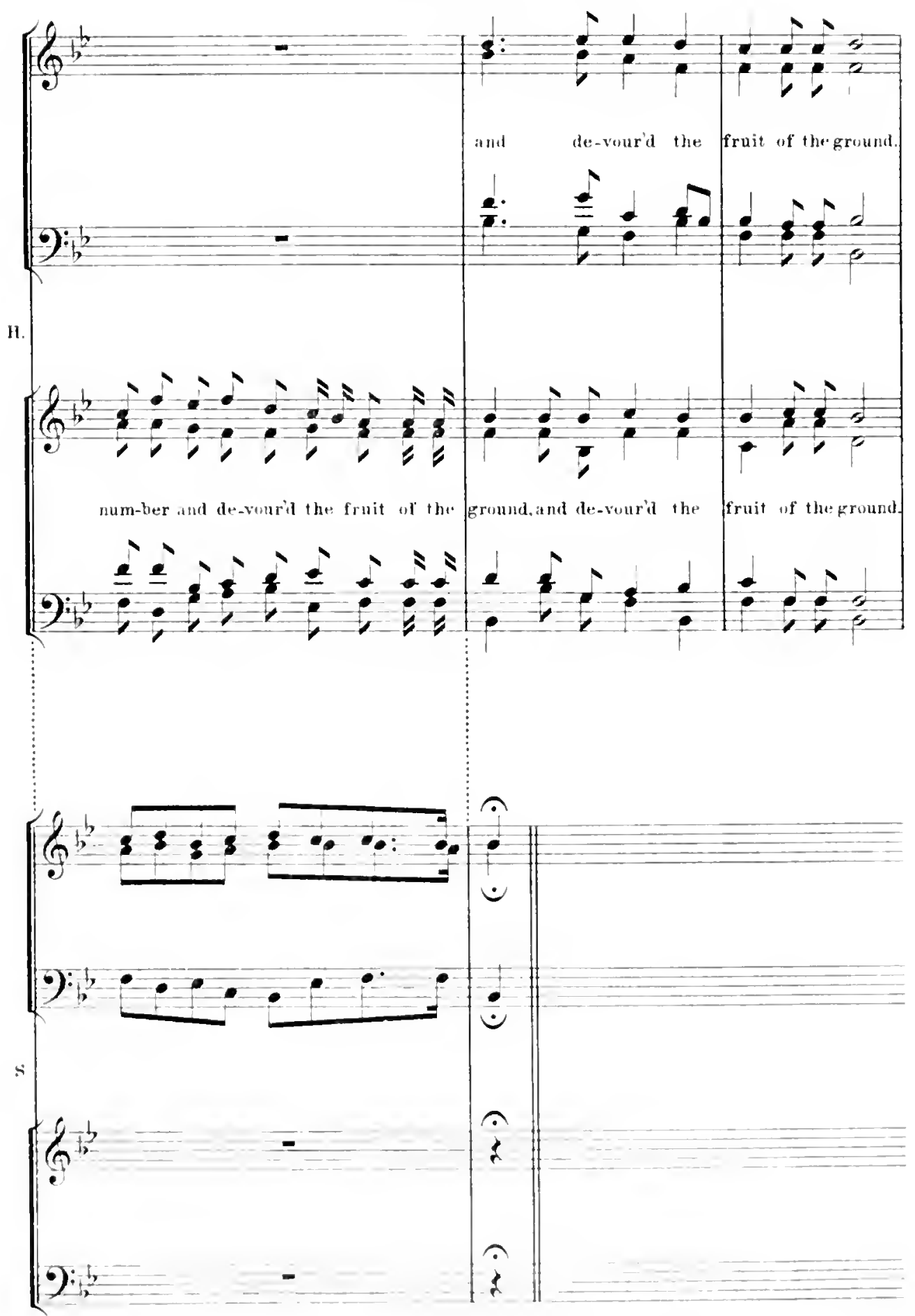


Ilandel opens his chorns with seven hars based on Stradella's material, but in five of these the sopranos and altos alone take part. Thus a sforrondo effect is produced when, after bar 8, where continnons borrowing from Stradella begins, mixed-roices harmony is for the first time lieard.

In bar 12 Handel obtains inerensed vigour by his added D in the first choir and by lowering Stradella's semi-quavers an octave.

In har 17 the two choruses overlap on the $3 \mathrm{rd}$ beat with a greatly enhaneed effect, which is hearl again in bars 22,23 and 25 .

In bars 22 and 23 there is a fine free movement in the two soprano parts where Stradella has none.

In bars 28 and 29 the connterpoint is immensely improved.

In the last beat of bar 30 and the first of bar 31 a wonderful impression of finality is conveyed by the Octave rise of the basses and the Fifth drop of the sopranos on "He spalie," where uothing of the kind exists in Stradella. Handel has reinforced these inprovements by an accompaniment of florid violin-passages in demi-semiquavers, which pervades the whole chorus, to suggest the buzzing of the flies, and in bars $31-34$ by a moving bass in semi-quavers, to illustrate the beavier calamity of the locusts coming "without number" to "devour the fruits of the grounl." "hrysander remarks that "the originality of the ehorus rests upon this accompraniucut." 1 Only if the narrowest and most literal meaning be assigned to "originality" can I admit this. In a higher sense true originality appears to me to be required in order to discern in Stradella's simple, and a trifle jorr-trot, piece of chamber-music the potentiality of being developed into a chorus which should present with almost terrifying energy the issuing of the supreme behest and its dire fulfilment. As was well said half-a-century ago:

"The imitation of the buzzing of insects in the accompaniment to Handel's chorus in Isracl in Egypt "He spake the word and there came all manner of flies" were merely an ingenious trifle, but for the superlative grandeur of the choral passages which tell of the Alnighty fiat." 3

The orchestral introduction to the next, the famons "Hailstone," chorus, (No. 7), probably the greatest popular favourite of the entire oratorio, is made up of eleven bars taken from the opening of the 'Sinfonia' to Stradella's Serenata, and four from that to a bass song in the same work, the former standing in the key of $D$, the latter in that of $\mathrm{A}$. Handel's contribution to his own prelude consists at most in three original bars as against fifteen taken from Stradella.

1 Life of Handei vol. III. p. 66.

2 Townsend: “Visit of Handel to Dublin:" Dublin 1852 p. 92. 
Ex. 28.
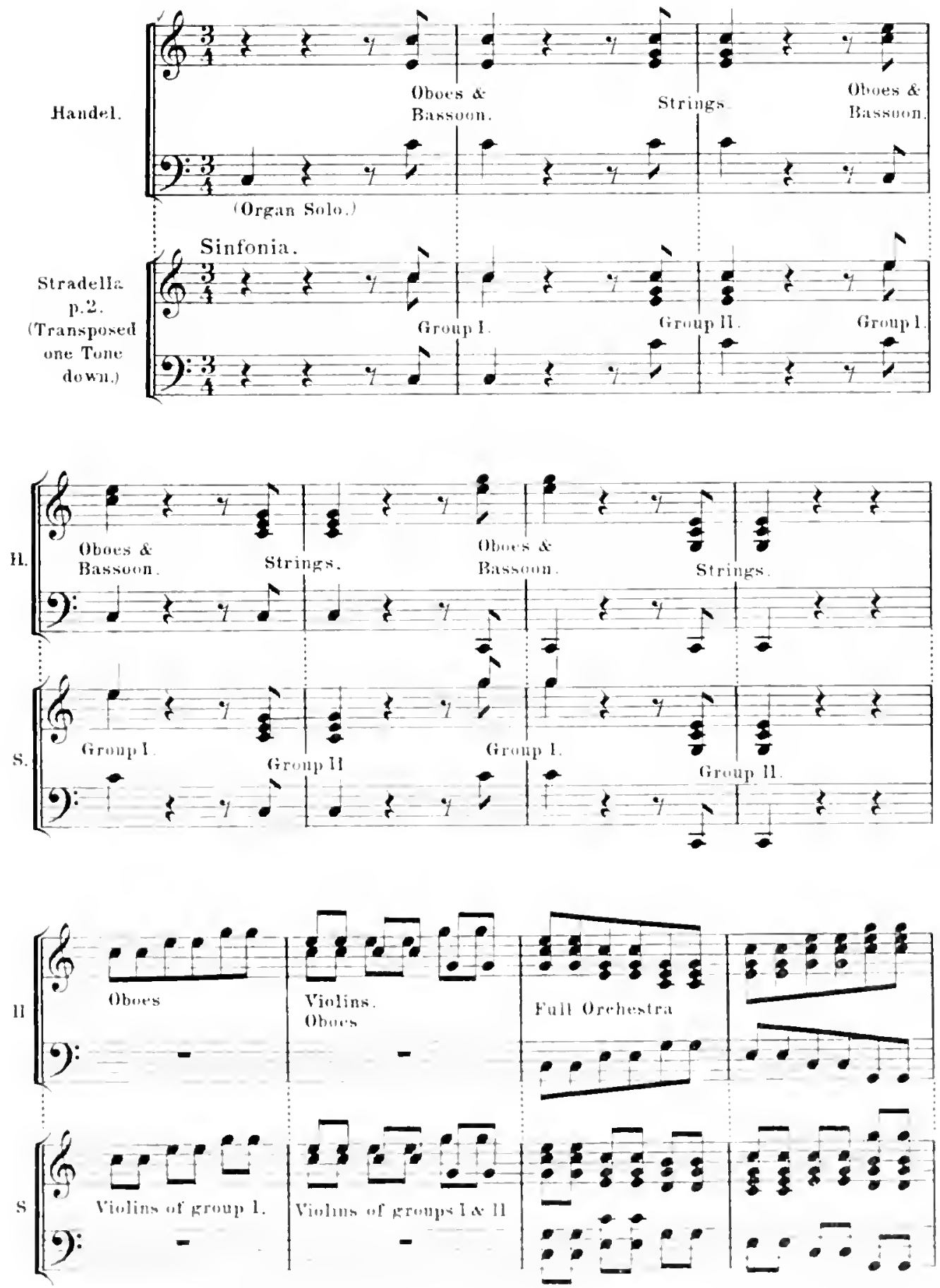
70

ISRAEL IN EGYPT

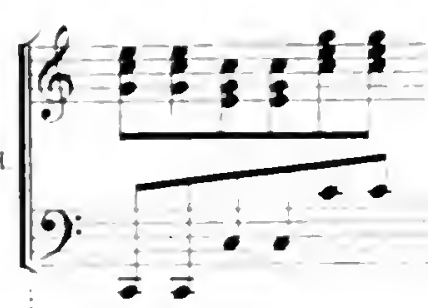

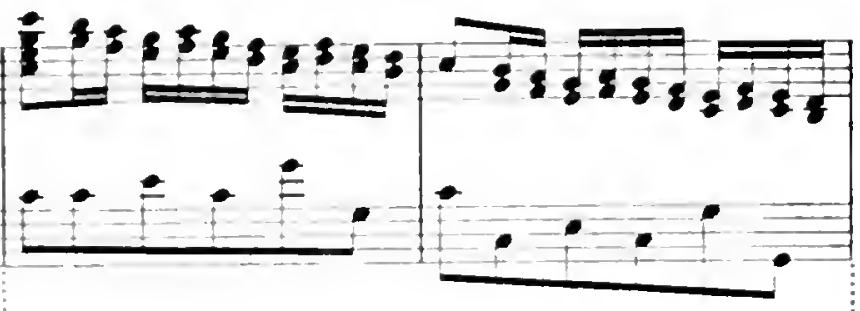

$\left[\begin{array}{l}6 \\ 6\end{array}: ?\right.$

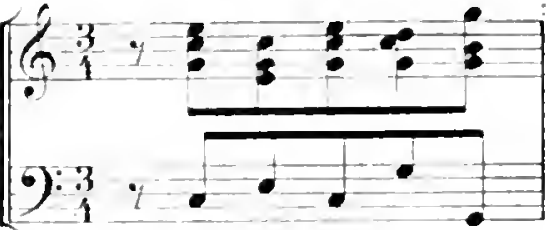

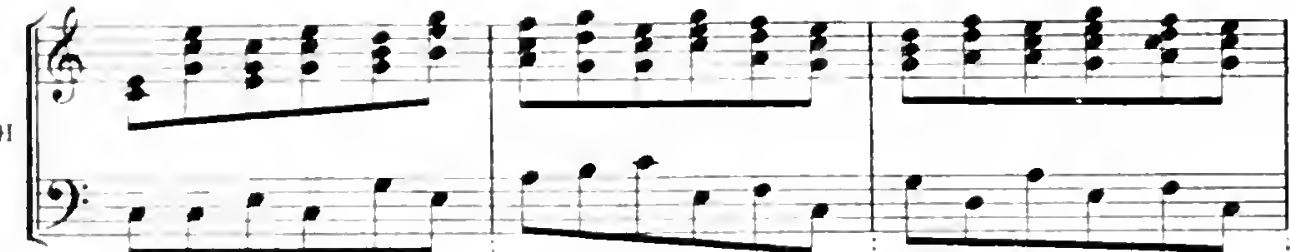
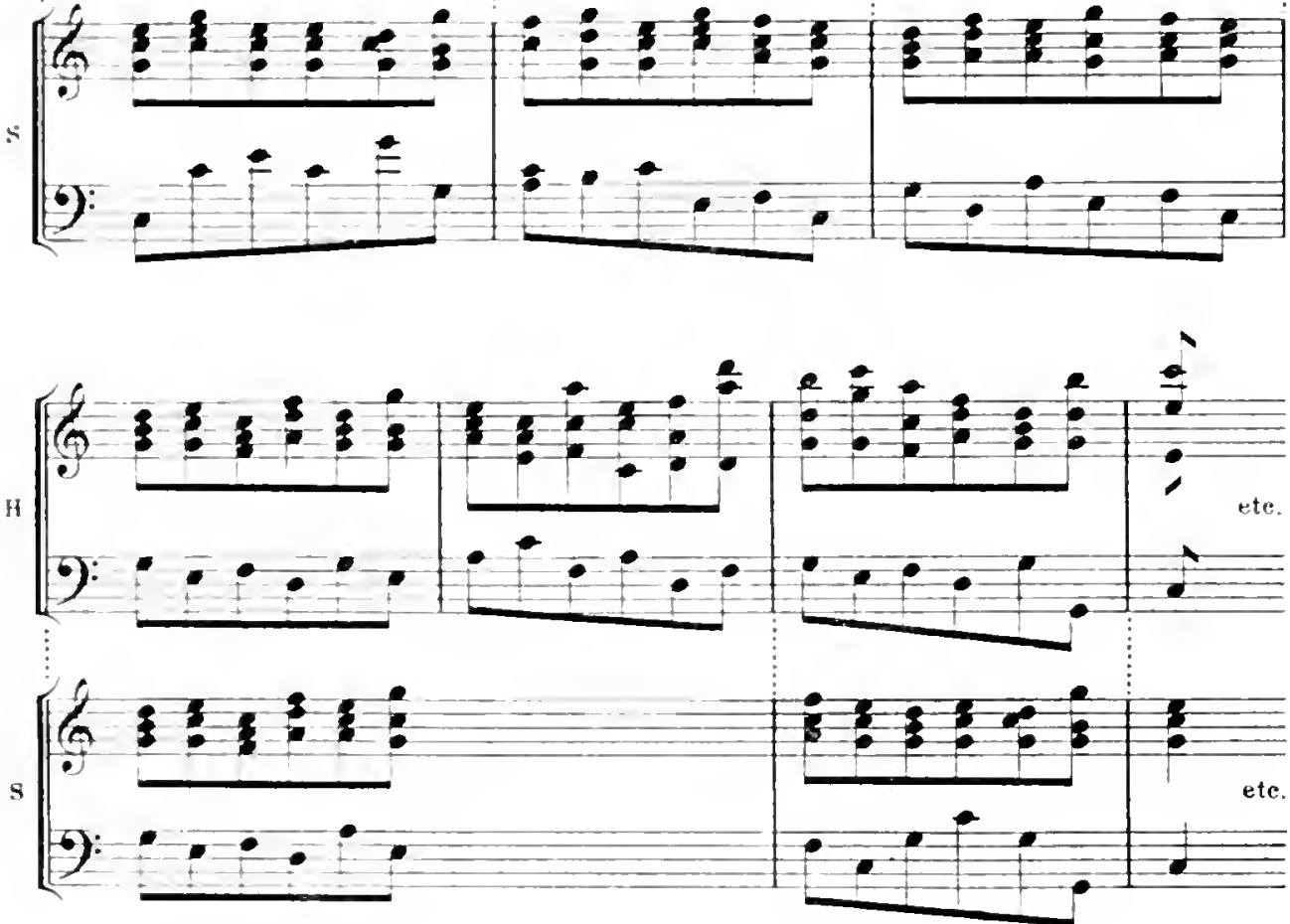
The fine flowing passage set to the words "ran along upon the ground" is written on a bass in Stradella's song, the second bar of which had already appeared in the symphony to it, and been incorporated in Handel's sixteenth bar:

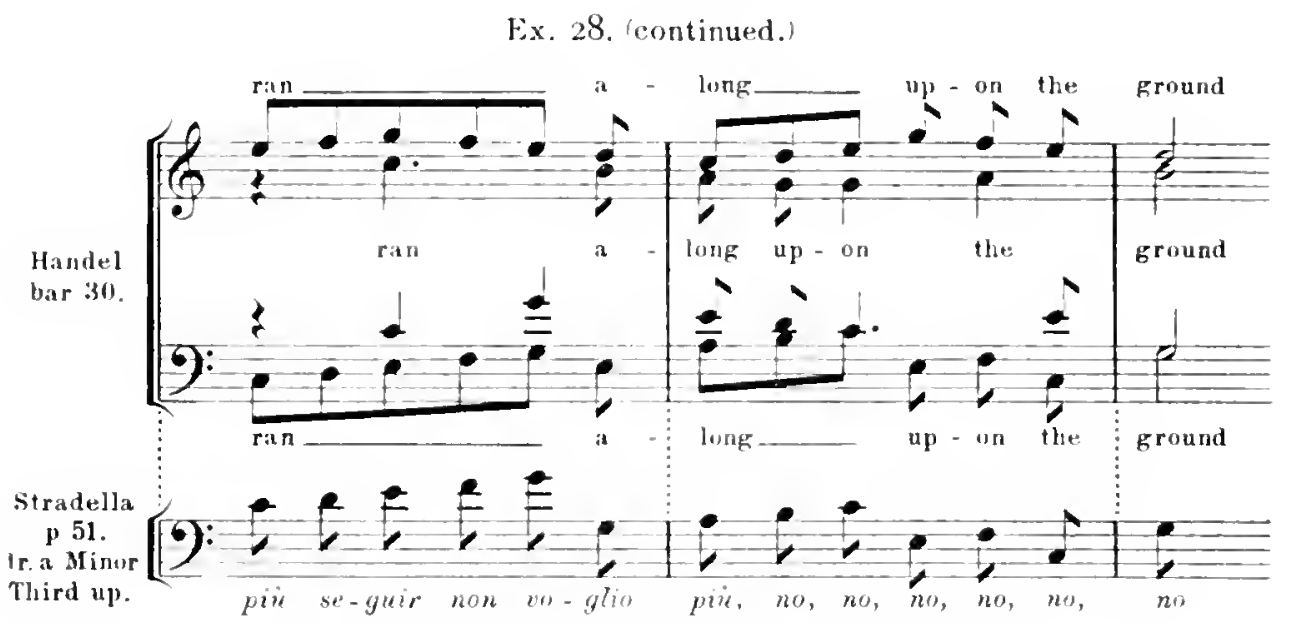

Finally an energetic plrase is taken from the same song, and its force greatly intensified by the repetition of its first bar and the extension of its descending scale.

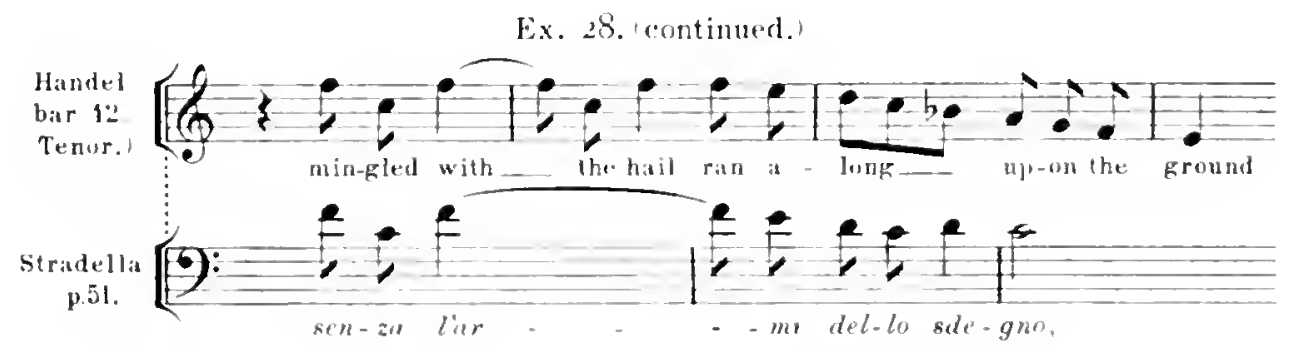

Of the chorus proper, apart from the opening symphony (which is repeated at the close, cut down to half its length and with no original matter introduced) nearly one-half is mere rearrangement, or contrapuntal development, of the phrases from Stradella which have been set out in Ex. 28.

It camot be denied that these supply the most interesting material to be fornd in the chorus, but there remain as IIandel's property the vigorous alternating entries of the two choirs and the wonderful choral shouts of "fire" first with simple accompaniment and at last with a magniticent moving bass. But, when all has been said, we are no nearer to understanding how it was that Handel could detect the possililities which lay hid in these, to ordinary observers rather nuinteresting passages, and work them up with other matter of his own into a colossal sound- 
ficture, vivd, subline, instinct with it terribe chergy and perfectly lomogeneous fron one eml to the other. While we must, I think, rank the power of doing this lus hinhly than that of produciug an entirely original composition of equal merit, the mane of genius can hardly be refused to it when it attains such results an are "mbodied in the "Hailstonc chorus."

l'assing ovel No. 8, the chorus "He sent a thick darkness," which appears to be urivinal, we come to No. ?, the chorus "He smote all the first-born of Egypt." The subjects of it are taken from another of the set of organ-fugues mentioned above," but, as the treatment of them diverges willely after their first entry, it will suffice tor conpare the openting eight bars of the two compositions, as is doue in the next lixample:
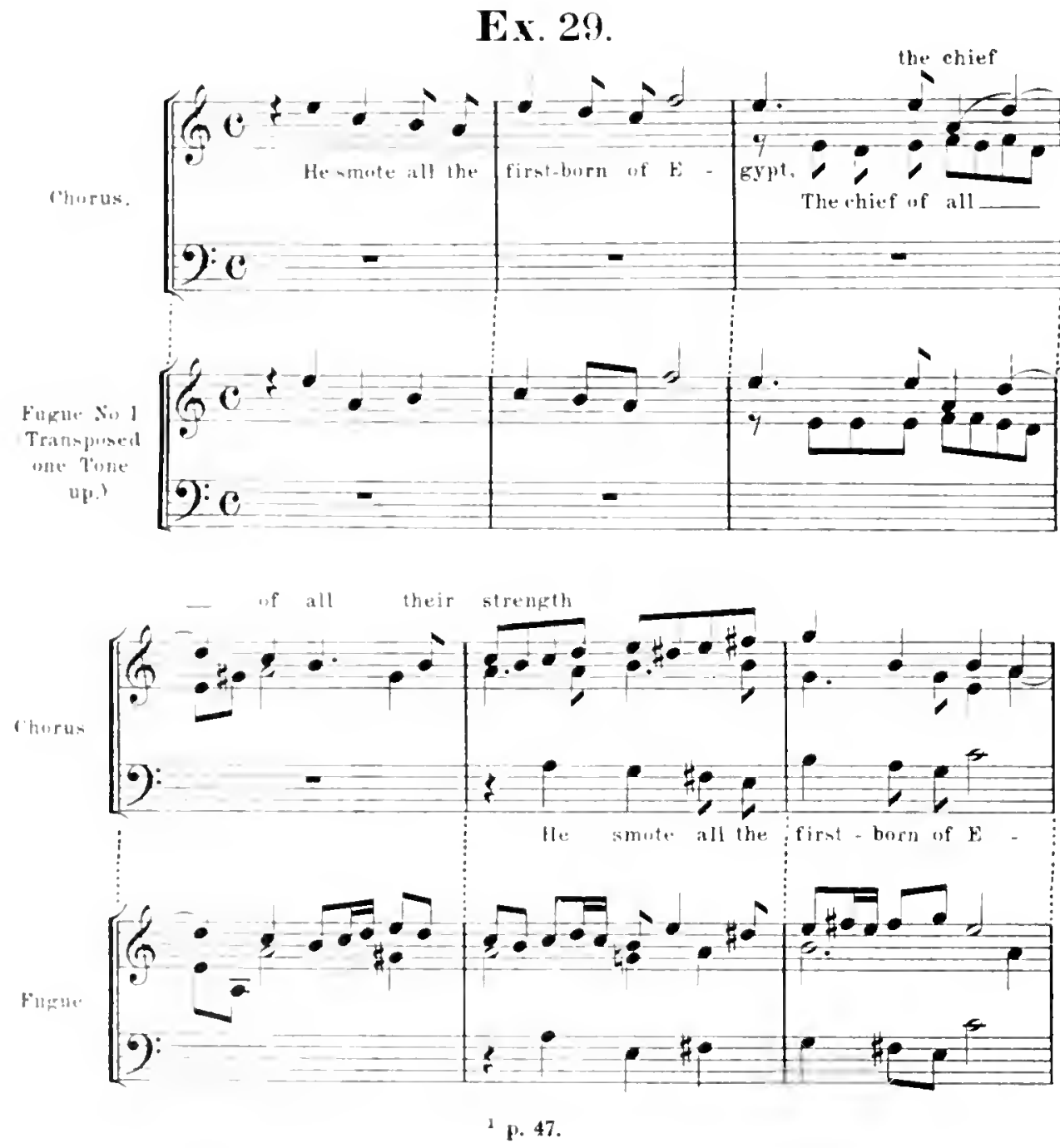


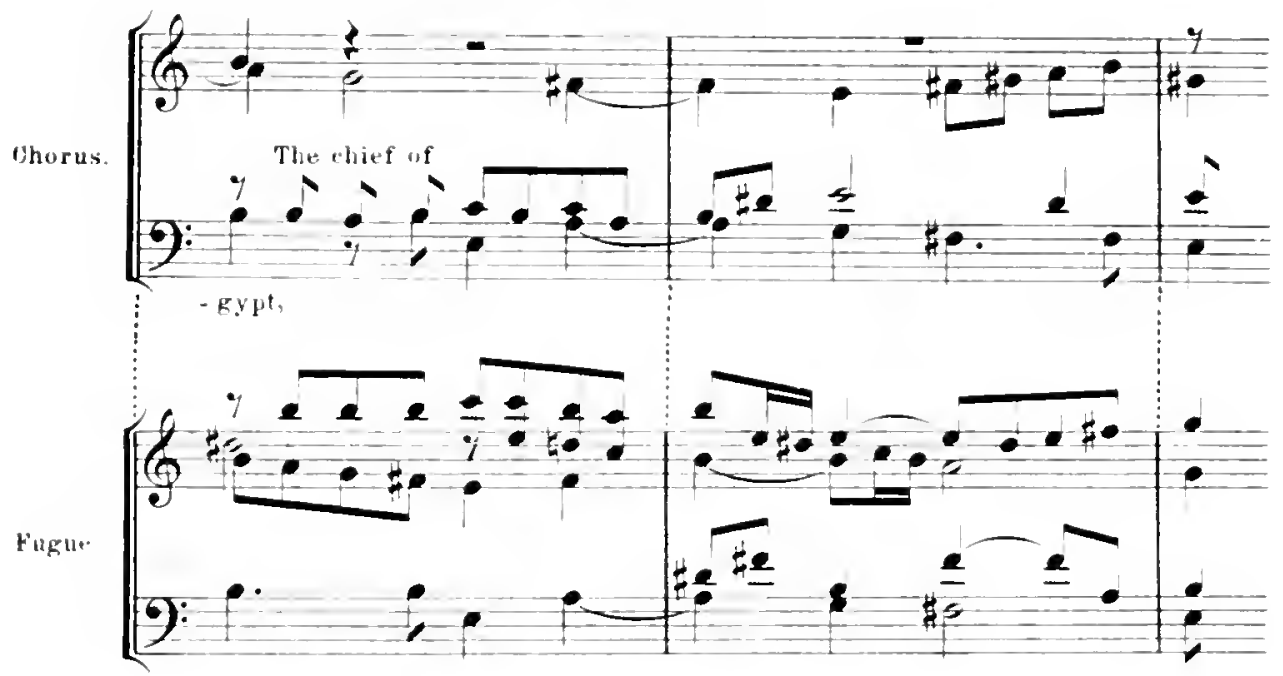

The next chorus (No. 10), "But as for His people," consists, of 168 bars of which 117 appear to be Handel's property, while 51 are evidently made out of a phrase in a soprano song in Stradella's Serenata which Handel has transferred borlily, with its canonic accompaniment shortened by one bar, as shown in the next Example:-

Ex. 30 .
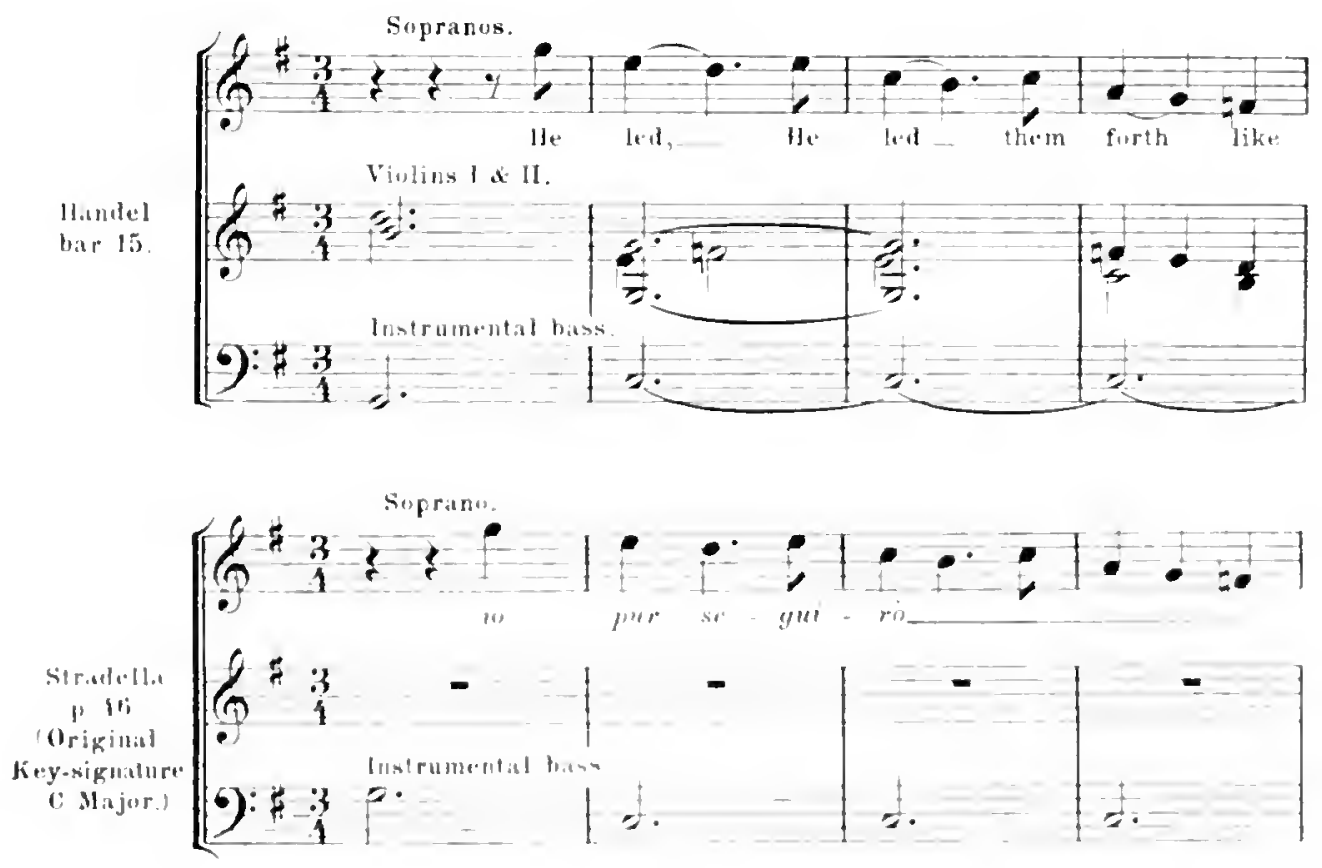


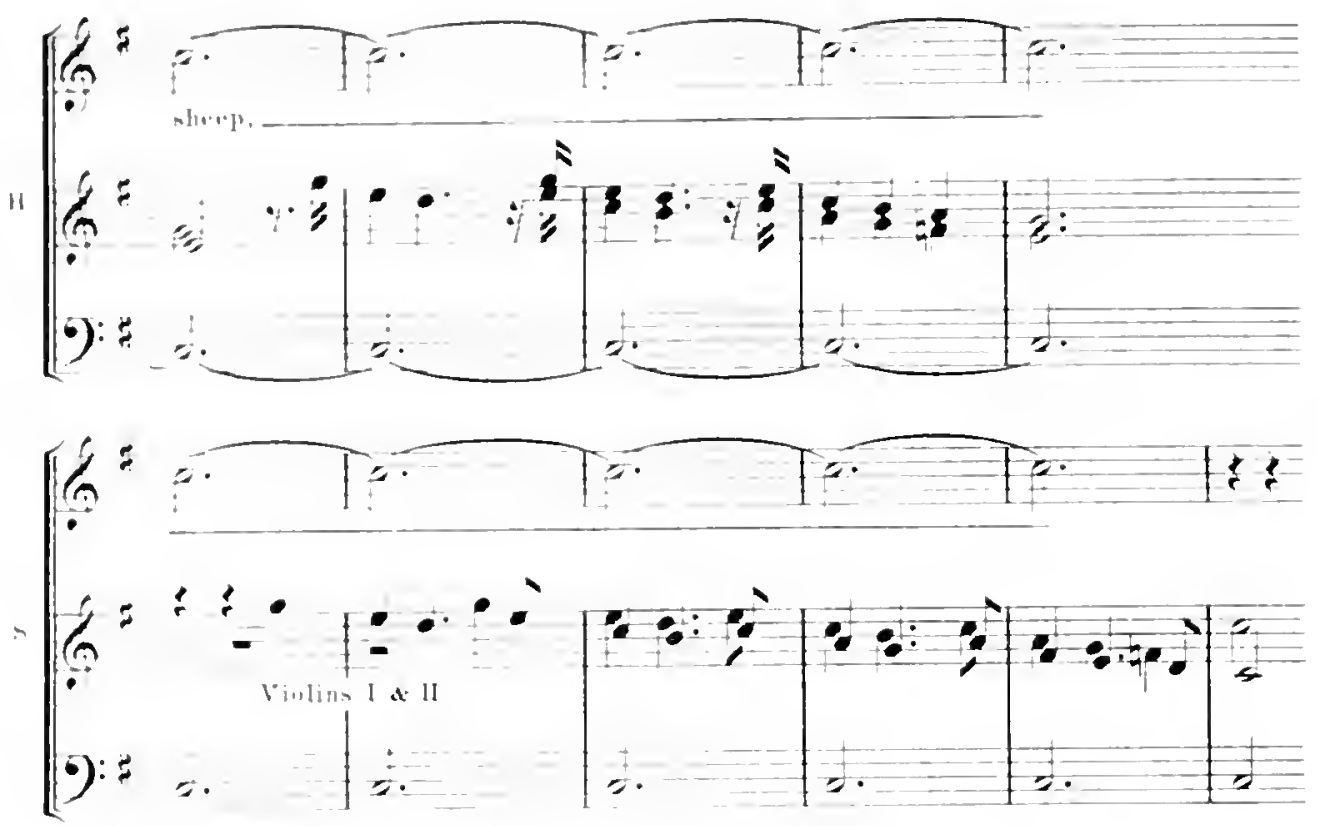

Handel first makes his Altos sing this phrase in the key of $\mathrm{G}$ and then his Sopranos in that of C (as in the Example): next the Tenors sing it in the same key, the Altos chiming in at the end with an ingeniously constructed little initative tag,
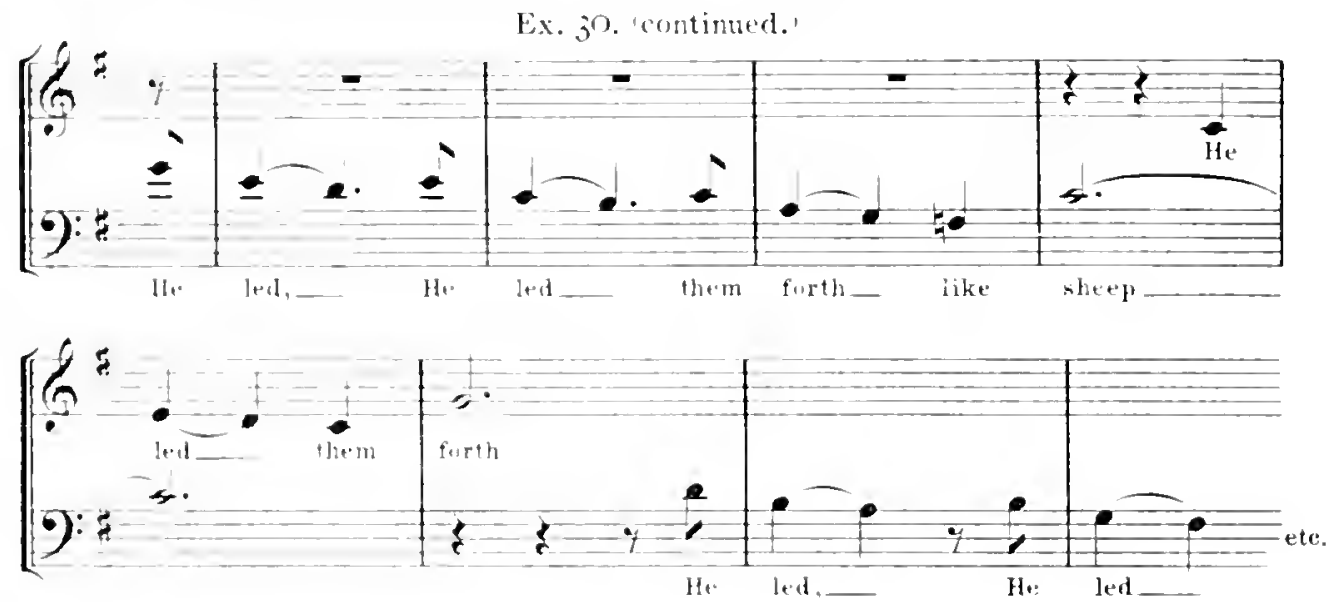

after which the Basses sing the phrase and the Tenors the tag. Finally the Sopranos sing the phrase again in the key of $\mathrm{D}$, the other voices taking over Stradella's figure of accompaniment, shortened as before, and the Sopranos emphasizing the close by an octave drop simultaneously with the entry of the Passes: 

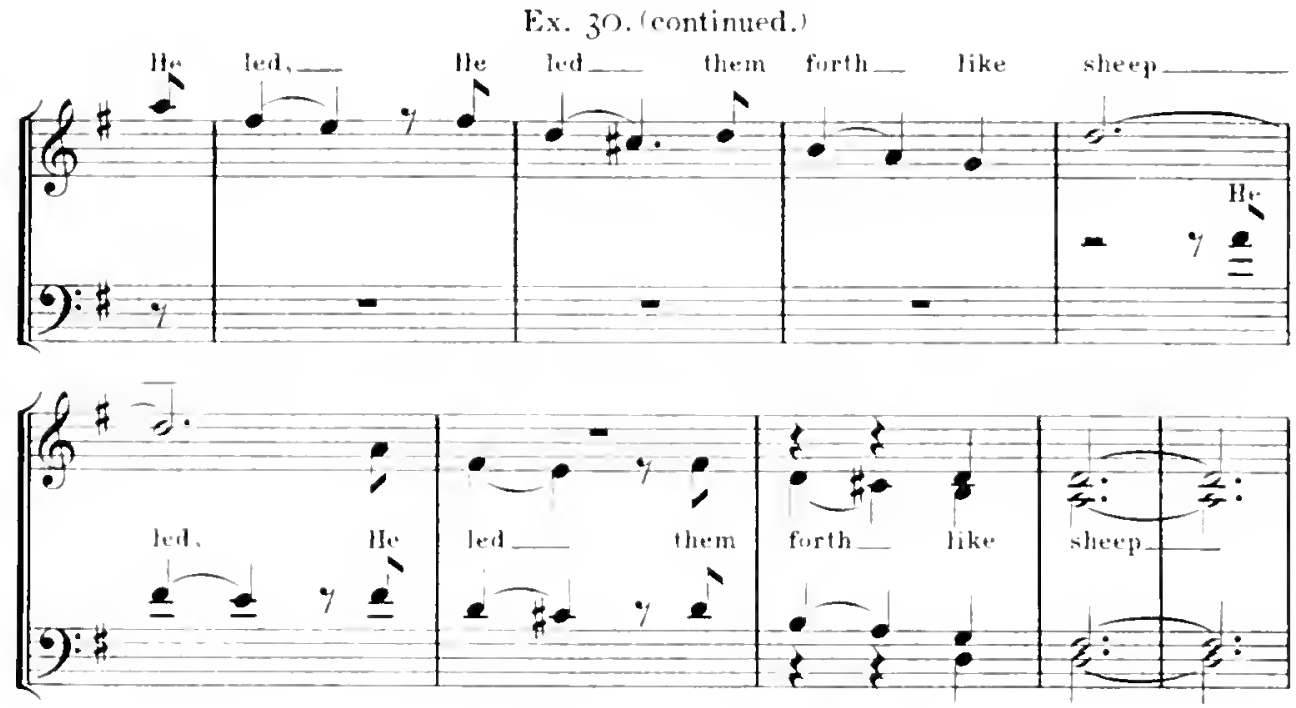

In this manner, if we count in two bars of orchestral continuation, Stradella's phrase of eight bars is elongated into thirty-nine. Iater on in the cliorus his bit of canonic imitation appears first for the Basses and Tenors and then for the Altos and Sopranos:

Ex. 3o. icontinued.
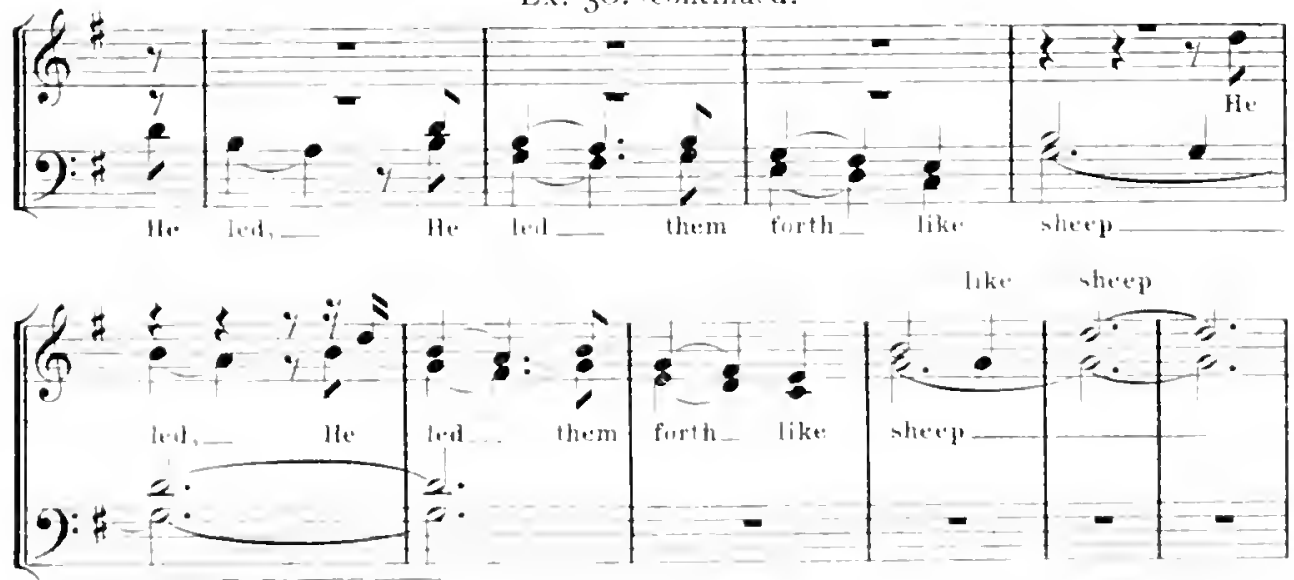

which, with two more hars of orchestral finish, complete the tale of fifty-one bars which Handel has contrivel to spin out of Stradella's phrase of less than nine bars. Bnt for all that, the effect produced is inflagringly fresh and completely congruons with the words sung. 
The chorus which comes next in order, (No 11), "Egypt was glad when they departed" presents an instance of appropriation which is extreme even for Handel. A celebrated German organist Johax: Caspal: Kell (1628-1693) published at Munich in 1686, one year atter Hamlel's birth, a work entitled Modulation

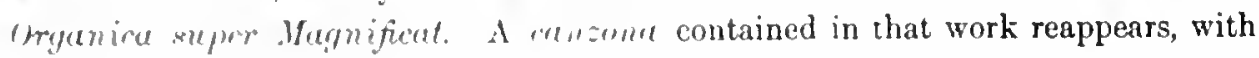
hardly any alterations heyond what were required to adapt an organ-piece for lerformance by voices, as the chorus now betore us. The following Example in which I have printed kell's consmu as it appears in an undated edition published wi Amsterlan' will make this surprising fact quite manifest.

\section{Ex. 31.}

Chorus "Egypt was glad when they departed."
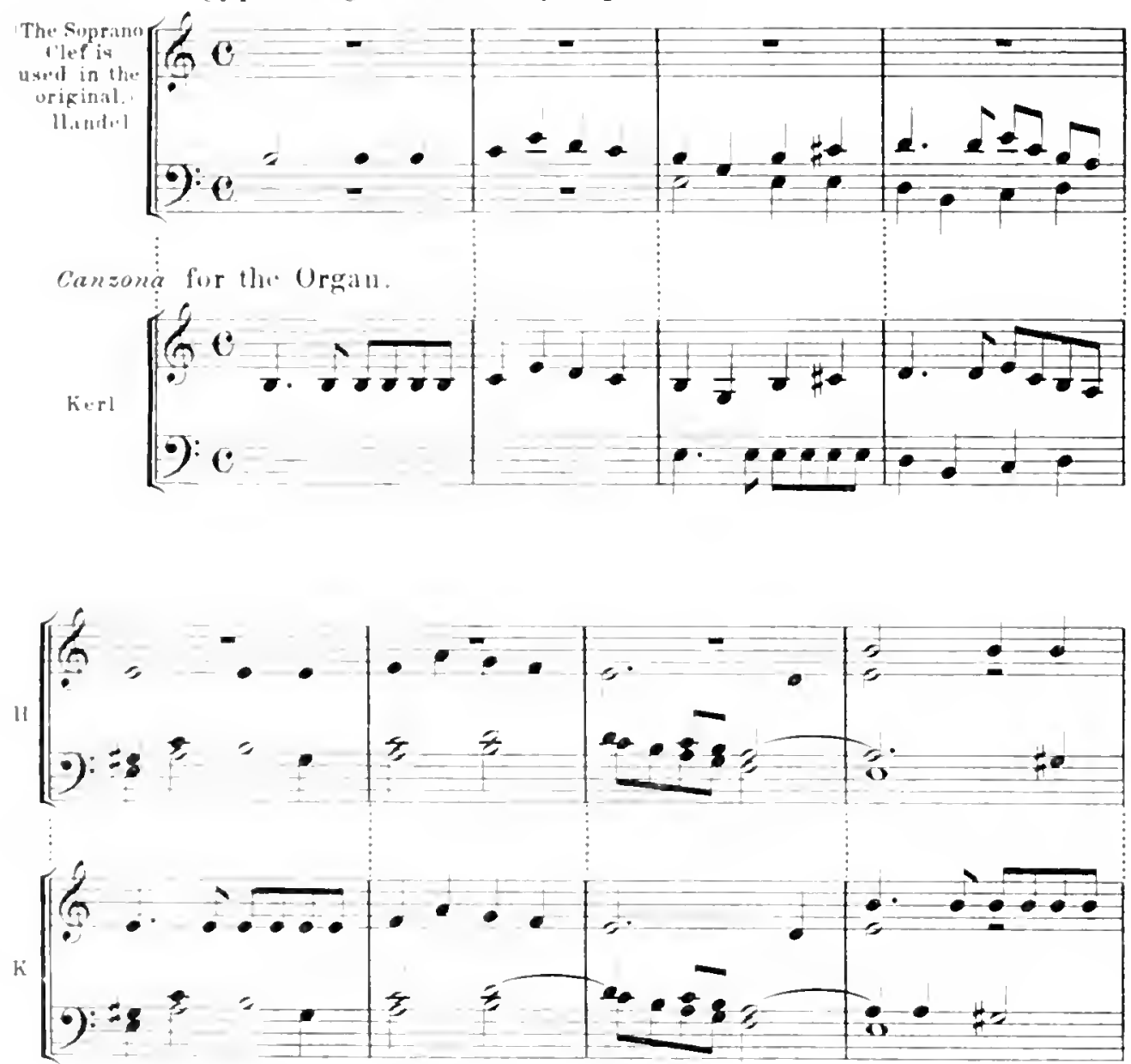

${ }^{2}$ Kindly placed at my disposat hy Dr. A. H. Mann 

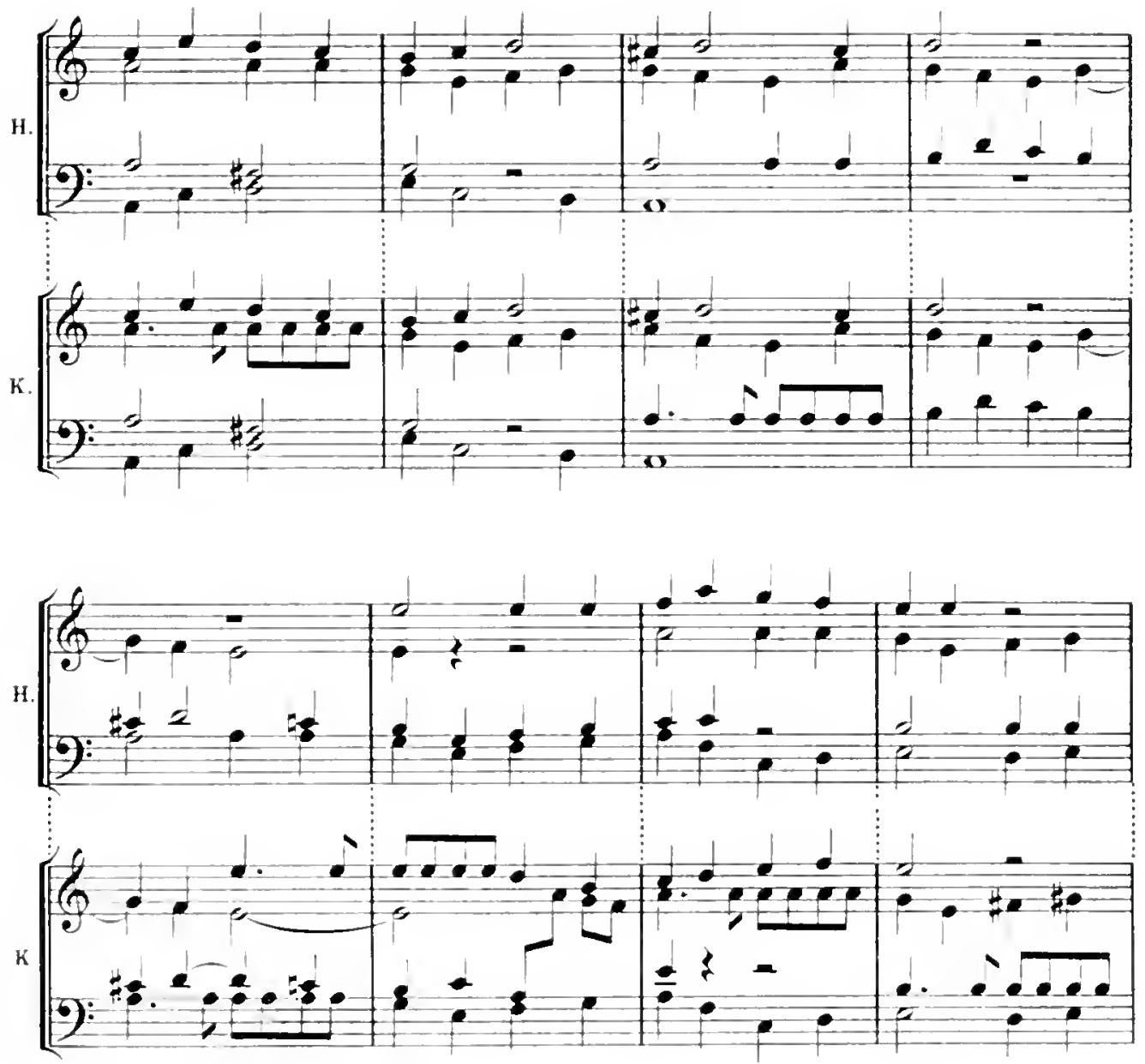

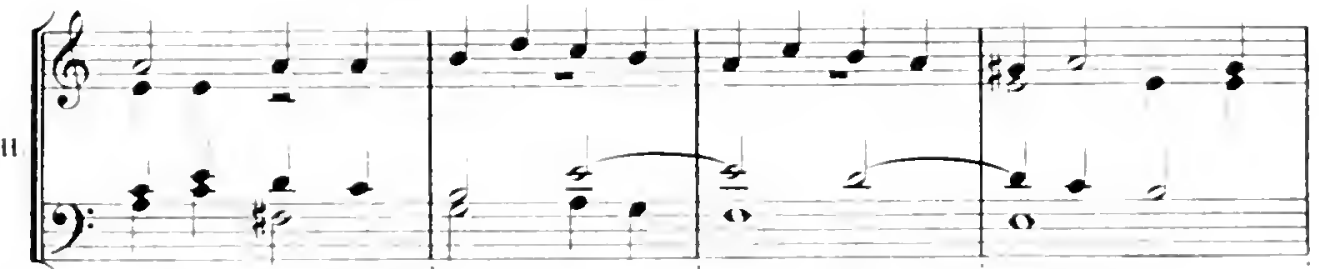

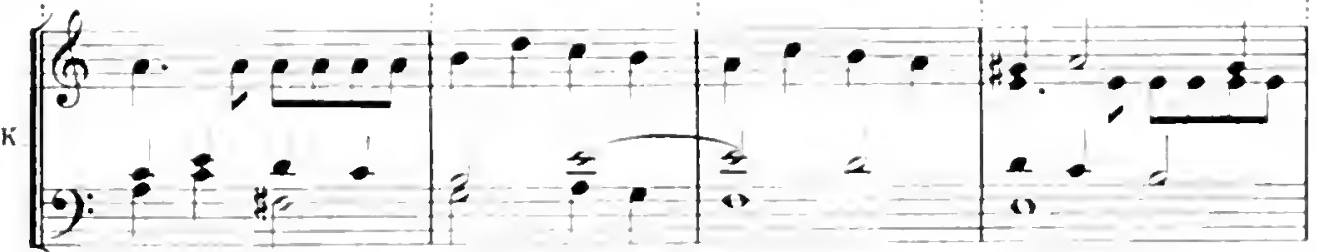


78

ISRAEL IN EGYP'T
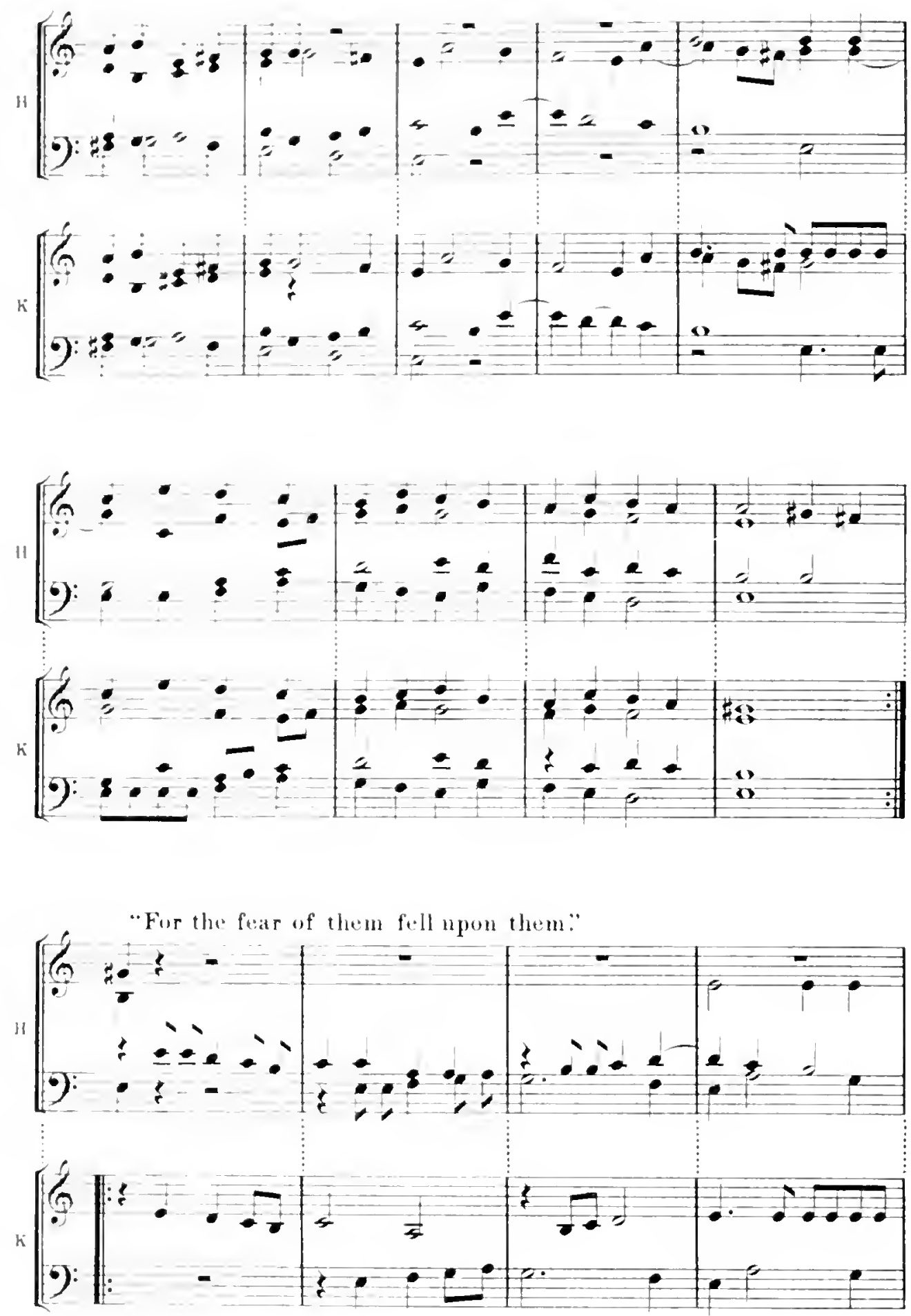


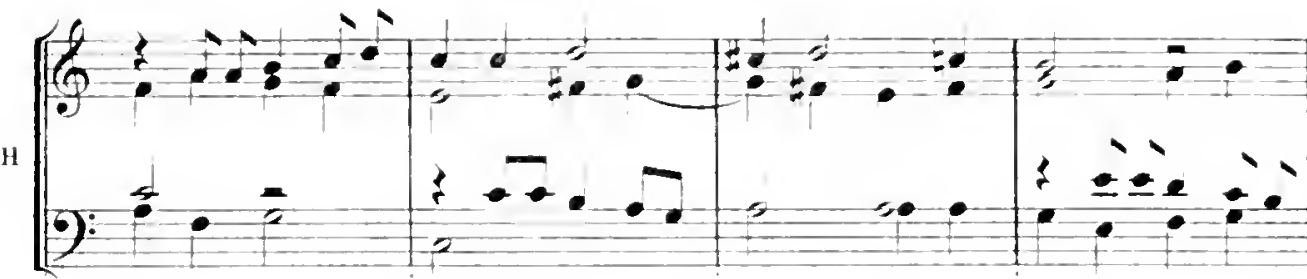

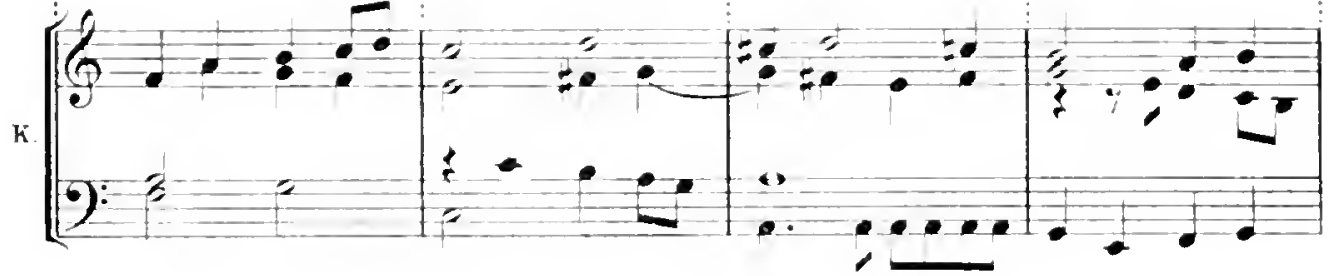

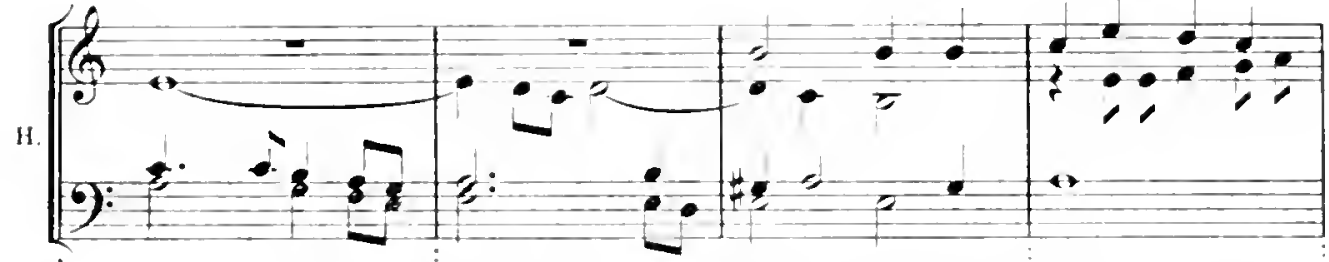

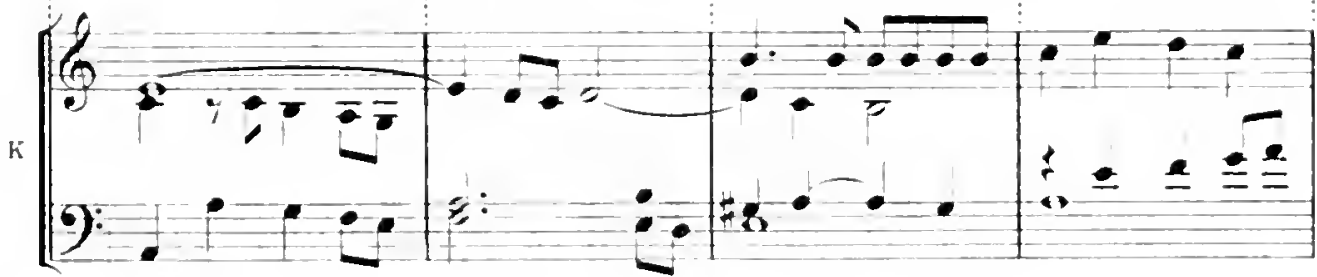

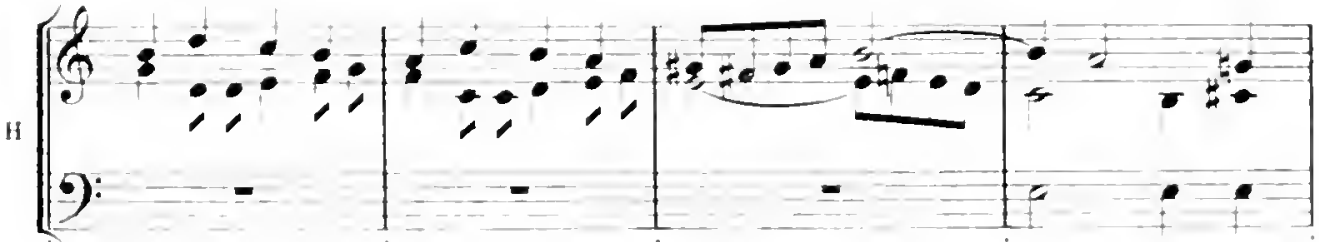

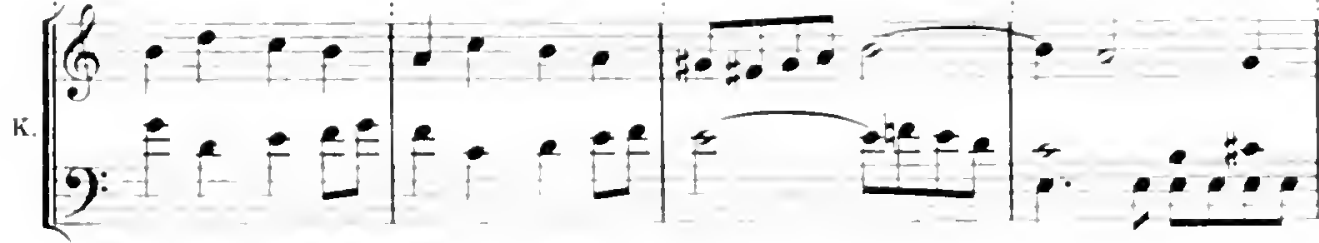


80

ISRALL IN EGYPT
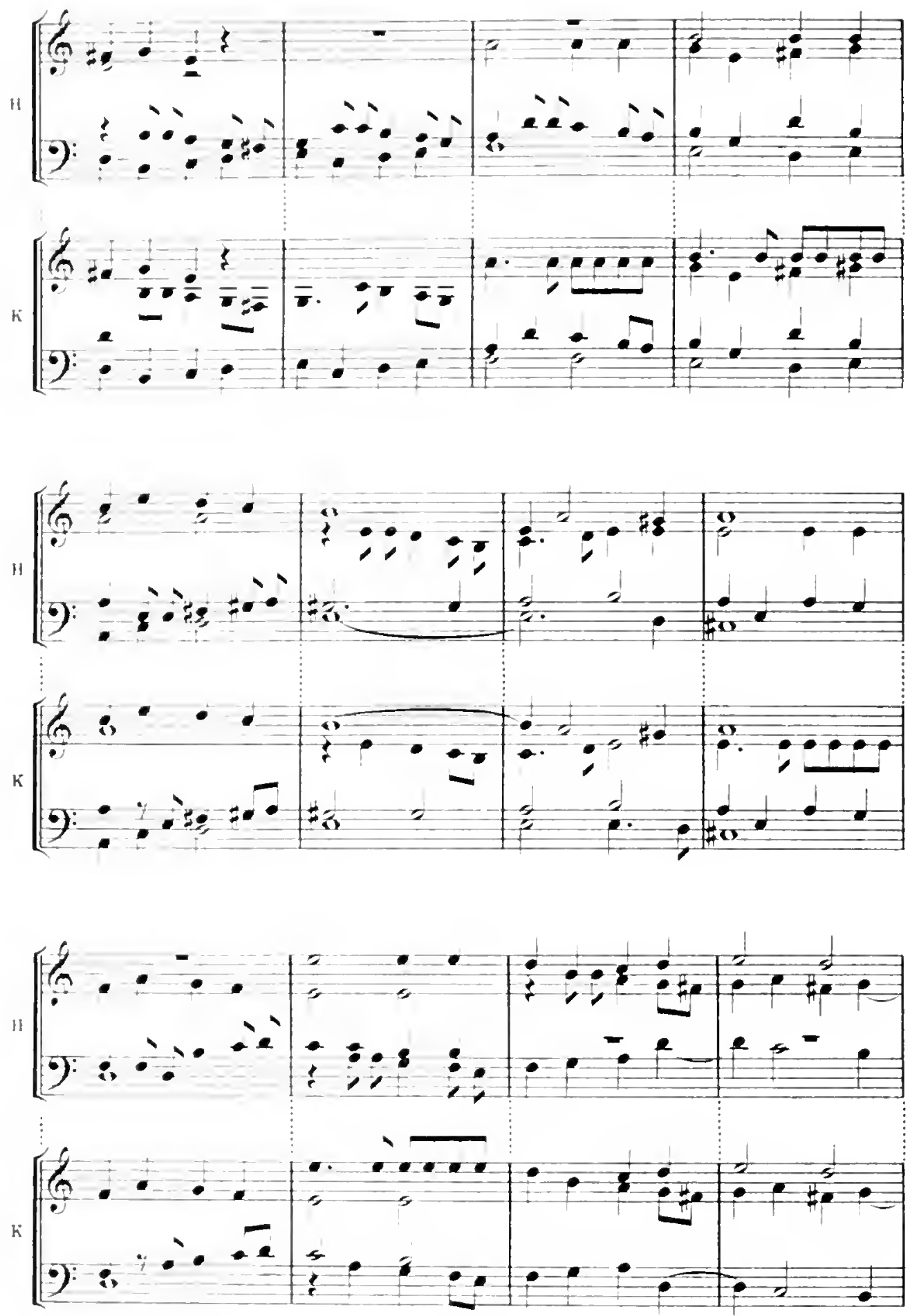


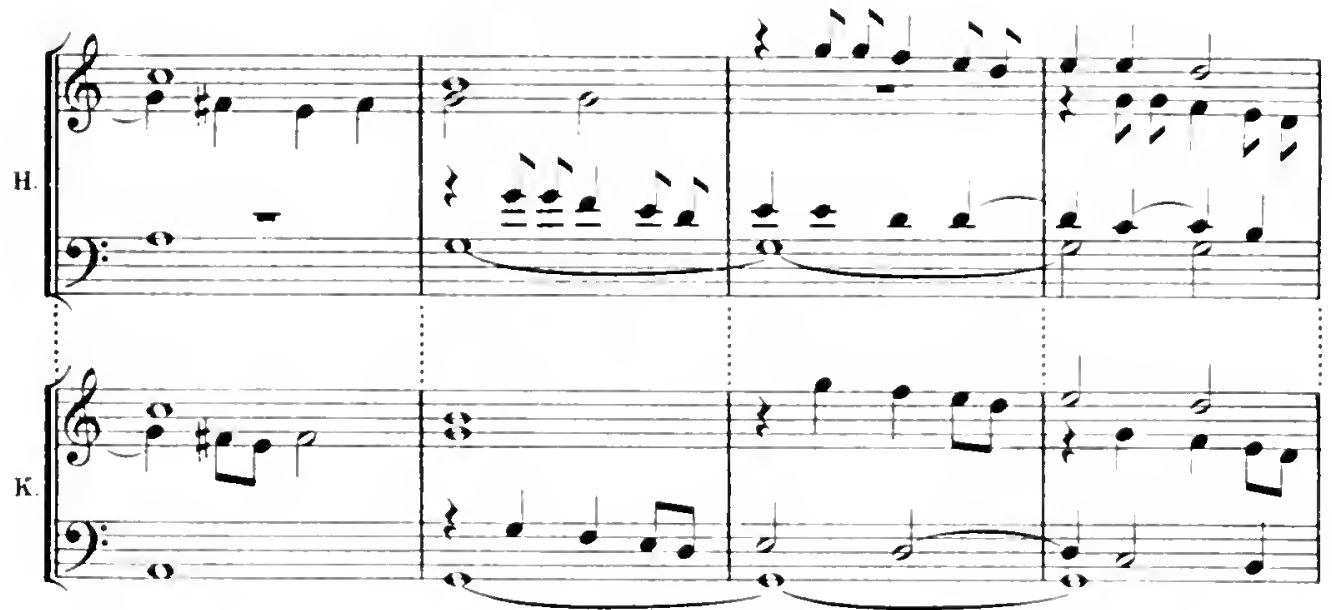

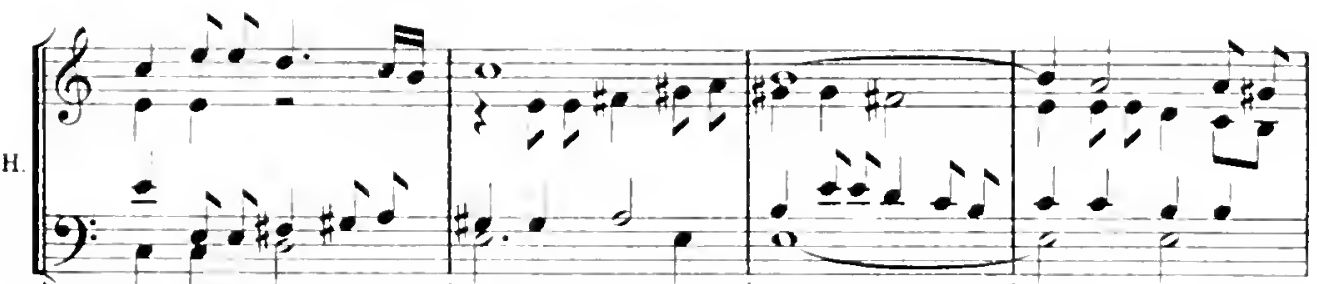

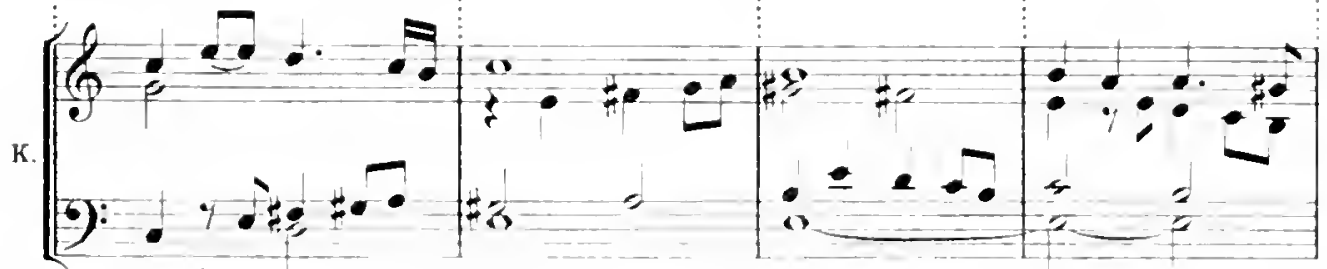

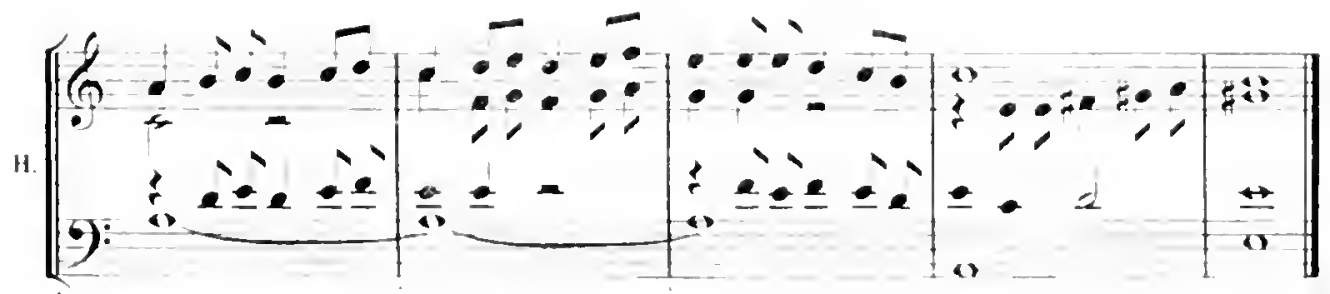

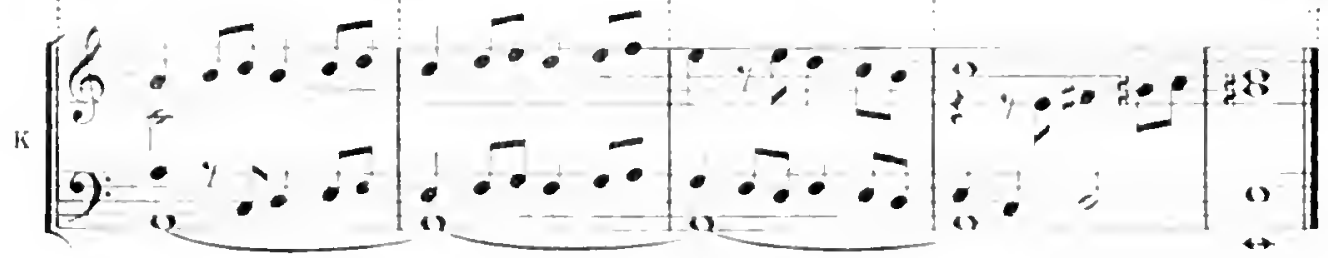


As Kerl published his cunzum in 1686, when Handel was only one year old, his priority is beyond lispute. Curbusly enough Sir John Havkins, in his 'History of Music,' which apleared in 1776 , published an inaccurate version of this "unsuma "as a specinen of Kerl's style of composition for the organ," cutire ignorance of the use to which Handel had turned it, 38 years earlier, in Isreel in tisyst.

Fortunately nothing prevents our regarding the next cliorus (No. 12), "He rebuked the Red Sca," as anytling but what it has always been taken for-a trenendous stroke of original genius. The remark attributed, I thiuk, to Beethoven, that when llamlel close, he conle "strike like a thunderbolt," thoroughly apulies to these mirghty cight hars. Nor does the inspiration take any lower level in that superb oceanic commingling of sublinity and loveliness, the chorts (No. 1.3) "lle led them through the deep," thuugh for its original form Handel went back more than thirty years to a work which he bad composed in liome in 1707," a setting of Psalm CX. in Latin (Dixit Deminus) for a five-part chorus, orchestra and organ. A donble fugue in this work to the words "Tu es sucerdos in erternum sriundum errlinem Melchisedech" contains the germ from which the chorus now und re consideration was developed.

In the Psalm? the movernent opens as follow's, the Basses singing the first subject while the upler voices take the much shorter and quicker second sulject in canonic imitation and development:

\section{Ex. 32.}

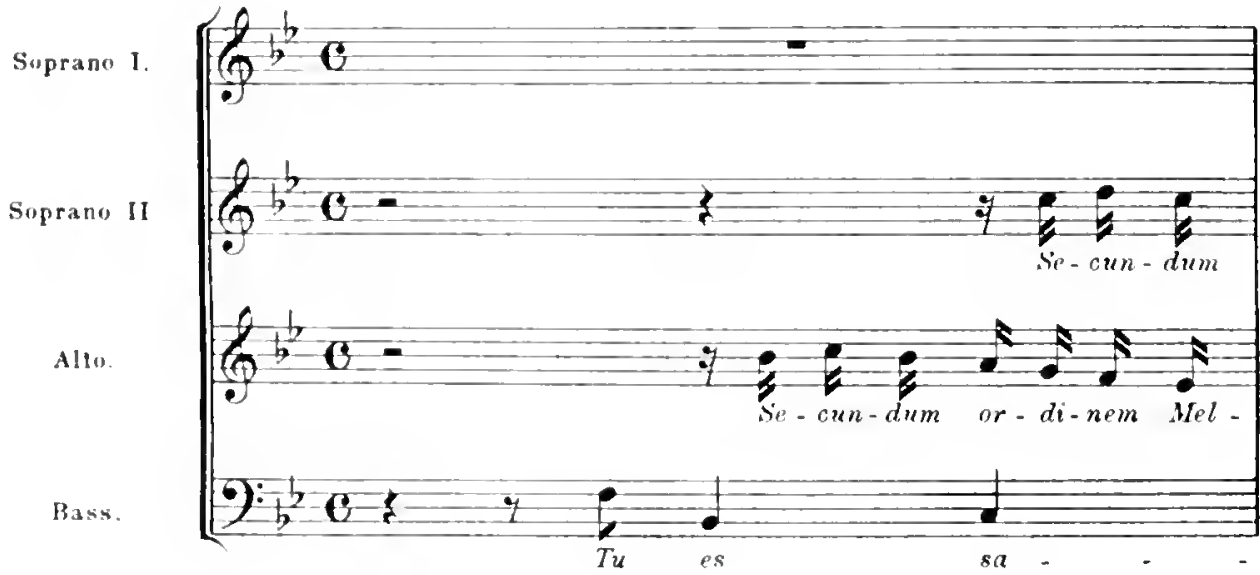

i Vol. V. p. $36 . \quad$ 'Chrysander: Life of Handel, vol. I. p. 162.

'Whioh I quote from the German IIandel Society's edition, vol. 38, p. 79. 

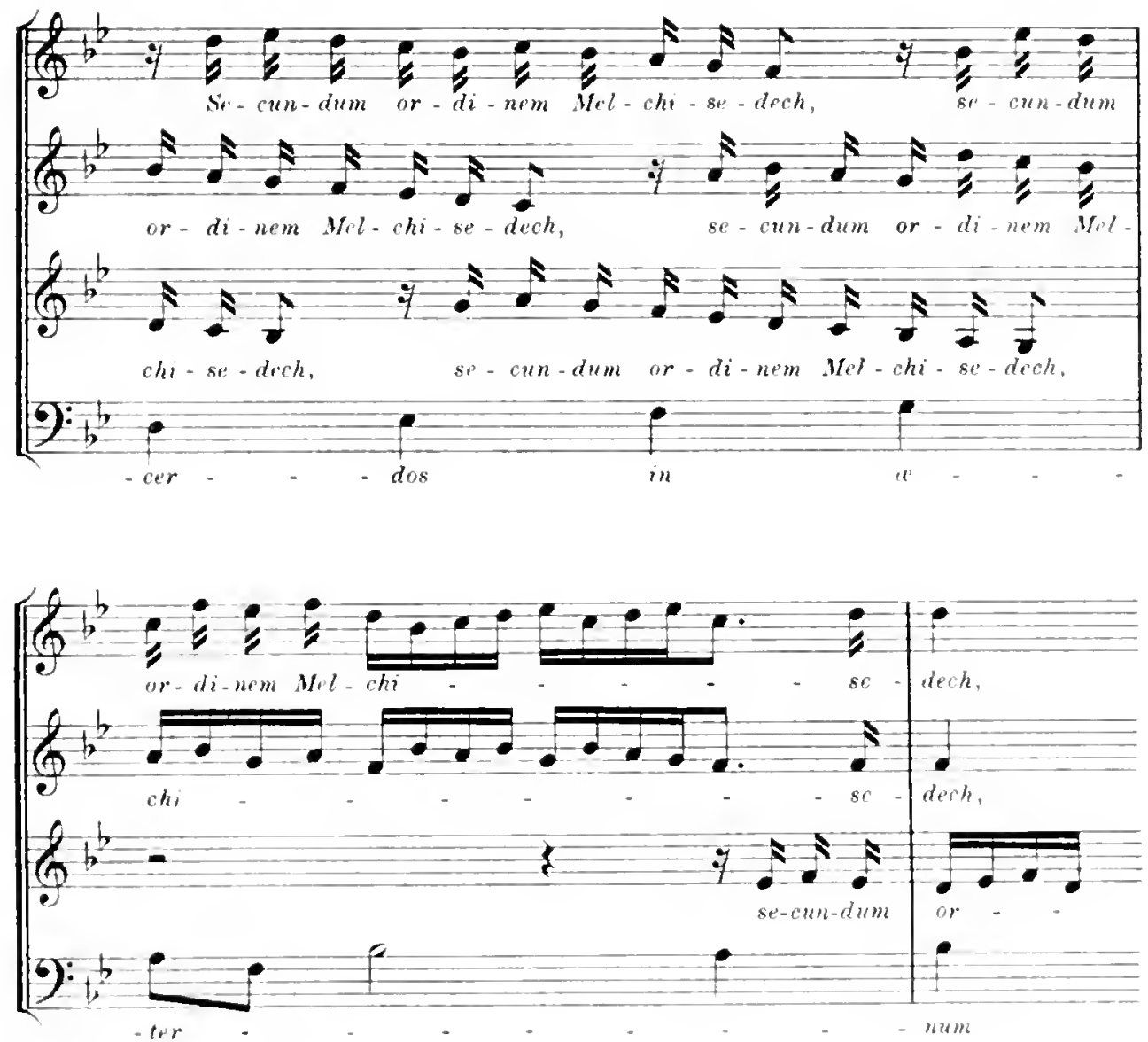

In Ixpel in Fyypt the double chorus opens by the Basses giving out the first surject accompanied, in unison, by the instrumental basses only, but instead of singing the whole octave-scale as in the Isalm, they plunge down a Seventh upon the word 'deep' with a wonderfully fine effect:

Ex. 32. (continued.)
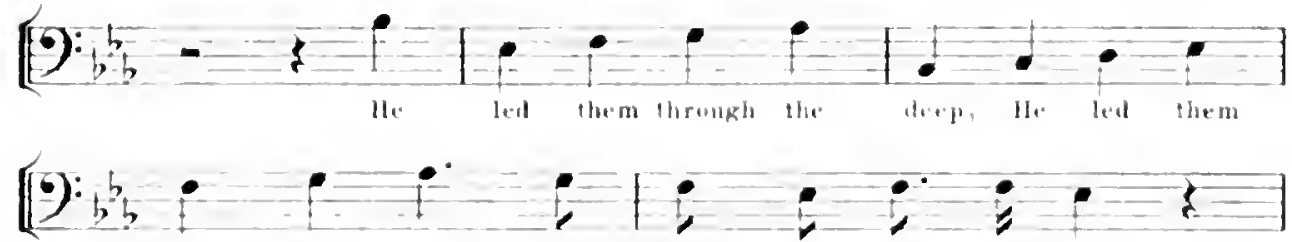

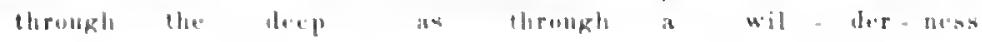


In the last Soprano entry of this subject the plunge is deferred, with increased effect until close upon the eud of the subject:

Ex. 32. 'centinued.'

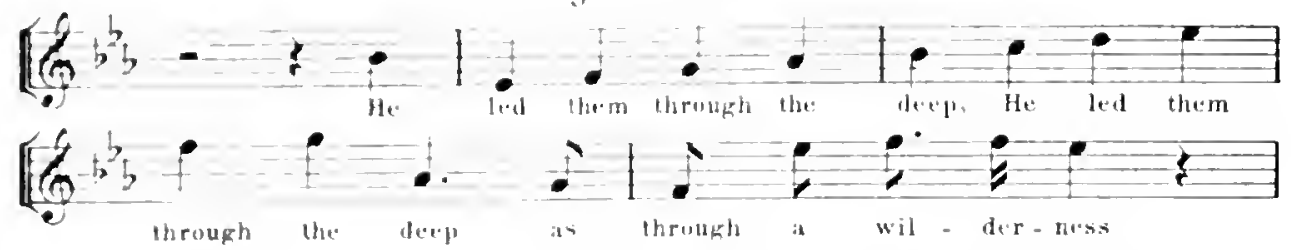

The second sulject, moditied in various ways, is constantly at work throughout, first in the orchestra only and then both there and in the voices. Thus the opening of the I'salm-movement grives a rough schene which is adhered to in the double chorus, but with a richness and exuberant rariety of effects which make the eallie. composition, fine as it undonbtedly is, pale into comparative insignificance.

The companion picture describing the destruction of Israel's pursuers is drawn with tremendous foree in the fullowing ehorns (No. 14) "But the waters overwhelmed their enemies." 'The original idea for this too was taken by Handel from one of his earlier works, the Chinlos anthem "The Lord is my light" composed between the years 1717 and $1520^{4}$ while he was music-director to the Duke of Chandos. It appears there in the form of the orchestral prelude ${ }^{2}$ to a soprano song set to the kindred words "It is the lord that ruleth the sea:"

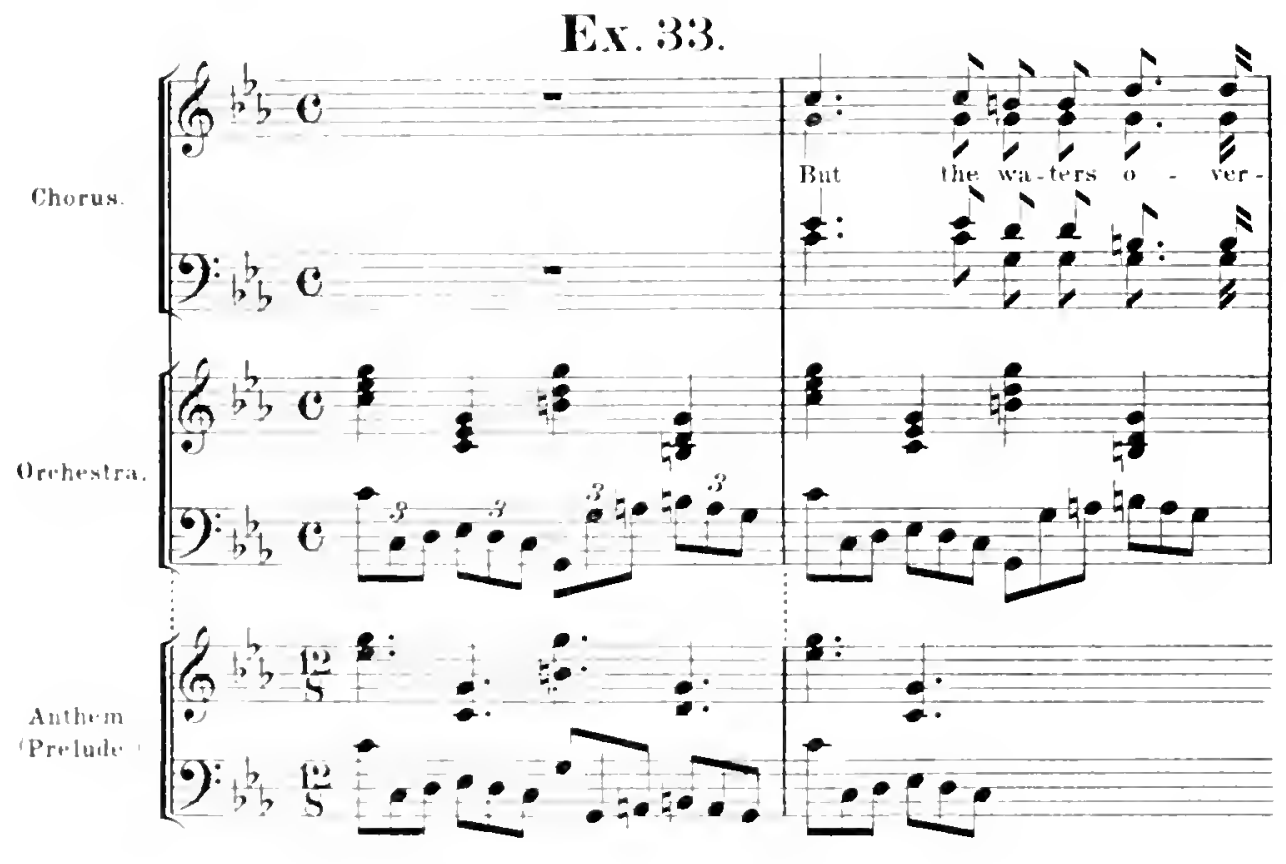

1 Chrysander: Life of Handel, vol I. P. 458.

2 Which 1 quote from the German Handel Society's edition, vol, 35, p. 198 sq. 

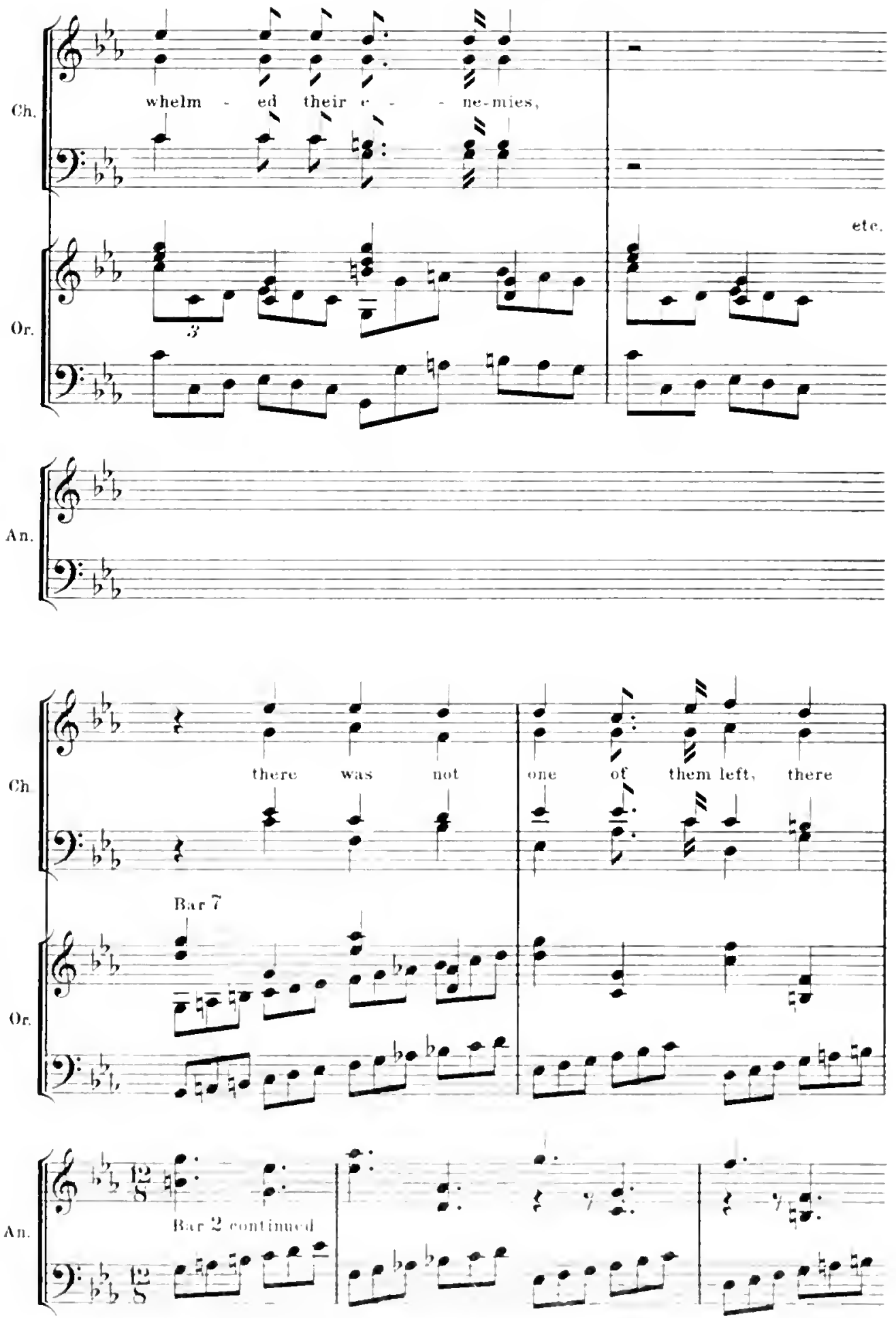


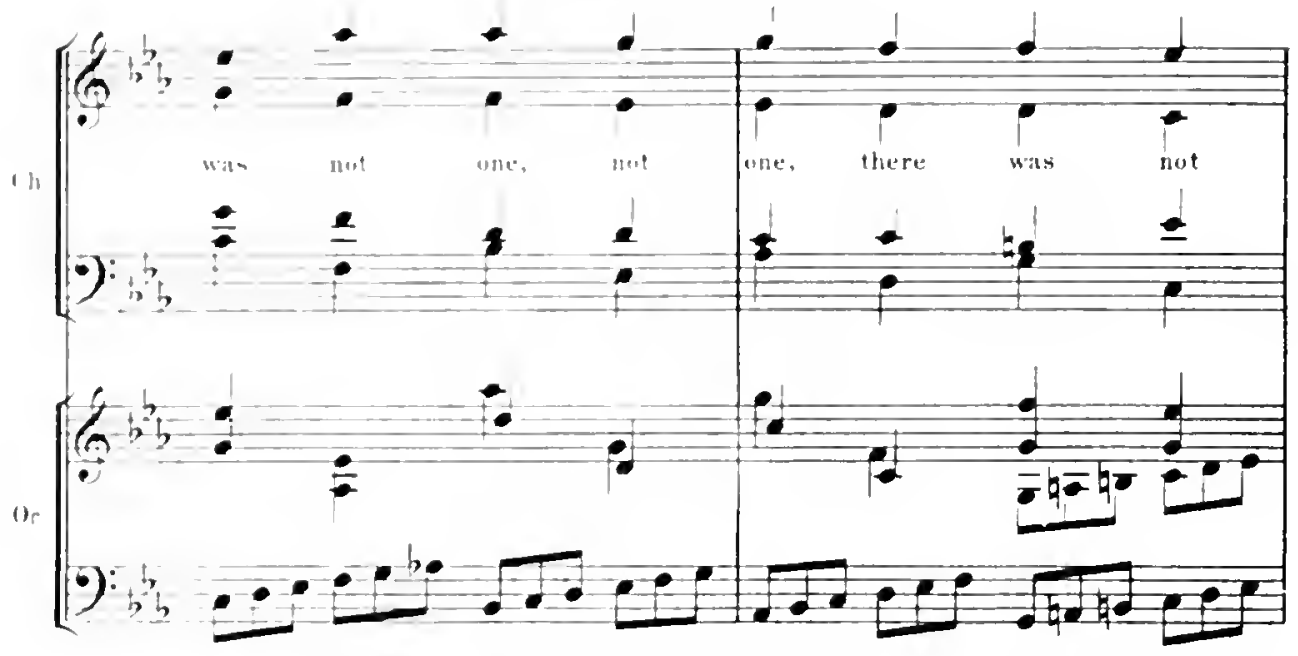

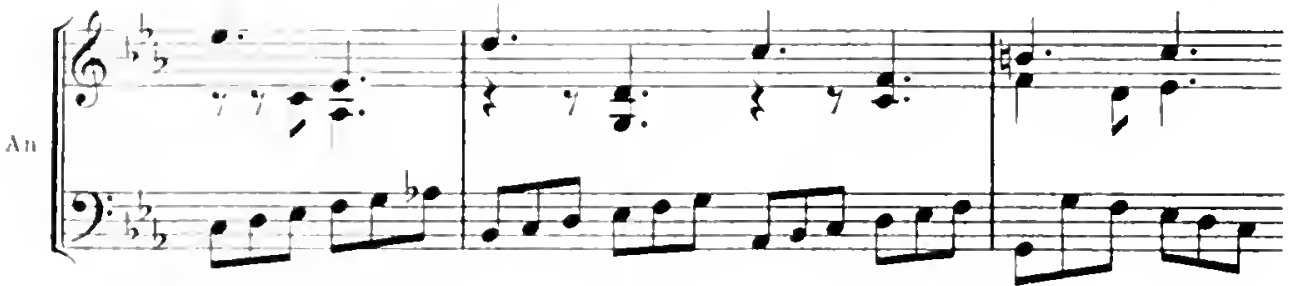

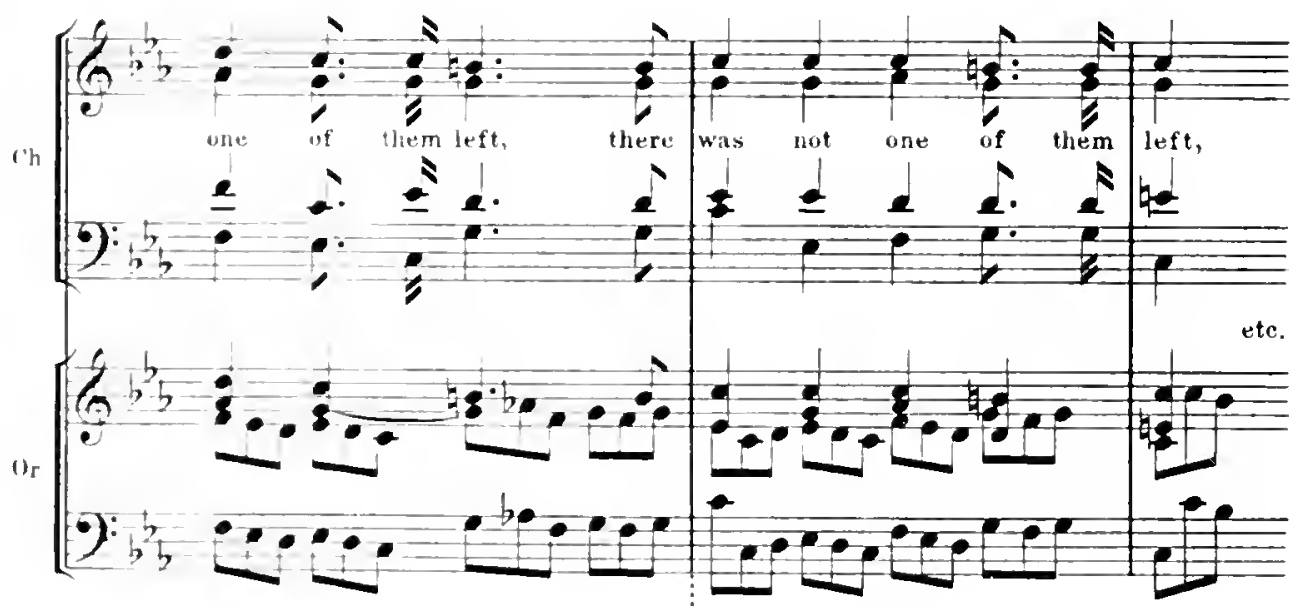

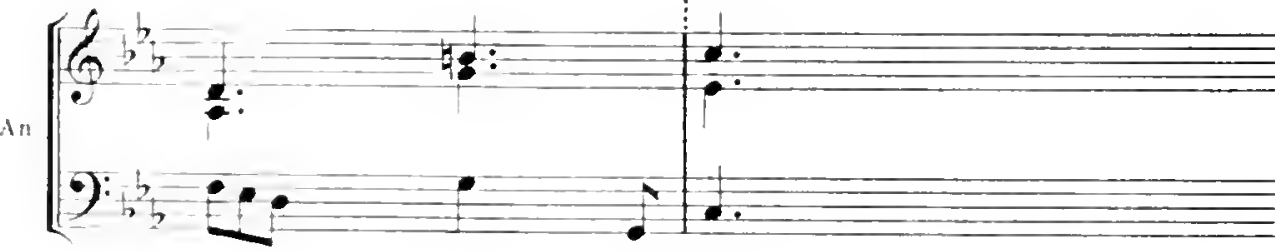


The short, but extraordinarily impressive, double chorus (No. 15), "And Israel saw that great work," contains such palpable discharges of creative energy that it may, I hope, be set down to Handel's sole initiative. It is followed by the chorus (No. 16), " $A$ nd believed the Lord," consisting of 63 bars, 46 of which, i.e. nearly three-quarters of the whole chorus, are, with but small modification, taken from, or built up on, a soprano song accompanied by two violins and a bass in Stradella's Serenata. Example 34 sets out the first 17 bars of the chorns with the corresponding passages in the song:

\section{Ex. 34 .}
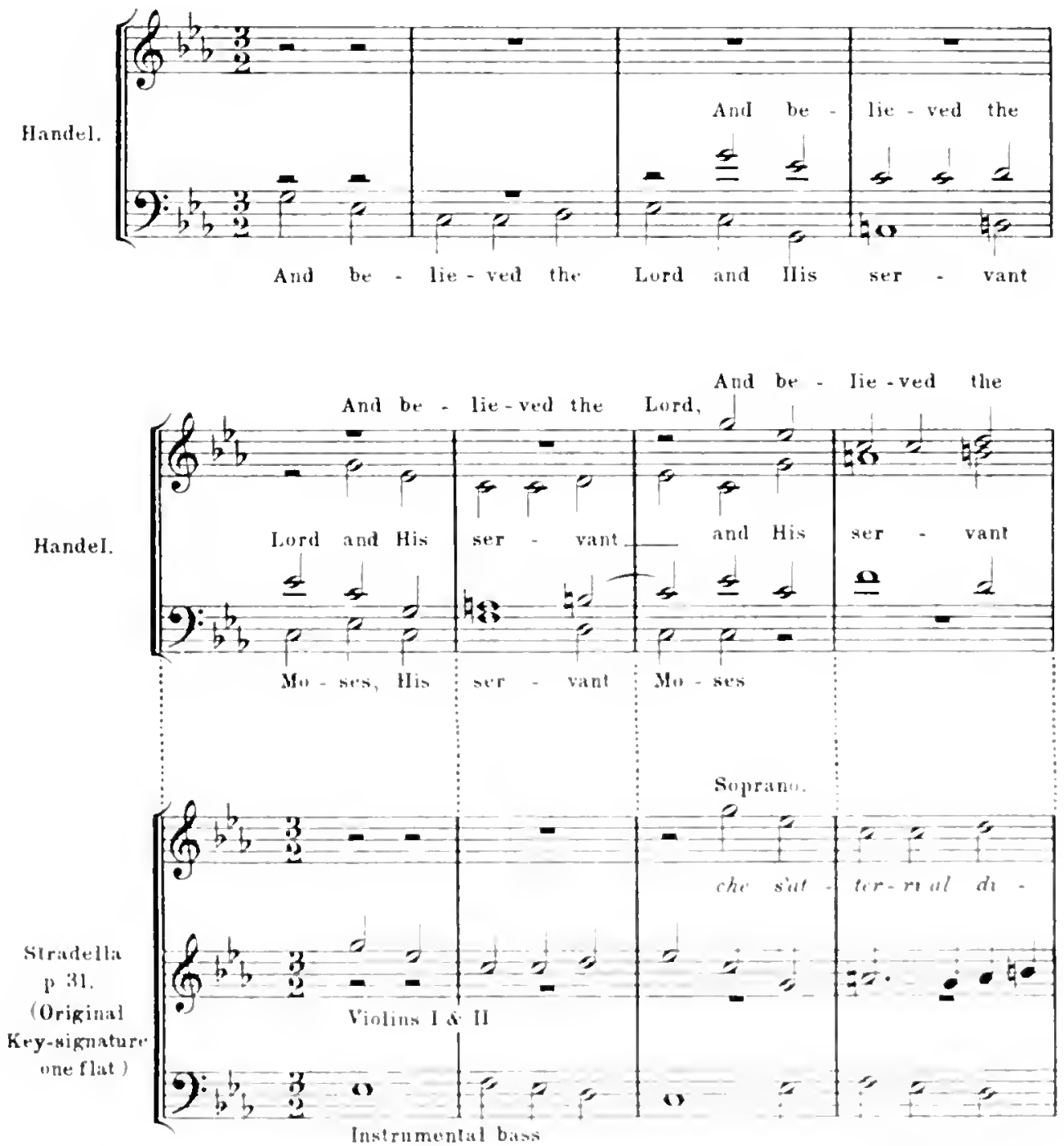
88

ISRAEL IN EGYP'T
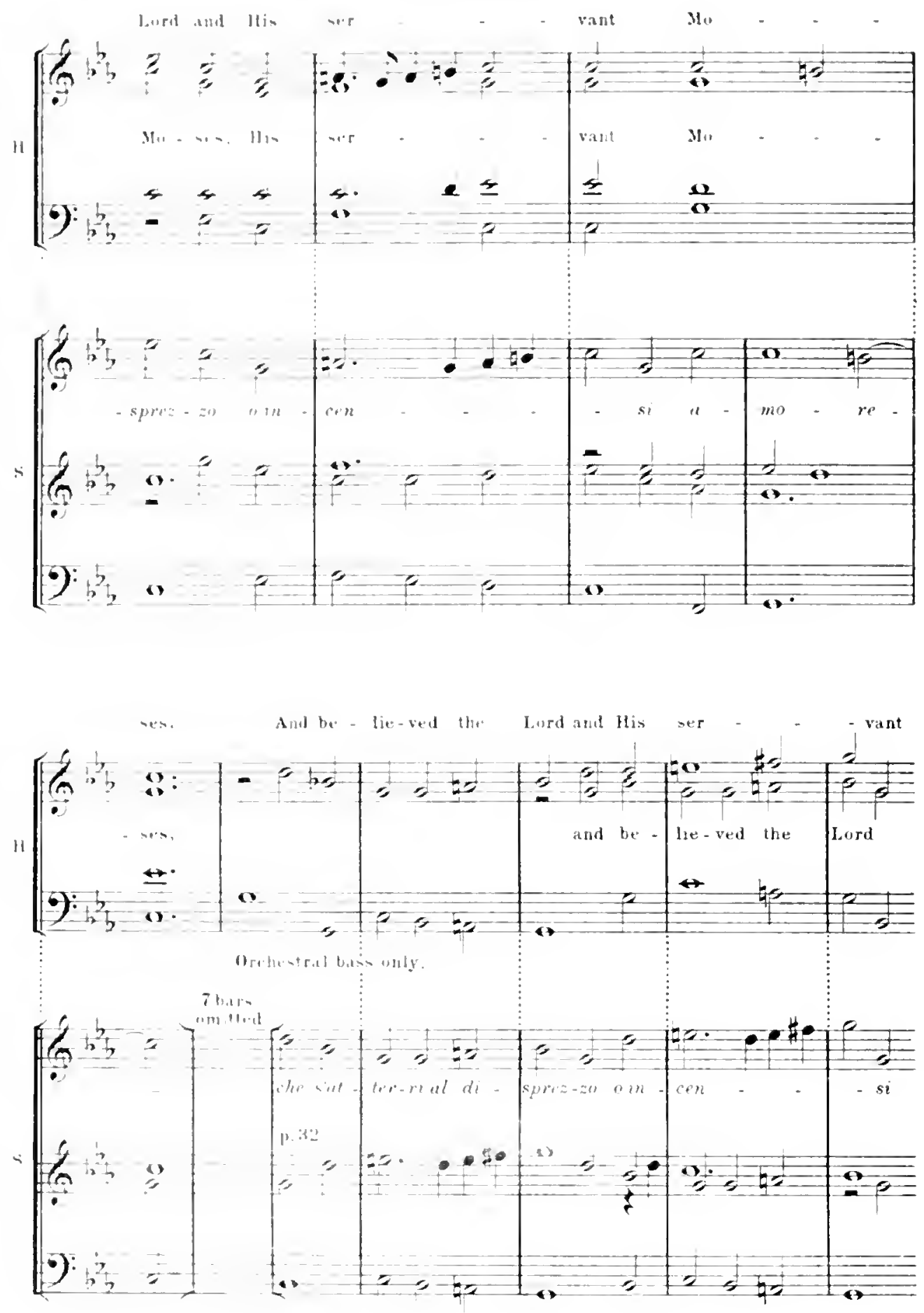
After four bars of continuation ch these materials Handel produces (bars 22-31) the following burst of inspiration:

Ex. 34. continued.
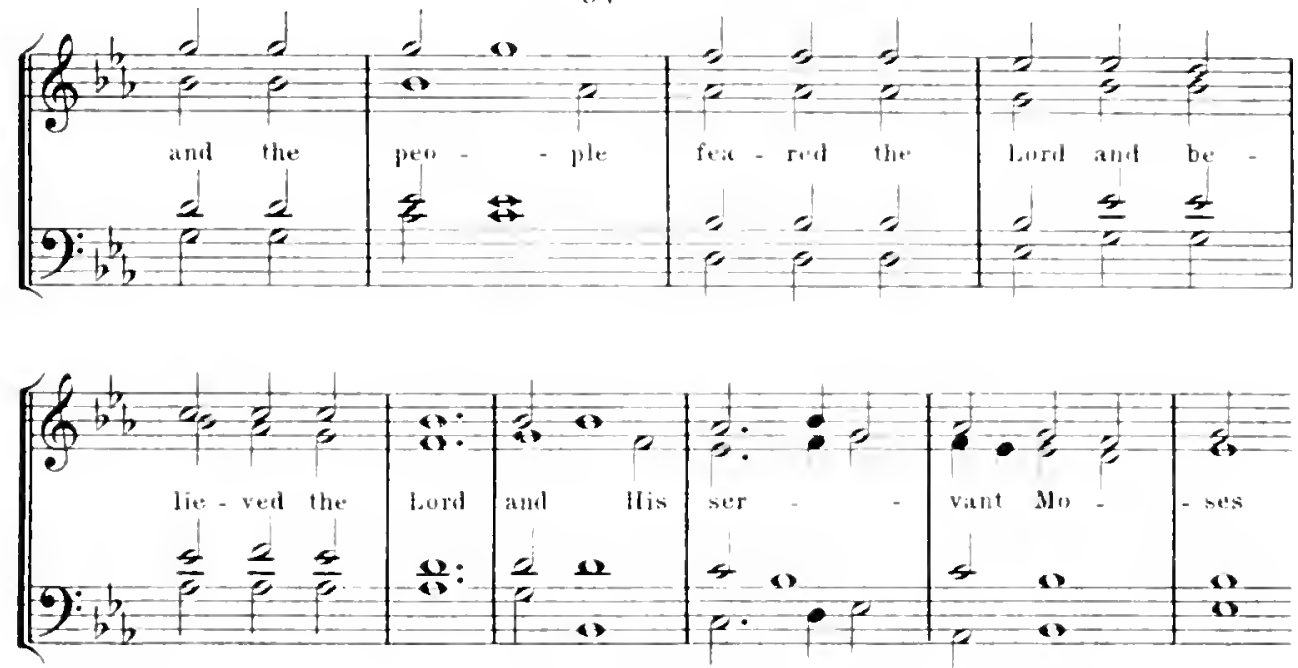

The rest of the chorus reverts to the Stradella material except in bars 45-52 where a descending scale-passage of four notes receives the folluwing fine treatment in callon :

Ex. 3.t. 'continued.'
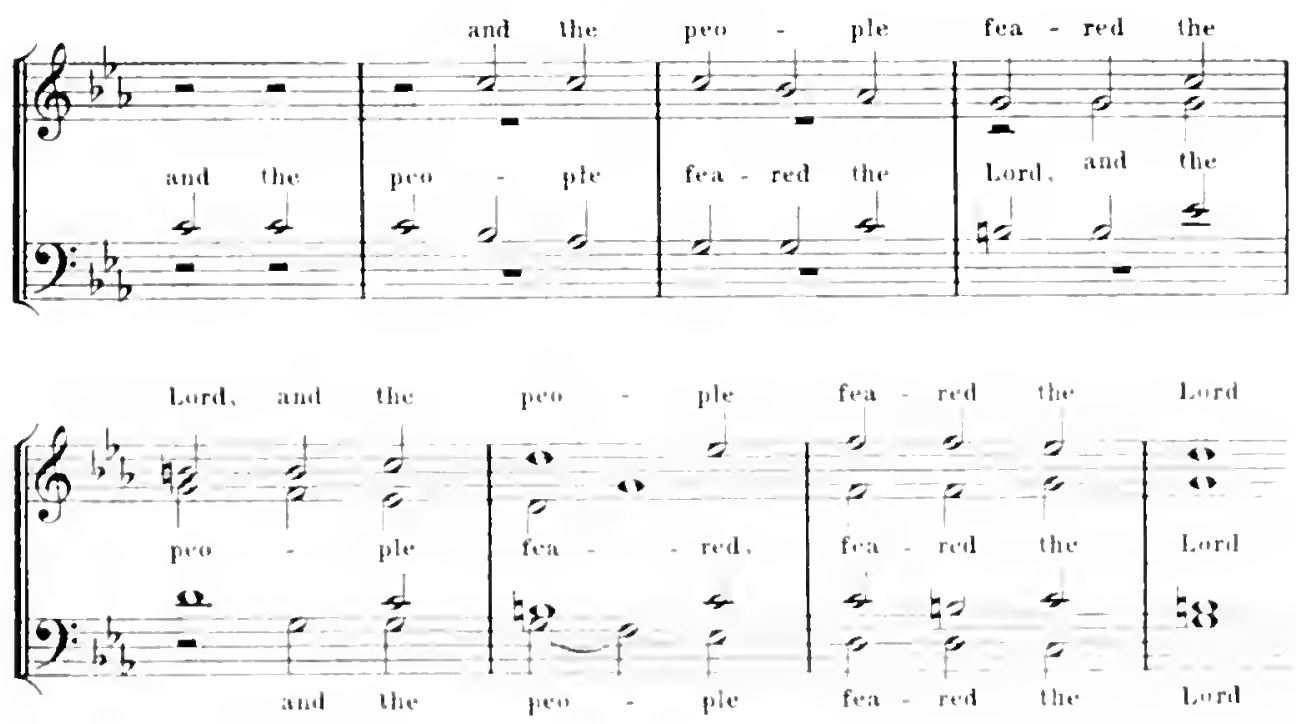

With this chorus l'art I. of Isruel in Egylt ends. 


\section{CHAPTER VII.}

Comparison of lart II. of Israel in Eglpt witu a luatin Magnificat the authorship of wilch is Disputed, and with a passage from a Latin t' $E$ Degar BY U?:10.

W E have seen the use that Handel maile of a serenata by Stradella in the first l'art of Israel in Egypt. In the second Part he made a still more cxtensive, indeed well nigh exhaustive, nse of a Latin Magnificat set for double chorus, orchestra and organ, the authorship of which presents a problem of much interest. Only two manuscript copies of it are known to exist, one in Handel's own hanlwriting, but without indication of authorship, which is preserved in the loyal Library at Buckingham Palace, the other in a different handwriting and inscribed "Magnificat Del Rd Sigr Erba," which is preserved in the Library of the lioyal College of Misic. After what we have seen of Handel's copying of choruses by Graun in the Fitzwilliam autographs, the mere existence of this Magnifecat in his handwriting cannot be accepted as proof that he composed it; indeed, in the opinion of Dr. Chrysander, Handel's manuscript presents clear internal evidence of not being an original work but a copy, and probably made from separate 'parts,' not from a score. The Royal College manuseript, on the other hand, supplies a piece of positive evidence by assigning the composition of the Magnificat to a priest (IR SIgr) named Erba. It has, however, been maintained by two supporters of the Handelian authorship that the words "Magnificat Del Rd Sigr Erba" meant only that the manuseript score now in the Library of the Royal College was once the property of-not had been composel by-the person named in the superseription. "I suppose," wrote, in 1857, Mr. (afterwards Professor Sir) G. A. Macfarren, "this superscription to signify that the copy had belonged to a Signor Erba." " "The obvious meaning of this inscription," asserted, in 1883, Mr. W. S. Rockstro, "is that the volume in which it is written had once belonged to a Priest named Erba. Had the Magnificat been composed by Signor Erba, the word used would have been 'dal, not "del." "s

In order to test the truth of the idiomatic rule thus confidently laid down by liockstro, I examined the titles of many old Italian manuscript scores in the Fitzwilliam Library.

${ }^{1}$ Mr. Barclay Squire informs me that the third word of this ingeription may be read either as 'Sigr' or as 'Sgr' and that the handwriting has two little character to be used as decisive evidence to show whether the copyist was Italian or English.

2 ['reface to an analysis of Israd in Eyype written for the Sacred Harmonio Society in 1857.

"Rockstro: Life of Handlel : Macmillan and Co., 15S3, p. 222. 
The following are a few of these titles, which, it will be observed, are exactly parallel to the "Magnificat Del Rd Sigr lirba" of the Royal College score:

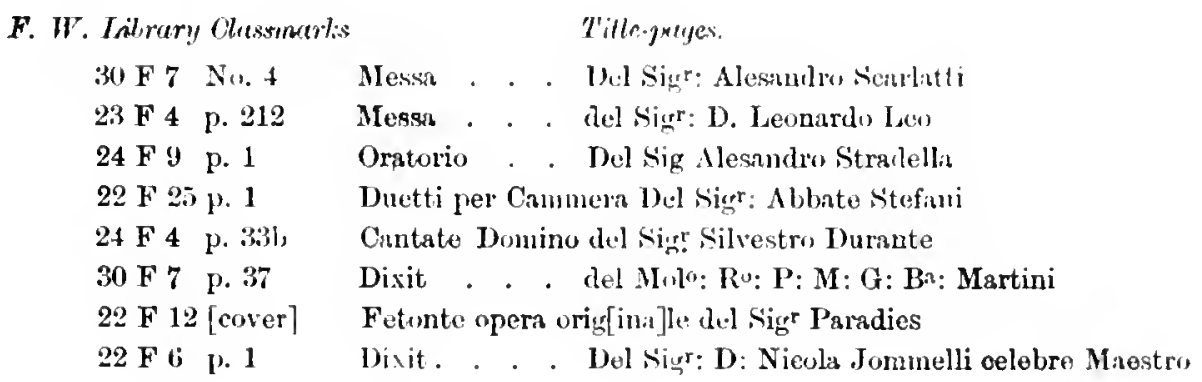

These examples suffice to refute the assertion that ilel, thus used, denotes mere ownerslip. That, indeed, used to be indicated in a different way. Thus in the preface to Bach's organ works, vol. 111. p. XIV. of the Leipzig edition, a manuscript is mentioned entitled "Sonata per il cembalo solo del Sigr J. S. Bach, poss. J. G. Miithel" and on the following page another entitled: "Fuga clamat" in B di Johann Seb Bach Poss. Joh Peter Kellner." The persons to whose names 'poss.' [i.e. 'possessore' or 'posseditore'] is prefixed are as evidently the owners of these scores as Bach is the composer of the sonata and of the fugue.

The general result of ny inspection of a large number of manuseript title-pages was that, for the purpose of designating autlrorship, 'del ' was in much the most common use, that ' $\mathrm{di}$ ' was not unfrequently employed and that ' $\mathrm{da}$ ' and 'dal' were but rarely met with.

We are now, I think, entitled to conclude that the entry on the Royal College manuscript was meant to assert that the Iid Sigr Erba composed the Magnificat written on its pages.

It remains to enquire who lirha was, and on this point we are again indebted to the researches of Dr. Chrysander. In his 'Life of IJandel' 2 he has shown that a compuser of much distinction, I Jou Dionigi Erha, was in the year 169.4 writing opern for Milan, and may well have been the author of our 'Magnifieat.' The prefix 'Don' indicating that lie was a priest, agrees with the 'lid Sygr' of the Royal College score, and the laying out of the work for a double chorus is consistent with its having been composel for the 'dnomo' at Milan where "opportunities were afforded, principally by means of two large organs placel facing each other, for. keeping the old polychoric chureh music longer in use than in the rest of Italy." 3 On these grounds Chrysander conjecturally assigned the composition of the Magnifieat to Dionigi Erba. Its stylo, he wrote, "is not in the most remote

'I do not know what "clamne means in this connexion.

2 Vol. I. p. 173.

a Ib. p. I75. My friend Mr. K. J. Dont tells me that he has frequently seven organs thus placed in ehurebes elsurbero in lualy. 
degree that of Handel, either in his carlier or his later period." 1 Macfarren, on the other hand maintained that the Magnificat "if not so mature, is perfectly congenial in sty.le with all the more carnest compositions of IIandel with which we are acpuainted." ' In the presence of opposite julgments pronounced with equal confilence by recognized authorities, the appeal to the 'cvidence of style' must be regarled - at any rate for the present-as indecisire. There remains the reasonably probable hypothesis, based on external evidence, assigning it to Dionigi Erba-a lypothesis which the coming to light of other copies of the score or 'parts' might at any time conclusively establish-or refute. Accordingly we are unable to say with certainty whether Handel, when incorporating practically the whole of this Hagnificat in the second part of Israrl, was appropriating a work by another composer or refurbishing one of his own. I shall, therefore, in order not to prejudge this alternative, indicate the Magnificat in the sequel by the neutral abbreviation 'Mag.' rather than by the question-begging names 'Handel' or 'Erba,' though personally I am inclined to regard as preponderant the arguments against a Handelian origin for the disputed work. For on immediate purpose, indeed, the question of autlorslip is unimportant, since, as las been seen, Handel's mode of dealing with earlier compositions of lis own did not differ from that which he applied to those of other Masters.

The second l'art of our oratorio opens with the majestic piece of choral declamation (No. 17) "Moses and the children of Israel," leading into the superbly jubilant double chorus (No. 18) "I will sing unto the Lord for He hath triumphed gloriously," in which no older material has been detected save, indeed, an ascending and descending scale passage, of four notes-a regular locus communis of contrapuntists-which Handel had used much less impressively in his Te Deum for the Peace of Utrecht in $1713 .^{3}$

The duet for two Trebles (No. 19), "The Lord is my strength," which immeliately follows this great effort, is simply a revised reproduction of a duet for the same voices in the Magnifieut, accompanied too in the same manner, by unison violins with a practically unfigured bass in the oratorio, and by a viola with a figured bass in the Magnificat. The comparison of the two settings is particularly instructive because it shows us Handel improving the earlier one exactly in the way in which a first-rate teacher of composition corrects the work of a promising pupl ; cutting it ahout quite frecly but without altering its essential character. What strikes one as really surprisirg is that, considering the great amount of correction expended on what was after all only a moderately meritorious piece of work, Ilandel should not in this instance have preferred independent composition to so tiresome a process of adaptation.

\footnotetext{
Ih. p. 173. = Analysis of Isreel in E!?mpt quoted by Chryeander. Ib. p. 168. note.

${ }^{3}$ Chrysander: 'Life of Handel,' vol. I. p. 393.
} 
In Ex. 35 and wherever the Muynificut is quoted in these pages Dr. Chrysanders edition is nsed; but I have omitted the figuring of the Bass as not required for the purposes of our comparison.

\section{Ex. 35.}
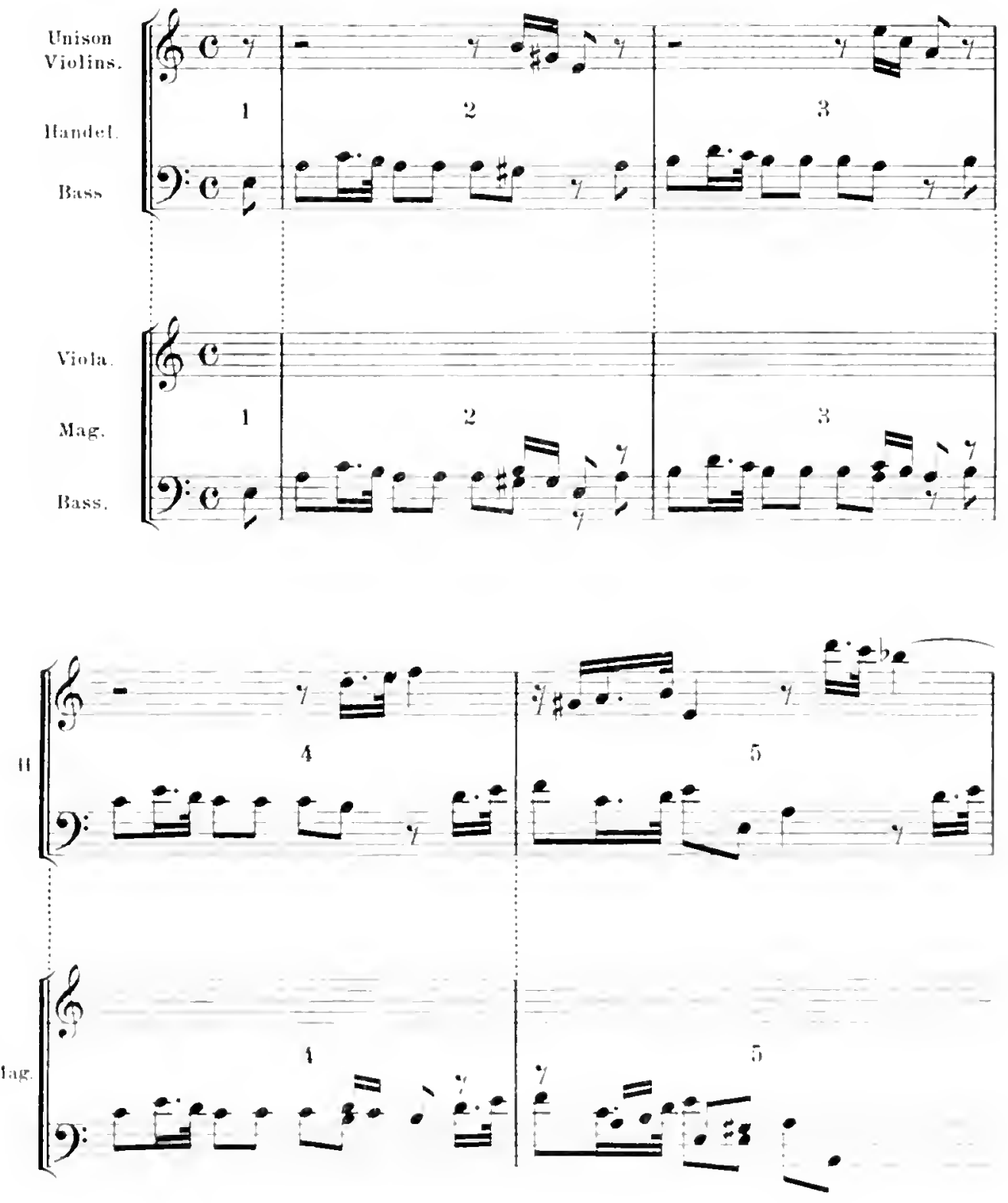


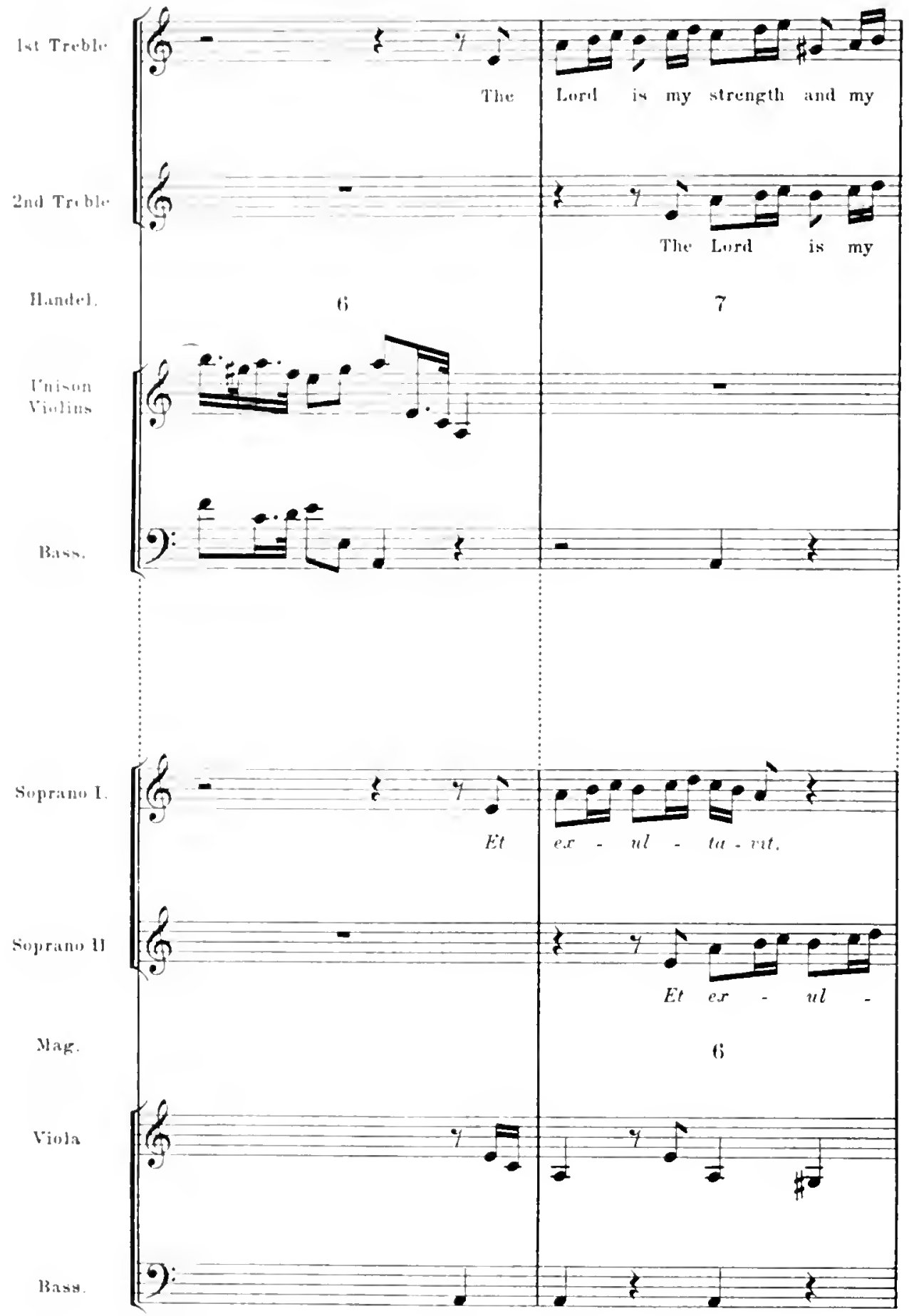



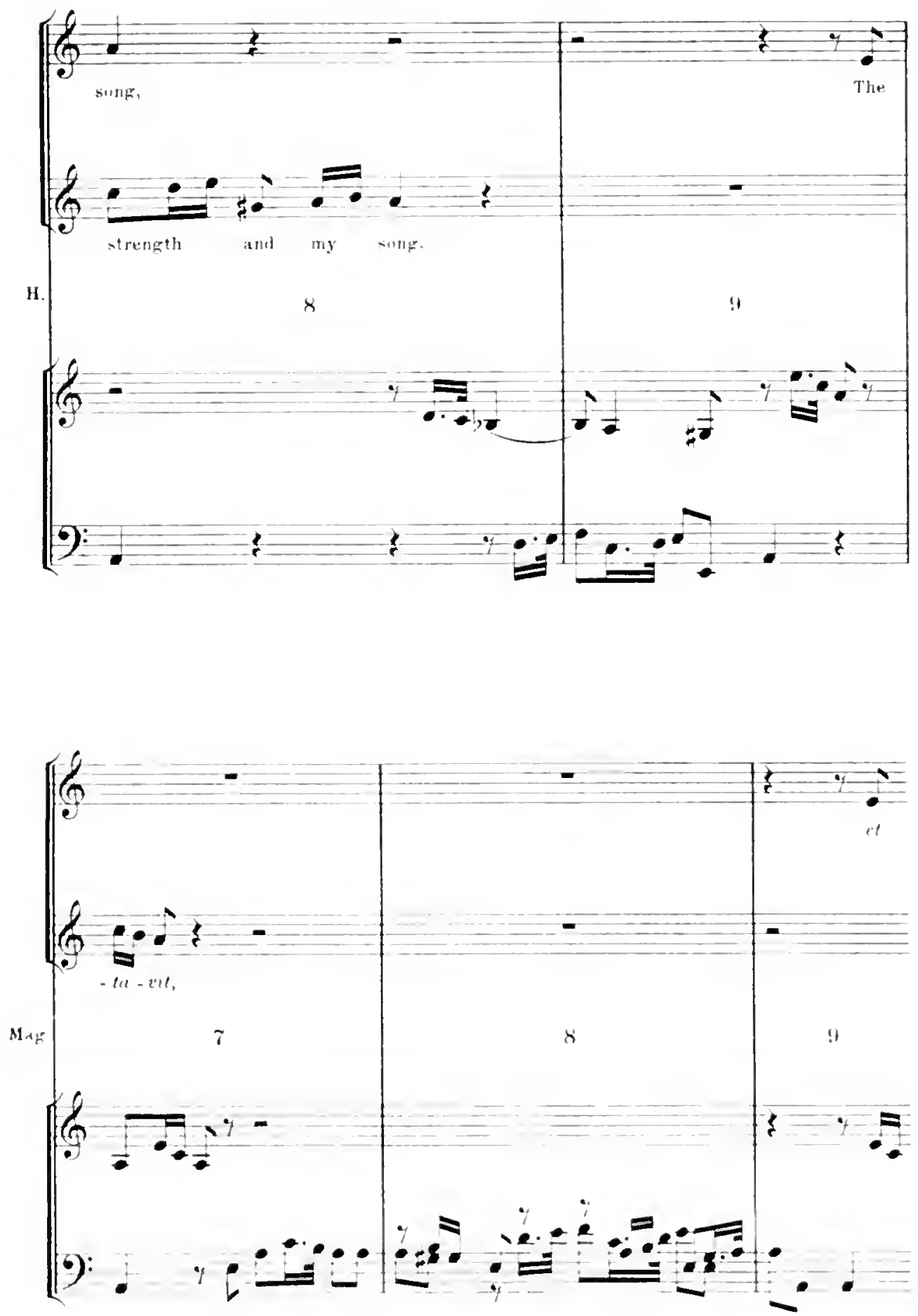

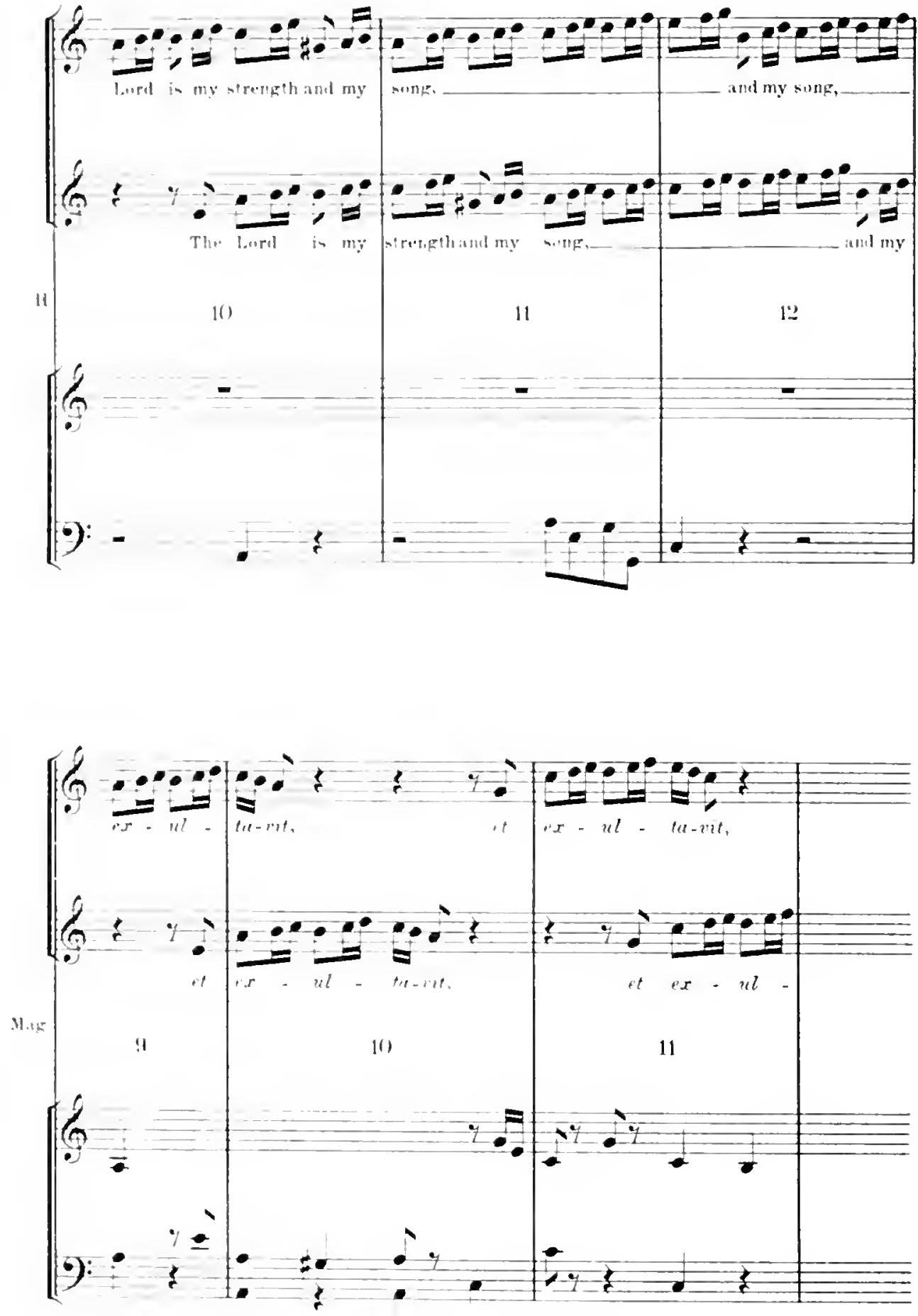
ISRAEL IN EGYPT
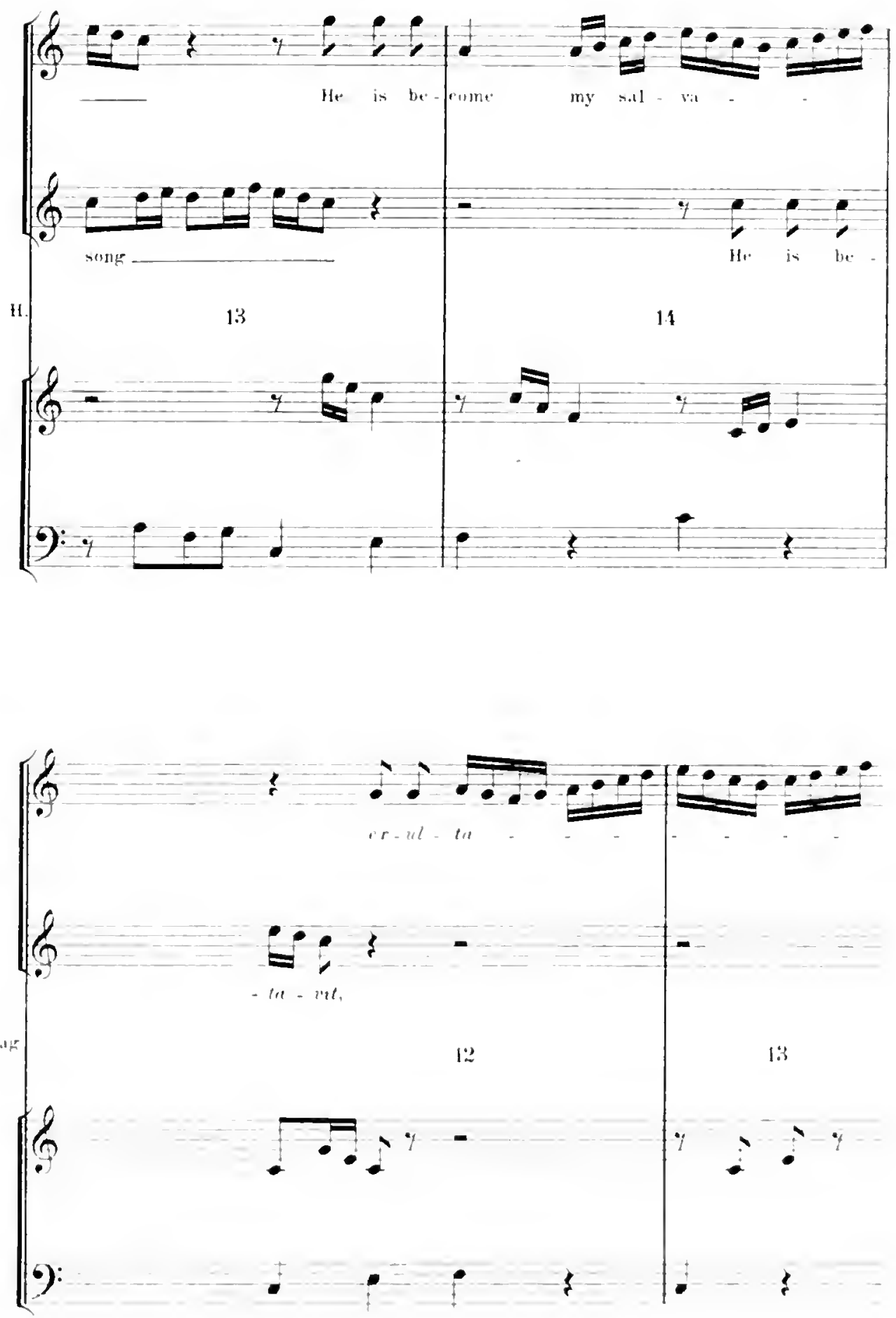
98

ISRAEL IN EGYPT
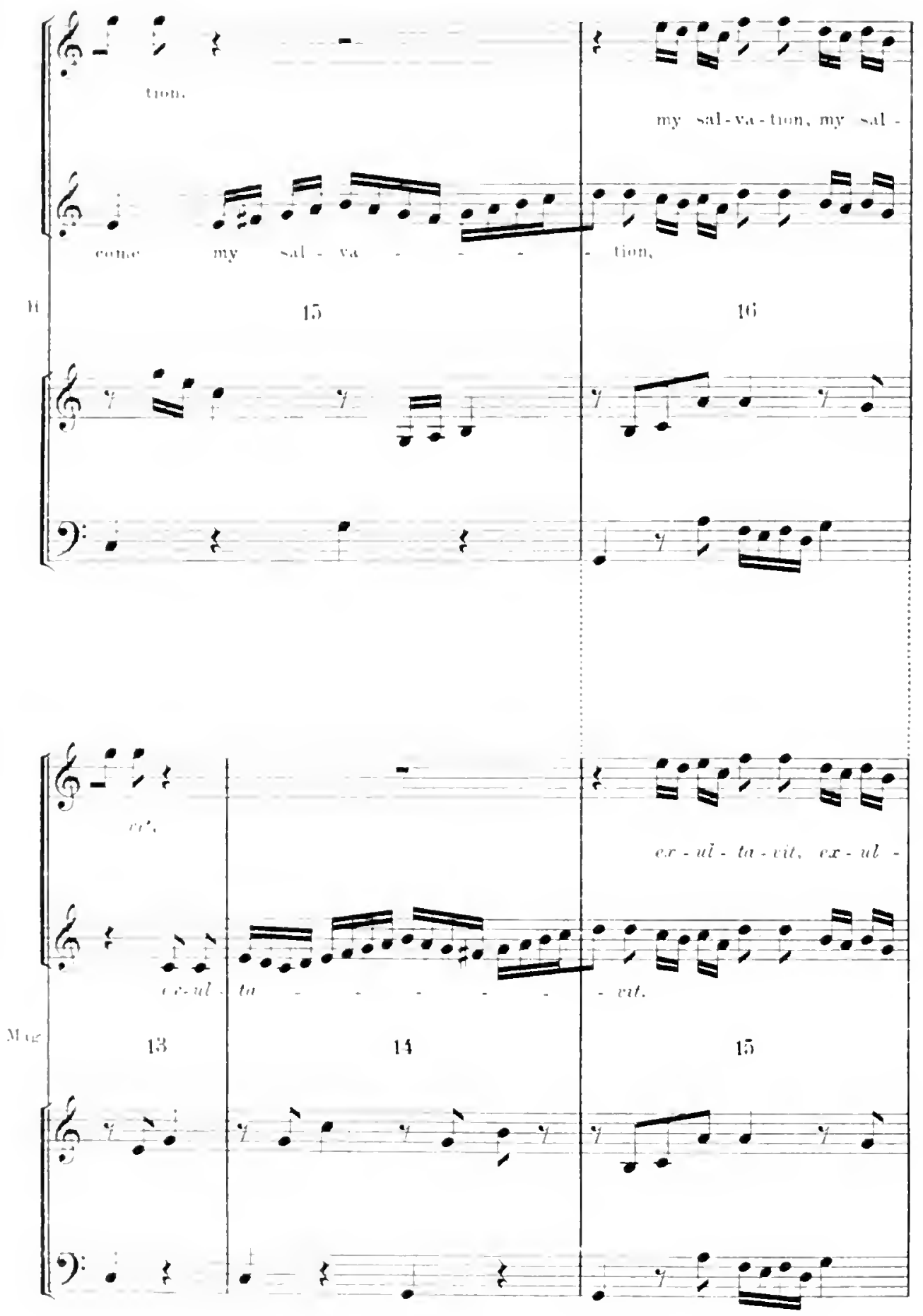

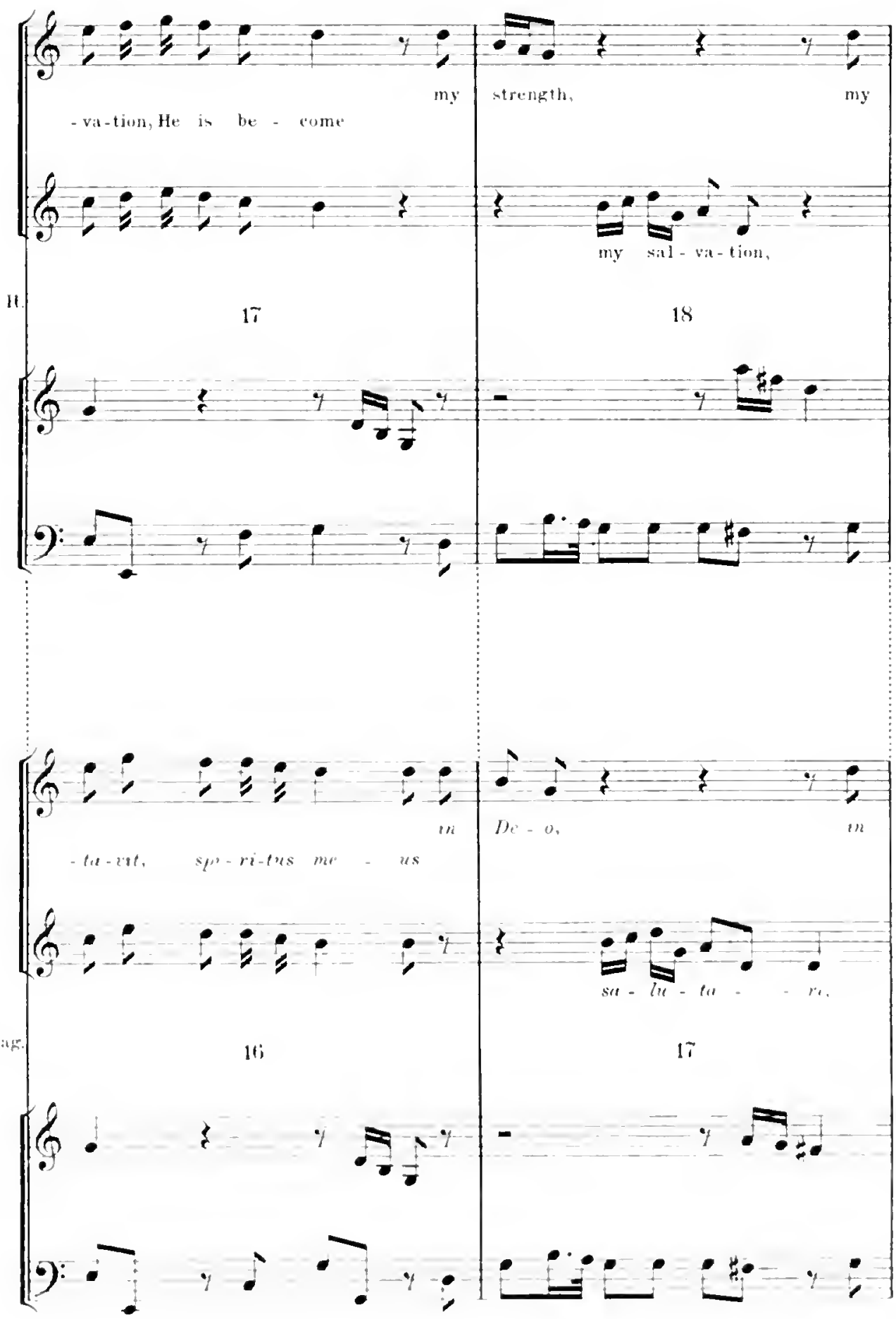

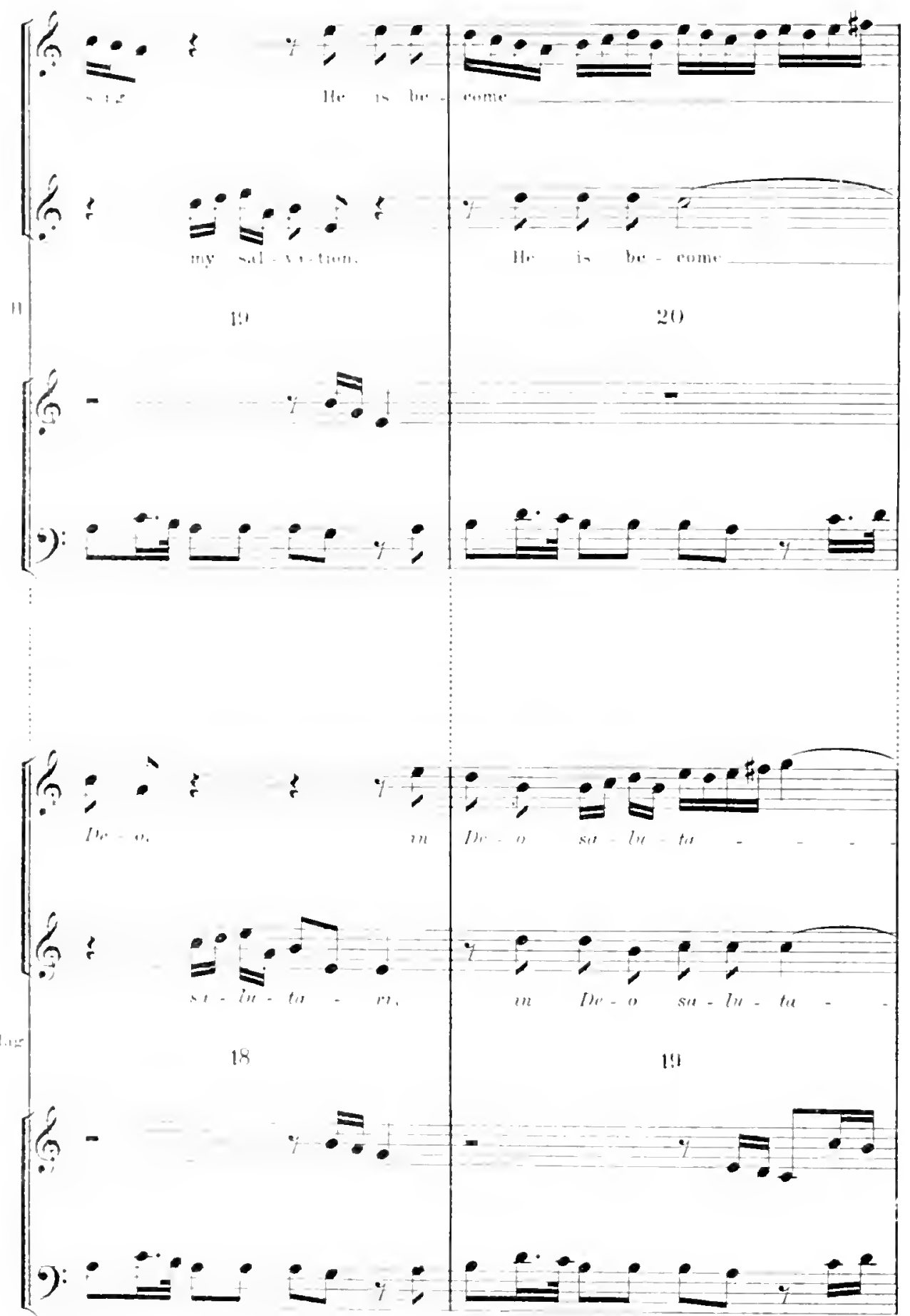


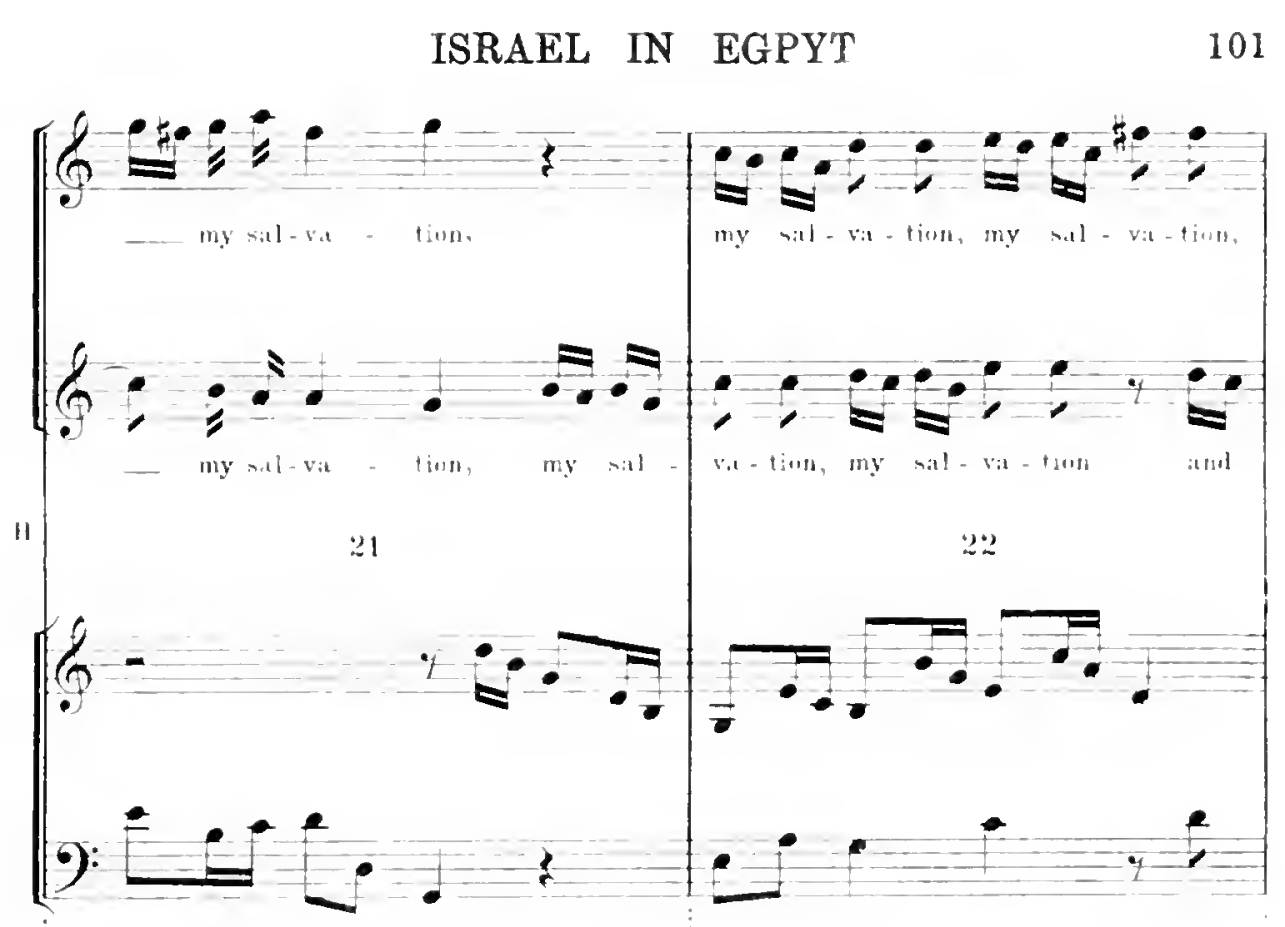

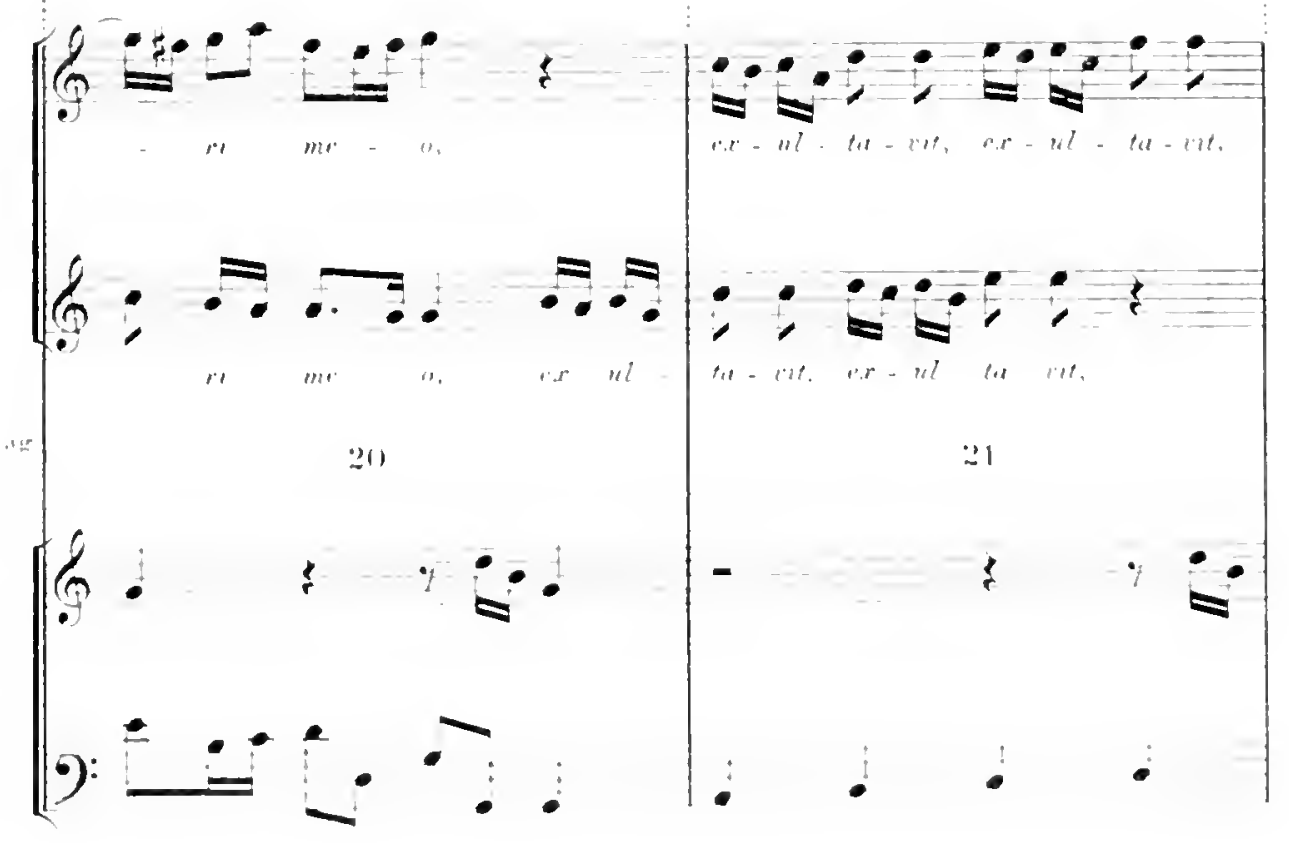



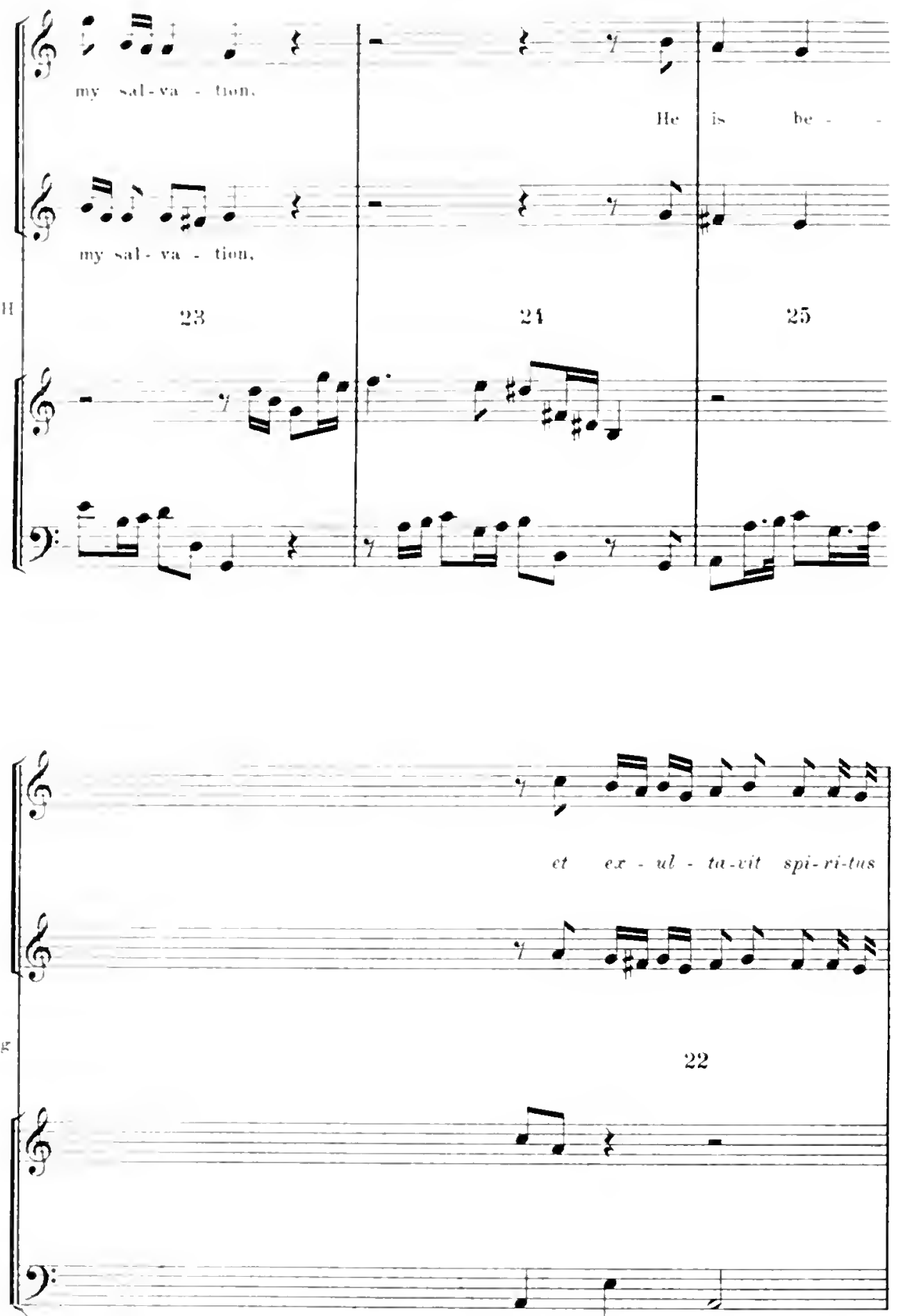

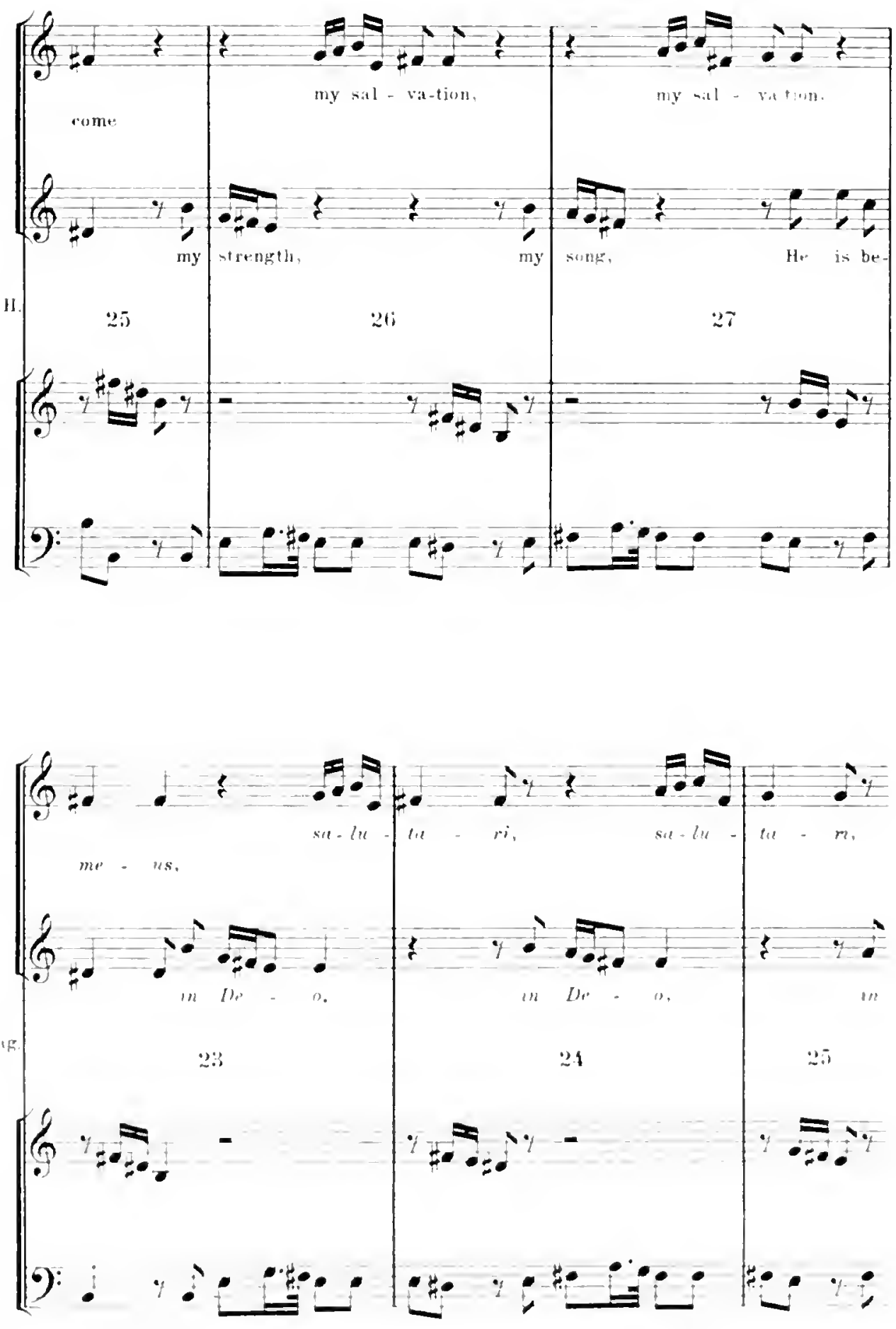

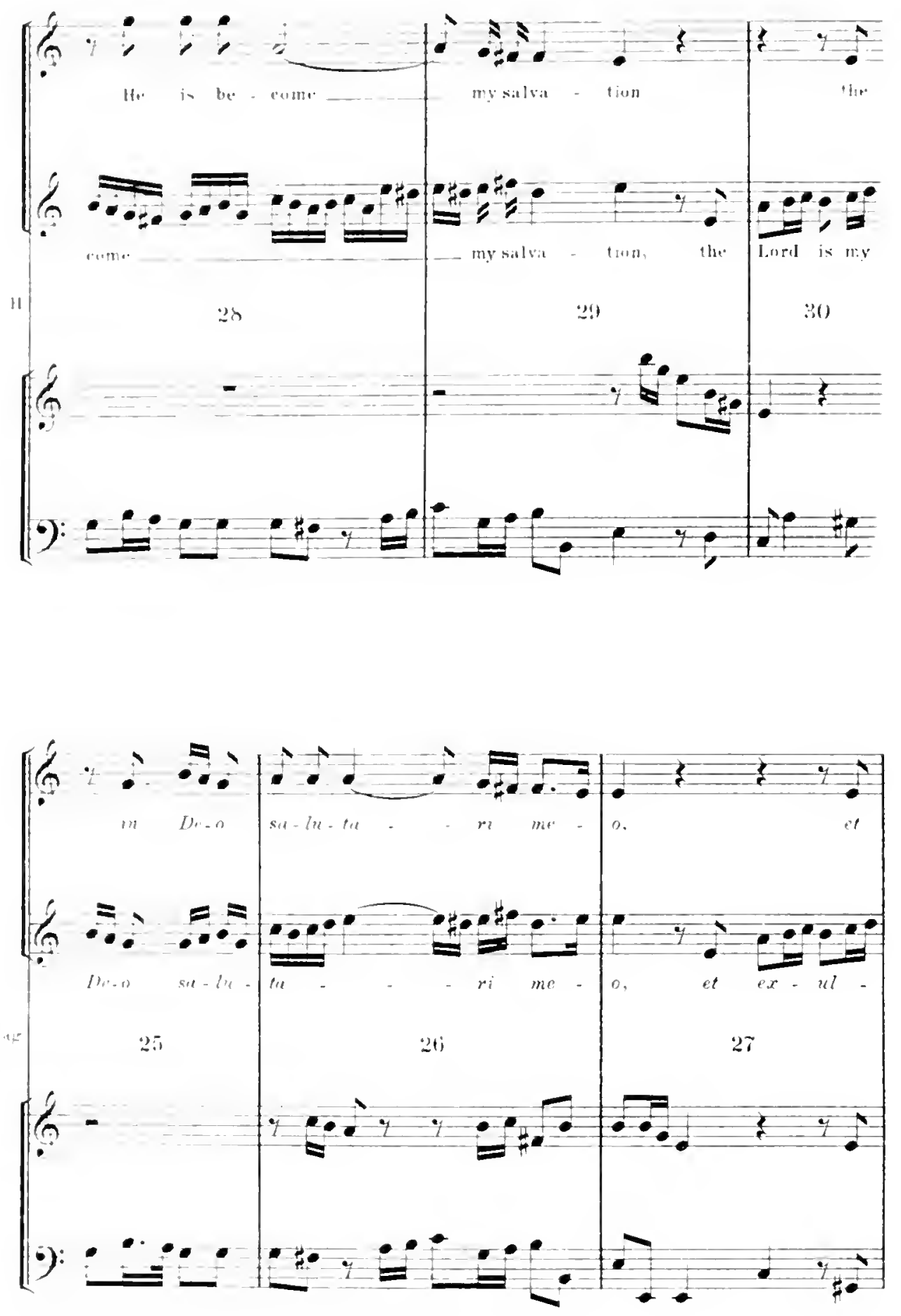
ISRAEL IN EGYPT

105
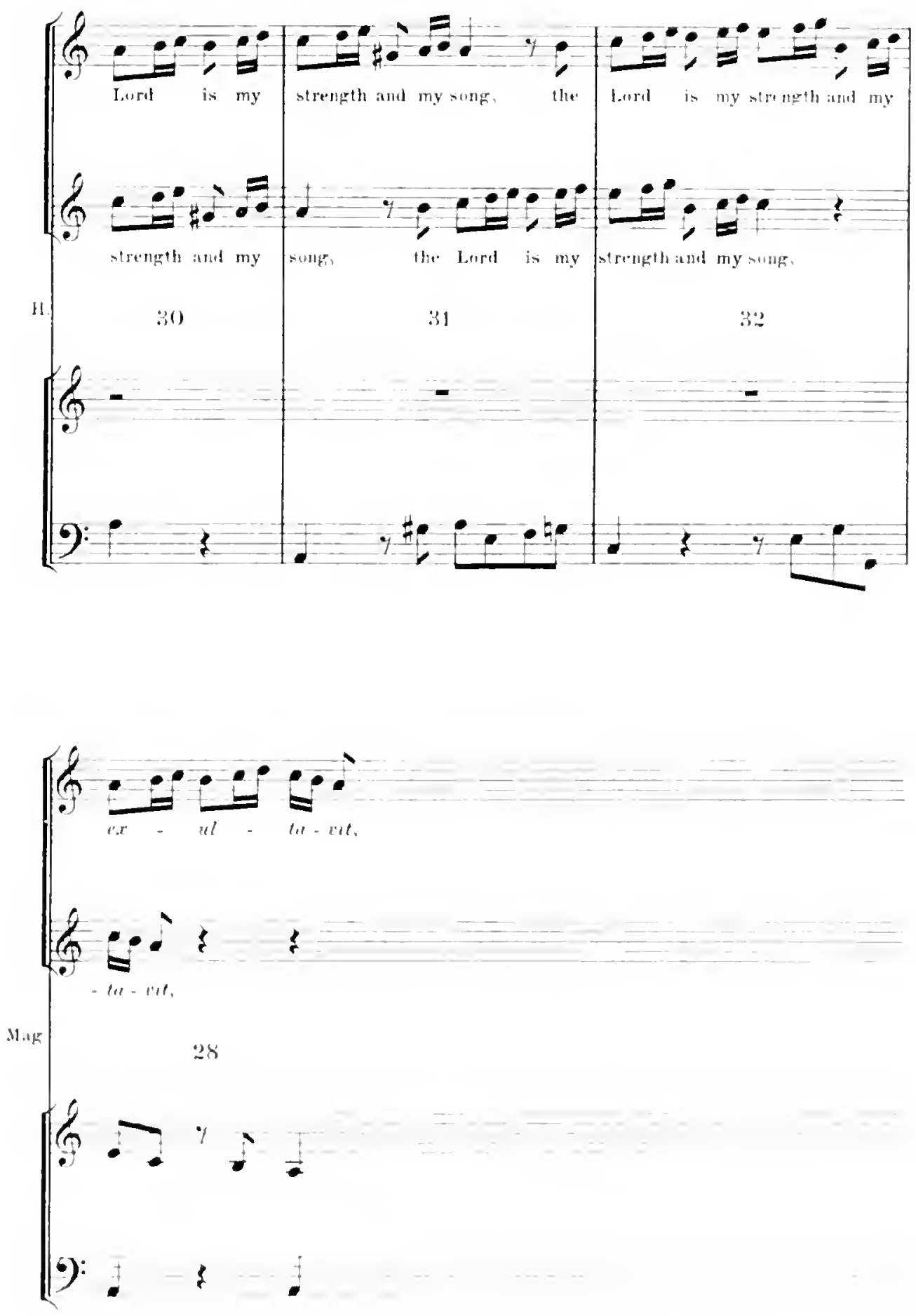
106

ISRAEL IN EGYPT
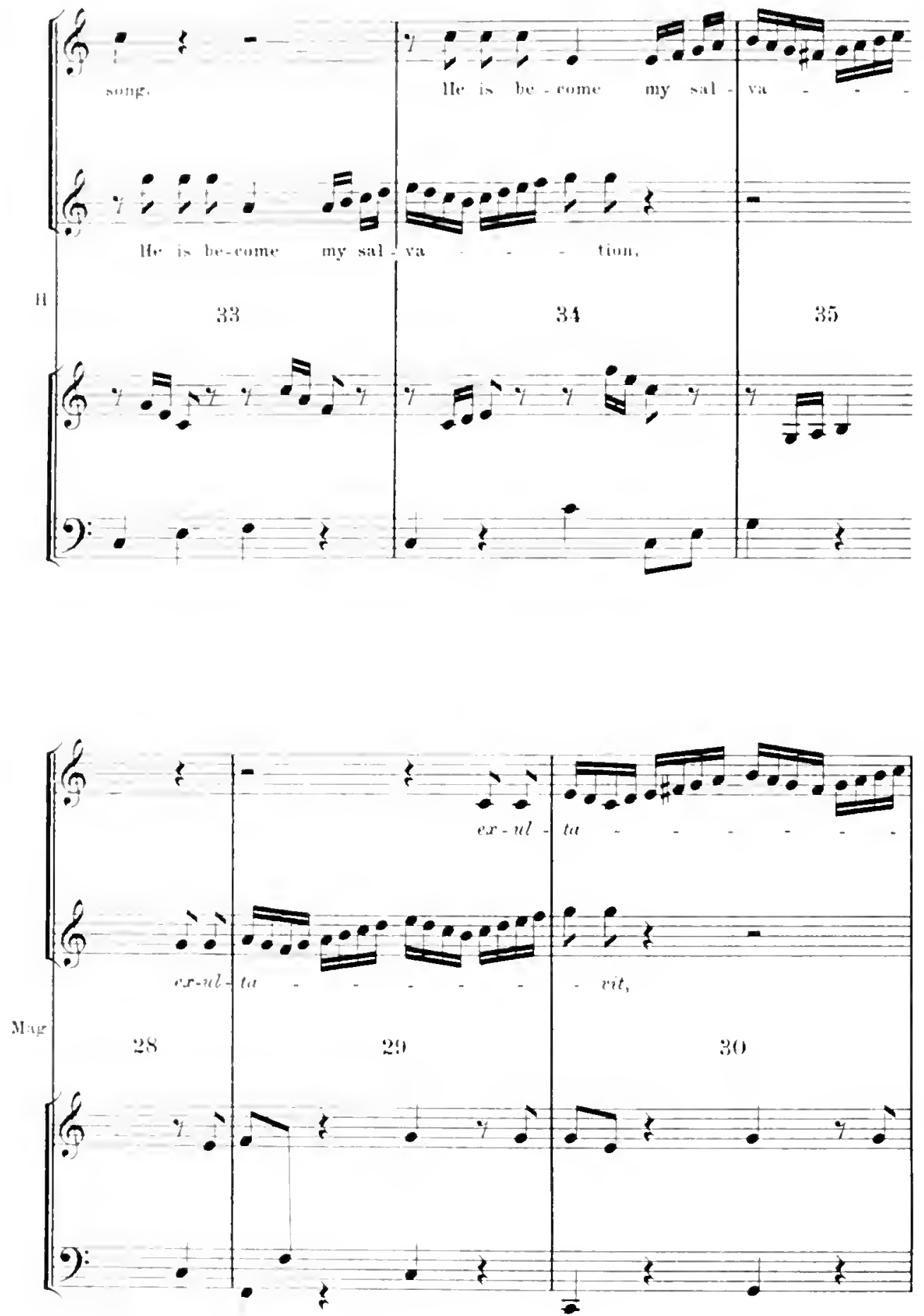

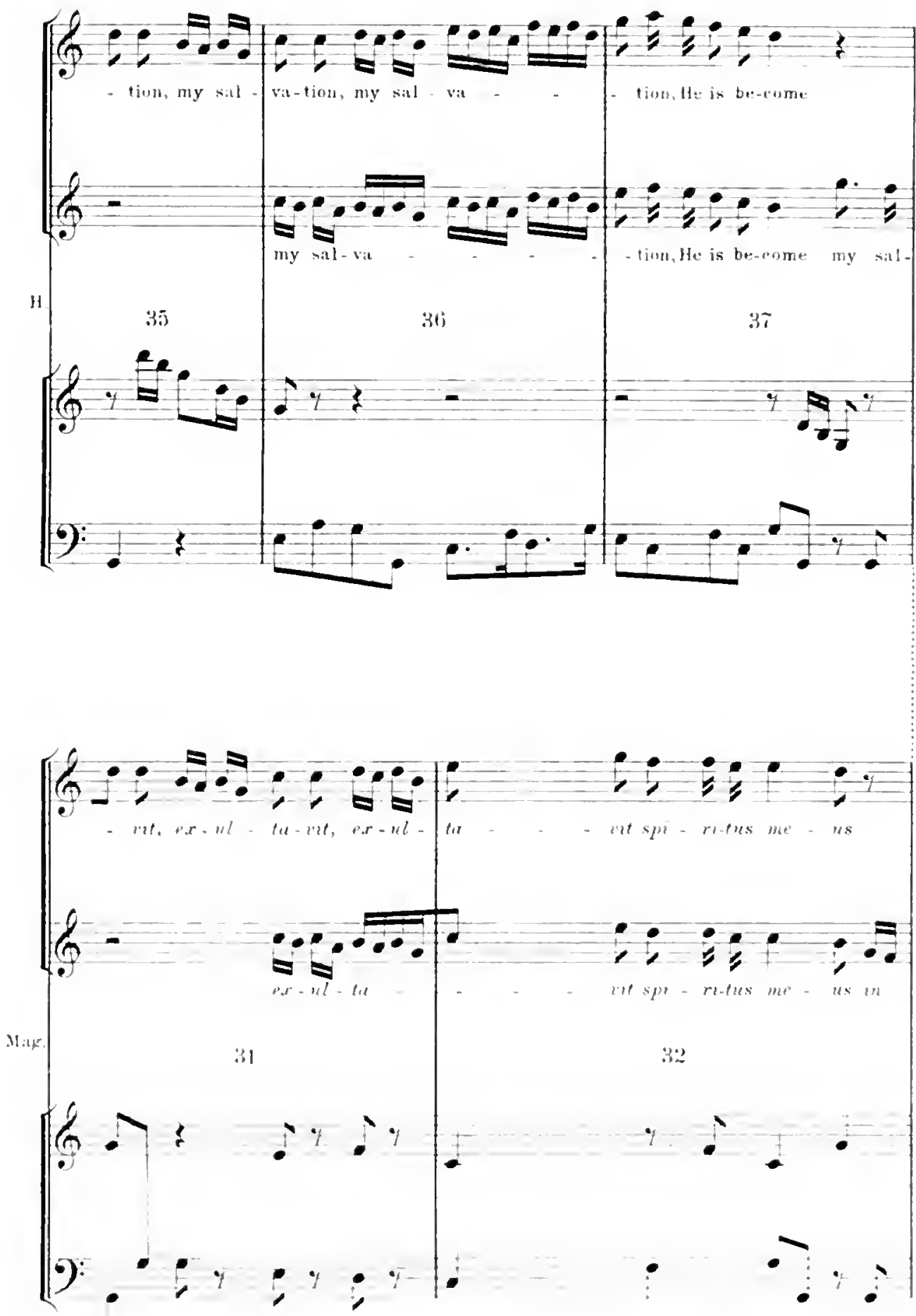

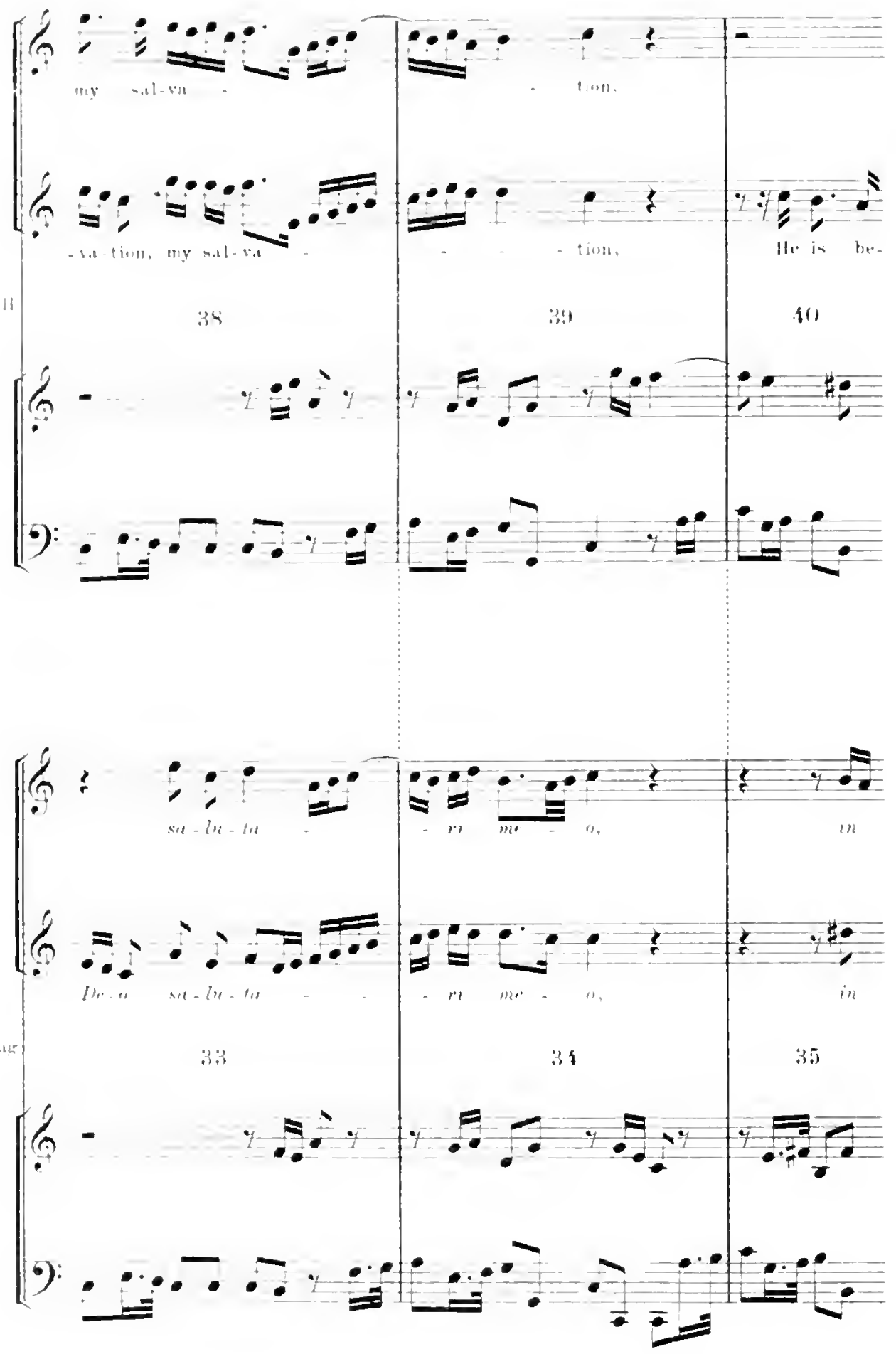
ISRAEL IN EGYPT

109

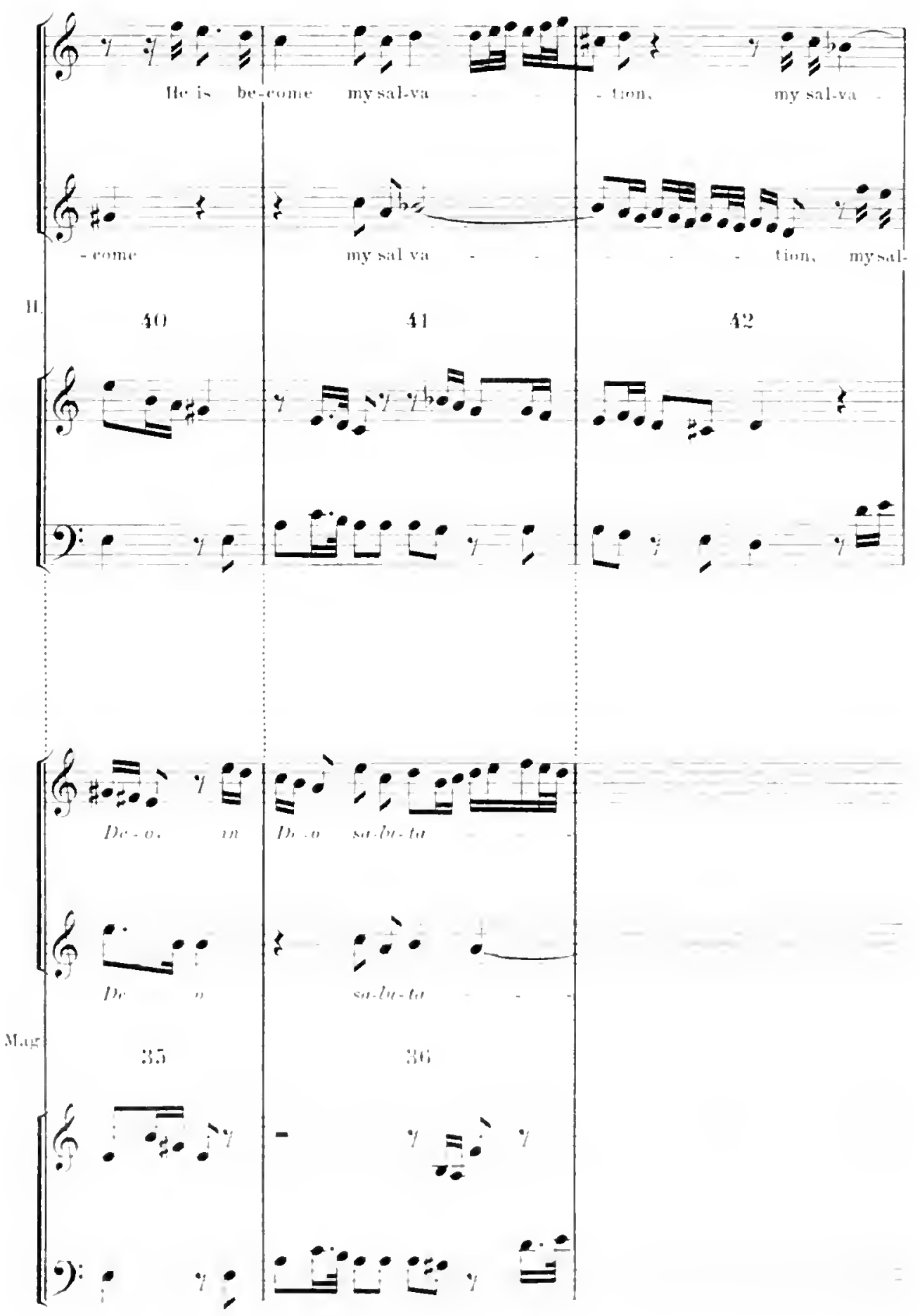


110

ISRAEL IN EGYPT

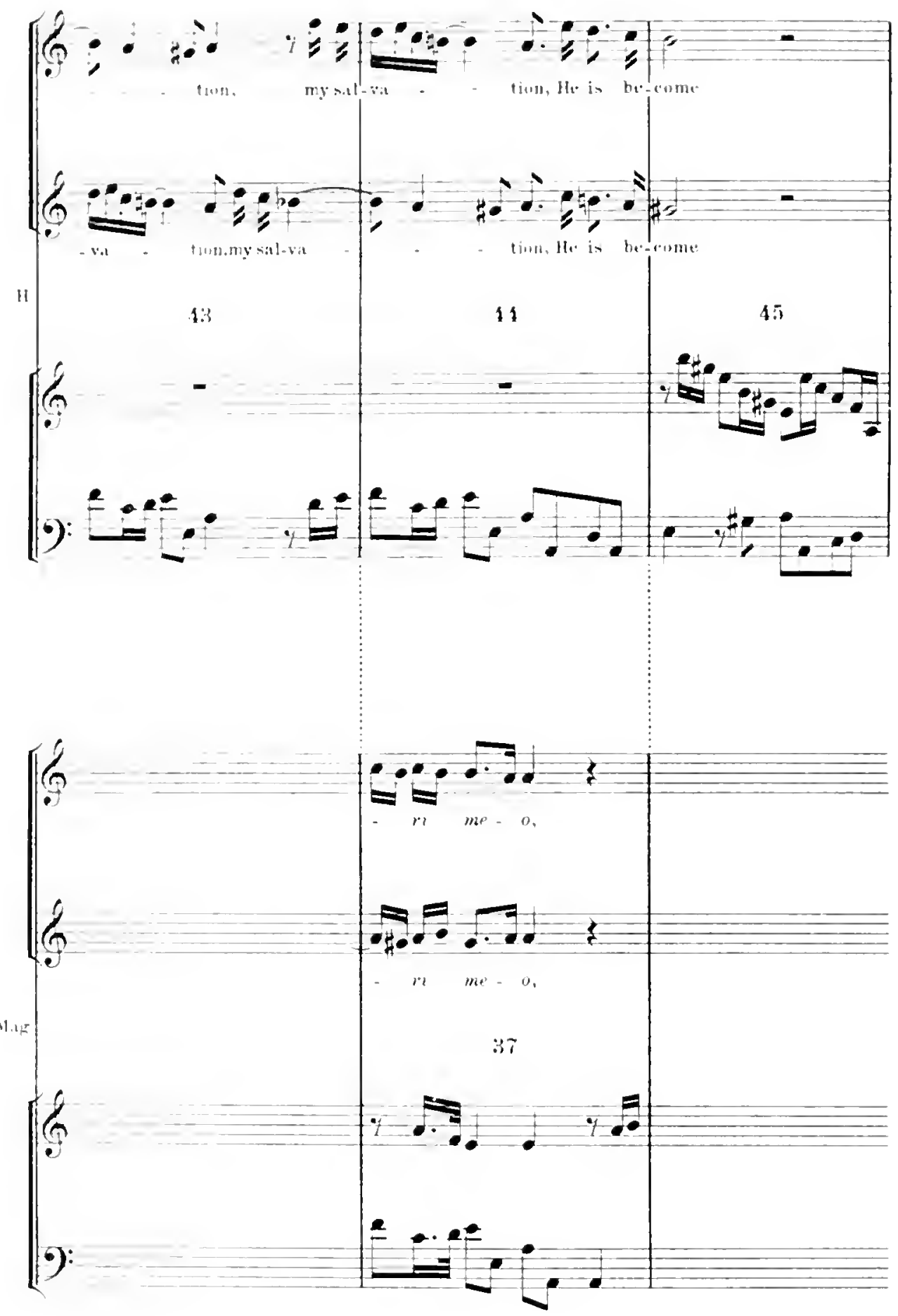




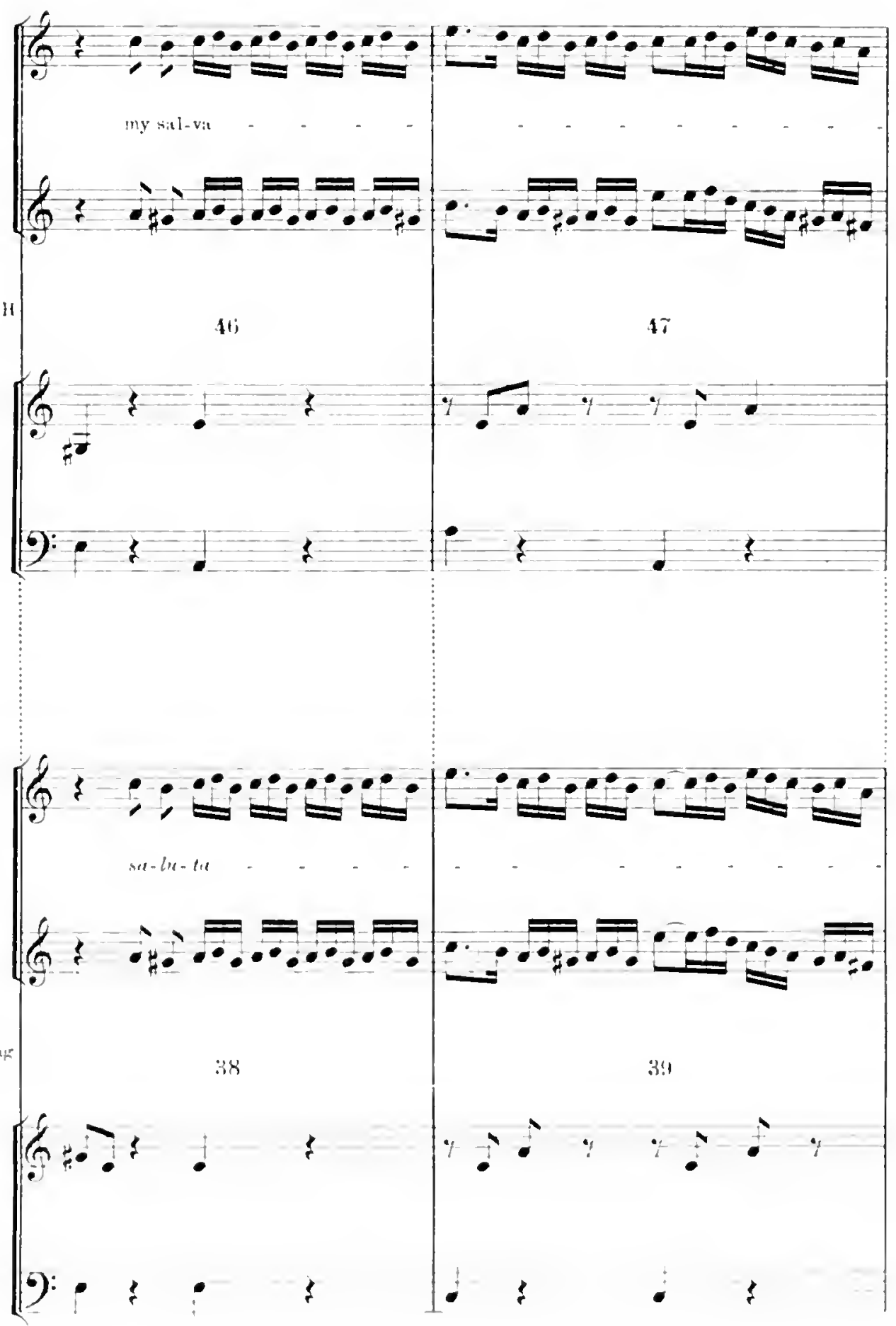


112

ISRAEL IN EGYPT
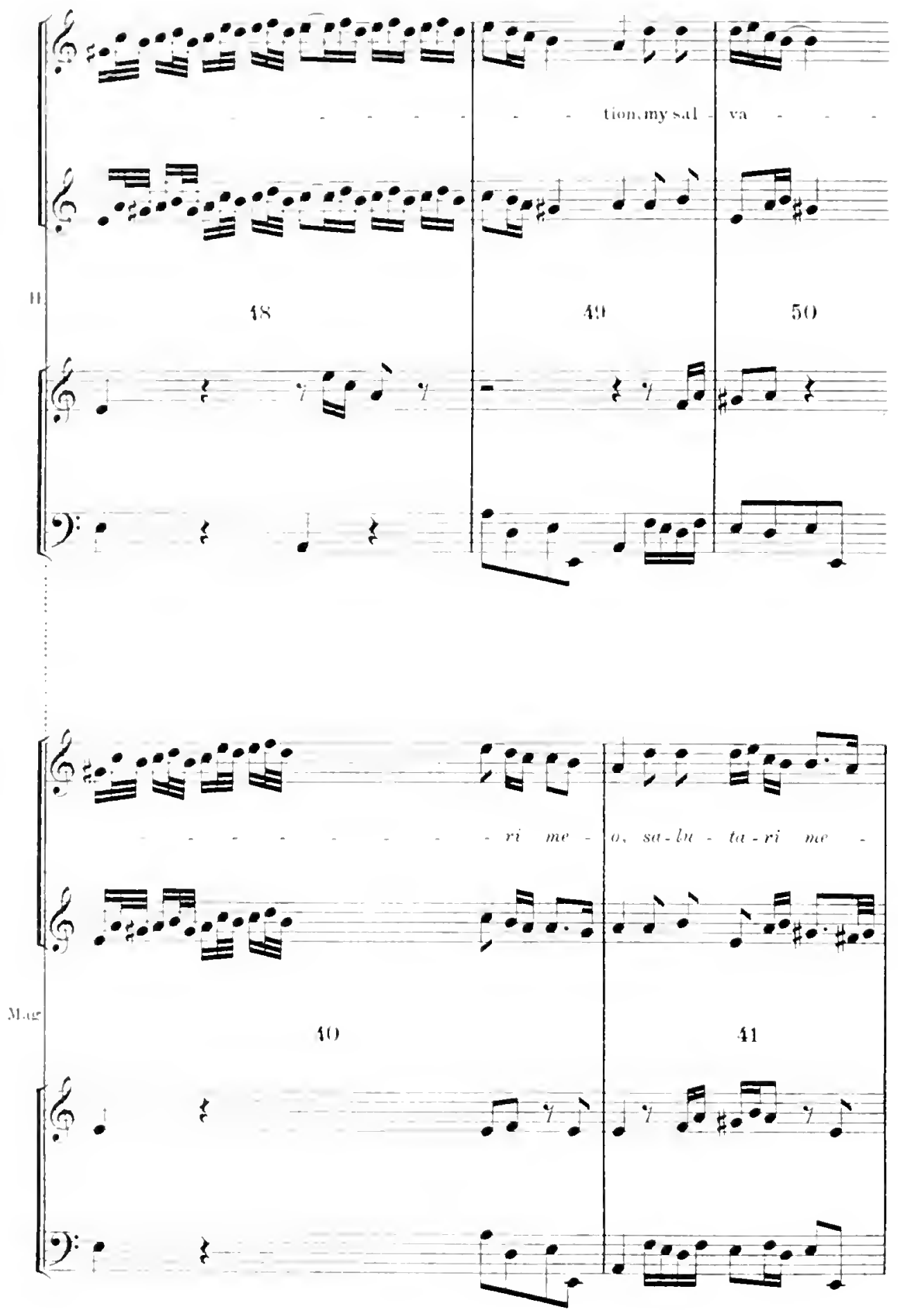


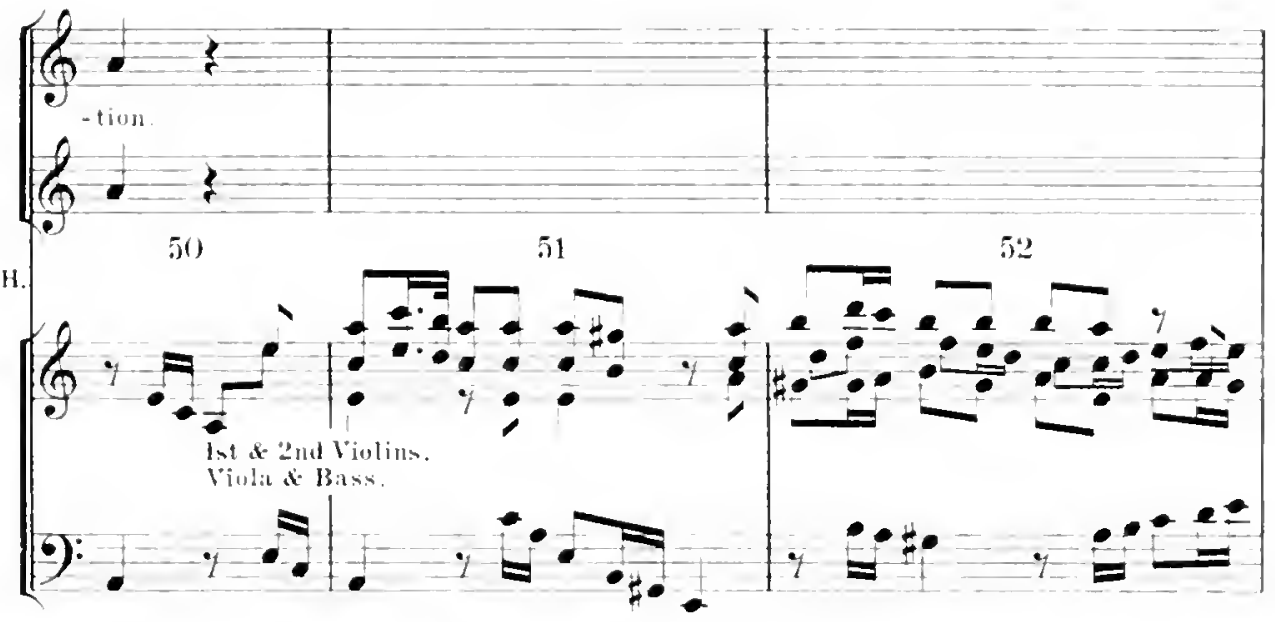

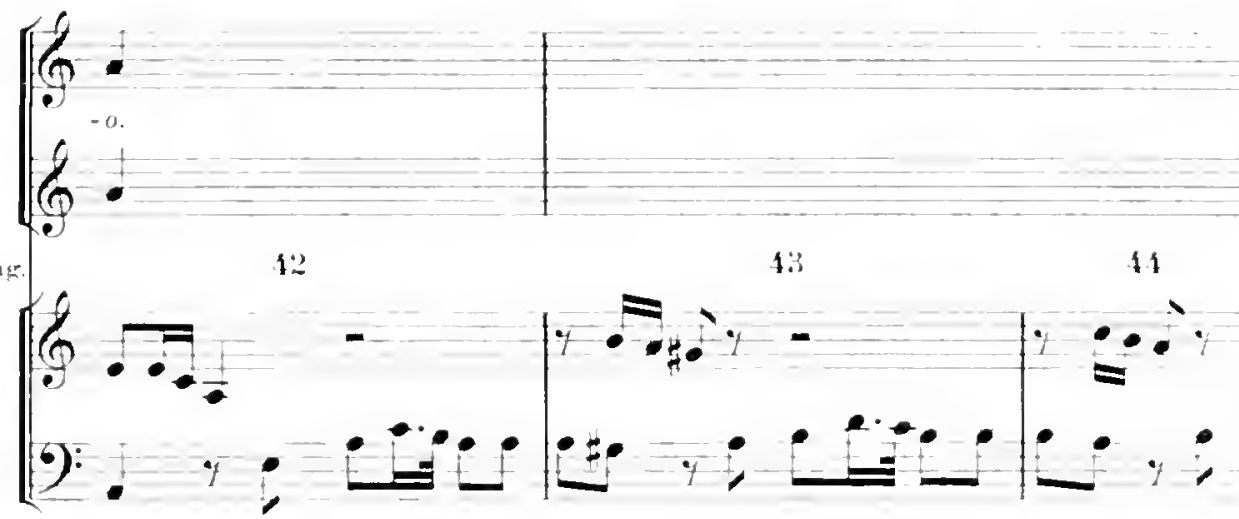

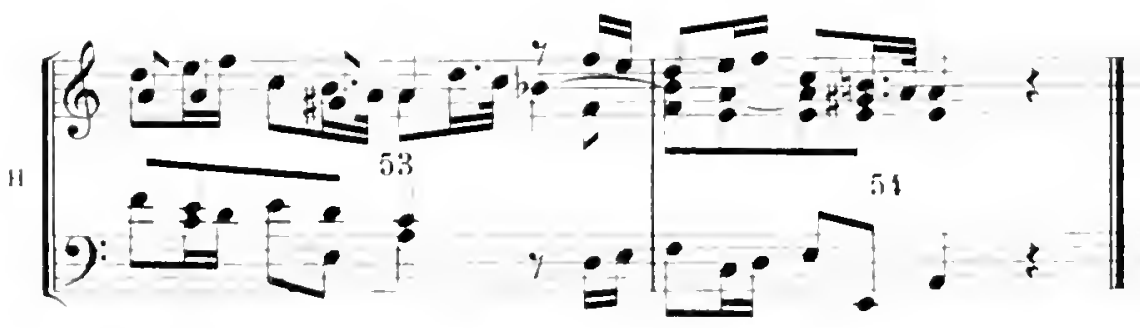

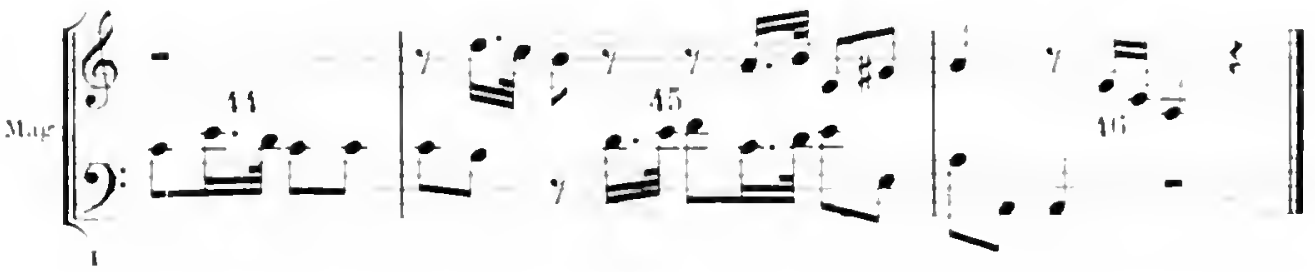


The double chorus (No. 20) "He is my God," which comes next in order, consists of ten bars, of which the first two contain only percussions of the chord of A minor. Bars 3-8, save for a slight alterntion in bar 4, reproduce almost note for notc the whole opening chorus of the Magnificut, and bars 9 and 10 contain the closing flash of genius which we have learned to expect from Handel when he has fuished working up a piece of old material. All this is shown in the following Example, in which I have not included the erchestral parts, as they possess no independent interest:

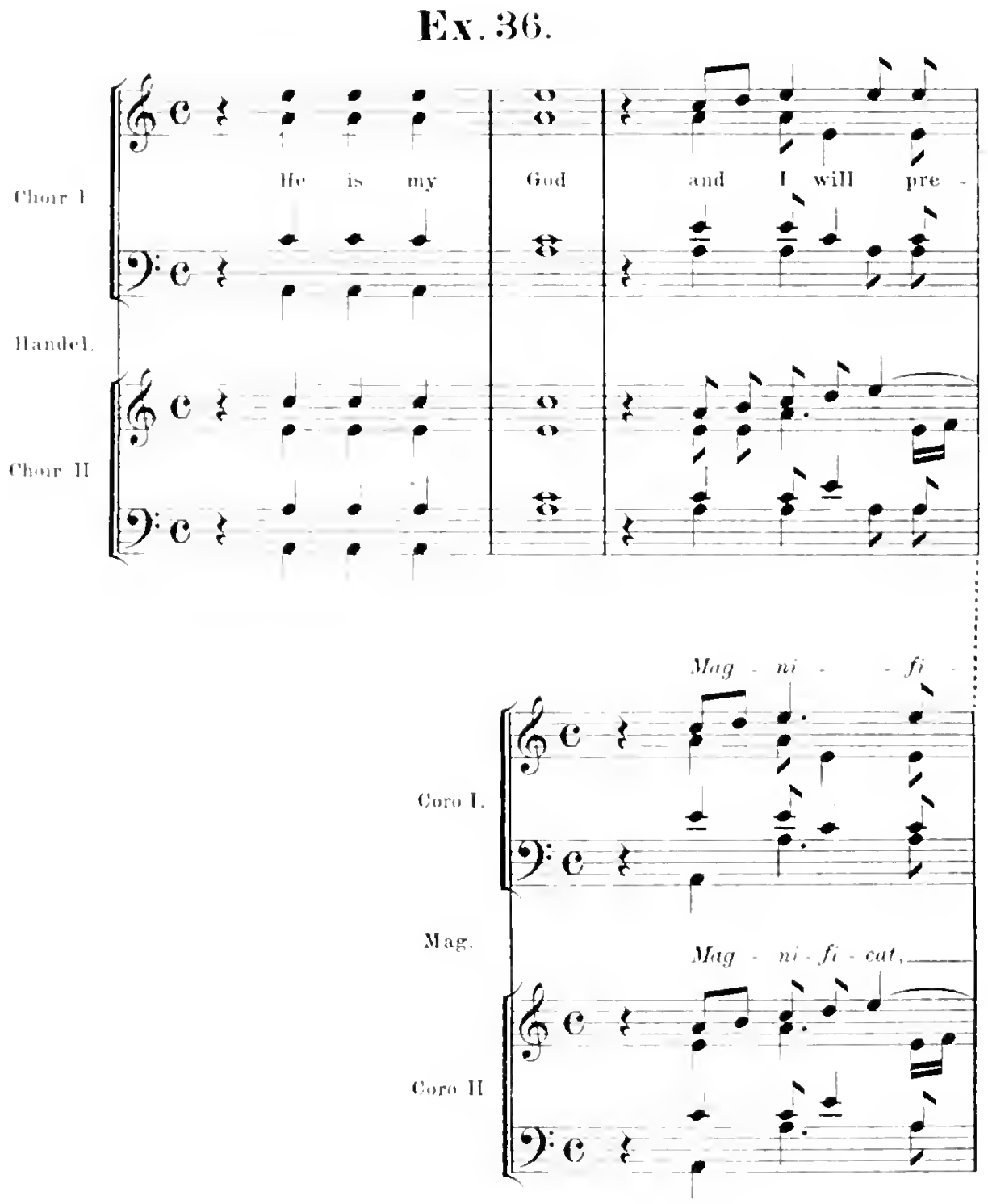



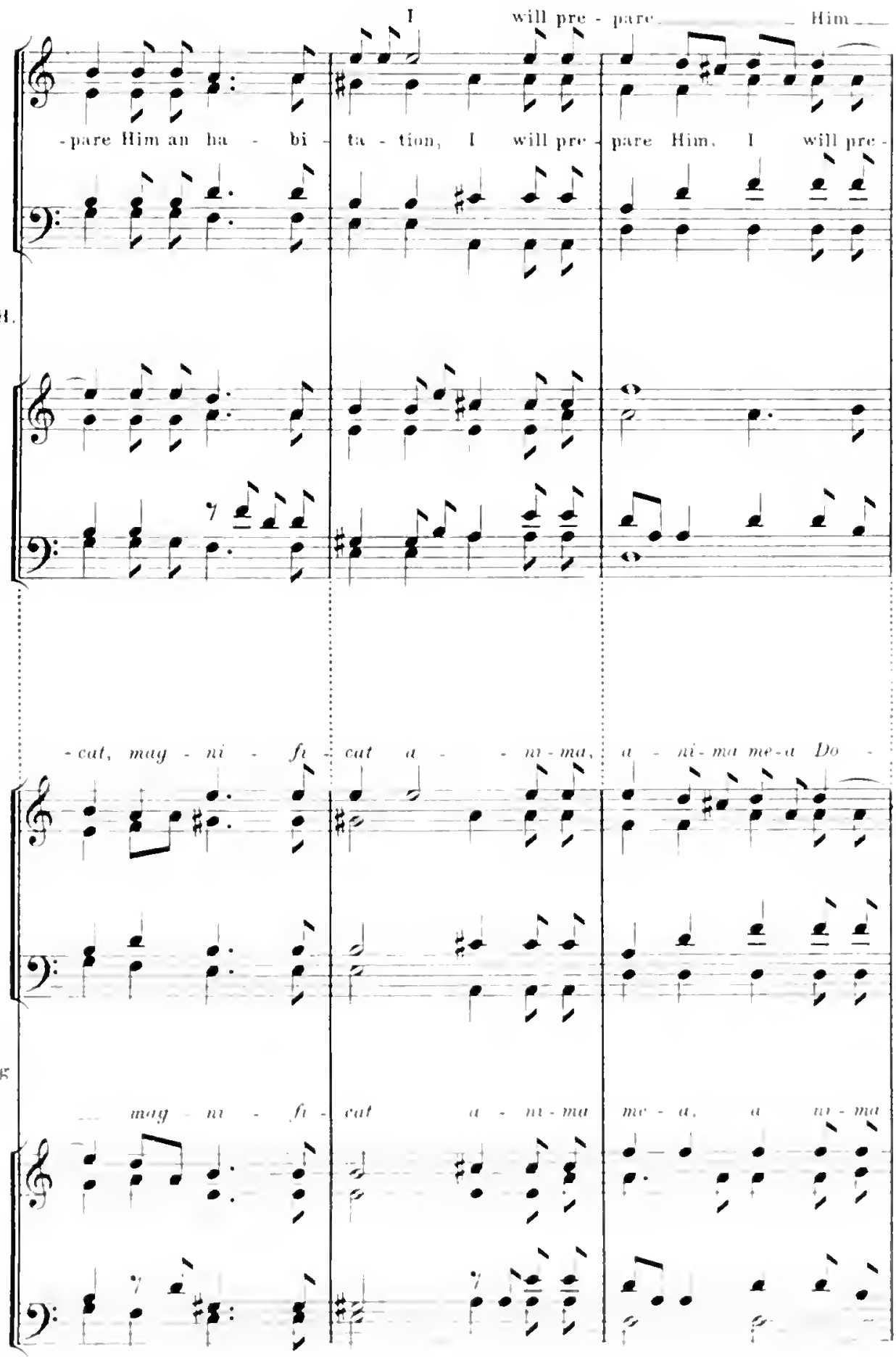

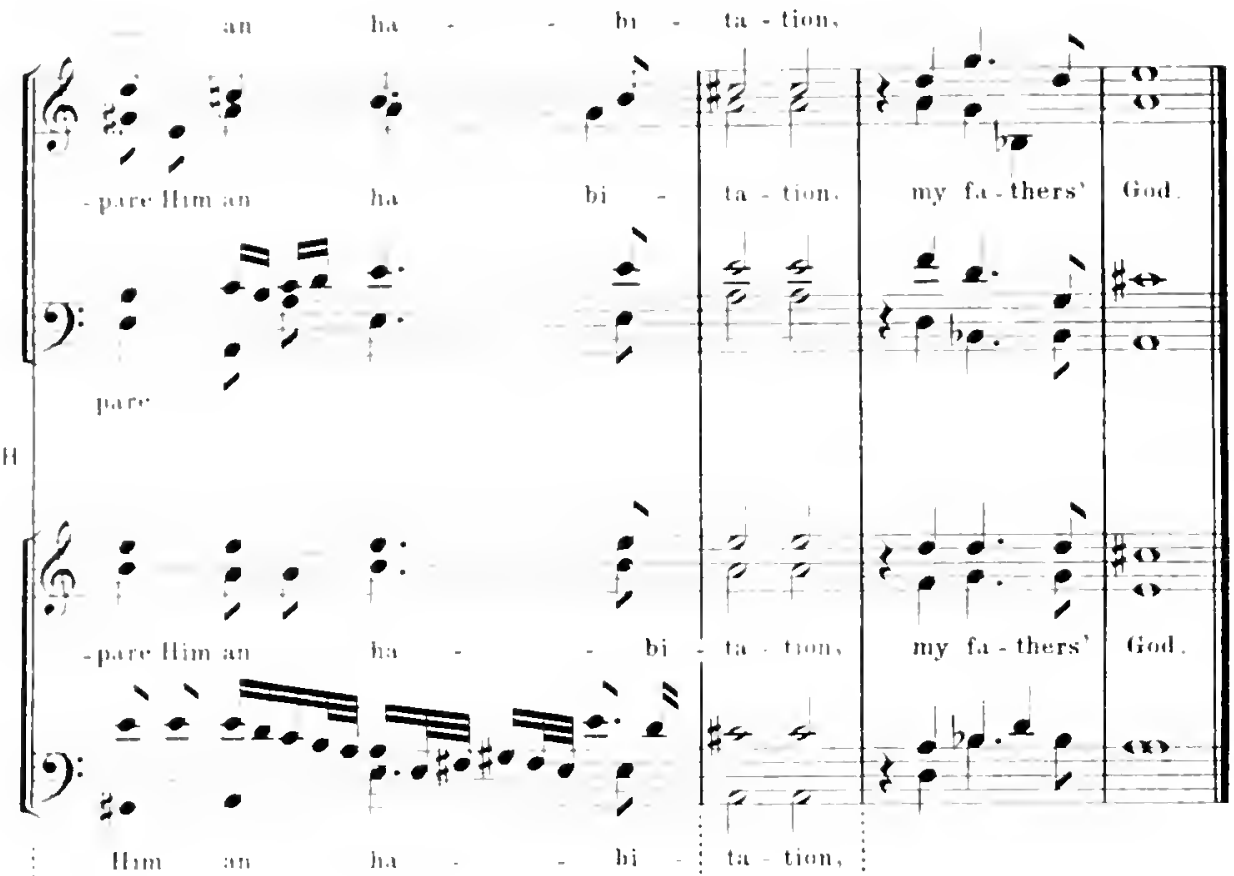

$\int h:$

9: :

- ,

${ }_{-1+2}=$

(I)

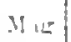

: $::$

In'

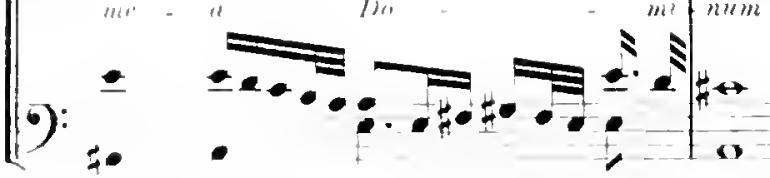

$m+-\vdots n m$.

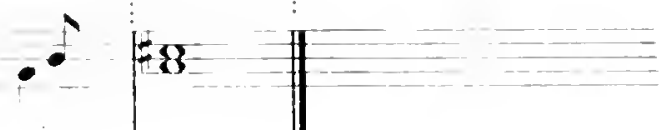

ii

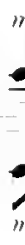

:

a

nnm.

$\because 0$

me num 
Passing over the chorus (No. 21) "And I will exalt him," which has not been shown to owe anything to pre-existing materials, we come to the famous duet for Two Basses, "The Lord is a man of war," in which Handel, besides making abundant use of a duet for the same voices in the Magnificat, has worked into the orchestral prelude and accompaniments a theme taken from a work by an earlier composer named Urio.

Of Francesco Antonio Urio hardly anything appears to be known except that he was a priest and lived at Bologna in the seventeeuth and beginning of the eighteenth centuries. The important fact for us is that he composed a Te Deum for voices and orchestra, a score of which, now in the Library of the Conscrvatoire at Paris, bears the heading "Te Deum, Urio, 1660." 1 Handel used this work very extensively in bis Dettingen Te Devm, and a theme from it, which had already done duty there, in the orchestral prelude to the chorus "All the earth doth worship Thee," leads off the introduction to "The Lord is a man of war," the rest of which is either directly copied from, or developed out of, the prelude to the duet in the Magnificat. This will be at once seen from the ensuing comparison, for the sake of which I have transposed the extract from Urio's Te Deum a Fourth down and that from the Magnificat a Minor Third down.

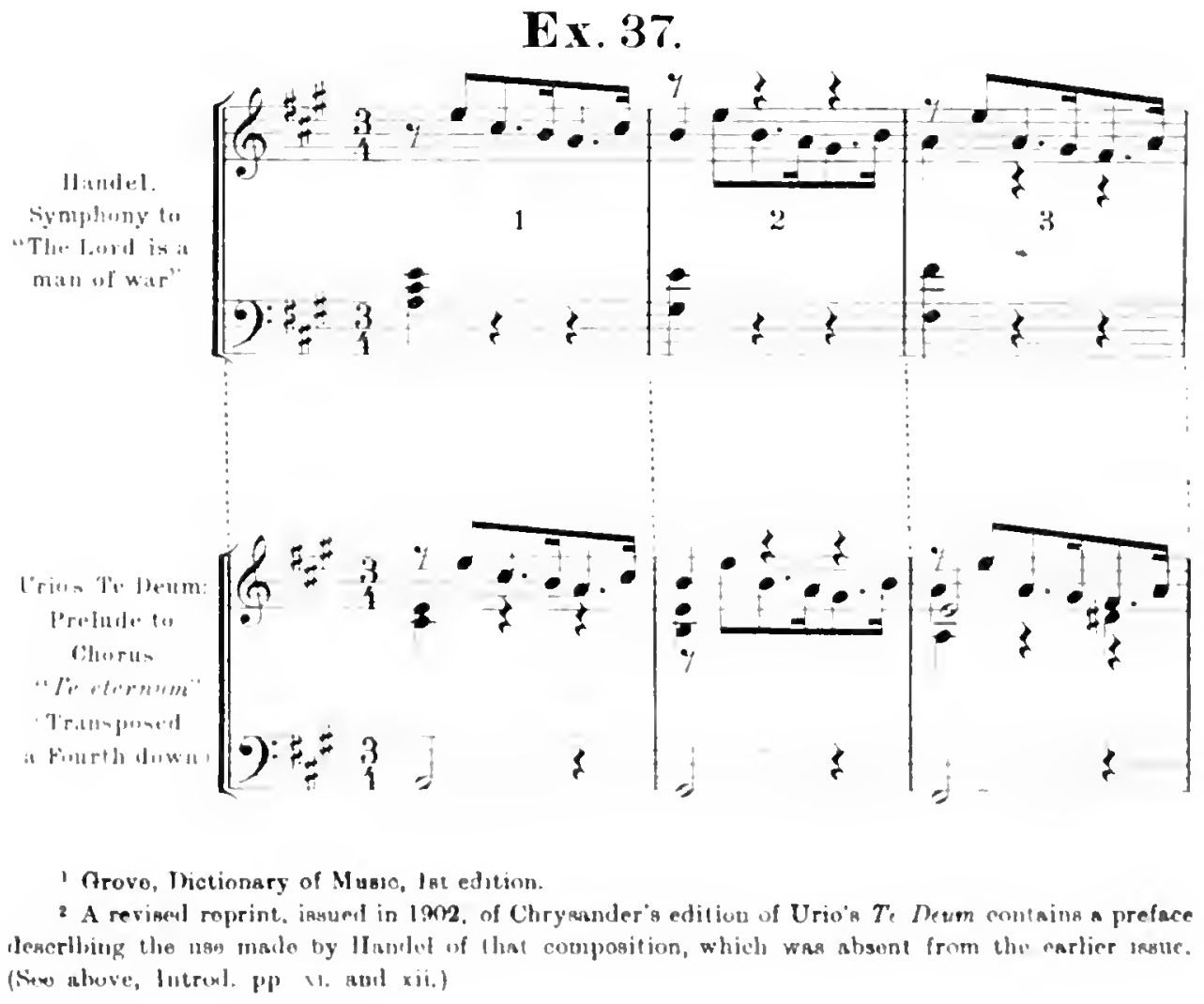


118 ISRAEL IN EGYPT

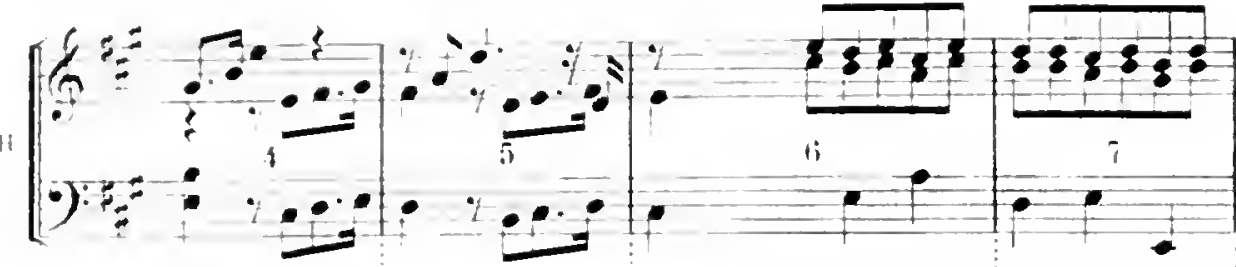

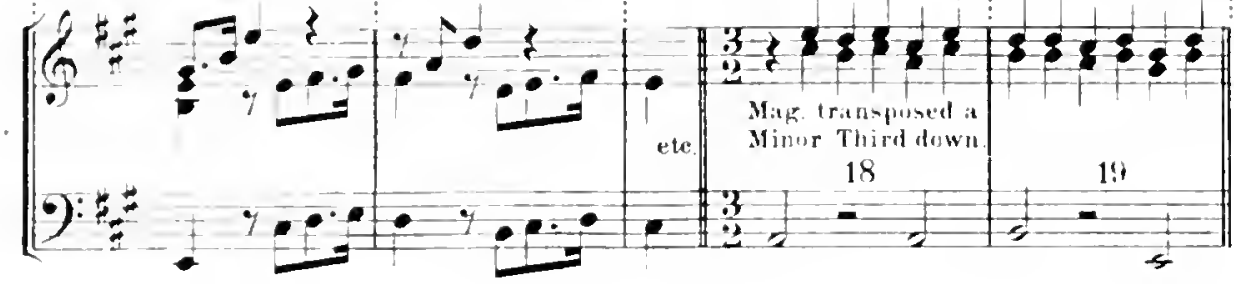

II. nute'

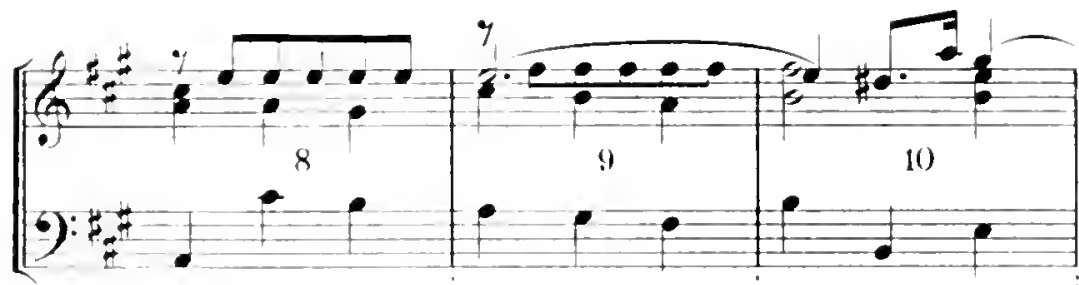

Mlagnifurat

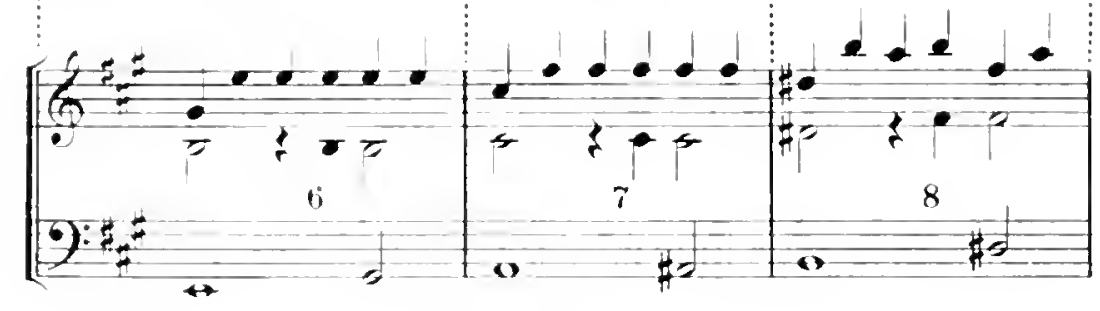

Thirdunsll
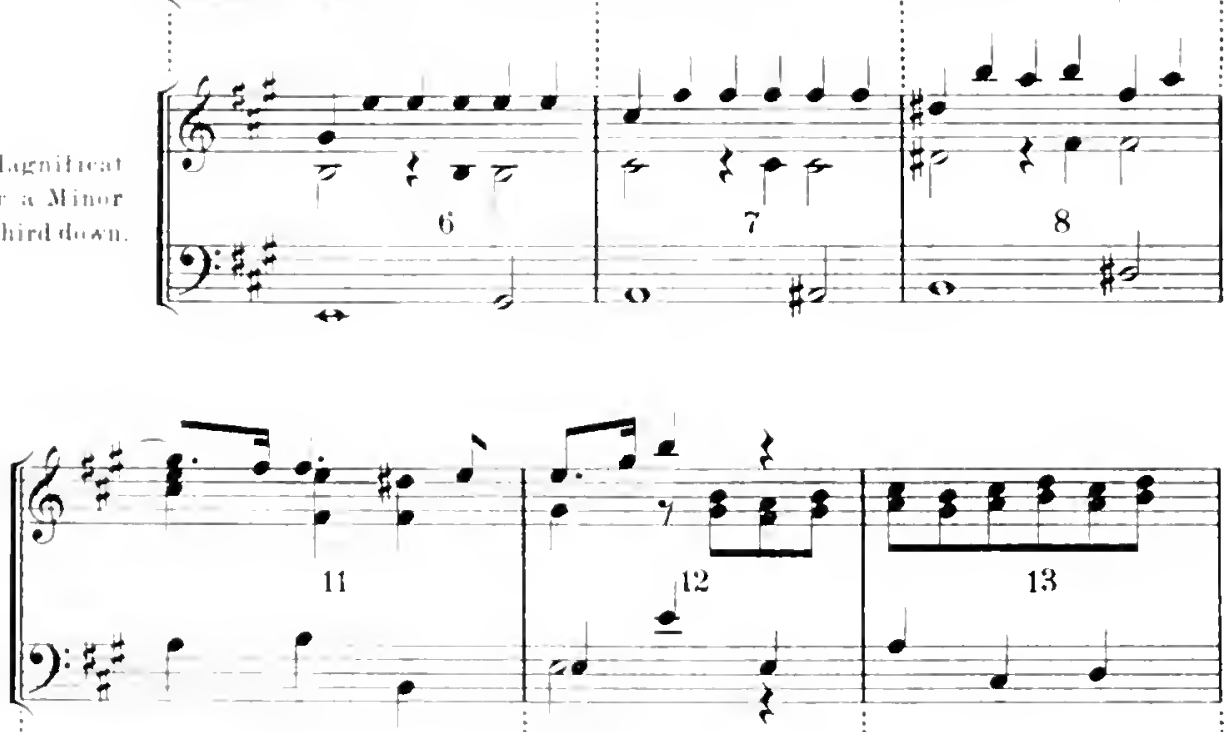

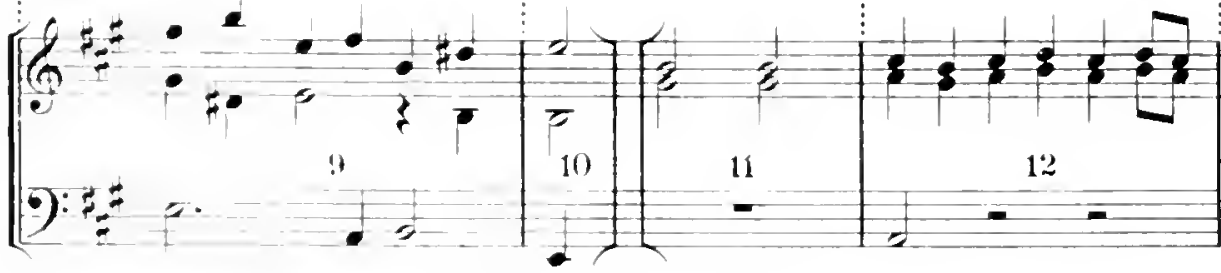


ISRAEL IN EGYPT

119
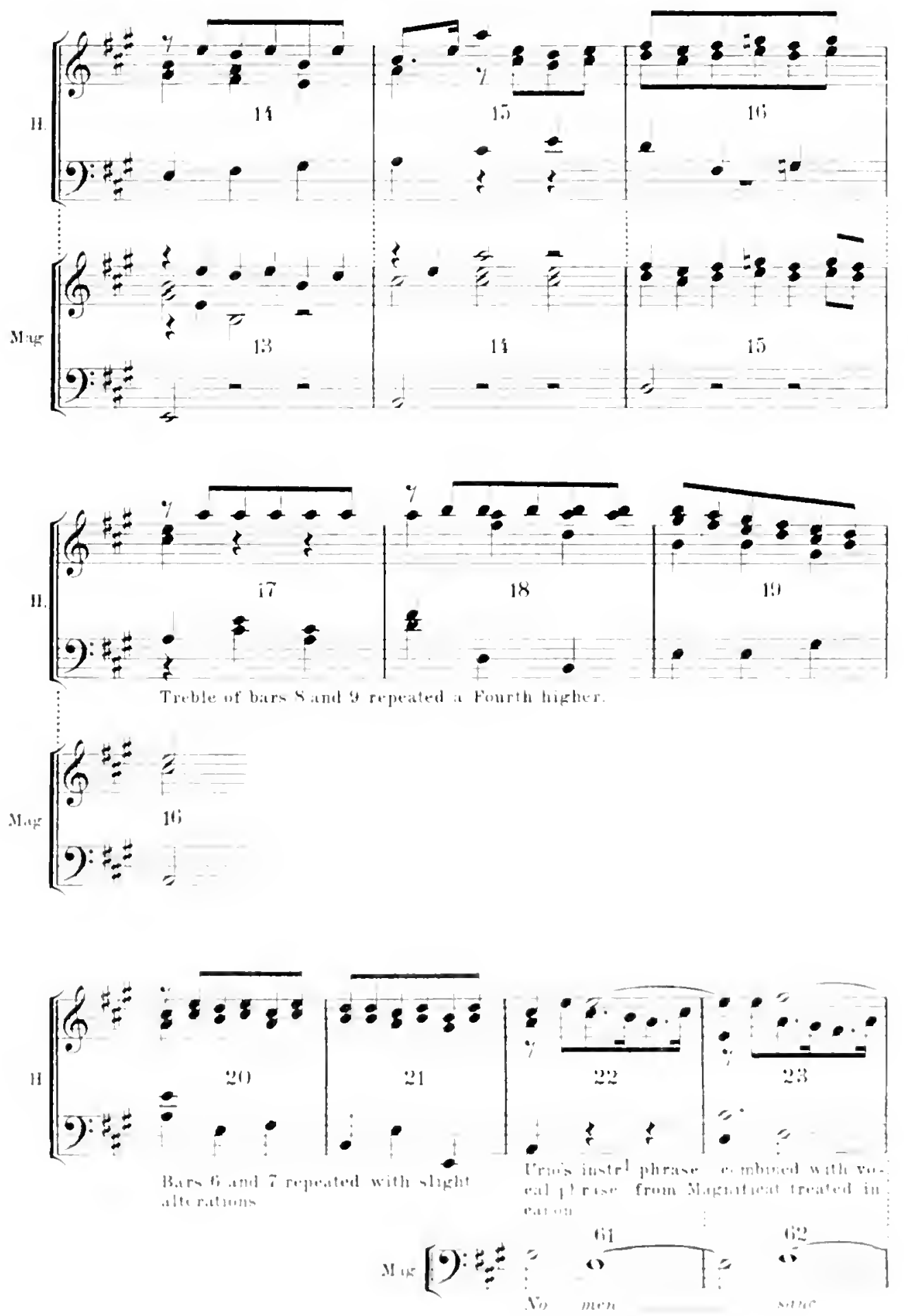
ISRAEL IN EGYPT

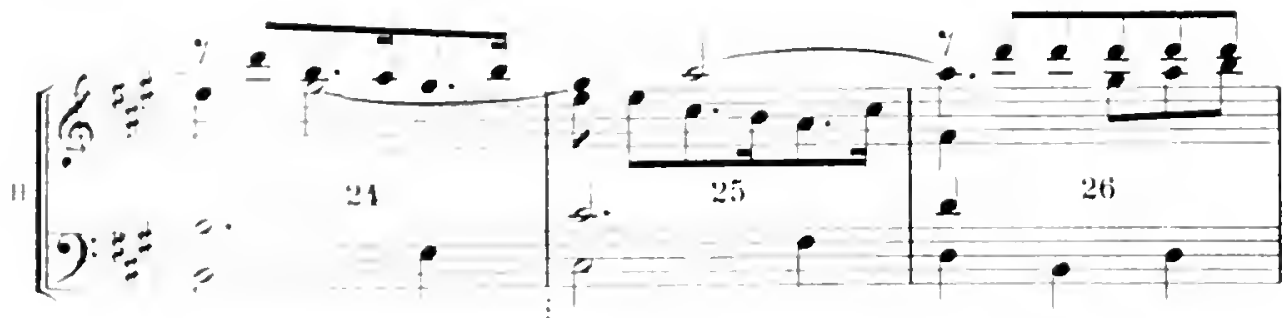

(6):

ti.:

lit

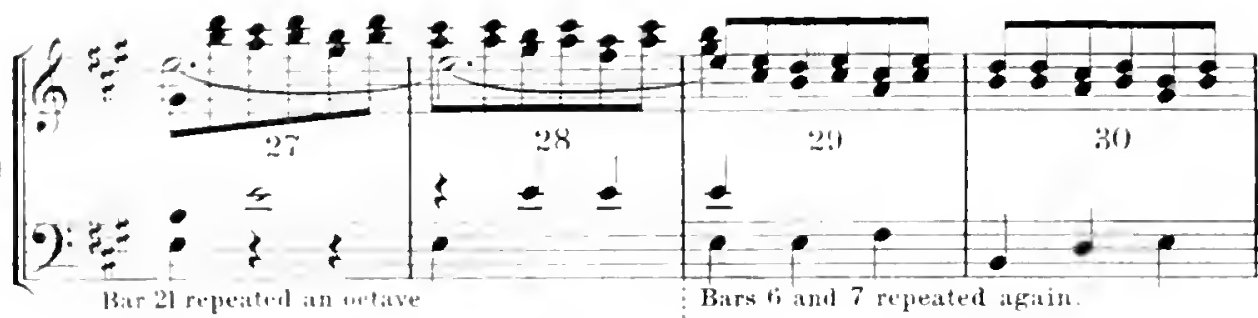

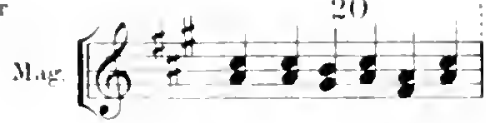

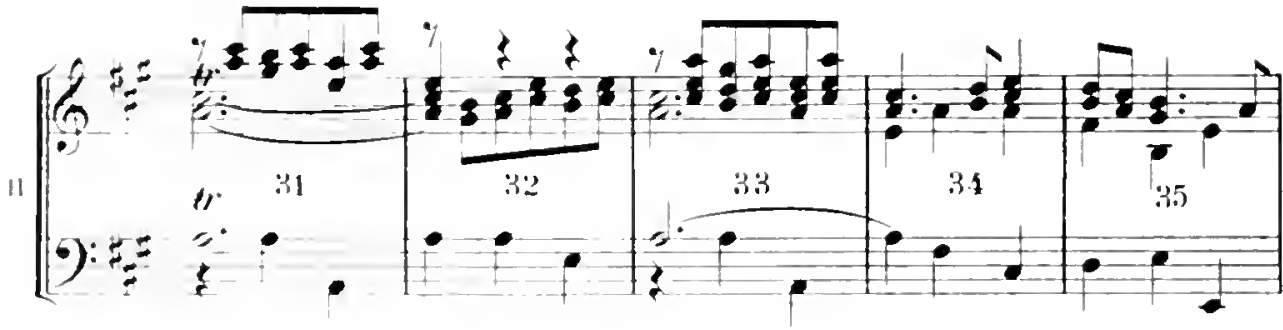

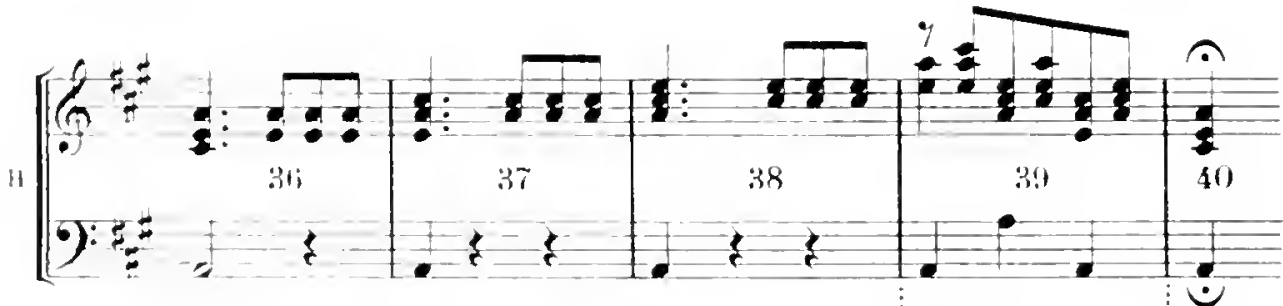

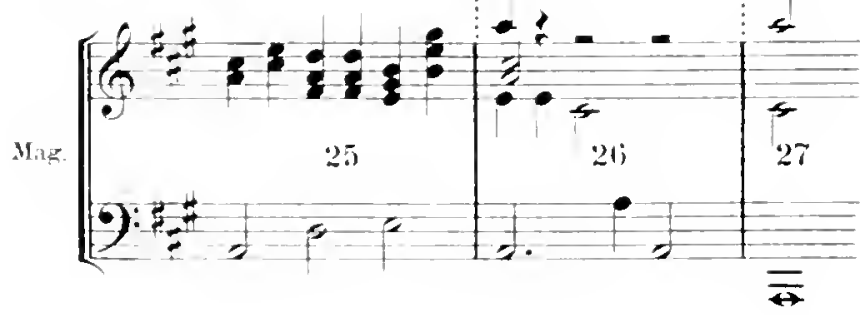


The duet proper opens with a phrase for the first Bass modelled on a lead for the vocal Altos in the Dettingen Te Deum chorus "All the earth doth worship Thee," where, as here, the Urio instrumental theme is used as accompaniment after having served as prelude.

Ex. 37. continued.
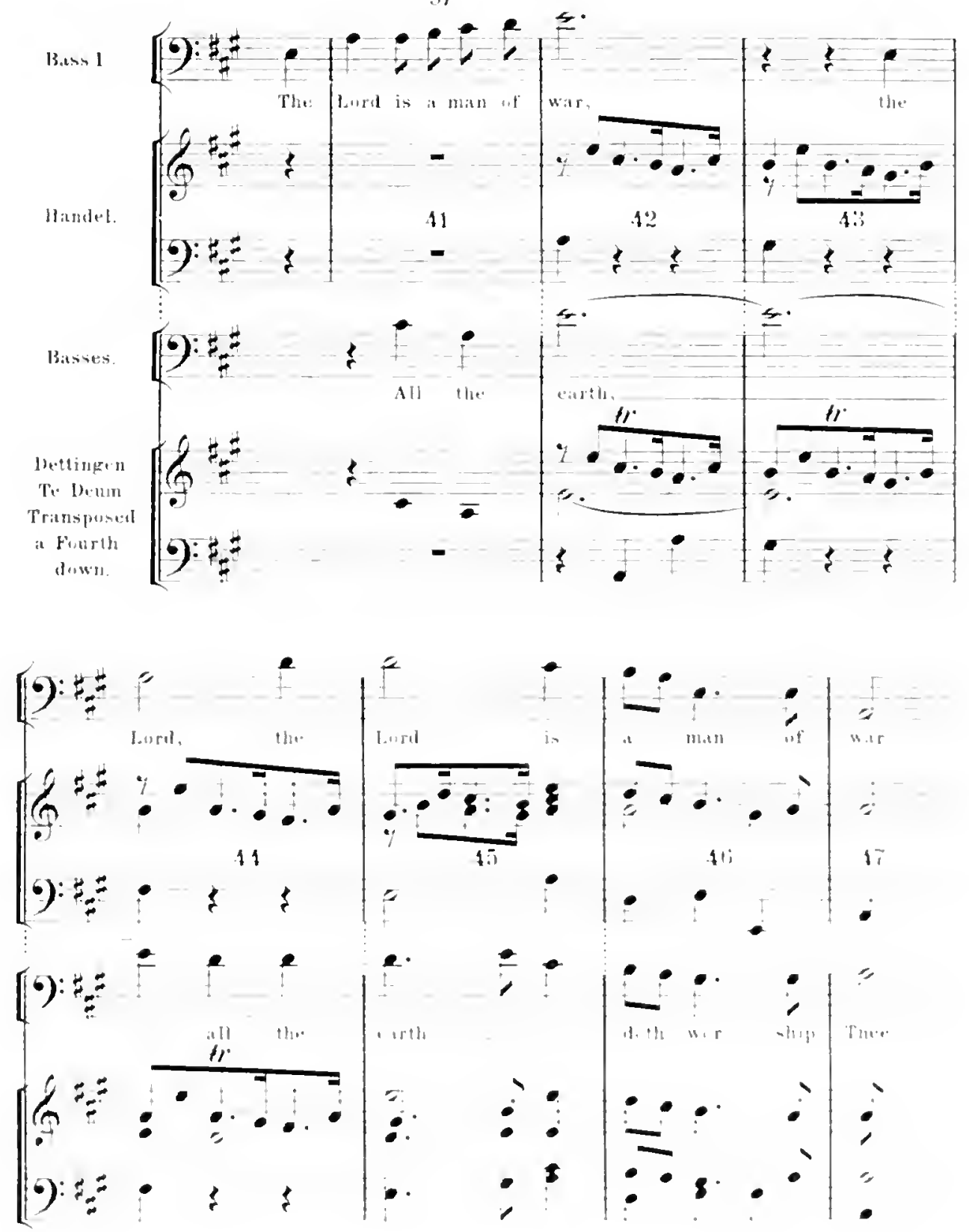
The next uineteen bars are made up of the same materials contrapuntally treated. Then coms a seciion 45 bars long in which the Magnificut is followed alnost bar fur bar:

Ex. 37. "ontinuect.

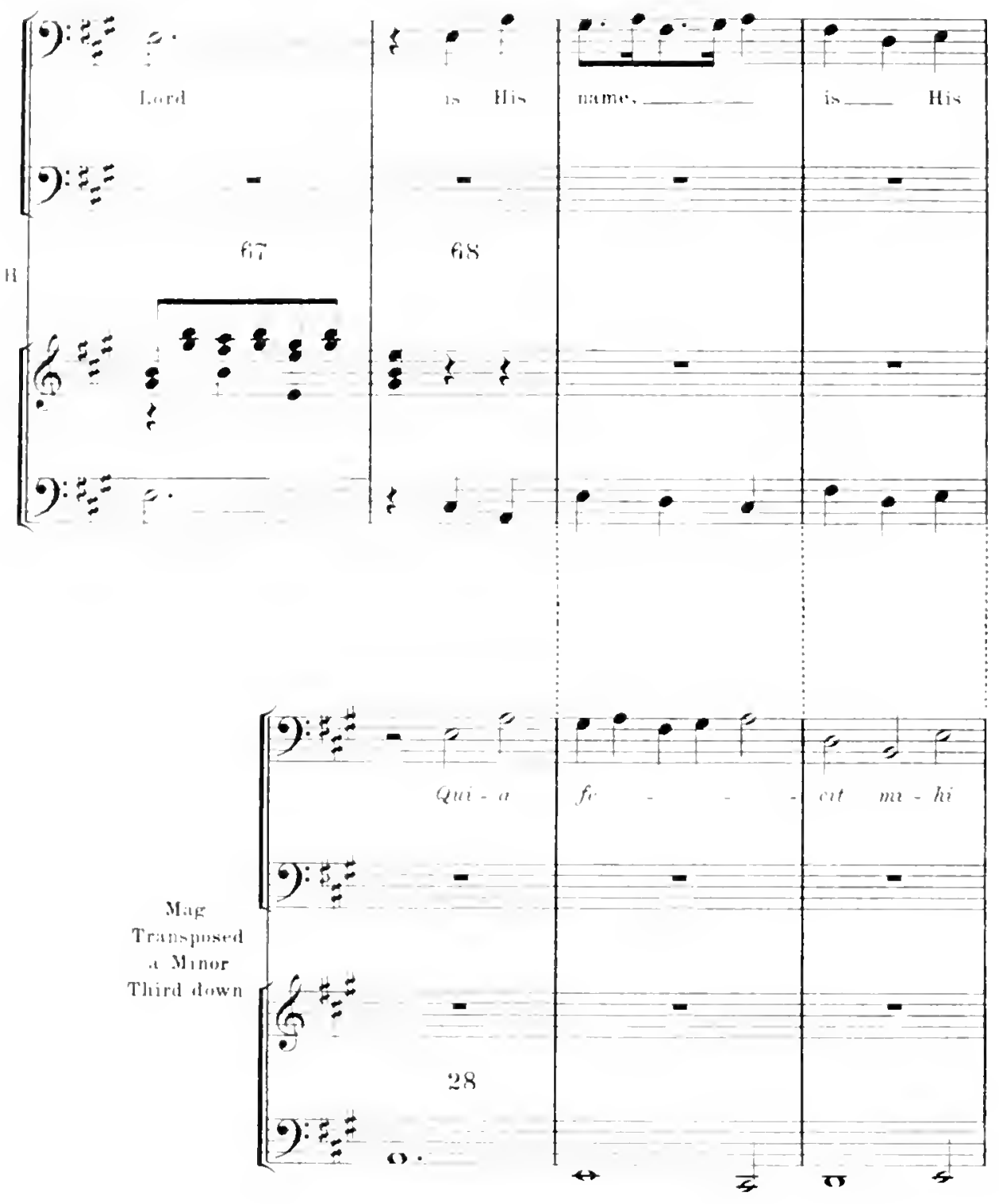


ISRAEL IN EGYPT

123
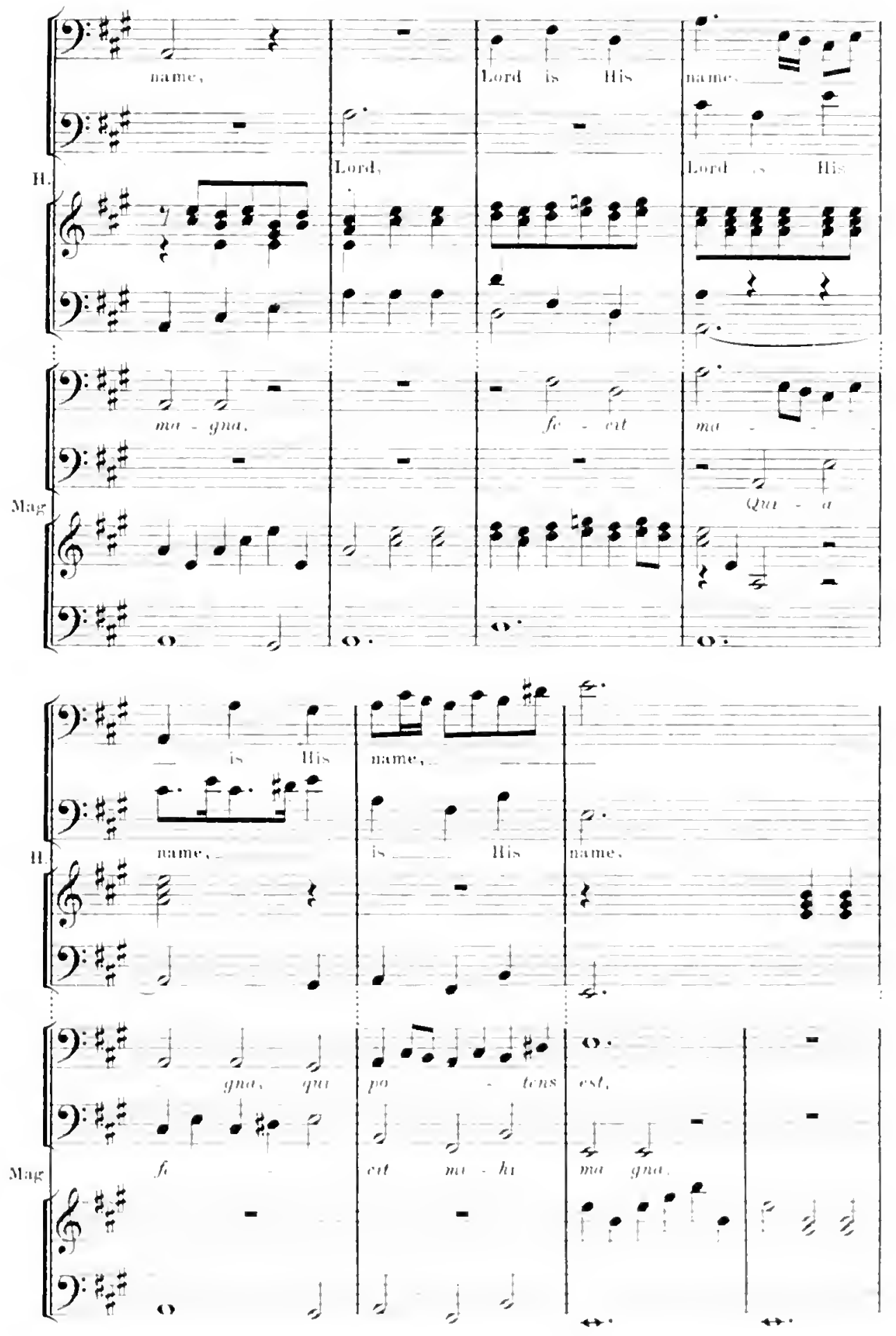


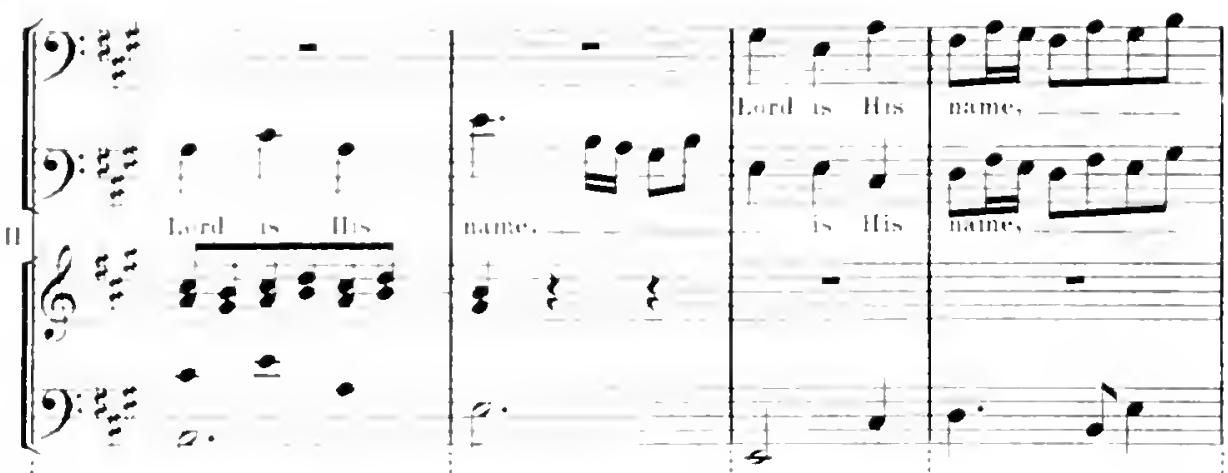

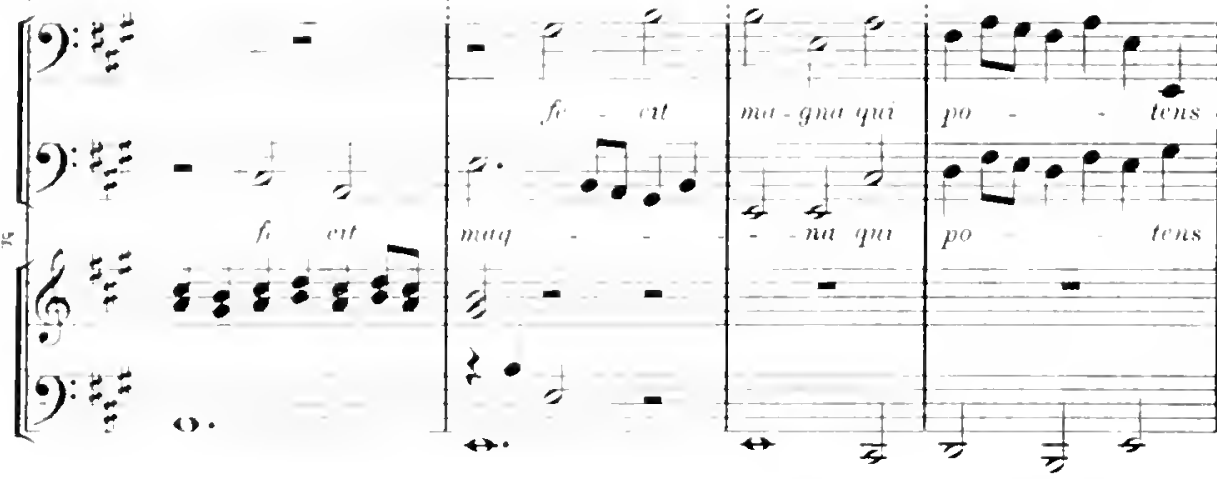

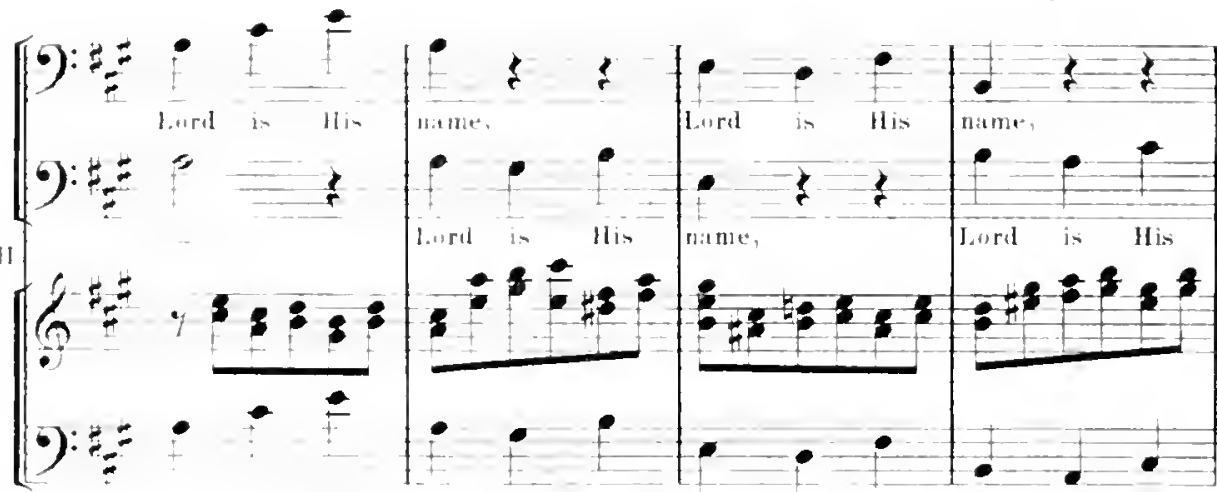

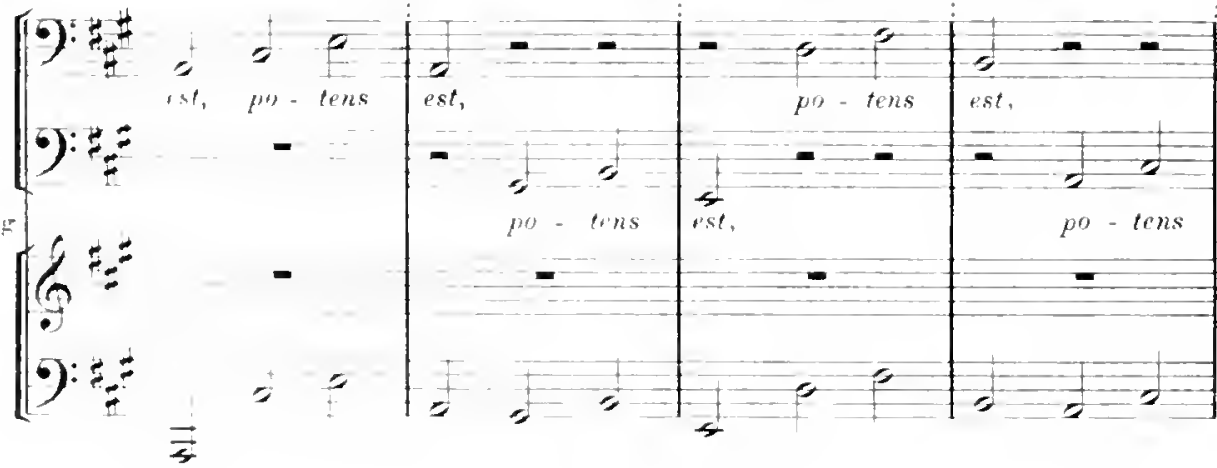


ISRAEL IN EGYP'T

125

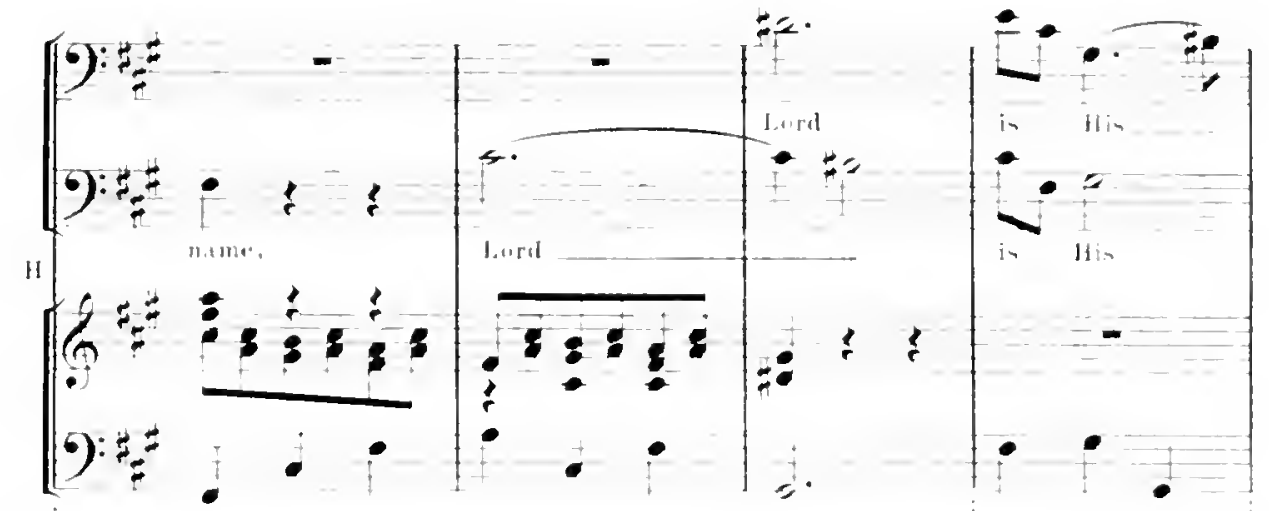

$\left(\frac{6}{9}=\right.$

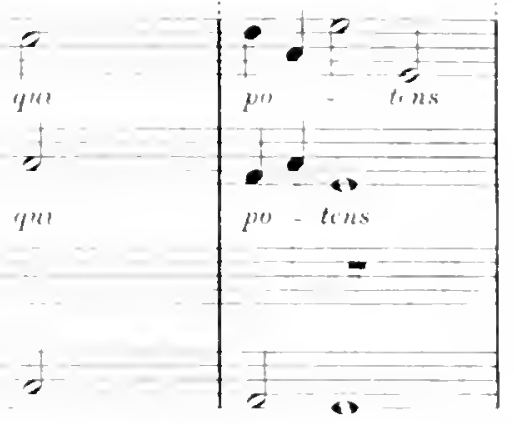

$\int$
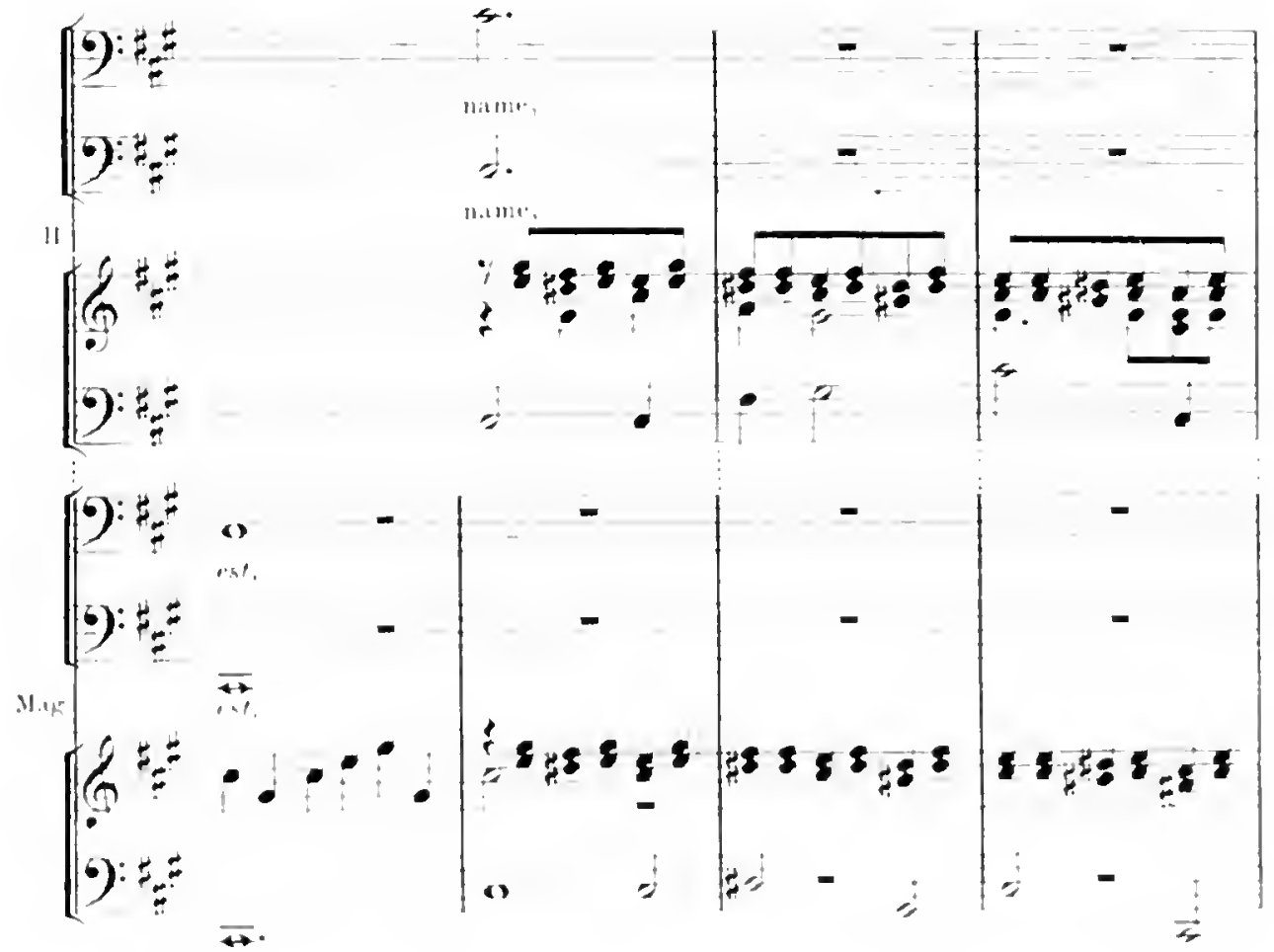


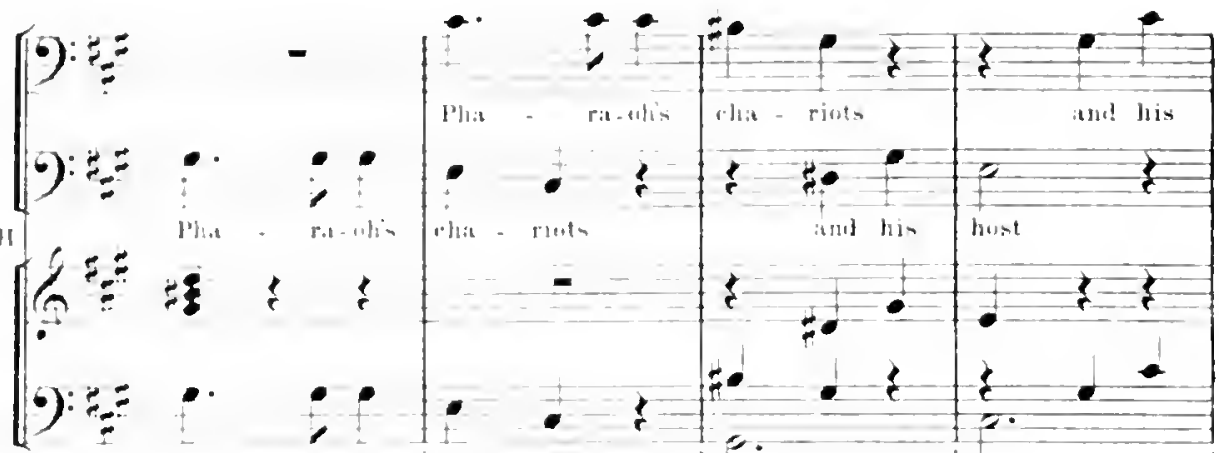

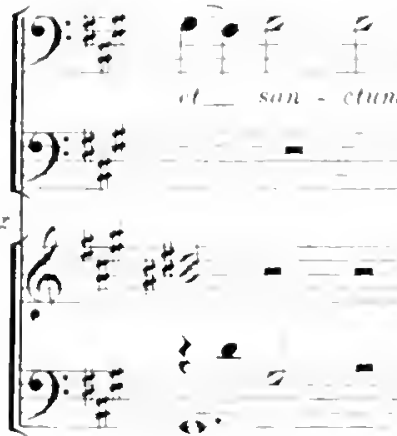

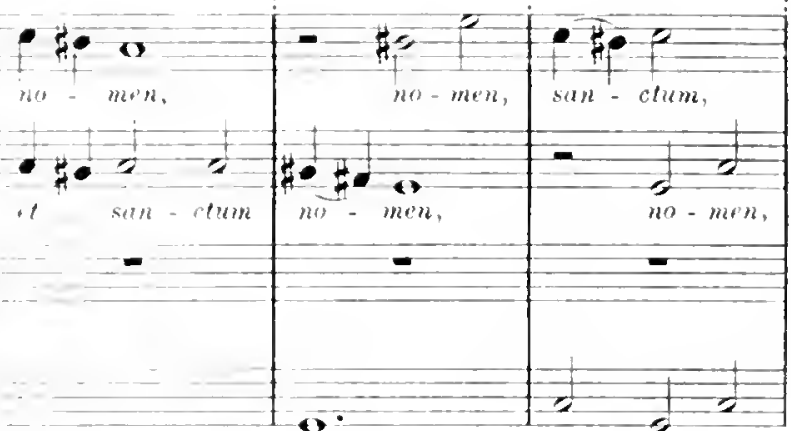

$\rightrightarrows$.

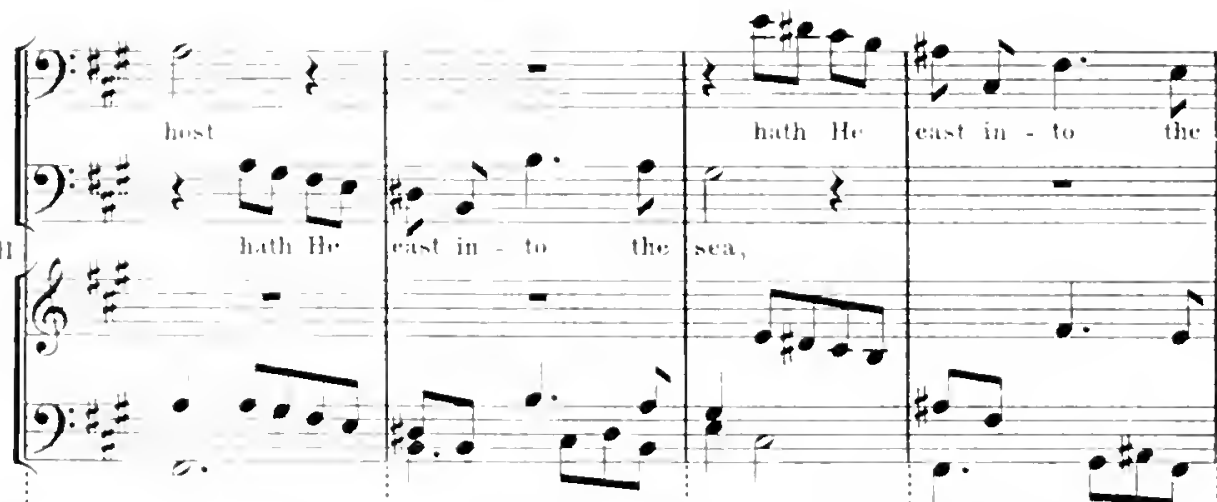

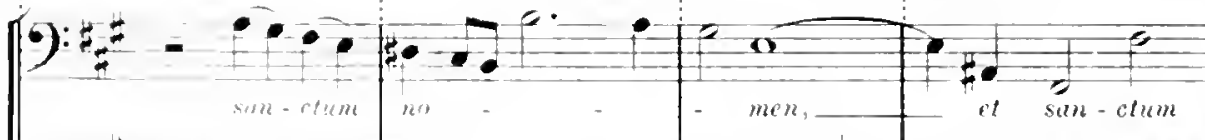

$0)=-\frac{1}{2}=$

$(a+5=$

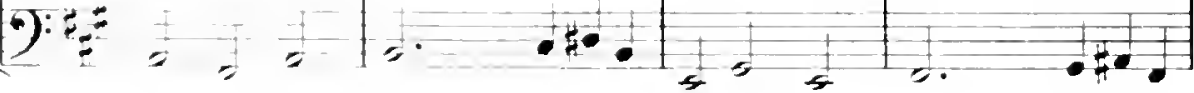




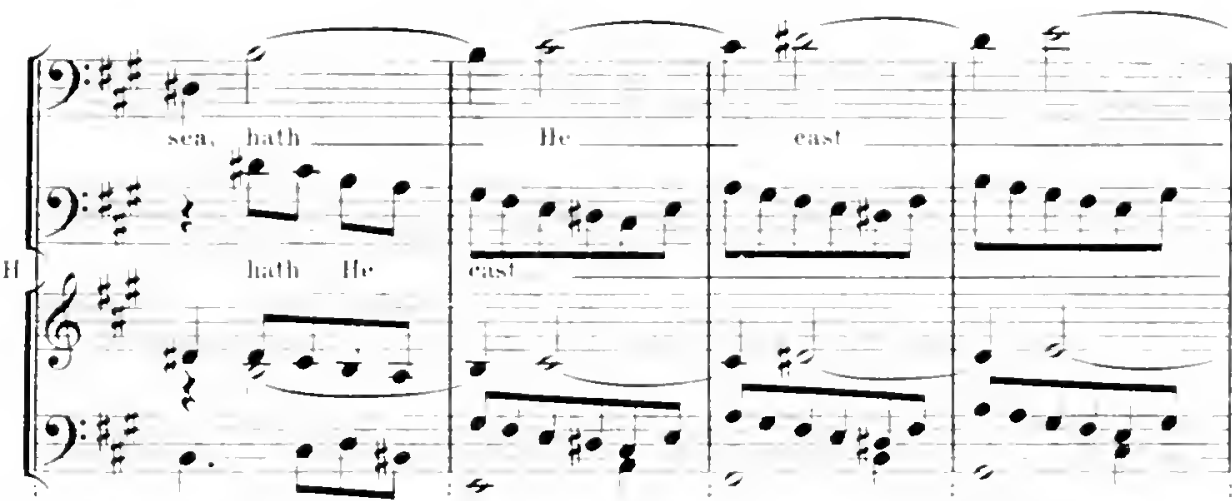

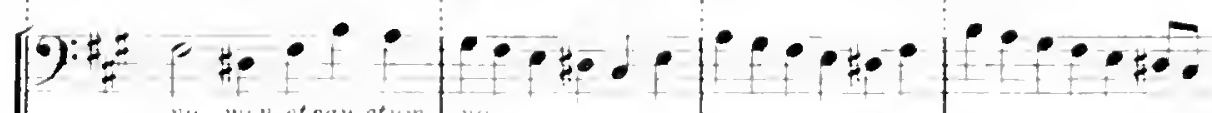
9): Mag.

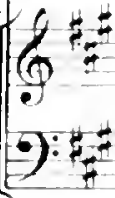

$$
-
$$

$=$

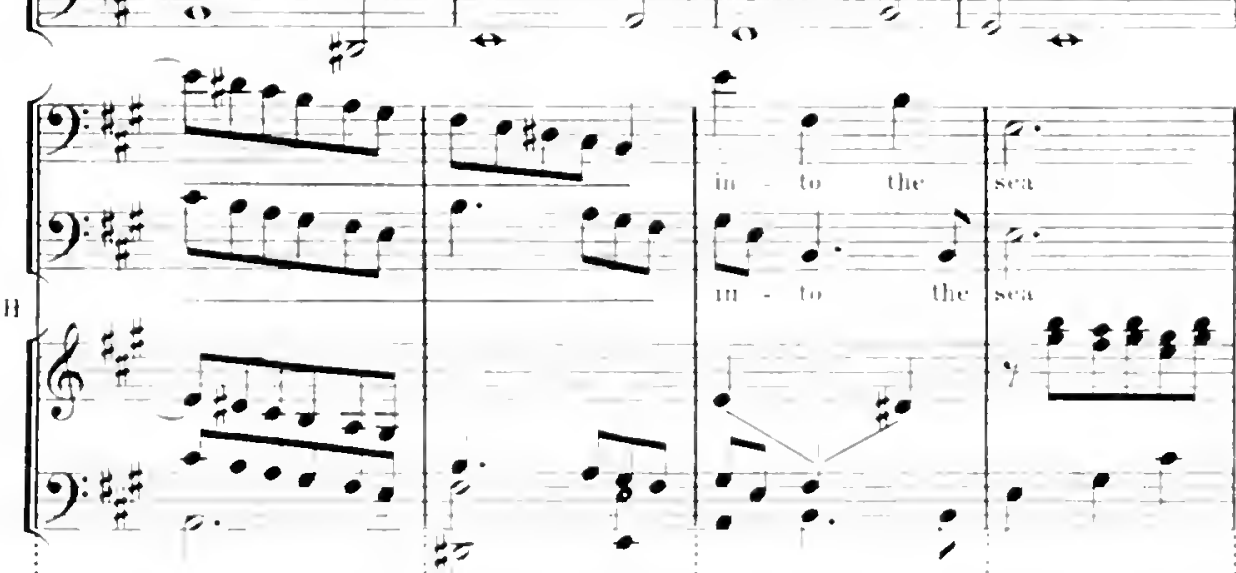
$=$

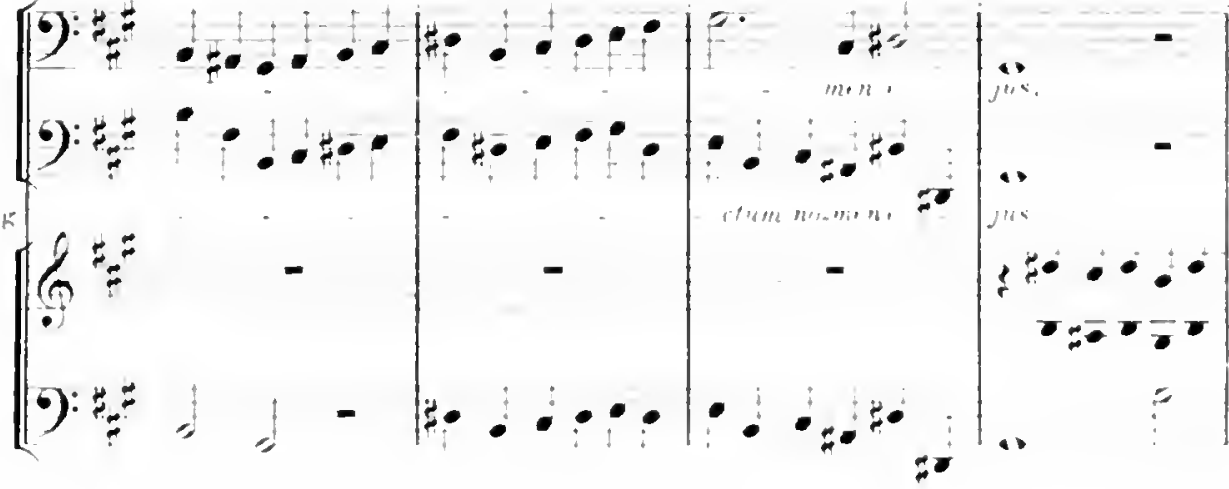




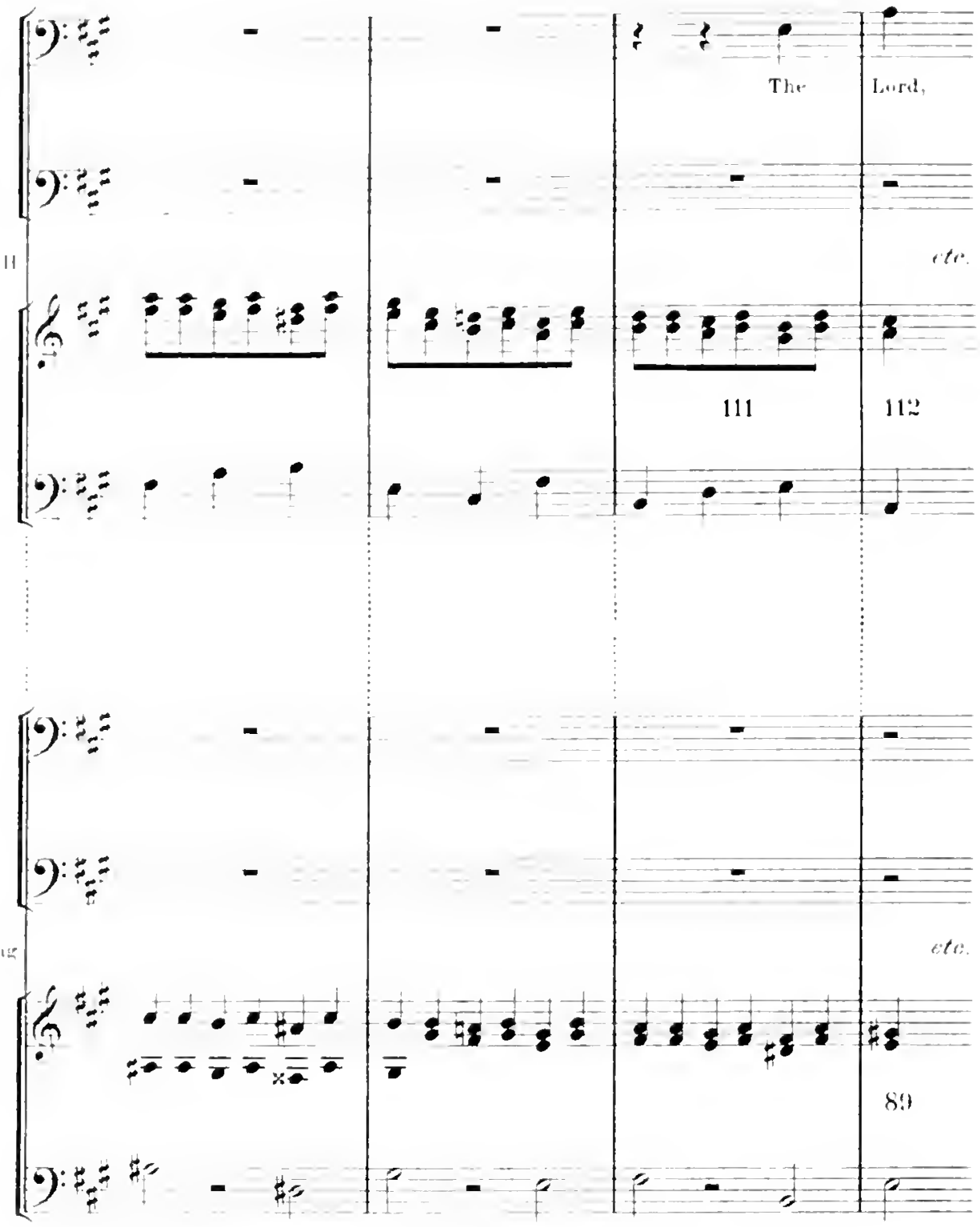

In bars 111 to 123 the two Basses sing successively a phrase beginning with that in bars 40 to 42 but lengthened by four bars, after which Handel works in a vocal phrase' of four bars with U'rio accompaniment and the proceeds for the inost part parallol with the Magnificat for 17 bars more :

"Which may itself have been taken from Urio's sotting of "Pleni sunt coeli" but is too short to Le dutinitely identutied as borruwed. 
Ex. 37. 'continued.'
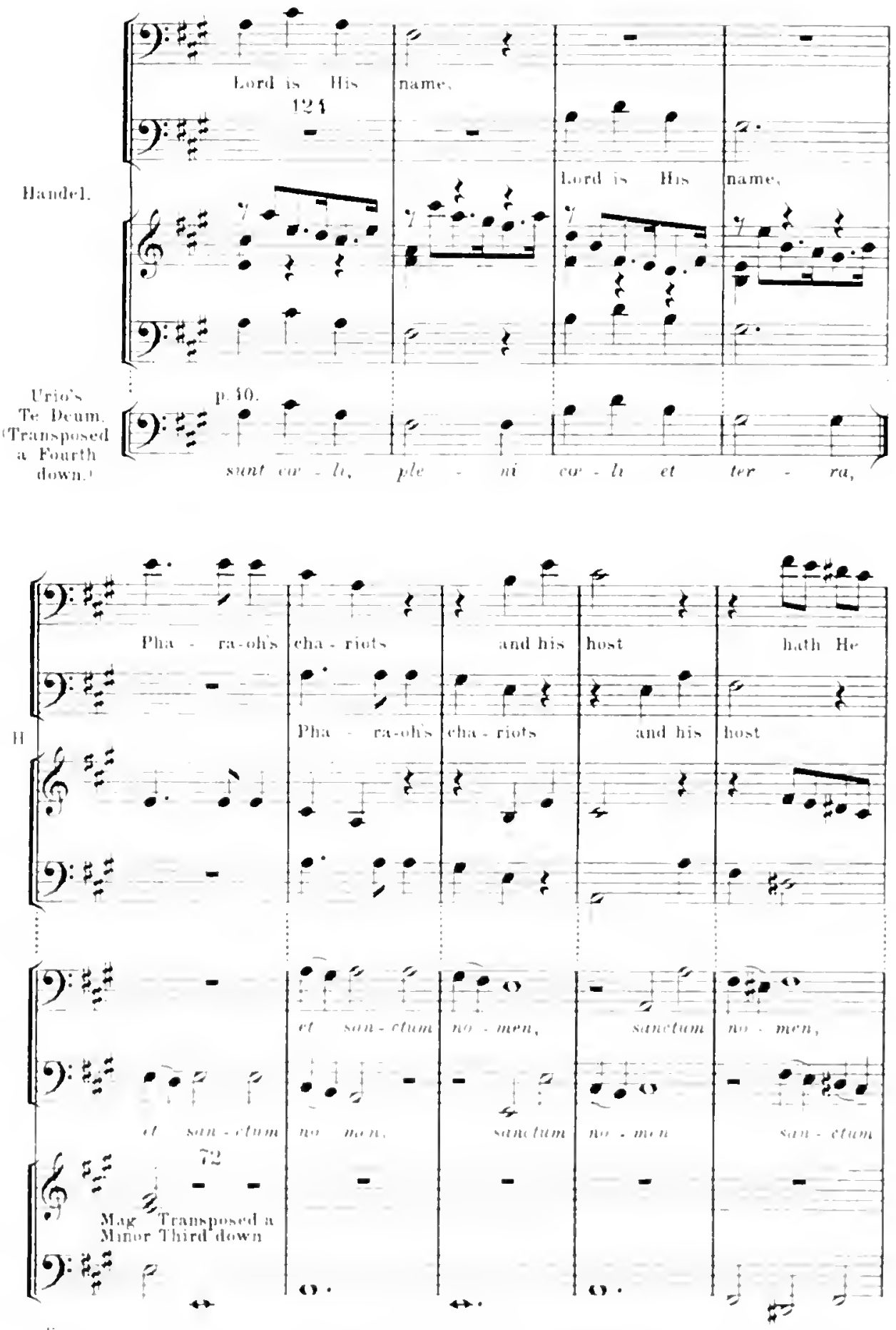
130

ISRAEL IN EGYPT
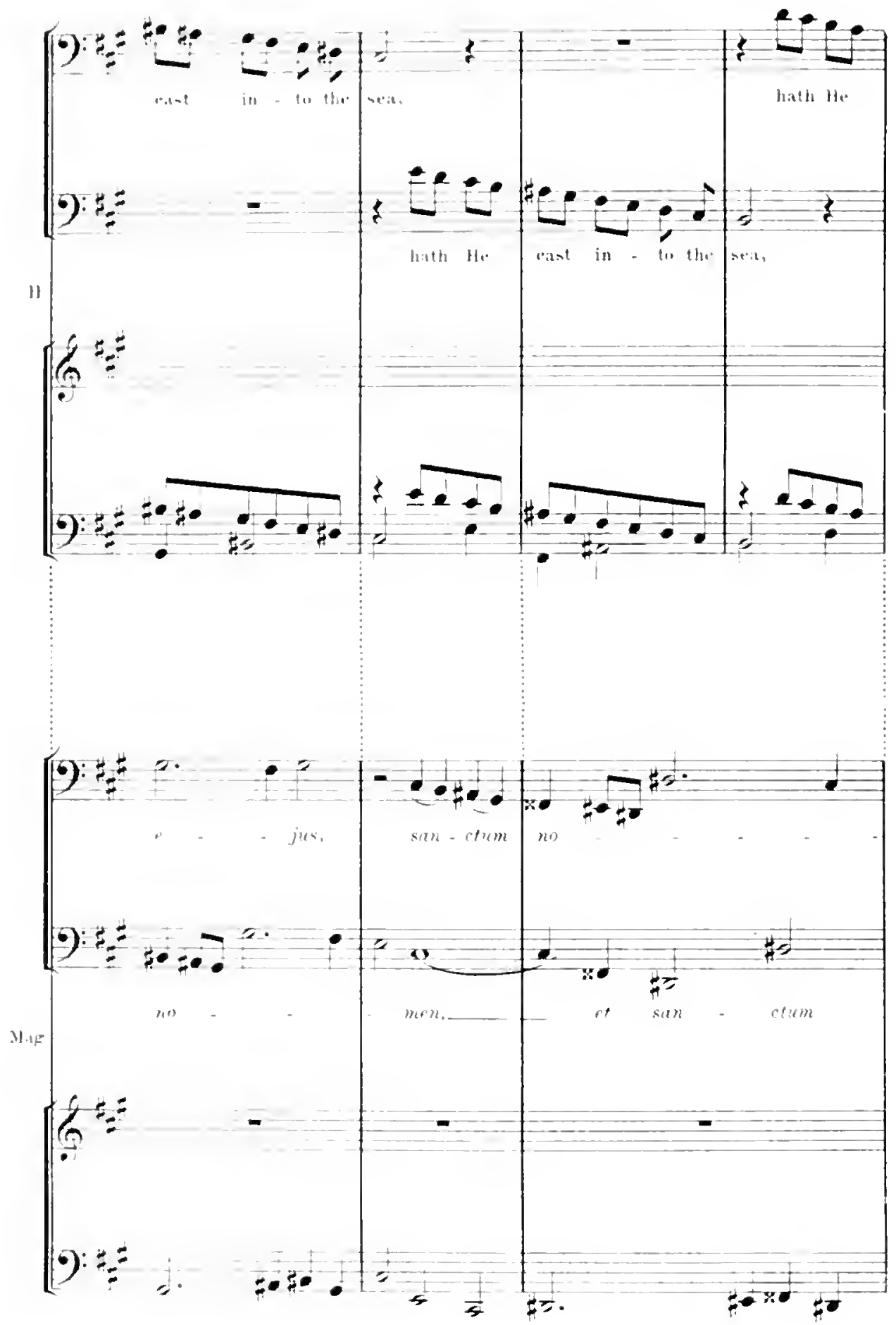
ISRAEL IN EGYPT

131
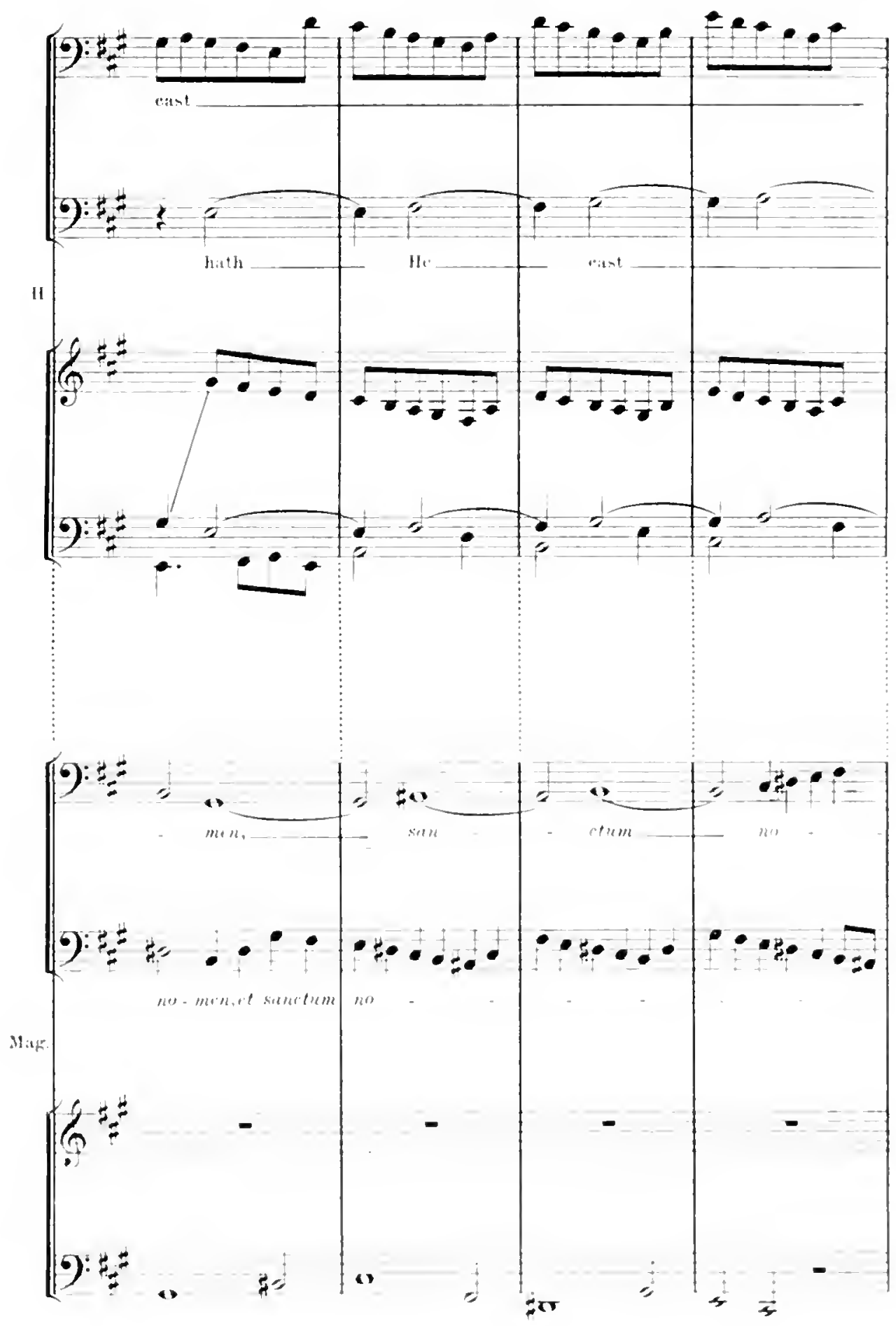

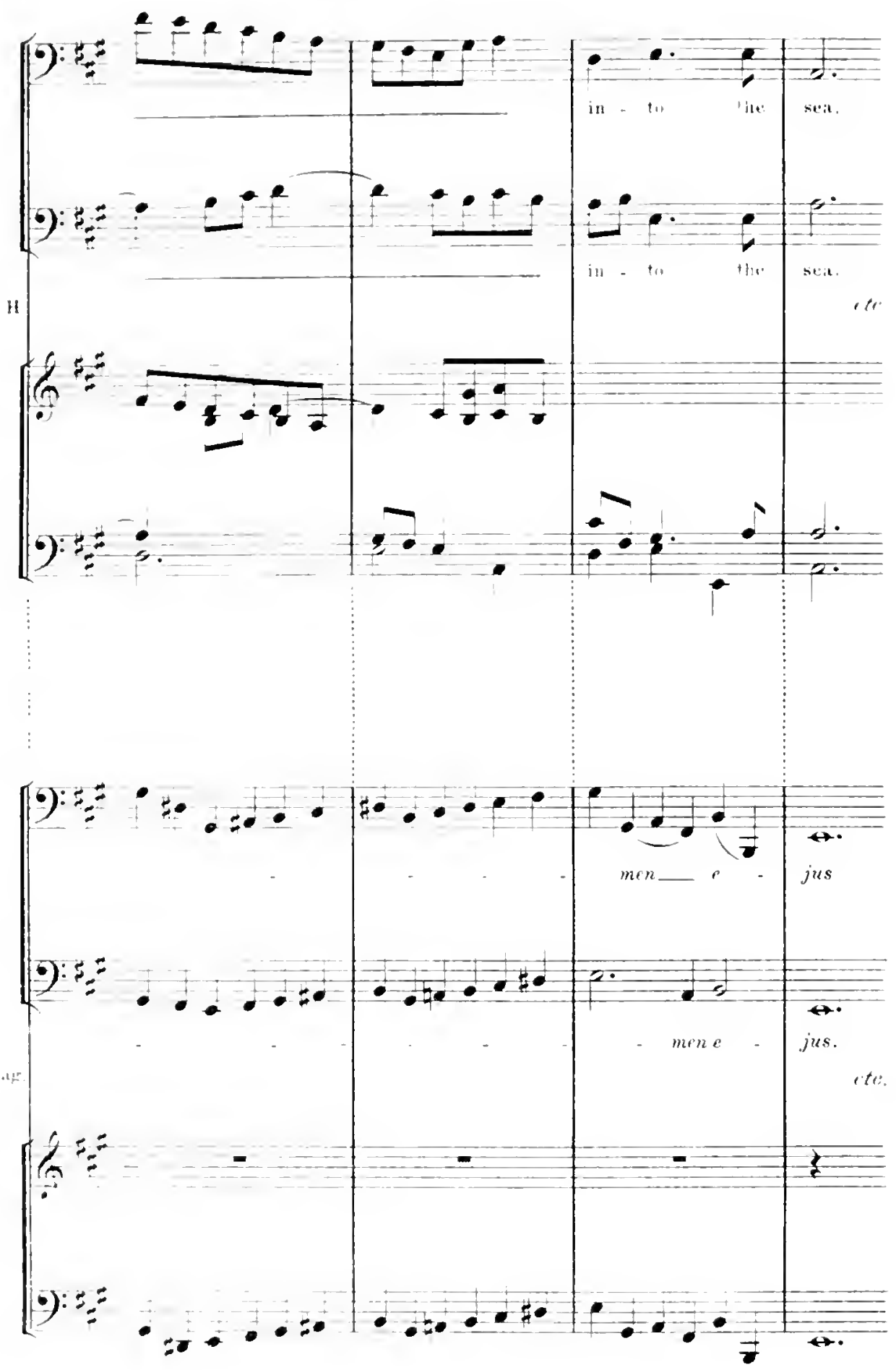
This section ends with bars 20-36 of the instrumental introduction repeated. Next come a few bars of vocal Canon leading to the fine descending Fifths on "also are lrowned" which occur, fittingly set to "misericordia," in the Magnifuat.

Ex. 37. 'continued.'
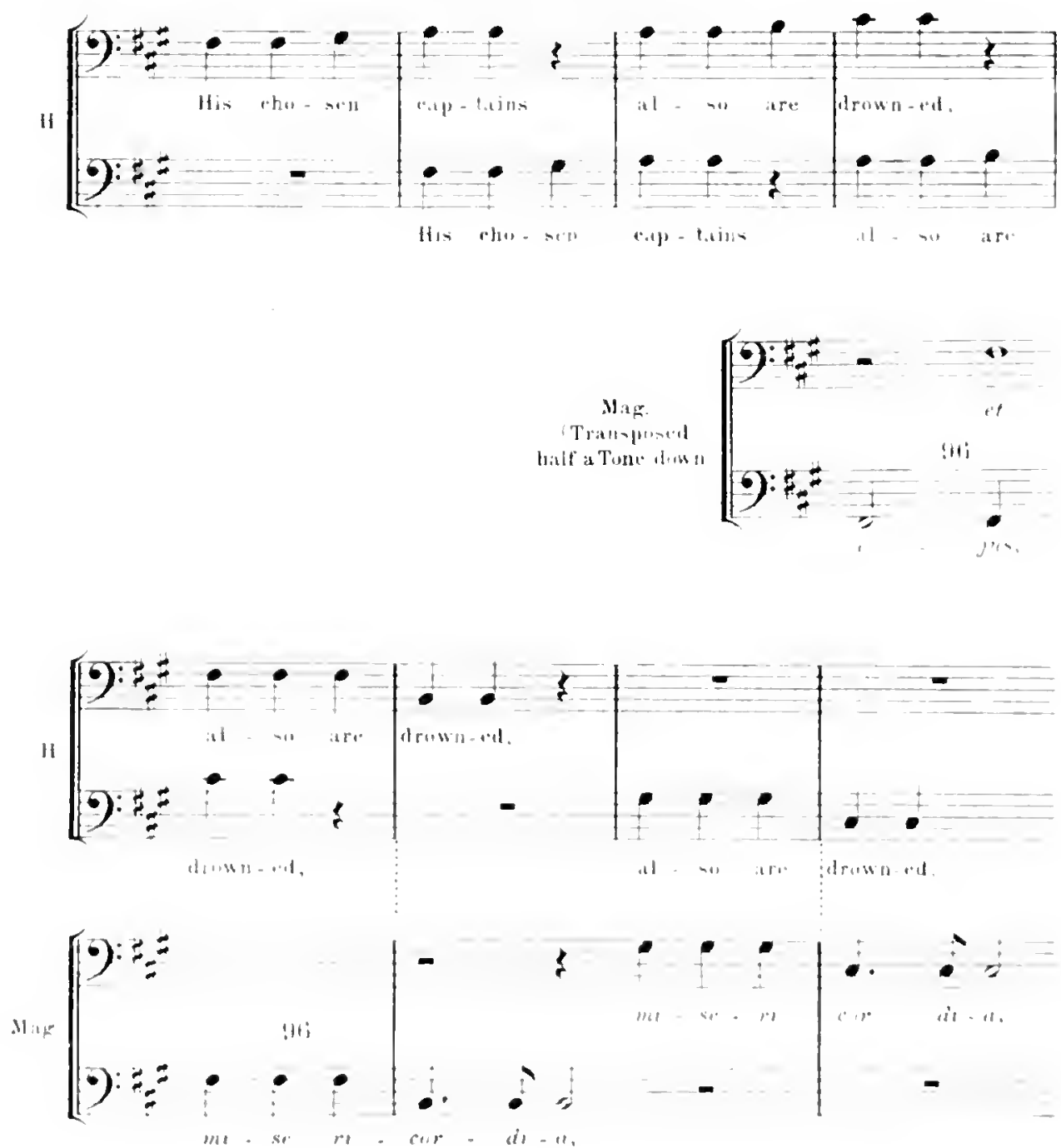

This short passage is, after eight hars of other matter, repeated in the key of E major, and then Handel again takes up the thread of the Mregnifuet wo form a famous passage: 
Ex. 37. continued."
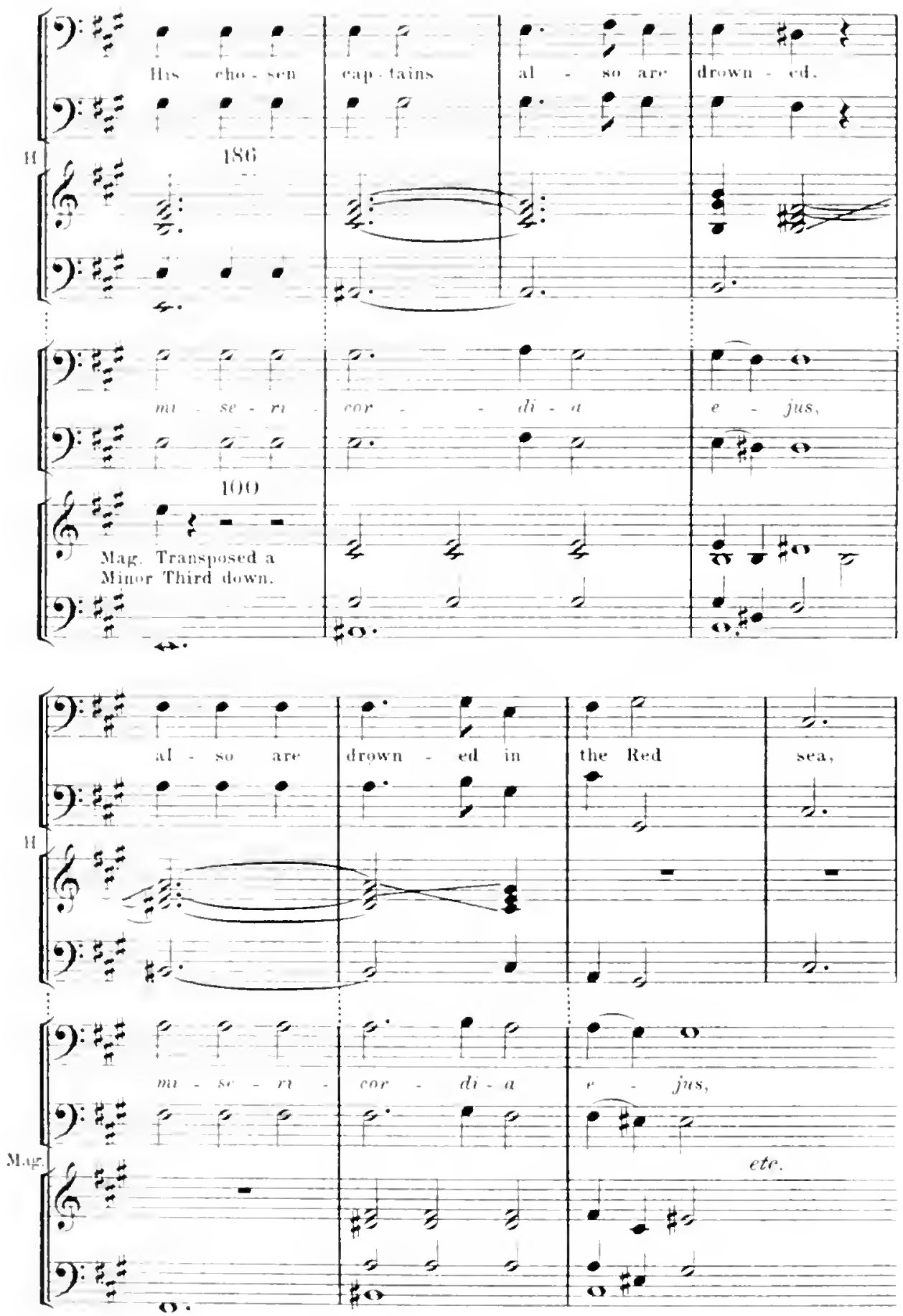
Ilandel purposes repeating this impressive passage with increased effect. Accordingly, in order to prepare a contrast for it, he takes tho little suljject already used in bars 124 and 125, adds to it a further bar of brisk quavers and works the result up into the following jubilant bit of canonic writing:

Ex. 37. 'ontinued.'
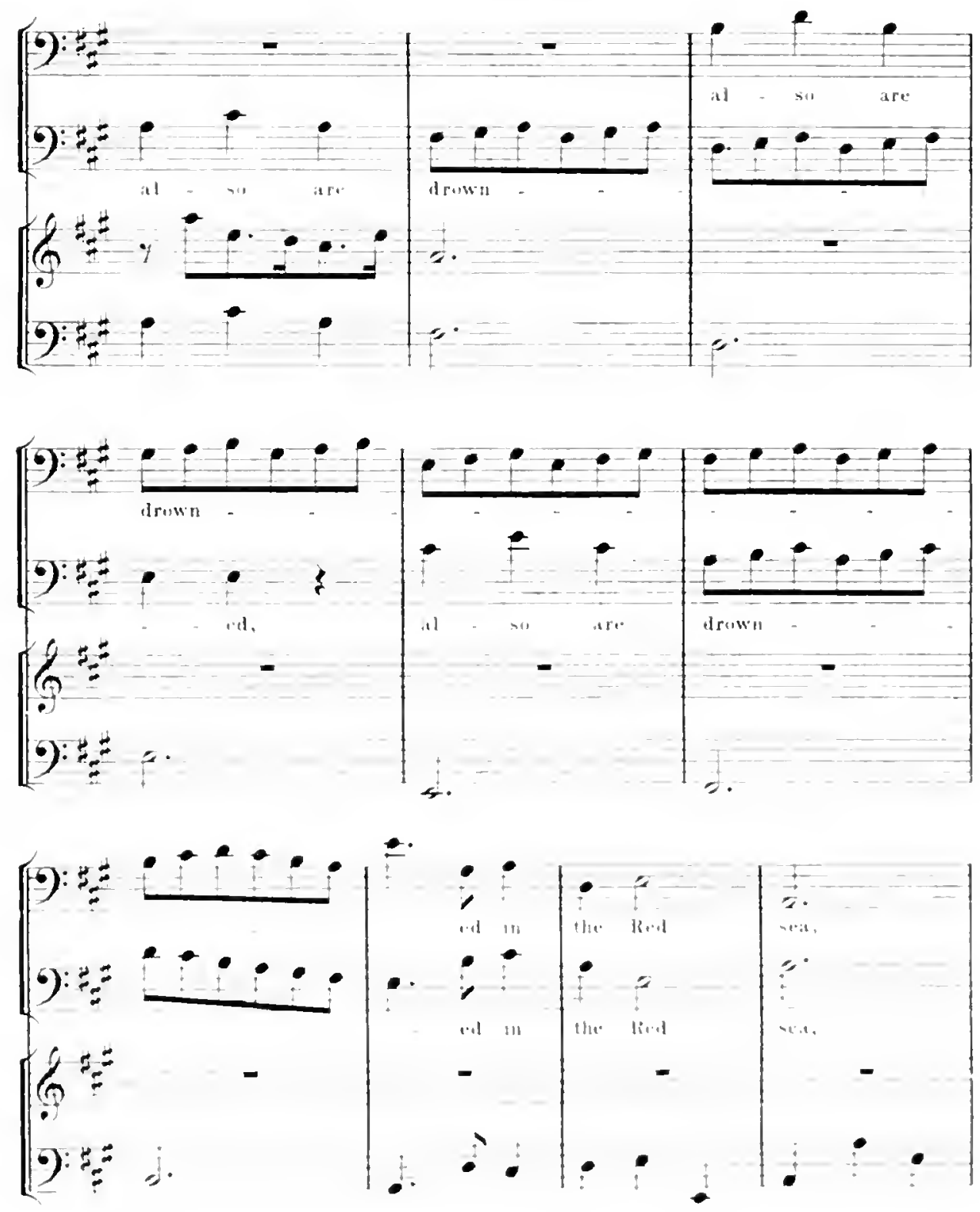
The previous passage then eomes in again, but this time in the key of A with the vocal parts in more sonorous positious in the Bass compass, and with the leading simger above, instead of, as before, below his colleague:
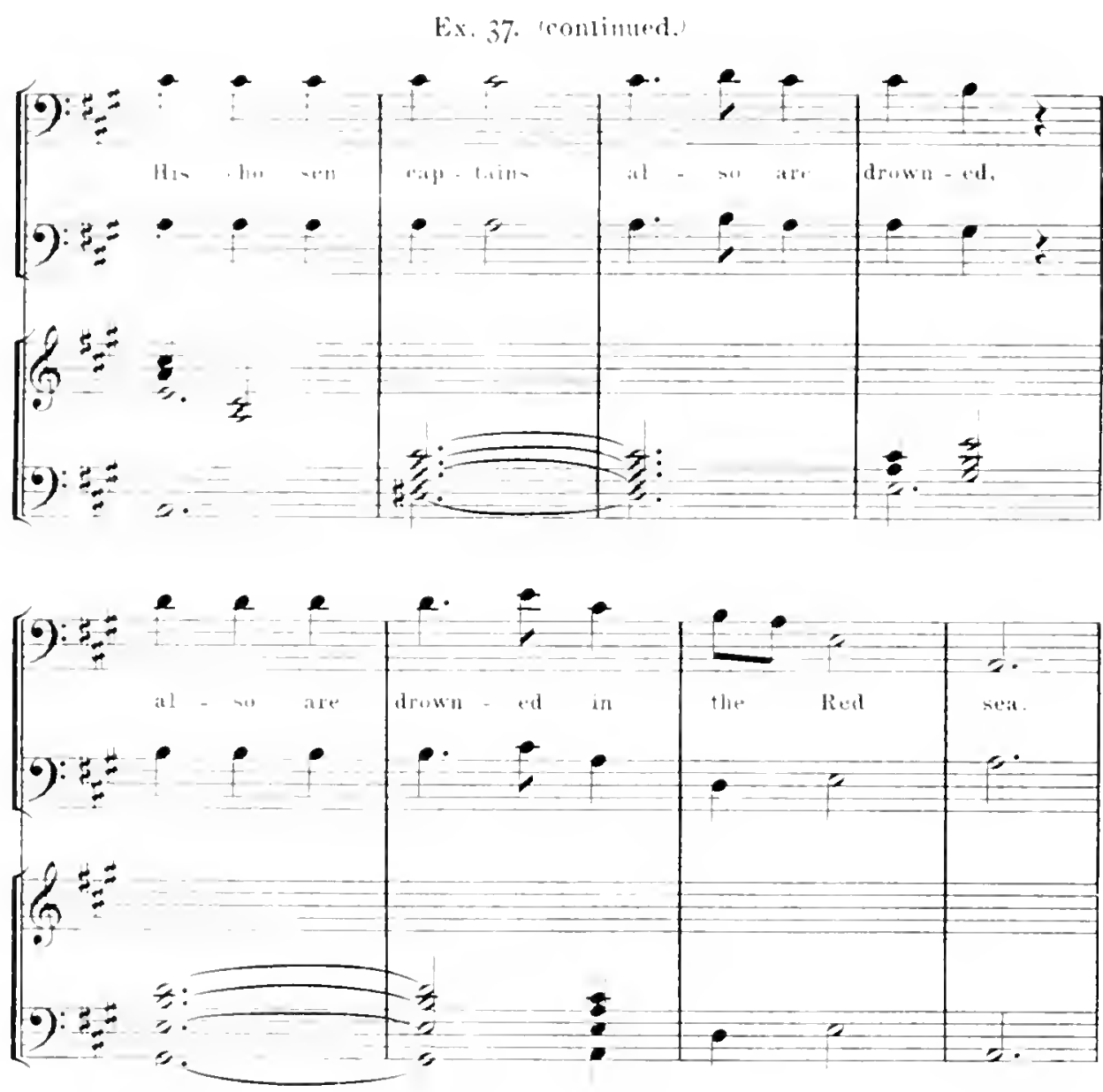

This is the real close of the duet, for though a repetition of the opening symphony is directed to follow here, its effect, after the magnificent matter which has preceded it, is necessarily somewhat of an anti-climax. Handel's power of welding together heterogeneous materials into a perfectly homogeneous whole, imbued with a far grander spirit than dwelt in its original elements, can nowhere that I know of be seen at work with such unrelaxing energy as throughout this duet.

The next number (23), the double chorus "The depths have covered them," consists of sixteen bars, twelve of which are a reproduction, with quite astonishing 
improvelaents, of matter from a chorus in the Magnificat. In hars 1 and 2 Handel has provided some simple chords in the orchestra to fix the tonality, and in bars 3 and 4 has written vocal phrases congruemt with those which he was about to transfer from the Magnificat. ${ }^{1}$
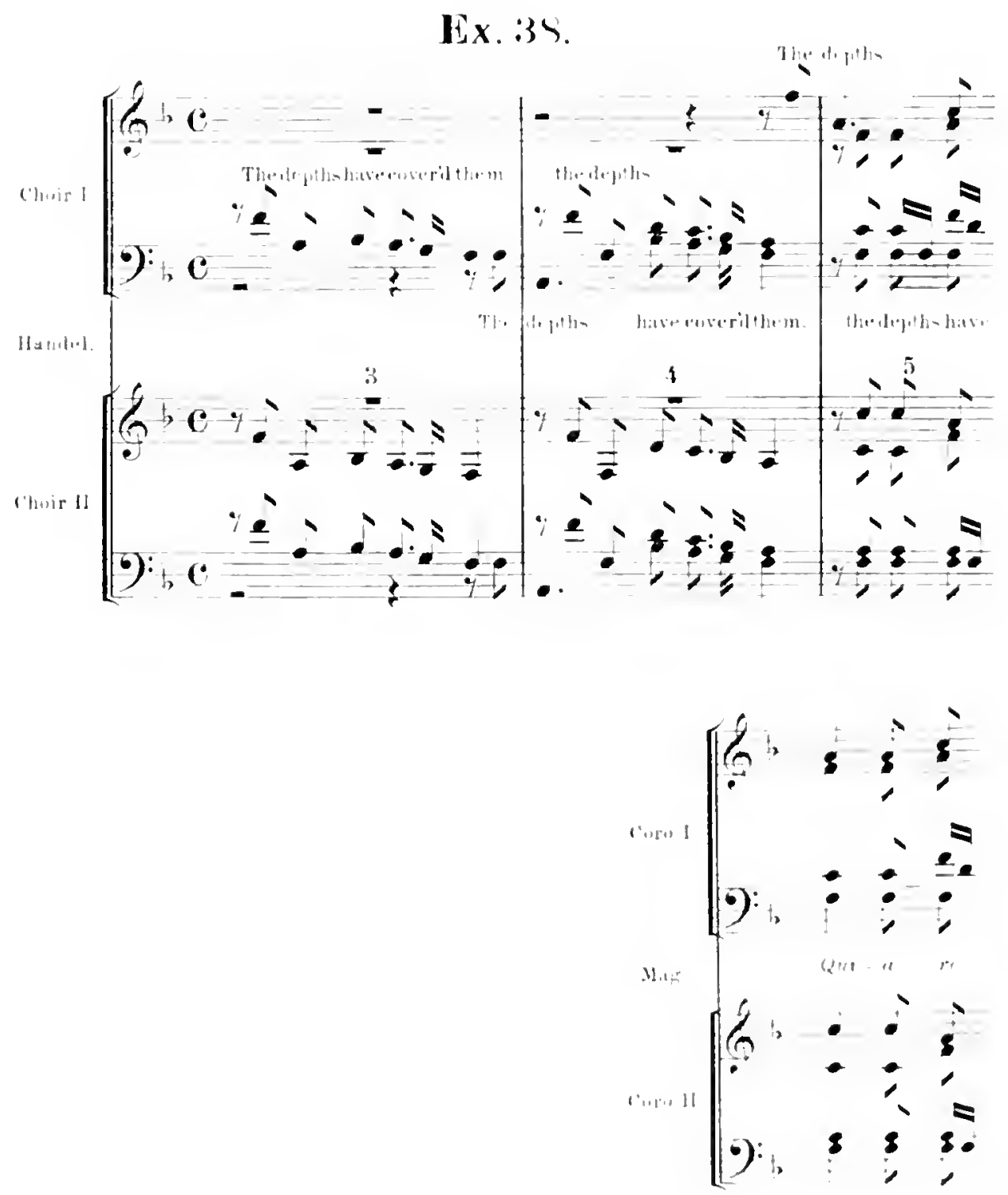

'Sicu, for another iastance of the latter proculure, bara 1.7 of "Ho spake tho viurd." bi, :27, p. 6. 

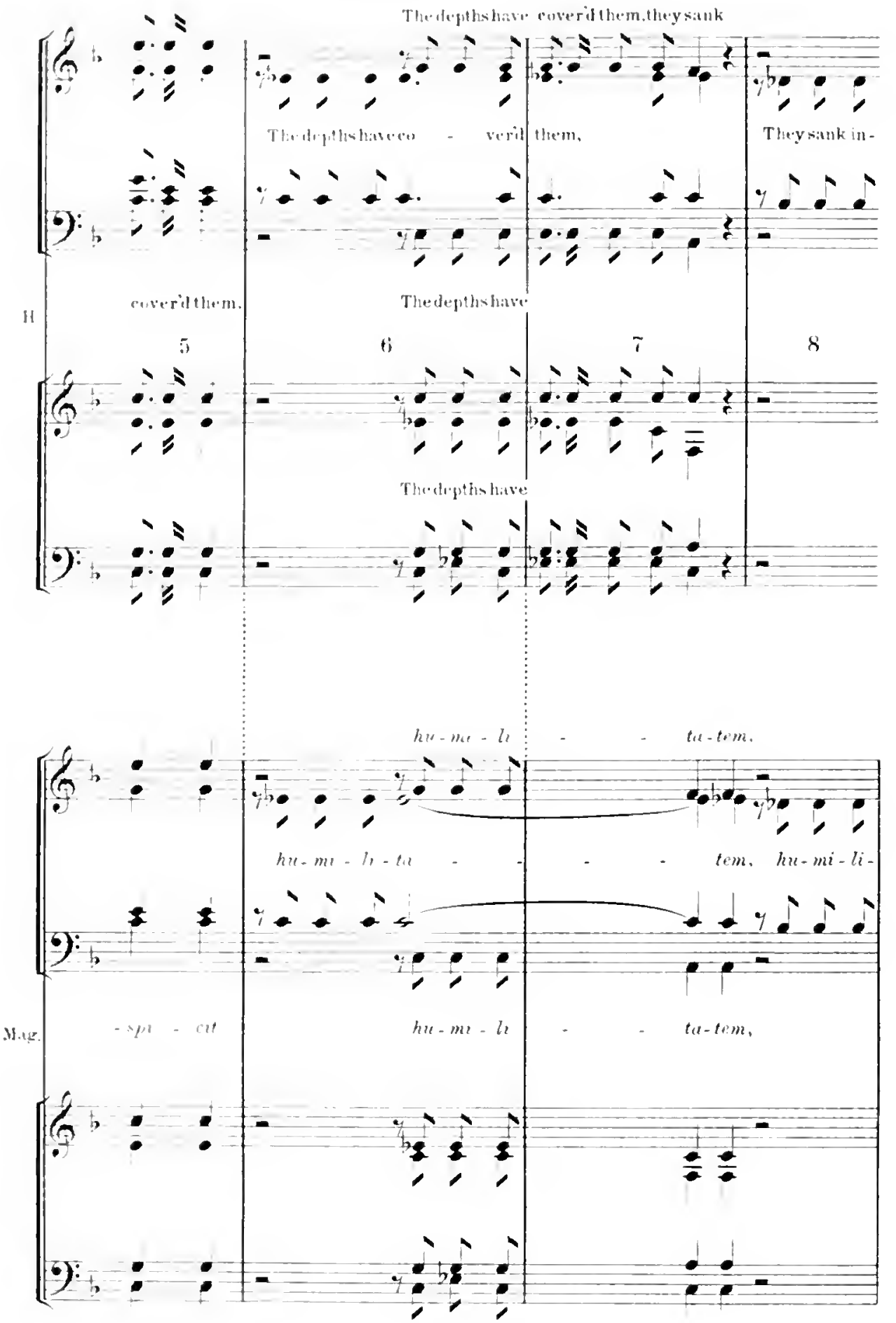

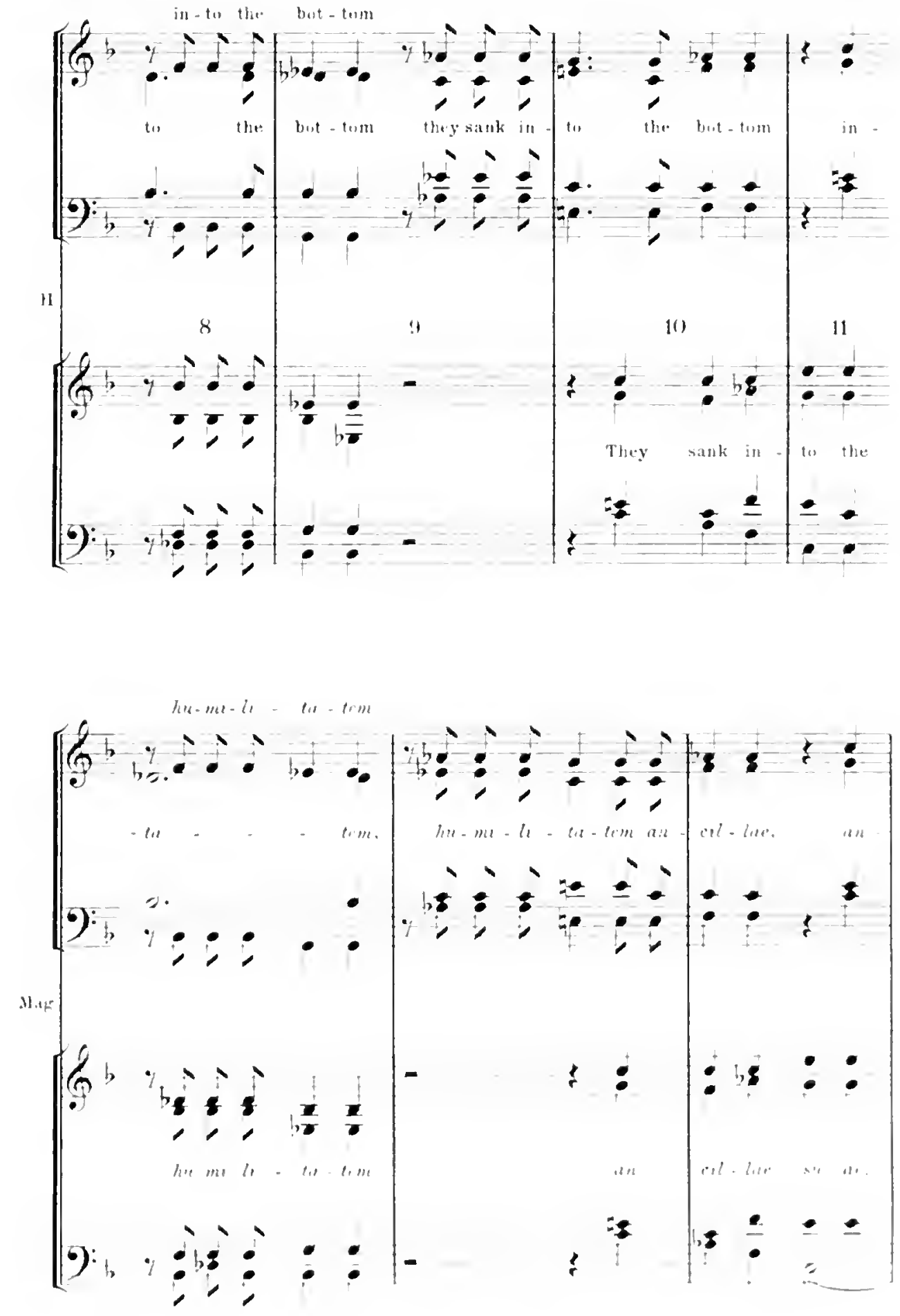




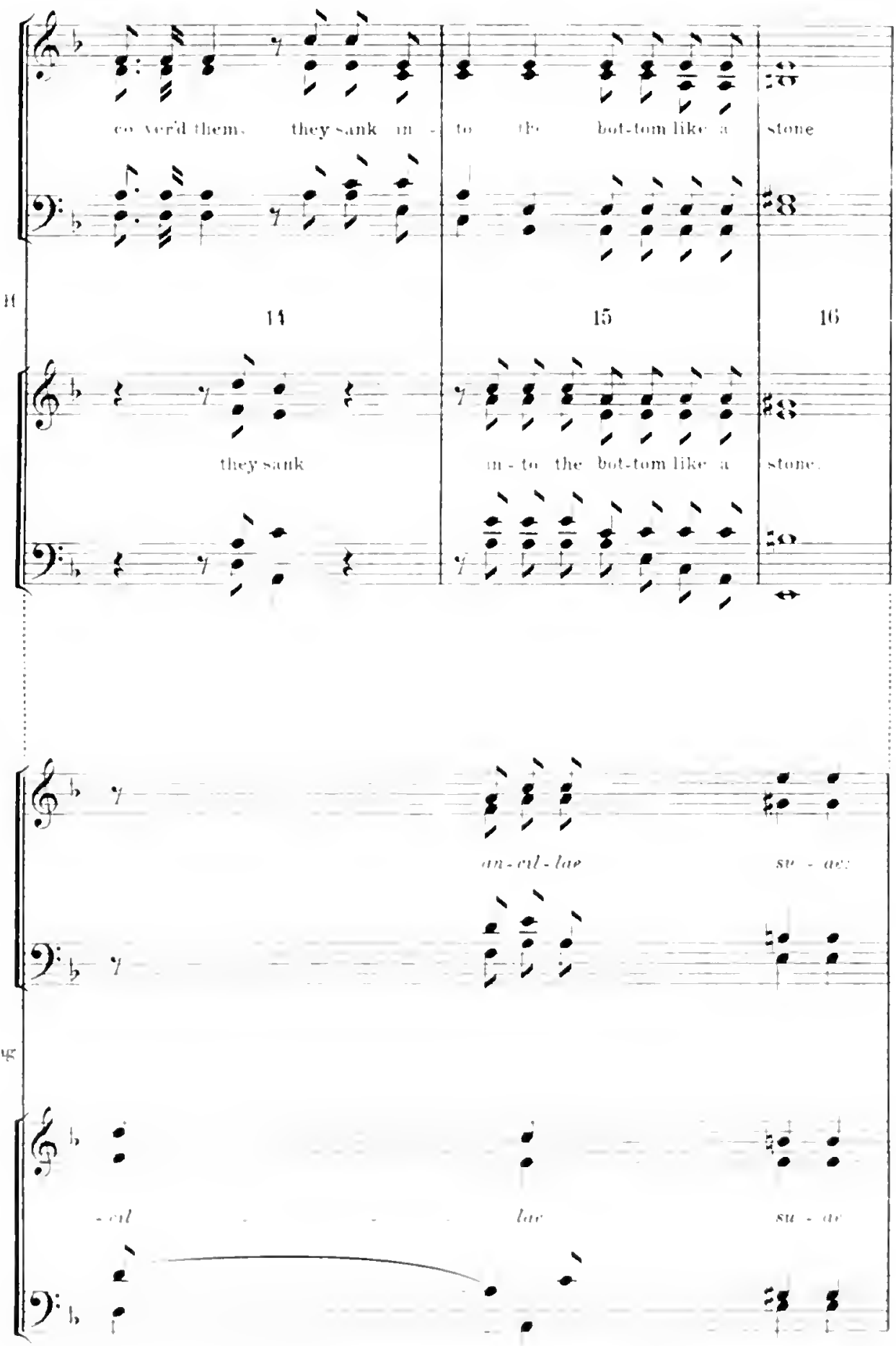


The next unuber (2t), the double chorus, "Thy right hand, O Lord," opens as follows:

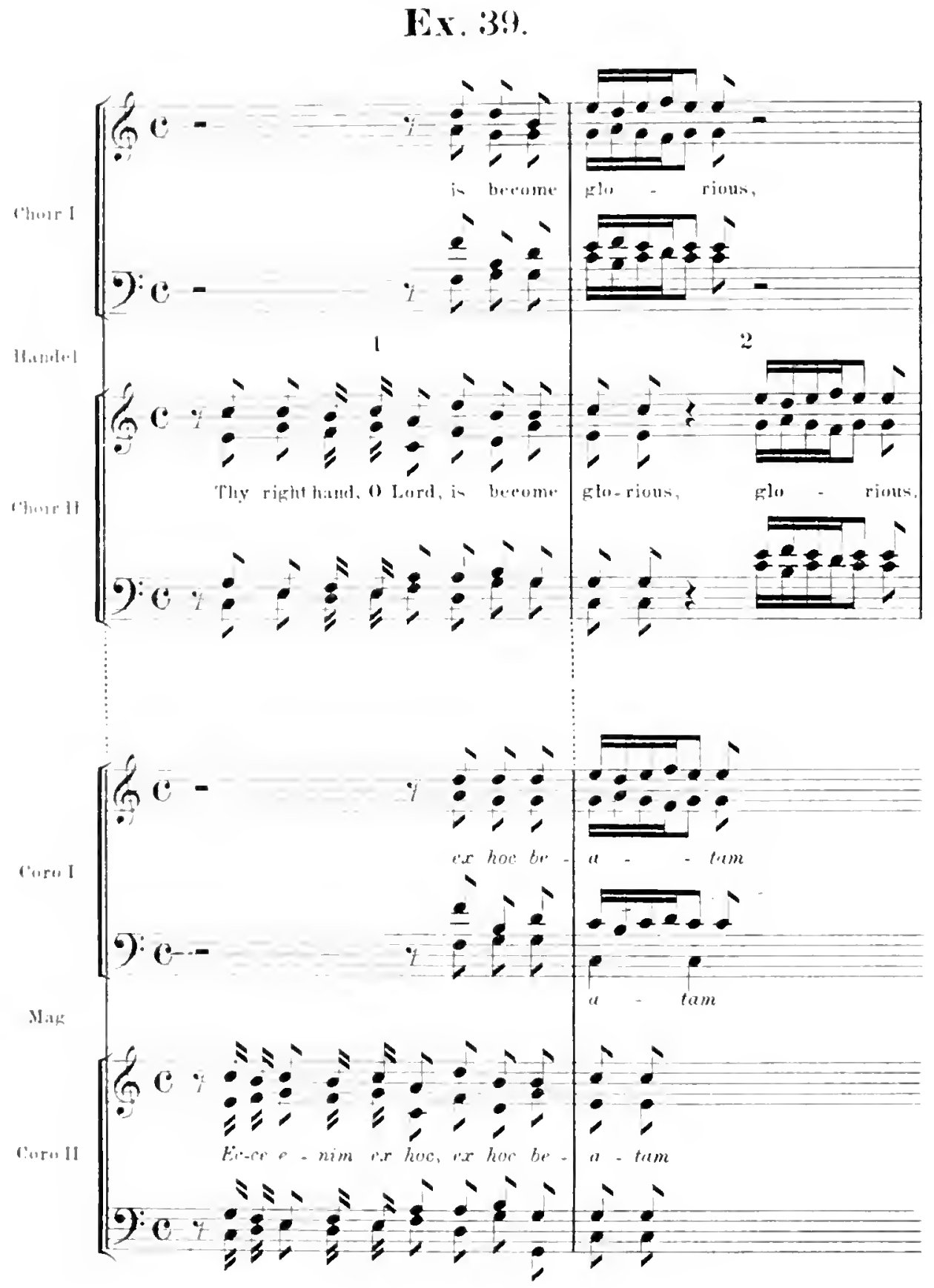


ISRAEL IN EGYPT

143
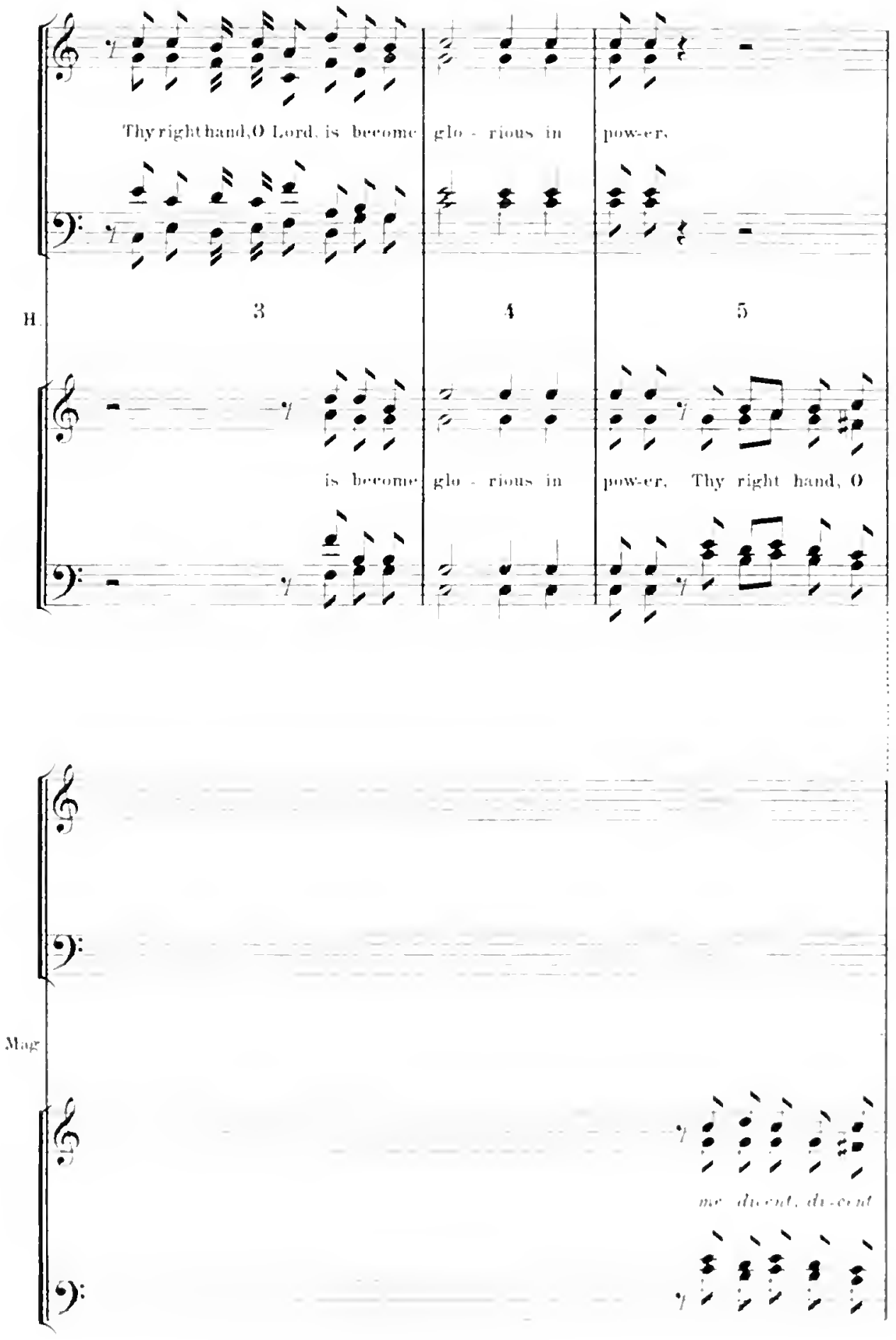

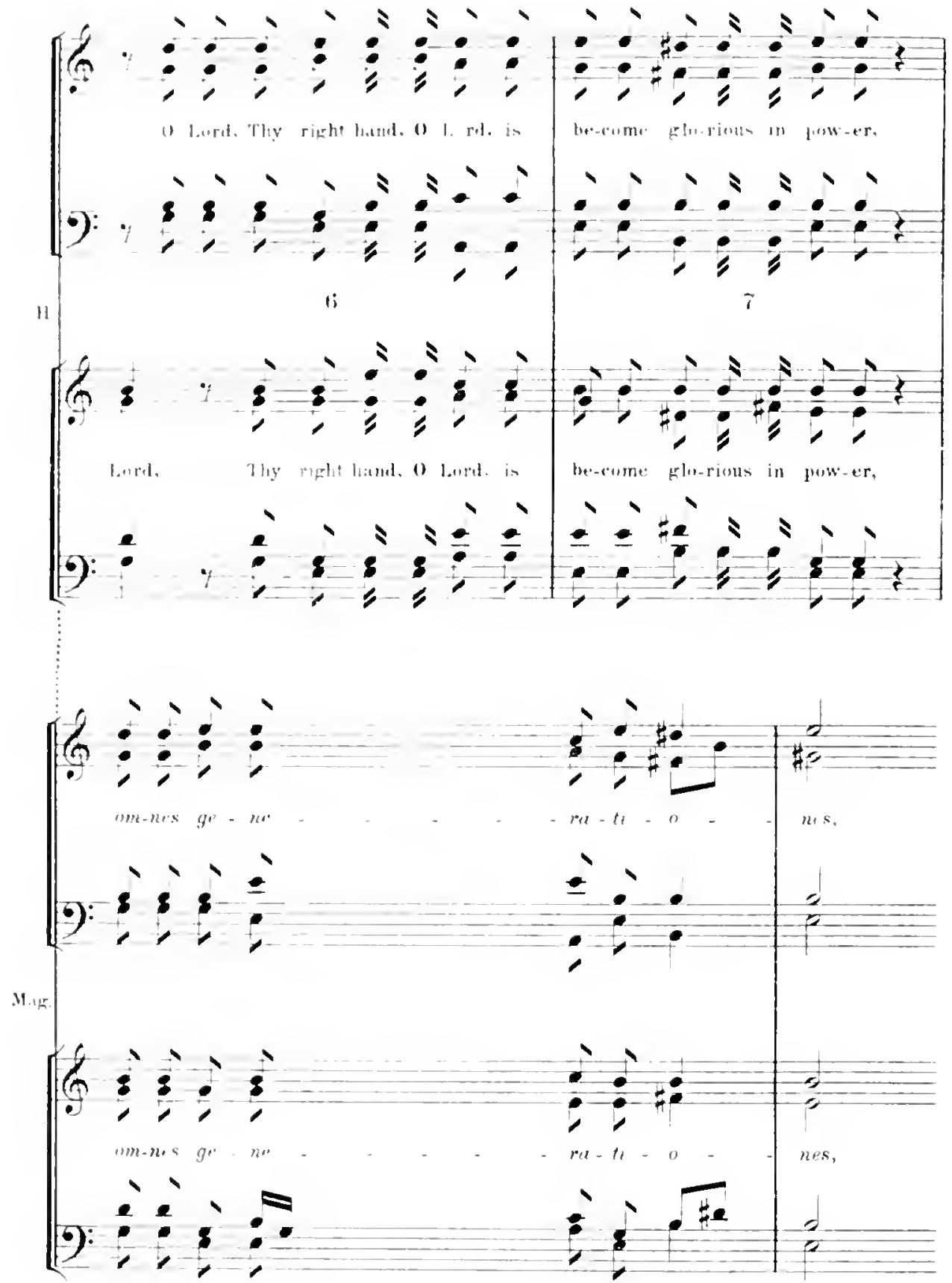

It will be observed that from the middle of bar 2 to the beginning of bar 5 Handel merely repeats the matter of bars 1 and half 2, slightly modified. He next, still following the Mugnificat, takes the same subject into the key of G and, after 
a repetition similar to the former one, completes his use of this section of the Magnificat, which has now been entirely absorbed:

Ex. 39. continued.
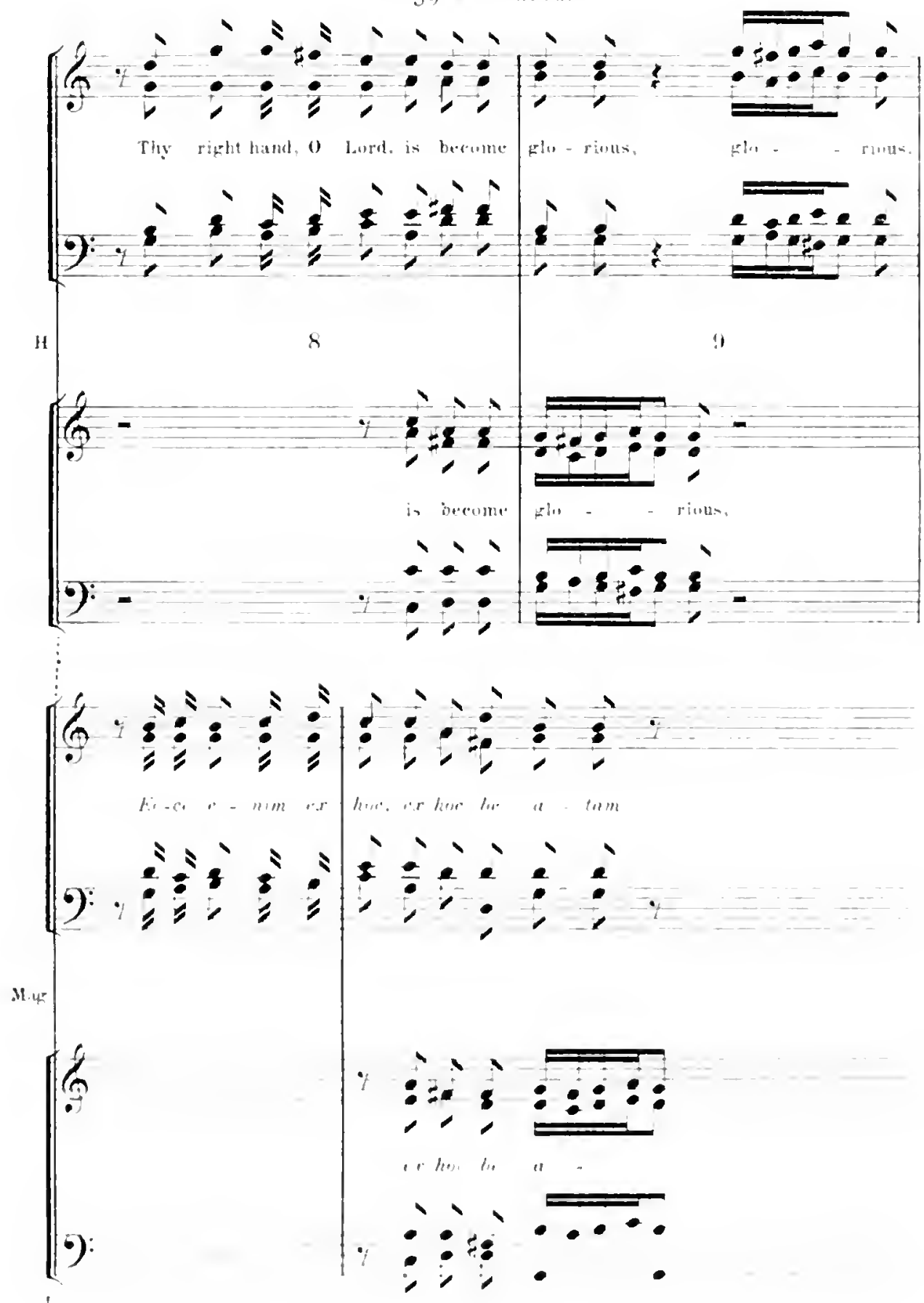

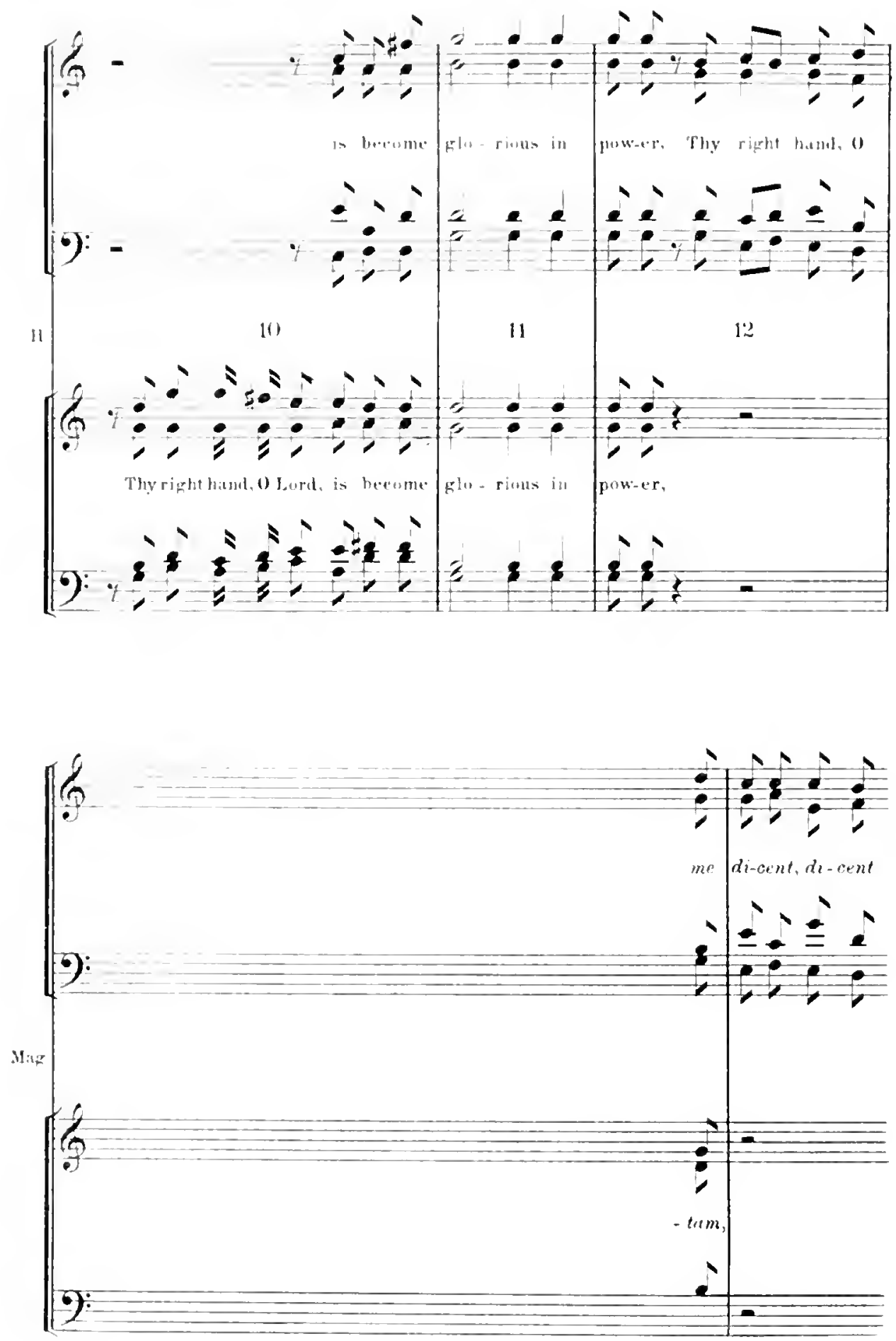


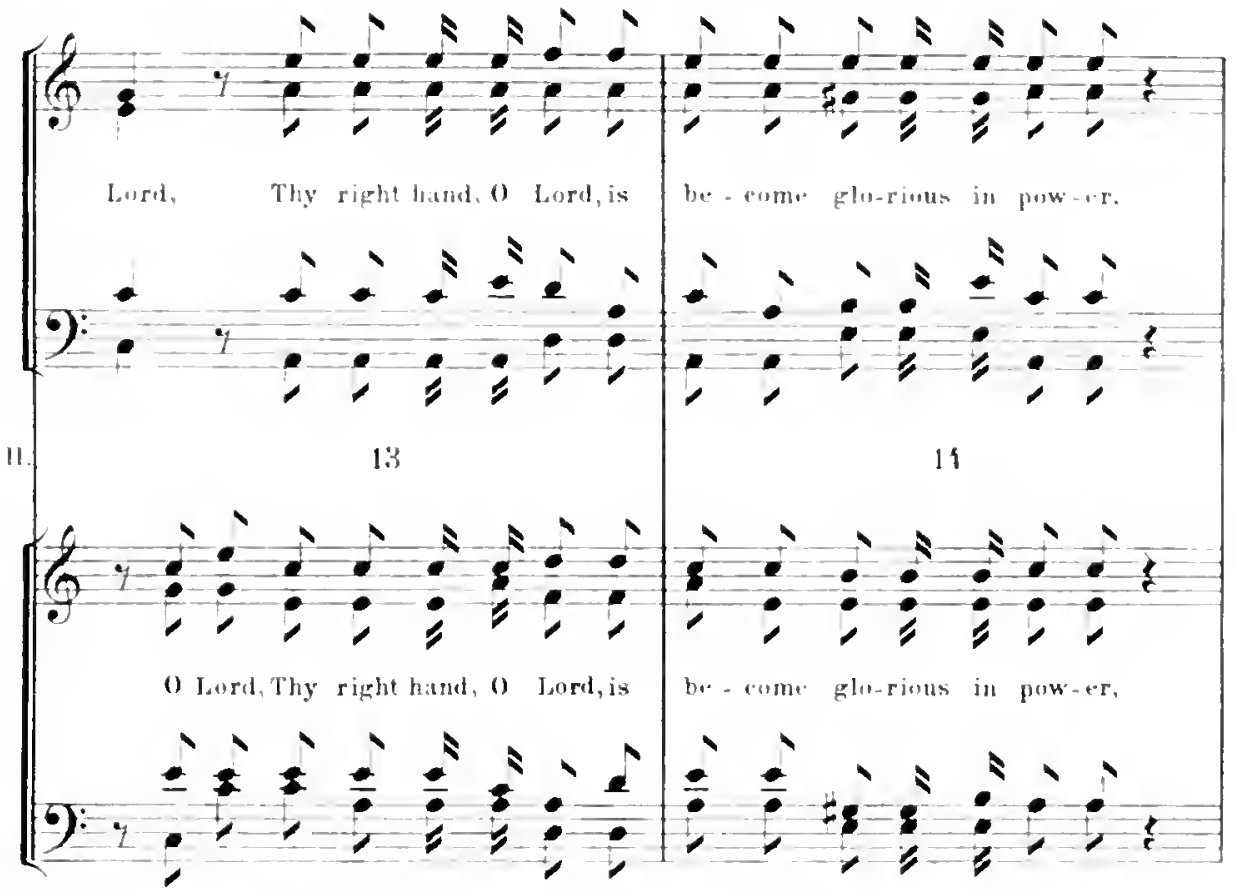

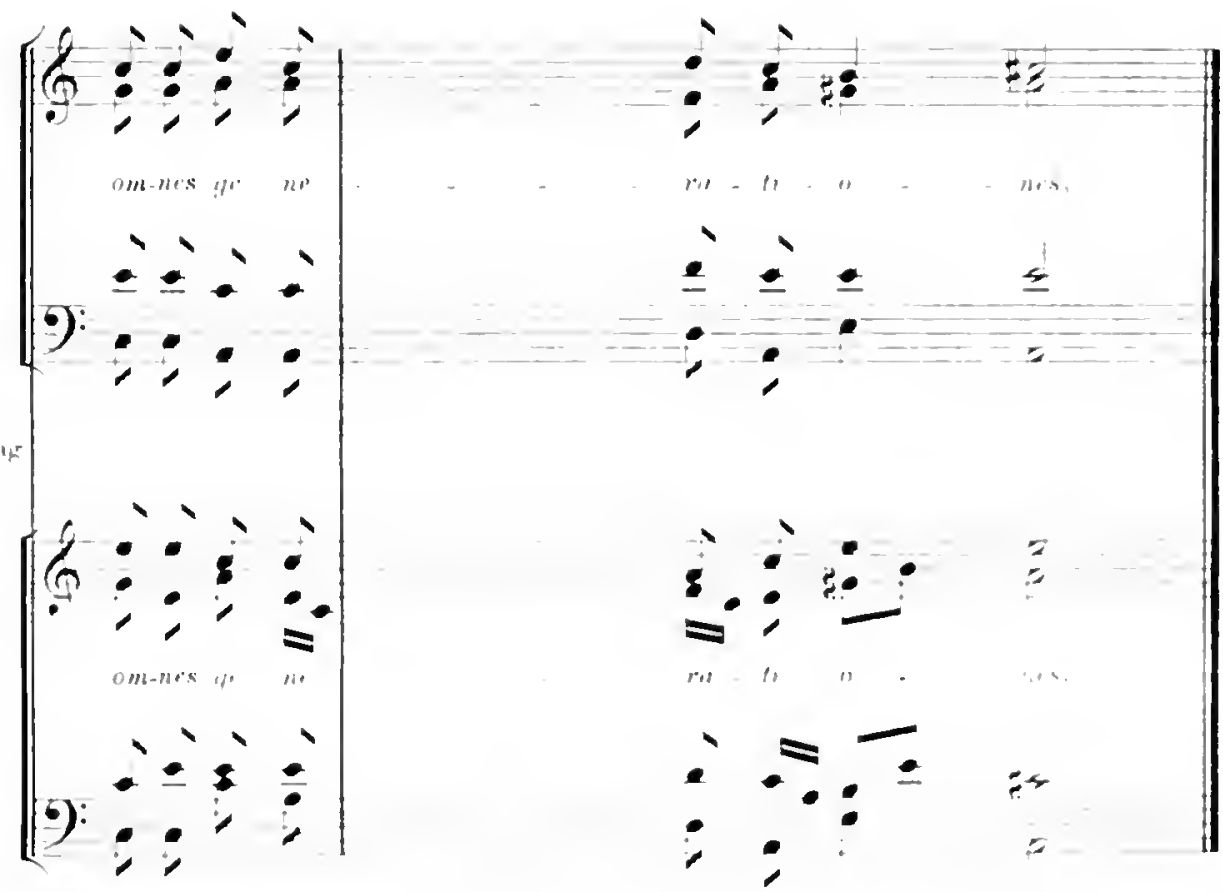


The rest of this chorus is a fine specimen of Handel's contrapuntal powers. At bar 15 he starts a splendid subject:

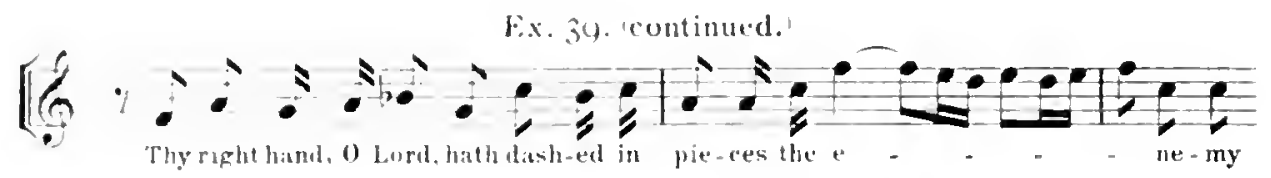

the first bar of which appears to have been developed from the bass of bar 1 of this section in the Magmificat. With this he makes play in Canon for half-a-dozen bars and then delivers again some of the earlier material, but greatly enriched, in a series of alternate utterances by the two ehoirs, which constantly inerease in grandeur until they finally unite in the following prodigiously jubilant and exultant close :
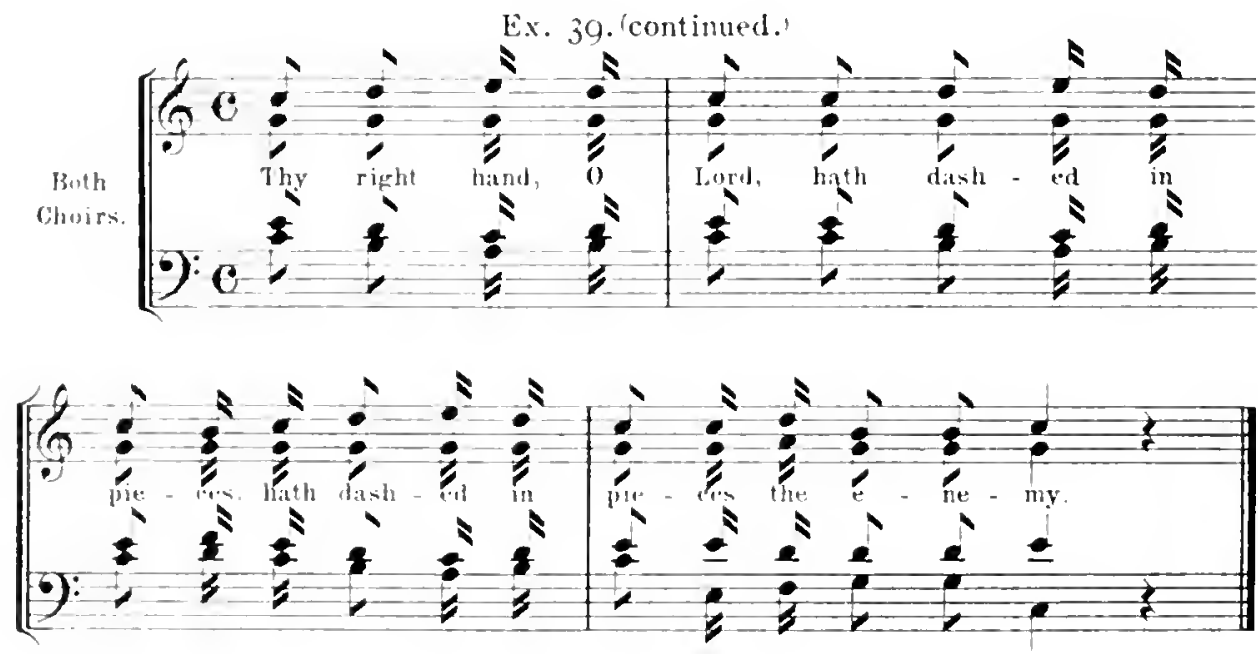

Had the Magnificat not come down to us, the apparent complete spontaneity of this wonderful chorus would have at once negatived the idea that it could lave been developed from a setting made to another text. There was, however, one indication pointing that way in the strong accent erroneously placed in this ehorus on the first syllable of the word 'become' every time that it occurs. Nor could this be attributed to Handel's incomplete knowledge of English, for in the duet for two sopranos "The Lord is my strength"' where the word 'become' occurs far more frequently than in this chorus, it is invariably accentuated correctly.

A sliort ehoral introduction (No. 25), "And in the greatness of Thine excellency;" leads into "Thou sentest forth Thy wrath which consumed them as

2 See pp. 97-110. 
stubble," a double chorus, 82 bars long, chiefly renarkable as being, with the exception of its last three bars, the entire ehoral setting in the Maynificat of the words "Fecit potentiam in brackio suo, dispersit superbos mente cordis sui," transferred bodily, with very few, and those quite insignificant, corrections, to the seore of Isrcel in Egypt. The orchestral accompaniment, too, is taken over from that in the Magnifieat, with parts for three tromboues added to it, but substantrally unchanged.

The three independent bars which Handel has appended by way of elose present no point of interest.

This number is followed by the ehorns (No. 27) "And with the blast" in which about 50 bars out of 71 are taken, or contrapuntally developed, from the Alto solo "Deposuit potentes" in the Magnificut. After one bar of orehestral prelude the chorus enters as shown in the following Example:
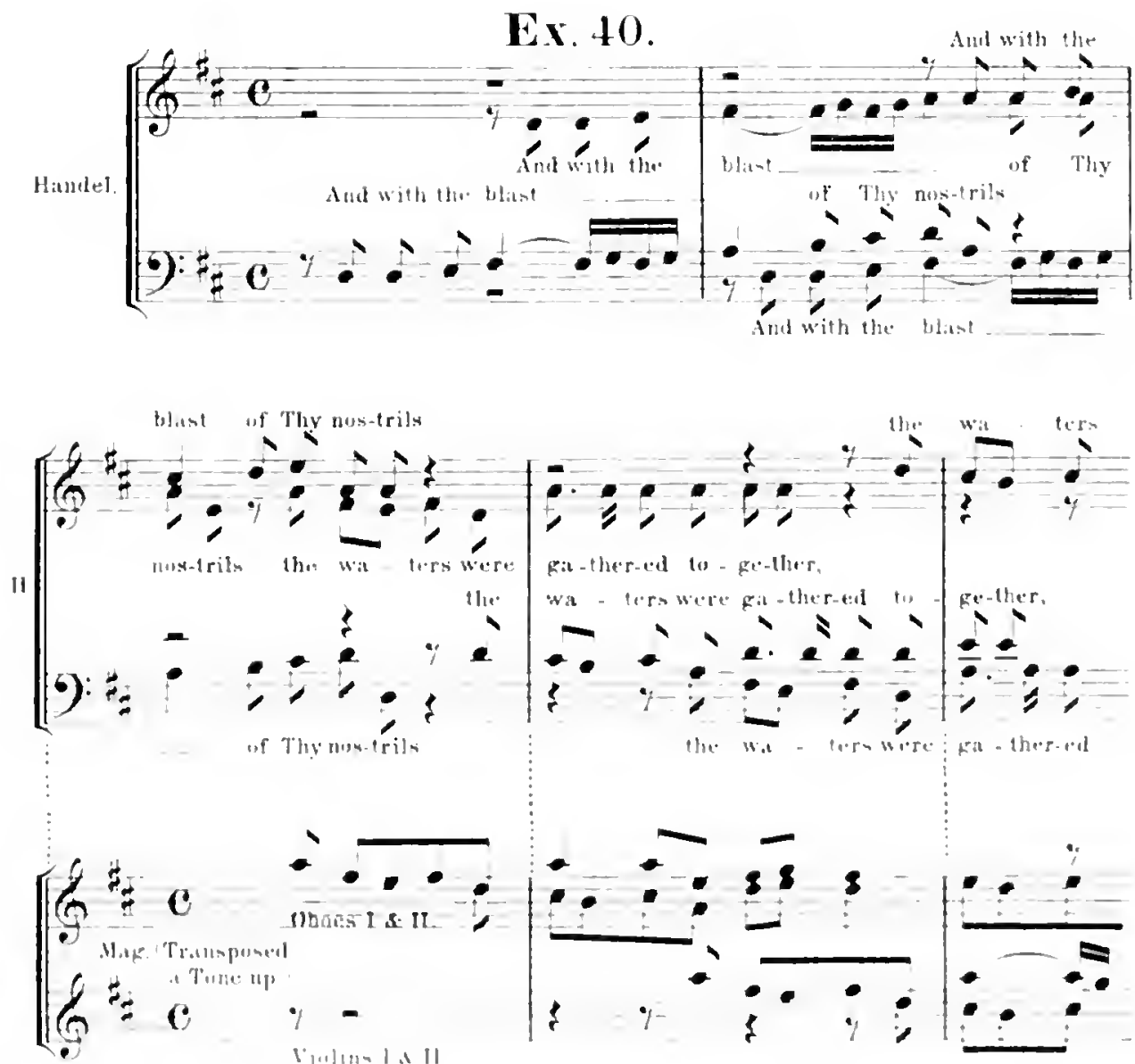
This Lxample shows Inandel, after writing a couple of bars in Canon on an independent subject, taking up, and playing contrapuntally with, a phrase from the prelule in the Mesnificut. He then modulates into the key of $G$ and repeats the Canon there. Next he borrows a phrase from the song to which the prelunle leads:

\section{Ex. 40. continued.}

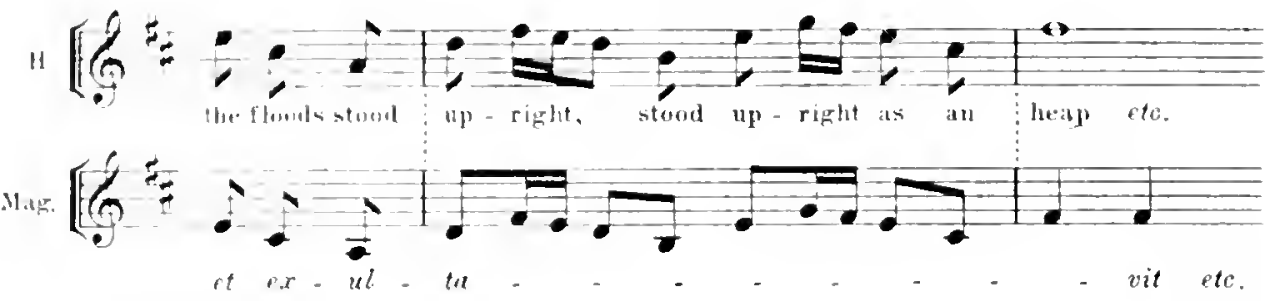

and occupies with it and a series of iterated crotchets the next twelve bars, after which he resumes continuous touch with his source as follows:

Ex. 40. 'continued.)
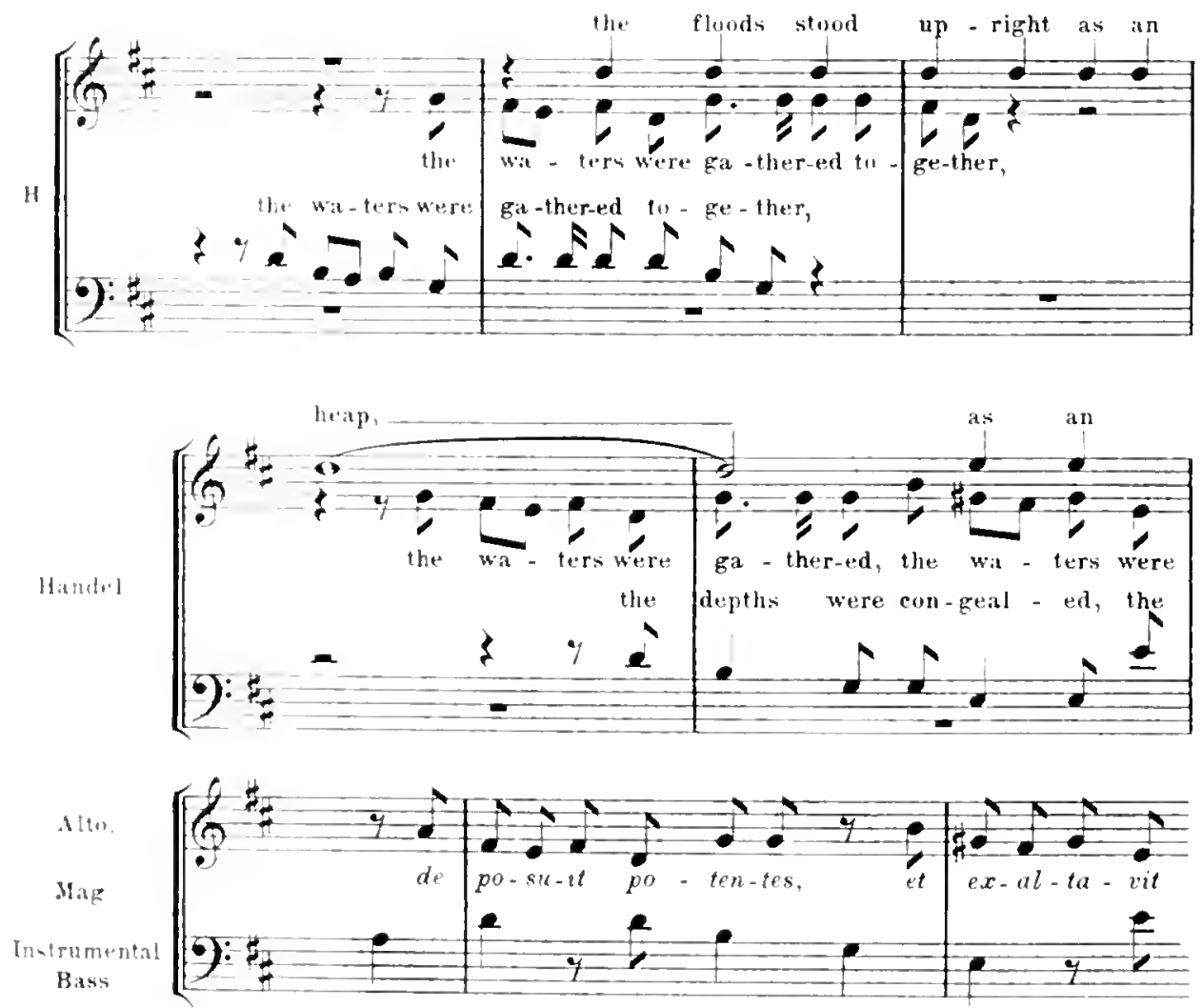

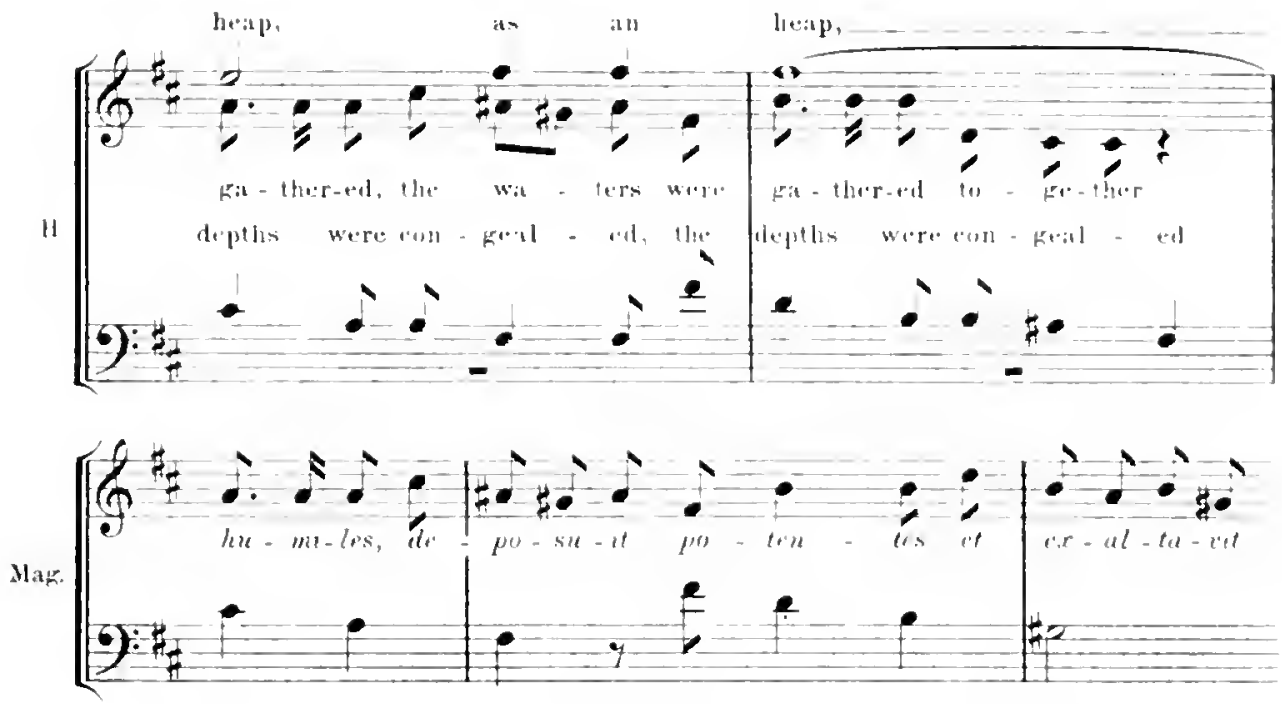

The rest of the chorus is supplied by contrapmintal working on materials alrealy used in it, more particularly on the groups of four notrs descending by Thirds in the bass of the last extract from the Magnificut. With these Handel produces effects of wonderful sublimity which culmimate at their last appearnnce just before the choral close :

\section{Ex. 40. Icontinued.}
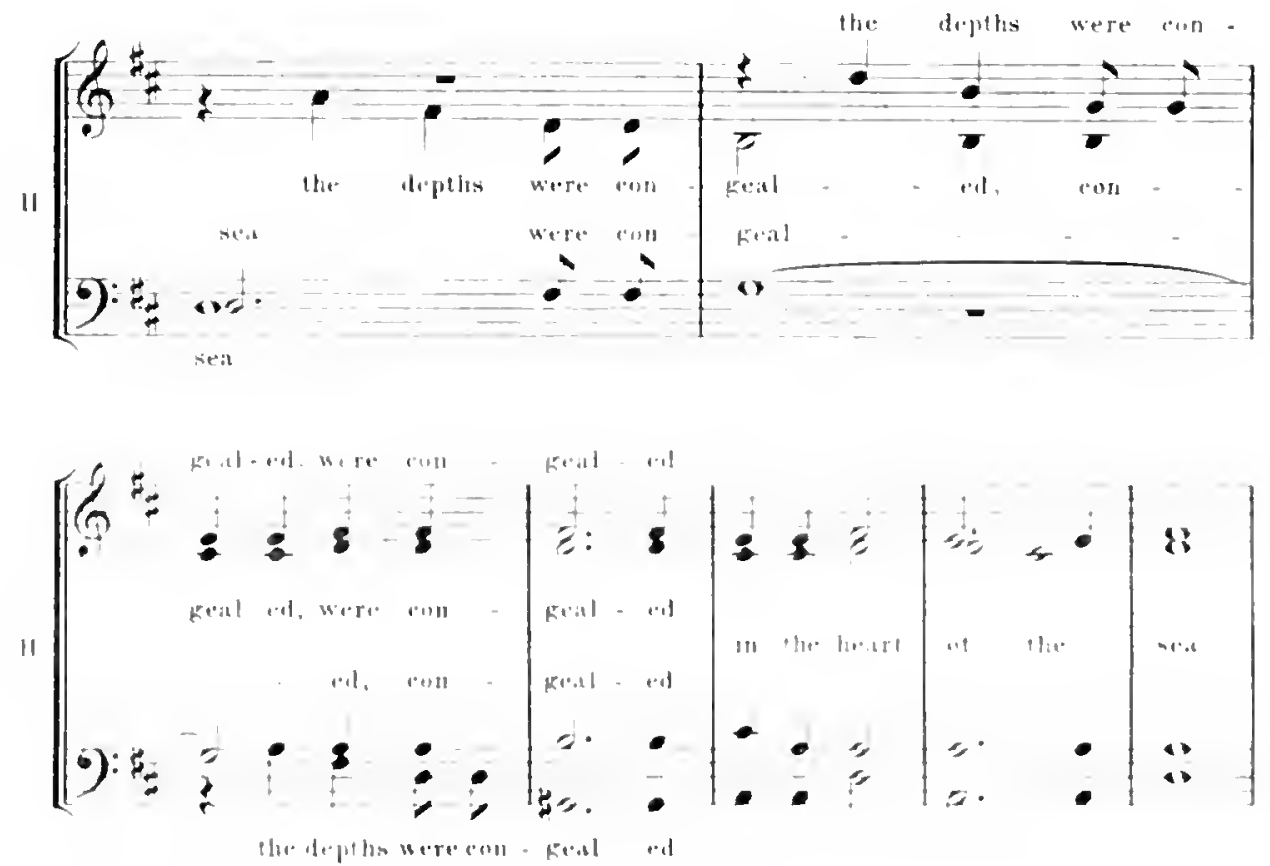
This is followed by twelve bars of concluding orchestral symphony closely modelled on those which perform the samo function after the Alto solo in the Mugnifurat:

Ex. .10.' continued.'
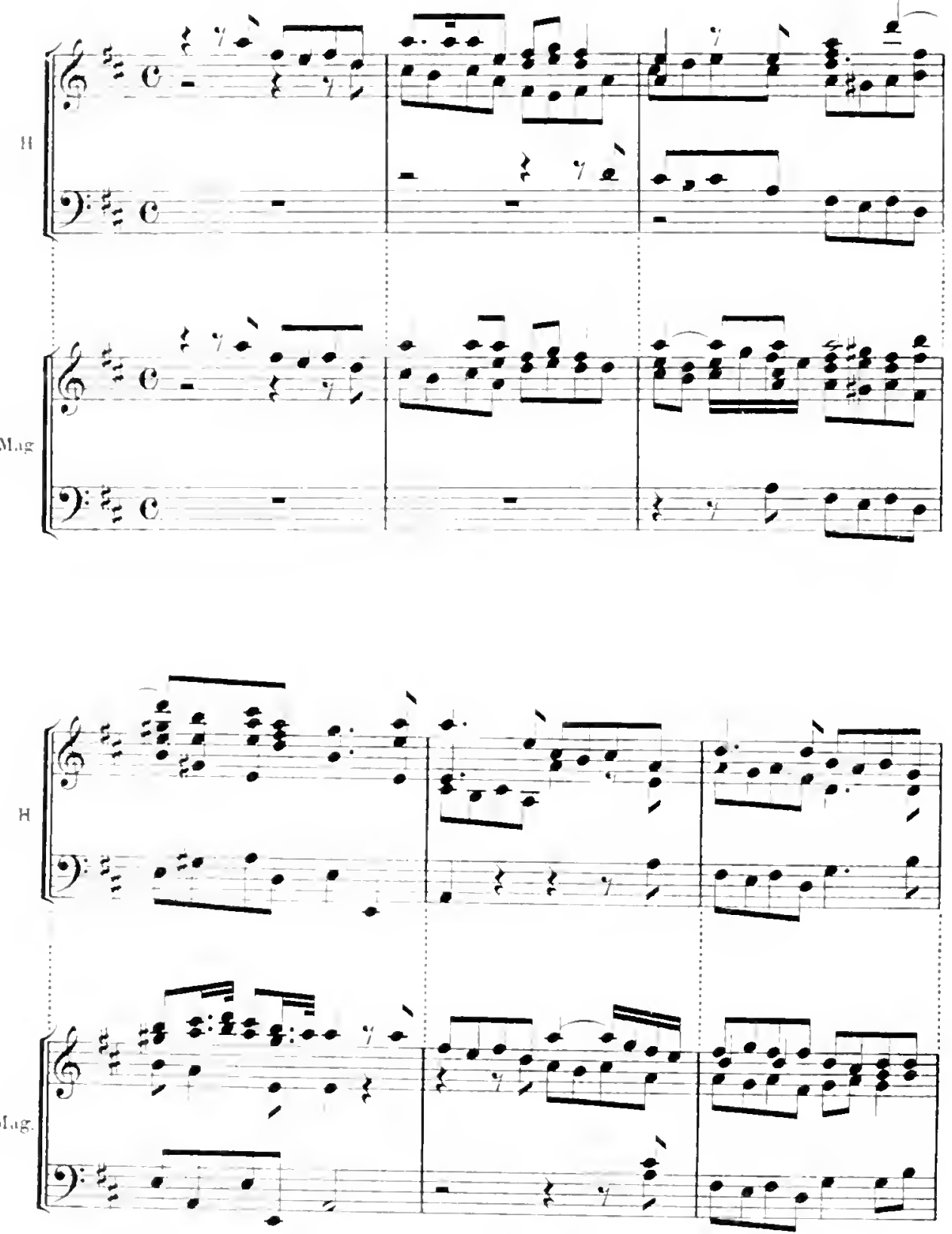

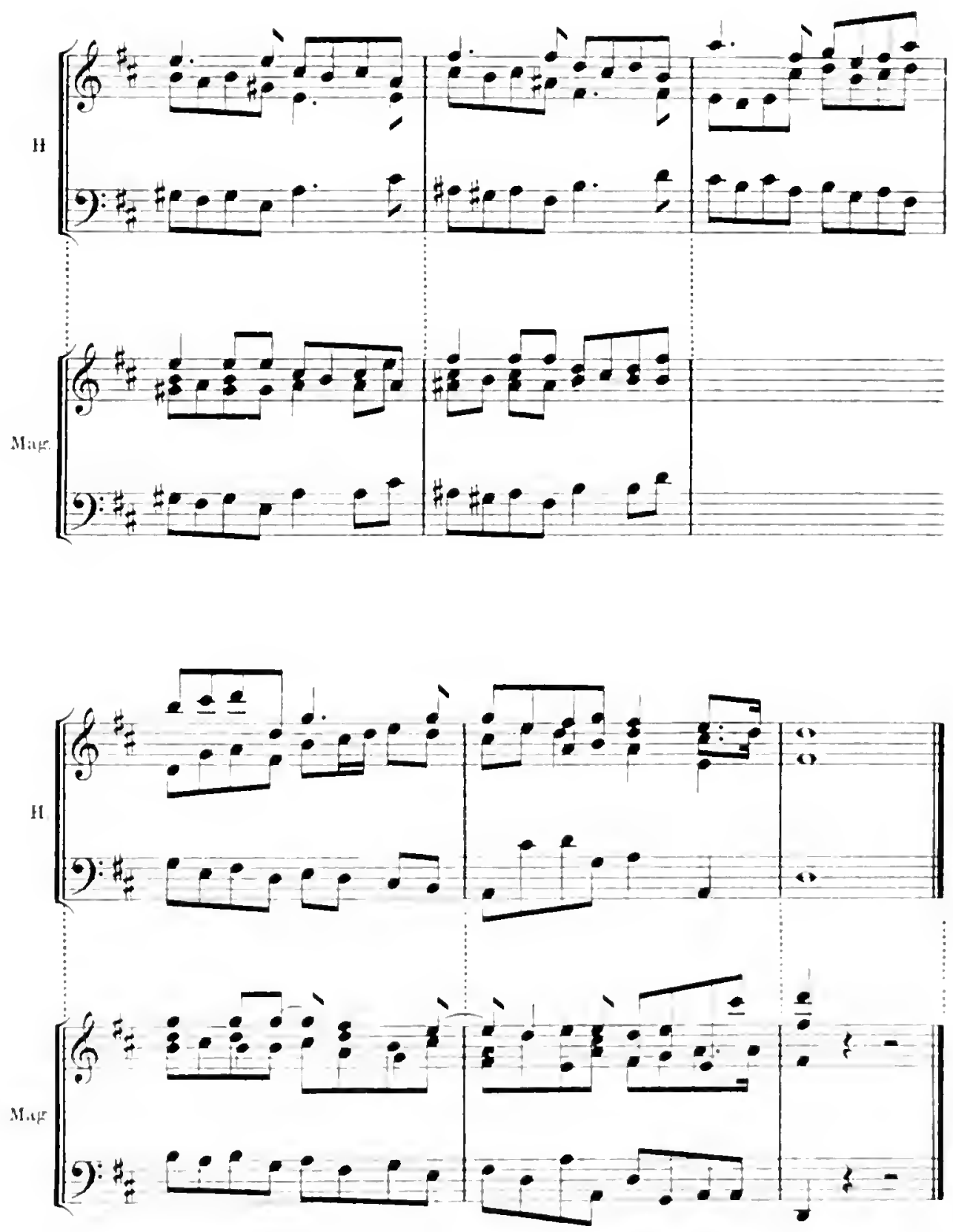

The reader will observe that, whereas in bars 3 and 4 on page 152 Handel reaches five-part writing, he drops abruptly into three-part writing at the begiuning of bar 5 and contiunes in it to the end of tho movonemt. 
A parallel Irop from six-part to four-part writing occurs at the same place in the Mennificel, the stave in which parts for two oboes are written-in for the first three hars hecoming abruptly vacant at the beginning of the fourth bar, and continuing so to the end of the symphony. Handel, however, does not silenee his oboes, hut direts them to play in mison with the first violin during the rest of the novement. In the Magnificat this symphony is also used as a prelude to the Alto solo, but with this difference that independent oboe-parts are there written-in throughout the ten bars of which it consists. The parts which Handel has discarted are certainly less interesting than that of the first violin, which hu: hats improvel and bidden the oboes to reinforce This will be secn from the following Example:
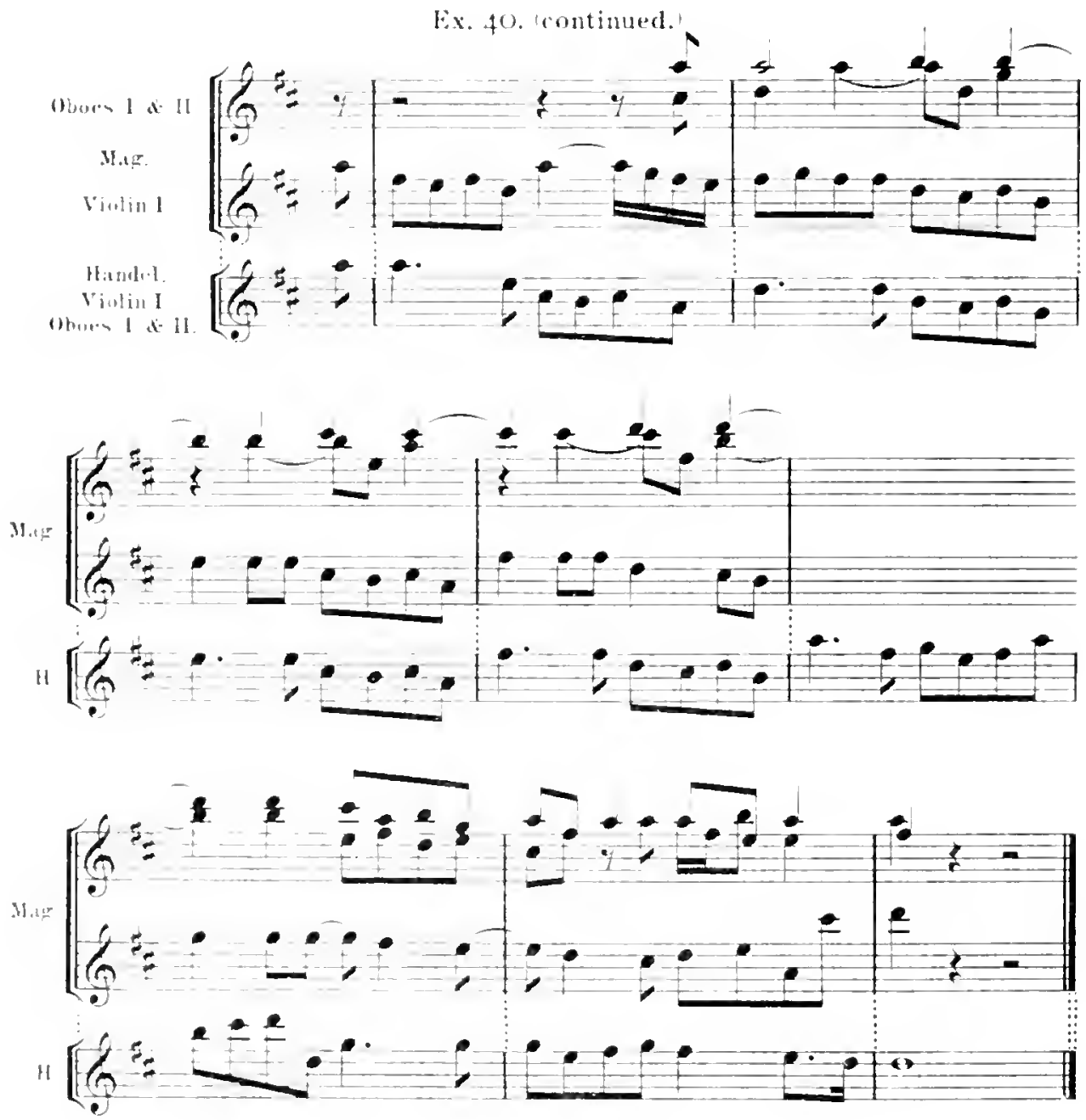
Passing over the two airs "The enemy said" and "Thou didst blow," and the double chorus "Who is like unto Thee," where there is ro reason to suppose that Handel was indebted to any previous sources, we reach the donble chorns (No. 31) "The earth swallowed them," which consists of 41 bars taken, as far as the voice parts are concerned, all but note for note from the setting in the Mlagnificat of "Sicut erut in principio" etc.

The false accentuation on 'The' in bar 1

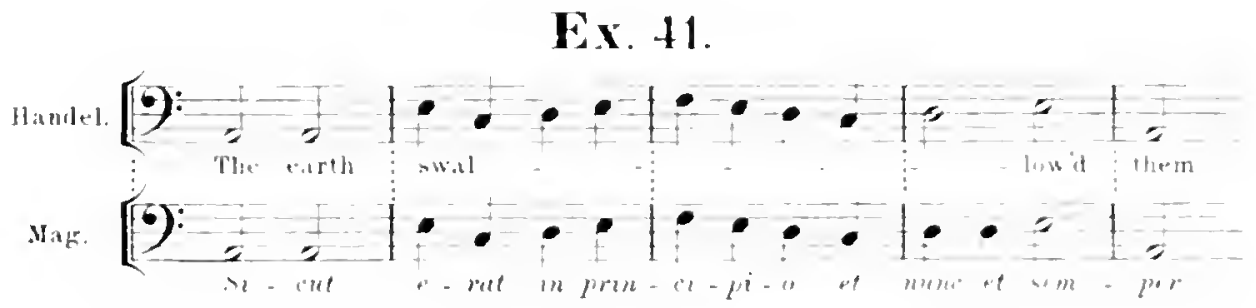

might, even without access to the Magnificat, have raised a suspicion that the setting here was not absolutely original.

The Alto and Tenor duet, "Thou in Thy mercy," is alunost wholly based on a composition for the same voices in the Magnificat set to the worls "Esurimtes implevit bonis." Out of the 115 bars which this movement accupies in Imrecl, only 26 appear to owe nothing to the Magnificat, and 17 more to contain a mixture of independent and derived matter. But the improvement eflected on the material taken over, especially by supplying an interesting string accompaninent where the Mugnificut had only a bare figured bass, is very great.

The duet in the Magnificat not being provided with an instrumental symphony, Handel has supplied one, the first half of which is made out of its opening veral sulject, and the second half appears to have been scored independently, as will be scen in the next Example:

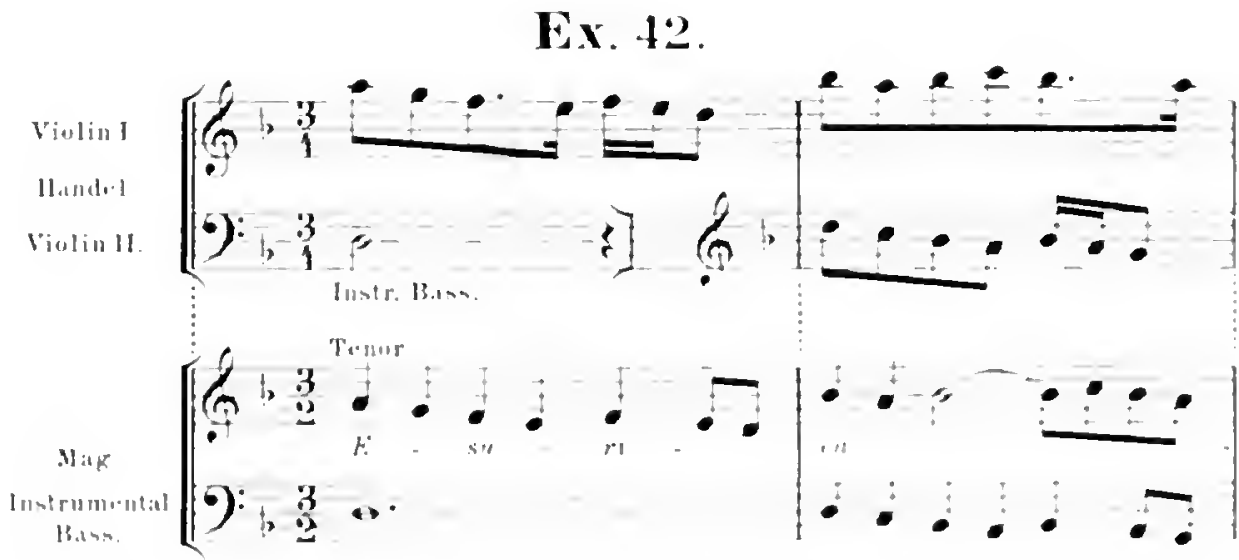




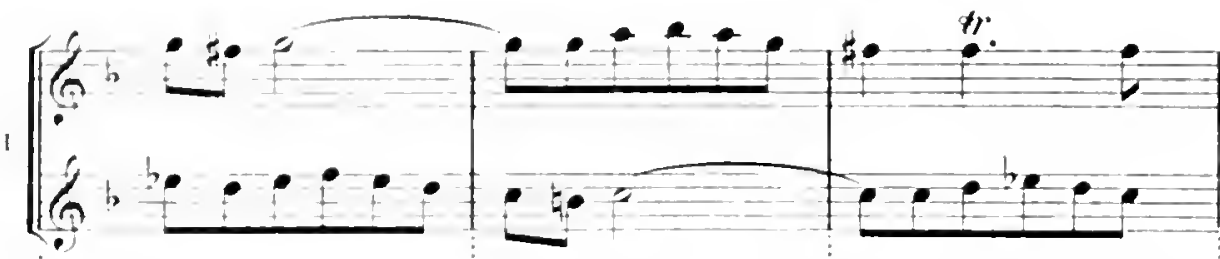

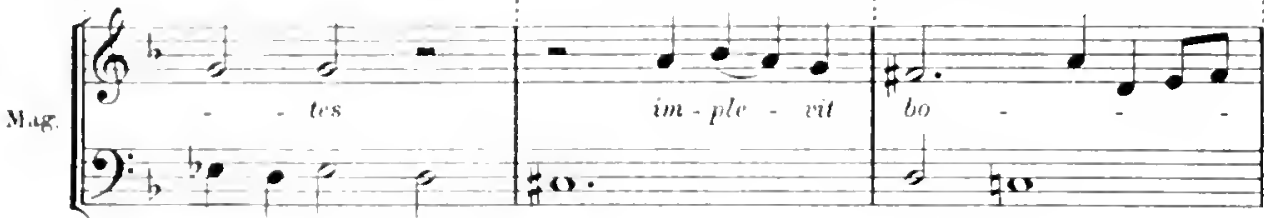

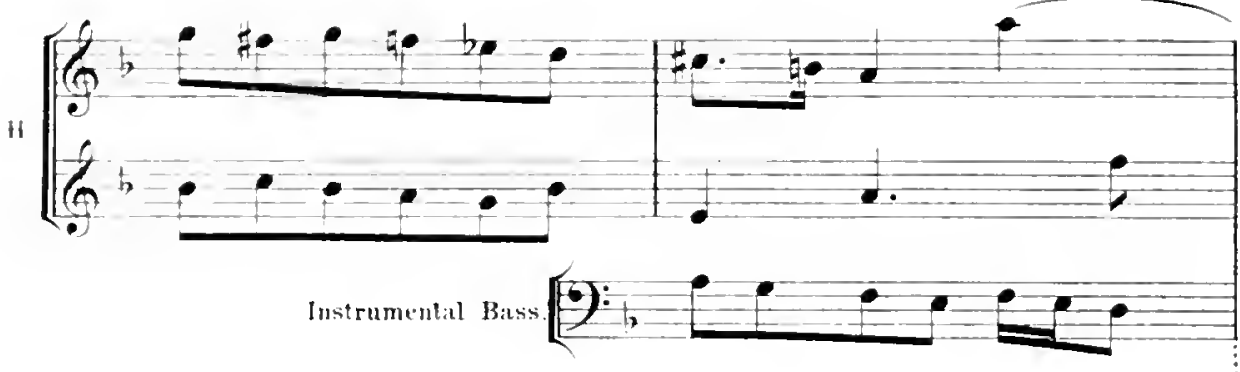

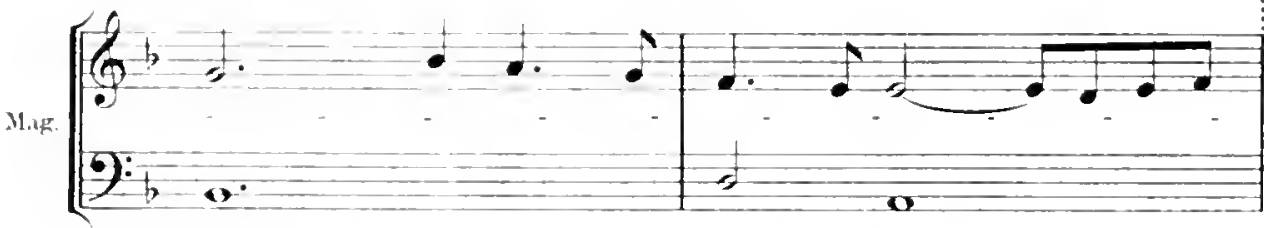

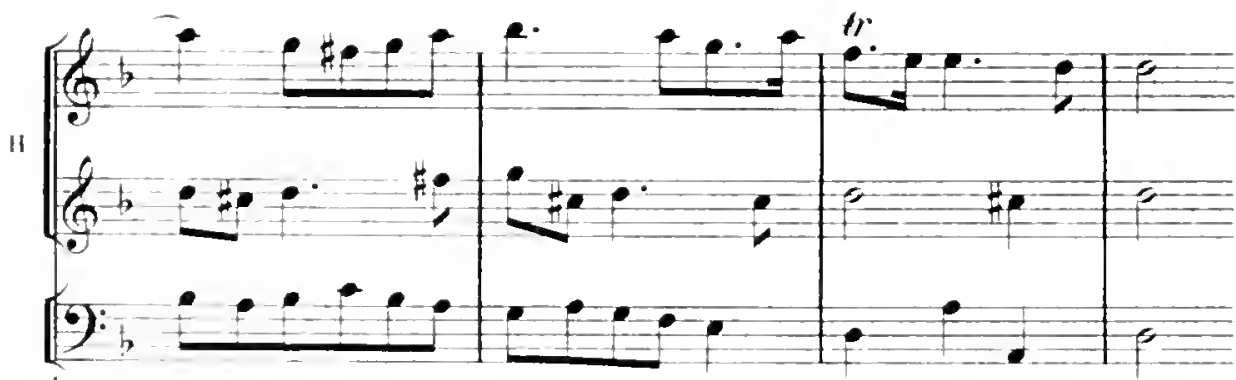

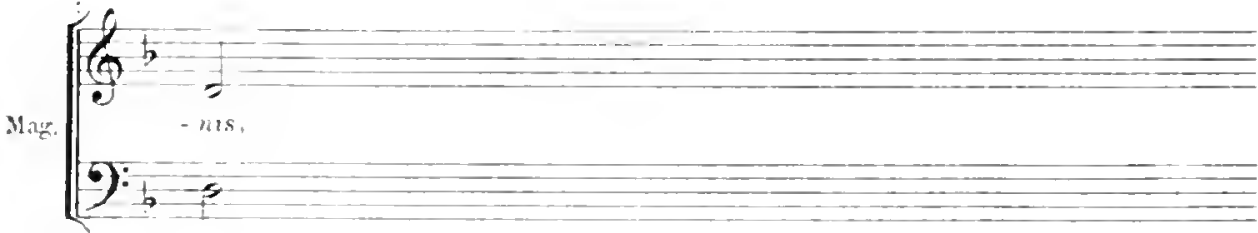


The duet then proceeds side by side in the two versions for many bars, as the next Example will show. The first five bars from the Magnificat already quoted are repeated here for convenience of comparison.

\section{Ex. f2. (continued.)}
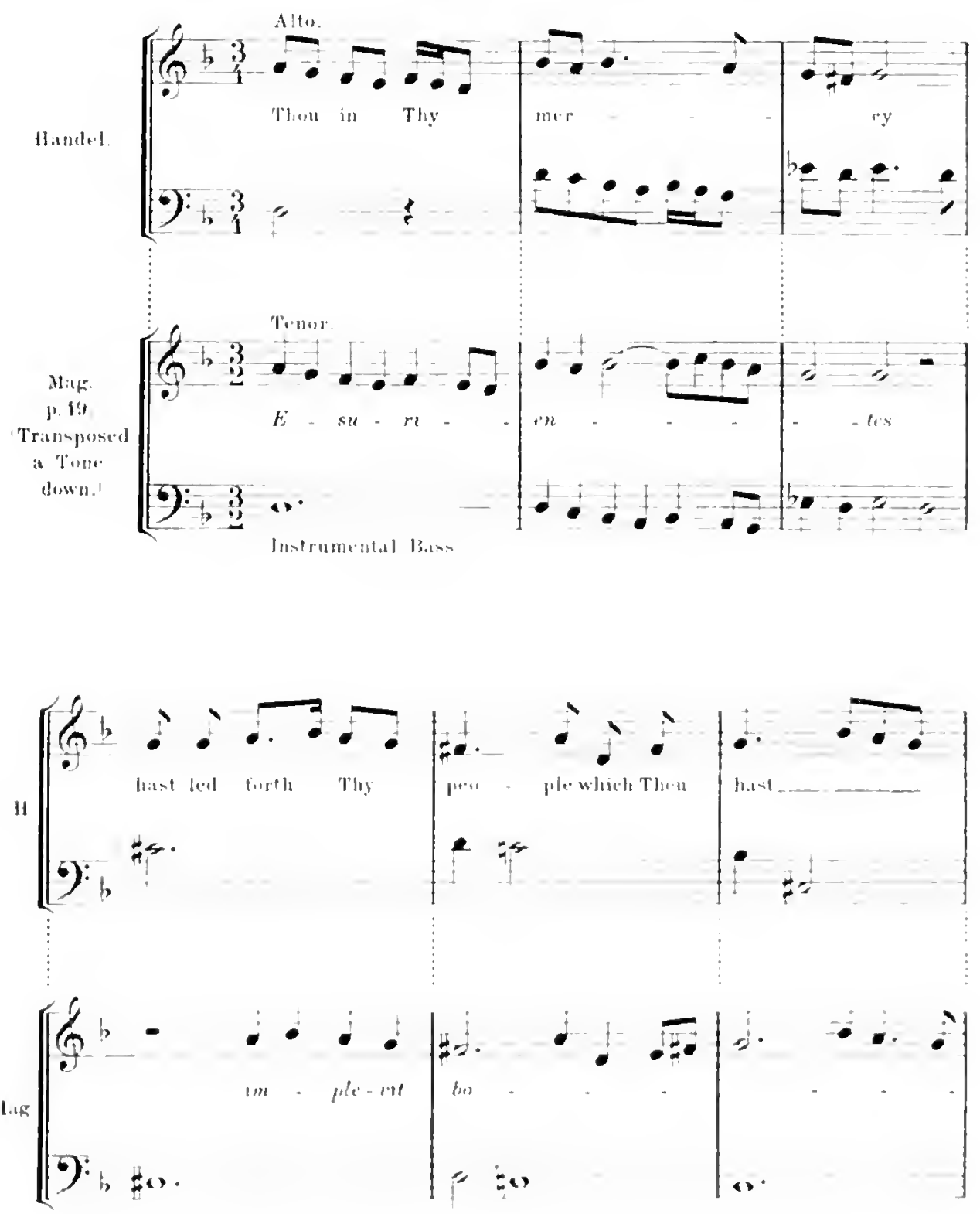
158

ISRAEL IN EGYPT

$\left[\begin{array}{ll}6 \\ 0\end{array}\right.$

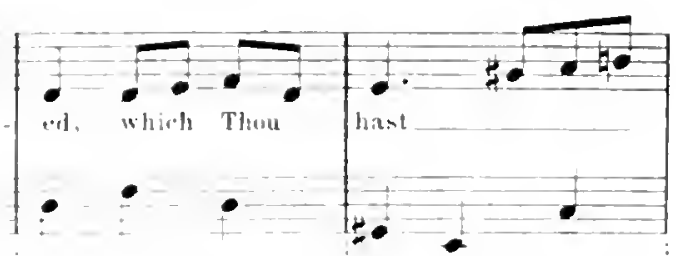

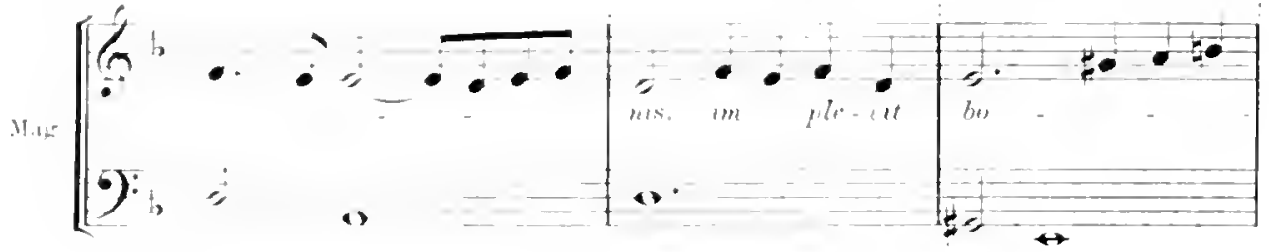
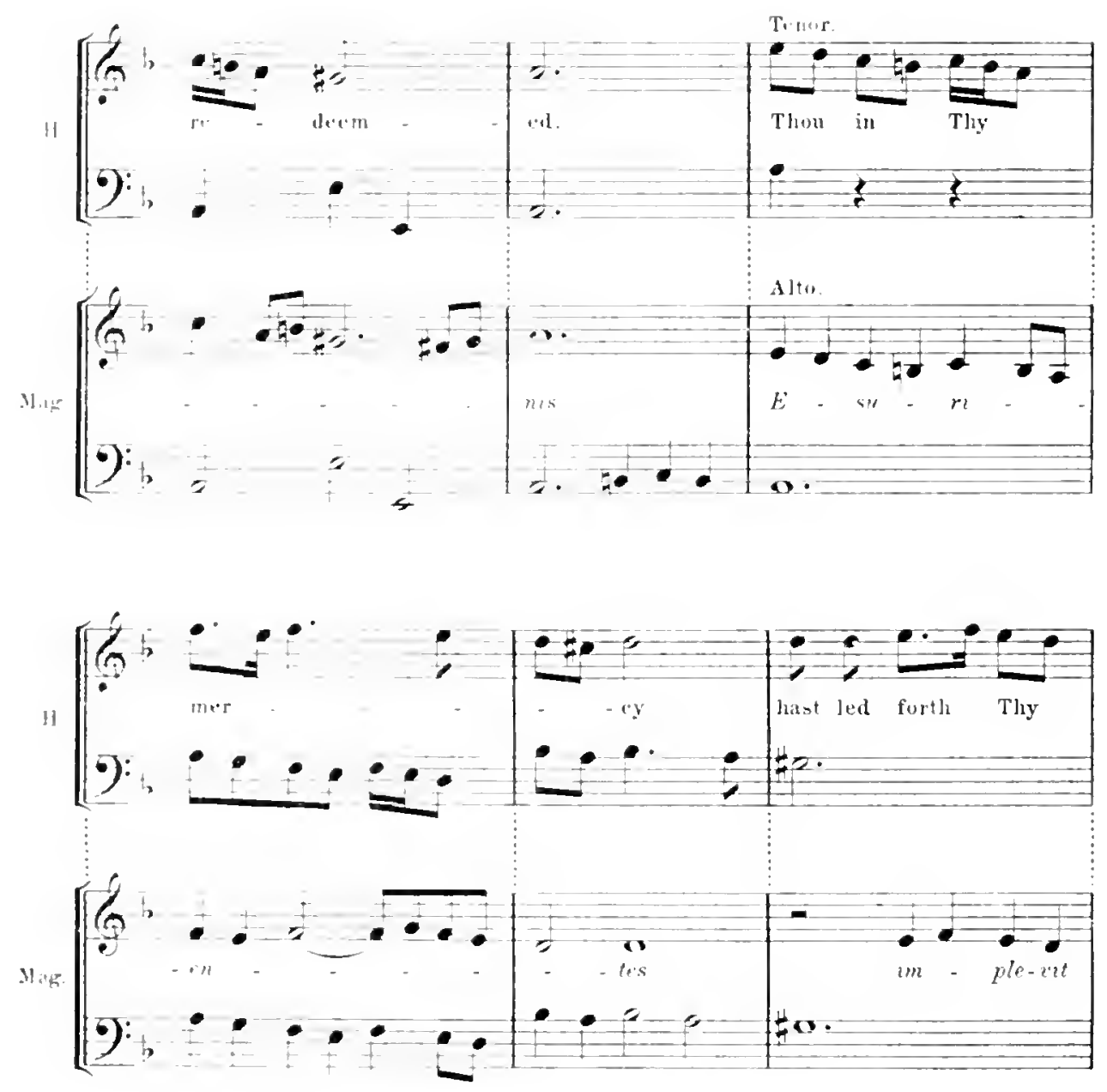
ISRAEL IN EGYPT

159
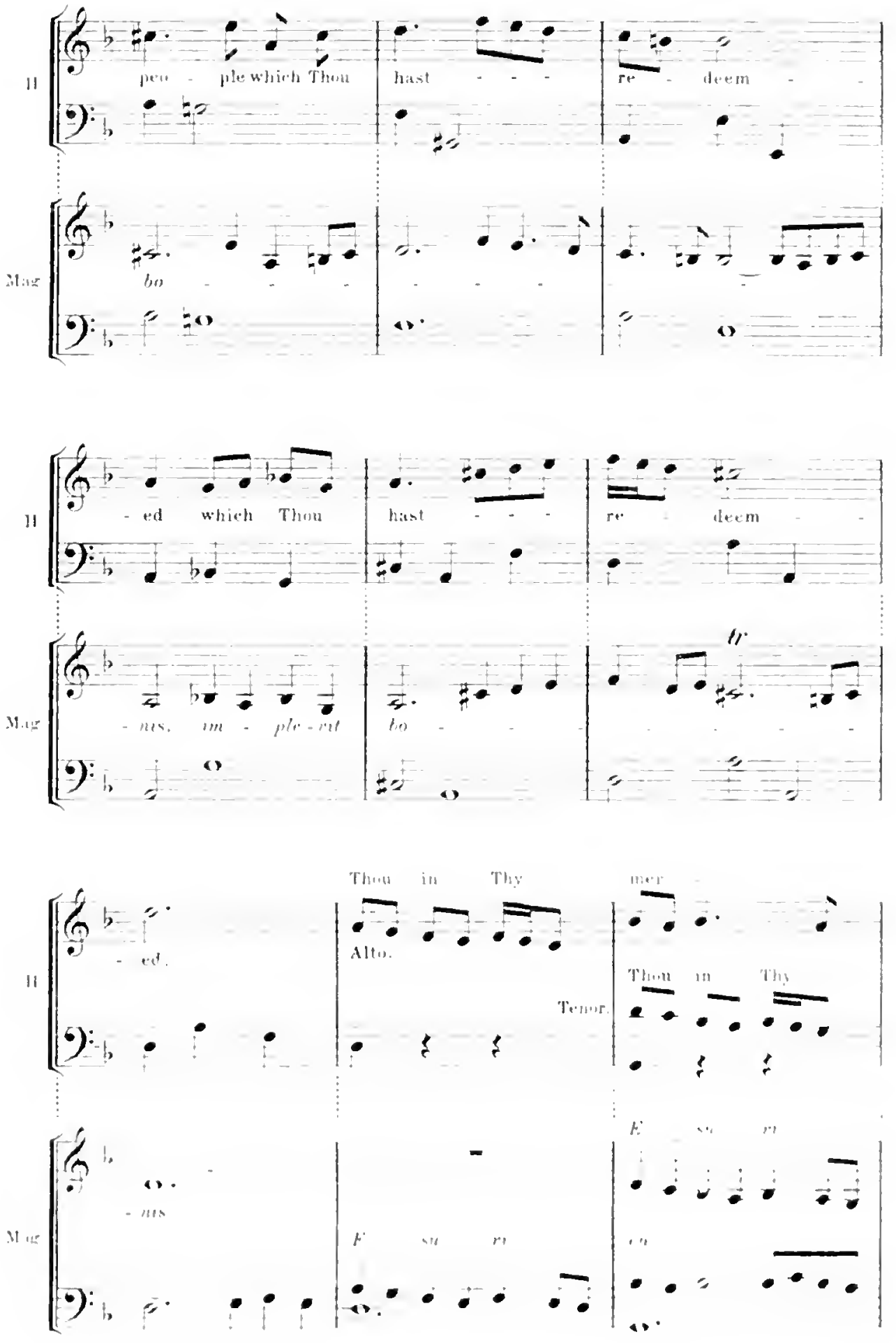
160

ISRAEL IN EGYPT
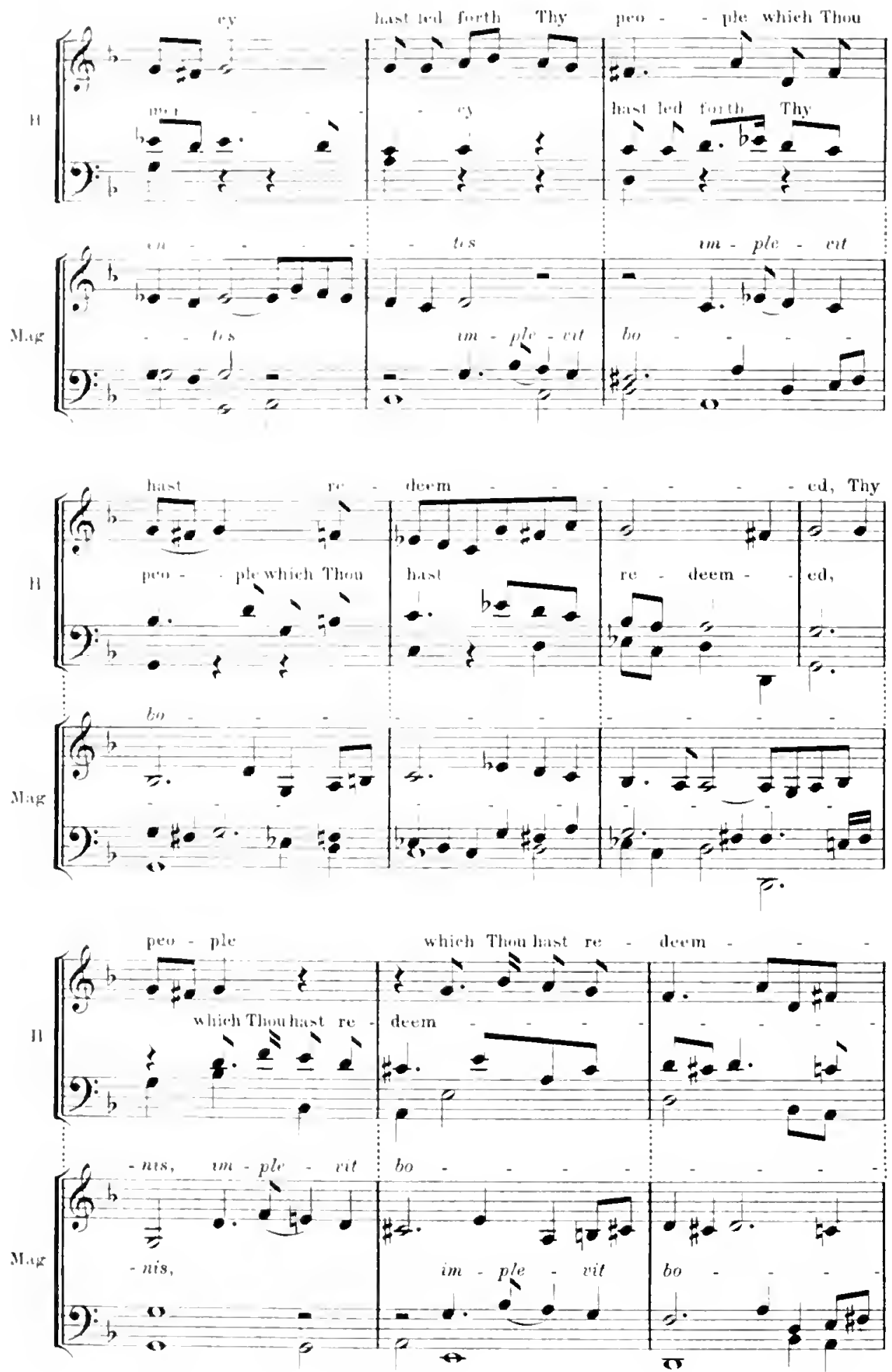
ISRAEL IN EGYPT

161

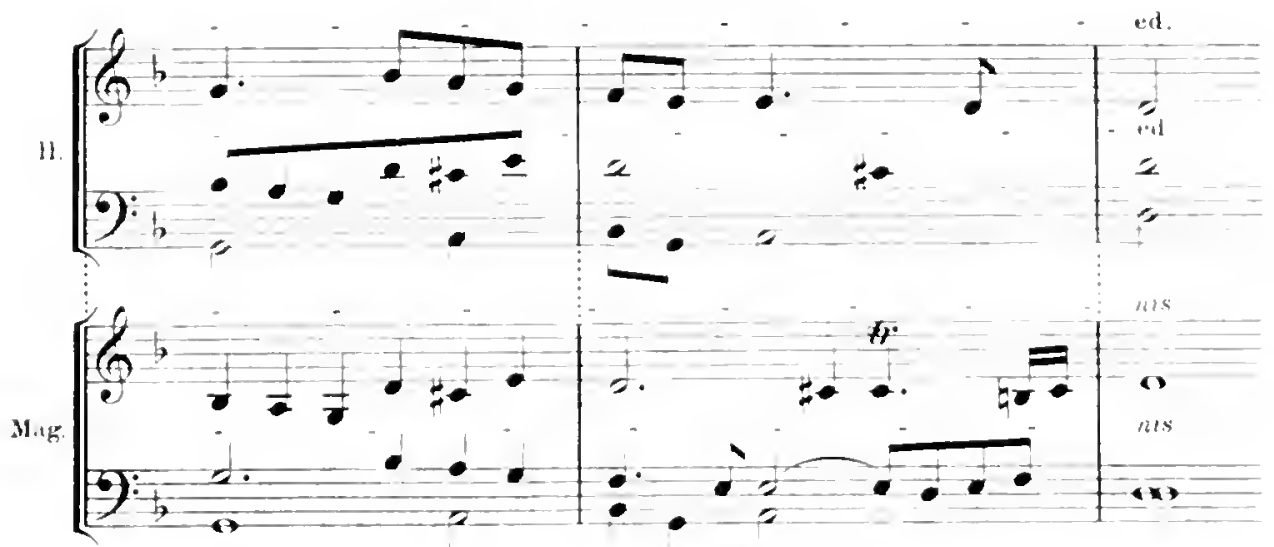

Handel constructs the next five bars by repeating the last five, transposed a Fifth higher, and with the voice-parts inverted:

Ex. 42. continued.)
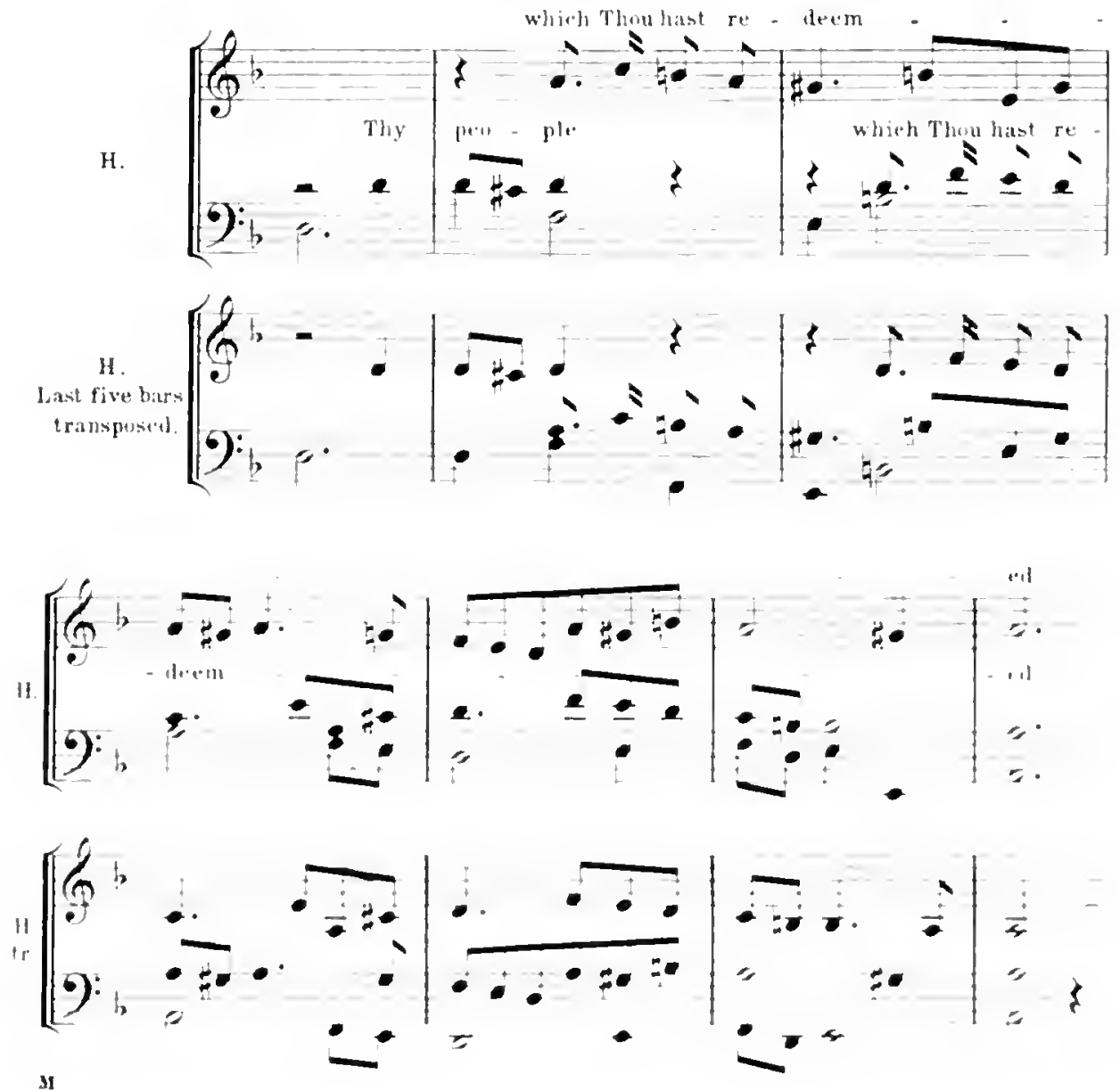
After a short instrumental interlude, abridged from the opening symphony to this duet, IInudel leads ofl' a scction not taken from the Magnificat, beginning with the beautiful phrase:

Ex.42. continued.'

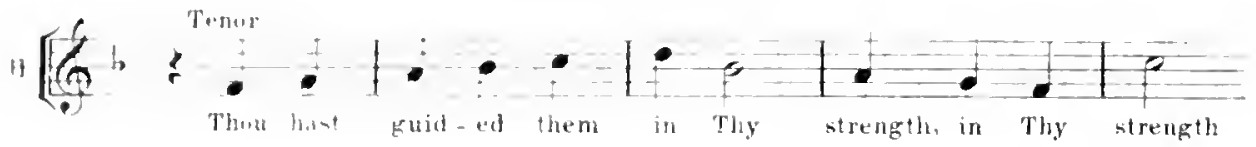

This he first works contrapuntally for the voices, and then modifies, while ingeniously constructing an instrumental accompaniment for it out of the vocal naterial of the duet, as shown in the following Example:

Ex. 42. 'continued.'

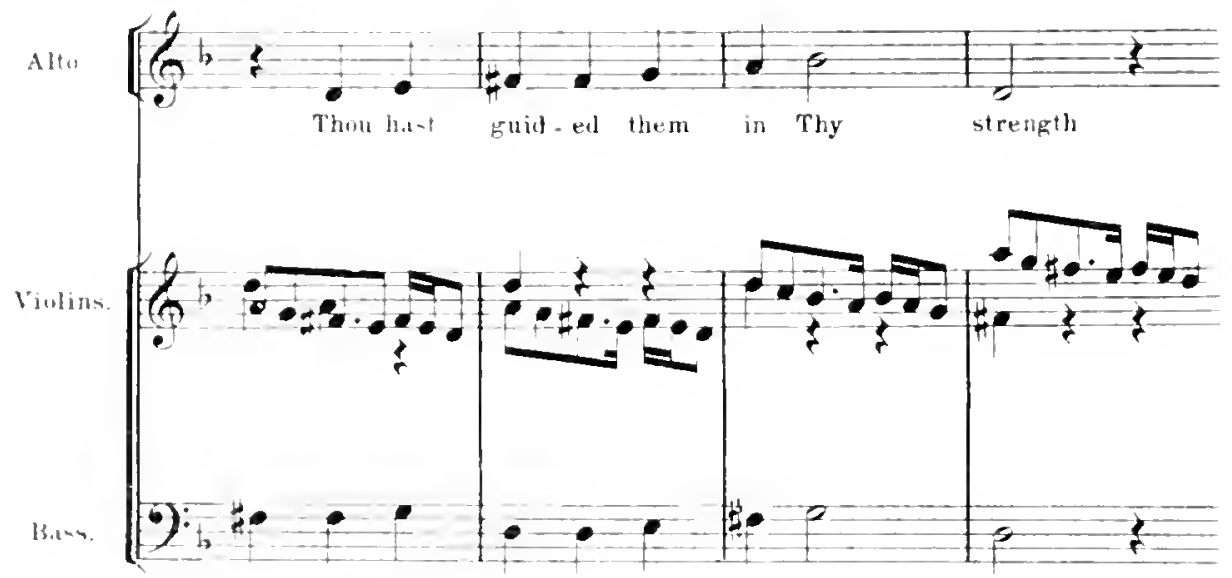

A complete repetition of the introductory symphony terminates the duet.

The succeeling number (33) is the colossal double chorus, "The people shall hear," probably the greatest of all Handel's polyphonic compositions, and certainly une which both as respects construction and sublimity has been surpassed by the choral masterpieces of $J$.S. Bacll alone. Fortunately there is no ground for doubting that it is a thoronghly spontaneous product of his genius. Dr. Chrysander lias, it is true, suggested that a morsel from Strarlella's Serenata may have given Jamlel the first germ of his wonderful setting of "slall melt away." 1 The passages in rquestion open thus:

1 Sise the table of contents prefixed to his edition of the Serenata. 


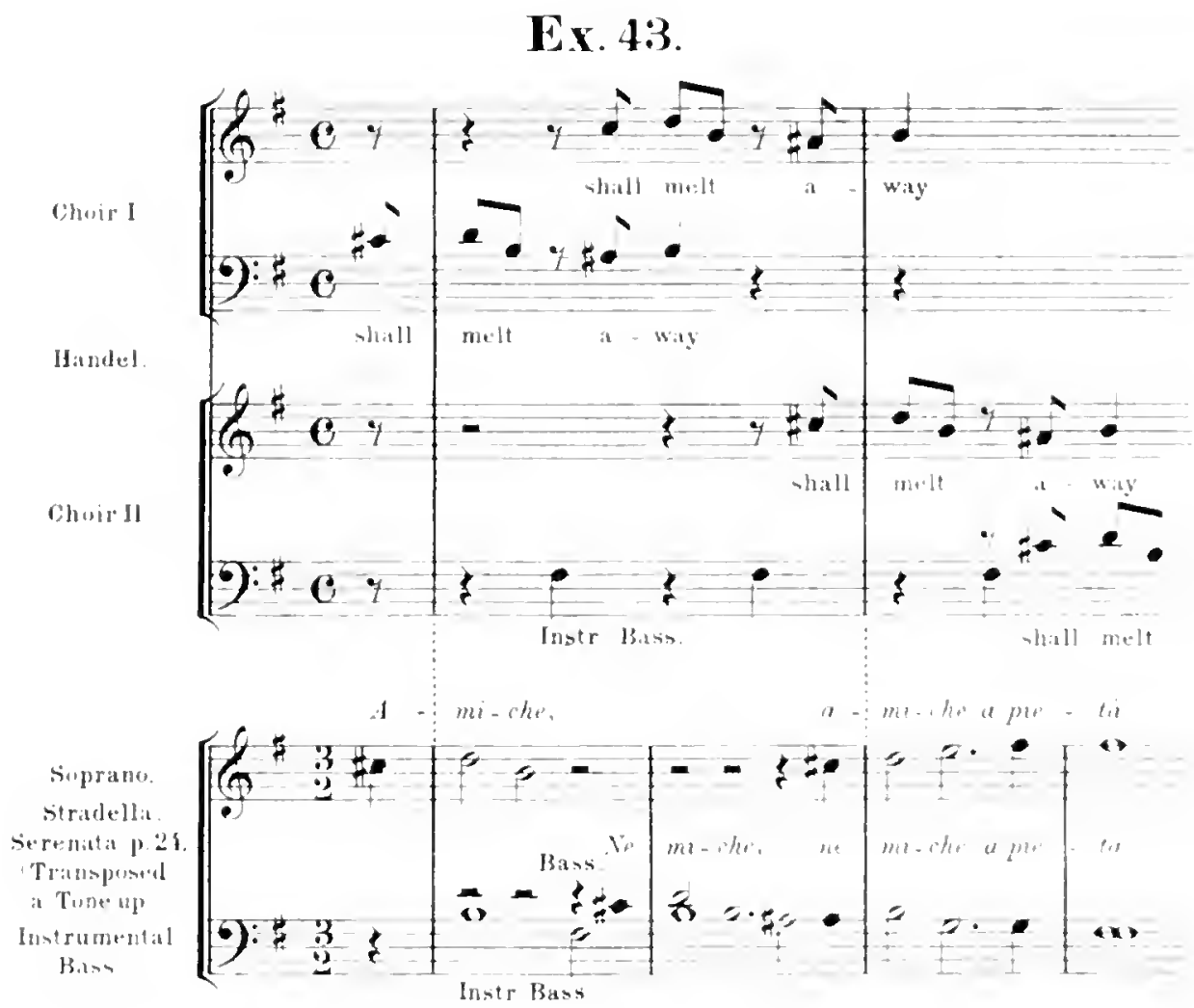

but the resemblance is evidently too slight to prove anything.

This terminates our survey of Isreel in Egypt, as its remaining matter (Nos. 34-39) contans nothing relevant to our present inquiry, indeed mainly consists in the repetition, with some additions, of the double chorus (No. 1S) which, with No. 17, opens Part II. of the oratorio. 


\section{CHAPTER VIII.}

Discussion of the question whether Handel's mode of dealing With compositioss by other Masters was morally justifiable.

I $\mathrm{N}$ our survey of parallel passages contained in chapters V. and VI. we saw by

numerous instances that Handel was in the habit of working up his own earlier compositions into new forms. In this he was, indeed, only following the practice of his time, even when, as we saw him doing in movements in the Messiuh, he diroreed music which he had previously written to extremely secular words and reset it to others of a strongly sacred character. It may interest my readers to see his great contemporary, John Sebastian Bach, doing exactly the same thing in his Drumma per Musica "The choice of Hercules" and his Christmus Oratorio. The former work contains a song in which 'Pleasure' Inlls Hereules to sleep with the advice to "follow the allurements of ragiug desire, revel in enjoyment and recognize no bounds." The music to this reappears, substantially unaltered, as the celebrated cradle-song in the Christmas Oratorio. Again, Herenles, in a vigorous aria, proclaims his refusal to listen to "abandoned Pleasure," and boasts that he has "long since erushed and torn to pieces the serpents that songht to eatch him in their toils." Save for a few alterations, the music set to these denunciatory words is that of the Alto song in the Christmas Oratorio ealling on Zion to prepare herself to receive with tender endearments the infant Messiah. Admirers of that song have doubtless wondered, as I have, why in its second part a moving bass with an undulating effect is introduced, though there is nothing in the praises of Zion's beanty, which form the text, to suggest such treatment. Inspection of the next Example will show that this accompaniment was, in the earlier form of the composition, an imitation of snake-motion, which, by simple transferenee, has come to oceupy an inappropriate place in the Christmas Oratorio. ${ }^{2}$

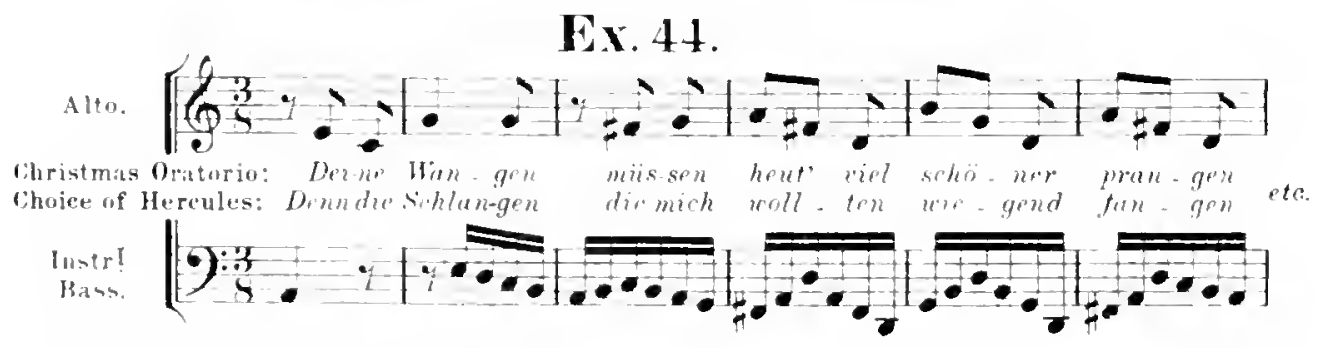

Comparisons such as the above and those which we have already made between settings by Handel of seeular words and their employment in the Messial ${ }^{2}$ are at

'My' attention was first drawn to the connexion between the Christmas Oratorio snd the Drammu per Mresica by that excellent Bach scholar, Mr. Donald Tovey. 2 Pages 36-16. 
first sight rather perturbing, but have their use in reminding us that music is not in itself either 'sacred ' or 'seeular.' It may, when set to saered or secular worls, gather to itself their respective associations: it may be grave or light in character, and so better tittek for the one destination than for the other. But, as religions emotion does not difler in essence from secular emotion of a hindred sort, musie, however splendidly adapted for assoeiation with either, ean express neither as distinguished from the other. Such, however, is the strength of association, that at the present lay no lealing composer would venture on transferences such as those we have seen effected by Handel and Bach. Nor is the reason of this difference far to seek, residing, as it does, in the vast exteusion of music-publishing since the days of those great men.

To us, who are apt to consider that an injury is done us if we camnot buy a pianoforte score of a great choral work for a shilling or two, it seems at first sight incredible that, in spite of Handel's enormous populanity, only one of his compositions of that class, Alexander's Feast, was published in a complete form during his life-time, the oratorios having appeared only in selections with the chornses left out. ${ }^{1}$ Of Bach's ehurch cantatas, also, only one' attained publication during his life, and that, perhaps, hess on account of its intrinsic merit than because it was composed to celebrate an election of town-councillors. 'The rest of his compositions of that elass, and they numbered hundreds, remained in mannscript at his death. Now the fact of publication or no publication would evidently greatly alfect a composer's attitude towards his works. If he had published a setting of a particular text, his music had thereby entered into a nuion with it for hetter for worse, a printed eertificate of which was producible at any moment. But if the setting had not been published, the composer occupied a freer position, and by attaching his musie to new texts might secure futher hearings for it-assuredly a legrimate object of ambition. We may thus explain, e.g., Bach's incorporation in the Mass in 3 minor of materials already used in his chureh cantatis, and Handel's manifold adaptations from bis own older choral compositions in Isreel in Egypt and elsewhere. Fen in the ease of seiting transferred from hight secular to decidedly religious texts, the fuct of non-publication prevented any fixed association growing up between musie and words such as would make a fresh destination given to the furmer appear incongruous or even lacking in reverence.

Enongh has, I think, now been sail on IJandel's readaptations of his own old materinls, in which he followed what was the practice, and, as I have tried to show, a not unreusonable practice, of his age His approprintions from the works of other composers, living and dead, went, on the contrary, both as to their character and their axtent, fnr beyoud anything that has heen established, or even asserted,

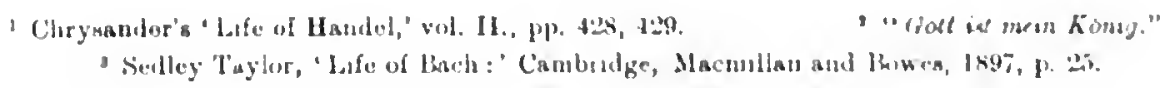


in the case of any other composer of the first rank. They give rise to a problem of remarkable interest and no suall difliculty, vi\%, how it was that Ilandel, who is recognised on all hamls as having been a thoroughly honourable man, can have thought himself at liberty to take such unprecedented liberties with the results of other men's labours. But before entering on the discussion of this problem, let us try to ascertain at what period of his career specimens of this method of procelure Grst show themselves.

It is well known that Handel's only teacher in music was Zachau (or to adopt the correct spelling, Zachow), the principal organist at Halle, under whose instruction lie remained from early boyhood until he was qualified to start as an imlepemlent nusician. As Zachow was a somewhat prolific composer, it seemed a not unreasonable eonjecture that when his works came to be published they would prove to have been a further quarry of Handelian ideas. Their recent appearance under the editorship of Dr. Max Seiffert ${ }^{2}$ has, however, failed to verify this forecast. A few instances of parallel treatinent and similarity of phrase present themselves and have been pointed out by Dr. Seiffert, but none of thematic appropriation such as Handel subsequently practised. Nor need this surprise us, for 'Zachow's nelodies were too dull and his harmonies too common-place to have stirred the emancipated Handel to thoughts of appropriation. But, for all that, Dr. Seiffert has ably shown' that Zachow was a thoroughly equipped church musician of a sonnd pre-Bachian type, who at the time when Handel was under his charge was himself actively endeavouring to advance in his art, and is therefore likely to have given the young genius exactly the kind of instruction best suited for his future development. Handel is known to have always spoken of his one and only teacher in music with the utmost respect, and through Dr. Seiffert's exertions we know in some measure why he did so.

In 1703 Handel, then in his eighteenth year, went to Hamburg, where he occupied, until 1706 , a post as violinist and accompanist at the harpsichord in the orchestra of the opera, at that time one of the first in Europe. His contemporary and associate, Matheson, has left us the following accouut of Handel's powers on his arrival at Hamburg:

"He used at that time to compose very long, long Arias and almost endless ('antatas, which yet had neither the right skill nor the right taste, though they possessed a complete harmony, but the high school of opera soon fashioned him iuto something quite different. . . . "

"He was strong on the organ: stronger than Kuhnaus in fugues and counterpoints, especially extempore, but he knew very little of melody before he had to do

1 Denlemäler deutscher Tontunat, Bde 21, 22, 1905.

"In the preface to his edition of Zachow's works and mere at large in an nopublished Paper which he has very kindly allowed me to see in manuseript.

J. S. Bach's immediato prodecessor at the Leıpzig Thomasschule. 
with the Hamburg operas.

Juring the last [seventeenth] century, hardly anybody thought of melody ; harmony was the one and only object aimed at." 1

Rerwiam KeIser (1673-1739), the direetor and leading composer of the Hamburg opera during Handel's time there, is deseribed by Chrysander" as a man whose morality was "equal to zero," and who was by no means remarkable for his acquirements in technical musicianship, but endowed by nature with a seemingly inexhaustible spring of beautiful ideas whence he poured out incessantly during forty years a stream of some hundred-and-twenty operas. We must think, then, of Handel as gathering, in this school, ideas concernung the formation of melory. Dr. Max Seiffert, in the proface to the edition of Keiser's opera Orfavia which forms No. 6 of the Hanlel 'Supplements,'s gives us the opportunity of observing this process at closer quarters, as will be seen by the folluwing passage which I translate thence :

"Keiser lad in the year 1704 begun to set "Almira" and finished some of it, but then, in the rush and turmoil of operatic management, had let the work drop and at last handed over the libretto by way of experinent to the young Handel, whose setting net with so warm a reception by the Hamburgers that, between the 8th of January and the 25th of February, 1705, it was given 19 or 20 tines running. Ifaudel strengthened the good impression which his first opera luad made by at once following it up with a second, "Nero." Its lirst performance took place on Feb. 25, thus interrupting the long rum of "Almira;" and, as "Nero" also made a success, Handel had the pleisure of heariug his own musie performed continnously until the beginning of Lent, during which theatrical performances were forbidlen. This suceess of the novice in opera causel the utmost annoyance to Keiser, who forthwith set to work to eompose the same dramatic materials hiurself. In the fullowing August he brought on the stage his "Oetavin," which displaced Iranlel's "Nero," and his "Almira" followed it later. Beside this Keiser sent to press a selection of the most beantiful Arias and Recitatives in his "Almira" and "Oetavia" with the purpose of challenging a comparison between his compositrons and those of Handel. . . . Ilandel took no notice of all this, and, moreover, the opera-intrigues led at that time to an abrupt disilpluearance of Keiser from Ilanburg. Ilandel, ton, quitted the town at the emb of 1706 in order to go to Italy; but he retained Keiser's proceedings in his momory in order on a fitting oceasion to jutlict an imnocent requital for them.

"Annong the German music which Hanlel took with him on his journey was a manuscript score of Keiser's "Octaviu." 'To stuly it serionsly and work it up exhaustively as a souree for his own activity, was the form which his reputal touk. Everything in the way of reminiseences of keiser's meluhes whin we lind in Handel's Italimn compositions points batek to "Uct.ria."

1 Quoted by chryauder, 'Lufe of Itandel, vol. I., 1. s.i.

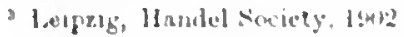


I)r. Seiffert follows up theso remarks by specifying ten phrases in "Octavia" one or more of which reappear in operatic and other works of Handel belonging to the years 1707, 1708, 1714 and 1715. The very popular opera Agrippina contains six of these phrases: one of them appears in three works, six occur in two each and three in one each. I will set out four of these belonging to the years 1707 and 1708 , as they supply materials for interesting comparisons showing Handel thus early in his career employing, on a small scale, the same system which he carried out, on so great an one, in later years.

\section{Ex. 45.}

From at settille of "Laudate pueri" (Rome, 17()T.)
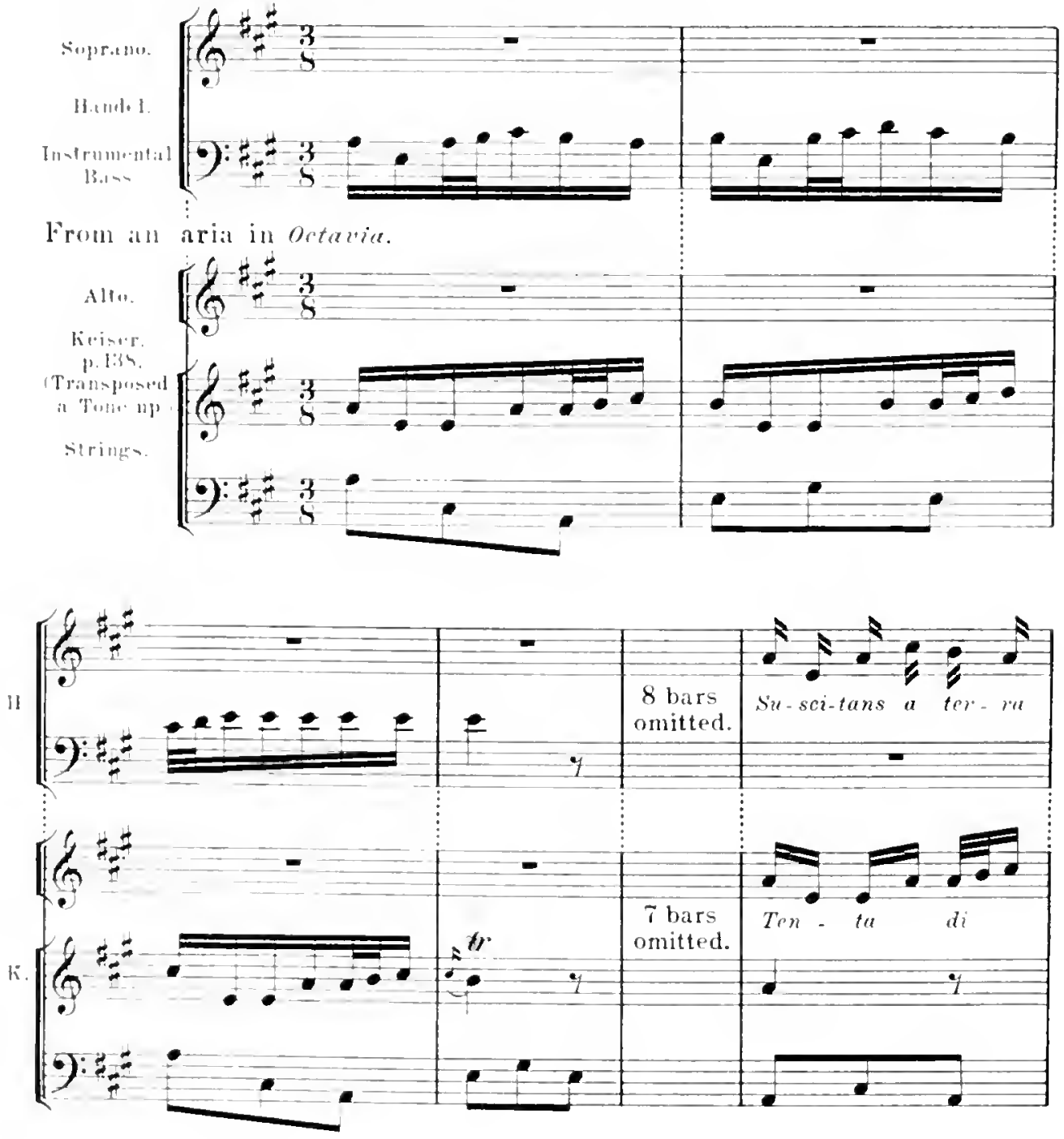


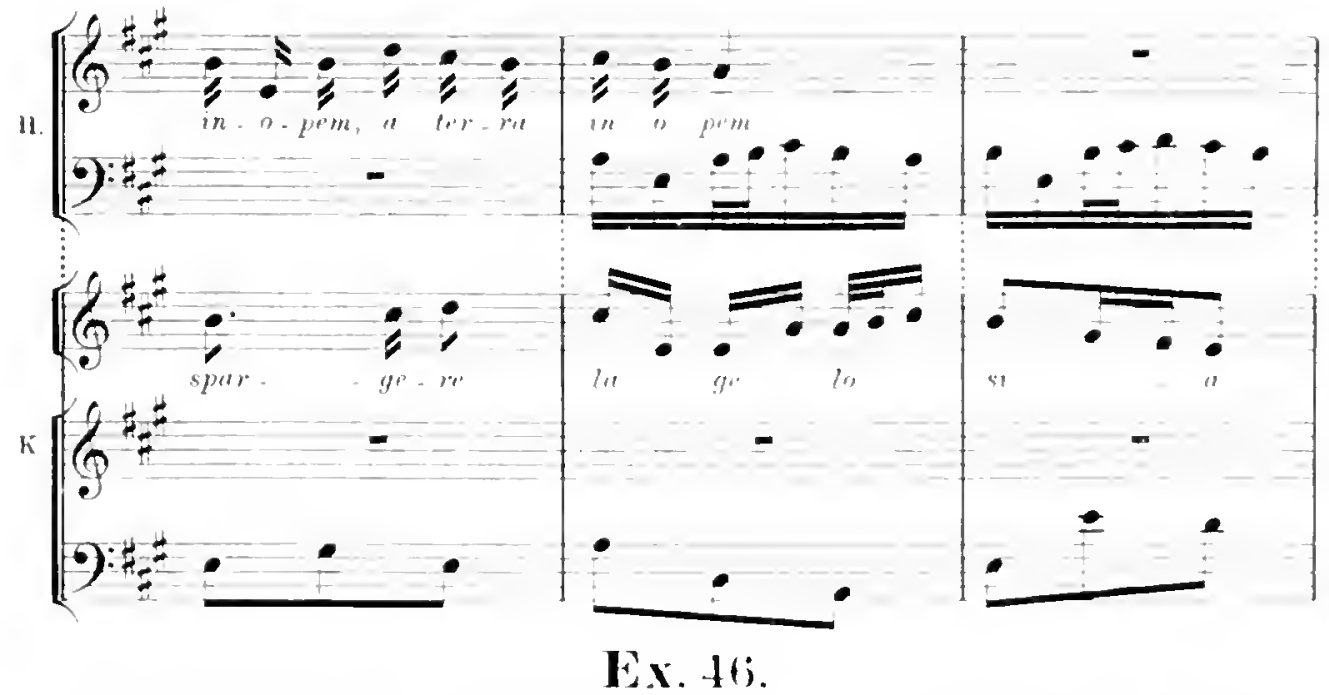

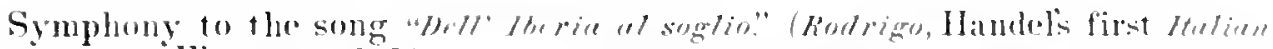
opera, Florence 1707.)

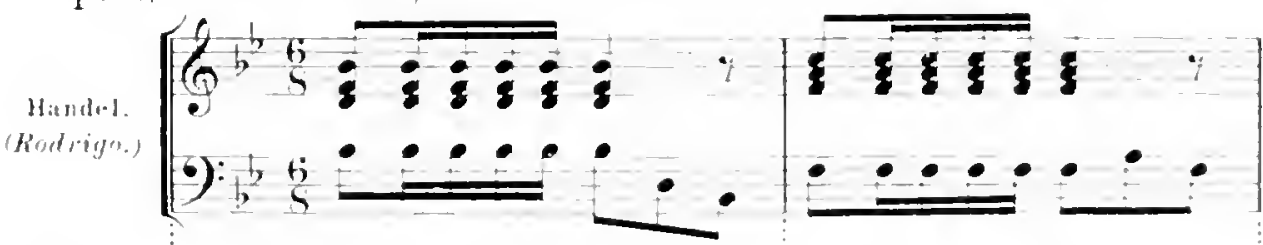

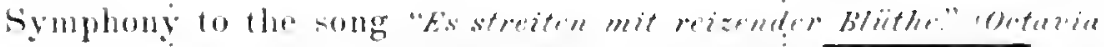
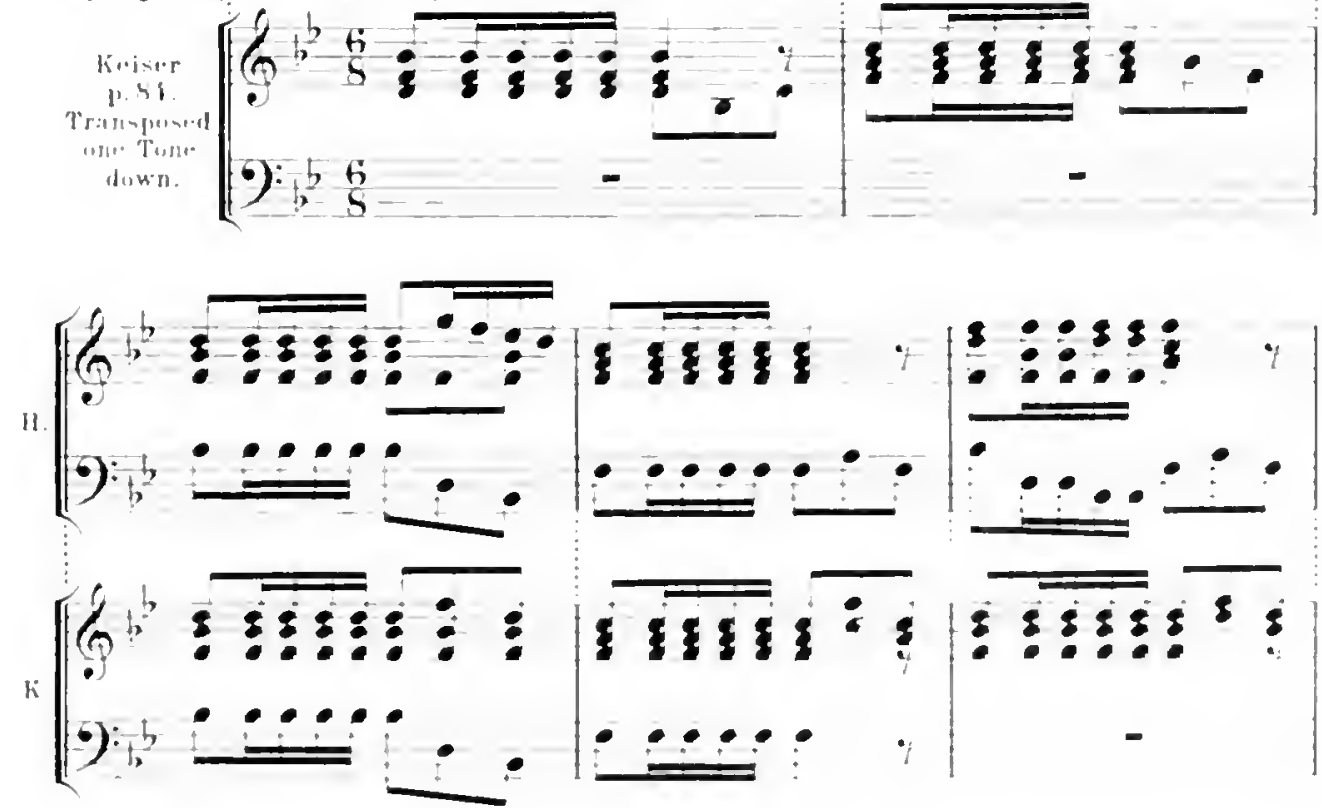


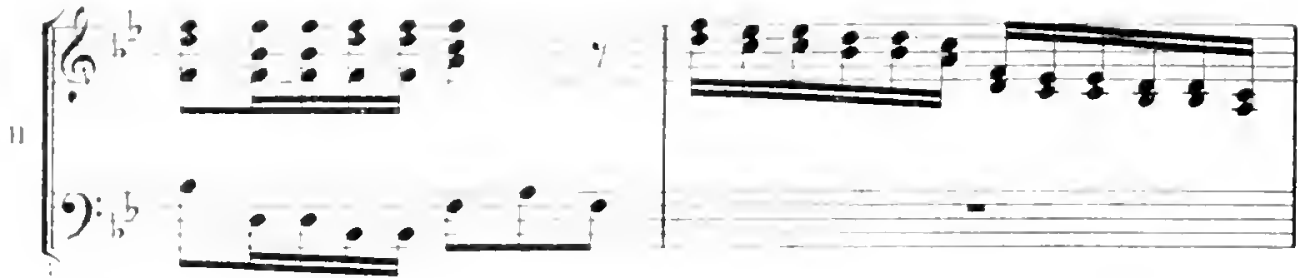

$\left\{\begin{array}{l}0,3 \\ 0 \\ 0\end{array}\right.$
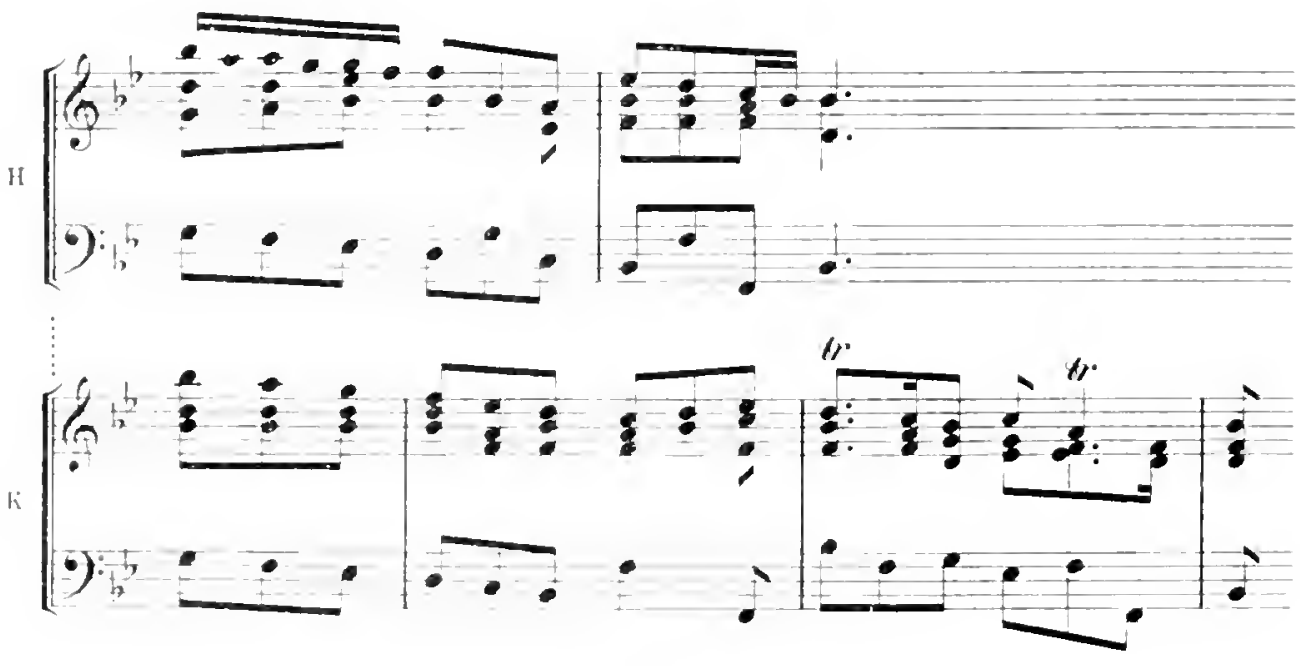

Ex. 47.

From a songe sung by "Lureifer" in Handel's cantata "Lee Resurvezione" Romm,

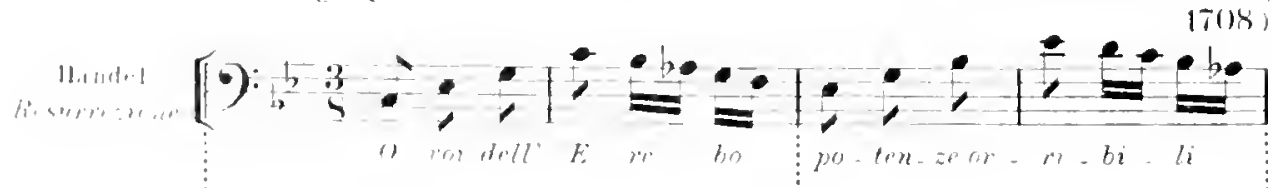

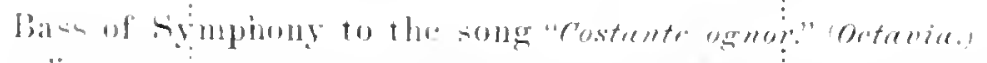

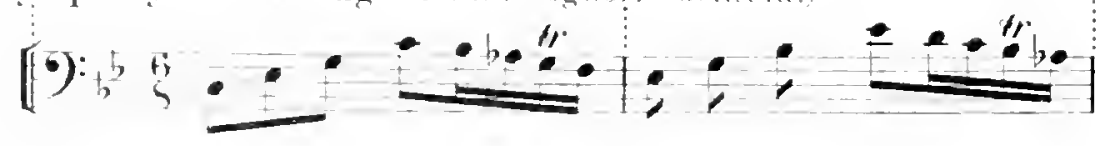


$(16) b=$
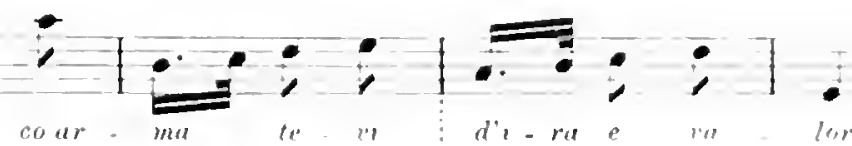

$(9), b^{2}:$ be

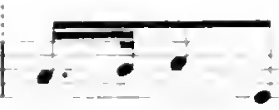

Ex. Is.

Symphong to the song "Inghe Fonte" lagrippma, 1768.

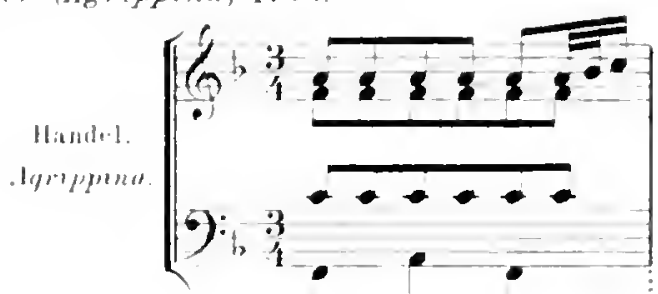

Symphony to the song "Ruhigr sriu."

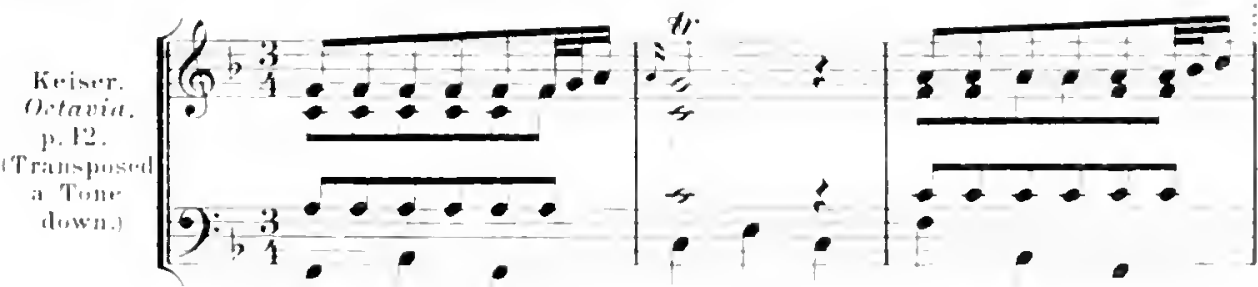

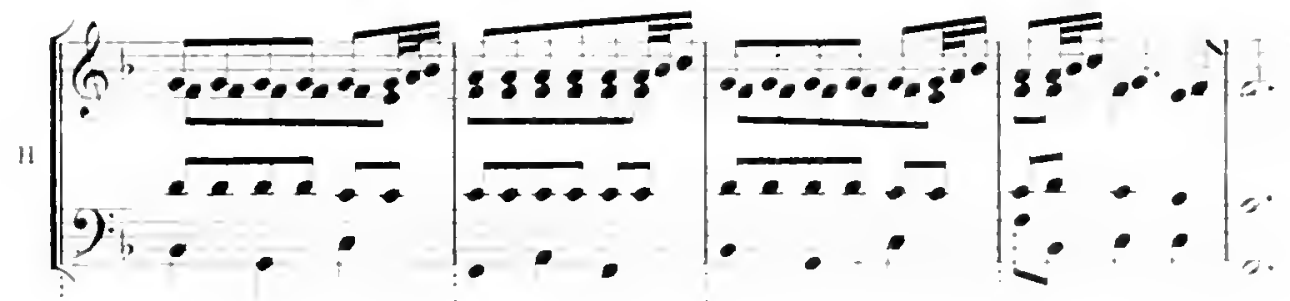

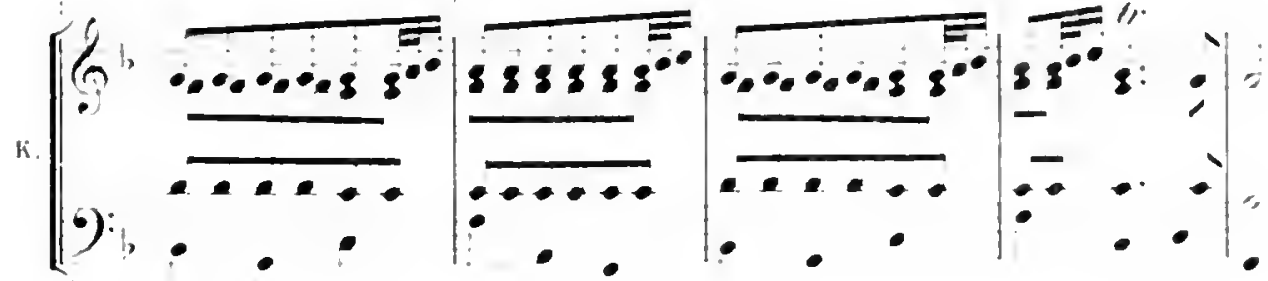

lixeept for the obligations to Keiser which have been mued ahove, nothing appears to have been found to show that Haudol in the long series of his Italian 
operas nuade any important use of extraneous sources. But the examples set out in the present volume sullice to show that in the scries of choral works composed between 1737 and 1757 he drew on such sources pretty continuously. The names of the works in which we have seen him doing this stand as follows in chronolugical order:

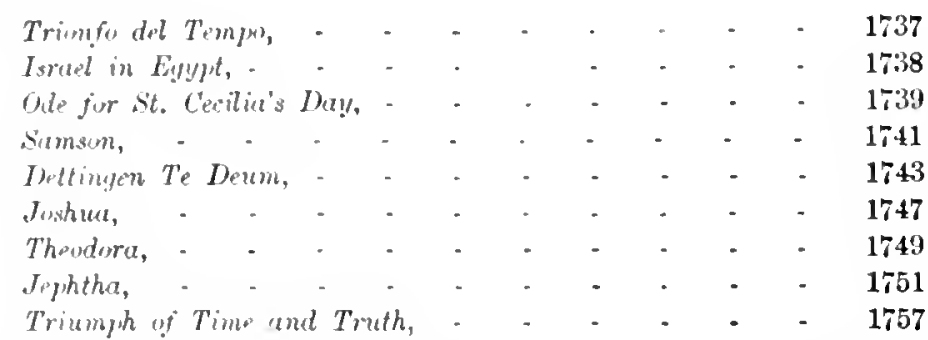

In 1752 the disease in Handel's eyes began, which, after three couchings, left him totally llind. This calamity fully accounts for the cessation of production between Jephtha and the Triumph of Time and Truth, which latter was mainly made up of older work and constituted his final effort.

That Handel appropriated consciously and deliberately would, I think, be clear eren if we possessed no other evidence than that supplied by comparison of passages. The similarities are much too minute and extensive to be accounted for either by fortuitous coincidence or by unconscious reminiscence. The former explanation would demand a series of gigantic improbabilities, the latter a conbination of superhuman memory of music with infrahuman forgetfulness of authorship. Iut the evidence supplied by the Fitzwilliam autographs removes any shadow of doubt remaining on this point. They constitute what is in effect Hanclel's common-place book into which he copied from works by other composers passages ranging from short phrases to entire long movements, many of which he subsequently incorporated, sometimes with much, sometimes with very slight, alteration, in his autograph scores.

We must therefore, I think, conclude that Handel's procedure was deliberate and thoroughly systematic. But before approaching the personal issues which this conclusion opens, it is necessary to consider the question whether public opinion in Handel's time regarded the unacknowledged appropriation of other men's musical ideas in the light in which it would be regarded now. Fortunately for us a corresponlence which took place in 1731 and was published in the following ycar ${ }^{1}$ throws a most instructive light on this question.

" "Iellers from the Acallemy of Ancient MI usiek at London, to Sigr. Antonio Lotti of Venice : with his Answers and Testimonies. London : Printed by (reo. James. MDCCXXXII."

I owe the perusal of this extrenely rare pampllet to the kindness of the Librarian of the Faculty of Alloncatea' Library at Edinburgh, who most obligingly gent the volume containing it to the custody of the University Library, Cambrilge, for my benefit. Tr. Chryander (Life of Handel, rol. II. pp. 293-297) and Victor Schelcher (Life of Handel, pp. 149.155) have both quoted extracts from these letters. 
On Feb. 5, 1731, Mr. Howley Bishop, Secretary of the Acadeny of Ancient Musie, addressed, by order of that body, a letter written both in English and Iatiu, to Signor Lotti at Venice, in which, after a few introductory paragraphs describing the scope and character of the Academy's work he eame to the gist of his communication in the following terms: "One of our Members having received from l'enice a Book entitled Duetti, \&e, and having look'd it over, pitch'd upon the XYIII. Madrigal, the only one for five Voices, inseribed La Vita Curluch, begimning In unc Siepe, to be performed in the Academy. Signor Buononcini, who is also one of our Members, and who three or four years before had presentel us this very Madrigal as lis own, being inform'd of this, immeliately sent a letter to the Academy, in which having greatly complained of the Person who introducel it among us under your Name, he accuses you as the Plagiary of his Works, and affirms that he composed this Madrigal thirty years ago, exactly as it is printed in your Book, at the command of the Emperor Leopolel; and for the P'roof of this appeals to the arehives of that Emperor."

After saying that he had also, by order of the Academy, applied for information to " $M I$. Fuchs, Chappel-Waster to the Emperor," Bishop alded: "I don't therefore in the least donbt but that you will have so much Regard for your own Fame and Reputation among ns, as to inform us as soon as possibly you can how this Matter stands."

To this direct and characteristically British appeal Iotti replied in a French letter dated Venice, March 29), 1731. After some courteous introductory remarks about the Academy he continued:

"Touching the object of your letter I confess the truth to you, Sir, when I say that I was extremely surprised to see myself aecused of being the debtor of my own property, and after twenty-six years that my book has been in the hands of the public, to find myself obliged to prove that it belongs to me. If this lasd been represented to me from any other quarter, I should have appealed to the public notoriety of the fact and have intrenched nyself in silence; but the esteen which I owe to yourself, and to the illustrious body whom you represent, calls on me to satisfy your request."

Lotti goes on to do this by saying that the 1)netti. Terzetti, and Madrigals were composed by him shortly before their publication and that there were professional musieians aud anateurs who had witnessed the progress of the disputed malrigil and taken part, some as singers and sone as hearers, when it was reluarsed from the rough iraft before being written out fair. Further that the words of it hat been specially written for and given to him by the Able l'eriati, whe wils then at Vienua, where the Madrigal was performed before the Emperor Leoplu.

After mentioning these and a few more evidences of his anthorship. Intti beges the Secretary to be on his guard "lest, in corler to do a bal turn to Il. Limnoncini, some one had falsely attributed to him the letter writum in his nane to the 
Acallemy, hecause it is incradible that, learned nusieian as he is, he should have been willing, ont of light-heartedness, in arlopt ny defects as his own."

The next move was a communication dated April 14, 1731, from the Seeretary adlressed by orler of the Acalemy to Signor Buononeini, enelosing eopies of the letters to aud from Signor Lotti. "The Acalemy," he wrote, "thought themselves ohliged in Justice to acquaint you with what he says in Support of his own Claim and in opposition to yours. I have therefore anitted a Post in returning him an Auswer, that 1 might lave an olportunity of receiving your Commands in relation to any thing you shall think proper for me to say in my Reply. I shall wait till the michle of next Week in Expectation of the Favour of a Letter from you. . ."

The non-result of this applieation is shown in a seeond letter to Signor Lotti datel . June 5, 1731, which had been delayed by a prolonged illness of the Secretary. It begins by informing lim that the Aeademy unanimously agreed that the Marlrigal was his, and continues thus:

"I also (which we thought just) wrote a letter to Signor Buononcini, which was delivered into his own Hands, in which I sent him copies of both our letters, and told him I wonld wait a Week before I wrote to you again, that he might, if he should think proper, have an opportunity of replying. But I waited a Fortnight to no Purpose. I then sent, a second Letter by the Keeper of our Library, and Signor Bnomoncini not being at home two or three times, I order'd it to be left with his Servant; but this also, which I am surprised at, was denied: For the Servant said he had Orders to receive no Letters but what came by the Post. Thus stands the affair with Signor Buononcini. Yet notwithstanding this, some Persons who pretend to be his Friends, and who have separated from the Academy on this very Account, as it appears since no other is pretended, obstinately assert the Madrigal to be his, still appeal to the Archives of the Emperor, and accuse you of Theft, and the Academy of Slander through the whole Town. No answer from M. Fichs has yet come to my Hands, from what Cause or by what Accident, if he be still alive, I can't so much as guess. The Academy, after hearing your Letter were willing to have prosecuted this Affair no farther, but they think it is your Interest as well as theirs, that these Calumnies should be answered. They intreat therefore, Sir, that entirely to refute these ill-minded Persons, you would be pleased to seud us some Certificates of the Count de Par, Abbat (sic) Periati, or some others who saw the Madrigal at Venice before it was published."

The letter ends with a request to Signor Lotti that he would allow his name to be entered on the list of Members of the Academy. Lotti's reply-this time written in Italian-is so very charming that, though it is rather long, I cannot resist reprolucing it almost in full.

"I have received, Illustrious Sir, your most gracious letter of June 5 and, much as the news of your ill health grieved me, so on the other hand was I equally consuled by that of its complete re-establishment. I thank you, the whole 
Academy and the worthy Members who compose it, for the justice they do me, and may God grant, since they agree as to the Author of the Maurigal, that they may also be able to agree in their approval of the work itself. I hear how Partisans of Sign. Buononcini are out of temper with the Acadeny and with me, and I could wish I possessed the art of that lost Music which excited and calined the Passions. I think too that they little cunsult the glory of their Friend, because, by withdrawing themselves on this account from the Academy they exhibit a degree of anger which would be just had an only Son ${ }^{2}$ been concernell, but is after all excessive for a Madrigal, when Sign. Buononcini can make sinnilar madrigals and better ones too. At Venice, on the contrary, and at Vienna, all is quiet, indeed my friends joke with me about a composition of mine having been set up in the arena as if it had been the Golden apple the possession of which was to be contended for. As for the certificates asked of me, I verily should have thought I stood in no need of this remedy, as I am in good health; but I ought to submit nyself to the opinion and command of the Acadeny; I therefore enclose some papers from Vienna and from Venice, sufficient even for any one who hates the Truth. I consigned to Mr. Smith, ${ }^{2}$ three months ago, in accordance with your command and with the courage which it gave me, some of my musical things, which shall be followed by others, and among these you will find a Madrigal for 5 voices, which I composed at Dresden, during the time that I was in the service of that Court, and you will recognize that it is Grist from the same Mill. I know not whether this will have the fate of being attributed to any one else; in which case I shall equally console myself, with the reflection that my parts are not judged so indifferent when they meet with people who wish to adopt them as their own. But let us make an end, Illustrious Sir, of this ridiculons business which was not set going by 11s, into which I cntered for obedience' sake, and from which, as I do not fear shame, so I claim no glory. Let us pass on to better things. A more laudable, a more profitable, a more grateful, study the Academy could not set before itself and as far as my forces will permit, they will always have in me an admirer and a disciple of the sublime models which Antiquity has left us, anong which it will be extremely agreeable and instructive to the to be able to see the works of old Englixh composers which you offer me with so much courtesy."

The rest of the letter contains only expressions of gratitude towarls the Academy. The accompanying certificates consist of athidavits made ly leading

\footnotetext{
'An anusing blunder in the version of this sentence given in Schuelchor's "lafe of lfabiel," p. 153, makes Lotti write that Buononciui' partiana slowewl a resentment which miglat bo juat were

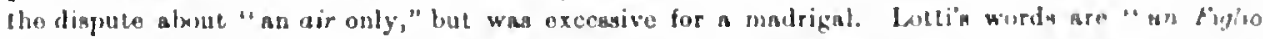

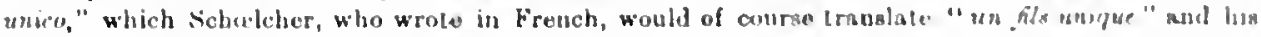

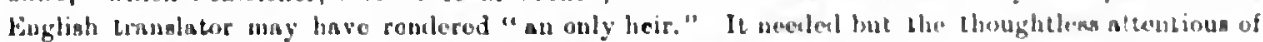

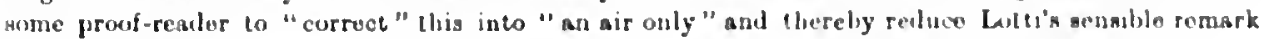
to shecr noturona.

' British Conoul al lenice.
} 
mnsicians at Venice and Vienna: they constitute overwhelning proof of Lotti's clain to be the composer of the Marlrigal.

The correspondence ends with an undated letter addressed to Signor Lotti ly the lirectors of the Academy in person, the Secretary being disabled by illness from discharging his official functions. After some preliminary matter they write:

"The testimonies, lear Sir, you transmitted to us, have had their due Weight with us, and abundantly confirm us in the good Opinion we had before conceived of you. It can be no disagreeable News to you to hear that we have sent them, together with the several letters that have passed between us, to be printed. This I'rocedure will serve eternally to convince you of our good and sincere Intentions towards you; and at the same time confound those who have taken upon them to arraign our conduct throughout this affair. We will take care you shall have some of the printed copies by the first opportunity. By the ship called the Ruby, you will receive from us two Pieces of Musick, the Work of two English Masters, Tho. Tullis and William Bird, the latter organist and composer to Henry VIII, the former Master of the Royal Chapel in the Reign of the same King. When you cast your Eye upon those Pieces, you will clearly perceive that true and sulicl Musick is not in its Infancy with us, and that, whatever some on your side of the Alps may imagine to the coutrary, the Muses have of old time taken up their abode in England."

The letter is signed

Directors of the $\begin{aligned} & \text { John Pelling, S.T.P. } \\ & \text { Hen. Needler, Philomus. } \\ & \text { Humpliny Wyrley, Philomus. } \\ & \text { J. C. Pepusch, Doctor of Musich. } \\ & \text { Bernard Crates, Master of the children of his Majesty's chappel. } \\ & \text { J. Freeman, we of the Gentlemen of his Majesty's chappel. }\end{aligned}$

This correspondence shows conclusively that plagiarism was regarded by educated musicians in the eighteenth century exactly as it is regarded by them in the twentieth. A charge of being a "Plagiary" is what no man who has "regard for lis own fame and reputation" can afford to leave unrebutted. To impute llaniarism is to impute "theft," and the imputation, if untrue, is "slander" and "calumny." And that public opinion viewed the matter in the same light is shown by the fact that when, through the publication of the correspondence, the condnct of linonuncin had become generally known, his adherents withdrew their support, his principal patrons, the Marborough family, severed their connexion with him, and he finally found himself practically obliged to leave the country.'

The same correspondence affords firm ground from which to approach another

'Arlicle in Grove's Dictionary, 2nd edition. 
question which now presents itself:-Was the fact of Handel's indebtedness to other composers, living and dead, at all generally known during his life-time? If so, it is hardly conceivable tlat the powerful party known to have been so furiously and relentlessly hostile to Handel should have one and all abstained from using against hin the weapon-a cluarge of plagiarism-to be convicted of which had proved so ruinous to his former rival, Bmononcini. That sueh a charge was not made by them appears certain from the silence of subsequent historians about it, and from the claim to absolute originality which they put forth, as we have seen, on Handel's belialf.

But it may be maintained that the term 'plagiarism' is totally inapplicable to Handel's appropriations which had so immensely improved and glorified the appropriated material that, even supposing them to have been eontemporaneously notorious, no charge of plagiarism could with any hope of success have been brought against him. This view, which was that of Dr. Chrysander, ${ }^{2}$ has been stated in the following terms by Dr. Max Seiffert: ${ }^{3}$

"During Handel's lifetime he had opponents and enviers enough: all their machinations, however, produced but a passing effect-IIandel always got the upper hand again with new deels and works, eompelling admiration by his art. His treatment of the works of other Masters could not at that time remain unnoticed: the works were for the most part accessible in print and played a part in musical life. There were also enough connoisseurs who conld have raised effective protest against the illegitinate use of other people's property, and have branded as such Handel's dishononrable proceeding. Nothing of the kind happened. Surely the only conclusion to be drawn from this fact is that Handel's contemporaries found nothing to blame in his procedure."

Expanding a hint given by Heinichen on the subject of musical plagiarism in general," Seiffert lays down as follows the conditions the presence of which renders that term inapllieable:

"Before one cim sleak of a plagiarism, it is necessary to examine whether the foreign ideas in their original connexion are literally taken over, or whether they are diflerently combined or subnitted to fresh harmonic treatment, melolic develoj. ment and contrapuntal interweaving. In the latter case the indepentence of the composer counts as assured. This exaetly hits It:mdel's case."

On this armmentation I have two critici- nts to wlier:

1. While some among the works of which Handel made free nse, e'y. Mullat's

I Sen Iurroducsion, Pp. 1x, x.

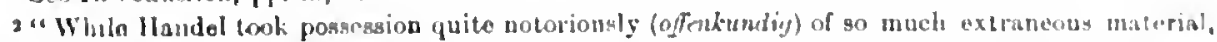
without any ono charing to call hum to account, his rival [linononcios] has, curiously chuogh, to werve

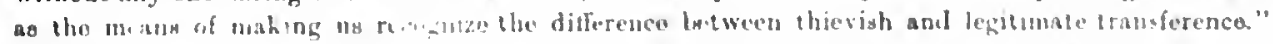

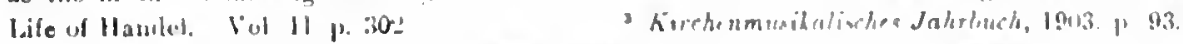

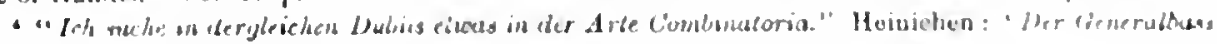

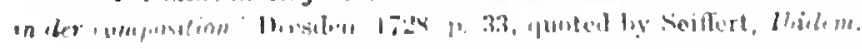


Componimenti, were accessible in print in his time, Dr. Seiffert goes, I think, a little beyond what the facts warrant in saying that this was the case with these works "for the most part." Several of those from which Iiablel borrowed most largely, composed by Stradella, Urio, Gram and IIabermann, were certainly not in frint at that time. But even if they had bern, this would not have necessarily led to a general knowledge of IIandel's appropriations, for lack of the other term of the comparison, as lis choruses, to which he transferred most of the borrowed materials, were, with the single exception named above, not published during his life-time. To detect and hunt down to some extraneous source a passage which one had only heard in performance, and cuuld not consult a scorc of, would involve an effort possible only to exceptionally tenacious memories. These considerations go far towards explaining how Handel's methods may have remained unsuspected by his contemporaries.

2. That there is often the greatest originality in the forms into which borrowed materials were worked up by Handel is indisputable, and has been amply proved in the present volume. But that infuriated opponents would have been withlueld by such refined distinctions as those laid down by Seiffert from cliarging IIandel with plagiarism, had they been aequainted with such transferences as those from Stradella and Kerl in Israel in Eqypt, or from Grann in The Triumph of Time and Truth-to mention only these-appears to me incredible. So far, therefore, as the evidence before us goes, it points, I think, to the conclusion that, if no contemporary voice was raised against Handel's annexations, this was because they were not publicly recognised as such during his life-time.

Be this as it may, however, thus much is indisputable-that Handel, though he apparently never acknowledged his sources, was yet far from acting as if he thought he had anything to fear from their detection and exposure. He laid under contribution works by distinguished contemporaries as freely as those of forgotten predecessors. Thus we have seen him inserting, in operas of 1707 and 170s, phrases taken from Keiser's Octavia composed in 1705. From his contemporaries Muffat, Irabermann and Graun, who all outlived him, he borrowed very deliberately. The retribution which fell on his old rival Buononcini, in 1732," can have had no terrors for Handel, who, only five years later, incorporated in his Trionfo del Tempo (1737) two entire choruses taken almost unchanged from a work by Graun. In the English Triumph of Time and Truth (1757), which was his last work, he not only repeated one of these choruses, but. proceeded to appropriate, though with alditions and manifest improvements, a chorus from a mass by Antonio Lotti ( +1740 ), the very man from whom Buononcini, with results so disastrous to himself, hat sought to filch the credit due for the composition of the inadrigal "In una siepe mbrosa" This final act of anuexation, to which notire

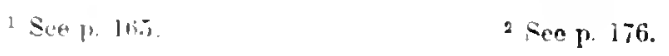


has not hitherto, as far as I am aware, been publicly called, was reconnism by Dr. Crotch $(+1847)$ with the aid of Latrohe's 'Selection of Sacred Music,' wheh contains a "Qui Tollis from a Nass by Antonio Lotti." In some manuseript nutes by Crotch in a copy of the Triumph of Time and Truth belonging to the lintish Museum he lias written against a passage in the chorus "Comfort them, O forld" the words "This passage all from Lotti-in Latrobe No. 16." Mr. liarelity Squire very kindly drew my attention to these notes by Croteh, ${ }^{1}$ and my friend Mr. A. M. Hind was good enough to copy for me the extract from Latrobe' which is set out in the following comparison. The accompaniment described by Latrobe as for the cembalo [i.e. harpsichord] is no doubt arranged from an orchestral accompaniment in Lotti's mass, the original form of which I have not seen.

\section{Ex. 49 .}

Chorus from "The Triumph of Time and Truth"
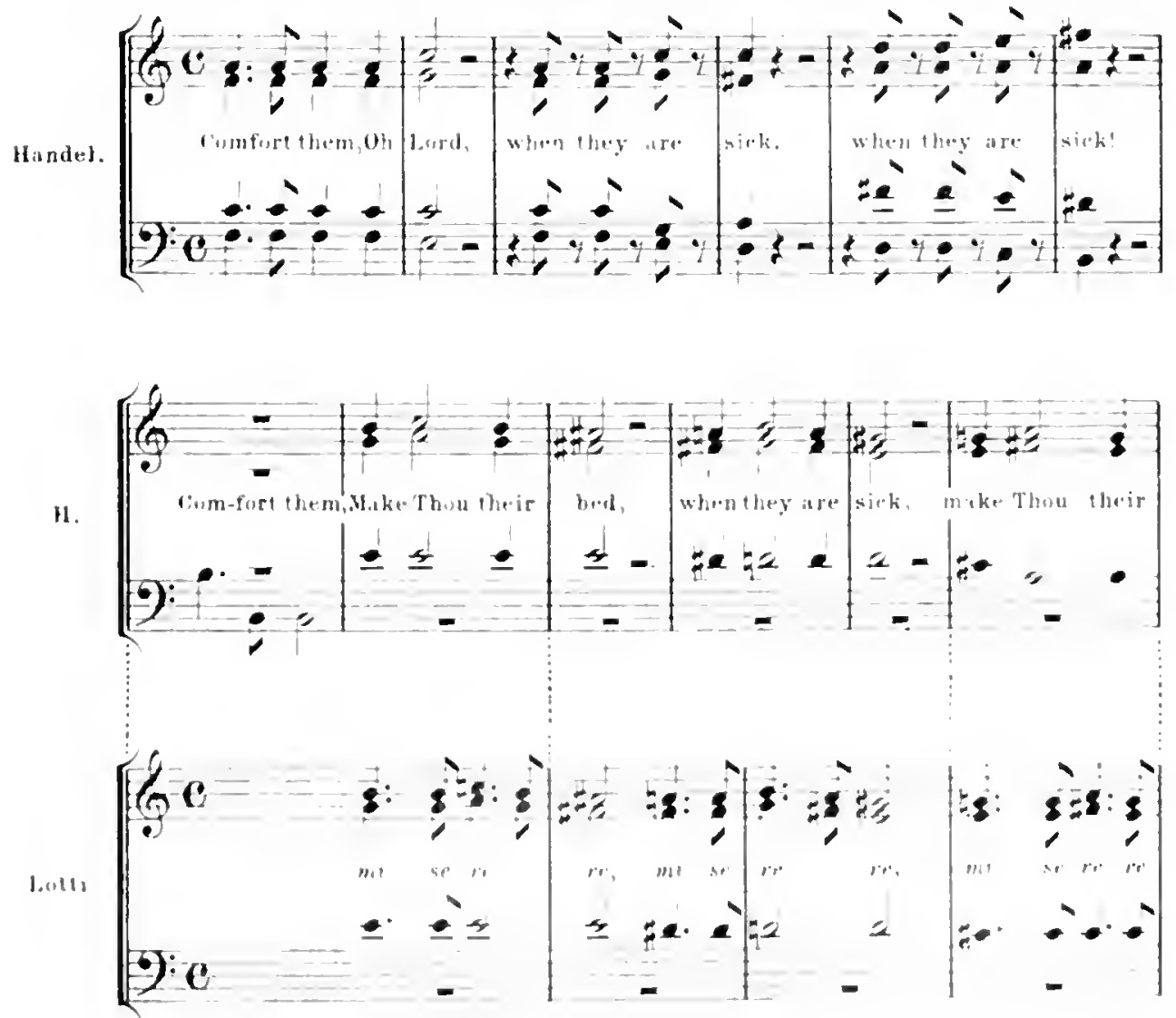

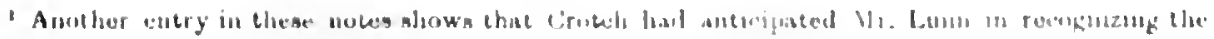

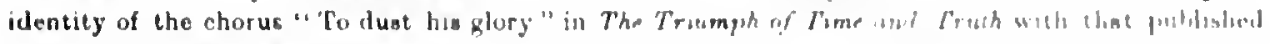

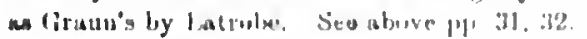



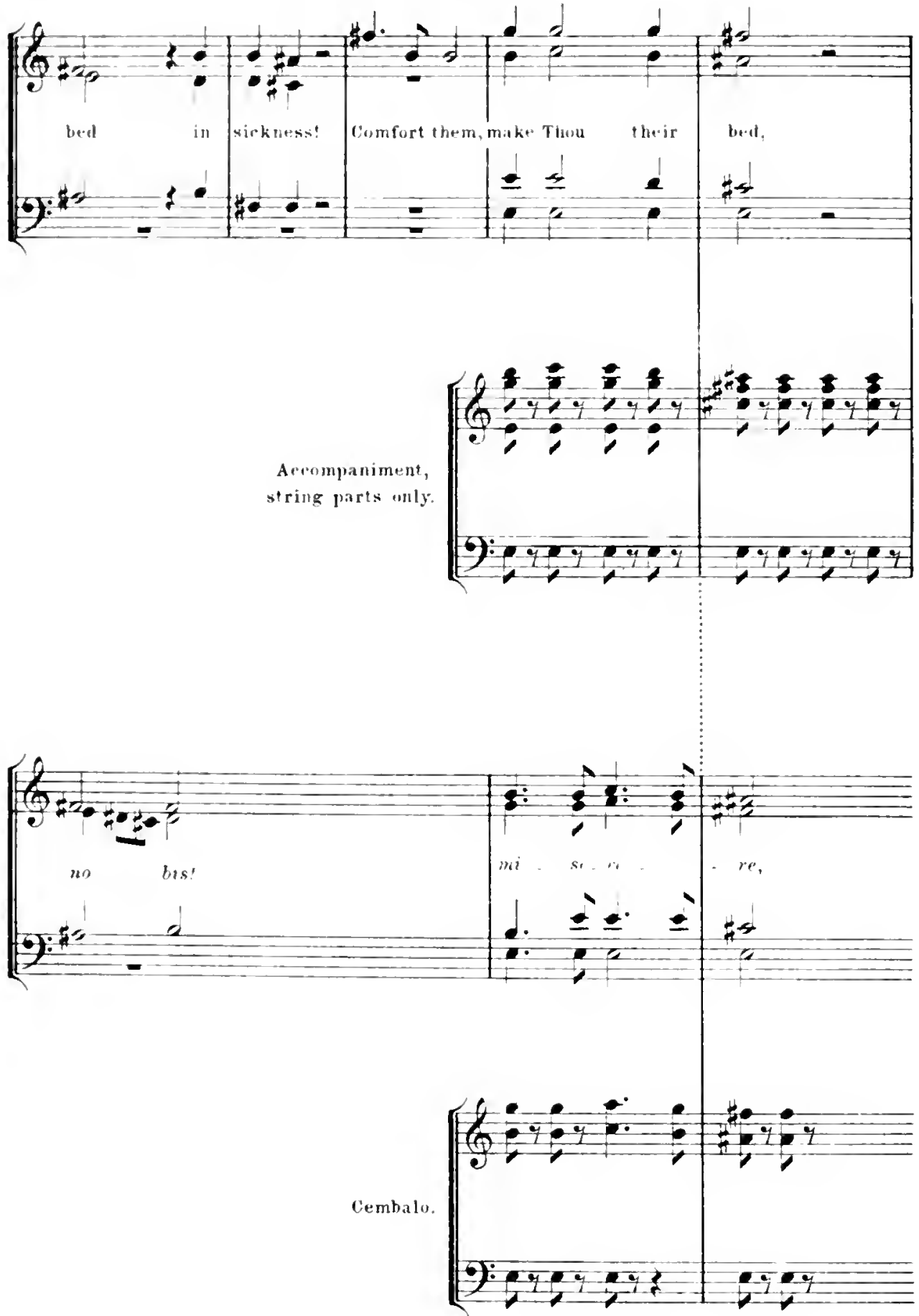

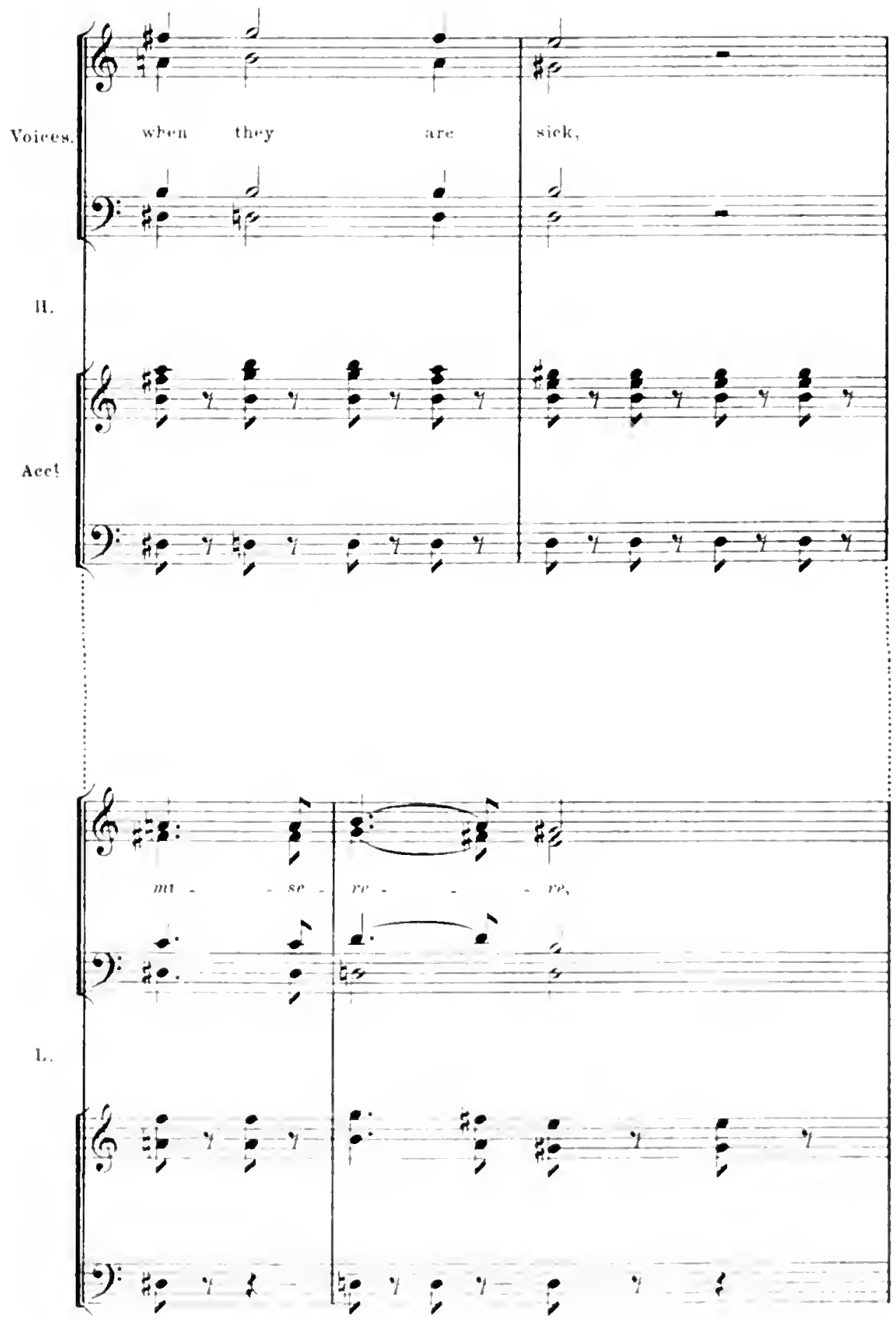


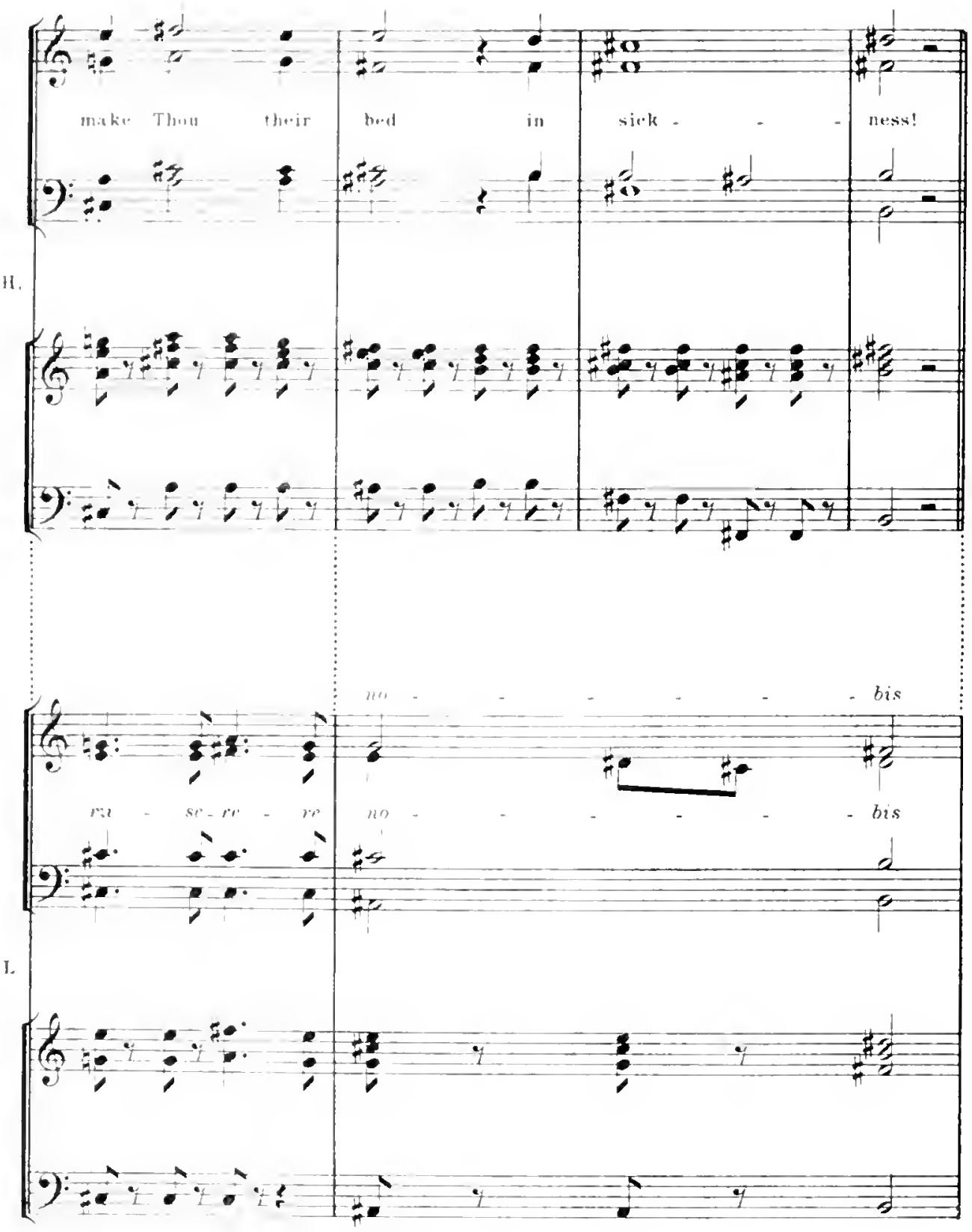

It will be observed here how Handel from his fifteenth bar onwards improves the effect by putting the treble of Lotti's accompaninent into the mouths of his own sopranos. 
In trying to form an idea what was Handel's object in adophung the procerlure which he carried out so extensively and systematically, we shall do well to begin by examining the views which have been put forth on this subject by Dr. Chrysander. He sets out by asking solnewhat indignantly, in reference to a remark made by Scholcher, an earlier biographer of Handel, whether "anything more disgraceful can be attributed to a composer than that he seeks to enrich himself illegitimately at the cost of his follows?" and continues: "If the treatment of the whole question had atarted with an examination of how Handel nacle use of the Magnificat for Iorael and Susanna, it would indeed have been shown, independently of all external proofs, that he did not compose the work, but his relation to it would also have appeared in a quite different aspect. In the course of this transformation things come to light which are completely new and so overwhelming that an observer finds it difficult to preserve the requisite balance during the investigation. What he retained note-for-note, and what in unexpected fashion he created entirely new, all has become his own. How great Handel is and what a commanding position be occupies towards other musicians becomes thoroughly palpable only through work of this kind. If sufficient insight has been gained into the relation here set before us the idea of robbery cannot present itself, and not less certain is it that it was not arrogance which drove him to sucb rearrangement. It was the impulse of his artistic nature to save from perishing musical ideas which he saw lying half-developed or in an environment foreign to them. That he iustantly recognized where they belonged to and saw them in complete form and full of dignified potentialities-this is the unintelligible part of the business. Here his mind worked like a force of Nature which far outstrips all calculating investigation." 1

Elsewhere Chrysander, in speaking of the Ode for St. Cecilia's Day, more than half of which contains elements derived from Muffat's harpsichord uusic, sayz:

"That everything has become Handelized down to its subtlest characteristics, no unbiassed judge can for a moment fail to recognize. But it is equally indulitable that Handel's rnusic has gained much in value in all directions by the insertion of melodious matter due to others. This practice of employing as molels mul material existing pieces of his own or others, was in him not an affail of acciveut but of principle, and perrades all his writings."

In our atudy of Israel in Egypt we saw decisive proofs that Handel possessed a quite astonishing power of suizing on older music, his own or that of others, raising it to a far ligher level, and trunsfusing it with a nobler life. Where he dicl this, it is not too much to saty, with Chrysanler, that the material taken over "beame his own" in the sense which 1 understaud to be here intendel, vaz. that

1 Chry ander: Lifo of Hagdel, vol. I, p. 176.

- Cbryandor. Profaco te enlition of Mutfatio Componimena, IV IV 
what Handel adked was of nu incomparably higher order than what he took. But this only applies to instances where lue is felt to be working with strokes of genius, or, to use Chrysander's happy phrase "like a force of Nature." In so 'inspired a work as Imrent there are, indeed, many such great moments, but also considerable tracts where the alterations effected lo not go beyond what might be expected from a first rate teacher of composition correcting, and improving on, work by a talented pupil. In these the "melorlious matter due to others" hy the insertion of which Handel's music "gnined nuch in value" may not unfairly rank equally with the greater man's contribution or, if the alterations have been insiguificant, inay oven clain the first place. In the case of practically note-for-note transference of entire movements such as the two choruses by Gram and the canzona by Kerl, it appears to me impossille to claim that they have by this simple process "become Handel's own."

-That, as a matter of fact, Jandel gave a new lease of life to musical ideas, his own or others', which if left in their original forms would have been no more heard of, is of course indisputable. But Dr. Chrysander, as we have just scen, while recognizing that "his music has gained much in value by the insertion of melodious matter due to others" asserts that Handel was led to his practice of working up pre-existing material by "the impulse of his artistic nature to save fron perishing musical ideas which he saw lying half-developed or in an environment foreign to them."

This is an hypothesis which one would be vely glad to believe true. Dealing, however, as it does, with the motives of a man dead nearly a century-and-a-half ago from whom no itterance about them has been handed down to us or even asserted to have been made to any of his contemporarics, it is evidently susceptible neither of proof nor of disproof. A probable judgment on it conld only be reached by examining in what proportions Handel's rearrangennents of material show developmeut and improved environment, or appear merely to have been made for the temporary convenience of a composer who was also an impressurio carrying on a campaign which involved the constant production of 'novelties.' The examination would be an interminable one and all the materials required for making it have probably even yet not been collected. That its result would bear out the sweeping assertions of Dr. Chrysander I hesilate to believe.

Quite apart from what may have been Hanlel's motives, his aetion raises a question of morals which must be consiclered here. The nature of that question has been stated and discussed vry elearly and suggestively by the Right Hon. A. J. Balfour, M.P., in the following passage extracted from his extremely able and interesting essay on Haudel: ${ }^{3}$

"lint, it will be said, the question of morality still remains. It cannot be right

1 Lisays and Addresses, 2od edition. Filnburgh : Davin Uouglas, 1893. 
for a great writer to appropriate the work of a small one, ard at the sarse tune, wrong for a sinall one to appropriate the work of a great one. Bare justice requires that a common rule should apply to hoth.

"I will not venture on a full liscussion of the casuistical problem thus raiscd. An interesting chajter remains to he written on thr history of " private proplinty in thought." When this is accomplished, it will Lecone clear, I believe, that while, at the revival of learning and lefore it, the unwilfon code regulating suel matters was so lax that it was by no means considerci incussary to ackm:wledge even direct quotations, the monupoly has become stricter and stricter lown to our own time. And it will also be found that some of the greatest and most original geniuses-Shakespeare, for instauce, und Molière-have distinguished thenselves by the readiness with which they hive made use of other men's inventions. Among such is Inandel: and with regarl to him, and before finally dismissing this topic, I will only make two furtlier observations

"The first is, that he does not himself seem to have regarded it as a thing to be ashaned of. Among the most astonishing feats of appropriation which are lail to lis charge is the wholesale transference of large fragments of a "Magnifieat" by an obscure musician of the name of Erba, to the score of "Israel in Egypt." Now, one of the only two copies of this "Magnificat" known to exist is in Handel's handwriting, and is preserved among his manuscripts at Buckingham Palace. But what is the history of these manuscripts? They are by no means casual ehips from his musical workshop, scraped together from holes and corners, and arranged for the first time after his death. On the contrary, Handel himself, always sedulous of his fane, set the greatest store by them. IIe intended leaving them to his ananuensis, the elder Snith. He yuarelled with Snitl, aml then proposed to leave them to the University of Oxford. If and smith afterwards becane reconciled, and he reverted to his original intuntions. If, therefore, we are to believe that in employing Erha's materials he was committing what he considered, or what, in his opinion, others unight consider, a breach of morality, we must suppose him to be guilty of the extroordinary lolly of leaving the evidenee of his misdemeanour in a convenient and carefully-preservel shape anong the paprers un which he relied for the homoumble perpetuation of his memury. Anl we must further suppose that he eould venture to quarrel with a man so intimately acquainted with all the secrets, mul accorling to the hypothesis the discreditalle secrets, of his method, as was Sulth; and that with the fate of linononcini before his eyes, in a country which prossessed its share of learned musicians, and where

\footnotetext{
" "Among the most learueel of wholl was lyr. Pepusch, whom Haudol had ousted at Cannons,

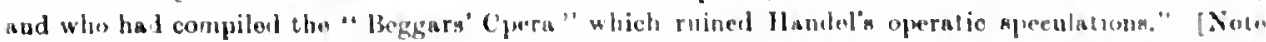
by Mr. Balfour.] Addutional forco 18 given to thas argument by the fact that lepuscli was, an we an abovo (1). 176), one of the Directorn of the Acmling of Ancient Music premonally active in brumguge about the publio exponare of Buonumin.
} 
Handel possessud mole than his share of open enemies and jealous friends, he was prepared to risk teputation and livelihood at once in order to save himself a few hours' extra exertion

"My second observation is this. If the main objection to robbery consists in the fact that the vietim of the robbery is injured by it, Handel's appropriation of the music of his predecessors would seem to be innocent, if not meritorious. So fnr from thair being injured by it in the quarter in which injury was alone possible, nancly, their reputation, it is not too much to say that their whole reputation is entirely fommled on it. Who would take the slighest interest in Urio if Handel had not condescended to use his "Te Deum" in "Saul" and the "Dettingen?" Who would ever have heard of Erba if Handel had not immortalised him by introducing parts of his "Magnificat" into "Israel?" "The fact is that Handel has not cheated them out of their due meed of fame, he has chented them into it. And I apprehend. that if this were made a preliminary condition of all literary or artistic pilfering, the art of plagiarisin would not in all probability be extensively practised or grossly abused." (pp. 152-156.)

A comparison between Shakespcare, Molière and Handel in regard to their use of sources might doubtless lead to interesting results, and the similarity between them as being all three connected with theatres, for which they had to produce under pressure, of itself invites such a comparison. Its result could not, however, supply evidence bearing on our present enquiry comparable in importance with that afforded us by the Buononcini affair as showing that in the time of Handel plagiarism in music was regarded just as it is now. The first Copyright Act ( 8 Anne, cap. 19), passed in 1709, under which proceedings were also taken in defence of musical property, ${ }^{1}$ shows, too, that a stricter view of literary ownership had by that time found utterance in legislation.

Mr. Palfour argues that Handel, if conscious of having used a Magnificat by Erba in a way which, once detected, was likely to ruin hoth himself and his reputation, would never have included his own autograph copy of that work among the collection of volumes which, bequeathed to his amanuensis, the elder Smith, are now in the Library of Buckingham Palace.

The case which Mr. Balfour makes out is undoubtedly strong, bit is subject, I think, to certain deductions. As Handel's autograph of the Magnificat bore no composer's name, it was only likely to be used against his authorship if and when independent external evidence was forthcoming to show that the work was the composition of another. Then, no doubt, Handel's autograph might play an important part in settling the question of priority, but equally possibly a nonIandelian authorship might be completely established without its aid. The risk

'Encyclopedia Britannica : article 'Copyright.' 


\section{FINAL CONSIDERATIONS}

of retaining the autograph in Handel's collection is somewhat reduced by these considerations. ${ }^{1}$

Mr. Balfour has limited his argument to the single case of the disputenl Magnificat, but it is equally applicable to the survival anong the Fitzwillian autographs of many passages copied by Handel from the works of Continental composers and afterwards incorporated in his own. That he did not destroy these copies may indeed be accepted as showing that he considered himself to have committed no breach of morality towards the eomposers concerned. Hut that $l_{4}$ " considered other people likely to take the same view of these appropriationsnotably of the two long ones from Graum, which in to the very verge of the Buononeini procedure-this I am unable to join Mr. Balfour in believing.

The point so forcibly put about the benefits whieh Handel conferred on the reputations of his predecessors hy alpropmiating their music, loses some of its fore if we remember that these appropriations were invariably made without acknciuledgment, just as in Handel's Fitzwilliam extracts the name of the eomposer copied from is in no single instance recorded. How then ean the reputation of a predeeessor he said to have gained by the credit due to him for something he had written having been absorbed by Handel? No doubt, now that the lact and sources of these appropriations have beeone known, an historical interes is taken in composess like Urio and Habermann which is wholly due to the use mate by Handel of music written by them. lint this interest is restrieted within the narrow eircle which concerns itself with musienl history, where these compusers' reputations will be measured by the intrinsic value of their works, not ly the fact that Handel saw fit to make use of them. To the bulk of the music-loving world the very nawes of Stradella, Clari, Muthat and the rest are unknown and hikely to remain so.

If, however, it be asked what has been the effeet of Handel's nction, not on the rputations but on the musical ideas, of the composers from whose works he borrowed, the answer given must be a very ditlerent onc. Even when he nerely took over matter substantially unchanged, he first gave it a fosh hearimg under, in most eases, greatly improvel conditions of performance, and then, by learim it embulicd in his own scores, bequenthed to it further opportunities of being hand. But in the much mo:e numerons instanes where he subjected what he hat borrowed to it process of reconstruction, he was alole to breathe a new life inte it and, hy wonking it up into one or other of his most insphent ellonts, seems to hase even secured-

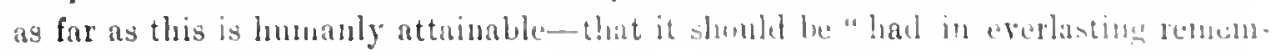
brance."

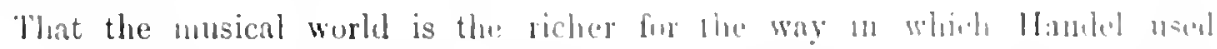

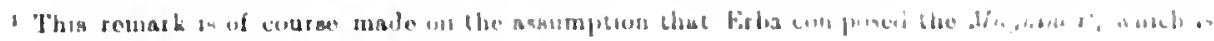

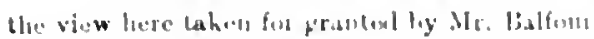


thematic materials due to his predecessors and his contemporaries can hardly be doubted. Surely, however, lie conle equally well lave conferred that boon if he har openly acknowledged his obligations to other composers. Iiut, as matters stand, the fact remains that he accepted, indeed practically elaimed, merit for what he must have known was not his own work. That this was wrong ean, it appears to me, be denied by those only who are prepared to estimate tho morality of an act according to the amount of genius shown in performing it. 


\section{APPENDIX.}

IAST OF WORK

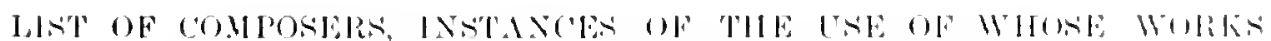

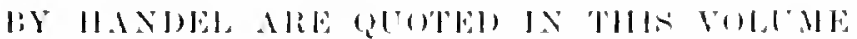

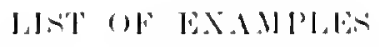





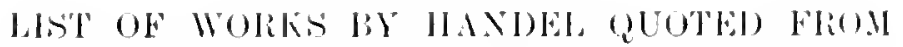
IN THIS VUI,UME.

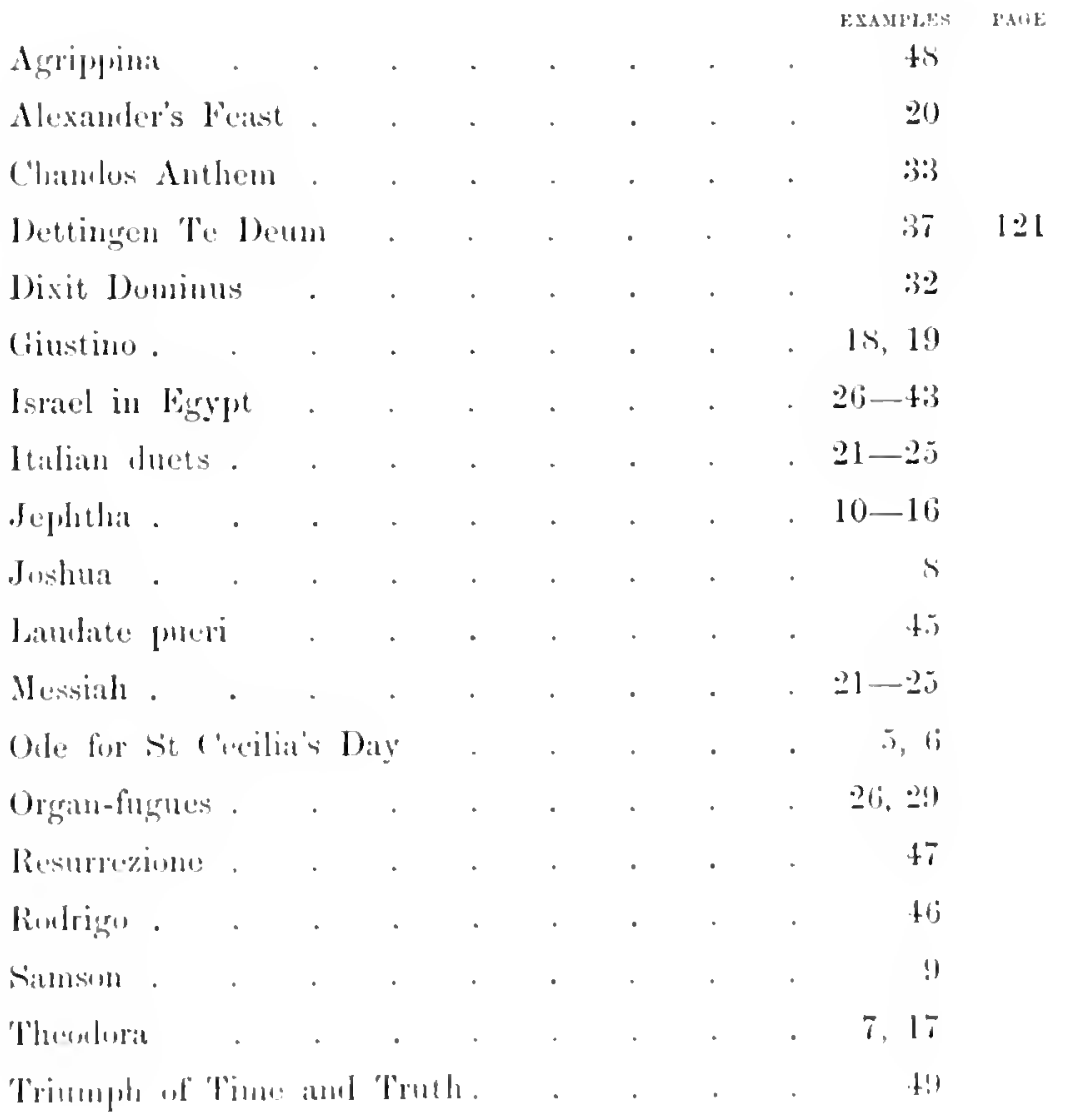


I.IT OF COMPOSLRS, INSTANCES OF THE USE OF WHOSE WORKS BY HANDEL ARE QUOTED IN THSS rOLUNE.

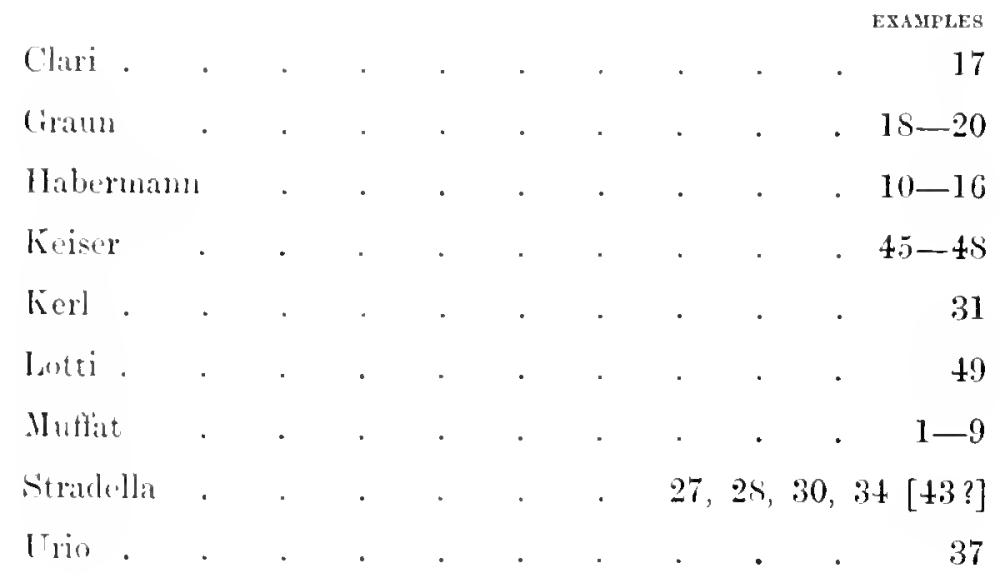




\section{LIS"I' OF EXAUPLES.}

Ex.MH't:

I.MOE:

I. Handel, autograph extract from IIullit, Prolude. . . . . .

3. Same continurol

4. Handel, antograph extract from Huflat, Ourerlure

5. Handel, Recitative in Ode for St C'reilie's lery-Mulfat, deleygo. . 6-s

6. Ilandel, instrmental movements in same-Mutlit, fentuisie . . s, s

7. Iandel, Trie in overture to Theodere-Muftiat, Trio . . . . 10-1:

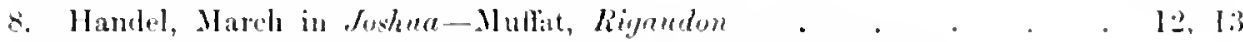

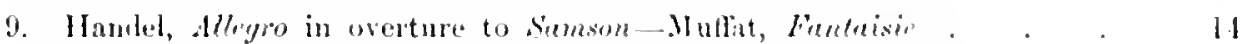

10. IIandel, Chorns "No more to Ammon's god" (Jophlhe)-Hahurmam, Chorus

11. Handel, Symphony to song "Hlis mighty arm" (of thhthe)-Hahermann, Prelude

12. Jandel, Chorus "O God, belohle" (Jephthe -JIabermann, Chorus "Qui tollis"

13. IIandel, Chorus "Theme sublime" (Jephtha)-Ifaberman, Chorus "Osanna" with Jlandel autograph copy.

11. Itandel, Chorus "Chemosls no more" (Jephethe)-Habermann, Chorus "Crem sanctu" with IIandw autograph copy. . . . . 2:3, ?21

15. Handel, Symphony to song "Hide thon" (ophthet)-Habermam, prelude

16. Handel, syuphony to song "Pour forth no usore" (J"phetha)-Hahruam,

17. IIandel, Chorus "Come mighty Father" (Thomlort)-Clari, duet .

$25-27$

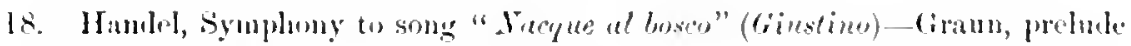
with Irandel autograph coly.

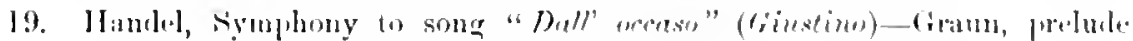
with Hambled automith copy . . . . . . . . .

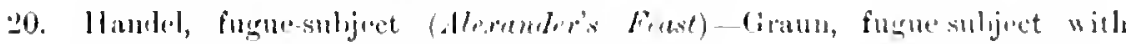
llandel autograple copy

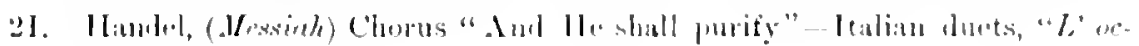
(1sit) he "

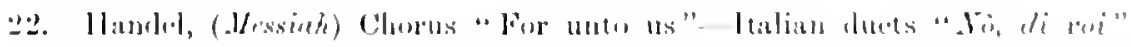

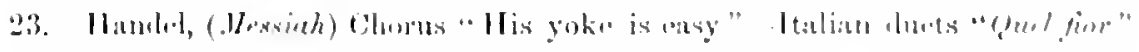

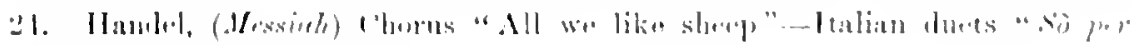

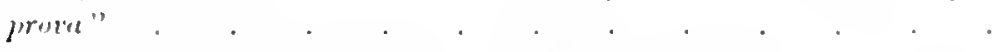

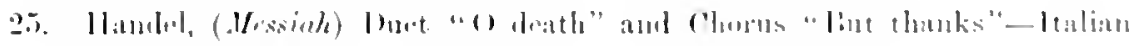

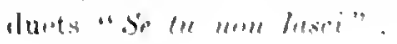




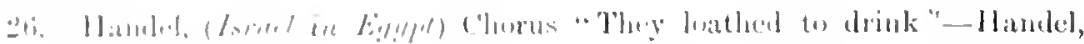
1) . . . . . . . . 15-52

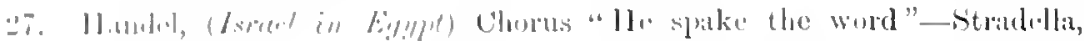
Sis melet

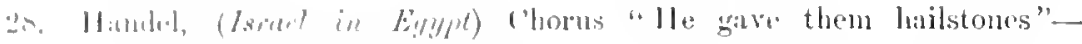
sitraledlat, sinenate

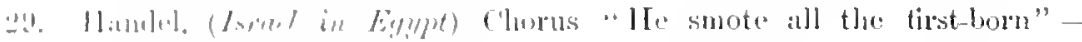

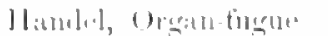

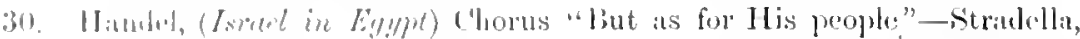
sireneter

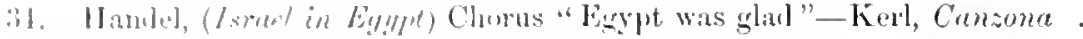

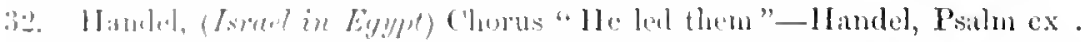

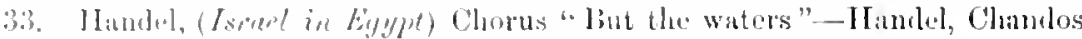
Inthem

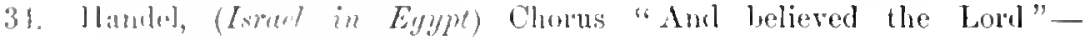

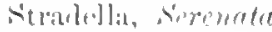

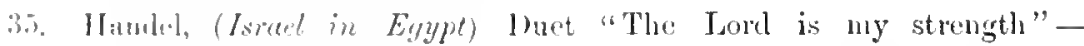
Jumifieret, louet.

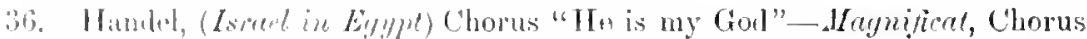

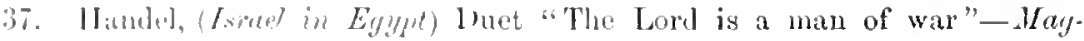
nifinal, lowet

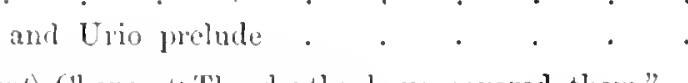

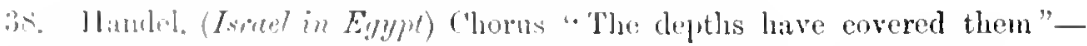
Mengifent, Ghorus

$117-136$ 117,118

$137-1+1$

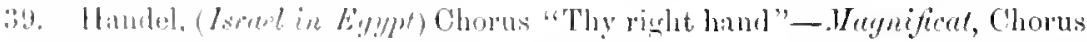
$112-118$

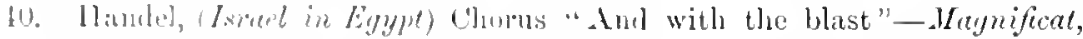
(') bolus.

11. Handol, (Is\%ml in E!lym) Choms "The earth swallowed them"Juynificat, (')urus

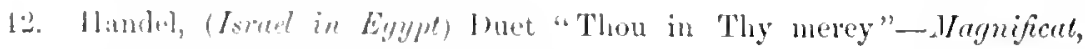
lollet

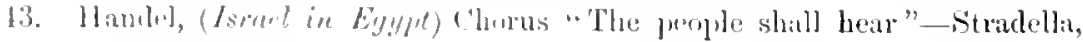

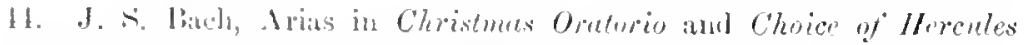

15. Ilandn, Aria in "Iombete more"-Konser, Aria in Oetaria

16. Ifambl, symplumy in Rodrigo-lieace, symphony in Octaria.

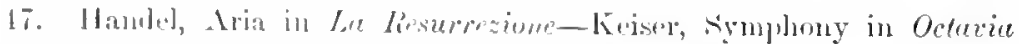

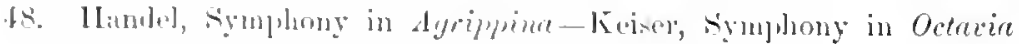

19. Handel, Chunte in Triumph of Time and Truth-Lotti, Chorus in a Mitss 


\section{NDEX.}

Acalomy of Ancint Musie, The, puldish

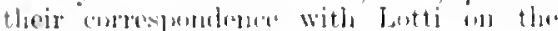

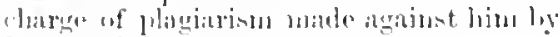
limorusucins, ]. 176.

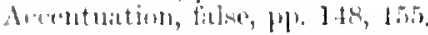

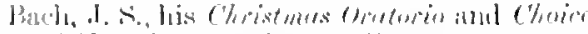

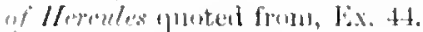

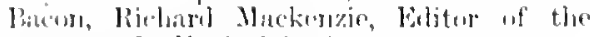

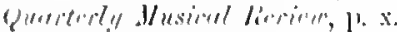

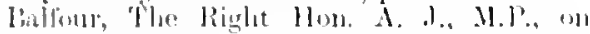

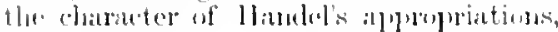
10. 184-186.

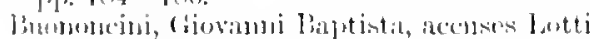
If pligiarism, f. 173.

- his attitude in the lutti contromersi, 1). 173, 174.

ferced to puit England, ats the jesmlt of it, $1 \% 176$.

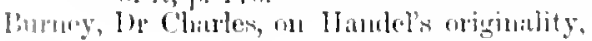
$1 \cdot x$

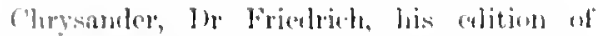
lifurlel sinurees, l. xii.

- his rinw al the uljoet of lIoundel's apropriations, jo 18.

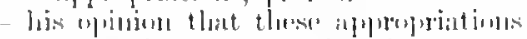

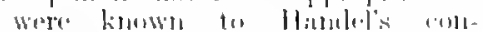

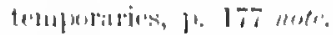

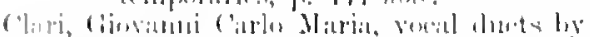

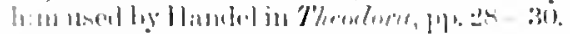

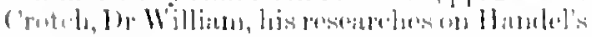
molteres, p. xi.

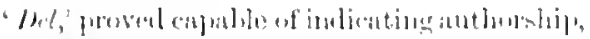
1. [M.

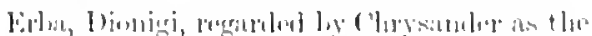

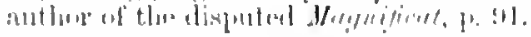

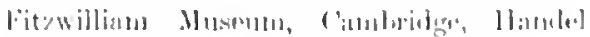

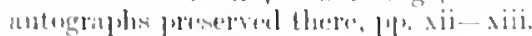

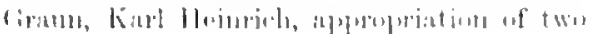

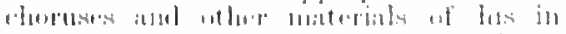

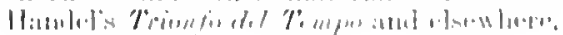
$11.32-33$.

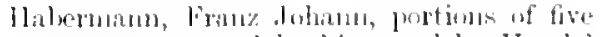

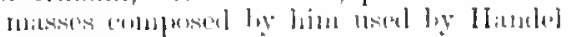
in eleplelen, 19. 17 -27.

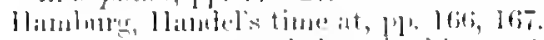

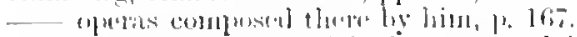

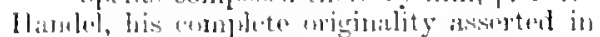

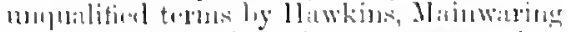

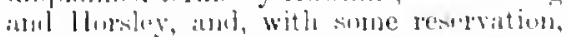
lyy linuey, pro ix, $x$.

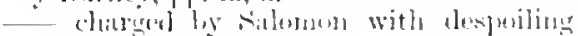
continental entupmers, and by simule? W"estey witli wholexill. pilfiginge p. it.

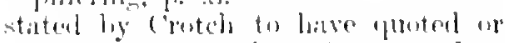
cepient the works at surne thiut

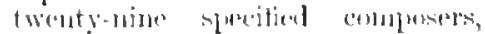
1). $x \mathrm{ij}$.

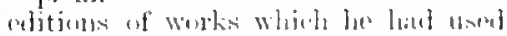

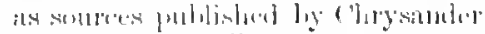
and siatlert, p. xii.

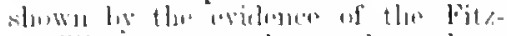

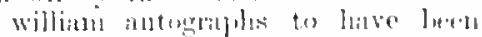

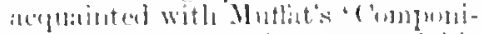
menti, jly. 1 - i) : justaluces of lij.

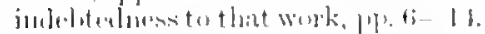

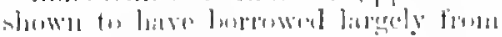

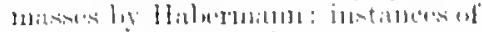

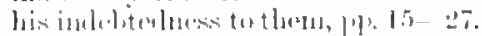

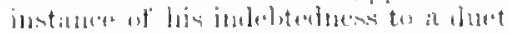

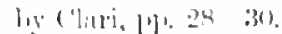

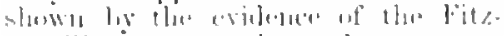

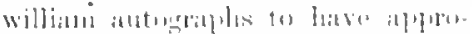

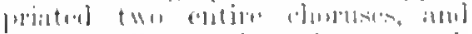

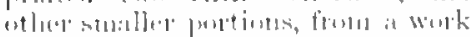

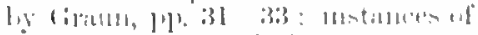

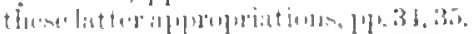

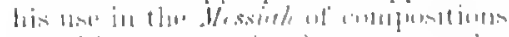

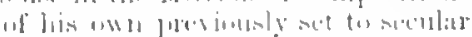

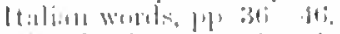

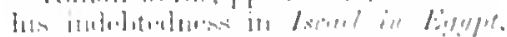

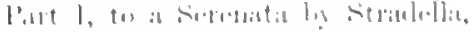

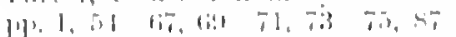
8!1: : 112. $71 ;-1$.

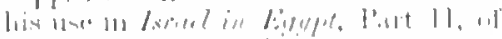

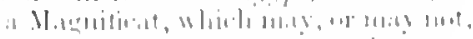

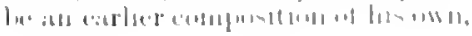




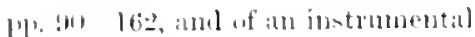

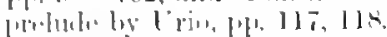

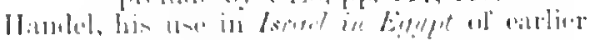

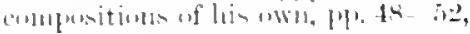
$7=73, \mathrm{~s}:-\mathrm{s}$.

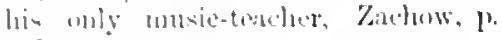
liti:

his munioganlip on abliving at llam-

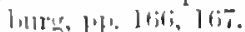

his rolittinls with keiser, ph, loi.

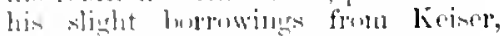
[1]. 11:- 17.

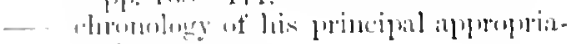
tions, 1. 17.2.

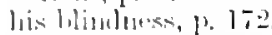

lise fintl ontumlinent of a clomens by

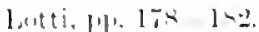

hatrater, whjert and momal ilspeet of his :

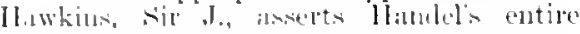
miginality, p. ix.

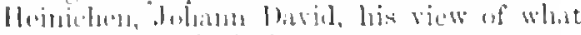
constitute platerariona, 1. 17.

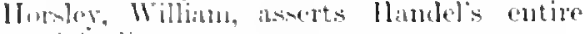
urigitulity, w. $x$.

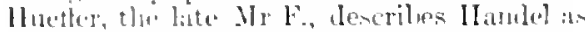

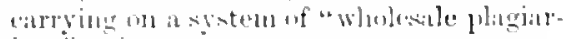
inla," lo ix.

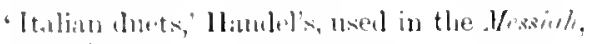
$11.33-41 \%$

Keiser, lieinhart, IIandel's relations with, $11,167$.

- Mamlel's homonings from, ly. lok171.

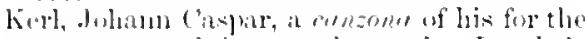

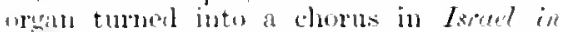

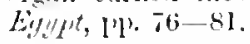

Losti, Autonio, lis letters to the Aendemy of Ancient Music, 1'l' 173-175. 1. 178.

a choms of hisalumouriated by Handel,

Lum, the late Rev. J. R., his share in hringing ahout Professor lrout's discovery in the Fitawillian Museum, I円. 31, 32.

Macfirren, Mr (afterwards Professul Sir) $(4$. A., lis oprinom that Ilandel wrote the disputed Ylegninient, 1.92.

Maguitiont, work the authorship of which is disputed, rery extensively used in l'art 11 of Isacel in Ey"lyt, 1). 915-92.
Mainwaring, fuln, asserts llandel's entire urigintlity, p. ix.

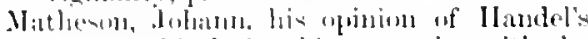
muscisuship hefore lis consexion with the

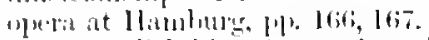

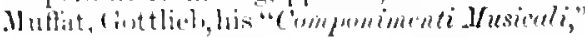
1.. 1 .

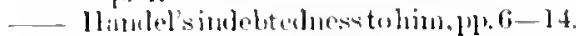

Musie, not in itsolf distinctively 'sacted' or 'seculiar," l'. 165.

Pepuseh, Dr I. C., persomally antive in the

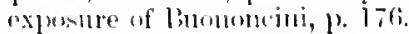

Plagiarism, luw mgarded in the eiglateenth century, 1'. 176

Puhl, the litte H. C. F., his article on Muffat, 1. 1.

Plout, loufessur, his reongnition of thandel mutoglathe at the loitzwilliau Museum as

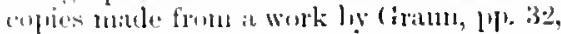
$3: 3$.

l'ubliation, effect of, om musical settings, 1). 16i.).

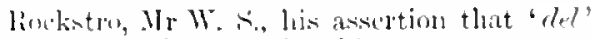

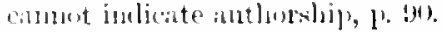

Silumun, duhn Poter, descrilues Homdel's reputation in Eugland as "wlully" consti.

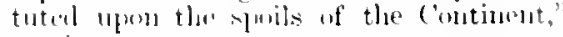
b. xi.

suffort, Wr Max, his arliele on Handeles

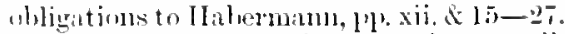
_L his enlition of Zachows works, ply. xii. and $167-171$.

— hisopinion that Handel'saly ropriations were known to his contemporaries, 1. $17 \%$.

Stratellit, Alessandro, a siremutre of his extensively used by Handel in Isred in Eynpt, l'1. $53-67,69-71,73-75,87-89$.

Trinutio ded Trmpo, $I$, earlier version of The Triusple of Tiste and Truth, 1']. 31-33.

Lrin, Francesco Antonio, une of an orchestral

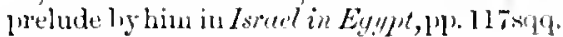

Wesley, Samuel, chancterizes Jandel's procedive as 'pilfering, $p$. xi.

Ziuduw, Fiedrich Wilhelm, Handel's only teather in masic, pullieation he l)r seiffert of his complete works, Jl. sii. \& 16 fif. 
